Sebastián Justo Cosola

\title{
LOS EFECTOS DE LA PUBLICIDAD EN EL
} DOCUMENTO NOTARIAL.

La decisión jurídica a partir de la convivencia de las instituciones jerarquizadas y de la conformación de una teoría de valores trascendentes

Tesis doctoral presentada en la Facultad de Derecho de la Universidad Austral para optar al título de Doctor en Derecho

Directora de tesis: Prof. Dra. Cristina Noemí Armella

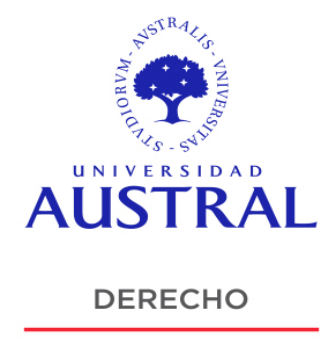

Buenos Aires, 2017 

A María Fernanda.

A mis padres.

A mi familia.

A mis maestros.

A todos mis afectos. 
"Lo que voy a deciros no está -afortunadamente- escrito en ninguno de mis libros: ello constituye, mas bien, un intento de superación, una de aquellas tentativas de superación, que son la necesidad de mi vida, porque en el fondo se trata de conseguir la libertad, tan amada por el hombre y siempre tan alejada de él ${ }^{1 "}$

${ }^{1}$ Cfr. Francisco CARNELUTTI, La figura juridica del notariado, Reus, Madrid, 1.954, pág.11. 


\section{INDICE GENERAL}

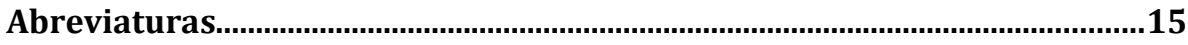

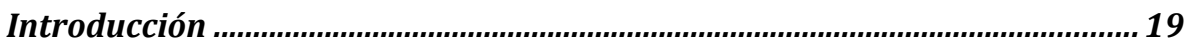

Fundamentos de mi elección por el ejercicio del notariado dentro del marco del oficio del jurista..............................................................................20

Ubicación curricular de la presente tesis.................................................24

Pretensión de la tesis.......................................................................................25

El método de investigación escogido........................................................27

El tratamiento de las publicidades jerarquizadas........................................28

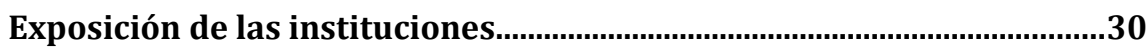

Resultado a obtener. ...................................................................................32

Créditos \& agradecimientos ……...................................................................33

\section{PARTE PRIMERA}

Los efectos de la tradición y de la relación posesoria

Capítulo I

Cuestiones elementales inherentes a los derechos reales y personales.

1.1. Introducción........................................................................................39

1.1.1. La hipótesis de trabajo. ............................................................................ 42

1.1.2. Confluencia del derecho público y del derecho privado.........................43

1.1.3. En torno al derecho de propiedad.......................................................... 44

1.1.3.1. La función social de la propiedad....................................................4

1.1.4. En torno al derecho de dominio...............................................................50

1.1.5. Derechos reales y personales. Los primeros conceptos........................51

1.1.6. La cuestión conceptual también determina los criterios

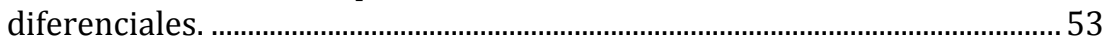

1.1.7. La lectura de los derechos personales y reales.......................................57

1.2. Posición notarial frente a los derechos reales y personales que conforman el contenido del documento. La proyección de las

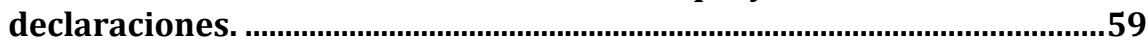

1.3. La tesis del título suficiente................................................................65

1.3.1. El planteo del modo suficiente (tradición) y de sus excepciones. ....72 
1.4. Las posiciones esgrimidas hacia la defensa del sistema traditivo y del inscriptorio respectivo.............................................................................77

1.5. Derecho comparado. ................................................................................84

3.5.1. El caso de los países de tradición anglosajona (Common Law)......85

3.5.2. Primer esbozo del concepto de autenticidad..........................................85

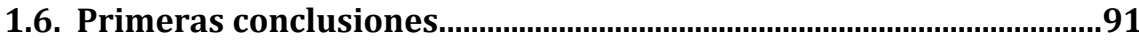

\section{Capítulo 2.}

Elementos y argumentos de la publicidad posesoria.

2.1. Aclaraciones previas. .97

2.1.1. Algunas dificultades que presenta el estudio de la teoría general de

la posesión

2.2. Los primeros antecedentes...................................................................101

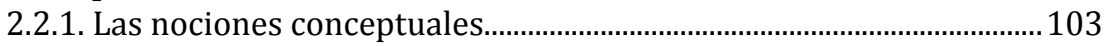

2.3. En torno de las teorías tradicionales de la posesión. .......................107

2.3.1. Una referencia a la teoría de la causa....................................................110

2.3.2. La tesis de la función social de la posesión...........................................112

2.3.2.1. Proyecciones y justificaciones que determinan la naturaleza

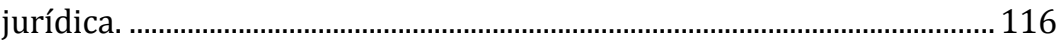

2.3.3. La posesión desde la exposición de Carnelutti: armonía entre la seguridad jurídica y la justicia............................................................................119

2.4. ¿Cuáles son los fundamentos de la protección posesoria?...............122

2.4.1. Excursus: El valor y la fuerza emergentes de la publicidad posesoria.

\section{Capítulo 3}

Los conflictos que desde la posesión importan al derecho notarial. El impacto en la teoría documental.

3.1. De nuevo sobre la relación entre los derechos reales y personales.

3.2. La figura del boleto de compraventa y las primeras interpretaciones académicas. Los primeros problemas originarios...131

3.2.1. Teoría del boleto de compraventa en el Código Civil. 
3.2.2. Boleto de compraventa en el Código Civil y Comercial de La Nación.

3.2.3. La adquisición de la posesión de inmuebles de buena fe mediante el boleto de compraventa......................................................................................... 141

PARTE SEGUNDA.

La Inscripción Registral y sus Efectos.

Capítulo 4

El Registro de la Propiedad Inmueble y la publicidad registral.

4.1. Introducción a los registros.

4.1.1. Funcionamiento, interrelación y adecuación de los registros.........150

4.1.2. Tipos de Registro

4.2. La publicidad registral de los derechos sobre las cosas con independencia de su naturaleza.

4.3. Situación del derecho registral en la República Argentina

4.3.1. La publicidad inmobiliaria en el Código Civil y Comercial de La

Nación. 159

4.3.2. Génesis del derecho registral y sustento de los otros derechos.....161 4.3.2.1. Fundamentos del funcionamiento del Registro Inmobiliario (I):

La función notarial. 162

4.3.2.2. Fundamentos del funcionamiento del Registro Inmobiliario (II): La función judicial. 166

4.3.2.3. Fundamentos del funcionamiento del Registro Inmobiliario (III): La profesión del abogado y de otros profesionales que tienen acceso a la información.

4.3.3. El contenido del derecho registral y la actuación del registrador..167 4.3.4. La cuestión de las normas y de los principios registrales. 168

\section{Capítulo 5}

El principio de publicidad registral.

5.1. Introducción a su tratamiento. .173

5.2. Publicidad formal y publicidad material. .176

5.2.1. La relación de la publicidad con la seguridad jurídica 
5.2.2. La seguridad jurídica estática y la seguridad jurídica dinámica.....180 5.2.2.1. Un ejemplo de conflicto entre seguridad jurídica estática y seguridad jurídica dinámica (o proyección de los conflictos entre la propiedad registrada y la posesión)..............................................................184 5.2.2.2. Las consideraciones axiológicas que necesariamente deben ser asumidas

\section{Capítulo 6:}

El deber de calificar.

6.2. La calificación notarial (principio de legalidad integrada) ...........194

6.2.1. El alcance académico de la calificación notarial. ................................196

6.2.2. El alcance actual de la calificación notarial............................................201

6.2.2.1. La trascendencia de la calificación notarial. ...............................207

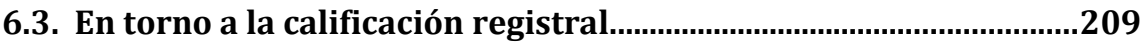

6.3.1. La necesaria separación de roles que implican ambas funciones.

Auxilio de la cuestión terminológica...............................................................215

6.3.1.1. Los problemas que no observamos de la disputa por el alcance de cada calificación..

6.3.1.2. Punto de acuerdo acerca de las calificaciones (desde la noción de seguridad jurídica)

6.3.2. Registro inmobiliario, publicidad y calificación registral: fin instrumental declarativo al servicio de la justicia.

6.3.3. El desarrollo de la función notarial en el momento donde opera la transmisión del dominio y el necesario complemento registral. ..............227 6.3.4. Las declaraciones de las partes en el documento y la prueba de confesión

6.3.5. Misión de la función calificadora registral (publicidad) y el aporte de la función notarial.

PARTE TERCERA

Los efectos del título notarial.

Capítulo 7

La proyección del documento Notarial. 
7.2. Los orígenes científicos y las razones actuales.

7.2.1. Desarrollo de la teoría del documento notarial: incidencias e influencias de acuerdo al momento histórico de su desarrollo académico.

72.2. ¿Por qué la búsqueda de un objeto científico como contenido del derecho notarial?.

7.2.2.1. La cuestión espacial: el paradigma científico vigente al momento del desarrollo del documento como objeto del derecho notarial.

7.2.2.1.1. Necesidad de destacar al documento notarial como un objeto de tipo científico dentro del positivismo. Lógica cuestión antecedente.

7.2.3. El estudio del derecho notarial y del documento en la actualidad.

7.2.3.1. Una adecuada interpretación del título preliminar del Código Civil y Comercial de la Nación y la elaboración notarial del derecho documental.

7.3. Los primeros conceptos acerca del objeto esencial del derecho notarial. .261

7.3.1. El tema de la cuestión terminológica. ..................................................263

7.3.1.1. Documento, instrumento o escritura pública notarial: la cestión conceptual en el derecho notarial argentino................................264 7.3.1.2. Las otras perspectivas propuestas para el análisis conceptual.

7.3.1.3. Teleología legal en la República Argentina..................................270 7.3.1.3.1. La cuestión de los conceptos en España proyectada hacia el derecho comparado. 276 7.3.1.3.2. El documento y una construcción academica sobre la idea de los principios. 282

\section{Capítulo 8}

EI documento y las disciplinas que resultan afines a su desarrollo.

8.1. Proyección del documento en el derecho civil. 285

8.2. Proyección del documento en el derecho de procedimientos. ...288

8.3. Proyección del documento en el derecho penal..................................290

8.4. Proyección del documento en el derecho administrativo...............293 
8.6. Conclusión de la cuestión conceptual: El documento notarial auténtico

8.6.1. Innecesaridad de otras perspectivas clasificatorias. .........................302

8.6.2. Los elementos formales externos del documento notarial auténtico.

8.7. La clasificación de la estructura y de los componentes del documento notarial auténtico.

\section{Capítulo 9}

La estructura del documento notarial.

9.1. Palabras iniciales

\subsection{Los aspectos intangibles del documento notarial: Justificación y} propuesta

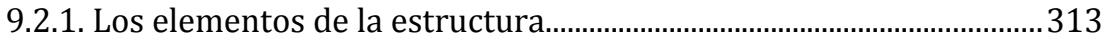

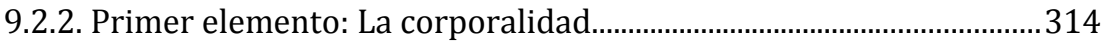

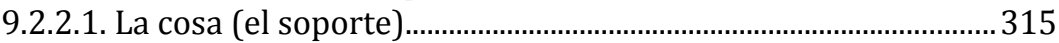

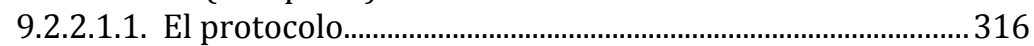

9.2.2.2. La publicidad cartular y la autenticidad externa..........................317

9.2.2.2.1. Casos más frecuentes de publicidad cartular extrínseca.

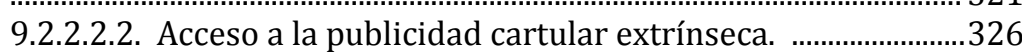

9.2.2.2.3. El estudio de los títulos antecedentes..................................328

9.2.2.2.4. El estudio de los antecedentes y la defensa de la seguridad jurídica. Casos detectables. ......................................................................... 331

9.3. La grafía..........................................................................................................332

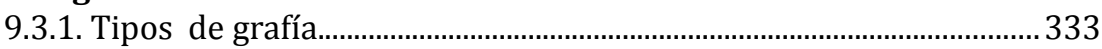

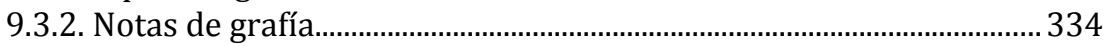

9.4. Segundo elemento: El autor...............................................................335

9.4.1. Los comparecientes en el documento...................................................336

9.4.2. La cuestión de los testigos instrumentales en sede notarial. ...........337

9.5. Tercer elemento: El contenido. .......................................................338

9.5.1. La publicidad cartular y la autenticidad interna....................................342

9.5.2. Los temas de la publicidad cartular intrínseca.....................................344

9.5.3. El acceso a la publicidad cartular intrínseca..........................................345

9.5.4. En torno a lo extrínseco e intrínseco de la autenticidad....................346 


\section{Capítulo 10.}

La conformación de los componentes en la estructura del documento notarial.

10.1. Palabras iniciales. 351

10.2. Los componentes materiales. .353

10.2.1. El derecho notarial como derecho formal. ..........................................355

10.2.1.1. La forma notarial. .............................................................................356

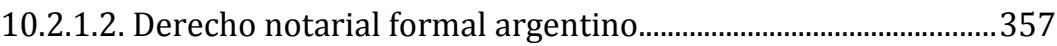

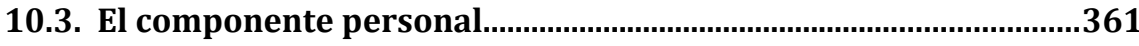

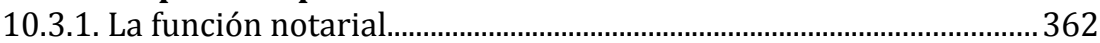

10.3.2. El régimen de las competencias notariales. ........................................367

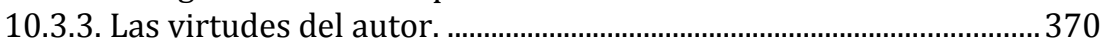

10.4. El componente relacional.....................................................................371 10.4.1. Situación inicial, (hecho-acto) y situación final (o nueva situación).

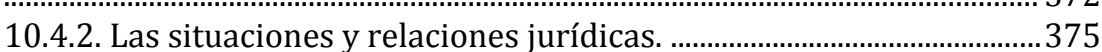

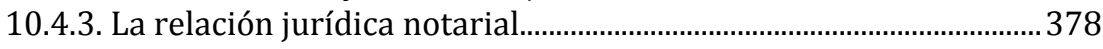

10.4.3.1. Clases de relaciones jurídicas notariales......................................379

10.4.3.1.1. La relación notarial formal...................................................381

10.4.3.1.2. La relación notarial funcional...............................................382

10.4.3.1.3. Relación jurídica social notarial..........................................386

10.4.4 La estructura y los componentes del documento notarial auténtico: el equilibrio receptivo de los cambios jurídicos y la justificación de las instituciones tradicionales. 389 10.4.4.1 Corolario: la comprensión y los alcances de la autenticidad externa del documento (Efectos de la publicidad cartular extrínseca)...393

\section{Capítulo 11}

\section{La búsqueda conceptual del contenido proveniente de la autenticidad interna.}

11.1. Palabras preliminares. 395

11.1.1. Una cuestión de elección por la adecuación de la designación de los baluartes esenciales del documento. 


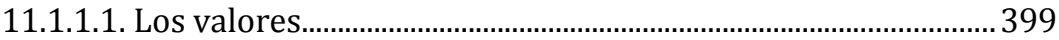

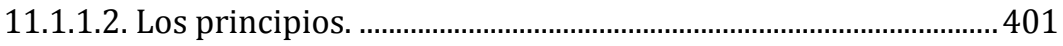

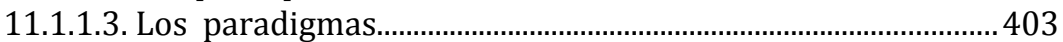

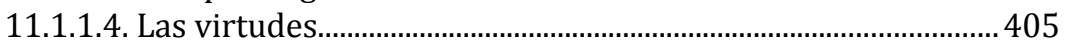

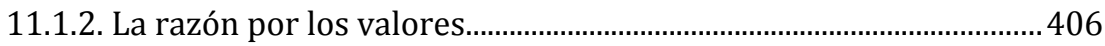

11.1.3. Los valores que coexisten en el documento notarial.........................408

\section{Capítulo 12}

Primer Valor: Fe pública.

12.1.1. Una introducción meramente conceptual. .........................................4 411

12.1.2. Las definiciones y los alcances.......................................................... 414

12.1.2.1. Las opiniones extranjeras.............................................................. 417

12.1.3. Cuestiones técnicas inherentes a la fe pública: Las notas. ..............421

12.1.3.1. Cuestiones técnicas inherentes a la fe pública (II): Las fases.

423

12.1.4. Función elemental (legal y axiológica) de la fe pública notarial. La

remisión constitucional. 424

12.1.5. Recepción de la fe pública en el Código Civil y Comercial de La Nación.

12.1.5.1. Los alcances relativos a la plena fe del instrumento...............427

12.1.5.2. La cuestión de la incolumidad formal. .......................................429

12.1.5.3. La figura del contradocumento. ...................................................429

12.1.6. La fe notarial, su eficacia y las expectativas sociales.........................430

12.1.6.1. La sociología del derecho notarial...............................................431

12.1.6.1.1. ¿Cómo el hombre común accede al documento notarial, en la plenitud de sus facultades y con el convencimiento de las bondades que el título le ofrece y garantiza?..........................................433

12.1.7. La idea de la verdad (fe) que protege el derecho...............................436

12.1.8. Documento, prueba y verdad: El valor de la fe pública en el proceso.

12.1.9. Las recapitulaciones esenciales: La fe pública y el sostén del sistema de responsabilidad notarial.

\section{Capítulo 13}

\section{Segundo Valor: La Justicia.}

13.1. Introducción..

13.1.1. Fundamentos de la corriente de pensamiento escogida. 
13.1.2. Fundamentos del tratamiento de la justicia en una tesis de derecho notarial

13.1.3. Esquema escogido para el desarrollo de la justicia. 459

13.2. Las bases y el punto de partida .460

13.2.1. Breve panorama de las teorías magistrales de la Justicia. 462

13.2.1.1. Las otras posiciones acerca de la justicia. .470

13.2.2. Las relaciones de la justicia: sus clases principales y el bien común.

13.2.2.1. Una referencia a la posición de Juan Berchmans Vallet de

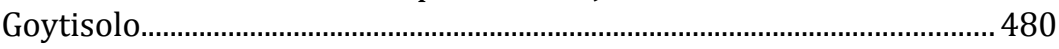

13.3. Las recapitulaciones esenciales......................................................486 13.3.1. El desenvolvimiento del valor justicia en el ejercicio de la función notarial. Necesidad de su comprensión primaria. 488

13.3.1.1. Casos frecuentes de ejercicio de tutela notarial frente a la concreción de la justicia en el documento notarial. .................................489 13.3.1.2. Observación de la elaboración notarial del derecho en las diferentes perspectivas de la justicia: conmutativa, distributiva y legal.

13.3.2. Excursus: la justicia y su valoración cartular intrínseca en el documento notarial. 495

\section{Capítulo 14}

Tercer Valor: La Seguridad jurídica.

14.1. Palabras introductorias. .497

14.2. La justicia y la seguridad.. .500

14.3. Los conceptos y los primeros alcances. .501

16.3.1. La expansión de la seguridad jurídica. . .503

16.3.2. El objeto de tutela. 507

14.4. Aproximaciones iusfilosóficas a la seguridad jurídica .507 14.4.1.1. La seguridad como valor en el plexo axiológico jurídico de

Carlos Cossio (fundamentos de la posesión).

14.4.2. La seguridad jurídica y el desarrollo del derecho privado..............517 14.4.3. La función de la seguridad jurídica en el ejercicio del derecho notarial

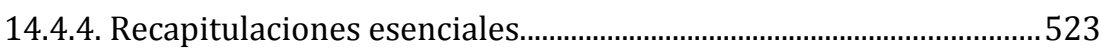

14.5. La seguridad jurídica y el documento notarial 
14.5.1. En torno a las sentencias judiciales.

14.5.2. Las "respuestas" a las sentencias. La teoría de la impugnación procesal y los dictámenes consultivos................................................................529

14.5.3. En torno a las escrituras públicas...........................................................532

14.5.4. Las respuestas a las escrituras públicas. Teoría general de las ineficacias y la impugnación de la autenticidad.

14.6. Cuestiones provenientes de los estudios comparativos entre las sentencias y las escrituras públicas.

14.6.1. a) Determinación de las bases que conforman los fundamentos.

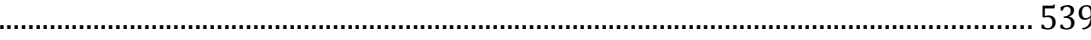

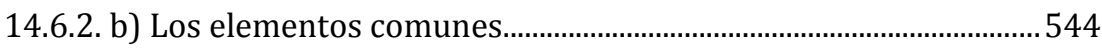

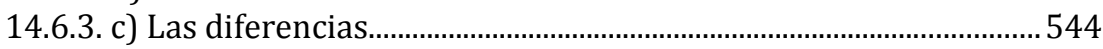

14.6.4. d) Conclusiones del método comparativo efectuado........................546

\section{Capítulo 15}

Los efectos de la publicidad en el documento notarial: trascendencia y valoración.

15.1. Palabras iniciales.

15.2. Las primeras comprobaciones

15.3. El documento notarial como elemento y argumento de decisión jurídica.

15.3.1. La naturaleza del documento notarial decisorio

15.4. La justicia y la seguridad jurídica se proyectan y conviven en armonía en el documento notarial, y determinan el cuarto valor consecuente: la paz..

15.4.1. La autorización notarial del documento y la consolidación de la paz.

15.5. La valoración de la publicidad del documento notarial: armonía y contención.

15.5.1. Resultado de la comprensión de los efectos publicitarios individualizados de la publicidad posesoria y registral. . .569

15.5.2. Esquemas de la exposición y del tratamiento. ..570

15.6. Consideraciones finales. .571

16. Bibliografía general .577 


\section{ABREVIATURAS}

AAFD: Asociación Argentina de Filosofía del Derecho.

AAMN: Anales de la Academia Matritense del Notariado.

AAVV: Autores Varios.

ACADERC: Academia Nacional de Derecho y Ciencias Sociales de Córdoba (Argentina).

Actual: Actualizador/a; actualización.

AFCJS-UNLP: Anales de la Facultad de Ciencias Jurídicas y Sociales, UNLP.

AFD-SEFJP: Anuario de Filosofía del Derecho, Sociedad Española de Filosofía Jurídica y Política (Madrid).

AFJS: Anuario de Filosofía Jurídica y Social (Argentina).

AIDN: Anuario Iberoamericano de Derecho Notarial (Madrid, España).

AMN: Academia Matritense del Notariado.

ANN: Academia Nacional del Notariado, Buenos Aires, Argentina.

Art.: Artículo.

Arts: Artículos.

BDaD: Boletín Informativo Derecho al Día, Facultad de Derecho (Oficina de Comunicaciones, UBA).

BICEPBA: Boletín informativo del Colegio de Escribanos de la Provincia de Buenos Aires.

BICNG: Boletín informativo del Colegio Notarial de Granada, España.

Cap: Capítulo.

CCA: Código Civil Argentino.

CCE: Código Civil Español.

CCCN: Código Civil y Comercial de La Nación.

CCF: Códe Civil Francés.

CECF: Colegio de Escribanos de la Capital Federal, hoy Ciudad Autónoma de Buenos Aires.

CEM: Colegio de Escribanos de Mendoza.

CGN: Consejo General del Notariado, España.

CGNE: Consejo General del Notariado Español.

CNB: Colegio Notarial de Barcelona.

CNCC-LP: Cámara Nacional Civil y Comercial de La Ciudad de La Plata.

CNM: Colegio Notarial de Madrid.

CNUE: Conferencia de los notariados de la Unión Europea.

CNCiv: Cámara Nacional Civil, Ciudad Autónoma de Buenos Aires, Republica Argentina.

CNE: Congreso Notarial Español.

CINL: Congreso Internacional del Notariado Latino. 
Codir: Codirector/a; codirección.

COLESCBA: Colegio de Escribanos de la Provincia de Buenos Aires.

Comp.: Compilador/a; compilación.

Concord.: Concordancias.

Conf: Conforme.

Coord.: Coordinador/a; Coordinación.

Cfr: Confrontar.

CN: Cuadernos Notariales, Buenos Aires.

CPCCNA: Código Procesal Civil y Comercial de la Nación Argentina.

CSJN: Corte Suprema de Justicia de la Nación Argentina.

Dir.: Director/a; dirección.

Dir. Gen.: Director General.

Dir. Tom.: Director del Tomo.

DGRNE (a): Dirección General de los Registros y del Notariado de España (Anuario).

DPFDUBA: Departamento de Publicaciones, Facultad de Derecho, Universidad de Buenos Aires.

DPCASI: Departamento de Publicaciones del Colegio de Abogados de San Isidro, Buenos Aires, Argentina.

DRAE: Diccionario de la Real Academia Española de letras on line, www.rae.es

EC: Editorial Civitas, Madrid.

ED: El Derecho, República Argentina.

EGCA: Ediciones Guatemala, C.A.

EJB: Enciclopedia Jurídica Básica, Civitas, Madrid.

EJO: Enciclopedia Jurídica OMEBA, Buenos Aires, Argentina.

ELL: Editorial La Ley, Buenos Aires, Argentina.

EM: Ediciones Madrid.

EUNSA: Ediciones de la Universidad de Navarra S.A.

FA(p): Fundación Aequitas, España (Publicaciones).

FEN: Fundación Editora Notarial, Colegio de Escribanos de la Provincia de Buenos Aires.

IACN: Instituto Argentino de Cultura Notarial.

IEF: Instituto de Estudios Filosóficos Santo Tomás de Aquino (Buenos Aires).

IER: Instituto Editorial Reus, Madrid.

Inc: inciso.

Inv.: Investigador/a; Investigación.

IRL: Imprenta de la Revista de Legislación, Madrid.

JDCNE: Junta de Decanos de los Colegios Notariales de España (Editores).

JNB: Jornadas Notariales Bonaerenses.

JNA: Jornada Notarial Argentina.

JNI: Jornadas Notariales Iberoamericanas.

LHE: Ley Hipotecaria Española.

LL: Editorial La Ley, República Argentina. 
LL(E): Editorial La Ley, España.

NdA: Nota del autor.

Núm: numero.

Ob. cit/op. cit: obra citada, opus citate.

OU: Oxford University.

Pág/Págs: Página/ Páginas.

Par: parágrafo.

Prel.: Preliminares.

Pto: Punto.

RAE: Diccionario de la Real Academia Española.

RdNER: Revista del Notariado del Colegio de Escribanos de Entre Ríos, Argentina.

RDD: Revista de Derecho de Daños, Rubinzal Culzoni, Santa Fe, República Argentina.

RDJSF: Revista de Doctrina y Jurisprudencia, Santa Fe, Argentina.

RDN: Revista de derecho notarial, Madrid, España.

RDP: Revista de derecho privado, Madrid, España.

RDPC: Revista de Derecho Privado y Comunitario, Rubinzal Culzoni, Santa Fe, Argentina.

RE: Revista Escribanos del Colegio de Escribanos de la Provincia de Buenos Aires.

RNC: Revista Notarial del Colegio de Escribanos de Córdoba, Argentina.

REN: Revista el Notario del Siglo XXI, Colegio Notarial de Madrid.

Recop: Recopilador/a; recopilación.

Rev: Revista/s.

RiNo: Rivista del Notariato, Italia.

RJdN: Revista Jurídica del Notariado, publicación del Consejo General del Notariado Español, Madrid, España.

RJF: Revista Jurídica FIDES, República Argentina.

RLN: Revista La Notaria, Barcelona, España.

RN: Revista Notarial, publicación del Colegio de Escribanos de la Provincia de Buenos Aires.

RNpC: Revista Notarial de la Provincia de Córdoba, República Argentina.

RdN: Revista del notariado, publicación del Colegio de Escribanos de la Ciudad Autónoma de Buenos Aires.

RIN: Revista Internacional del Notariado.

RNCF : Revista Noticias (Consejo Federal del Notariado Argentino).

RP: Revista Podium, Colegio de Notarios de Jalisco, México.

Superv.: Supervisión.

Supl: Suplemento.

RTFD: Revista telemática de Filosofía del Derecho, España.

TD: Tesis doctoral original.

TDI: Tesis doctoral impresa por editorial. 
TN: Tribunal Notarial de la Provincia de Buenos Aires.

To: Tomo.

Trad.: Traductor/a; traducción.

UA: Universidad Austral.

UAM: Universidad Autónoma de Madrid.

UB: Universidad de Belgrano, República Argentina.

UBA: Universidad de Buenos Aires.

UCLA: Universidad de Castilla-La mancha, España.

UCSA: Universidad Católica San Antonio, Murcia, España.

UdU: Universidad de Uruguay.

UEC: Universidad del Externado, Colombia.

UNA: Universidad Notarial Argentina.

UNAM: Universidad Nacional Autónoma de México.

UNAV: Universidad Notarial Argentina Virtual.

UNNOBA: Universidad Nacional del Noroeste de la Provincia de Buenos Aires.

UG: Universidad de Granada, España.

UIMP: Universidad Internacional Menéndez Pelayo, Santander, España.

UNLP: Universidad Nacional de la Plata.

UPF: Universidad Pompeu Fabra (Barcelona).

USC: Universidade de Santiago de Compostela, España.

V.: Ver.

Vol.: Volumen.

VTRP: Versión digital de la aplicación Thomson Reuters Proview. 


\section{Introducción}

Es verdaderamente profunda la satisfacción que siento al escribir estas palabras introductorias como bienvenida a la tesis doctoral que con el más puro convencimiento entrego a las autoridades del doctorado de la Facultad de Derecho de la Universidad Austral. No puedo dejar de sentir ciertas emociones particulares, que dirigen mi pensamiento hacia tiempos algo alejados del presente, a momentos especiales de mi vida y de mis circunstancias; a esos espacios en donde desde mi ilusión, había motivos suficientes para creer que en el mundo del porvenir todo estaría por hacerse de manera sana y segura, entendiendo para ello al desarrollo como resultado y complemento de la bondad del hombre y de su natural buena fe en las actuaciones diarias o cotidianas, determinantes del reparto equitativo de los bienes protegidos por los valores del orden, la seguridad, la justicia, la cooperación, la solidaridad y la paz.

En ese imborrable marco de recuerdos, no puedo dejar de pensar que una de las primeras respuestas que ofrecí automáticamente al momento de intentar justificar mi elección por la carrera de grado -en pleno desarrollo de una adolescencia extendida y notablemente escasa de contenidos firmes y decisorios-, fue la que ponía en evidencia que había una necesaria unión entre el derecho y la justicia. ¿Por qué quiere estudiar derecho? Porque pienso y creo en la justicia, respondí hace ya veinte años, al momento de finalizar mis estudios en el colegio secundario en mi ciudad natal [Junín (B)].

Sin embargo, en aquel entonces, la profesional especialmente contratada por el Instituto Marianista al que yo concurría con el fin de cumplir la etapa media obligatoria de educación indispensable para tener la posibilidad de acceso a la facultad, me puso al tanto -entre otros bemoles no menos relevantes- que la carrera en realidad, no era derecho, sino abogacía, y que era indispensable que comenzara por aprender a designar las cosas por su nombre, para poder así asumir desde el inicio, cuál sería mi futuro y con él, mi destino laboral y de vida de relación. 
Desde ese mismo momento comprendí que algo no funcionaba bien en el esquema jurídico primario que como un sistema cerrado de comprensión casi perfecta, por aquellos entonces funcionada en mí. Si el derecho era la abogacía, ¿qué función cumplían los jueces, los defensores, los fiscales, y también los escribanos como egresados de la misma Facultad? ¿Acaso ellos no estudiaban también el derecho?

Fue necesario entonces iniciar los estudios de derecho para poder felizmente desasnarme y comprender el verdadero alcance de lo que yo suponía como cierto, y que en ese momento de elección de vida tan importante para mí inicial esperanza, había sido puesto en duda por una de las mejores profesionales de mi ciudad.

\section{Fundamentos de mi elección por el ejercicio del notariado dentro del marco del oficio del jurista}

Mi padre ejerció la función notarial por casi cincuenta años. Mi madre es escribana de título, y por un tiempo similar al referido de mi padre, desempeñó su actividad dentro del Poder Judicial de la Provincia de Buenos Aires, en el Departamento Judicial de Junín. Y si bien hoy ambos disfrutan del merecido tiempo libre que la vida les ha ofrecido a través de la justa obtención de los beneficios jubilatorios, cierto es que aun siguen estando muy cerca nuestro para ofrecer, en cada caso arduo y difícil, la inigualable $v o z$ de la experiencia. Es así que desde niño - motivado por ese sentimiento bello e inexplicable de admiración a los padres que ineludiblemente, se traslada hacia el desarrollo de sus propias actividades-, algo cercano a mis actuales convicciones me hacía pensar que la primera noción de justicia, de todas las que el hombre puede llegar a conocer y justificar, ocurría en la escribanía. Acaso en la felicidad del hombre o la mujer que suscriben con seguridad su primera escritura de adquisición de la propiedad -momento donde se consolidan los sueños y se escapan para siempre los temores sobre 
las pérdidas o los despojos-; o en esas alegrías inexplicables que en las notarías se celebran como logros que parecen inalcanzables, como cuando se protege a los hijos en la transmisión del patrimonio, o se los autoriza a que realicen, en pleno estado de minoridad o adolescencia, un viaje que comienza por enseñarles que muchas de las ilusiones de la infancia pueden cumplirse a través del esfuerzo y del sacrificio de la familia.

Sea como haya sido mi discernimiento y especialmente, mi capacidad de imaginación en el momento en que fui niño y adolescente, lo ciertamente comprobable es que desde ese entonces acompaño a mi padre en la escribanía, cumpliendo así absolutamente todas las etapas de jerarquía posibles en estos casi cuarenta años de vida de vida que llevo en el este mundo repleto de buenas intenciones como también, de ciertas maldades a las que intento decididamente desviar de m rumbo.

Hoy miro hacia atrás y observo lo que expreso con tanta claridad que me asombro incluso de mí mismo. Esa fue y es la única razón que explica que en el presente, me encuentre ejerciendo hace poco más de quince años, la función notarial, con los conocimientos universitarios adquiridos con profunda vocación y natural dedicación, pero por la senda y la escuela que mi padre ha escogido oportunamente para ejercerla hace ya tantísimo tiempo. En definitiva, siempre me he sentido hijo del más puro amor, y por ello me siento deudor y también protagonista, de la más sensible admiración. Debo decir que durante todo el tiempo referido de ejercicio, la observación que he venido realizando de los casos notariales que se plantean cotidiana y habitualmente, me ha permitido advertir con claridad como primera justificación de la profesión notarial, que la misma se debe edificar sobre la necesidad de alcanzar en cada cuestión concreta, lo justo que cada requirente pretende para sí. En el ejercicio de la función fedante, estas pretensiones ya se advierten en las primeras operaciones de ejercicio. Desde ellas es que puede fácilmente determinarse que en la actualidad, esa propia cosa justa que pretende el requirente para sí puede o no puede compadecerse con lo justo concreto, esto es, con lo que verdaderamente le corresponde de acuerdo a la ley y de acuerdo con el derecho. Y ésta es sin duda, la razón que justifica que en el ejercicio práctico del derecho notarial, la correcta adecuación de los primeros deberes éticos notariales aplicados de información, asesoramiento y consejo, se torne tan oportuna como imprescindible. 
Según esta posición, lo justo notarial comienza a determinarse a través de la aplicación de un método de la función notarial que intenta acercar al hombre, a la mujer y a la familia de nuestros días a los derechos que le pertenecen en una etapa anterior al conflicto; un método que cobra valor y trascendencia en el documento notarial, que es en definitiva el elemento que viene a proyectar una publicidad digna de consideración.

Es que en circunstancias mucho más habituales que excepcionales, el hombre que llega a la escribanía ni imagina que sus pretensiones pueden llegar a ser injustas, y que por esa propia naturaleza, pueden alcanzar a generar un conflicto posterior. Por ello mismo, en el análisis del método de la determinación concreta de lo justo notarial debe vivir la imparcialidad y la independencia, con los valores propios de la función fedante, todo esto dentro de un esquema protectorio a cargo del deber ético de legalidad integrada, hoy felizmente comprensivo de las reglas, de las normas, de los valores y de los principios generales del derecho que el escribano o notario debe captar naturalmente por evidencia. Para poder consolidarse, la función notarial definitivamente tiene que familiarizarse con la utilización de las herramientas que le provee el derecho vigente.

Un primer convencimiento me orienta a asumir que en los tiempos actuales no existen razones suficientes que puedan sólidamente argumentar que la única diferencia que reside entre el documento público notarial y el documento privado es la que se advierte desde el propio concepto de autenticidad formal y material que emerge del primero y del cual carece el segundo $^{2}$. No es solo la fe pública lo que diferencia a uno de otro documento. Esas teorías, las primeras en la elaboración de doctrinas tendientes a consolidar un derecho notarial autónomo diferenciado del derecho civil y del derecho de procedimientos, ya han sido superadas notablemente a través de los fundamentos esgrimidos por juristas de todo el mundo, que han vertido sus acertadas opiniones, muchas de ellas justificadas incluso desde las más variadas y diversas fuentes del derecho. Muy a pesar de ello, debe reconocerse que la extensión de los efectos publicitarios del documento no se ha dirigido hacia la conformación de otros valores cercanos a los emergentes de la fe, como la justicia o la seguridad entendida no como

${ }^{2}$ Cfr. Celia MARTíNEZ ESCRIBANO, Control notarial de la legalidad, Cuadernos Civitas, Thomson Reuters, Pamplona, 2.010, p. 185. 
aseguramiento del tráfico (consecuencia de la fe), sino como el más óptimo resultado proveniente de la voluntad particular tutelada por quien oficia de notario. Si el derecho actual positivo y vigente postula a la justicia como el máximo valor trascendente, no es posible asumir que el documento notarial carece de ese valor trascendente. La refundación de la teoría del documento notarial, objeto y centro del estudio del derecho notarial formal y sustantivo, no puede entonces esgrimirse como una opción, sino más bien como una necesidad.

Esta tesis doctoral intenta como primera medida, formalizar de aquí en más en la mente del jurista, una nueva lectura del documento notarial. Para ello es necesario realizar un verdadero trabajo de campo, que involucre a ciertas y determinadas disciplinas de derecho, y que permita inicialmente reordenar su estructura para poder adaptar a ella, los reales componentes que la deben fundamentar y sustentar a partir del derecho que nos asiste. Esta reformulación, sin lugar a dudas, impactará notablemente en la comprensión que pueda alcanzarse acerca de su contenido.

Se vuelve entonces prudente adelantar que para alcanzar este objetivo, debí recurrir en ocasiones, a los fundamentos que sustentan no ya al derecho notarial, sino al propio derecho como parcela de la realidad del hombre que oscila, al decir de Juan Vallet de Goytisolo y según veremos, entre el amor y la fuerza.

Esta situación ha incidido para que tuviera que optar decididamente por la elección de una determinada escuela de pensamiento jurídico, que claramente -y sin mayores distinciones que la lucha por alcanzar lo justo-, es la denominada iusnaturalista. A estos fines, optaré por circunscribirme genéricamente a la clásica definición de derecho brindada oportunamente por Georges Renard ${ }^{3}$, que sostenía que el derecho es y debe ser considerado como una expresión de la justicia ${ }^{4}$. La misma que en nuestro país fuera adoptada por el recordado Jorge Joaquín Llambías quien en líneas más o menos generales, suscribía a la del primer autor para argumentar que en

\footnotetext{
${ }^{3}$ Cfr. Georges RENARD, Introducción filosófica al estudio del derecho. El derecho, la justicia y la voluntad, $\mathrm{t}^{\circ}$ I, Debedec- Ediciones Desclée de Brower, Buenos Aires, 1.947, p. 73 y ss.

${ }^{4}$ Ibídem, p. 21 y ss.
} 
definitiva el derecho es un orden social justo ${ }^{5}$. Empero, con los fines de alcanzar la necesaria objetividad, esta tesis compulsa el pensamiento por mí escogido con las diversas posiciones provenientes de otras escuelas de pensamiento, que sin duda alguna viene a enriquecer en determinados casos, los resultados a los que voy arribando a medida que la lectura va adelantando su rumbo.

La segunda medida de este trabajo tiene que ver con mi deseo de contribuir al espacio jurídico con una investigación inédita, que acerque definitivamente el derecho notarial a la filosofía del derecho, para evitar, en palabras de Miguel Reale ${ }^{6}$, el divorcio entre los filósofos y los juristas, que tanto mal genera al ejercicio de las profesiones jurídicas en la actualidad, que cuentan para su actuación y desenvolvimiento -y como en ninguna otra parte de la historia del país-, con las modernas herramientas jurídicas positivizadas que se desprenden de los principios establecidos en el título preliminar del Código Civil y Comercial de La Nación, de su propio articulado, y también de los postulados que ordena seguir la teoría de la argumentación jurídica.

\section{Ubicación curricular de la presente tesis.}

El denominado ejercicio del oficio del jurista ${ }^{7}$ es tan amplio como disperso en relación con las actividades que -una vez escogidas de acuerdo a la vocación o a la oportunidad- cada uno comienza por habituarse a desarrollar cotidianamente ${ }^{8}$. Desde esta posición, al notario o escribano puede bien caberle la descripción del intérprete jurídico, que en palabras de

${ }^{5}$ Cfr. Jorge Joaquín LLAMBÍAS, Tratado de Derecho Civil. Parte General, act. Patricio RAFFO BENEGAS, t ${ }^{\circ}$ I, Perrot, Buenos Aires, 1.991, p. 20.

${ }^{6}$ Cfr. Miguel REALE, Teoría tridimensional del derecho, Edeval, Valparaíso, 1.978, p. 21.

${ }^{7}$ Cfr. Javier HERVADA, Lecciones de Filosofia del derecho, EUNSA, Pamplona, 1.990, p. 86. De aquí surge que el oficio del jurista está compuesto principalmente por el juez, el abogado, el notario o escribano, el legislador y el profesor de derecho.

${ }^{8}$ Cfr. Fernando M. TOLLER, Sistema de citas y redacción en derecho, Marcial Pons, Buenos Aires, 2.016, p. 34. Al referirse al significado de los libros y la biblioteca para el ejercicio del oficio del jurista, el autor se refiere mucho más ampliamente a los juristas designando a los abogados, a los consultores, a los jueces, a los funcionarios, a los legisladores, a los notarios, a los profesores, a los investigadores y a los estudiantes de grado y postgrado. 
Rodolfo Vigo, “...es una especie de mediador que comunica a otros aconsejando, enseñando o mandando- cuál es la conducta que corresponde hacer y omitir o que puede hacerse y omitirse, según el significado que se le reconoce a ciertos comportamientos, cosas, palabras o cualquier otro texto jurídico"." Se sostiene así que el saber de los juristas tiene como misión el decir el derecho, y por eso a los mismos se les reconoce una función inventora, elaboradora, creadora, formuladora o determinadora del derecho, que requiere de interpretación jurídica ${ }^{10}$. De todos los que ofician de juristas, es el notario quien, -incluso desde su propio origen histórico- se encuentra naturalmente formado y dirigido para decir el derecho que tutela en la paz. De ninguna manera puede el escribano avalar o promover el conflicto, lo que implica asumir que documento que alcanza notarialmente a autorizarse merece resguardar los derechos y valores que contiene de una manera especial. Conjuntamente con otras cuestiones que iré desarrollando, esta aseveración implica volver a realizar una lectura de la naturaleza del documento notarial, para poder sobre las ideas expuestas hasta hoy, sostenerlo y presentarlo a la comunidad jurídica en general como un elemento o instrumento de decisión jurídica.

De acuerdo a lo expresado, y sin perjuicio que en el desarrollo general se proyectan otras teorías, pretendo entonces que la presente tesis se enmarque dentro de la disciplina reconocida como derecho notarial y registral.

\section{Pretensión de la tesis}

La misma se dirige a probar que es necesario aplicar en la actualidad una valoración diferente del documento notarial a la cual estamos habituados a aceptar, y todo ello puede alcanzarse a través del análisis esencial de los efectos que proyecta la publicidad cartular que de él emerge. La conformación estructural y componencial del documento notarial auténtico como elemento o instrumento decisorio, que en su contenido admite la

${ }^{9}$ Cfr. Rodolfo Luis VIGO, Interpretación constitucional, LexisNexis-Abeledo Perrot, Buenos Aires, 2.004, p.16.

${ }^{10}$ Ídem, p. 23. 
convivencia pacifica y ordenada de valores trascendentes que son los que terminan por consolidar los referidos efectos publicitarios se plantea entonces como el cometido esencial a alcanzar a través de la presente investigación.

Desde el claro convencimiento del planteamiento que sostengo, es que decido poner a prueba el tratamiento en conjunto de tres valores esenciales que considero no deben dejar de tenerse en cuenta y elaborarse adecuadamente para que puedan definitivamente cobrar vida en el contenido del documento notarial:

a) La fe (determinante de la certeza y de la verdad),

b) La justicia (originada en la voluntad y bajo el ámbito de la tutela notarial), y

c) La seguridad (compuesta de la previsibilidad y también de la conservación).

La interrelación armónica y equilibrada de los mismos determina la $p a z$, como cuarto valor trascendente que es en definitiva, la que naturalmente se asume que proyecta, salvo ineficacia o falsedad, la publicidad cartular. La exposición de los valores que procedo a efectuar, descarta de antemano la posibilidad de aplicar algún tipo de criterio que tienda a sobrevalorar a uno sobre el otro; no existen jerarquías en la investigación que entrego con total confianza del contenido que la misma proyecta. La prueba de la convivencia y movimiento de los valores en el documento conforma el espíritu esencial de la tesis.

De esta forma, para alcanzar los resultados deseados, se me impuso primeramente determinar un sentido a la percepción notarial previa a la elaboración notarial del derecho documental, que en los tiempos presentes, se consolida definitivamente como una función creadora de derecho destinada a prever tanto el litigio como la controversia ${ }^{11}$. Asumida entonces la tarea de proyectar los deberes éticos notariales aplicados en la tarea previa a la conformación del derecho documental, la función notarial que

${ }^{11}$ Cfr. Néstor O. PÉREZ LOZANO, La función notarial creadora de derecho, RN 942, La Plata, 2002, p. 437. 
crea el derecho se encontrará apta para reflejar equitativa y equilibradamente los valores en el documento. $\mathrm{Y}$ de aquí que surjan curiosidades fenomenales, que intentaré comprobar en del cuerpo de la presente obra $-v . g r$, la prueba que confirma que el único instrumento jurídico que puede contener amigablemente a la justicia y la seguridad jurídica -enemistadas en el seno de la filosofía del derecho al menos desde el iluminismo ${ }^{12}$ - es el documento notarial).

\section{El método de investigación escogido.}

Además de los aspectos conceptuales implicados, los temas que aquí se desarrollan tienen especialmente en cuenta los contenidos históricos, legales, académicos, jurisprudenciales y prácticos tanto de los derechos como de las instituciones implicadas, todo lo que intentaré explicar y fundamentar esencialmente, a partir del método comparativo. Para ello he adoptado un sistema de investigación especial, que José Castán Tobeñas sugiere dentro de lo que considera son las direcciones universalistas ${ }^{13}$. Esto explica por ejemplo -e independientemente de una clara tendencia natural a realizarlo-, la copiosa y abundante existencia de referencias o notas al pie, y no sólo de citas académicas, sino también explicativas de ciertos puntos relevantes de las discusiones académicas, que por su propio desarrollo no pueden ni deben encontrar ubicación en el cuerpo central del trabajo. Estoy seguro que definitivamente, es el escogido el método más apropiado para ir advirtiendo

\footnotetext{
${ }^{12}$ Cfr. Enrique Horacio DEL CARRIL, El notariado a la luz del neoconstitucionalismo (Una nueva mirada sobre la seguridad jurídica), presentación en el postgrado de Derecho Notarial, Registral e Inmobiliario, UNNOBA, Junín, 2.014.

13 José CASTÁN TOBEÑAS, "Reflexiones sobre el derecho comparado y el método comparativo", Revista General de Legislación y Jurisprudencia 203 (1957), ps. 237-285 y 533585. V. método universalista a partir de la pág. 263. Son direcciones universalistas las que enlazan la comparación jurídica con el método histórico-evolucionista, en la búsqueda de un derecho común legislativo (y principialista), del cual se podrían extraer luego criterios de interpretación para los derechos nacionales en la esperanza de hacer posible la realización del ideal de unidad legislativa de los países cultos.
} 
en el avance pausado de la lectura, el progreso que pretendo tenga la tesis doctoral.

Todo este sistema de planteo del tema por mi escogido terminará por revelar otra circunstancia singular y relevante - totalmente inesperada ab initio-, que es la que termina por demostrar que lo que en algún momento decido en denominar el documento notarial auténtico, se instituye como elemento o instrumento rector frente a los sistemas de publicidades jerarquizadas que fundamentan y enriquecen en nuestro derecho, el tratamiento de la adquisición de los derechos reales que se ejercen por la posesión. Él método comparativo es el que me ha permitido realizar las propuestas a consideración descriptas en el capítulo final.

\section{EI tratamiento de las publicidades jerarquizadas.}

A partir de ese descubrimiento, se consideran además los efectos de la publicidad posesoria y de la publicidad registral. Los principios esenciales determinantes de los valores que cada una proyecta inclusive, con la emergente del documento, son por sí mismo, incompatibles. Se trata entonces de encontrar la alternativa que ayude a que los mismos se vuelvan armónicamente realizables en el seno del documento notarial.

El hecho de la posesión, el nacimiento del derecho real a partir de la tradición y conformación de un documento auténtico, y la adecuada publicidad registral a partir del sistema de inscripción declarativa no convalidante viene a conformar definitivamente, las tres instituciones indispensables para el desarrollo en paz de los derechos reales que importan al derecho tal cual lo conocimos, lo adoptamos y lo ejercemos. Su histórico abordaje parcializado, y quizás, sus teorizaciones individualizadas, han dejado como resultado la idea generalizada que confirma que el derecho se encuentra preparado para proyectar tres únicas y diferentes perspectivas, con diversos alcances y soluciones admitidas por la jurisprudencia, que son las que vienen sirviendo de guía para aportar soluciones ante el acaecimiento de 
los conflictos que se generan entre los que poseen la tierra, los que poseen el titulo y los que ostentan una posición registral.

Esos mismos análisis también contribuyeron a marcar mucho más profusamente, las diferencias de estos tres elementos esenciales jerarquizados de los derechos reales, situación que la jurisprudencia nacional con denodado esfuerzo viene resolviendo, intentando adoptar criterios similares para los casos equivalentes, en espacios en donde la lucha por la supremacía de los derechos reales o personales se viene histórica y naturalmente imponiendo.

Esta tesis asume que las tres instituciones referidas son absolutamente relevantes y necesarias y por ello, me alejo definitivamente del intento por justificar la importancia o relevancia de una sobre la otra. Como lo han declarado las XXIII Jornadas Nacionales de Derecho Civil celebradas en San Miguel de Tucumán en el año dos mil once: "Una futura reforma del Código Civil debe mantener la coexistencia de las publicidades posesoria, cartular y registral". Haciendo caso a las presentes deliberaciones, lo que propongo es la realización de una especie de tratamiento de cada institución en el intento por alcanzar la coexistencia y no las diferencias. Destacar los puntos de contacto, o los lugares o espacios de donde pueda obtenerse un resultado que como común denominador ayude a alcanzar la paz en esa acción de relación que cada una proyecta o debiera proyectar para alcanzar el mencionado valor.

La manera de visualizar esto, es a partir de su adecuada ubicación axiológica en el documento notarial. Las tres pueden convivir si se ubican dentro del contenido del mismo a describir, y de ello dependerá el no conflicto y la armonía y complementariedad entre cada una de ellas. Solo de esta manera todas las formas de publicidad expuestas podrán alcanzar la máxima expresión de excelencia, teniendo especialmente en cuenta además que las publicidades referidas desde siempre fueron, son y serán parte del derecho argentino proyectado, como integrantes esenciales del sistema de los derechos reales referido. Por ello, deben coexistir para siempre y de manera permanente, y siempre y cuando no nos sorprenda - a mi modo de ver, sorpresiva e injustamente- un cambio de sistema fundamentado en otras costumbres y raíces, alejadas del sistema traditivo, que arbitrariamente pueda eventualmente imponer la legislación. Hasta tanto eso no ocurra, la 
convivencia de las instituciones implicadas en nuestro derecho será innegable y primordial para alcanzar los resultados esperados por el ordenamiento, y por ello, los efectos que cada una proyecte podrán determinar un resultado dirigido hacia la paz o hacia el conflicto. Como lo ha afirmado hace un tiempo atrás, nuestro siempre vigente maestro ya referido Juan Vallet de Goytisolo: "La propiedad y la posesión tienen una función natural; el documento notarial tiene la suya, y el Registro de la Propiedad tiene una función de publicidad. Por lo tanto, a cada una de estas instituciones les corresponde distinta función que es delimitada por la misma naturaleza de las cosas. Si esos límites naturales son abandonados, retirándose la función más acá de ellos, o bien si se los desborda, la naturaleza termina por vengarse ${ }^{14, "}$.

En definitiva, mi tarea en esta tesis se dirige a lograr que el lector pueda advertir la armonía emergente de los efectos publicitarios de cada institución referida, desarrollada y justificada axiológicamente dentro del documento, en la búsqueda de la consolidación del valor de la paz.

\section{Exposición de las instituciones.}

El tratamiento de los temas que siguen a estas líneas supone una asimilación natural de ciertos conceptos fundamentales provenientes de la doctrina que investiga el derecho público y privado en su generalidad. Únicamente me propondré abordar los elementos y los fundamentos esenciales, los puntos de contacto y de conflicto y los conceptos precisos de las instituciones mencionadas. La tesis, precedida por una necesaria introducción que da cuenta de la relación que en el documento existe entre los derechos reales y personales, se conforma sobre tres ejes bien diferenciados:

a) Tratamiento de los efectos publicidad posesoria y sus posibles efectos;

\footnotetext{
${ }^{14}$ Cfr. Juan Berchmans VALLET DE GOYTISOLO, Seguridad jurídica estática y seguridad jurídica dinámica, $\mathrm{RJdN}$ n³3, CGN, Madrid, 2.003, p. 213.
} 
b) Tratamiento de los efectos emergentes del principio de publicidad registral;

c) Los efectos publicitarios que emergen documento notarial auténtico.

El desarrollo profundo corresponde claramente a la teoría del documento notarial y todos los efectos que el mismo proyecta, que es la que en última instancia tiene que probar la autosuficiencia para contener a las otras dos instituciones y con ello, a equilibrar todos los efectos publicitarios. En torno a esto, creo oportuno hacer algunas nuevas aclaraciones en este espacio, que ya he adelantado con anterioridad.

No es mi pretensión imponer grados de importancia a las instituciones ni jurídicas ni axiológicas implicadas. Realizar esa tarea implicaría cabalmente, optar por el camino del conflicto (si los efectos del documento notarial son los más importantes, cualquier ocupación sin título aparente o suficiente, inclusive una registración que no se condiga con la realidad extrarregistral generará el conflicto con quien precisamente, exhiba un titulo de estas características). Esas situaciones que inclusive, comprenden cierta parte expositiva de la tesis, cuentan ya en nuestro derecho con un tratamiento sistematizado que en sustancia, es ajeno al que yo me he propuesto realizar. En un país como el nuestro, con notables necesidades vitales en permanentes vías de concreción, las situaciones relativas a las ocupaciones, a la irregularidad en la tenencia de los títulos antecedentes, las implicancias de las usucapiones con todo lo que ello conlleva, entre otras realidades relevantes que llevan a los Tribunales los conflictos emergentes de las publicidades en referencia, van a seguir existiendo hasta tanto la población en general no alcance a concretar primaria y elementalmente, las necesidades básicas, que son las primeras que inician el camino de la familia hacia la dignidad. Van a existir porque la lucha del hombre por la subsistencia se impone ante todo y frente a todo, porque en definitiva el mismo se va determinando la circunstancia a medida que las necesidades van creciendo o decreciendo. 
Por eso mismo, el planteo de la tesis se aparta de las consideraciones generales en estas materias, que claramente determinan vencedores y vencidos con todas las herramientas que el derecho brinda al juez para que a partir del imperium razonable pueda determinar ante el conflicto, cual es el efecto publicitario pondera sobre el otro (acciones posesorias, reales, interdictos, tercerías, prescripción adquisitiva o usucapión, etcétera).

El centro de atención de esta investigación entonces debe ubicarse en la comprobación de la armonía de todos los efectos publicitarios en el seno del documento notarial, a partir de una conformación de valores que considero trascendentes y que son los que se encuentran aptos y dispuestos a convivir conteniendo todos los efectos en armonía y complementariedad. Muchas de las respuestas a los interrogantes, se van aclarando a medida que la tesis va avanzando.

\section{Resultado a obtener.}

La recreación de los temas estudiados permitirá entonces visionar una nueva teoría del documento notarial auténtico, que se erige como indudable elemento o instrumento de decisión jurídica, justificando su cometido a partir de los efectos emergentes de la publicidad que genera, sustentados en los valores filosóficos que contiene y que proyecta. La convivencia armónica de los valores determina que en ellos también encuentren reparo los efectos que surgen tanto de la publicidad posesoria como de la publicidad registral, instituciones que claramente adscriben a algunos, pero no a todos los implicados en el documento. El documento que reconoce una estructura afirmada sobre los componentes necesarios e indispensables que la determinan, consolida en su seno la teoría de los valores referida, generando el efecto de la paz. 


\section{Créditos \& agradecimientos}

Muchas han sido las personas que durante todo este tiempo han colaborado conmigo para que yo pudiera alcanzar la meta de la elaboración, concreción y entrega de la tesis doctoral. Enumerarlos a todos es definitivamente una tarea imposible y además, absolutamente innecesaria. Todos los que aquí tienen un pedacito de idea saben de mi estima, de mi aprecio, de mi admiración y de mi respeto. Pero además, como bien me conocen, también alcanzan a aceptar que desde mi forma de sentir la existencia, un sólo agradecimiento no alcanza a ser suficiente.

Muy a pesar de ello, razones de estricta justicia me imponen mencionar aquí en primer lugar, a mi tutora, Dra. Not. Cristina Noemí Armella, sin más palabras para expresar que las del agradecimiento entero y perpetuo. Como ella, nadie jamás ha estado tan presente en mi vida académica, y además, en la cobertura de todos los aspectos de relación humana, que oscilan desde las notables exigencias de perfección, hasta los cuidados propios de quien siente por sus pupilos, un afecto que se aleja de lo común para transformarse en extraordinario. En segundo lugar, quisiera recordar tanto a Dn. Juan Francisco Delgado de Miguel como a Dn. Juan Berchmans Vallet de Goytisolo, mis admirados maestros y tutores, quienes ya no se encuentran físicamente en este mundo. Debo a ellos mi feliz y plena estancia jurídica y emocional transcurrida en Salamanca y en Madrid respectivamente -durante los años dos mil cuatro y dos mil cinco-, y también, a su tiempo y esfuerzo para la enseñanza, el fruto de mi primera investigación, los deberes éticos notariales, que siempre será para mí, el aporte más amado y más querido que pude haber realizado al mundo del derecho, con todos los aciertos y desaciertos que pueda contener por ser mi primera investigación relevante. En esa línea hoy se encuentra sin duda alguna en España, Isidoro Lora Tamayo-Rodríguez. Cada conversación que con él llevo adelante, es un motivo más que acrecienta mis deseos de investigar con pasión y compromiso en pos de la comunidad necesitada de paz y de esperanza. 
El Dr. Andrés Sánchez Herrero ha sido una figura esencial para que pudiera yo nuevamente creer que era capaz de llevar adelanta la presente investigación. Su omisión en este espacio sí que sería una verdadera injusticia. Como así también el reconocimiento a Fernando Toller, Juan Cianciardo y Romina Pittondo, por el estímulo físico y psíquico permanente y constante. En esta línea de agradecimientos, quisiera decir que soy afortunado por haber coincidido en el tiempo y en el espacio con Enrique Horacio Del Carril. No hay palabras adecuadas que describan esta fantástica amistad que desde comienzos del año dos mil seis iniciamos con la idea de persistencia hasta el fin. En la Facultad de Derecho de la Universidad Austral pude descubrir no sólo la absolutamente reconocida excelencia académica, sino -y lo que es más importante-, a personas que con verdadero optimismo pusieron su alma y sabiduría a mi entera y plena disposición para colaborar en todo lo que fuera necesario a los efectos que pudiera yo en definitiva alcanzar con tenacidad y orgullo el presente objetivo.

La Facultad de Ciencias Jurídicas y Sociales de la Universidad Nacional de La Plata merece en este espacio una mención que emerge de forma natural de lo más profundo del mí ser. Mi familia entera se compone de diez personas, no más que ello. Somos una familia pequeña en cantidad pero como siempre hago referencia, enorme en calidad. Con la última graduación familiar, somos cinco los egresados en esa querida y amada casa de Altos Estudios, todos en diferentes épocas, aulas, edificios y circunstancias. Aun no logro dimensionar con total esplendor que es lo que hubiera sido de mí, si mi padre primero y mi madre luego, con los pocos gastados instrumentos con los que contaban para sostenerse, no hubieran tenido la oportunidad de tener las puertas abiertas en esa fantástica ciudad en el tiempo que a cada uno le tocó definitivamente en suerte. Mi compromiso con la educación pública es y será siempre irrenunciable, y por ello, siempre que tengo la posibilidad afirmo que si tuviera la chance de elegir el momento exacto en donde mi vida deje terrenalmente de existir, que sea ese en el que me encuentre frente a un curso, con un libro y con un pizarrón a mi lado, en el mismo momento mágico que para nosotros es y será siempre el instante en el que ocurre la transmisión del más puro conocimiento. Transmitir todo lo que uno puede conocer, para que quien lo recepte pueda con ello mejorar y superar al propio maestro, es el verdadero sentido de la vida académica, y 
consecuentemente de mi vida. Si mis alumnos me superan, la evolución del derecho estará comprobada. Si no lo hicieran, también lo estará mi fracaso como profesor.

Merece una mención especial también en este espacio el Ateneo de la Academia Nacional del Notariado, dirigido por nuestra querida e infatigable Eleonora $R$. Casabe, que integro ya hace un tiempo prudente. Ese espacio maravilloso, compartido con pares de excelente nivel académico y humano, es el lugar al que frecuentemente recurrimos todos los que tenemos una marcada vocación académica, para poder encontrar las respuestas a los interrogantes usuales, que siempre son provistas por amigos desinteresados que se preocupan porque cada cual proyecte lo mejor de sí. Mi enorme admiración y agradecimiento a todos ellos.

El agradecimiento institucional debe extenderse con justa causa al Colegio de Escribanos de La Provincia de Buenos Aires y especialmente, a la Delegación Junín, como así también al Consejo Federal del Notariado Argentino, todas instituciones que, desde diferentes posiciones y actividades, orgullosamente formo parte. Mención especial en este espacio merece el Consejo Consultivo de Ética del Consejo Federal del Notariado Argentino y con él a los apreciados colegas que lo componen, organismo que tengo el honor de presidir.

En resumen, los créditos que asumo se extienden con entera gratitud hacia todos mis afectos cotidianos, a quienes están más lejos en el tiempo pero sin duda alguna, mucho más cerca a través de las palabras, en fin, a la vida que he tenido el privilegio de gozar hasta aquí, lógicamente aceptada tanto con las alegrías como con los bemoles.

Finalmente, deseo que se me permita hacer las últimas dos consideraciones especiales. En este espacio, mis padres, Eduardo y Graciela, mi hermano Juan Eduardo, mi abuela Norah, mi padrino Oscar Suárez y mis sobrinos Juan Bautista y Valentín Eduardo ocupan un lugar especial. Cada línea que escribo en este momento, me recuerda cualquier circunstancia que he con ellos sentido o soportado, y por ello mismo no puedo dejar de agradecer a Dios la fantástica posibilidad que me ha brindado de ser parte firme y presente de esta hermosa familia. El transcurso de los afortunados acontecimientos de mi vida ha permitido, casi mágicamente, que Alicia y Juan Pablo, la mamá y el hermano de mi esposa, hayan ingresado 
naturalmente a formar parte de nuestro equipo, y hoy, somos todos en lugar de nosotros solos los que sonreímos y los que soñamos, los que tenemos la misión de seguir firmes en la búsqueda de la consolidación de un mejor presente y de un más prometedor futuro.

En el final, quisiera dedicar las últimas palabras de esta introducción a mi esposa, María Fernanda. Y lo haré inmejorablemente desde dos enfoques diferentes, que comprenden por un lado lo científico y por otro lado a los sentimientos. Desde lo primero, deseo con toda mi fuerza que este aporte le sirva de guía y de luz, y que además le sea de utilidad especialmente frente a los momentos difíciles que tenga que enfrentar en el transcurso de su vida profesional. Esta dedicatoria coincide con los tiempos de celebración familiar en razón de su relativamente reciente incorporación a la escribanía, luego de su paso para nada fugaz por el Poder Judicial de La Nación y también luego del eterno -y quizás justo tiempo- de pausada reflexión para la toma de la decisión final. Consecuentemente, quizás nunca mejor empleada la presente expresión: ¡Bienvenida al notariado!

Más importante que ello sean quizás estas últimas palabras. Todos los que nos rodean saben lo que significamos, en equipo, el uno con el otro; pero únicamente solo Dios conoce lo que en definitiva sentimos, lo que natural y accidentalmente vivimos hasta hoy y muy especialmente, lo que muchas veces lamentamos y sufrimos en silencio, siempre unidos, siempre tomados de la mano, siempre juntos. Mi familia con ella ha ido creciendo, de manera increíble -iy aunque por ahora sólo seamos dos!- desde el mismo momento en que la divisé por primera vez y comencé a sentir que la suerte definitivamente comenzaba a contar para mí. María Fernanda es para mí la ilusión y la esperanza; es el deseo de despertar todos los días para seguir adelante a pesar de los tropiezos del corazón y del alma, que son los únicos que en definitiva, nos pueden dejar afuera del camino si no existe a nuestro lado una persona fuerte y valiente como ella, dispuesta a dar todo lo mejor de sí para alcanzar los objetivos programados y propuestos ya sea de forma mediata o inmediata, natural o accidental.

En algún tiempo he escrito una dedicatoria que expresaba, en líneas generales, que yo no era ni podía ser sin ella. En esta oportunidad, iré lo más 
lo lejos que me permita la razón, para decir que yo no puedo existir como realmente soy sin su compañía, sin su comprensión, sin su paciencia y sin su sonrisa. El conjunto de sus cualidades pudo combatir el tirano tiempo que dedique al presente estudio, y además, son las que pudieron sostenerme cuando en reiteradas ocasiones la angustia por no encontrar el camino adecuado de la tesis amenazaba con dejarme afuera de la carrera. Consecuentemente, todo debo a la fortaleza emergente de su acompañamiento, y por ello esta tesis nace en un ámbito de amor indescriptible, virtud que junto a las demás que ella posee, siempre se encuentra firme y presente en lo más íntimo y profundo de mi corazón.

Sebastián Justo COSOLA

(Cerrito Colorado), Ciudad de Junín, Buenos Aires, 29 de Agosto del año 


\section{PARTE PRIMERA.}

\section{Los efectos de la tradición y de la relación posesoria.}

\section{Capítulo I.}

Cuestiones elementales inherentes a los derechos reales y personales.

\subsection{Introducción.}

Los derechos reales y personales que de manera constante y creciente se proyectan en la vida de relación, están destinados a convivir en el mundo jurídico tanto de forma regular como de manera irregular. Ésta es una verdad indiscutible del derecho, por cuanto los mismos encuentran un fundamento inicial en la potenciación que cada hombre, cada mujer y cada niño pueden realizar de cualquiera de los atributos de la personalidad. Los atributos, a través del innegable desarrollo de la teoría de la personalidad humana, le son al hombre tanto inherentes como correspondientes ${ }^{15}$.

Al mismo tiempo, la constante y persistente evolución del desarrollo de los denominados derechos personalísimos, viene a demostrar que desde el derecho privado, la evolución en el reconocimiento de los derechos de las personas humanas se muestra cada vez más amplia, más profunda pero también, más dificultosa ${ }^{16}$. Es así que los diversos estudios presentados

${ }^{15}$ Cfr. Carlos FERNANDEZ SESSAREGO, Derecho de las personas, Editora Jurídica Grijley, Lima, 2.004, p. 1 y ss y Derecho y Persona, Astrea, Buenos Aires, 2.015, p. 3 y ss.

16 La lectura de la evolución del derecho civil en esta materia es tan importante como evidente. Un maestro como Jorge Joaquín Llambías brinda un perfecto panorama de los atributos de la persona, pero resta importancia al desarrollo de los derechos personalísimos, a los que considera derechos subjetivos. Otro maestro, Guillermo Borda, ofrece un tratamiento 


\section{SEBASTIÁN JUSTO COSOLA}

acerca de la personalidad en general siempre han presentado problemas de las más variadas naturalezas. La evolución del hombre que pretende con cada paso mejorar su condición de vida contando sólo con las herramientas que la desdicha o la fortuna le han brindado para poder proveerse, vuelve confusa la determinación equilibrada del ejercicio de los derechos. Referirse al sujeto y a la personalidad definitivamente importa asumir lo más entrañable, lo más sentido, y lo más profundo del derecho ${ }^{17}$.

Debe no obstante tenerse en cuenta, que si bien es una obligación indelegable del Estado el velar por que tanto los atributos como los derechos de la personalidad sean alcanzados por las personas sin mayores dificultades, lo cierto es que en la realidad algunos de ellos se alcanzan y se cumplen con mayor facilidad que otros. Esta cuestión excede inclusive los límites y las fronteras propias del derecho: razones inherentes a la política, a la economía y a la sociología inciden notablemente para que esta realidad no sólo sea así, sino que además no pueda nunca llegar a alcanzar un cierto y determinado equilibrio de manera definitiva. En suma, son cuestiones que en países como el nuestro - y en ocasiones cada vez más frecuentes- se vuelven extremadamente complejas, cuando los derechos esenciales para el desarrollo del hombre se encuentran totalmente alejados de la posibilidad real y del alcance de cada miembro y de cada familia componentes del núcleo social.

La presente tesis doctoral intenta demostrar, de manera razonable y justificada, la innegable importancia de la publicidad cartular emergente del documento notarial, y su consecuente rectoría frente a las demás publicidades jerarquizadas: la posesoria y la registral. ¿Por qué razón la elección de un tema como el referido? Precisamente, porque desde la adecuada comprensión de la publicidad emergente de un documento

de los derechos personalísimos como parte relevante de los atributos de la personalidad, a los que denomina derechos de la personalidad. En la actualidad, uno de los desarrollos mas acabados de los derechos personalísimos -inclusive con mayor énfasis que los propios atributos de la personalidad-, se encuentra en la obra de Julio Cesar Rivera. Cfr. Jorge J. LLAMBÍAS, Tratado de Derecho Civil. Parte General, Actualización a cargo de Patricio Raffo Benegas, $\mathrm{t}^{\circ}$ I, Editorial Perrot, Buenos Aires, 1.991, p. 275 y ss; Guillermo A. BORDA, Tratado de Derecho Civil-Parte General, Actualización a cargo de Guillermo J. Borda, t ${ }^{\circ}$ I, La Ley, Buenos Aires, 2.008, p. 301 y ss, y Julio C. RIVERA, Instituciones de Derecho Civil, $\mathrm{t}^{\circ}$ I, Abeledo Perrot, Buenos Aires, 2.010, p. 681 y ss.

${ }^{17}$ Cfr. Santos CIFUENTES, Derechos personalísimos, Astrea, Buenos Aires, 2.008, p. XIII. 


\section{LOS EFECTOS DE LA PUBLICIDAD EN EL DOCUMENTO NOTARIAL}

realizado de acuerdo a los valores y los principios que proyecta tanto de manera interna como externa, emerge la más precisa protección jurídica que es posible alcanzar desde el ordenamiento jurídico a favor de quien oficie de destinatario, y siempre en la búsqueda de la consolidación de algunos de los derechos fundamentales más perseguidos y valorados por la humanidad ${ }^{18}$. La apropiada lectura y comprensión del documento ya no sólo se dirige a establecer pautas técnicas de conformación formal del derecho, sino que además adecúa los valores esenciales que la sociedad necesita para desenvolverse en un ámbito de paz. Por esta razón, la publicidad cartular bien entendida deja de ser el fundamento principal y único de la seguridad jurídica, para extenderse inclusive hacia otros valores absolutamente trascendentes, como la fe (certeza + verdad) y la justicia. La suma de esos tres valores -cuya convivencia es imposible tanto técnica como sustancialmente en los otros medios de publicidad conocidos y adoptados por el ordenamiento jurídico-, determina el cuarto valor trascendente, que es la paz.

Esta comprobación de ninguna manera significa profundizar un debate jurídico relativo a los alcances, las defensas y las excepciones de cada una de las mencionadas instituciones que a través de la ley, la doctrina y la jurisprudencia se nos ha venido enseñando a lo largo del tiempo, desde un sistema legal que sin lugar a dudas, ha priorizado la influencia del derecho romano tanto en el tratamiento del derecho de dominio (derecho privado), en el desconocimiento de la publicidad registral -a través de la valoración de la conformación del título y la tradición-, y también en la consolidación del derecho de propiedad (derecho público) que reconoce la influencia de la

18 CSJN: Fallos 145:307 (1925). Don Pedro Emilio Bourdieu c. Municipalidad de la Capital. Allí se argumentó lo siguiente: "El término 'propiedad', cuando se emplea en los artículos 14 y 17 de la Constitución o en otras disposiciones de ese estatuto comprende, como lo ha dicho esta Corte, 'todos los intereses apreciables que un hombre pueda poseer fuera de si mismo, fuera de su vida y de su libertad'. Todo derecho que tenga un valor reconocido como tal por la ley, sea que se origine en las relaciones de derecho privado sea que nazca de actos administrativos (derechos subjetivos privados o públicos), a condición de que su titular disponga de una acción contra cualquiera que intente interrumpirlo en su goce así sea el Estado mismo, integra el concepto constitucional de "propiedad". Cfr. Juan Cruz AZZARRI, El fallo "grupo Clarin": El derecho de propiedad y los derechos adquiridos: http://www.colabogados.org.ar/larevista/pdfs/id18/el-fallo-grupo-clarin.pdf (Ultimo Acceso: 13/08/2017). 


\section{SEBASTIÁN JUSTO COSOLA}

ilustración, proyectada también en la codificación decimonónica nacional. En todo caso implica -luego del desarrollo de la parte general introductoria a cada figura- exponer los puntos fuertes y débiles de cada una de las instituciones implicadas, para luego proyectar ciertos valores trascendentes pero muchas veces en pugna, que son los que reflejados en ellas, pueden alcanzar a garantizar el mejor derecho posible para cada hombre, mujer, niño, anciano o adolescente que se encuentre bajo la tutela del derecho.

\subsubsection{La hipótesis de trabajo.}

En este sentido, la presente investigación asume que el atributo de la personalidad implicado es el patrimonio, y el derecho de la personalidad -o personalísimo- tutor es el referido al acceso al derecho de propiedad para el desarrollo potencial del concepto tanto del hombre en su soledad como en interacción con el grupo familiar. Esto significa primeramente asumir que, de todos los documentos notariales que proyectan los valores publicitarios provenientes de la fuerza de la autenticidad extrínseca y de la potencia de la autenticidad intrínseca, el que se toma como guía o referencia para el desarrollo de la presente tesis doctoral es el que consolida cualquier tipo de transmisión del derecho real de dominio desde un consentimiento libre, voluntario y tutelado, en procura de generar una protección constitucional de los derechos y eventualmente, de los deberes en su seno contenidos y publicitados ${ }^{19}$. Éste es el modelo documental a considerar, teniendo especialmente en cuenta que del mencionado derecho se derivan todos los valores que considero, son los que deben comenzar por advertirse en cada lectura de los documentos notariales de aquí en más -comenzando por el análisis de la seguridad jurídica en su faceta estática- y más allá de los que

${ }^{19}$ El Código Civil y Comercial de La Nación exige admitir y aplicar diferentes criterios argumentativos para considerar las respuestas necesarias frente a los hechos que se suceden desde la ley y también desde el derecho. Estas fuentes se diferencian desde el mismo título preliminar, y ambas se proyectan desde la teoría de los principios jurídicos. De esta manera, la lectura del documento notarial tiene que proyectar tanto la ley como el derecho en el contenido. 
emergen técnica o formalmente desde la aplicación de la técnica notarial correctora destinada a brindar información cartular.

Precisamente por ser temas que por sí mismos, generan diversas inquietudes que ameritan una investigación del tenor de la presente ${ }^{20}$, es que el supuesto fáctico desde el que inicio para realizar los análisis que considero pertinentes es sólo una hipótesis, un esquema de estructura para la conformación de los contenidos; es el que tengo en mente para realizar las descripciones de los documentos tal cual lo creo conveniente, y esencialmente, para consolidar en ellos la convivencia armónica de los valores esenciales y necesarios, ya que no todos los documentos presentan la misma estructura ni persiguen los mismos fines, aunque todos sean contenedores de los valores emergentes de la publicidad cartular. En definitiva, en la proyección del derecho de propiedad se consolida el ejemplo más elocuente de los derechos reales, mientras que en las relaciones jurídicas entre acreedor $\mathrm{y}$ deudor $-\mathrm{y}$ en este caso, las relaciones jurídicas de las partes en el documento-, posicionan lo más característico de los derechos personales ${ }^{21}$.

\subsubsection{Confluencia del derecho público y del derecho privado.}

La hipótesis escogida se justifica incluso por sí misma, teniendo en cuenta que uno de los puntos centrales de mayor confluencia del derecho público y del derecho privado tendiente a brindar a la ciudadanía la mayor protección que sea previsible, tiene íntimamente que ver con el estudio del acceso de la misma a la propiedad comprendida desde lo legítimo y también desde lo consuetudinario. El análisis del tema reconoce aristas interesantes, y en este sentido deben destacarse los aportes brindados oportunamente tanto por Michel Villey ${ }^{22}$ como por Juan Vallet de Goytisolo ${ }^{23}$; los mismos tienden a

\footnotetext{
${ }^{20}$ Esta elección también permite advertir en las otras publicidades ciertos temas trascendentes, como por ejemplo, el valor de las ocupaciones desde la posesión -si existe o no existe legalidad en ellas-, y la valoración de las anotaciones en los asientos registrales -una fuga en la titularidad de un asiento es mucho más cara al derecho que una omisión de la anotación de una medida cautelar ya cumplida-.

${ }^{21}$ Cfr. Rubén H. COMPAGNUCCI DE CASO, Manual de obligaciones, Astrea, Buenos Aires, 1.997, p. 20.
} 


\section{SEBASTIÁN JUSTO COSOLA}

determinar de la manera más clara posible, la importancia de la propiedad considerada desde el derecho y como elemento de la iusfilosofía.

En nuestro país, los conceptos de propiedad y de dominio siempre se han confundido, a través de autores motivados por aclarar ciertas imprecisiones etimológicas o consideradas desde una inadecuada cita de fuentes de origen, como así también por una sencilla -y hasta más cómoda- utilización de los términos como sinónimos ${ }^{24}$.

De esta manera, se nos comenzaba por recordar en algún tiempo que no debe confundirse la propiedad como género, del dominio como especie de ese género ${ }^{25}$. En el mismo sentido, se ha precisado que el vocablo propiedad es omnicomprensivo de todos los derechos subjetivos de contenido patrimonial, mientras que el dominio es el derecho real mediante el cual una cosa se encuentra sometida a la voluntad de una persona o una $\operatorname{cosa}^{26}$. En interpretación similar también se alcanzó a aclarar que todo esto es así porque en Roma no existía una palabra que sintetizara, el concepto jurídico de dominio tal cual hoy lo conocemos, ya que en épocas de esplendor del derecho romano el término propietas es el que llega a consolidarse como más común ${ }^{27}$. De ahí que existan algunos autores que distingan los conceptos de propiedad y dominio mientras que otros afirmen que los mismos deben ser utilizados como sinónimos ${ }^{28}$. En resumen, se expone que la palabra propiedad en la Constitución Nacional es comprensiva tanto del concepto de patrimonio cómo también de todos los derechos apreciables en dinero que una persona puede tener fuera de sí mismo, de su vida y de su libertad, mientras que en el código civil la misma palabra es utilizada como sinónimo

\footnotetext{
${ }^{22}$ Cfr. Michel VILLEY, En torno al contrato, la propiedad y la obligación, Ghersi Editor, Buenos Aires, 1.981, p. 95 y ss.

${ }^{23}$ Cfr. Juan Berchmans VAllet DE GOYTISOlO, Panorama de Derecho Civil, Bosch, Barcelona, 1.973, p. 147 y ss.

${ }^{24}$ No debemos dejar de pasar por alto que en la clásica enciclopedia jurídica Omeba, la voz propiedad remite para su tratamiento a la voz dominio. Cfr. Mateo GOLDSTEIN, Dominio, Enciclopedia Jurídica OMEBA, $t^{\circ}$ IX, Driskill, Buenos Aires, 1.993, p. 325.

${ }^{25}$ Cfr. Jorge Joaquín LLAMBÍAS, Tratado de Derecho Civil..., t ${ }^{\circ}$ II, ob. cit., p. 205.

${ }^{26}$ Cfr. Héctor LAFAILLE y Jorge Horacio ALTERINI, Tratado de los Derechos Reales, $\mathrm{t}^{\circ}$ II, La Ley, Buenos Aires, 2.010, p. 4.

${ }^{27}$ Cfr. Carlos Mario CLERC, El derecho de dominio y sus modos de adquisición, Ábaco, Buenos Aires, 1.982, p. 50 .

${ }^{28}$ Ibídem, p. 51.
} 
de bien, derecho real y derecho real de dominio ${ }^{29}$. Esta situación se traslada a la legislación. El Código Civil de Vélez regulaba el derecho real de dominio, sin embargo, el propio codificador utiliza las voces dominio y propiedad indistintamente ${ }^{30}$. El Código Civil y Comercial de La Nación omite brindar una definición del dominio como género, y solo se limita a dar un concepto de dominio perfecto, contracara del dominio imperfecto ${ }^{31}$. Si bien queda relativamente claro que la voz propiedad es más amplia y que la voz dominio debe orientarse pura y exclusivamente a la consideración de los derechos reales, parte de la doctrina actual aun sigue considerando el tema con un tratamiento idéntico, advirtiendo dentro del análisis de derecho de dominio, las bondades del más amplio derecho de propiedad que puede tenerse sobre una cosa ${ }^{32}$. En efecto, aun siguen los autores explayándose acerca de la cuestión intercambiable de los términos ${ }^{33}$, sin embargo, las visiones ofrecidas relacionadas con la intelección de los textos en estudio, son absolutamente trascendentes porque cada visión jurídica se dirige a proteger aspectos diferentes de tutela efectiva. Siendo así, ciertas precisiones y aclaraciones merecen la pena en el cuerpo del presente estudio.

\subsubsection{En torno al derecho de propiedad.}

\footnotetext{
${ }^{29}$ Cfr. Raúl NAVAS (h), Derechos reales de propiedad, uso y goce, Oxford, Buenos Aires, 1.999 , p. 84.

${ }^{30}$ Carlos Mario CLERC, El derecho de dominio y sus modos de adquisición, ob. cit., p. 52.

${ }^{31}$ Cfr. Roberto MALIZIA, Del dominio, Código Civil y Comercial de La Nación. Comentado, Julio César RIVERA y Graciela MEDINA (Dir.), Mariano ESPER (Coord.), t ${ }^{\circ} \mathrm{V}$, La Ley, Buenos Aires, 2.014, p. 328.

${ }^{32}$ Ibídem, p. 329.

33 Cfr. María Angélica GELLI, Constitución de la Nación Argentina. Comentada y concordada, $\mathrm{t}^{\circ} \mathrm{I}$, La Ley, Buenos Aires, 2.014, págs. 262-263. En el presente caso, la autora nos dirá que: "En el derecho civil argentino, la propiedad se identifica con el dominio perfecto o imperfecto- $y$ sus desmembramientos; se la caracteriza con las notas exclusivas de exclusividad y perpetuidad; y se establece que es inherente a la propiedad el derecho a poseer la cosa, disponer o servirse de ella, usarla y gozarla conforme a un ejercicio regular".
} 


\section{SEBASTIÁN JUSTO COSOLA}

El estudio del derecho de propiedad impone la necesidad de realizar algunas primeras reflexiones desde la teoría del derecho constitucional ${ }^{34}$. La mencionada disciplina suele explicar la institución como una categoría dentro o de los derechos civiles ${ }^{35}$ o de los derechos patrimoniales ${ }^{36}$, ya que le pertenecen al hombre por el solo hecho de ser persona humana. En la concepción actual, los derechos civiles son considerados derechos naturales exigidos por la justicia ${ }^{37}$ y el derecho de la propiedad, ampara el uso y la disposición de todos los bienes, tanto materiales como inmateriales, que pueden o tienen posibilidad de integrar el patrimonio de una persona ${ }^{38}$.

En este esquema, la propiedad, aunque no definida en la Constitución Nacional, es un derecho natural que la misma reconoce, protege y garantiza $^{39}$. Desde aquí entonces se reconocen los titulares de la propiedad personas humanas o de existencia ideal $^{40}$-, los sujetos pasivos de la propiedad -el Estado y los particulares ${ }^{41}$-, y especialmente, se afirma el doble carácter de la propiedad en nuestro derecho, privada y social, ya que atiende al interés de los particulares y mira al bienestar común ${ }^{42}$. Es posible acordar con Germán Bidart Campos que en torno al bienestar común, en el tratamiento académico existe una especie de trilogía encaminada a definir el contenido y alcance del bien común público, del bienestar general y del interés público ${ }^{43}$, como bienes, valores y realidades materiales e inmateriales que rinden utilidad y provecho al conjunto de personas que integran la totalidad de una sociedad política ${ }^{44}$. Es público entonces, porque no es

${ }^{34}$ La Constitución recepta al mencionado derecho implícitamente en los siguientes artículos 14,17 y 20 respectivamente, haciendo referencia al contenido, las defensas y los derechos de los extranjeros -en este caso, en relación al derecho de propiedad- respectivamente.

${ }^{35}$ Cfr. Helio Juan ZARINI, Constitución Argentina. Comentada y concordada, Astrea, Buenos Aires, 1.996, p. 51.

${ }^{36}$ Cfr. Miguel Ángel EKMEKDJIAN, Manual de la Constitución Argentina, LexisNexis, Buenos Aires, 2.007, p. 143.

${ }^{37}$ Helio Juan ZARINI, Constitución Argentina ..., ob. cit., p. 51.

${ }^{38}$ Cfr. Adolfo Gabino ZIULU, Derecho Constitucional, t ${ }^{\circ}$ I, Depalma, Buenos Aires, 1.997, p. 260.

${ }^{39}$ Ibídem, p. 57.

${ }^{40}$ Ibídem.

${ }^{41}$ Ibídem.

${ }^{42}$ Ibídem, p. 58.

43 Cfr. Germán J. BIDART CAMPOS, Nociones constitucionales. Las intersecciones iusnaturalistas de la Constitución, Ediar, Buenos Aires, 2.007, p. 196.

${ }^{44}$ Ibídem. 
exclusivo o propio de alguna o ciertas personas, sino de la generalidad del grupo $^{45}$. Así comprendido, en indudable opinión de Alfonso Santiago, el bien común se posiciona y erige como fin de toda la comunidad humana ${ }^{46}$.

Sobre lo antedicho, se reconoce que no se admite en nuestra Nación un derecho de propiedad absoluto e ilimitado. El derecho de propiedad se encuentra sometido a las reglas y limitaciones que son indispensables tanto para el orden social como para el bien común ${ }^{47}$. De aquí entonces que la propiedad privada reconozca las mencionadas limitaciones ${ }^{48}$ que tienen como objeto el interés privado (derecho privado, especialmente el Código Civil y hoy el Código Civil y Comercial de La Nación) y aquellas que tutelan el interés público (derecho administrativo) ${ }^{49}$. Esto sin dejar de reconocer las garantías que ofrece el derecho de propiedad en nuestro país, a fin de evitar entre otras cosas, que el Estado se apropie de los bienes de las personas $^{50}$. En definitiva, digamos que el principio en nuestro derecho constitucional es la protección de la propiedad, por ello es que solo puede privarse de ella por causa de utilidad pública -mediando la correspondiente indemnización- y por alguna razón fundamental que sea excepcional y perfectamente fundada ${ }^{51}$.

Se admite además que los derechos reales, los derechos crediticios o personales, los derechos patrimoniales regidos por el derecho administrativo, los derechos de transmisión de bienes por causa de muerte, los derechos de propiedad intelectual, industrial y comercial, la propiedad de la tierra, y los denominados derechos adquiridos -hoy constitucionalmente considerados y protegidos- conforman los más importantes derechos concretos que integran el concepto de propiedad ${ }^{52}$.

\footnotetext{
${ }^{45}$ Ibídem.

${ }^{46}$ Cfr. Alfonso SANTIAGO (h), En las fronteras entre el Derecho Constitucional y la Filosofia del Derecho, Marcial Pons, Buenos Aires, 2.010, p. 90 y ss.

${ }^{47}$ Helio Juan ZARINI, Constitución Argentina ..., ob. cit., p. 58.

${ }^{48}$ Ibídem. El autor se refiere genéricamente a limitaciones enunciando las restricciones, servidumbres, expropiación, ocupación extemporánea, requisiciones y decomiso.

${ }^{49}$ Helio Juan ZARINI, Constitución Argentina, ob. cit., p. 58.

${ }^{50}$ María Angélica GELLI, Constitución de la Nación Argentina ..., t ${ }^{\circ}$ I, ob. cit., p. 264.

${ }^{51}$ Cfr. Carlos Mario CLERC, La posesión de cosas muebles, Biblioteca de la Facultad de Derecho de la Universidad de Buenos Aires, $n^{\circ}$ topográfico 253.231/1994, pto. 1.7 (TD).

${ }_{52}$ Miguel Ángel EKMEKDJIAN, Manual de la Constitución Argentina, ob. cit., p. 143-144.
} 


\section{SEBASTIÁN JUSTO COSOLA}

\subsubsection{La función social de la propiedad.}

En el derecho moderno, la propiedad tiene una función social que cumplir. Si bien el propietario tiene derecho a servirse de la cosa, usarla, gozarla y disponer de ella, ya no puede desnaturalizarla, degradarla o destruirla sin razón suficiente ${ }^{53}$. La ley no ampara el ejercicio abusivo de la propiedad, y por esta razón, cada vez que el derecho de propiedad sea utilizado o esgrimido de manera antisocial o en contra de los derechos de la comunidad, no tendrá el amparo legal establecido en la legislación ${ }^{54}$. Esta mencionada función social recoge en los tiempos actuales una innumerable cantidad de apreciaciones que a simple vista, parecieran escapar al análisis sistemático del derecho. En efecto, se comprueba entonces la importancia que tiene la memoria de la propiedad -perteneciente a un individuo que piensa en ella- de la memoria en la propiedad, en donde es la propiedad la que almacena la memoria ya sea individual o colectivamente ${ }^{55}$. De ahí que los hombres expongan teorías que tiendan a valorar el sentido de la propiedad y a justificar la función social de protección y guarda, propias de las naciones civilizadas.

\footnotetext{
${ }^{53}$ Guillermo A. BORDA, Manual de Derecho Civil. Derechos Reales, Delfina M. BORDA (Actual.), La Ley, Buenos Aires, 2.008, p. 146.

${ }^{54}$ Ibídem. Con el mismo énfasis, los Mazeaud ya exponían claramente que la evolución en el derecho de la propiedad hace ver que la misma se socializa cada día más, siendo el ejercicio del derecho de propiedad una función social, que la jurisprudencia sanciona ante el posible sometimiento por el propietario de abuso del derecho. Y también expone Marta Fazio que el concepto acerca de que la propiedad privada debe servir a los intereses sociales ya aparece cuando los primeros hombres superan el denominado estado primitivo y se organizan creando las bases de las instituciones. Así, en concordancia con las expresiones de Comte y de Duguit la profesora argentina enseña que para esta posición el individuo tiene la obligación de cumplir en la sociedad una cierta función en razón directa del lugar que en ella ocupa. De esta manera, la propiedad ya no es un derecho subjetivo del propietario sino una función social del tenedor de la riqueza. Cfr. Henri MAZEAUD, León MAZEAUD y Jean MAZEAUD, Lecciones de derecho civil, Parte Segunda, Vol. IV, trad. Luis ALCALÁZAMORA Y CASTILLO, EJEA, Buenos Aires, 1.960, p. 2, y Marta Encina FAZIO, La función social de la propiedad privada en el derecho contemporáneo (TD), Biblioteca de la Facultad de Derecho de la Universidad de Buenos Aires, nº topográfico 252.251/1973, p. 8.

55 Cfr. Eduardo M. PEÑALVER, Memorias de la propiedad, en Daniel BONILLA MALDONADO (Coord.), La función social de la propiedad, Eudeba, Buenos Aires, 2.013, p. 83 y ss.
} 
La noción de función social de la propiedad recobra importancia a través de las presentaciones que efectuara en Buenos Aires el célebre León Duguit $t^{56}$. Para el jurista francés, la propiedad no es un derecho sino una función social, y así, la propiedad tiene y presenta límites internos que determinan que el propietario tiene obligaciones en relación con su cosa, que no puede hacer lo que quiera con la propiedad por más que sea suya; y la riqueza que la misma genera debe ponerse al servicio de la comunidad mediante su explotación económica ${ }^{57}$. De esta manera, la idea de función social se fundamenta y cobra impulso desde una descripción de la realidad social que reconoce a la solidaridad como uno de sus ejes constitutivos ${ }^{58}$. Puede consecuentemente entonces deducirse que se pretende con ella garantizar el fin de la prosperidad humana para todos los ciudadanos de todos los Estados ${ }^{59}$, sin descuidar aspectos de relevancia para los tiempos actuales como los referidos a la profusión de tipos de $\operatorname{propiedad~}^{60}$ y los problemas de sustentabilidad y crisis ambientales producidos por la actividad humana descontrolada ${ }^{61}$. La idea de prosperidad humana en relación a la función social de la propiedad estará dada entonces por la importancia que se le dé en el contexto adecuado: la misma será útil porque se concentran los deseos y necesidades individuales en un contexto más amplio, sometido a consideración de todos ${ }^{62}$. En definitiva, es una respuesta desde la solidaridad a las consideraciones individualistas que concluyen que la propiedad privada es el camino para la libertad social y económica ${ }^{63}$.

\footnotetext{
${ }^{56}$ Cfr. Sheila FOSTER y Daniel BONILLA MALDONADO, La función social de la propiedad en perspectiva comparada, en Daniel BONILLA MALDONADO (Coord.), La función social de la propiedad, ob. cit. p. 13.

${ }^{57}$ Ibídem.

${ }^{58}$ Ibídem.

${ }^{59}$ Cfr. Colin CRAWFORD, La función social de la propiedad y la capacidad humana de prosperar, en Daniel BONILLA MALDONADO (Coord.), La función social de la propiedad, ob. cit., p. 95.

${ }^{60}$ Ibídem, p. 98.

${ }^{61}$ Ibídem, p. 99.

${ }^{62}$ Ibídem, p. 102.

${ }^{63}$ Ibídem, p. 103.
} 


\section{SEBASTIÁN JUSTO COSOLA}

\subsubsection{En torno al derecho de dominio.}

El dominio considerado como derecho real es el mayor sometimiento de que puede ser objeto una $\operatorname{cosa}^{64}$. Los autores son pacíficos en reconocer al dominio desde el Código Civil velezano como un derecho real por el cual una cosa se encuentra sometida a la voluntad y a la acción de una persona, aunque advierten de la necesidad de agregar a esta definición los caracteres esenciales que lo destacan como absoluto, exclusivo y perpetuo ${ }^{65}$. El dominio en el derecho privado argentino se circunscribe a los objetos corporales, a las cosas singulares, íntegras y específicamente determinadas ${ }^{66}$. De aquí que se derive, de conformidad con el Código Civil y Comercial de La Nación vigente, que es inherente a la propiedad del derecho a poseer la cosa, a disponer o servirse de ella, y a usarla y a gozarla conforme a un ejercicio regular, no pudiendo ese ejercicio ser restringido siempre y cuando no fuere abusivo aunque privare a terceros de ventajas o comodidades ${ }^{67}$.

Sin ofrecer mayores desarrollos, comenzaré entonces por destacar el desenvolvimiento de los derechos reales y personales dentro de esta perspectiva, para luego poder avizorar, en los capítulos siguientes, como es que cada derecho puede advertirse a través de la adecuada comprensión de la publicidad cartular (documento), la publicidad posesoria, y la publicidad registral.

\footnotetext{
${ }^{64}$ Cfr. Ricardo J. PAPAÑO, Claudio M. KIPER, Gregorio A. DILLON y Jorge R. CAUSSE, Derecho Civil. Derechos Reales, t ${ }^{\circ}$ I, Astrea, Buenos Aires, 2.012, p. 187.

${ }^{65}$ Ibídem. También Raymundo M. SALVAT, Tratado de Derecho Civil Argentino. Derechos Reales, Manuel J. ARGAÑARAZ (Actual.), $\mathrm{t}^{\circ}$ II, TEA, Buenos Aires, 1.961, p. 21; Guillermo a. BORDA, Manual de Derecho Civil. Derechos Reales, ob. cit., p. 144.; Luis Alberto PEÑA GUZMÁN, Derecho Civil. Derechos Reales, t $^{\circ}$ II, TEA, Buenos Aires, 1.975, p. 26; Lilian GURFINKEL DE WENDY, Derechos Reales, t ${ }^{\circ}$ I, Abeledo Perrot, Buenos Aires, 2.010, p. 277 y entre otros, Héctor LAFAILLE y Jorge Horacio ALTERINI, Derecho Civil, Tratado de los derechos reales, $\mathrm{t}^{\circ}$ II, ob. cit., p. 21.

${ }^{66}$ Héctor LAFAILLE y Jorge Horacio ALTERINI, Derecho Civil, Tratado de los derechos reales, $\mathrm{t}^{\circ} \mathrm{II}$, ob. cit., p. 22 . En referencia a las aludidas calificaciones, los autores admiten que se excluyen del dominio los bienes inmateriales, inclusive los derechos de cualquier categoría, como también las universalidades de hecho o de derecho, el dominio sobre "partes de un objeto" y consecuentemente, las cosas calificadas por genero o cantidad que pueden ser objeto de obligaciones pero no de derecho real de dominio.

${ }^{67}$ Guillermo A. BORDA, Manual de Derecho Civil. Derechos Reales, ob. cit., p. 146.
} 
LOS EFECTOS DE LA PUBLICIDAD EN EL DOCUMENTO NOTARIAL

\subsubsection{Derechos reales y personales. Los primeros conceptos.}

El significado y el alcance del patrimonio se advierte claro y contundente en aquellas teorías sobresalientes de nuestro país y del extranjero, que tanto desde el derecho romano tradicional como desde el desarrollo del derecho privado clásico han permitido justificar su importancia ${ }^{68}$.

El derecho romano presenta entonces una parte generalísima descriptiva de contenidos firmes y decisorios, que una vez comprendidos son desarrollados y relacionados por el derecho civil, desde diferentes disciplinas que componen su estructura, para alcanzar una mayor comprensión. De esta forma, la diferenciación que se realiza de los derechos personales y reales, y de todos aquellos institutos esenciales determinantes de la consolidación del derecho de dominio en un documento público -teoría del acto jurídico, análisis de los vicios, proyección de la causa de la relación jurídica y argumentos de la teoría de las formas- resultan ser determinantes para comenzar a comprender como el derecho privado atribuye a las personas derechos y también distribuye cargas y deberes específicos y determinados, con la única finalidad de conformar -a partir del paradigma de la autonomía privada-, los ya referidos atributos de la personalidad, y que especialmente importan a esta tesis, ya que todos se encuentran contenidos y desarrollados en el documento notarial. De esta manera, el análisis en conjunto de los derechos reales y personales implicados en temas de relevancia para el derecho notarial resulta ser esencial e ineludible, porque es determinante de su eficiencia.

Sobre lo antedicho, es preciso comenzar por recordar que en nuestro país, los autores advierten que los derechos reales se diferencian de los personales

\footnotetext{
${ }^{68}$ Pocas frases tan esclarecedoras como la siguiente: "La necesidad de negocios entre individuo e individuo sólo se aprecia en aquellos ordenamientos económico-sociales que reconocen a los individuos una esfera de bienes de su pertenencia, o sea: en ordenamientos fundados en el reconocimiento de la propiedad individual". Cfr. Emilio BETTI, Teoría general del negocio jurídico, Comares, Granada, 2.000, p. 48.
} 


\section{SEBASTIÁN JUSTO COSOLA}

esencialmente, en razón de sus elementos ${ }^{69}$, de su constitución ${ }^{70}$, de sus ventajas $^{71}$, en torno a la duración ${ }^{72}$, en relación a la prueba ${ }^{73}$, a la variedad ${ }^{74} \mathrm{y}$ al número ${ }^{75}$ entre otros puntos de relevancia. Más específicamente, la doctrina especializada mayoritaria se viene esforzando por definir a los derechos reales haciendo alusión a las diferencias, a las similitudes, a los puntos de contacto y conexiones con los derechos personales ${ }^{76}$. A nivel académico, puede reconocerse un buen punto de partida en los primeros aportes que Raymundo Salvat efectuara con la finalidad de esbozar los caracteres propios de los derechos reales para diferenciarlos de los derechos personales $^{77}$; se consolidaban así los primeros como un poder inmediato del titular del derecho real sobre la cosa objeto del mismo, que requiere para su ejercicio la cooperación de otro sujeto ${ }^{78}$. Tanto los derechos personales como los reales hacen a la composición del patrimonio, y en este sentido, mientras que los primeros son una obligación pasivamente universal que acarrea

\footnotetext{
${ }^{69}$ Cfr. Horacio VALDES y Benito ORCHANSKY, Lecciones de derechos reales, $\mathrm{t}^{\circ} \mathrm{I}$, Ediciones Lerner, Buenos Aires, 1.969, p. 17. En el derecho real se encuentran la persona y la cosa; en el derecho personal existen sólo los sujetos.

${ }^{70}$ Ibídem. El derecho real nace de la conjunción entre tradición y causa, mientras que el derecho personal nace inmediatamente a que el hecho o acto esgrimido como condición se produce.

${ }^{71}$ Ibídem, p. 18. El derecho real concede el derecho de perseguir la cosa en cualquier mano en que se encuentre, mientras que el derecho personal solo otorga al acreedor la posibilidad de exigir el cumplimiento de la prestación a la persona del deudor.

72 Ibídem, p. 20. Los derechos reales se ejercen por la posesión y consecuentemente, su ejercicio es inagotable. Los derechos personales en cambio es transitorio ya que, salvo en supuestos excepcionales como los que ocurren cuando los mismos toman forma de cuerpo en un documento al portador, se agota en el ejercicio que del mismo se realiza.

${ }^{73}$ Ibídem. Los derechos reales pueden ser presumidos, pero los personales nunca se presumen. Deben probarse.

${ }^{74}$ Ibídem. Los derechos reales, si bien limitados, tienen fisonomía propia, mientras que los derechos personales, aun siendo ilimitados, todos presentan similar naturaleza.

${ }^{75}$ Ibídem, p. 21. Los derechos reales son limitados. Los derechos de crédito son ilimitados.

${ }^{76}$ En el análisis de los derechos subjetivos, el origen de la distinción conceptual entre derechos reales-derechos personales se remonta a la ley poetelia papiria, que comienza a plantear que la ejecución de la deuda contra la misma persona del deudor se comienza por transformar en una ejecución contra sus bienes. Cfr. Edmundo GATTI, Derechos subjetivos (Poderes y facultades) y Relaciones Jurídicas (Absolutas y relativas), LexisNexis, Buenos Aires, 2.005, p. 35.

${ }^{77}$ Raymundo M. SALVAT, Tratado de derecho civil argentino. Derechos Reales, t $^{\circ} \mathrm{I}$, ob. cit., p. 3.

${ }^{78}$ Ibídem.
} 
además una creación institucional ${ }^{79}$, los derechos personales son los que se tienen contra una persona determinada y que autorizan o dan espacio para que pueda exigírsele a la misma, el cumplimiento tanto de un hecho específico como el hecho de una determinada abstención ${ }^{80}$. En similar orientación se dirigen los aportes de Manuel Arauz Castex destinados a describir las teorías expuestas originariamente por Salvat ${ }^{81}$, y como era previsible, la consolidación definitiva de los temas tratados llegarán luego en los legados de Jorge Llambías ${ }^{82}$. Desde ahí que una infinidad de autores clásicos argumenten que según sean considerados los elementos constitutivos de uno y otro derecho, mientras que el derecho personal cuenta con dos sujetos unidos por el cumplimiento de una determinada prestación (acreedor y deudor), el derecho real consta de un solo sujeto activo y una cosa que es el objeto del derecho ${ }^{83}$.

\subsubsection{La cuestión conceptual también determina los criterios}

\section{diferenciales.}

Al carecer el derecho real de una definición o concepto en el Código Civil de Vélez Sarsfield -que inclusive orientara a relacionarlo tan siquiera con el derecho personal-, fueron verdaderamente esclarecedoras las

\footnotetext{
${ }^{79}$ Cfr. Raymundo M. SALVAT, Tratado de derecho civil argentino. Parte General, Víctor N. ROMERO DEL PRADO (Actual.) t ${ }^{\circ}$ II, TEA, Buenos Aires, 1.958, p. 21. En este punto, el autor expone que la noción y concepto de los derechos reales traen la controversia que los expone a enfrentar la doctrina clásica, que apoya al derecho real como obligación pasivamente universal, y la doctrina que consolida la teoría de la creación institucional.

${ }^{80}$ Ibídem, p. 19.

${ }^{81}$ Cfr. Manuel ARAUZ CASTEX y Jorge J. LLAMBÍAS, Derecho Civil-Parte General, t ${ }^{\circ}$ II, Editorial Perrot, Buenos Aires, 1.955, p. 39 y ss, y con una orientación similar pero no idéntica, con ampliación de algunos aportes anteriores: Manuel ARAUZ CASTEX, Derecho Civil. Parte General, t ${ }^{\circ}$ II, Empresa Técnico Jurídica Argentina, Buenos Aires, 1.965, p. 36 y ss.

${ }^{82}$ Jorge Joaquín LLAMBÍAS, Tratado de Derecho Civil. Parte General, to II, ob. cit., p. 199 y ss.

${ }^{83}$ Cfr. Luis M. VALIENTE NOAILLES (h), Obligaciones reales, Depalma, Buenos Aires, 1.961, p. 14
} 


\section{SEBASTIÁN JUSTO COSOLA}

manifestaciones de autores como Edmundo Gatti ${ }^{84}$, Héctor Lafaille ${ }^{85}$, Edmundo Gatti y Jorge Horacio Alterini ${ }^{86}$, Luis Alberto Peña Guzmán ${ }^{87}$, Fernando López de Zavalía $^{88}$, Marina Mariani de Vidal ${ }^{89}$, Guillermo Borda $^{90}$, Ricardo Papaño, Claudio Kiper, Gregorio Dillon y Jorge Causse ${ }^{91}$, Carlos Clerc ${ }^{92}$, Claudio Kiper ${ }^{93}$, Lilian Gurfinkel ${ }^{94}$ y Liliana Abreut ${ }^{95}$, entre tantos otros, a las que correspondientemente remito. Sobre esas ideas directrices ejerció y actualmente ejerce el derecho quien oficia de jurista práctico, mientras que aquellos dedicados al estudio de la doctrina además se vieron enriquecidos con algunas de las cuestiones teóricas esenciales emergentes de la disputa en nuestro país de los recordados maestros Guillermo Allende ${ }^{96}$ y Alberto Molinario ${ }^{97}$. Fueron ellos, en primerísima instancia, quienes han sin duda contribuido a brindar mayor rigor científico a esta disciplina (puede recordarse a modo de ejemplo, la audacia del primero al realizar aclaraciones metodológicas en la aplicación de los derechos

\footnotetext{
${ }^{84}$ Cfr. Edmundo GATTI, Derechos Reales. Teoría General, Lajouane, Buenos Aires, 2.006, p. 47. (TD)

${ }^{85}$ Héctor LAFAILLE y Jorge Horacio ALTERINI, Derecho Civil. Tratado de los derechos reales, $\mathrm{t}^{\circ} \mathrm{I}$, ob. cit., p. 16 y ss.

${ }^{86}$ Cfr. Edmundo GATTI y Jorge Horacio ALTERINI, El derecho real. Elementos para una teoría general, Abeledo Perrot, Buenos Aires, 1.998, p. 133.

${ }^{87}$ Luis Alberto PEÑA GUZMÁN, Derecho Civil. Derechos Reales, to I, ob.cit., p. 20 y ss.

${ }^{88}$ Cfr. Fernando LOPEZ DE ZAVALÍA, Derechos Reales, $\mathrm{t}^{\circ}$ I, Zavalía, Buenos Aires, 1.989, p. 64 y ss.

${ }^{89}$ Cfr. Marina MARIANI DE VIDAL, Curso de derechos reales, $\mathrm{t}^{\circ}$ I, Zavalía, Buenos Aires, 1.993 , p. 29 y ss.

${ }^{90}$ Guillermo A. BORDA, Manual de derecho Civil. Derechos Reales, ob. cit., p. 4 y ss.

${ }^{91}$ Ricardo J. PAPAÑO, Claudio M. KIPER, Gregorio A. DILLON y Jorge R. CAUSSE, Derecho Civil. Derechos Reales, t ${ }^{\circ} \mathrm{I}$, ob. cit., p. 13 y ss.

92 Cfr. Carlos M. CLERC, Derechos Reales en el nuevo Código Civil y Comercial de La Nación, Erreius, Buenos Aires, 2.016, p. 6 y ss.

${ }^{93}$ Cfr. Claudio KIPER, Tratado de los Derechos Reales. Código Civil y Comercial de La Nación, $\mathrm{t}^{\circ} \mathrm{I}$, Rubinzal Culzoni, Santa Fe, 2.016, p. 42 y ss.

${ }^{94}$ Lilian GURFINKEL DE WENDY, Derechos Reales, t ${ }^{\circ}$ I, ob. cit., p. 15 y ss.

${ }^{95}$ Cfr. Liliana ABREUT de BEGHER, Derechos Reales, Hammurabi, Buenos Aires, 2.016, p. 38 y ss.

${ }^{96}$ Cfr. Guillermo L. ALLENDE, Panorama de derechos reales, La Ley, Buenos Aires, 1.967, p.19.

${ }^{97}$ Cfr. Alberto D. MOLINARIO, Derecho patrimonial y derecho real, La Ley, Buenos Aires, 1.965, p. 43.
} 


\section{LOS EFECTOS DE LA PUBLICIDAD EN EL DOCUMENTO NOTARIAL}

reales $^{98}$, y la coherencia del segundo al establecer el concepto de relaciones reales $\left.^{99}\right)$. Desde aquí la riqueza del tratamiento en nuestro medio de los derechos reales y de su proyección actual, y nuevamente: de su diferenciación con los derechos personales.

Sin embargo - y muy a pesar de lo antedicho-, otras voces se han alzado en contra de estas manifestaciones. Luis Diez-Picazo y Antonio Gullón en España se esmeran por explicar las teorías clásicas, negatorias y eclécticas referidas a la distinción entre los derechos reales y personales denominados de crédito en aquel país-. Y si bien en cierto que en España la teoría del derecho real se construye sobre ideas totalmente ajenas a nuestro derecho, resulta importante destacar que los autores recomiendan no trabajar sobre la distinción de los derechos reales y personales - no tan útil y problemática- sino mas bien atender a las situaciones jurídicas dotadas de oponibilidad a terceros y aquellas que carecen de ese cualidad ${ }^{100}$. También la consolidada obra de Manuel Fairén ${ }^{101}$ viene a comprobar una actitud pesimista hacia la clasificación, diferenciación y distinción de los derechos reales y personales ${ }^{102}$. En efecto, desde aquella teoría se advierte -como muchos españoles contemporáneos aún lo hacen- que no debe atribuirse ningún tipo de valoración a la investigación que pretenda separar a los derechos personales de los reales desde el orden científico y dogmático, teniendo en cuenta que el derecho tiene pretensión de totalidad ${ }^{103}$. Para esta

\footnotetext{
${ }^{98}$ Cfr. Guillermo L. ALLENDE, Metodología y modernas orientaciones en materia de derechos reales, Cooperadora del Centro de Derecho y Ciencias Sociales, Buenos Aires, 1.962 , p. 8 y ss. En este ensayo imperdible, comienza por fundamentar el autor que la cuasiposesion en nuestro derecho no existe.

${ }^{99}$ Cfr. Alberto D. MOLINARIO, De las relaciones reales, Universidad, Buenos Aires, 1.981, p. 35 y ss. El autor parte de la idea de considerar que el derecho real expone el contacto continuo del hombre con las cosas que los circundan y también con aquellas que se encuentran alejadas de él, dando lugar a lo que él denomina relaciones reales.

${ }^{100}$ Cfr. Luis DIEZ-PICAZO y Antonio GULLÓN, Sistema de derecho civil, vol. III, to I, Tecnos, Madrid, 2.013, p. 29.

${ }^{101}$ Cfr. Manuel FAIRÉN, Derechos reales y de crédito (Apuntes dogmáticos para el criterio de su distinción), RDN n ${ }^{\circ}$ XXIII, Colegio de Notarios de España, Madrid, 1.959, p. 95-256; Segunda Parte: RDN n XXIV, Colegio de Notarios de España, Madrid, 1.959, p. 139-266; Tercera Parte: RDN n ${ }^{\circ}$ XXV-XXVI, Colegio de Notarios de España, Madrid, 1.959, p. 155362; y Cuarta Parte (Conclusión): RDN n ${ }^{\circ}$ XXXI, Colegio de Notarios de España, Madrid, 1.961, p. 171-341.

${ }^{102}$ Manuel FAIRÉN, Derechos reales y de crédito, Parte Tercera, ob. cit., p. 358.

${ }^{103}$ Ibídem, p. 359.
} 


\section{SEBASTIÁN JUSTO COSOLA}

posición, lo trascendente en el tratamiento de los derechos reales y personales es alcanzar una postura que logre explicar su utilidad teórica y práctica, y eso se logra a través de la contemplación de la realidad de las $\operatorname{cosas}^{104}$. De esta manera se concluye que la pretendida categoría de derechos reales y personales no es posible, ya que unos y otros suponen una amalgama de principios inspiradores e ideales de vida que muy dificilmente pueden agotarse en una explicación ${ }^{105}$.

En medio de estas teorías extremas, otros autores derivan la atención hacia otras vías de tratamiento del tema de los derechos reales y personales, relacionándolos desde el posicionamiento de uno sobre el otro ${ }^{106}$; también partiendo desde el análisis de las situaciones intermedias entre los mismos, vale decir, situaciones confusas que no son posibles de ubicar hábilmente en una determinada categoría sin cierta polémica ${ }^{107}$ o incluso advirtiendo la consecuente rigidez o flexibilidad de las normas estatutarias de los derechos reales en relación con la teoría del orden público ${ }^{108}$. Pero es destacable también advertir que comenzaban hace tiempo a florecer en nuestro país claros aportes que remarcan cuestiones por demás de trascendentes acerca del tema en estudio entendido en su conjunto, asociando la idea de aplicar ciertos derechos reales cómo sucedáneos de determinados derechos personales. En efecto, la tesis doctoral de Jorge Alterini proyecta de manera audaz las implicancias teóricas y prácticas que derivan de la constitución de usufructos y los derechos de habitación a los casos tradicionalmente reservados para la locación ${ }^{109}$, tema que en la actualidad es considerado

\footnotetext{
${ }^{104}$ Ibídem, p. 360.

${ }^{105}$ Manuel FAIRÉN, Derechos reales y de crédito, Parte Cuarta (Conclusión), ob. cit., p. 340.

${ }^{106}$ Cfr. Gabriel B. VENTURA, Los derechos reales incorporados en el Código Civil y Comercial de La Nación y la publicidad registral, en Claudio KIPER (Dir.)- Luis O. DAGUERRE (Coord.), Aplicación notarial del Código Civil y Comercial de La Nación, tº III, Rubinzal-Culzoni, Santa Fe, 2.015, p. 626.

${ }^{107}$ Rubén H. COMPAGNUCCI DE CASO, Manual de obligaciones, ob. cit., p. 25.el autor se refiere a los casos de ius ad rem, las vocaciones al derecho real y las obligaciones reales.

${ }^{108}$ Cfr. Marcelo A. PEPE y Gonzalo A. MENDIZÁBAL, El orden público y la rigidez o flexibilidad en los derechos reales, LL 2009-D, p. 871.

${ }^{109}$ Cfr. Jorge H. ALTERINI, La locación y los derechos reales con función equivalente, Editora Platense, La Plata, 1.970, p. 63 (TD).
} 
inclusive como uno de los tantos casos dudosos de los que se denominan derechos reales discutidos ${ }^{110}$.

Sea como fuere que existan o no las distinciones entre unos y otros derechos, lo importante es advertir que ambos -sea en conjunto, sea separadamenteviven y se desarrollan en el documento notarial, y también se advierten desde la publicidad posesoria y registral, para que desde allí se proyecten de la mejor manera, en el intento por alcanzar su máxima eficacia.

\subsubsection{La lectura de los derechos personales y reales.}

La lectura del documento notarial destinado a transmitir y consolidar el dominio (escritura pública) permite al intérprete descubrir esta simbiosis de los derechos reales y personales que conviven en ella, y que en algún punto se confunden para alcanzar en esfuerzo en conjunto la consolidación de un derecho ejercido por la ciudadanía para tal fin (dominio) y anhelado históricamente por la misma a partir de la comprensión del desarrollo familiar (propiedad). En los tiempos actuales, variadas son las formas que ofrece el derecho para alcanzar la eficacia de la documentación como elemento continente del contenido que se proyecta (el acto o el hecho jurídico), a través de los efectos naturales que de ella se desprenden como los formales y los probatorios. Una de ellas es la referida a la intervención notarial creadora del derecho documental que en cierta manera determina uno de los primeros acercamientos al derecho sin controversias ni contiendas al que acceden los hombres libres en el ejercicio pleno de su voluntad $^{111}$.

\footnotetext{
${ }^{110}$ Luis DIEZ-PICAZO y Antonio GULLÓN, Sistema de derecho civil, ob. cit., págs. 38 y ss.

${ }^{111}$ El esplendor de la función notarial creadora del derecho se advierte desde su resultado, el documento, pero también desde las operaciones notariales previas, denominadas por la doctrina como "operaciones de ejercicio" y que desde mi visión, siempre fueron las más relevantes. Jurídicamente, las operaciones de ejercicio se refieren a las audiencias previas que el notario realiza con los requirentes del hecho o del acto jurídico a instrumentar, momentos donde los alcances de las pretensiones pueden ser consolidados o convenientemente desarticulados. Éticamente, es donde comienzan a proyectarse los deberes éticos notariales aplicados, de información, asesoramiento, consejo, imparcialidad, independencia y concreción de la legalidad comprensiva de reglas, normas y principios generales del derecho. Todo esto se realiza en un ámbito de paz, y de ahí que la función notarial se diferencie totalmente de
} 


\section{SEBASTIÁN JUSTO COSOLA}

Ya desde aquí puede inferirse que la adecuada atribución de los derechos subjetivos y objetivos para cada parte requirente se cumplen de manera gradual y sistemática desde las prescripciones de los ordenamientos jurídicos establecidos y vigentes en cada lugar. En nuestro país, estas atribuciones vienen presentando consecuencias concretas, que se encontraban y se encuentran metodológicamente estipuladas, tanto en el centenario y ya derogado Código Civil Argentino de Vélez Sarsfield como en el actual y vigente Código Civil y Comercial de la Nación. De esta manera, cada persona intenta posicionar de la mejor manera posible su derecho con los fundamentos que le sirven de origen, para alcanzar el mejor resultado posible y conveniente para el desarrollo de los efectos que pretende sean consolidados para sí o para su entorno. Sin embargo, el campo de acceso para alcanzar este tipo de información se encuentra limitado a quienes efectivamente tienen derecho a la mencionada información, que aunque no sean únicamente los dueños, los propietarios o los que cuentan con un determinado y legitimado interés ${ }^{112}$, de ninguna manera se equipara con los hechos comunes que se demuestran naturalmente por la sola exhibición.

De esta manera, otras lecturas son también las que ofrece el mundo del derecho. La sola y mera ocupación de una determinada cosa hace suponer que el derecho real se encuentra al máximo de su plenitud; y también que para ello, hayan existido oportunamente como antecedente derechos personales implicados para que esa situación se haya llegado a consolidar (causa contractual) o también otras cuestiones que han legitimado a través del tiempo, el derecho real que se exhibe como afianzado (prescripción adquisitiva o usucapión). Dada la posesión continua, ininterrumpida, publica y pacífica a titulo de dueño, la conformación del derecho real que se ejerce

otras creaciones o argumentaciones jurídicas a las que estamos quizás más dirigidos a comprender desde las aulas universitarias, que definen o exponen las decisiones una vez acontecido el conflicto. v. alcance de los principios deontológicos en Juan Francisco DELGADO DE MIGUEL, Acerca del fundamento moral de los principios deontológicos profesionales, en Ética de las profesiones jurídicas: Estudios sobre deontología, Vol. I, UCSM, Murcia, 2.003.

${ }^{112}$ La lista se amplía hacia ciertos y determinados profesionales autorizados para ello, los mandamientos de la justicia y de los organismos administrativos, entre otros casos. 
por la posesión es también posible de acuerdo al derecho ${ }^{113}$, con todos los efectos previstos atribuidos en el ordenamiento jurídico ${ }^{114}$.

Finalmente, existe una última lectura, para el caso de las cosas que acceden a un determinado registro, que es la que emerge de la interpretación de los asientos registrales, a través de la solicitud de diversos informes o certificados al Registro correspondiente. Los mismos exhiben, a través de la publicidad formal o material, una determinada situación registral que a la postre, se supone cierta, pero de ninguna manera es confirmatoria de la realidad extrarregistral hasta su comprobación real efectiva. La lectura de los derechos reales y personales desde esta perspectiva ofrece la garantía de la publicidad registral a los dueños de las cosas, independientemente que hayan o no nacido los derechos con la inscripción registral, y lógicamente, el campo de información de este tipo de publicidad, también se encuentra limitado a ciertas y determinadas personas que son las que cuentan con un determinado y legitimado interés.

\subsection{Posición notarial frente a los derechos reales y personales que} conforman el contenido del documento. La proyección de las declaraciones.

No puede prescindirse de ciertos análisis concretos, correspondientes a temas en donde el notariado encuentra cotidianamente los motivos suficientes y convincentes para crear y argumentar el derecho en un ámbito de paz definitivamente consolidada, fundamento de la prevención de posibles conflictos posteriores. Las obras de derecho notarial consolidadas

${ }^{113}$ Cfr. Pablo M. CORNA, Prescripción adquisitiva, Ediciones Carra, Buenos Aires, 1.984, p. 47.

114 Ídem, p. 90. En este punto el autor explica que uno de los principales efectos de la usucapión es la transformación del poseedor ilegítimo en legítimo. De esta manera lo argumenta: "El derecho real que nazca, como por ejemplo el dominio, será de carácter originario y en nada tendrá relación con el dominio anterior. Si el adquirente respetara derechos constituidos sobre el fundo como una servidumbre pasiva, en nada alterará su adquisición originaria". 


\section{SEBASTIÁN JUSTO COSOLA}

tanto en nuestro país ${ }^{115}$ como en el extranjero ${ }^{116}$ son una referencia concreta que evidencia que el tratamiento del tema de los derechos reales y personales en general no ha sido de ninguna manera ajeno a la reflexión académica notarial.

Es de esta manera que los documentos notariales que son causa para la transferencia formal del dominio contienen clausulas de indudable e innegable importancia, que demuestran su verdadera y elemental esencia en el cuerpo principal de la escritura pública, y que responden a la más variada naturaleza ${ }^{117}$. Muchas declaraciones y comprobaciones notariales relevantes quedan plasmadas en el contenido del documento notarial, lugar donde de alguna manera viven y conviven los argumentos convincentes de los derechos personales y reales que cada una de las partes fundamenta para sí, ya sea incorporando, ya sea transmitiendo o declarando alguna cuestión relacionada con el patrimonio. Algunas de ellas, están claramente definidas en las manifestaciones personales de los comparecientes y otras, en las mencionadas comprobaciones notariales, algunas con el imperio de la fe y otras sin ello pero también, de indudable importancia.

En el derogado Código Civil, esta situación había sido prevista por Vélez Sarsfield. En efecto, el valor de la publicidad cartular fue ya tenido en cuenta en materia de dominio revocable ${ }^{118}$. En ese momento, el valor de la

${ }^{115}$ Cfr. José María MUSTAPICH, Tratado teórico y práctico de derecho notarial, $\mathrm{T}^{\circ} \mathrm{III}$, Ediar, Buenos Aires, 1.957, p. 9 y ss; Jorge Horacio ALTERINI (Dir.) e Ignacio Ezequiel ALTERINI (Coord.), Derecho Notarial, Registral e Inmobiliario. Doctrinas Magistrales 1897-2012, $\mathrm{T}^{\circ}$ VI, La Ley y Colegio de Escribanos de la Ciudad de Buenos Aires, Buenos Aires, 2.012; y Cristina Noemí ARMELLA (Dir.) y Mariano ESPER (Invest.), Summa Notarial, Registral e inmobiliaria, $\mathrm{T}^{\circ}$ III, Abeledo Perrot y Universidad Notarial Argentina, Buenos Aires, 2.013.

${ }^{116}$ Cfr. Juan Berchmans VALLET DE GOYTISOLO, Estudios sobre derecho de cosas, Montecorvo, Madrid, 1.973, p 15 y ss; Antonio RODRIGUEZ ADRADOS, Escritos jurídicos, $\mathrm{t}^{\circ} \mathrm{V}, \mathrm{CFN}$, Madrid, 1.995, p. 209 y ss.

${ }^{117}$ Similar contenido suelen tener otros documentos notariales no destinados a transmitir o adquirir, porque en sede notarial el principio de rogación se impone, razón por la cual la voluntad de los comparecientes o requirentes -salvo en aquellos casos puntuales y específicos receptados por la legislación-, pero el análisis de los mismos excede el marco principal de esta investigación.

${ }^{118}$ Artículo 2.663 del CCA: "Dominio revocable es el que ha sido transmitido en virtud de un título revocable a voluntad del que lo ha transmitido; o cuando el actual propietario puede ser privado de la propiedad por una causa proveniente de su título". La nota general, con los remarcados correspondientes en letra cursiva por mí efectuados, expresa: "Zachariae, § 278. El dominio es por su naturaleza irrevocable; pero por una excepción es revocable en los casos 
LOS EFECTOS DE LA PUBLICIDAD EN EL DOCUMENTO NOTARIAL

publicidad emergente del documento respondía esencialmente, a cuestiones relacionadas con la lógica jurídica inclusive, más que con la buena fe. No obstante, el centenario codificador de manera adrede, fundamentó el valor de la publicidad que se anoticiaba desde la lectura del documento. Similar orientación presenta el Código Civil y Comercial de La Nación, que en el tratamiento del dominio revocable (dominio imperfecto), autoriza el efecto retroactivo a la revocación del dominio de cosa registrable, excepto que lo contrario surja del título de adquisición o de la ley ${ }^{119}$.

De esta manera, las escrituras públicas contienen clausulas relativas a las declaraciones de las partes, donde las mismas manifiestan y reconocen frente al escribano autorizante diversos hechos jurídicos concretos relativos:

a) Cuestiones inherentes a su persona (como los referidos al estado civil y las manifestaciones privadas en general);

b) Cuestiones relacionadas con el aspecto patrimonial (origen propio o ganancial del dinero utilizado para la adquisición; asentimiento para efectuar la transmisión de un determinado bien sujeto a afectación familiar; la declaración sobre la adquisición del régimen de vivienda o inversión; entre otros);

c) Cuestiones relacionadas con hechos cumplidos oportunamente por los comparecientes o requirentes (como los referidos a encontrarse en posesión de la cosa por haberla recibido antes de este acto, o los

del artículo; por ejemplo, cuando el vendedor se ha reservado durante un plazo, la facultad de dejar sin efecto el contrato, o la facultad de volver a tomar la cosa vendida devolviendo el precio recibido. Maynz, en el § 164, y principalmente en el $\S 180$, núm. 3, sostiene, al parecer con buenas razones, que el dominio es irrevocable, y que las convenciones de revocación, en los casos convenidos por las partes, no pueden dar nunca acciones reales contra terceros a quienes el adquirente hubiese transmitido su derecho. Sea cual fuere la lógica de la jurisprudencia, no puede oponerse razón alguna para que las partes que contratan la enajenación de una cosa no puedan poner condiciones o plazos resolutorios de dominio que transmite la una y adquiere la otra. Esas cláusulas revocatorias debiendo estar en el mismo instrumento público por el cual se hace la enajenación, no pueden dejar de ser conocidas por el tercer adquirente, pues constan del mismo instrumento que crea el dominio del que lo transmite. Hablamos de escrituras públicas, porque sólo por ese medio puede transferirse el dominio de los bienes raíces, pues respecto de los muebles, el dominio sólo será revocable en el caso que se determina en uno de los artículos de este título.

${ }^{119}$ Art. 1967 CCCN. 


\section{SEBASTIÁN JUSTO COSOLA}

que se dirigen a comprobar que se recibe la posesión en este $a_{c t o}{ }^{120}$; o incluso según los acuerdos de voluntad específicos ocurre la posibilidad de que en el documento quede expresada la conformación del constituto possesorio o de la traditio brevi $\operatorname{manu}^{121}$ );

d) Las declaraciones que contienen verdaderas manifestaciones juradas relacionadas con el derecho impositivo y tributario que tanta relevancia tienen en la actualidad, ya que posicionan a la figura notarial como colaborador del Estado en su lucha contra los delitos que facilitan o permiten el lavado de activos (declaraciones relativas al origen del dinero, o a inversiones que se han realizado oportunamente con alguna finalidad específica, entre otras), y

e) Todo tipo de declaración que las partes que comparecen para transmitir o adquirir los derechos sobre un determinado bien consideren pertinentes o relevantes, las que, previo asesoramiento notarial, puedan ser adecuadamente incorporadas al documento para que tengan el reflejo de la publicidad cartular.

También las escrituras públicas contienen las comprobaciones notariales, que a través del imperio de la fe pública, garantizan no solo la realización del acto, sino lo que es más relevante: la certeza, la verdad y con ello, la consecuente validez y vigencia del mismo:

\footnotetext{
${ }^{120}$ Declaraciones absolutamente válidas y contundentes entre las partes, con efectos relativos frente a terceros interesados según el derecho positivo actual (Art. 1924 CCCN). Esta situación sin embargo no obsta a la prueba de la buena fe en las declaraciones a los efectos de comprobar que no se ha pretendido, frente a un potencial conflicto, causar un daño previsible desde la razón o el sentimiento. En cierta manera, esta situación jurídica que puede plantearse se encuentra tutelada en el documento notarial a través de la concreción del deber ético de independencia notarial, que ordena al notario abstenerse de instrumentar un acto que puede, tangencial o potencialmente causar un daño a terceras personas ajenas al mismo.

${ }^{121}$ El tema de los alcances de las manifestaciones en las escrituras públicas a partir del análisis del Código Civil y Comercial de La Nación es considerado de manera elemental por la doctrina actual. Cfr. Juan Pablo BADRAN, Acciones posesorias y reales. Teoría y práctica, Lerner Editora S.R.L, Córdoba, 2.015, págs. 215-221.
} 
a) Comprobación de entrega de dinero, valores o títulos que sirvan para consolidar la causa del negocio jurídico (contrato de compraventa) para que nazca el derecho real de dominio;

b) Comprobación de otros actos materiales relevantes, como puede ser una donación de dinero para que sea afectada a una determinada finalidad; la entrega de llaves del transmitente al adquirente, entre otros;

c) Justificación de los límites legales y tributarios del acto que se instrumenta, a partir de la adecuada realización de las atestaciones o constancias notariales que impactan en la publicidad cartular.

Finalmente, también el notario se expresa de manera expresa o tácita en el cuerpo del documento que autoriza. Y si bien esas expresiones no contienen el imperio de la fe, ayudan a comprender el derecho que se desarrolla documentalmente bajo el principio de la legalidad y de la buena fe. El caso más trascendente, es el de la concreción de los juicios notariales de conocimiento o acreditación de la identidad, de capacidad y de legitimación. Sobre esas manifestaciones o expresiones notariales no existe la dación de fe, salvo en hechos que ocurran en su presencia para alcanzar una mayor argumentación de los juicios, como la exhibición e incorporación de documentos que acreditan la identidad, o instrumentos que demuestren alguna alteración en la capacidad que merece ser protegida y resguarda en el documento. Pero para acreditar la identidad, la capacidad y luego la legitimación, el notario ayuda a cumplir no solo con la legalidad impuesta para este tipo de actos, sino a conformar la buena fe en general que las personas deben proyectar al momento de ejercer los derechos y cumplir los deberes que le son correspondientes. Cada una de esas declaraciones o comprobaciones, con o sin el imperio de la fe pública, encuentran motivos suficientes para vivir en el interior del documento, con posibilidad de proyección exterior $^{122}$.

${ }_{122}$ Para algunas autoras, la configuración de los derechos reales que se ejercen por la posesión en el derecho argentino y en el seno de la escritura pública, alcanzan la máxima seguridad jurídica, por cuanto: a) Ocurre frente a un notario que asume la autoría del documento, legitimándolo en todas sus partes a partir del deber ético integrado de legalidad; b) La escritura pública, como instrumento publico reconocido como principal en los códigos modernos, hace prueba de sí misma, y su contenido (manifestaciones auténticas) se prueba 


\section{SEBASTIÁN JUSTO COSOLA}

Sin embargo, no me resulta ajeno que algunos de los temas considerados, han sido verdaderamente polémicos durante la vigencia del hoy derogado Código Civil, como el caso de las manifestaciones relativas a la cuestión posesoria en el seno del documento ${ }^{123}$. A pesar de ello, el paso del tiempo y la elaboración de importantes estudios han permitido consolidar ciertos criterios lógicos de interpretación que son algunos de los que se han venido sosteniendo en los últimos tiempos, y que han ido determinado ciertas pautas de actuación que son las que se utilizan en la actualidad en la cotidianeidad $^{124}$. Encontrándose perfectamente comprobados los diferentes alcances de la titularidad cartular, la titularidad registral y la titularidad real, ciertas cuestiones como la de las declaraciones de las partes en la escritura pública se deben considerar comprendidas dentro del ámbito de la buena $\mathrm{fe}^{125}$, y por lo tanto, aunque las mismas no conforman un supuesto corroborado desde la fe pública ${ }^{126}$, deben considerarse a priori como

per se, lo que refleja la integridad de la fe a través de la fuerza probatoria; c) La prueba de la veracidad de la fecha en el cuerpo de la escritura, sin necesidad de reconocimientos posteriores; d) Una adecuada distinción de los juicios de valor efectuados por el notario, que advierten los alcances de la fe de conocimiento (hoy juicio de identidad), de la valoración de la capacidad y de la instrumentación y adecuación de la legitimación, y El cumplimiento del asesoramiento, imparcialidad y secreto profesional notarial. Cfr. Marta Rosa PIAZZA, Responsabilidad civil del notario. El seguro llamado de mala praxis. Sus diferencias con el seguro de título, Cristina Noemí ARMELLA (Colab.), AIDN n 3, Madrid, 2.004, p. 198 y ss.

${ }^{123}$ En definitiva, tanto en la teoría como en la práctica, el tema referente a la posesión y su publicidad es de indudable importancia en sede notarial, y por ello siempre será un tema de tratamiento relevante. Y todo esto sin considerar cuestiones absolutamente trascendentes que se proyectan desde el articulado actual del Código Civil y Comercial de la Nación. Entre otros casos interesantes para el ejercicio cotidiano de la función notarial, el tratamiento normativo del boleto de compraventa presenta cuestiones importantes referidas a la tutela de la prioridad y el derecho del comprador de buena fe frente al derecho de los terceros que hayan trabado medidas cautelares sobre el inmueble vendido, entre otras cosas, si el mismo se ha adquirido con publicidad suficiente, sea registral, sea posesoria. (Art. $1170 \mathrm{CCCN}$ ).

${ }^{124}$ Cfr. Luis MOISSET de ESPANÉS y Gabriel B. VENTURA, La tradición escrituraria, Zeus, Rosario, 1.986, $\mathrm{T}^{\circ}$ 40, J-50. Lógicamente se encuentran a salvo en casos puntuales y específicos, que son los que por tener una naturaleza especial, requieren de ciertas diligencias previas como la realización, por ejemplo, de actas notariales de comprobación.

${ }^{125}$ Cfr. Gabriel B. VENTURA, Los títulos notariales y la posesión, Anuario de Derecho Civil de la Universidad Católica de Córdoba, $\mathrm{t}^{\circ}$ VIII, 2.003, pág. 27 y ss.

${ }^{126}$ Claramente el Código Civil y Comercial de La Nación contempla las mencionadas declaraciones en el supuesto que se encuentra fuera del alcance de la redargución de falsedad, propia de la comprobación contraria de las manifestaciones y comprobaciones de fe pública (Art. 296). Al referirse a la cuestión de la eficacia probatoria de los instrumentos públicos se aclara que los mismos hacen plena fe: a) en cuanto a que se ha realizado el acto, la fecha, el 
LOS EFECTOS DE LA PUBLICIDAD EN EL DOCUMENTO NOTARIAL

verdaderas entre ellas en razón del mencionado principio, que en la codificación actual hasta se encuentra previsto normativamente, circunstancia que permite incluso una mejor elaboración de argumentación jurídica $^{127}$. Las polémicas actuales se han orientado en la actualidad, hacia otros puntos también relevantes y ajenos a esta tesis, como los relativos al derecho fiscal en general y penal tributario en especial.

Esta es la posición notarial frente a los temas trascendentes de los derechos reales y personales comprometidos en el seno del documento, y en especial para este estudio, en la escritura pública. En los tiempos actuales, puede afirmarse que efectivamente, la reducida base del Código de Vélez para conformar una teoría general del derecho real, en el actual Código Civil y Comercial de La Nación se consolida notoria y útilmente ampliada con el fin de evitar reiteraciones y contradicciones que existían indudablemente en el anterior cuerpo normativo ${ }^{128}$. De esta manera se deducen de la misma algunos principios y ciertas clasificaciones relevantes que sirven para argumentar más precisamente todo el moderno derecho ${ }^{129}$. Entre ellas, las cuestiones relativas al cumplimiento o no cumplimiento del título y del modo para la adquisición, conformación estructural y publicidad de los derechos que ocurren y se desenvuelven en el documento, en el registro o en la ocupación, una realidad comprobada por el hecho perceptible a través de los sentidos.

\subsection{La tesis del título suficiente.}

lugar y los hechos que el oficial público enuncia como cumplidos por él o ante él hasta que sea declarado falso en juicio civil o criminal, mientras que en el inciso b) se deja en claro que en relación al contenido de las declaraciones sobre convenciones, disposiciones, pagos, reconocimientos y enunciaciones de hechos directamente relacionados con el objeto principal del acto instrumentado, la plena fe dura hasta que se produzca prueba en contrario.

${ }^{127}$ Art. 9 del CCCN.

${ }^{128}$ Cfr. Juan José GUARDIOLA, Apostillas de los derechos reales en el nuevo código civil y comercial de la Nación, eldial.com (2015), p. 5.

${ }^{129}$ Ibídem. 


\section{SEBASTIÁN JUSTO COSOLA}

Dentro del tratamiento de la dinámica de los derechos reales se encuentra el estudio de los sistemas de adquisición del dominio, de donde surge palmario el tratamiento de la teoría del título y modo, surgida desde una interpretación causalista de la traditio romana ${ }^{130}$. El análisis de la historia de Roma permite que en la actualidad tomemos conocimiento de tres sistemas diferentes de trasmisión de la propiedad ${ }^{131}$ :

a) El de transmisión mediante traditio que reconoce su causa en los negocios obligatorios antecedentes (teoría del título y el modo), o sea, en contrato causal con finalidad traslativa (título) que opera como justa causa de la tradición (modo) ${ }^{132}$;

b) El de transmisión mediante traditio abstracta, que reconoce la transferencia de la propiedad únicamente por la tradición (acto voluntario) en donde se advierte decisión de transferir y decisión de adquirir, sin necesidad alguna de que el contrato causal subyacente sea válido ${ }^{133}, \mathrm{y}$

c) El de la transmisión puramente consensual que se origina en el contrato que traslada el dominio, es decir, la transmisión de la propiedad se produce únicamente a partir de la celebración del contrato causal ${ }^{134}$.

Dada la historia, el maestro cordobés Luis Moisset de Espanés comienza por explicar que nuestro sistema jurídico de derechos personales alcanza a constituirse solo por el consentimiento, diferenciándose del sistema de los

\footnotetext{
${ }^{130}$ Luis DIEZ-PICAZO y Antonio GULLÓN, Sistema de derecho civil, ob. cit., p. 55.

${ }^{131}$ Cfr. Gunther GONZALES BARRÓN, Tratado de Derechos Reales, to II, Jurista Editores E.I.R.L, Lima, 2.013, p. 1213 y ss.

${ }^{132}$ Ibídem, p. 1251. Son ejemplos de este tipo de sistema los códigos civiles de Austria, Chile, Colombia, Ecuador, España y el de nuestro país. En Perú, es el sistema que rige para la transmisión de bienes muebles.

${ }^{133}$ Ibídem. Sistema que se inspira, según comenta el autor, en una interpretación particular de las fuentes romanas que fue tomada al momento al momento de sancionarse el BGB alemán.

${ }^{134}$ Ibídem, p. 1216. Es el sistema adoptado en el còde francés, la legislación italiana y portuguesa, y en Perú es el sistema que rige para la transmisión de los inmuebles.
} 
derechos reales que además del consentimiento necesita de la tradición ${ }^{135}$. Es decir: además del título es necesario el modo ${ }^{136}$. Sencillo resulta advertir en este esquema, que el modo tiene una doble función: una función publicitaria y una función constitutiva ${ }^{137}$. Desde otras perspectivas, Mariana Mariani de Vidal enseña que título suele ser la denominación común que se le adjudica a la escritura pública o al instrumento que formaliza el título suficiente ${ }^{138}$, aunque el mismo vocablo también cuente con variadas acepciones en el derecho ${ }^{139}$. Desde similares tendencias también se ubica el maestro tucumano Fernando López de Zavalía, quien especialmente considera la plurisignificación del vocablo título y la distinción entre títulonorma $^{140}$, títulos-negocio $^{141}$ y el título-instrumento ${ }^{142}$, todo sin dejar de recordar la novedosa propuesta que ha oportunamente presentado, significativa para comprender claramente la pluralidad de sistemas de adquisición de derechos reales que se adoptan en nuestro derecho ${ }^{143}$. Así se

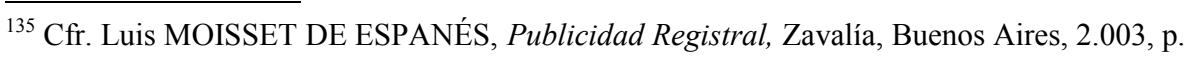
85.

${ }^{136}$ Ibídem.

${ }^{137}$ Ibídem. Explica el autor que este sistema encuentra su excepción en la hipoteca, en donde el modo es indudablemente la inscripción. Al analizar los efectos que produce el modo en la hipoteca, se puede advertir que mientras que para las partes y los terceros que concurrieron a suscribirla la misma produce efectos desde la celebración del acto, para los terceros se vuelve oponible desde la inscripción registral. Por ello se conviene en que Vélez quebrantó el sistema de constitución de los derechos reales con la hipoteca. En el mismo sentido, V. Marina MARIANI DE VIDAL, Curso de derechos reales..., $\mathrm{T}^{\circ} \mathrm{I}$, ob. cit., p. 90.

${ }^{138}$ Marina MARIANI DE VIDAL, Curso de derechos reales..., $\mathrm{t}^{\circ} \mathrm{I}$, ob. cit., p. 91

139 Cfr. Adriana Nélida ABELLA, Derecho inmobiliario registral, Zavalía, Buenos Aires, 2.009 , p. 23 y ss. Argumenta la autora que la palabra título es asimilable a la designación del negocio jurídico que contiene la causa mediata o única de adquisición; a la modificación o extinción de un derecho real; al hecho o acto jurídico que sirve de causa a la tradición, o a la designación del instrumento o documento en el cual se encuentra contenido el titulo-causa.

${ }^{140}$ Fernando LOPEZ DE ZAVALÍA, Derechos Reales, t $^{\circ}$ I, ob. cit., p. 264. Se refiere al que los modos son hechos jurídicos, y para que un hecho cobre relevancia en el mundo jurídico, precisa que una norma lo prevea como tal. A la relación de la norma con el modo se la denomina titulo-norma.

${ }^{141}$ Ibídem, p. 267. Se debe entender por títulos-negocio a los negocios jurídicos que sirven de causa.

${ }^{142}$ Ibídem, p. 269. Clasificación que cobra relevancia cuando es necesario conectarse con la institución registral, por cuando a los Registros ya sean constitutivos o declarativos únicamente llegan los actos instrumentados.

${ }^{143}$ Cfr. Fernando LOPEZ DE ZAVALÍA, Adquisición de derechos reales, en Carlos Gustavo VALLESPINOS (Dir.) y A.A.V.V, Cuestiones Esenciales en Derechos Reales, LexisNexis, Buenos Aires, 2.002, p. 64. 


\section{SEBASTIÁN JUSTO COSOLA}

refiere a la familia dilecta para referirse a la teoría del titulo y modo de Vélez (en reacción contra el consensualismo francés ${ }^{144}$ ); a la familia rebelde, que llamativamente recoge algo de ese criticado consensualismo mitigado francés en la cesión de derechos ${ }^{145} \mathrm{y}$ en el derecho real de hipoteca ${ }^{146}, \mathrm{y}$ finalmente a la familia adoptiva, que hija de las provincias, recepta la inscripción registral ${ }^{147}$.

En definitiva, puede estarse de acuerdo en sostener que título suficiente "es el acto jurídico muñido de las condiciones de fondo y de la forma en que cada caso resulte exigible y dotado por la ley de aptitud para transferir derechos reales ${ }^{148}$ ", y de acuerdo a lo afirmado, también pueden deducirse cada uno de los presupuestos que debe reunir el mencionado titulo para ser tal y así, poder cumplir con el cometido que según el derecho le sea correspondiente:

a) Acto jurídico con los alcances previstos en la legislación vigente $^{149}$;

\footnotetext{
${ }^{144}$ Ibídem.

${ }^{145}$ Ibídem, p. 65. En coherencia con la teoría del título y el modo, debería haberse previsto que la notificación fuera el modo, o sea considerar que antes de la notificación de la cesión, ningún derecho queda transmitido. Sin embargo en nuestro derecho, la cesión se traspasa por la sola prueba del consentimiento.

${ }^{146}$ Ibídem. La tradición de la cosa no puede funcionar en la hipoteca, porque es un derecho real de garantía sin desplazamiento. Advierte el genial autor que Vélez podría haber reemplazado la tradición por la inscripción, pero no lo hizo, estatuyendo un sistema híbrido: la hipoteca se constituye por el consentimiento y la inscripción es necesaria para la oponibilidad a ciertos terceros.

${ }^{147}$ Ibídem, p. 66. Teoría de los registros y análisis de la crítica de Vélez en las nota al art. 3203. Decía el codificador centenario en la parte final de la nota: “(...) En un país como el nuestro, donde el dominio de los inmuebles no tiene en la mayor parte de los casos títulos incontestables, la necesidad del registro público crearía un embarazo mas al crédito hipotecario. El mayor valor que vayan tomando los bienes territoriales, ira regularizando los titulos de propiedad, y puede llegar un día en que podamos aceptar la creación de los registros públicos. Hoy en las diversas Provincias de la República sería difícil encontrar personas capaces de llevar esos registros, y construir el catastro de las propiedades, y sus mil mutaciones por la división continua de los bienes raíces que causan las leyes de la sucesión, sin sujetar la propiedad a gravámenes que no corresponden a su valor para satisfacer los honorarios debidos por la inscripción o transcripción de los títulos de propiedad".

${ }_{148}$ Marina MARIANI DE VIDAL, Curso de derechos reales, $\mathrm{t}^{\circ} \mathrm{I}$, ob. cit., p. 90.

${ }^{149}$ Ibídem.
} 


\section{LOS EFECTOS DE LA PUBLICIDAD EN EL DOCUMENTO NOTARIAL}

b) Análisis de la capacidad del transmitente y del adquirente y análisis de la titularidad del derecho que se transmite;

c) Cumplimiento de las formalidades necesarias para la transmisión en bienes inmuebles y en determinadas cosas muebles, y

d) Aptitud legal determinada que otorga la posibilidad de transferencia de los derechos reales ${ }^{150}$.

El Código Civil y Comercial de La Nación presenta la temática en un artículo profuso $^{151}$. La extensión de los preceptos legales brinda espacio a un sinnúmero de interpretaciones que intentan acertar en el tratamiento del contenido de sus disposiciones. Así, para alcanzar la justa y precisa opinión ante una necesidad de argumentación, el planteo explicativo de un artículo de tamaña envergadura se torna una tarea difícil y compleja. Por ello es que mi propuesta se orienta a dividirlo en tópicos de importancia, como si fueran principios que emergieran naturalmente del precepto, a los fines de una adecuada -o tan siquiera, más adecuada- armonización de su contenido. Del artículo en referencia se deducen los siguientes tópicos:

a) La adquisición derivada por acto entre vivos de un derecho real requiere de la concurrencia de título y modo suficiente;

\footnotetext{
${ }^{150}$ Ibídem, p. 91. Similar orientación y descripción de presupuestos presenta la definición propuesta por los autores Papaño, Kiper, Dillon y Causse respectivamente: Ricardo J. PAPAÑO, Claudio M. KIPER, Gregorio A. DILLON y Jorge R. CAUSSE, Derecho Civil. Derechos Reales, $\mathrm{t}^{\circ} \mathrm{I}$, ob. cit., p. 38.

${ }^{151}$ Art. 1892 del CCCN: "Título y modos suficientes. La adquisición derivada por actos entre vivos de un derecho real requiere la concurrencia de título y modo suficientes. Se entiende por título suficiente el acto jurídico revestido de las formas establecidas por la ley, que tiene por finalidad transmitir o constituir el derecho real. La tradición posesoria es modo suficiente para transmitir o constituir derechos reales que se ejercen por la posesión. No es necesaria, cuando la cosa es tenida a nombre del propietario, y éste por un acto jurídico pasa el dominio de ella al que la poseía a su nombre, o cuando el que la poseía a nombre del propietario, principia a poseerla a nombre de otro. Tampoco es necesaria cuando el poseedor la transfiere a otro reservándose la tenencia y constituyéndose en poseedor a nombre del adquirente. La inscripción registral es modo suficiente para transmitir o constituir derechos reales sobre cosas registrables en los casos legalmente previstos; y sobre cosas no registrables, cuando el tipo del derecho asi lo requiera. El primer uso es modo suficiente de adquisición de la servidumbre positiva. Para que el título y el modo sean suficientes para adquirir un derecho real, sus otorgantes deben ser capaces y estar legitimados al efecto. A la adquisición por causa de muerte se le aplican las disposiciones del Libro Quinto".
} 


\section{SEBASTIÁN JUSTO COSOLA}

b) Es título suficiente el acto jurídico revestido con las formalidades legales, cuya finalidad es la transmisión o constitución del derecho real;

c) La tradición posesoria como modo suficiente únicamente es necesaria para transmitir o constituir derechos reales que se ejercen a través de la posesión ${ }^{152}$;

d) La inscripción registral será modo suficiente únicamente para poder transmitir o constituir derechos reales sobre cosas registrables en los casos previstos por la ley y sobre cosas no registrables cuando el tipo de derecho así lo requiera, $\mathrm{y}$

e) Para la conformación del título y modo suficientes debe tenerse especialmente en cuenta la capacidad y la legitimación de sus otorgantes ${ }^{153}$.

Como actualmente se sostiene, no hay innovación en los preceptos aludidos, salvo por las cuestiones eminentemente metodológicas ${ }^{154}$. En la nueva normativa entonces, titulo suficiente es el acto jurídico que reúne los requisitos de fondo y formales para transmitir el derecho real ${ }^{155}$, lo que

${ }^{152}$ Aquí se continúa explicando que no es necesaria la tradición para los casos de traditio brevi manu y constituto posesorio.

${ }^{153}$ Destaquemos además que en el artículo en estudio existen otros tópicos de tratamiento, parcialmente ajenos al tema que ocupa mi atención, como los que se refieren al primer uso como modo suficiente para la adquisición de la servidumbre positiva, y la mención a la adquisición por causa de muerte a la que se le aplicarán las disposiciones del libro pertinente.

154 Cfr. Lilian N. GURFINKEL DE WENDY, Adquisición, transmisión, extinción y oponibilidad, en Julio César RIVERA- Graciela MEDINA (Dir.), Mariano ESPER (Coord.), Código Civil y Comercial de La Nación Comentado, t ${ }^{\circ}$ V, La Ley, Buenos Aires, 2.014, p. 232. Sin embargo, la autora se inclina por considerar que se ha perdido una notable oportunidad para cambiar el sistema de publicidad posesoria a la que opina que debe considerarse, en los tiempos actuales, como insuficiente. Para la misma, se ha perdido la oportunidad de conformar un régimen de adquisición y transmisión de derechos reales más moderno, ágil, transparente y de mayor facilidad para la prueba, ya que advierte que la complejidad de los negocios jurídicos y la celeridad propia de ellos vuelven a la publicidad posesoria como insuficiente para la enorme función que tiene asignada. Y afirma: " $\mathrm{La}$ publicidad registral brinda, precisamente, esa posibilidad: que toda persona interesada conozca el tipo y extensión de los derechos reales a que está sometido un inmueble (...) De haberse adoptado un sistema de publicidad registral constitutivo de derechos reales, esto es: reemplazar la tradición por la inscripción en el registro respectivo como modo suficiente, se habrían evitado muchos conflictos hoy existentes".

${ }^{155}$ Ibídem. 
LOS EFECTOS DE LA PUBLICIDAD EN EL DOCUMENTO NOTARIAL

evidencia la vinculación entre los contratos y los derechos reales ya que la referencia al título hace alusión no solo a la forma sino al documento portante del mencionado acto jurídico ${ }^{156}$. Y modo suficiente es el que unido al título suficiente hace adquirir tanto el dominio como los derechos reales que se ejercen por la posesión ${ }^{157}$, en un acto jurídico bilateral mediante el cual el tradens desplaza idealmente el inmueble y lo coloca en cabeza del accipiens, quien lo recibe de conformidad, y que además también supone la capacidad y legitimación de las partes ${ }^{158}$.

La vinculación entre el derecho de los contratos y los derechos reales, si bien más frecuente que infrecuente, encuentra una de sus máximas expresiones de certeza en su unión, como bloque, dentro del esquema que plantea el documento notarial. La tutela del principio de legalidad notarial -omnicomprensivo de reglas, normas y principios-, resulta ser esencial para configurar una de las máximas expresiones posibles previstas por los ordenamientos jurídicos de seguridad jurídica en su faz preventiva, teniendo en cuenta que la argumentación notarial del derecho debe encaminarse en la actualidad a relacionar temas de derechos reales tan emparentados con las legislaciones positivas, como temas del derecho de los contratos tan cercanos a los principios generales del derecho como los que ordena seguir, a modo de ejemplo, las reglas de Unidroit ${ }^{159}$. En definitiva, como bien se desprende de los fundamentos de la comisión redactora del entonces Anteproyecto del Código Civil y Comercial de la Nación, es la "esencia de la función notarial...la de brindar protección a los ciudadanos en los actos y negocios de máxima trascendencia ${ }^{160}$ ".

\footnotetext{
${ }^{156}$ Ibídem, p. 233.

${ }^{157}$ Ibídem.

${ }^{158}$ Ibídem.

${ }^{159}$ Cfr. Eduardo GALLINO, Introducción a los principios de Unidroit para los contratos del comercio internacional, en Ana Raquel NUTA (Dir.) y Julieta GALLINO (Coord.), Tratado de Derecho Privado Notarial, Ad Hoc, Buenos Aires, 2.006, págs. 243-266.

160 Cfr. Ricardo Luis LORENZETTI, Elena HIGHTON de NOLASCO y Aída KEMELMAJER de CARLUCCI, Código Civil y Comercial de la Nación. Proyecto del Poder Ejecutivo de La Nación redactado por la Comisión de reformas designada por decreto 191/2011, Rubinzal Culzoni, Santa Fe, 2.012, p. 543.
} 


\section{SEBASTIÁN JUSTO COSOLA}

\subsubsection{El planteo del modo suficiente (tradición) y de sus}

excepciones.

Como oportunamente también se viene refiriendo, si bien la tradición material es un requisito necesario para el nacimiento del derecho real ${ }^{161}$, hablar de la teoría del título y modo implica de alguna manera vincularla con la tradición como modo de adquirir el dominio ${ }^{162}$. Es que en nuestro derecho la tradición tiene varias funciones ${ }^{163}$, entre ellas $-\mathrm{y}$ nuevamente reitero-, la ser un requisito constitutivo de los derechos reales que se ejercen por la posesión o que necesitan de actos posesorios y además, ser uno de los modos de la adquisición de la posesión ${ }^{164}$. En sentido lato, la tradición consiste en poner a alguien en posesión de una cosa, mientras que en el estricto sentido, se entiende la entrega de una cosa hecha por el propietario a otra persona con la intención de que ésta ocupe su lugar ${ }^{165}$. Al referirse al significado de la tradición, se enseña que la misma tiene una especie de doble carácter: es constitutiva de los derechos reales y es eficiente como medio de publicidad ${ }^{166}$. Ya el maestro Allende enseñaba que la tradición es la publicidad por excelencia adoptada en el Código de Vélez, tanto para muebles como para inmuebles, ya que su función es esencialmente constitutiva $^{167}$. El concepto-definición de la tradición en el código velezano $^{168}$, al decir que habrá tradición cuando una de las partes entregare voluntariamente una cosa, y la otra voluntariamente la recibiese ${ }^{169}$ era claro

${ }^{161}$ Cfr. Marcelo R. QUATROMANO, Tradición y consenso como modos diferentes de adquirir el dominio. El sistema de la tradición en la Argentina y sus excepciones, ED 212923.

${ }^{162}$ Carlos Mario CLERC, El derecho de dominio y sus modos de adquisición, ob. cit., p. 121.

${ }^{163}$ Cfr. Marcela H. TRANCHINI, María M. BUSTINGORRI, Jorge B. MARRUPE y Marcelo N. FALBO, Tradición, posesión y registro, RN nº 891, La Plata, 1.987, p. 19.

${ }^{164}$ Ibídem.

${ }^{165}$ Cfr. Luis A. PEÑA GUZMÁN, Curso de Derecho Privado Romano. Derechos Reales, Talleres Gráficos Miguel Violetto S.R.L, Tucumán, 1.952, p. 139.

${ }^{166}$ Marina MARIANI DE VIDAL, Curso de derechos reales, $\mathrm{t}^{\circ} \mathrm{I}$, ob. cit., p. 90.

${ }^{167}$ Guillermo L. ALLENDE, Panorama de derechos reales, ob. cit., p. 221.

${ }^{168}$ Ibídem.

${ }^{169}$ Art. 2377 CCA: "La posesión se adquiere también por la tradición de las cosas. Habrá tradición, cuando una de las partes entregare voluntariamente una cosa, y la otra voluntariamente la recibiese". 
y contundente para advertir que la tradición es un acto jurídico real ${ }^{170}, \mathrm{y}$ como tal, encuentra asidero en el estudio de la causa de los derechos reales, porque la tradición opera como requisito constitutivo del derecho real ${ }^{171}$. En el Código Civil y Comercial de La Nación, la tradición se refiere a la entrega de una cosa desde una parte hacia otra que la recibe, y consiste en la realización de actos materiales de al menos una de ellas, que otorgan un poder de hecho sobre esa cosa, que no se suplen frente a terceros por la mera declaración de quien da o de quien recibe ${ }^{172}$. De esta manera, el tema traditivo se erige como de enorme importancia para el ejercicio del derecho documental.

De la lectura de la tesis doctoral de Beatríz Areán puede concluirse que la tradición es un dar especial, porque comporta un desplazamiento material pero al mismo tiempo opera un efecto ideal de trasladar y transmitir ${ }^{173}$. El hecho material de la entrega de la cosa es en sí mismo un hecho incoloro y equívoco $^{174}$, ya que en efecto puede entregarse una cosa a una persona para que la posea por si (transmisión de la posesión) o para que la posea a nuestro nombre (transmisión de la tenencia); también puede transmitirse la posesión precedida de un acto jurídico que tenga como fin la traslación del dominio (tradición traslativa del dominio propiamente) o constitución de usufructo o prenda (tradición constitutiva de derechos reales sobre cosa ajena ejercibles por la posesión $)^{175}$. Así, pueden existir casos de entrega de la cosa que correspondan a circunstancias sobrevinientes que obliguen al que la obtiene

\footnotetext{
${ }^{170}$ Guillermo L. ALLENDE, Panorama de derechos reales, ob. cit., p. 223.

${ }^{171}$ Edmundo GATTI, Derechos Reales, ob. cit., p. 246. Es esta la manera que encuentra justificación para poder distinguirla entonces de la tradición como modo derivado de adquisición de la posesión que no es ni acto ni hecho jurídico real. De ahí es que también se deduzca este doble sistema de la causa, referido a la causa fuente (adquisición que se identifica con el título) y la causa eficiente (tradición). V. también Lilian N. GURFINKEL DE WENDY, Adquisición, transmisión, extinción y oponibilidad, ob. cit., p. 231.

${ }^{172}$ Art. 1924 CCCN.

${ }^{173}$ Cfr. Beatriz Alicia AREÁN, La tradición y sus distintas funciones en el campo de los derechos reales y de las relaciones posesorias (TD), Biblioteca de la Facultad de Derecho de la Universidad de Buenos Aires, $\mathrm{n}^{\circ}$ topográfico 252.343/1981, p. 9. Desde aquí que jurídicamente se considere que se está en presencia de la tradición cuando ocurre el traspaso de la posesión de una cosa, hecho por un sujeto tradens a favor de otro sujeto accipiens, con la finalidad de transmitirle algún derecho sobre esa misma cosa.

${ }^{174}$ Ibídem.

${ }^{175}$ Ibídem.
} 


\section{SEBASTIÁN JUSTO COSOLA}

por cualquier titulo a restituirla a quien lo hacía antes él, dando lugar a la denominada tradición restitutiva del dominio ${ }^{176}$. Todo esto hace pensar que existen variadas funciones de la tradición, y que la misma siempre supone un acto previo por el cual se ha creado la obligación de entregar la cosa, obligación que se extingue cuando la entrega efectivamente se produce ${ }^{177}$.

Desde el notariado, sobresale la caracterización que realiza Miguel Falbo ${ }^{178}$. El autor considera a la traditio como entrega, siempre referida al hecho físico, pero que además en el derecho conforma un requisito impuesto por la ley, de realización voluntaria, que causa efectos en relación al ciclo de transmisión de la titularidad de los derechos reales derivativos, dándole a los mismos la debida publicidad para que la titularidad sea finalmente oponible erga omnes $^{179}$. La tradición es para Falbo un acto que se realiza con la intención de integrar al negocio transmisivo, y que se cumple en un determinado momento ya sea mediante el hecho físico de su entrega material, o también por actos fictos a los que se les atribuye igual resultado, siempre con eficacia para las partes y para los terceros ${ }^{180}$. Para completar esta fantástica ecuación, bastará decir que para que la tradición tenga por efecto provocar el desplazamiento de la propiedad de las cosas del transmitente hacia el adquirente, será necesario que la misma se efectúe con base en un título suficiente ${ }^{181}$. En definitiva, "el cumplimiento de la tradición no se publicita por vía registral, sino por la posesión que se

\footnotetext{
${ }^{176}$ Ibídem, p. 10.

${ }^{177}$ Ibídem. En especial, deben tenerse presentes las palabras de la autora: "la tradición es siempre traspaso de la posesión o, en su caso, de la tenencia, pero si conjuntamente con el acto que ella implica, concurre un segundo acto jurídico que es título suficiente para transferir el dominio o para constituir otro derecho real, celebrado también entre el tradens y el accipiens, con plena capacidad de ambos y legitimación del primero, la tradición ya no solo hará adquirir la posesión, sino que también operará la transmisión del dominio u otro derecho real".

${ }^{178}$ Cfr. Miguel Norberto FALBO, La inscripción registral y sus efectos, en Cristina Noemí ARMELLA (Dir.) y Mariano ESPER (Invest.), Summa notarial, registral e inmobiliaria, $\mathrm{t}^{\circ} \mathrm{I}$, ob. cit., p. 1272.

${ }^{179}$ Ibídem.

${ }^{180}$ Ibídem. En sintonía, las conclusiones de las XXVI Jornadas Notariales Bonaerenses han puesto énfasis en destacar que el principal modo de adquisición de la posesión requiere el cumplimiento del acto jurídico bilateral y formal de la tradición, que se concreta cuando el tradens entrega la cosa y el accipiens la recibe Cfr. Norma Elena CIURO DE CASTELLO y Laura GARATE (Compil.), Jornada Notarial Bonaerense. Colegio de Escribanos de la Provincia de Buenos Aires, FEN, La Plata, 2.007, p. 233.
} 


\section{LOS EFECTOS DE LA PUBLICIDAD EN EL DOCUMENTO NOTARIAL}

establece como consecuencia de ella y por una serie de presunciones legales $^{182, "}$.

De esta manera, la tradición es la causa inmediata de la adquisición del derecho real por actos entre vivos, es decir, la entrega voluntaria del inmueble que se cumple con las solemnidades legales ${ }^{183}$, debiéndose cumplir con tres requisitos esenciales:

a) La misma debe ser hecha por el propietario de la cosa,

b) Deben estar determinadas las capacidades de las partes y,

c) Debe ser realizada por título suficiente para poder así transferir el dominio ${ }^{184}$.

Según la opinión de Jorge Alterini, la tradición destaca además su importancia en dos perfiles relevantes: uno positivo, ya que antes de ella no hay relación directa con la cosa, y uno negativo, que reconoce que al exigirse la posesión se tutelan los fenómenos posesorios ${ }^{185}$. De ahí que con razón se afirme que la tradición, analizada desde el modo suficiente, se conforme desde tres casos especiales: la posesoria ya analizada; la registral, únicamente para los casos previstos, y la del primer uso, reservado para la servidumbre positiva ${ }^{186}$.

Debe concluirse entonces que la figura de la tradición se erige como una norma general por excelencia y cardinal en materia de adquisición de los

\footnotetext{
${ }^{181}$ Cfr. Ricardo Javier SAUCEDO, Los límites de la calificación registral respecto de los titulos que provocan mutaciones reales inmobiliarias, en Cristina Noemí ARMELLA (Dir.) y Mariano ESPER (Invest.), Summa notarial, registral e inmobiliaria, t ${ }^{\circ}$ I, ob. cit., p. 1352.

${ }^{182}$ Cfr. Zulma Aurora DODDA y Marcelo Eduardo URBANEJA, Principio de inscripción. Rogación. Documento inscribible. Publicidad previa y sus efectos en la seguridad jurídica, RN 956, La Plata, 2.007, p. 3.

${ }^{183}$ Adriana Nélida ABELLA, Derecho inmobiliario registral, ob. cit., p. 25.

${ }^{184}$ Ibídem.

${ }^{185}$ Cfr. Jorge Horacio ALTERINI, Seguridad jurídica con costos razonables, fortaleza del régimen jurídico inmobiliario argentino, Reunión Plenaria de la Comisión de Asuntos Americanos de La UIN, Mar del Plata, 2.005, p. 9 y ss. Cuadernillo de la UNA- El Crédito Inmobiliario Hipotecario, Biblioteca Central del COLESCBA.

${ }^{186}$ Cfr. Karina V. SALIERNO, La adquisición legal del derecho real del subadquirente de buena fe y la trascendencia del estudio de títulos, $\mathrm{RN} \mathrm{n}^{\circ}$ 978, La Plata, 2.014, p. 879.
} 


\section{SEBASTIÁN JUSTO COSOLA}

derechos reales ${ }^{187}$. Sin embargo, el reconocimiento que ordena aceptar que antes de la tradición de la cosa el acreedor no adquiere sobre ella ningún derecho real reconoce las excepciones de los casos de traditio brevi manu y el constituto posesorio. Es que la tradición reconoce dos elementos característicos que son la voluntad coincidente de las partes de transmitir y adquirir la posesión (lo que supone la capacidad y el consentimiento) y la entrega efectiva de la cosa (exigencia de la presencia de las partes, cosa poseída por el transmitente y realización de actos materiales ${ }^{188}$ ); por ello, tanto la traditio brevi manu (perfección del acto jurídico en donde el tenedor se eleva a la categoría de poseedor, y perfección del acto jurídico que luego de notificado al tenedor, éste comienza a poseer a nombre de quien haya resultado nuevo poseedor ${ }^{189}$ ) como el constituto posesorio (poseedor que transmite a otro la posesión pero queda como tenedor de la $\operatorname{cosa}^{190}$ ) operan como excepción. Esto es así precisamente porque la tradición tiende a investir el poder sobre la cosa, y en razón de ello, la misma es innecesaria cuando la mismísima relación real puede establecerse sin ningún tipo de desplazamientos ${ }^{191}$. En acertada apreciación, el modo tradición puede ser reemplazado por sus sucedáneos, la traditio brevi manu y el constituto posesorio, que son los casos en donde continúa respetándose la teoría del título y modo ${ }^{192}$.

\footnotetext{
${ }^{187}$ Marina MARIANI DE VIDAL, Curso de derechos reales, ${ }^{\circ}$ I, ob. cit., p. 89.

${ }^{188}$ Marcela H. TRANCHINI, María M. BUSTINGORRI, Jorge B. MARRUPE y Marcelo N. FALBO, Tradición, posesión y registro, ob. cit., p. 20. Sin embargo esta doctrina advierte de las excepciones posibles de cuando la presencia de las partes no es necesaria, como por ejemplo la entrega de llaves de un lugar que basta para la tradición de las mercaderías que allí se guardan, entre otros.

${ }^{189}$ Marina MARIANI DE VIDAL, Curso de derechos reales, T ${ }^{\circ}$ I, ob. cit., p. 159. También se incluye dentro de este supuesto la denominada traditio per indicationem, que es la que ocurre cuando el locatario se encuentra ocupando el inmueble, y el propietario se lo enajena a otro; en este caso, solo basta que se notifique a este 'tenedor' que en adelante en vez de poseer para el primer propietario lo hará para el segundo.

${ }^{190}$ Ibídem, p. 161.

${ }^{191}$ Cfr. Jorge Horacio ALTERINI, Gravitación de la reforma al artículo 2505 del Código Civil (Con especial referencia a las proyecciones de la tradición y al concepto de terceros), ED to 43 , Buenos Aires, 1.972, p. 1188.

${ }^{192}$ Cfr. Marcelo Eduardo URBANEJA, Tradición, "constituto posesorio", "traditio brevi manu" e inmueble ocupado por un tercero: su reflejo escriturario, $\mathrm{RN} \mathrm{n}^{\circ}$ 957, La Plata, 2.007, p. 766.
} 
LOS EFECTOS DE LA PUBLICIDAD EN EL DOCUMENTO NOTARIAL

\subsection{Las posiciones esgrimidas hacia la defensa del sistema traditivo y del inscriptorio respectivo.}

Expuesto el tema de la cuestión de la tradición o de la inscripción para que las mismas, conjuntamente con el titulo suficiente operen como necesarias para el nacimiento del derecho real, queda entonces por exponer de manera clara y contundente, cuales son los argumentos que esgrimen los juristas para realizar las defensas de uno u otro sistema de adquisición de los derechos reales. En efecto, no debe dejar de recordarse que ya Guillermo Borda se encontraba frente a la posibilidad de conformar un sistema constitutivo de los derechos reales al momento de efectuar la más trascendente reforma que ha tenido, hace ya más de cuarenta y cinco años, el Código Civil de Vélez Sarsfield ${ }^{193}$. Por aquellos entonces, en el momento de explicar la trascendencia de la reforma en razón de haberse impuesto el artículo específico que ordenaba que la adquisición o transmisión de los derechos reales solamente se juzgará perfeccionada mediante la inscripción de los respectivos títulos en los registros inmobiliarios de la jurisdicción que corresponda y que las mismas no serán oponibles a terceros mientras no estén registradas ${ }^{194}$, el notable civilista aclaraba que si bien se enfrentaba a un tema discutible, la comisión reformadora había optado por mantener la tradición teniendo en cuenta algunas razones de indudable importancia, entre ellas:

a) La que demuestra que la supresión de la tradición traería un gran impacto en la estructura de los derechos reales ${ }^{195}$;

\footnotetext{
${ }^{193}$ Cfr. Guillermo A. BORDA, La reforma de 1968 al Código Civil, Perrot, Buenos Aires, 1.971, p. 376.

${ }^{194}$ Art. 2505 CCA según Ley 17711/68: "La adquisición o transmisión de derechos reales sobre inmuebles, solamente se juzgará perfeccionada mediante la inscripción de los respectivos títulos en los registros inmobiliarios de la jurisdicción que corresponda. Esas adquisiciones o transmisiones no serán oponibles a terceros mientras no estén registradas".

${ }^{195}$ Guillermo A BORDA, La reforma de 1968..., ob. cit., p. 377.
} 


\section{SEBASTIÁN JUSTO COSOLA}

b) La que eleva a la tradición como garantía de la seriedad de los actos de trasmisión de dominio evitando la realización de actos a espaldas del poseedor, impidiendo así, en casos especiales, maniobras de vendedores poco escrupulosos ${ }^{196}, \mathrm{y}$

c) La que la presenta como un instituto de protección de los adquirentes de buena fe, no habiéndose advertido hasta esos tiempos que el sistema traditorio vigente durante largos años haya producido algún efecto disvalioso o inconvenientes que anunciaban los contrarios al mencionado sistema ${ }^{197}$.

Por ello, aclara que a partir de la reforma mencionada, la inscripción en el registro no tenía carácter constitutivo, sino declaratorio ${ }^{198}$, conformando una sólida estructura de los derechos reales que a partir de la sanción del artículo pertinente ya citado, ordena que la transmisión no será oponible a terceros mientras no esté registrada, aunque la misma tenga valor entre las partes, descartándose de plano y absolutamente, la inscripción constitutiva ${ }^{199}$. En aquella oportunidad, también complementaba esta afirmación el apoyo del articulado de la ley de Registro de la Propiedad Inmueble, que establecía -y actualmente establece- que las partes, sus herederos y los que intervienen en la formalización del documento incluidos el notario y los testigos, no pueden prevalerse de la falta de inscripción y respecto de ellos el derecho que se ha documentado se considerará registrado ${ }^{200}$. En definitiva, no quedan dudas que "El derecho nace con la tradición y la escritura, pero no es oponible a terceros mientras no esté inscripto ${ }^{201}$ ".

Desde otra vertiente totalmente diferente, Alberto Spota explicaba que durante muchos años nuestro país vivió con un Código Civil que ordenaba el requisito de la escritura pública y de la tradición como modo de constitución de los derechos reales mediante actos jurídicos entre vivos, con

\footnotetext{
${ }^{196}$ Ibídem.

${ }^{197}$ Ibídem.

${ }^{198}$ Ibídem, p. 378.

${ }^{199}$ Ibídem.

${ }^{200}$ Cfr. Art. 20 Ley 17801/68.

${ }^{201}$ Guillermo A. BORDA, La reforma de 1968 al Código Civil, ob. cit., p. 378.
} 


\section{LOS EFECTOS DE LA PUBLICIDAD EN EL DOCUMENTO NOTARIAL}

la excepción de la hipoteca y por extensión, de la anticresis ${ }^{202}$. Esta aseveración se justificaba en los artículos específicos del derogado Código, como el ya citado referido a la tradición y con la interpretación del artículo -también ya citado- que en materia de dominio advertía que se perdía igualmente el dominio por enajenación de la cosa inmueble después de firmado el instrumento público de enajenación seguido de la tradición ${ }^{203}$. Esto respondía al principio que ordenaba que nadie puede transmitir un derecho mejor del que lo posee, y consecuentemente, nadie puede recibir un derecho mejor del que lo gozaba anteriormente ${ }^{204}$, principio general del derecho que continua en plena vigencia. El civilista también se refería al alcance de la expresión relativa a la perfección del título, impuesta por la reforma de $1968^{205}$. Advertía entonces que la mencionada reforma se inclinaba por un sistema intermedio, que no es del todo completo, pero que es superior al establecido originariamente por Vélez Sarsfield ${ }^{206}$, ya que es un sistema que prevé la inscripción pero la misma no bonifica al título ${ }^{207}$, siendo no convalidante, pudiendo únicamente obtenerse la bonificación referida de aquel que adquiere sobre una base de una apariencia y demostrando su buena fe, adquiriendo a título oneroso $\mathrm{o}^{208}$. Sobre la inscripción registral entonces se encuentra amparada la buena fe propia del registro: "creer en lo que surge de un acto estatal", dice Spota ${ }^{209}$.

El sistema entonces es intermedio, porque el dominio se adquiere frente al enajenante, al autorizante y a los que intervienen en el acto por la escritura y la tradición ${ }^{210}$, mientras que para los terceros les resultará oponible a partir

${ }^{202}$ Cfr. Alberto Gaspar SPOTA, Curso sobre temas de derecho civil, IACN, Buenos Aires, 1.971, p. 242. El autor recuerda la polémica suscitada con los Registros de la Propiedad creados por las provincias.

203 Art. 2.609 CCA in fine.

204 Art. 3.270 CCA: "Nadie puede transmitir a otro sobre un objeto, un derecho mejor o más extenso que el que gozaba; y reciprocamente, nadie puede adquirir sobre un objeto un derecho mejor y más extenso que el que tenía aquel de quien lo adquiere".

${ }^{205}$ Alberto Gaspar SPOTA, Curso sobre temas de derecho civil, ob. cit., p. 248.

${ }^{206}$ Ibídem.

${ }^{207}$ Ibídem.

${ }^{208}$ Ibídem.

${ }^{209}$ Ibídem. Este concepto desarrollado en el estudio en referencia, no puede ser aplicable en la actualidad, por cuanto la buena fe creencia no ampara de ninguna manera al adquirente que para defender su derecho, deberá invocar el ejercicio de la buena fe diligencia.

${ }^{210}$ Alberto Gaspar SPOTA, Curso sobre temas de derecho civil, ob. cit., p. 248. 


\section{SEBASTIÁN JUSTO COSOLA}

de la inscripción ${ }^{211}$. Pero el profesor de derecho civil se cuestiona lo siguiente: ¿Por qué conservamos la tradición? Si tenemos escritura pública e inscripción en el registro, ¿a qué viene la tradición? ${ }^{212}$. Reconoce que si bien la misma es un instituto antiguo, propio de la arqueología jurídica, no es unívoca $^{213}$. Puede haber tradición al transferir la mera tenencia, comprendiendo la posesión inmediata, convirtiéndose el tenedor en poseedor inmediato, como el caso del arrendamiento: el arrendatario es el poseedor inmediato, el propietario arrendador el poseedor mediato, y los dependientes del arrendatario como servidores de la posesión ${ }^{214}$. En este esquema, el tercero se presenta frente a hechos equívocos, porque no sabe si a quien se llama poseedor inmediato es el arrendatario, el dueño, o un huésped o dependiente $\mathrm{e}^{215}$. Sumado a esto, la inscripción en el registro no es autosuficiente, lo que genera del sistema traditivo pueda inclusive trasladar algo equívoco ${ }^{216}$. El autor entonces se inclinaba por un sistema inmobiliario que reconozca base en dos elementos indispensables: la escritura pública y la inscripción, dejando para la tradición algunos supuestos de relevancia ${ }^{217}$. En sus propias palabras: "insisto, pues, en que un buen sistema inmobiliario tiene que estar regido sobre la base de la inscripción y del acto notarial exclusivamente $218, "$

Ya en el fin, el autor agrega que para que el dominio y los derechos reales sobre inmuebles presenten la eficacia frente a terceros se debe requerir -por cuanto la inscripción no purifica el título-, escritura pública, tradición, inscripción inmobiliaria y para algunos, justo titulo ${ }^{219}$, recordando que lo que la ley quiere, más que justo título, es apariencia de justo título, esto es,

\footnotetext{
${ }^{211}$ Ibídem, p. 249.

${ }^{212}$ Ibídem.

${ }^{213}$ Ídem, p. 250

${ }^{214}$ Ibídem. Este caso se fundamenta en la importancia de las acciones posesorias, conferidas al arrendatario que no tiene animus domini pero tiene las acciones mencionadas.

${ }^{215}$ Ibídem.

${ }^{216}$ Ibídem, p. 251.

${ }^{217}$ Ibídem. Por ejemplo, el caso en donde el esposo constituye una hipoteca sobre el bien que es sede del hogar conyugal o que vende el bien no siendo notificada la esposa y los hijos de esas operaciones, para que un buen día apareciera el acreedor hipotecario pretendiendo ejecutar el crédito o el comprador por boleto sosteniendo que se le había transmitido la posesión habiendo mediado tradición.

${ }^{218}$ Ídem, p. 252.

${ }^{219}$ Ibídem.
} 
que haya un justo titulo aparente, aunque no real, existiendo buena fe creencia y onerosidad, para que se convalide la constitución o transmisión del derecho real a través de la institución del tercer adquirente de buena fe y de la teoría de la apariencia ${ }^{220}$. Como ya he referido, esta posición en los tiempos actuales es de aplicación al menos dudosa, en razón de no establecerse el principio de la buena fe diligencia requerido para este tipo de acciones.

En sentido similar al argumentado por Alberto Spota, pero advirtiendo que lo que el Registro inscribe es el acto -y no el título- se expide, en defensa del sistema inscriptorio, Nelson López del Carril, para quien la inscripción debe ser un requisito del acto, porque viene a garantizar su existencia ${ }^{221}$, razón por la cual ni siquiera es adecuada la referencia a la perfección de la tradición con la inscripción en el Registro, ya que la misma requiere que sea cumplida y no meramente perfeccionada ${ }^{222}$.

Finalmente, no deben dejar de destacarse las conclusiones de las XXIII Jornadas Nacionales de Derecho Civil celebradas mucho más recientemente en San Miguel de Tucumán ${ }^{223}$. Allí se ha considerado de manera firme y decisoria, el valor de la tradición posesoria como modo de constitución de los derechos reales frente a las posibles ventajas que en el mundo moderno pueda promover el modo inscriptorio. Recordemos que en los fundamentos

\footnotetext{
${ }^{220}$ Ibídem, p. 253. En especial, plantea una posición que une tres preceptos del Código Civil de Vélez, referidos a los efectos de la trasmisión inmobiliaria frente a terceros; al amparo que surge al tercer contratante de buena fe a titulo oneroso y finalmente a la apariencia jurídica. Sobre esta idea, mas adelante afirmará: "Ese es el precio que hay que pagar en aras de la seguridad jurídica (...). La ley que organizó el Registro de la Propiedad no ha hecho más que establecer corolarios. Ese articulo 2505 fue suficiente para sembrar a manos llenas seguridad, siempre que apliquemos ese precepto concatenado con el artículo 1051 y, en su caso, con el 3430. He dicho que, a mi juicio, rige todo este sistema nuevo a pesar de un delito, a pesar de un crimen, a pesar que haya sustitución del verdadero titular, a pesar de que la apariencia jurídica haya sido fruto de una estafa, de una defraudación, de una adulteración, de un instrumento falso (...) (En ocasiones) es duro para los legítimos dueños de los bienes relictos, que se ven desamparados por el Estado para que los adquirentes tengan seguridad. Quizás el desorden debiera cubrirse con un seguro estatal, pero lo que nunca debe atacarse es la seguridad en la adquisición inmobiliaria".

${ }^{221}$ Cfr. Nelson J. LÓPEZ DEL CARRIL, Publicidad de los derechos reales, Depalma, Buenos Aires, 1.965, p. 78.

${ }^{222}$ Ídem, p. 83.

${ }^{223} \mathrm{http} / / /$ jndcbahiablanca2015.com/wp-content/uploads/2014/02/Ed-anteriores-27-XXIIIJornadas-2011.pdf (Ultimo Acceso: 13/08/2017).
} 


\section{SEBASTIÁN JUSTO COSOLA}

del entonces anteproyecto de Código Civil y Comercial de la Nación, la comisión redactora encargada de su elaboración exponía con énfasis que un sistema de constitución de derechos reales debía fundamentarse en un modo suficiente constitutivo de derechos que ya no exija la tradición posesoria sino la inscripción registral como fundamento del alcance de la máxima seguridad. Se citaban allí entonces todos los antecedentes de reformas anteriores que intentaron sustituir el modo traditivo por el modo inscriptorio, los que se hace verdadera mención y alusión ${ }^{224}$. Las mencionadas jornadas realizadas en la Universidad Nacional de Tucumán ${ }^{225}$ originaron conclusiones trascendentes, de severa crítica a la posibilidad de conformación de un nuevo régimen constitutivo de los derechos reales, en defensa de las tradiciones, las costumbres, el modo de ser y la seguridad que desde hace tiempo viene estableciéndose a través del sistema declarativo registral, que reconoce el nacimiento del derecho real fuera del registro, a través de la ya analizada teoría del título suficiente y del modo suficiente. De esta manera, en el tema referido al régimen de adquisición de los derechos reales inmobiliarios que se ejercen por la posesión, las declaraciones del despacho de la mayoría ${ }^{226}$ fueron más que elocuentes: "La adopción de un

\footnotetext{
${ }^{224}$ Sin embargo, la comisión creadora del proyecto de Código Civil y Comercial que con algunas modificaciones finalmente fuera aprobado en el cuerpo que hoy rige el derecho privado argentino unificado, se inclinó por seguir manteniendo un sistema de inscripción declarativo, con las siguientes palabras: "En un primer momento, la comisión pensó en actualizar y tecnificar el sistema, sobre el criterio de sustituir la tradición posesoria por la inscripción registral como modo suficiente para los bienes registrables y abandonar la milenaria teoría del título y el modo del sistema romano puro como pilar del sistema transmisivo entre vivos de los derechos reales que se ejercen por la posesión (...) Sin embargo, a pedido de escribanos y registradores, con invocación en la falta de preparación de los registros para tal modificación, el anteproyecto mantiene el sistema vigente en el cual la inscripción constitutiva solamente se incluye como excepción para la adquisición, transmisión, etcétera, de ciertos objetos (por ejemplo, automotores), mas no para todas las cosas cuyo dominio es registrable, especialmente los inmuebles para los cuales mantiene la tradición posesoria como modo suficiente". Y seguidamente continúa: "Ello demuestra la disposición de la comisión para redactar un código que satisfaga los intereses de la comunidad sin hacer prevalecer ideas propias sobre las necesidades de la población". v. Ricardo Luis LORENZETTI, Elena HIGHTON DE NOLASCO y Aída KEMELMAJER DE CARLUCCI, Código Civil y Comercial de la Nación, Proyecto del Poder Ejecutivo de la Nación ..., ob. cit., p. 679 y ss.

${ }^{225}$ Las jornadas se realizaron en el año 2.011, año de elaboración y presentación del entonces anteproyecto de Código Civil y Comercial de la Nación, hoy Código Civil y Comercial aprobado según ley 26.994/2014.

${ }^{226}$ Obtuvo 40 votos.
} 
LOS EFECTOS DE LA PUBLICIDAD EN EL DOCUMENTO NOTARIAL

sistema registral inmobiliario con efectos constitutivos significa un retroceso en la dinámica adquisitiva de los derechos reales. La inscripción constitutiva no responde ni atiende a la realidad de los hechos, desprotege a los poseedores y ello repercute negativamente en la seguridad jurídica tanto dinámica como estática ${ }^{227}$. $\mathrm{Y}$ de ahí, surge una propuesta de agregado de cuatro puntos, que operan básicamente como principios consolidados del régimen de adquisición de los derechos reales en nuestro medio, propuesto por la mayoría:

a) Una futura reforma del Código Civil debe mantener la coexistencia de las publicidades posesoria, cartular y registral;

b) La protección de los intereses legítimos de los poseedores hace aconsejable la conservación de la tradición material como constitutiva del derecho real inmobiliario;

c) El registro debe continuar cumpliendo su función de registración de títulos, con carácter meramente declarativo y no convalidante, y

d) La mutación a un sistema de registración constitutiva que desplace a la tradición material tendrá consecuencias perjudiciales para distintos actores sociales ${ }^{228}$.

El despacho de minoría en cambio $^{229}$, propone en líneas generales que no debe adoptarse un régimen que combine la publicidad posesoria y la publicidad registral porque ambas son incompatibles (...) y por lo tanto, al realizar un análisis de lo esencial de las figuras, llegan a considerar que la inscripción registral debe reemplazar a la tradición como modo de adquisición de los derechos reales sobre inmuebles para que, una vez

\footnotetext{
${ }^{227}$ V. Conclusiones Pto. II. Despacho A.

${ }^{228}$ Continúa la comisión en su conformación mayoritaria: "Entre otras, el avasallamiento a la tradición jurídica de nuestro país y graves perjuicios para los más pobres y marginados de la sociedad, ya que en la mayoría de las provincias argentinas existen innumerables familias que sólo ostentan la posesión de las tierras en que se asientan sus viviendas o donde generan el sustento económico familiar. De acuerdo a los Arts. 14 bis, 75 incisos 19, 22 y 23 CN y a la constitucionalización del Derecho Civil, es reprochable constitucionalmente un sistema de registración constitutiva".

${ }^{229}$ Obtuvo 4 votos.
} 


\section{SEBASTIÁN JUSTO COSOLA}

constituidos los derechos reales sobre inmuebles queden definitivamente constituidos y sean oponibles a todos sin excepción.

\subsection{Derecho comparado.}

En Perú, la transmisión de la propiedad en los bienes inmuebles se produce por el sistema consensual, esto es, un sistema donde el fundamento de la transmisión se produce a partir del contrato traslativo del dominio ${ }^{230}$. La teoría del título y el modo en ese país se aplica a la transmisión de la propiedad de los bienes muebles ${ }^{231}$. En España, se mantiene a pesar de algunas doctrinas no coincidentes, el sistema de la transmisión de inmuebles que exige la existencia del título causal que justifica la transmisión derivativa de los derechos reales, conjuntamente con el modo, que no es otra cosa que la tradición ${ }^{232}$. El caso de España es interesante porque a pesar de mantener este sistema, desde alguna doctrina se viene insistiendo en el valor de la inscripción por sobre la tradición ${ }^{233}$, de manera similar a lo que venía sucediendo en nuestro país hasta la sanción del Código Civil y Comercial de La Nación que aun con argumentaciones contrarias, siguió optando por el método de la traditio. Esto lleva a algunos autores a decir con fundamento que el sistema jurídico español consagra la fe pública registral ${ }^{234}$. En México cada estado tiene un Código Civil, y según el civilista Rafael Rojina Villegas ninguno de ellos ha reglamentado la transmisión de los derechos reales ni las obligaciones correlativas a los mismos ${ }^{235}$. La doctrina general de transmisión de los derechos reales en ese país se comienza por interpretar a partir de lo que se establece para la transmisión de los derechos personales,

${ }^{230}$ Gunther GONZÁLES BARRÓN, Tratado de Derechos Reales, t ${ }^{\circ}$ II, ob. cit., p. 1216.

${ }^{231}$ Ibídem, p. 1217.

${ }^{232}$ Cfr. Carlos LASARTE, Derechos reales y derecho hipotecario. Principios de Derecho Civil, $\mathrm{t}^{\circ}$ V, Marcial Pons, Madrid, 2.009, p. 309.

${ }^{233}$ Ibídem, p. 306 y ss.

${ }^{234}$ Cfr. Maritel M. BRANDI TAIANA, La transmisión de dominio de inmuebles en el derecho español, $\mathrm{RN}^{\circ}$ 48, La Plata, 2.004, p. 530.

${ }^{235}$ Cfr. Rafael ROJINA VILLEGAS, Derecho Civil Mexicano, Adriana ROJINA GARCÍA (Concord.), t III, Porrúa, México, 2.012, p. 243. 
LOS EFECTOS DE LA PUBLICIDAD EN EL DOCUMENTO NOTARIAL

especialmente en materia de cesión de derechos reales -en la actualidad vigente en el código de Morelos $^{236}$-, y se insta, lógicamente a que las cuestiones relacionadas con los derechos reales queden reguladas eficazmente por el derecho positivo. De ahí se desprende que los derechos reales pueden cederse sin el consentimiento del dueño o poseedor de una cosa gravada, y para que la misma sea oponible debe inscribirse en el Registro Público de la Propiedad" ${ }^{237}$. Y desde allí el autor destaca: "El contrato es el principal acto jurídico que no solo sirve para constituir derechos reales o personales, sino también para transferirlos ${ }^{238}$ ".

A modo de noticia, digamos que en Cuba, si bien se postula el derecho de propiedad y sus derivados, el mismo no se encuentra regulado, atribuyendo consecuentemente la adquisición y distribución de los bienes fundamentando la tesis que posiciona al trabajo como fundamento de la riqueza y de la propiedad, apartándose de las teorías que se conocen como liberalistas ${ }^{239}$.

\subsubsection{El caso de los países de tradición anglosajona (Common} Law).

Es oportuno destacar que nuestro sistema de adquisición de los derechos reales a través de la teoría del título y del modo suficiente tal cual ha quedado expuesto, difiere notoriamente en esencia y en naturaleza con el sistema que impera en los países de raíz anglosajona. En nuestro medio, ya las XVI Jornadas Notariales Argentinas pusieron el tema en discusión, recomendando la inconveniencia de tomar o recibir influencias del sistema del common-law $w^{240}$. En efecto, en aquellos países de tan cercana tradición en

\footnotetext{
${ }^{236}$ Ibídem, p. 244.

${ }^{237}$ Ibídem.

${ }^{238}$ Ibídem, p. 245

${ }^{239}$ Cfr. Orlando RIVERO VALDÉS, Temas de derechos reales, Editorial Félix Varela, La Habana, 2.007, p. 17-18.

${ }^{240}$ Las XVI Jornadas Notariales Argentinas celebradas en Mendoza (1976) proponen un tema absolutamente interesante y poco común. Bajo el título estudio comparativo y crítico del sistema estadounidense en relación a la penetración de normas en los países de sistema latino en materia de constitución y transmisión de los derechos reales, los notarios allí reunidos consideraron que en los países de sistema de derecho anglosajón la constitución y transmisión
} 


\section{SEBASTIÁN JUSTO COSOLA}

materia de derecho constitucional pero de tan lejana tendencia en materia de derecho privado, se implementa el sistema conocido como seguro de títulos, a través del cual se intenta cubrir los riegos que nacen de los defectos reales que ocurren, como en todos los países en donde el derecho es puesto en manos y ejercicio del hombre, en la celebración de contratos que tienen como objeto a los inmuebles ${ }^{241}$. Con Olsen Ghirardi puede recordarse que el common-law es un sistema que reconoce dos cuerpos de normas: un derecho escrito, las leyes ordinarias originadas en el Congreso, y un derecho común, denominado common-law, surgido de la actividad judicial, en las causas que constituyen en los conflictos privados un case law $w^{242}$. Por esta

de los derechos reales opera mediante instrumento privado sin intervención legal impuesta por un profesional del derecho, lo que en conjunto con un deficiente sistema de registración determina la existencia de vicios que afectan seriamente la seguridad jurídica que debe necesariamente imperar en el tráfico jurídico negocial. Reflexionan acerca del seguro de títulos, al que consideran absolutamente ineficaz e insuficiente como medio de acceso hacia la seguridad jurídica, ya que su misión no es suprimir riesgos sino de superar los males originados por un sistema viciado. Asimismo destacan las virtudes del sistema latino, que mediante la instrumentación publica en manos de una profesional del derecho que trae consigo el asesoramiento jurídico adecuado y la imparcialidad, conforma el más importante sistema de consolidación de los derechos reales. Las conclusiones de este punto del temario son realmente importantes, pero su tratamiento in extenso escapa a las necesidades de esta tesis. Es por ello que a estas alturas, quizás resulte únicamente conveniente destacar que en las mencionadas recomendaciones se insta a no admitir bajo ningún concepto el trasplante del sistema estadounidense para la transmisión y constitución de los derechos reales, por cuanto ello implicaría condenar parámetros fundamentales de seguridad jurídica, debiéndose en consecuencia rechazar el sistema de seguro de titulo, que se aleja de los principios propios de la función notarial como la matricidad, la idoneidad, la fe pública y la imparcialidad, intensificando positivamente la interacción de los notariados americanos y europeos a fin de evitar el desarraigo de la intervención, las costumbres y las tradiciones notariales. Cfr. Norma Elena CIURO DE CASTELLO (Recop.), Jornadas Notariales Argentinas (19442008), FEN, La Plata, 2.010, p. 155 y ss.

${ }^{241}$ Marta Rosa PIAZZA, Responsabilidad civil del notario. El seguro llamado de mala praxis. Sus diferencias con el seguro de título, ob. cit., p. 208 y ss. Argumenta la autora que el análisis jurídico del seguro de títulos se encuentra unido, indefectiblemente, al análisis económico de cada país. y la utilización que se pretende instaurar es la del sistema imperante en los países como los Estados Unidos de Norteamérica y todos aquellos que estén regidos por el derecho anglosajón, que avalan el sistema en razón de ser necesario para el desarrollo de la economía que se encuentra únicamente sostenida por las entidades bancarias, las financieras, y las compañías aseguradoras que son las que emiten la póliza del seguro, asimilada a un contrato de indemnización contra la pérdida o el daño monetario efectivo que sufre el demandante asegurado.

${ }^{242}$ Cfr. Olsen GHIRARDI, El common-law de los Estados Unidos de Norteamérica. Génesis y Evolución, Academia Nacional del Derecho y Ciencias Sociales de Córdoba, p. 1. http://www.acaderc.org.ar/doctrina/articulos/artcommonlawestadosunidos (Ultimo acceso: 
LOS EFECTOS DE LA PUBLICIDAD EN EL DOCUMENTO NOTARIAL

razón, uno de los elementos esenciales de la perdurabilidad del common law es la existencia de la doctrina del precedente obligatorio ${ }^{243}$. Desde aquí entonces que pueda decirse que el sistema de common-law, no otorga verdadero sustento al documento como medio de prueba en juicio, ya que hace prevalecer el régimen de prueba consuetudinario fundamentado en el desarrollo oral de la misma. Por el contrario, el civil-law no sólo otorga prioridad al elemento escrito, sino que además la forma escrita se erige como elemento indispensable tanto para la existencia del negocio jurídico como para su desarrollo como prueba en juicio, mucho más si se le reconoce al mismo la dación de $\mathrm{fe}^{244}$. Desde aquí entonces que la función notarial en los países de tradición anglosajona no tenga la trascendencia e importancia que tiene en todo el resto del mundo que adscribe al régimen de notariado latino puro, y que posiciona al notario como creador del documento e intérprete de la voluntad de las partes. El propio sistema anglosajón no permite que la función cumpla acabadamente la misión innata de la justicia, la fe y la seguridad. Y por ello es que encontramos a un oficial que en los países referidos lleva el nombre de notary public, que si bien reconoce orígenes en los funcionarios judiciales, no comparte en lo más mínimo ni los requisitos de acceso ni los de ejercicio de la función notarial tal cual nosotros la conocemos y valoramos. Su función es claramente certificante, y en ciertos estados modelo, como el de Nueva York, el notary es tanto oficial del estado como oficial del condado ${ }^{245}$, naturaleza que es compartida en general en ese país del norte de América ${ }^{246}$.

Podemos entonces recordar con Álvaro Gutiérrez Zaldivar que en general los países que presentan este sistema de ejecución jurídica-y a pesar de algunas diferencias meramente formales- reconocen a un oficial que no es un profesional del derecho, que no brinda asesoramiento legal - salvo que sea abogado, aunque en la práctica es altamente infrecuente-, ni puede aconsejar

$13 / 08 / 2017)$

${ }^{243}$ Ibídem, p. 4.

${ }^{244}$ Cfr. Álvaro GUTIERREZ ZALDIVAR, Los notarios en el common law, RdN n 866 , Buenos Aires, 2.001, p. 187.

${ }^{245}$ Cfr. Alfred E. PIOMBINO, Notary Public HandBook. A guide for New York, East Coast Publishing, Poughkeepsie, New York, 1.993, p. 1.

${ }^{246}$ Cfr. Emilio CARDENAS MONTFORT, Notarial services in Nafta. The North American Free Trade Agreement, Author Edition, Montreal Cánada, 2.004, p. 17. 


\section{SEBASTIÁN JUSTO COSOLA}

sobre la redacción jurídica de un documento; es además un oficial que cumple para el acceso mínimos requisitos formales -en general, no tienen examen de aptitud para el ingreso al oficio-, como tener la edad mínima requerida, sin exigencia de la ciudadanía, saber leer y escribir, entre otros recaudos meramente formales ${ }^{247}$.

\subsubsection{Primer esbozo del concepto de autenticidad.}

Debe destacarse en el presente desarrollo del derecho comparado y más específicamente, del último sistema descripto, la propia consideración de la autenticidad. Si bien en la presente investigación la noción importa tener en cuenta un análisis profundo, bien vale la pena una introducción a su desarrollo en este espacio, con el fin de dejar establecidas las diferencias entre los dos sistemas, y para afirmar nuevamente, las bondades del sistema de transmisión de derechos reales felizmente consolidado en nuestro país y en aquellos que profesan el derecho continental, circunstancia que se demuestra con el sólo hecho de su cabal consideración y comprensión en el Código Civil y Comercial de la Nación vigente.

En torno a la autenticidad, prestigiosos autores españoles argumentaron con acierto que los términos autenticidad y auténtico son anfibológicos, son equívocos, es decir, reconocen diversos significados con los cuales se los suele emplear para expresar lo mismo ${ }^{248}$. Pero es una diferencia sustancial al tener en cuenta la verdadera función del mencionado notary public ${ }^{249}$. Así, se afirma que desde la etimología, la palabra auténtico significa original, y considerado en una íntima relación con lo verdadero, es algo contrario a la reproducción, a la copia, al traslado, y consecuentemente, a todo aquello que

${ }^{247}$ Cfr. Álvaro GUTIERREZ ZALDIVAR, II Reunión Anual de la National Notary Association: informe del delegado del Colegio de Escribanos de Capital Federal, RdN 772, Buenos Aires, 1.980, p. 1047.

248 Cfr. Vicente FONT BOIX, Vicente L. SIMÓN SANTONJA, Antonio DE LA ESPERANZA MARTINEZ-RADIO y José MADRIDEJOS SARASOLA, Sistemas jurídicos y documento, la forma escrita en las legislaciones latinas, sociales y anglosajonas, RDN 117118, Madrid, 1.982, p. 93.

${ }^{249}$ Ibídem, p. 94. 


\section{LOS EFECTOS DE LA PUBLICIDAD EN EL DOCUMENTO NOTARIAL}

sea falso ${ }^{250}$. Pero también lo auténtico hace referencia a una especial coincidencia entre el autor aparente y el autor real ${ }^{251}$. En relación a la intervención notarial en los países que adoptan el sistema de common-law, es éste segundo aspecto el que se tiene en cuenta - se lo denomina sistema de notarización-, y tiene como única finalidad alcanzar la seguridad suficiente para afirmar que un determinado documento es el verdaderamente auténtico, y que no es ni el falso ni el apócrifo ${ }^{252}$. Muy por encima de ello, el concepto de auténtico que hace referencia a los hechos que dentro del proceso un juez valora y considera indubitables, es el que impera, además del mencionado requisito, en los países de tradición romana, donde funciona el sistema de notariado latino. En opinión de los autores entonces existe una analogía evidente que se da entre la noción de autenticidad y la prueba legal, como así también en relación al concepto de plena fe o fe pública, para afirmar a un determinado hecho como auténtico, precisamente porque hace fe en juicio, y porque hace fe, goza de autenticidad ${ }^{253}$. Desde aquí que el documento notarial creado por un notario de tipo latino, es aquel que en razón de la persona del cual emana-que actúa por imposición de la ley y bajo un cuidado y exigente sistema de responsabilidad moral-, posiciona a una parte de su contenido en valoración directa de la ley y por esa razón ese contenido debe ser aceptado como probado, quedando sustraído a la libre valoración judicial ${ }^{254}$. En definitiva, no puede afirmarse que el sistema de derecho común ofrezca en este sentido la máxima seguridad a las transacciones, por cuanto su finalidad es la de alcanzar, ante el defecto producido, una determinada y pretendidamente justa indemnización ${ }^{255}$.

\footnotetext{
${ }^{250}$ Ibídem.

${ }^{251}$ Ibídem. "En este sentido puede decirse, por ejemplo, que un determinado cuadro es un auténtico Picasso, cuando resulta acreditada la procedencia de este pintor; que no es una falsificación".

${ }^{252}$ Ibídem.

${ }^{253}$ Ídem, p. 95

${ }^{254}$ Ibídem.

${ }^{255}$ Además, es totalmente ajeno a nuestras tradiciones occidentales, y ha quedado demostrado en diversas situaciones que la costumbre en nuestras naciones aun exigen un titulo seguro y autosuficiente que no deje la entrada supuesta a un error que perjudique a los adquirentes en su buena fe. Cfr. Jorge H. ALTERINI, David FIGUEROA MÁRQUEZ, José Manuel GARCÍA COLLANTES, Bernardo PÉREZ FERNÁNDEZ DE CASTILLO y Aldo PIGNANELLI, Mesa redonda: El notariado latino. Análisis comparativo entre el sistema jurídico documental latino y el anglosajón. Costo del contencioso y de las indemnizaciones,
} 


\section{SEBASTIÁN JUSTO COSOLA}

También en España Vallet de Goytisolo ha dedicado tiempo a estos estudios, y en el tratamiento del valor seguridad jurídica, nos ha legado la enseñanza siguiente: "La sustitución de la seguridad jurídica propiamente dicha por la seguridad económica de recibir, en su caso, una indemnización en dinero, no sólo no reparará en bastantes casos el daño en su debida medida, sino que puede redundar en un detrimento, cada vez mayor, de la titulación constituyente del contenido de los registros inmobiliarios. De este modo, al incrementarse en lo sucesivo ese detrimento, por razón de inscribirse títulos defectuosos, serían cada vez más numerosos los fallos de la seguridad jurídica propiamente dicha, que el seguro tendría que remediar ${ }^{256 " . ~ E l ~}$ inolvidable maestro terminará por advertir que ninguna indemnización compensa real y totalmente al adquirente que se queda sin el inmueble, por cuando entre otros factores, la demora para el cobro del seguro y la creciente inflación hará que su derecho se vea definitivamente vulnerado ${ }^{257}$. Inclusive insistirá en afirmar que en última instancia, no es el seguro de títulos un medio profiláctico para salvaguardar la seguridad jurídica, ya que el mismo no es un sistema preventivo, sino reparatorio o indemnizatorio ${ }^{258}$.

En el último tiempo en nuestro país, se han demostrado las bondades del sistema del título y modo tal cual lo conocemos y estudiamos y sus notables diferencias con el sistema de seguro de títulos ${ }^{259}$, que se erige como insuficiente para la protección integral de los derechos adquiridos a través de la simple titulación, muy a pesar que desde sus líneas se afirme con

RdN n ${ }^{\circ} 888$, Buenos Aires, 2.007, p. 79 y ss.

${ }^{256}$ Cfr. Juan Berchmans VALLET DE GOYTISOLO, Seguridad jurídica estática y seguridad jurídica dinámica, RJdN n 33, CGN, Madrid, 2.003, p. 210.

${ }^{257}$ Ibídem, p. 211.

${ }^{258}$ Ibídem. Dice el autor: "Es decir, sería algo así como la sustitución, en medicina, de las vacunas y de las medidas higiénicas y profilácticas por un seguro dinerario que indemnizara las invalideces y defunciones producidas por las enfermedades que hubiesen dejado de ser prevenidas". Debe dejarse en claro además que algún tiempo antes de estos estudios en España, tres estudios de notable importancia nacían para demostrar que el sistema de notariado latino es el que históricamente mejor ha sabido consolidar la protección y la seguridad jurídica preventiva en la tutela de la transmisión del dominio de inmuebles por escritura pública. Cfr. Cándido PAZ-ARES, El sistema notarial. Una aproximación económica, CGN, Madrid, 1.995, 153 p.; Benito ARRUÑADA, Análisis económico del notariado, CGN, Madrid, 1.995, 166 p., y Pedro GARRIDO CHAMORRO, La función notarial, sus costes y sus beneficios, CGN, Madrid, 2.000, $201 \mathrm{p}$.

259 Marta Rosa PIAZZA, Responsabilidad civil del notario. El seguro llamado de mala praxis. Sus diferencias con el seguro de título, ob. cit., p. 198 y ss. 


\section{LOS EFECTOS DE LA PUBLICIDAD EN EL DOCUMENTO NOTARIAL}

vehemencia lo siguiente: "The notary public holds a trusted role in our legal and comercial systems. Is it not a right, but a privilege to receive an appointment as a notary public. A person admitted into this honorable class

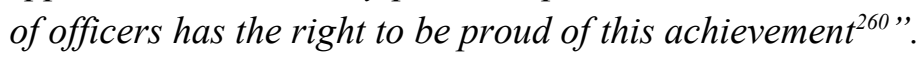

\subsection{Primeras conclusiones.}

En el capítulo inicial de la presente tesis doctoral me he propuesto exponer ciertas cuestiones trascendentes que permiten corroborar que las diferentes proyecciones de los derechos reales y personales implicados -tanto de manera natural como accidental en las relaciones humanas-, se pueden advertir desde un documento, desde un hecho fáctico determinado o desde una inscripción o anotación registral de manera absolutamente diversa y confusa. Este es sólo un efecto del denominado fenómeno publicitario, que dirige sus esfuerzos a analizar la cuestión jurídica, pero también se encuentran implicadas cuestiones económicas, sociológicas, y educativas ${ }^{261}$ que irán también desprendiéndose del contenido de la presente investigación. No he negado, de ninguna manera, la importancia de cada institución, ni ha sido mi intención enfrentarlas para que alguna de ellas se imponga victoriosa frente a las otras. Nada más alejado de mis actuales pretensiones. Por sobre toda interpretación, tengo bien en cuenta la conclusión ya analizada propuesta por la doctrina mayoritaria nacional, que ordenaba que una posible reforma de la legislación privada argentina debiera mantener la coexistencia de todas las publicidades implicadas en el presente análisis: cartular, posesoria y registral. Debo reiterar entonces que la idea no es confrontar ni imponer, sino de destacar cuál de ellas puede oficiar como rectora, porque es definitivamente la que mejor alcanza la consolidación de los derechos en su seno, para poder así proyectar, ante su vulneración, las defensas y

\footnotetext{
${ }^{260}$ Alfred E. PIOMBINO, Notary public handbook..., ob. cit., p. 1.

${ }^{261}$ Estos son los alcances de la publicidad a los que refiere MUGUILLO, desarrollándolos en su obra, en donde explica además que existen ciertos autores que se refieren, exageradamente, a que el aire que se respira se encuentra compuesto de oxigeno, nitrógeno y publicidad. v. Roberto A. MUGUILLO, Publicidad, Astrea, Buenos Aires, 2.005, p. 1.
} 


\section{SEBASTIÁN JUSTO COSOLA}

protecciones que sean necesarias a los efectos de restaurar o recuperar los derechos que se encuentren afectados o vulnerados.

Queda claro entonces que la adquisición de los derechos reales adecuadamente se debe realizar a la manera expuesta del título y modo, ambos bajo la modalidad de suficientes. Sin embargo, las diferentes realidades imponen la necesidad de advertir que la ductilidad que refleja la adquisición del modo - de manera legítima o ilegítima, a través de la ley o del derecho que da lugar y preeminencia a la fuerza-, vuelve preciso considerar la fortaleza del derecho a través de la recuperación de los valores esenciales que el hombre necesita para obtener desde la ciencia y del arte jurídico, la mejor respuesta posible. En efecto, si la libertad y la igualdad son los valores que emergen de la carta magna -siendo además considerados como los más preciados y de ahí la referencia en el presente capítulo-, debe lograrse en cualquier institución que sea fiel a ello, la consolidación y estructuración de los valores de fe (certeza + verdad), de justicia y de seguridad, los que unidos tutelarán de la mejor forma, los derechos que a cada cual corresponde de acuerdo a la circunstancia en la que cada uno se encuentre frente al negocio jurídico. En definitiva, de los medios referidos de publicidad en materia de derechos reales -y los especialmente conformados a través del cumplimiento de los derechos personales antecedentes-, sólo uno de ellos se erige como rector, precisamente porque a través de sus efectos consolida no sólo la parte formal sino lo que es más importante: la parte axiológica y sustancial del derecho. Esa publicidad, según tendré el espacio para justificar, es la que emerge del documento notarial auténtico.

El tema en estudio, analizado desde la perspectiva académica vigente, no ofrece mayor relevancia que lo que hasta ahora se ha considerado con respecto, en esencia, análisis de la ley vigente. Si tuviéramos que advertir cuál es la disciplina del derecho privado que no ofrece prácticamente dudas en la interpretaciones de las figuras legales previstas, sin duda alguna, los derechos reales ocupan la primera posición, y jamás podrán compararse a nivel interpretativo con el derecho de de los contratos, de la familia, inclusive con muchos de los institutos desarrollados desde la parte general del derecho hoy unificada y constitucionalizada, que presentan temas de proporciones argumentativas inimaginables. 
Pero lo que realmente realza el interés de este tesista y auguro, de todo aquel que desee profundizar el presente estudio, es el análisis esencial que se efectúa sobre el documento notarial, que permite advertir no sólo las cuestiones clásicas y tradicionales derivadas de la autenticidad externa, sino también los valores emergentes de la autenticidad interna, que presentan otras vías de acceso al conocimiento, y que suponen además, una tutela en el desarrollo del derecho documentado que ayuda a alcanzar los objetivos del derecho en paz. Entonces debe tenerse en cuenta que la autenticidad externa proyecta la fuerza del documento que emerge del análisis de los siguientes objetos y elementos deslindados únicamente y por ahora, a modo informativo:

a) Los documentos matrices y sus notas (especialmente en el estudio de los antecedentes);

b) Las copias, los testimonios, y todas sus notas;

c) Las planchas y demás sellos de inscripciones, provenientes de las diversas y variadas registraciones que impones la ley o la costumbre;

d) Las constancias tributarias;

e) Los instrumentos anexos a los documentos matrices aptos para la legitimación o para la prueba (Actas, autorizaciones judiciales o documentos de origen judicial, documentos de origen administrativo, de entidades privadas que ostentan a su cargo los servicios públicos, o entre otros, las instituciones financieras reconocidas);

f) Las constancias registrales, con los efectos atribuidos por la ley, y entre otros

g) Las constancias fiscales, que colaboran con el Estado frente al lavado de activos;

La autenticidad interna por el contrario, se ocupa de demostrar la potencia que desde un análisis diferente permite caracterizar a los valores del instrumento, los que advertidos a través de la lectura, vienen a confirmar que el derecho notarial del presente se proyecta como una disciplina especial, que por su propia singularidad y naturaleza, puede contribuir a desarrollar los derechos auténticos, en la plenitud de sus efectos, en el 


\section{SEBASTIÁN JUSTO COSOLA}

referido ámbito de paz. Si el derecho actual se justifica a través de la instauración y argumentación de los principios por sobre cualquier otra cuestión técnica o formularia, se justifica entonces, más que en ninguna otra época, el desarrollo de lo que considero son los valores esenciales del documento notarial, que se suman a la fuerza exterior que emerge de los mismos, y que vienen a comprobar tanto la fuerza como la potencia de la publicidad cartular. Consecuentemente, deben existir al menos dos medios publicitarios de diferente naturaleza a nivel cartular, a las que el hombre puede recurrir en la búsqueda de respuestas:

a) La publicidad cartular extrínseca, comprensiva de la autenticidad externa, compuesta de las notas descriptivas a las que hice alusión anteriormente que suponen la certeza (fe objetiva) y seguridad del tráfico (previsibilidad);

b) La publicidad cartular intrínseca, dentro del análisis de la autenticidad interna, que es la que emerge de la lectura del documento en su total magnitud, para poder advertir claramente en él, otros valores trascendentes y esenciales como la verdad (fe subjetiva), la justicia (voluntad + tutela) y la seguridad (libertad), que terminan por consolidar su posición rectora (potencia del documento).

Publicidad Cartular Extrínseca.

Principio de autenticidad externa.

Fe (certeza) + Seguridad dinámica (previsibilidad)

Publicidad Cartular Intrínseca.

Principio de autenticidad interna.

Fe (verdad) + Justicia (voluntad + tutela) + Seguridad estática (libertad). 
LOS EFECTOS DE LA PUBLICIDAD EN EL DOCUMENTO NOTARIAL

La publicidad cartular en modalidad extrínseca siempre estará dirigida a tutelar la cuestión formal instrumental, justificada desde el ordenamiento jurídico (fe pública objetiva) y comprensiva de lo previsible que circula en el tráfico instrumental (seguridad jurídica dinámica). La publicidad cartular en modo intrínseco siempre será la encargada de proteger la cuestión sustancial del documento, que en definitiva conforma la tutela de la verdad (fe pública subjetiva), la consolidación de la voluntad tutelada (justicia) y la actuación en absoluta libertad de quienes actúan como partes en el negocio jurídico destinado a vivir en el documento (seguridad jurídica dinámica). Desde la publicidad cartular extrínseca se advierte la fuerza del documento - esencialmente, la probatoria y la ejecutiva-; mientras que la publicidad cartular intrínseca viene a comprobar, asumir y ratificar la potencia del mismo -valores que justifican los efectos de la autenticidad exterior-. De esta manera, los valores del documento notarial interactúan en el mismo, a través de diferentes proyecciones, equilibrando sustancialmente el contenido que en él se contiene, y adecuando la comprensión tanto de la estructura como de los componentes que lo conforman.

Para poder llegar a estas consideraciones, se me impone primero destacar los efectos de la publicidad emergentes tanto de la posesión como de la cuestión registral, que comprenden algunos de los alcances descriptos, pero con ciertas particularidades interesantes, lo que dejará demostrado que las mismas consolidan, aunque con matices interesantes a tener en cuenta, tanto la fuerza exterior como la interior, pero sin la posibilidad de convivencia en su núcleo, de la totalidad de los valores descriptos y proyectados. 
SEBASTIÁN JUSTO COSOLA

.96 . 


\section{Capítulo 2.}

Elementos y argumentos de la publicidad posesoria.

\subsection{Aclaraciones previas.}

Los autores son consistentes en reconocer que referirse a la teoría general de la posesión equivale a penetrar en un laberinto repleto de peligros de interpretación y de desavíos jurídicos. Así se ha afirmado oportunamente -y con énfasis y rigor considerable-, que de ninguna manera puede desconocerse que el estudio de la posesión enfrenta al jurista a uno de los temas más controvertidos del derecho ${ }^{262}$. Hasta hace relativamente un corto tiempo, se seguía afirmando que la cuestión de la posesión, y más trascendente que ello, el análisis de su naturaleza jurídica, era una de las cuestiones más debatidas del derecho ${ }^{263}$, a la vez que se arriesgaba a encontrar la solución a los problemas que se presentaban desde los más impensados fundamentos, como por ejemplo, los que proponían un análisis de la propia definición de la posesión en clave filosófica, totalmente alejada de su encuadre jurídico ${ }^{264}$. En definitiva, todos los antecedentes académicos con lo que cuento a la hora de realizar este análisis me dirigen a creer que de

${ }^{262}$ Cfr. Elena Inés HIGHTON, Derechos reales. Volumen 1: Posesión, Ariel, Buenos Aires, 1.979 , p. 1.

${ }^{263}$ Cfr. Manuel ADROGUÉ, La transmisión de la posesión por causa de muerte, en Manuel I. ADROGUÉ, Álvaro GUTIÉRREZ ZALDIVAR, Mario O. ARRAGA PENIDO y Juan Carlos AMUY, Temas de derechos reales, Plus Ultra, Buenos Aires, 1.986, p. 17. El autor afirma que no debe participarse de la opinión que quienes consideran que abocarse al estudio e interpretación de la posesión conforma un esfuerzo estéril y para nada provechoso.

${ }^{264}$ Cfr. Zenón MARTINEZ, La posesión, Universidad Nacional del Litoral, Santa Fe, 1.939, p. 18. 


\section{SEBASTIÁN JUSTO COSOLA}

algún modo debe terminar por asumirse que no hay construcción dogmática más cerrada que la teoría posesoria ${ }^{265}$, lugar desde donde el encadenamiento de sus elementos es, en consecuente expresión, casi matemático ${ }^{266}$.

Tanto la parte general de la teoría posesoria, como la teoría general de los derechos reales y desde ella, los análisis correspondientes al concepto del derecho de propiedad o dominio ya referidos con sus respectivos alcances, viven y se desarrollan en la escritura pública con un avanzado grado de $f e$, certeza, justicia y seguridad, todos valores que en la actualidad se encuentran cobijados por el principio jurídico del derecho privado que ordena ejercer todos los derechos de buena $f^{267}$.

Hasta nuestros días, no se ha presentado algún sistema de transmisión, constitución, conformación, ampliación, adquisición, o extensión de derechos reales que parezca ser más exitoso o insumir menos riesgos que los que se proyectan en la escritura pública -siempre a partir de una adecuada interpretación de la voluntad y con la tutela del agente notarial-. En tiempos de cambios sustanciales en las proyecciones de nuevas teorías jurídicas que brinden reparo y resguardo a los hombres y mujeres que viven y habitan nuestro suelo, se sigue escogiendo el sistema de transmisión de derechos reales tal cual lo conocemos y lo aplicamos siempre, el que fue receptado y estructurado con similar impronta en el actual cuerpo normativo vigente ${ }^{268}$.

\footnotetext{
${ }^{265}$ Cfr. Raúl NAVAS (h), Derechos reales de propiedad, uso y goce, ob. cit., p. 53.

${ }^{266}$ Ibídem.

${ }^{267}$ Art. 9 CCCN.

${ }^{268}$ En consonancia con ciertos autores, puede decirse que en este tema, el equilibrio se logra ponderando la publicidad registral y la publicidad posesoria, otorgándole preeminencia a la primera en el tiempo, pues, como ha quedado expuesto en las citadas jornadas "(...) una abrumadora mayoría se inclinó por resolver el conflicto entre la publicidad posesoria y la registral inmobiliaria a favor de la primera en el tiempo y por considerar que la protección de los intereses legitimos de los poseedores hace aconsejable la conservación de la tradición material como constitutiva del derecho real inmobiliario, asi como que el Registro de la Propiedad debe continuar cumpliendo su función de registración de títulos, con carácter declarativo y no convalidante". De esta manera entonces se alcanza a proteger al tercero que ha actuado con pautas de razonabilidad en el examen de los antecedentes y en el estado de ocupación del bien pronto a adquirir, y por esta razón, prescindir de la tradición y de la consecuente publicidad del fenómeno posesorio puede conducir a situaciones reñidas con la justicia, ya que dar preeminencia a la registración en exclusividad termina por destruir el equilibrio alcanzado por la doctrina y la jurisprudencia mayoritaria hasta nuestros días. Cfr. Marina MARIANI DE VIDAL, Derechos reales inmobiliarios: ¿inscripción constitutiva?, LL 22/02/2012, I, p. 2.
} 
LOS EFECTOS DE LA PUBLICIDAD EN EL DOCUMENTO NOTARIAL

El presente capítulo no pretende ahondar de ninguna manera en el instituto posesorio y sus derivaciones, más allá de la mención de algunas teorías necesarias para poder realizar el balance final conclusivo. El mismo cobra relevancia a los efectos de poder establecer ciertas coordenadas básicas, primarias y elementales de los efectos publicitarios tanto de la tradición como de la posesión, que necesariamente deben conocerse a los fines de establecer relaciones, vinculaciones y trascendencia en las relaciones que se generen y se contienen en el documento notarial. Para ello debo tener en cuenta determinados aportes que la doctrina generalizada viene sosteniendo en razón del tema que me ocupa, al mismo tiempo que se me impone como un deber el de hacer base en la proyección del valor que se le brinda, en el derecho argentino actual, a quien obtiene y ejerce una relación de poder sobre una determinada cosa a titulo de poseedor. Como nos lo recordara Juan Vallet de Goytisolo, diferentes son las miradas que debemos tener frente a la posesión ya sea que la misma sea considerada como una situación o como un hecho; mientras que desde lo primero se debe atender el instante del despojo, desde lo segundo se tiene que tener en cuenta un determinado período de tiempo examinando, como en una proyección cinematográfica, la vida y movimiento de la posesión ${ }^{269}$.

Consecuentemente, realizo la presente advertencia, para que pueda asumirse de antemano que lo que prosigue a estas líneas introductorias es la presentación de un esbozo general de los puntos cardinales tanto de la teoría posesoria como de la traditio, tan necesarios para entender su funcionamiento desde el documento notarial y tan oportunos para advertir con claridad los efectos que se proyectan a nivel publicitario.

\subsubsection{Algunas dificultades que presenta el estudio de la teoría} general de la posesión.

\footnotetext{
${ }^{269}$ Cfr. Juan B. VALLET DE GOYTISOLO, Estudio sobre derecho de cosas, Montecorvo, Madrid, 1.973, p. 20.
} 


\section{SEBASTIÁN JUSTO COSOLA}

En algún tiempo y lugar, Antonio Hernández Gil afirmó lo siguiente: "La posesión tiene ganada fama de tema difícil. Sería presuntuoso negar un fondo de certeza al aserto tradicionalmente repetido. Así y todo, hay que deslindar terrenos y no confundir la dificultad intrinseca con la oscuridad expositiva ${ }^{270 " . ~ S o b r e ~ e s t a ~ i d e a, ~ d i g a m o s ~ q u e ~ c i e r t o s ~ a s p e c t o s ~ p r o b l e m a ́ t i c o s ~}$ del estudio de la posesión comienzan por poner en evidencia que más allá del voluminoso tratamiento que le ha brindado la doctrina en general, aun no existe entre los autores acuerdo generalizado en temas elementales para su entendimiento estandarizado, como los que se refieren a su conformación y estructuración, los que se relacionan con el alcance del concepto o con la determinación de su naturaleza jurídica; aquellos referidos al desarrollo de los elementos constitutivos, de las causas y de los fundamentos de la protección posesoria, como así también existen discrepancias en la exposición de los principios que rigen la adquisición, la conservación y la pérdida de la posesión ${ }^{271}$. Inclusive aquellos aportes que a lo mejor acuerdan en algún punto -por ejemplo en el tema de la definición legal de la posesión-, no dejan de advertir que la misma resulta pobre, confusa e insuficiente, precisamente por la excesiva generalidad en la consideración desde la cual la misma resulta definida o encasillada: ejercicio de hecho de uno de los poderes inherentes a la propiedad, poder de hecho, señorio de hecho, entre otras singulares apreciaciones ${ }^{272}$. A esto debe además agregarse que el estudio profundo de la posesión ocurre en el marco de los derechos reales, y cobra verdadera importancia al momento de reflexionar sobre las relaciones materiales que pueden ocurrir entre la persona y la cosa, la asimilación o separación con ciertas figuras afines tales como la tenencia, la relación de yuxtaposición local -hoy histórica-, y las derivadas de las relaciones de dependencia, hospedaje $u$ hospitalidad ${ }^{273}$.

De todo lo antes expuesto, la discusión acerca del alcance y posicionamiento de la posesión frente a la tenencia, nos trae el recuerdo de las críticas que ha

${ }^{270}$ Cfr. Antonio HERNÁNDEZ GIL, La función social de la posesión (Ensayo de teorización sociológico-jurídica), Real Academia de Jurisprudencia y Legislación, Madrid, 1.967, p. 12.

${ }^{271}$ Elena Inés HIGHTON, Derechos Reales. La posesión, ob. cit., p. 1.

${ }^{272}$ Gunther GONZÁLES BARRON, Tratado de Derechos Reales, T ${ }^{\circ}$ I, ob. cit., p. 412.

${ }^{273}$ Ricardo J. PAPAÑO, Claudio M. KIPER, Gregorio A. DILLON y Jorge R. CAUSSE, Derecho Civil. Derechos Reales, ob. cit., p. 42. 


\section{LOS EFECTOS DE LA PUBLICIDAD EN EL DOCUMENTO NOTARIAL}

efectuado Ihering de las teorías expuestas por Savigny, absolutamente relevantes y dignas de cierta consideración, como así también la referencia a determinados estudios filosóficos complejos, aportes y teorías que merecen ser destacados -tan siquiera sucintamente-, como prueba del enorme y trascendente legado que desde esta disciplina nuestra generación debe recibir con verdadero beneplácito. De esta manera, fue Inmanuel Kant quien se refería al tema de la propiedad y de la posesión como la manera de tener alguna cosa exterior como suya. Y así lo describía el genial filósofo: "Lo mio en derecho (neum juris) es aquello con lo que tengo relaciones tales, que su uso por otro sin mi permiso me perjudicaría. La condición subjetiva de la posibilidad de un uso cualquiera, es la posesión; pero una cosa exterior no es mía, sino en cuanto puedo con justicia suponerme agraviado por el uso que otro haga de esta cosa, aun cuando yo no esté en posesión de ella. Es, pues, contradictorio tener como suyo algo exterior, si la noción de la posesión no es susceptible de dos sentimientos diferentes; es decir: si no hay una posesión sensible, y una posesión inteligible, y si no puede por la primera entenderse la posesión física de un objeto, y por la segunda la posesión simplemente jurídica de este mismo objeto ${ }^{274, " .}$

\subsection{Los primeros antecedentes.}

El derecho romano no presenta ni una elaboración dogmática ni una terminología técnica unitaria en el tratamiento de los derechos reales desde el punto de vista sustancial, por cuanto la ley y la con ella la doctrina especializada, partían de analizar los fenómenos jurídicos desde su dinámica procesal ${ }^{275}$. De esta manera se daba comienzo al estudio de la temática a partir de la discriminación entre las acciones reales (vindicatio) y las acciones personales ${ }^{276}$. En este esquema, la posesión se erige como uno de

\footnotetext{
${ }^{274}$ Cfr. Inmanuel KANT, Principios metafisicos del derecho, Ediciones Espuela de Plata, España, 2.004, p. 63.

${ }^{275}$ Cfr. Alfredo DI PIETRO y Ángel Enrique LAPIEZA ELLI, Manual de Derecho Romano, Abeledo Perrot, Buenos Aires, 2.010, p. 196.

${ }^{276}$ Ibídem.
} 


\section{SEBASTIÁN JUSTO COSOLA}

los más arduos problemas del derecho en referencia, y desde aquí, un buen punto de partida es el que considera que -bemoles aparte-, la mayoría de los romanistas consideran a la possesio como un hecho ${ }^{277}$.

Los romanos distinguieron tempranamente las diferencias entre la posesión -señorío o disposición de hecho sobre una cosa con la pretensión de tenerla como propia- y la propiedad - señorío jurídico absoluto, protegido por el ordenamiento y oponible erga omnes- ${ }^{278}$. Autores como Juan Iglesias hacen referencia puntual a lo antedicho, advirtiendo que entre posesión y propiedad media la diferencia que corre entre el hecho y el derecho ${ }^{279}$.

La posesión, sin embargo, fue investida de distintos efectos jurídicos que determinaron tanto su impronta como su notable importancia. Así, la misma servía de base a tres modos de adquisición de la propiedad como la ocupación, la tradición y la usucapión; servía también de fundamento del poseedor para la legitimación pasiva en un proceso de reivindicación, no teniendo el mismo que proporcionar ninguna prueba; también daba derechos frente a la adquisición de frutos si la misma era de buena fe y además, encontraba asidero y protección frente a los actos de perturbación a partir de la conformación de los interdictos posesorios ${ }^{280}$. Desde Roma, possesio o possesio ad interdicta, proyecta la consolidación de dos elementos: uno objetivo (corpus) y el otro subjetivo (animus); de esta manera se constituye como núcleo esencial del derecho la teoría posesoria ${ }^{281}$.

${ }^{277}$ Cfr. Cristina FUENTESECA DEGENEFFE, La posesión mediata e inmediata, Ediciones Legales, Lima, 2.013, p. 48.

${ }^{278}$ Alfredo DI PIETRO y Ángel Enrique LAPIEZA ELLI, Manual de Derecho Romano, ob. cit., págs. 224-225.

279 Cfr. Juan IGLESIAS, Derecho Romano (Instituciones de derecho privado), Ariel, Barcelona, 1.958, p. 287.

${ }^{280}$ Alfredo DI PIETRO y Ángel Enrique LAPIEZA ELLI, Manual de Derecho Romano, ob. cit., p. 225.

${ }^{281}$ Ibídem, p. 226. Acerca de la figura del interdicto recordemos con Mariani de Vidal que los mismos se originan en el derecho romano y, los relativos a la posesión -con las características que acentuaban el carácter provisional y la sumariedad procesal- se alineaban por aquellos tiempos en tres grupos: a) recuperatorios, que eran aquellos que tenían como finalidad hacer recuperar la cosa perdida; b) conservatorios, que eran los que se daban como defensa contra una turbación de la posesión, y c) los destinados a hacer adquirir la posesión, referidos a los interdictos que persiguen como finalidad el hacer adquirir una posesión que nunca se tuvo, teniendo como objeto la puesta en la posesión real y corporal que le pertenece a una persona en relación a algunos bienes. Cfr. Marina MARIANI DE VIDAL, Interdicto de adquirir, Víctor P. de Zavalía, Buenos Aires, 1.971, p. 9 y ss. 
En el mismo sentido Eugène Petit sostenía que la posesión -en la comprensión romana-, podía ser definida como "el hecho de tener en su poder una cosa corporal, reteniéndola materialmente, con la voluntad de poseerla y disponer de ella como lo haría un propietario ${ }^{282}$ ". La teoría que la contenía se fue desarrollando lentamente en el derecho romano, y fue elaborándose con mucho mayor rigor a partir de las necesidades prácticas que surgían de ideas generales propiamente concebidas ${ }^{283}$, siendo necesario, para poder poseer, tanto el hecho como la intención, por cuanto se posee con corpore (elemento material) y también con ánimo (elemento intencional) ${ }^{284}$. En importante declaración de Vicenzo Arangio-Ruiz, cada uno de nosotros puede sentir que vive en un mundo que tiene forma jurídica y que por ello, en relación a los objetos externos que tienen y ofrecen utilidad, se presenta la figura de un dueño, en la realidad o en la imaginación ${ }^{285}$. Para éste autor, la distinción neta entre propiedad y posesión como lo presentan las sociedades evolucionadas no era propia de la primera parte de la elaboración romana del derecho, y por ello la generalizada tendencia social era la de presumir desde el derecho la posesión ajena ${ }^{286}$.

Esta situación irá mutando con el derecho romano posterior, altamente evolucionado ${ }^{287}$. En líneas generales es así como se conforma la protección de la posesión como exigencia fundamental del derecho, ya sea en una posición de tutela avanzada de la propiedad (Ihering) o en la tutela de la paz social (Savigny) ${ }^{288}$.

\footnotetext{
${ }^{282}$ Cfr. Eugène PETIT, Derecho Romano, Porrúa, México, 2.013, p. 238.

${ }^{283}$ Ibídem, p. 239.

${ }^{284}$ Ibídem.

${ }^{285}$ Cfr. Vicenzo ARANGIO-RUIZ, Instituciones de Derecho Romano, Depalma, Buenos Aires, 1.986, p. 299. Mas adelante el autor argumenta lo antedicho con el siguiente ejemplo: Sin embargo, al no poder afirmar con pleno conocimiento que de tal cosa útil es propietario Ticio, o de tal otra Cayo, volviéndose en circunstancias imperioso el conocimiento del hecho sobre el cual Ticio o Cayo la han adquirido, adquiere relevancia la presunción que nace del hecho por sobre la persuasión sobre el derecho: "al respeto por la facultad de otro para disponer de la cosa, se sustituye el respeto por la disposición que otro tiene visiblemente de ella".

${ }^{286}$ Ibídem, p. 302.

${ }^{287}$ Ibídem, p. 303 y ss.

${ }^{288}$ Ibídem, p. 301.
} 


\section{SEBASTIÁN JUSTO COSOLA}

\subsubsection{Las nociones conceptuales.}

Atendiendo sólo parcialmente al sentido gramatical de la palabra, se establece que posesión "significa tanto el acto de tener una cosa corporal para si o para otro, con voluntad de conservarla, como el objeto mismo, que de este modo, guardamos en nuestro poder ${ }^{289 " . ~ E n ~ s e n t i d o ~ m a ́ s ~ e s t r i c t o, ~}$ solemos considerar la posesión para referirnos a un poder de hecho que se ejerce sobre las cosas de la naturaleza exterior que se unen al individuo de un modo estable ${ }^{290}$. El Código Civil de Vélez esbozaba una suerte de conceptualización al establecer que hay posesión de cosas cuando alguna persona por sí o por otro, tenga una cosa bajo su poder, con intención de someterla al ejercicio de un derecho de propiedad ${ }^{291}$, que se complementa con la que el centenario codificador argentino dedicara también a la tenencia, al advertir seguidamente que quien efectivamente tiene una cosa pero reconoce la propiedad en otro es un simple tenedor de la misma y representante de la posesión del propietario, aunque la ocupación de la cosa repose sobre un derecho ${ }^{292}$. Según opinión de López de Zavalía, la definición de la posesión en el hoy histórico cuerpo normativo es de tipo generalizable, ya que la misma permite, alternando ciertas palabras -propiedad, personal, entre otras- definir otros señoríos como la cuasiposesion y la tenencia fuerte, entre otros ejemplos interesantes ${ }^{293}$. A partir de la puesta en vigencia del Código Civil y Comercial de La Nación vigente, la doctrina actual es conteste en considerar a la posesión como una relación de poder -e independientemente si existe entre la persona y la cosa vínculo jurídico además del vinculo de hecho-, conjuntamente con la tenencia y con las

289 Héctor LAFAILLE y Jorge Horacio ALTERINI, Derecho Civil, Tratado de los derechos reales, $\mathrm{t}^{\circ} \mathrm{I}$, ob. cit., p. 111.

${ }^{290}$ Luis Alberto PEÑA GUZMÁN, Derecho civil. Derechos reales, $\mathrm{t}^{\circ} \mathrm{I}$, ob. cit., p. 186.

${ }^{291}$ Art. 2351 CCA: "Habrá posesión de las cosas, cuando alguna persona, por sí o por otro, tenga una cosa bajo su poder, con intencion de someterla al ejercicio de un derecho de propiedad".

${ }^{292}$ Art. 2352 CCA: "El que tiene efectivamente una cosa, pero reconociendo en otro la propeidad, es simple tenedor de la cosa, y representante de la posesión del propietario, aunque la ocupación de la cosa repose sobre un derecho".

${ }^{293}$ Fernando LOPEZ DE ZAVALÍA, Derechos Reales, t I, ob. cit., p. 356. 


\section{LOS EFECTOS DE LA PUBLICIDAD EN EL DOCUMENTO NOTARIAL}

demás relaciones que se derivan de relaciones de dependencia, servicio, hospedaje $u$ hospitalidad ${ }^{294}$.

Sin embargo, como ya lo he dejado expuesto, la doctrina clásica argentina viene advirtiendo ciertas dudas interpretativas al momento de determinar el alcance de esta institución. Algunas primeras obras alcanzaron a presentar un primer panorama relativamente sencillo de tratamiento del instituto posesorio, que permitía admitir a simple vista que la posesión presentaba ciertos elementos esenciales, como los de hecho -relación del hombre con las cosas exteriores con el fin de someterlas bajo su poder y en razón de sus necesidades- y los psicológicos -propósito de dominación o ejercicio efectivo sobre la cosa-, que permitían definirla como el poder que el hombre ejerce de una manera efectiva e independiente sobre las cosas, con el fin de utilizarlas económicamente, siendo ese poder una protección jurídica que tutela la relación con prescindencia de saber si la misma se corresponde o no se corresponde con la existencia de un derecho ${ }^{295}$. Desde allí que se haya afirmado que propiedad y posesión no eran términos sinónimos: la posesión consiste en un acto (poseo), la propiedad consiste en un título (debo poseer) ${ }^{296}$.

Estas primeras posiciones comenzarían a generar ciertas perturbaciones en torno al alcance de los conceptos esgrimidos. De hecho, ya con anterioridad se venía comprobando que muchos de los conflictos que surgen del estudio de la posesión se debían esencialmente, a su tratamiento e interpretación en conjunto, en paralelo, con el derecho de propiedad. Por ello es que ciertas posiciones de la época absolutamente reconocidas terminarían por argumentar que la posesión confería un poder jurídico que se confundía con el derecho de propiedad, y por ello es que se la protegía a través de acciones especiales instituidas para proteger el derecho de propiedad en su estado

${ }^{294}$ V. Claudio KIPER, Tratado de derechos reales, to I, ob. cit., p. 80; Liliana ABREUT de BEGHER, Derechos reales, ob. cit., p. 101; Marina MARIANI DE VIDAL y Adriana N. ABELLA, Derechos reales, t ${ }^{\circ}$ I, Zavalía, Buenos Aires, 2.016, p. 63 y entre otros, Julio R. PEÑA, La posesión y la tenencia (Relaciones de poder), en Carlos M. CLERC, Derechos reales en el nuevo Código Civil y Comercial de La Nación, ob. cit., p. 69.

${ }^{295}$ Cfr. Daniel OVEJERO, La posesión, Compañía Impresora Argentina S.A, Buenos Aires, 1.942, págs. 14-15.

${ }^{296}$ Ibídem, p. 9. 


\section{SEBASTIÁN JUSTO COSOLA}

normal, biológico, de paz, momento en el que el propietario se encuentra gozando sin contradicción de su derecho ${ }^{297}$.

Las referencias realizadas no dejan de poner en evidencia la relevancia de los análisis hasta aquí expuestos. Desde ellos puede inferirse que la posesión presenta un primer principio que opera como condición jurídica $-\mathrm{y}$ publicitaria por excelencia- en razón del hecho de la demostración: a través de la misma, se ejerce en definitiva, un derecho por signos exteriores ${ }^{298}$. Por ello y para evitar contradicciones o choque de conflictos entre el ejercicio del derecho de propiedad y el ejercicio del hecho fáctico de la posesión, algunos autores han recurrido a explicar las diferencias que desde Roma se advierten entre el ius possidendi y el ius possessionis ${ }^{299}$; mientras que el ius possidendi presenta a la posesión como objeto de un derecho real, en el ius possessionis la posesión es una causa generadora de derechos ${ }^{300}$.

Entre los autores latinoamericanos contemporáneos, sorprende gratamente el aporte del profesor Gunther Gonzáles Barrón. El jurista peruano propone un nuevo concepto de posesión, que se aleja de las definiciones generalistas que según su visión, no hacen más que causar dudas en relación al tema que nos ocupa, considerando a la misma como "el control voluntario y autónomo de un bien, destinado a tenerlo para sí, en beneficio propio, con relativa permanencia o estabilidad, cuya finalidad es el uso y disfrute, aunque sea en modo potencial ${ }^{301 " .}$. Desde aquí se desprenden entonces sus elementos configurativos:

\footnotetext{
297 Zenón MARTINEZ, La posesión, ob. cit., p. 73. Y agrega el autor: "Según nuestro sistema, en la posesión se protege a la propiedad en su estado normal; y como todo lo normal se presume, nuestra tesis esta igualmente confirmada por los argumentos que se aducen en la teoría de la propiedad presunta".

${ }^{298}$ Cfr. Julio DASSEN y Enrique VERA VILLALOBOS, Manual de Derechos Reales (Parte General. Posesión. Defensa posesoria), Tea, Buenos Aires, 1.962, p. 34.

${ }^{299}$ Ídem, p. 35. Los autores argumentan que mientras que en el ius possidendi equivale al derecho de poseer, ya que implica una atribución legal que tiene el sujeto de ejercer la posesión y de realizar una infinita variedad de hechos en razón de detentar un derecho adquirido en forma legal (derecho real de dominio), el ius possessionis es un derecho que deriva del hecho de la posesión, y que es equivalente con un conjunto de facultades y defensas que la ley acuerda a quien a través de un hecho enmarcado en determinadas condiciones, ejerce un señorío sobre una cosa prescindiendo en realidad de un derecho real sobre la misma (poseedores de facto que pueden convertirse en titulares del dominio a través de instituciones como la prescripción).

${ }^{300}$ Ibídem.

${ }^{301}$ Gunther GONZALES BARRÓN, Tratado de Derechos Reales, t ${ }^{\circ}$ I, ob. cit., p. 413.
} 
LOS EFECTOS DE LA PUBLICIDAD EN EL DOCUMENTO NOTARIAL

a) El control que explica la injerencia que tiene el sujeto sobre el bien $^{302}$;

b) La autonomía del control, por cuanto el poseedor no recibe instrucciones ni indicaciones de un tercero, y ejerce la posesión en interés propio $^{303}$;

c) La constitución mediante acto de voluntad, en el sentido de que la misma es un hecho jurídico que exige la intención de sujeción con exclusión de terceros ${ }^{304}$

d) Situación posesoria de relativa permanencia o estabilidad que excluye de antemano los contactos esporádicos ${ }^{305}$;

e) Implicancia del uso potencial o hipotético del bien, ya que la posesión no implica uso y disfrute actual e ininterrumpido, sino potencial $^{306}, \mathrm{y}$

f) Conformación de la posesión como situación de hecho, entonces la existencia de título jurídico se vuelve irrelevante ${ }^{307}$.

\subsection{En torno de las teorías tradicionales de la posesión ${ }^{308}$.}

A partir de las ideas expuestas por Savigny, el tratamiento del tema de la teoría subjetiva que presenta a la posesión como un hecho comienza por

${ }^{302}$ Ibídem.

${ }^{303}$ Ibídem, p. 414.

${ }^{304}$ Ibídem.

${ }^{305}$ Ibídem, p. 415.

${ }^{306}$ Ibídem.

${ }^{307}$ Ibídem.

308 Para estudiar un esquema explicativo de sus principales alcances, inclusive con las fórmulas explicadas: Guillermo L. ALLENDE, La posesión, Abeledo-Perrot, Buenos Aires, 1.959 . 


\section{SEBASTIÁN JUSTO COSOLA}

argumentar que para que se configure la existencia de la posesión, se vuelve necesaria la concurrencia de dos elementos concretos: el corpus y el animus $^{309}$. De esta forma, la primera caracterización relevante ordena que mientras la posesión exige la detención de una cosa y la intención de tenerla para sí (detención material y animus domini) la tenencia solamente se conforma con la mera detención material ${ }^{310}$ (Cuando hay intención, hay posesión; sin intención, lo que hay es tenencia ${ }^{311}$ ).

Existe además consenso entre los autores en admitir que el hecho posesorio otorga no solo la posibilidad de disponer fisicamente de la cosa, sino que también de "defenderla contra toda acción extraña $a^{312 " . ~}$

$\mathrm{Al}$ reconocer el corpus, se hace referencia a un poder de hecho sobre la cosa, un poder de tipo físico, pero que no basta por sí mismo para conformar la posesión por cuanto requiere de un mínimo de voluntad ${ }^{313}$. De esta manera, coherentemente se interpreta que la posesión existe mientras se pueda reproducir a voluntad el estado de hecho que permite disponer de la cosa poseída $a^{314}$, ya que en general los autores equiparan el acto físico al contacto inmediato, y de ahí es que se admitan los dos tipos de aprehensión posibles según el objeto: en cosas muebles, tomar el objeto con la mano, y en las cosas inmuebles, poner un pie sobre las mismas ${ }^{315}$.

En cambio el reconocimiento del animus hace alusión a la intención de comportarse con la cosa como si uno fuese el propio dueño, y más preciso que ello, implica una actitud de no reconocimiento en otras persona de un derecho superior sobre la cosa que el que uno detenta ${ }^{316}$. También se argumenta que -inspirados en la idea de la posesión como hecho-, toda detentación debe ser intencional, ya que no es suficiente para ser poseedor

\footnotetext{
${ }^{309}$ Ricardo J. PAPAÑO, Claudio M. KIPER, Gregorio A. DILLON y Jorge R. CAUSSE, Derecho Civil. Derechos Reales, $\mathrm{t}^{\circ} \mathrm{I}$, ob. cit., p. 42.

${ }^{310}$ Raymundo M. SALVAT, Derecho Civil Argentino. Derechos Reales, T I, ob. cit., p. 39.

${ }^{311}$ Ibídem.

${ }^{312}$ Elena Inés HIGHTON, Derechos Reales. La posesión, ob. cit., p. 14.

${ }^{313}$ Ricardo J. PAPAÑO, Claudio M. KIPER, Gregorio A. DILLON y Jorge R. CAUSSE, Derecho Civil. Derechos Reales, $\mathrm{t}^{\circ} \mathrm{I}$, ob. cit., p. 42.

${ }^{314}$ Elena Inés HIGHTON, Derechos reales. La posesión, ob. cit., p. 15.

${ }^{315}$ Ibídem.

${ }^{316}$ Ricardo J. PAPAÑO, Claudio M. KIPER, Gregorio A. DILLON y Jorge R. CAUSSE, Derecho Civil. Derechos Reales, $\mathrm{t}^{\circ} \mathrm{I}$, ob. cit., p. 43.
} 
LOS EFECTOS DE LA PUBLICIDAD EN EL DOCUMENTO NOTARIAL

detentar la cosa sino que además "es necesario querer detentarla $a^{317}$ ", lo que no implica otra cosa que la intención de ejercer el derecho de propiedad o tratar la cosa como que pertenece al sujeto de acuerdo al derecho ${ }^{318}$. Desde la visión de Savigny, se concluye, es poseedor toda persona que dispone de hecho como lo haría el propietario, sin reconocer en otro un derecho superior al suyo ${ }^{319}$.

Desde otro lado, la teoría objetiva que impulsó Ihering -en crítica a la tesis expuesta por Savigny- supone que la posesión -ya no como hecho, sino como derecho- consiste en el ejercicio de un poder de hecho sobre las cosas conforme a su destino natural ${ }^{320}$, y que no es necesario recurrir al animus domini, porque se parte de la idea de aceptar que toda relación entre el hombre y las cosas implica ya la posesión, a menos que una disposición legal establezca que habrá únicamente tenencia ${ }^{321}$. Para los defensores de la presente teoría, el animus domini en Savigny conforma un elemento subjetivo que difícilmente pueda llegar a ser probado, ya que determinar si ese ánimo efectivamente existe en una persona implicaría penetrar en su mente en una tarea que resulta ser imposible ${ }^{322}$. De ahí entonces es que debe de prescindirse de la voluntad de quien tiene la cosa, y por ello se recurre a la posición de que la posesión es "el ejercicio de un poder de hecho sobre las cosas conforme a su destino natural ${ }^{323}$ ".

Enseña Salvat que ambas teorías aceptan que para que exista posesión no alcanza con la simple detención material, y que por ello debe concurrir un elemento psicológico que es la voluntad de poseer ${ }^{324}$. Pero esa voluntad de poseer que para la teoría subjetiva es el animus, para la teoría objetiva lo conforma simplemente el hecho que el derecho no niegue la existencia de la posesión $^{325}$. En la visión de Ihering entonces, el corpus no es ni más ni menos que un estado normal externo, que en la posesión se traduce como

\footnotetext{
${ }^{317}$ Elena Inés HIGHTON, Derechos reales. La posesión, ob. cit., p. 16.

${ }^{318}$ Ibídem.

${ }^{319}$ Ibídem, p. 18.

${ }^{320}$ Raymundo M. SALVAT, Derecho Civil Argentino-Derechos Reales, t ${ }^{\circ}$ I, ob. cit., p. 42.

${ }^{321}$ Ibídem.

${ }^{322}$ Ricardo J. PAPAÑO, Claudio M. KIPER, Gregorio A. DILLON y Jorge R. CAUSSE, Derecho Civil. Derechos Reales, t ${ }^{\circ}$ I, ob. cit., p. 43.

${ }^{323}$ Ibídem, p. 44.

${ }^{324}$ Raymundo M. SALVAT, Derecho Civil Argentino-Derechos Reales, tº I, ob. cit., p. 42.

${ }^{325}$ Ibídem.
} 


\section{SEBASTIÁN JUSTO COSOLA}

una manera de ver cómo se exterioriza la propiedad, y que comprende a la cosa "bajo el cual cumple el destino económico de servir a los hombres ${ }^{326 " . ~}$ En este sentido, Ihering admite que la cuestión de la posesión es un asunto de pura experiencia, una cuestión de la vida ordinaria ${ }^{327}$, y más gráfico que ello: "Es un poder fisico del que se burlan las liebres que se comen las hierbas de mi campo y los niños que juegan en mis mieses 328 ". En cuanto al animus, el autor admite que el mismo es el hecho de la voluntad ${ }^{329}$ que puede denominarse abstracta, porque reemplaza la voluntad individual subjetiva como elemento intencional, con la ley, que es la conformación de la voluntad objetiva ${ }^{330}$. De esta manera se facilita notoriamente la cuestión probatoria, porque únicamente habrá que demostrar la existencia del corpus para que la relación sea considerada como posesión ${ }^{331}$; en suma, es una teoría que conduce a estudiar la causa de la posesión ${ }^{332}$. Finalmente, debe tenerse presente que el corpus no puede existir sin el animus, lo que explica entonces que la voluntad es imprescindible para que el hecho tenga y produzca consecuencias jurídicas ${ }^{333}$. En definitiva, “(...) en principio, toda relación de hecho acompañada de un mínimo de voluntad implica posesión (elemento objetivo), a menos que la ley niegue su existencia por medio de una causa detentionis ${ }^{334, "}$

\subsubsection{Una referencia a la teoría de la causa.}

\footnotetext{
${ }^{326}$ Elena Inés HIGTHON, Derechos Reales. La posesión, ob. cit., p. 19.

${ }^{327}$ Ibídem, p. 20.

${ }^{328}$ Ibídem.

${ }^{329}$ Ibídem, p. 21.

${ }^{330}$ Ricardo J. PAPAÑO, Claudio M. KIPER, Gregorio A. DILLON y Jorge R. CAUSSE, Derecho Civil. Derechos Reales, $\mathrm{t}^{\circ} \mathrm{I}$, ob. cit., p. 44.

${ }^{331}$ Ibídem.

${ }^{332}$ Ibídem.

${ }^{333}$ Elena Inés HIGHTON, Derechos reales. La posesión, ob. cit., p. 21.

${ }^{334}$ Ricardo J. PAPAÑO, Claudio M. KIPER, Gregorio A. DILLON y Jorge R. CAUSSE, Derecho Civil. Derechos Reales, ${ }^{\circ}$ I, ob. cit., p. 44.
} 


\section{LOS EFECTOS DE LA PUBLICIDAD EN EL DOCUMENTO NOTARIAL}

Resulta interesante mencionar que la teoría de Saleilles, conocida como teoría de la causa posesoria, encuentra sustento en el factor económico de la posesión: el corpus supone un vínculo de explotación entre el poseedor y la $\cos a^{335}$. Saleilles intenta realizar una teoría general de la posesión desde el Código Civil Alemán ${ }^{336}$; según su criterio, para la prueba de la configuración de la relación posesoria no basta ni el simple contacto corporal con la cosa ni el titulo jurídico en que el mismo se funda: "la relación posesoria es un todo complejo que encierra ambos elementos como factores reales de la situación económica y social del que la ejerce ${ }^{337}$ ". El derecho está destinado a proteger esta situación, inclusive antes de que la misma conforme su legitimidad jurídica, porque "todo el que aqui en la tierra usa en paz y como dueño de los bienes de este mundo, llena una función útil en sí, buena para él y buena también para el organismo social a que pertenece ${ }^{338 " . ~ L a ~}$ comunidad -concluye- debe defenderlo y asegurarle el triunfo contra cualquier persona -agresor- que no pruebe un derecho mejor o superior al que lo tiene en carácter de poseedor, porque "todo acto útil y pacificamente realizado conforme en la apariencia con el orden social, es ya un derecho naciente, y no puede ceder sino ante un derecho anterior, más enérgico y mas integralizado ${ }^{339, "}$

\footnotetext{
335 Cfr. Mario Antonio ZINNY y Silvia Maela MASSICCIONI, Manual de Derechos Reales, Juris, Rosario, 2.009, p. 51.

${ }^{336}$ Cfr. Raymundo SALEILLES, La posesión. Elementos que la constituyen y su sistema en el Código Civil del Imperio Alemán, Librería General de Victoriano Suarez, Madrid, 1.909, p. 335. Más adelante el autor expresará: "En trabajos publicados hace tiempo y en los que, si bien tenían por asunto al derecho romano, comprendian un concepto más amplio y moderno de la teoría posesoria, trate de sostener que el fondo del problema en esta delicada materia consistía más bien en una cuestión de carácter económico más que jurídico; y esta opinión tan trascendental en el orden social parece haberla sancionado implícitamente el Código Civil Alemán..."; "El concepto económico de la posesión ha venido a sustituir al concepto jurídico. La posesión es la apropiación económica de las cosas sin relación alguna con la posible existencia de un derecho sobre la cosa. Esta fórmula resume toda la tesis de la nueva teoría alemana".

${ }^{337}$ Ibídem, p. 396

${ }^{338}$ Ídem, p. 397.

${ }^{339}$ Ibídem.
} 


\section{SEBASTIÁN JUSTO COSOLA}

\subsubsection{La tesis de la función social de la posesión.}

Un estudio meduloso y expositivo que hace confluir diferentes análisis que se corresponden con los datos reales -estadísticos-, con los factores históricos positivos y con tratamiento científico de la posesión hace presumir que el tema en estudio merece además una respuesta desde lo sociológico ${ }^{340}$. El esfuerzo de Hernández Gil entonces por transmitir que desde Ihering se pretendió proteger a la posesión, cuando en los tiempos presentes el problema es más profundo y dificultoso ya que los esfuerzos se encuentran destinados a defender a la propiedad, se erige como un tema polémico que dista de seguir siendo un análisis de teorías pacíficas ${ }^{341}$-. Así, el autor recuerda que existen tres grandes concepciones posesorias tradicionales que ayudan a inquirir su dimensión social ${ }^{342}$ :

a) La teoría de Savigny de la independización de la noción posesoria ${ }^{343}$;

b) La teoría de Ihering de la subordinación de la posesión a la propiedad $^{344}, \mathrm{y}$

c) El aporte del Marqués de Olivart, referido a la posesión y el ejercicio de los derechos ${ }^{345}$.

La teoría de Savigny expone los fundamentos de la posesión desde las fuentes romanas, $\mathrm{y}$ en esa tarea tiene especial significación lo puramente

\footnotetext{
${ }^{340}$ Cfr. Antonio HERNANDEZ GIL, La función social de la posesión, Alianza Editorial, Madrid, 1.969, p. 12. [NdA: La edición aquí en estudio corresponde a otra editorial y a otro año de edición de la citada con anterioridad].

${ }^{341}$ Ibídem, p. 10.

${ }^{342}$ Ibídem, p. 14.

${ }^{343}$ Ibídem. Agrega el autor que este resultado, socialmente valioso, se encuentra neutralizado por el animus domini.

${ }_{344}$ Ídem, p. 22. Continúa el autor argumentando que esta tesis es un retroceso en el orden social y que existen ciertas contradicciones internas.

${ }^{345}$ Ídem, p. 16. Afirma el autor que existe en esta teoría una generalización de la tesis de Ihering destinada a conformar la posesión en el ejercicio de los derechos.
} 
racional y lógico sobre lo racional y empírico ${ }^{346}$. Así puede destacarse que la aportación culminante de Savigny "consiste en haber reducido la posesión a un mínimo básico dotado de autonomía respecto de la propiedad ${ }^{347}$ ”. Desde esa consideración, no se desconoce que la posesión puede ser una emanación del derecho de propiedad, y se afirma la existencia de derechos estrictamente derivados de la posesión ${ }^{348}$; esto es lo que justifica que la misma comience por separarse tanto de la propiedad como de la tenencia, en la misma medida en que se contraponen el hecho y el derecho frente a la primera, y en la producción o no producción de efectos jurídicos en la segunda ${ }^{349}$. En cuanto a los mencionados efectos, Savigny afirma que en relación al derecho romano, la posesión solo produce dos efectos: la usucapión y los interdictos $^{350}$. Destaca Hernández Gil que la tesis de la independencia de la posesión es socialmente valiosa, ya que da a entender que el uso y goce de los bienes logra adquirir verdadera significación jurídica fuera de la estructura de la sociedad y de todos los derechos derivados ${ }^{351}$ y así, toda referencia a la posesión como estado de hecho que es tutelado sin considerar la propia legalidad en razón de las razones de convivencia pacífica, no hace más que pensar que la misma es una institución directamente enraizada en la realidad social ${ }^{352}$.

Sin embargo, según lo expone el maestro español, el avance de la noción del derecho en Savigny se ve neutralizado por el sentido que se le otorga a la voluntad o ánimo de poseer (animus possidendi) como elemento constitutivo de la posesión ${ }^{353}$. Así, adquiere relevancia el presupuesto de la detentación, que carece de voluntad de poseer ${ }^{354}$. Voluntad de poseer implica querer actuar y comportarse como si se fuera propietario ${ }^{355}$-por eso animus possidendi equivale a animus domini ${ }^{356}$-; implica además el no reconocer la

\footnotetext{
${ }^{346}$ Ibídem, p. 17.

${ }^{347}$ Ibídem, p. 18.

${ }^{348}$ Ibídem, p. 18.

${ }^{349}$ Ibídem.

${ }^{350}$ Ibídem.

${ }^{351}$ Ibídem, p. 19.

${ }^{352}$ Ibídem.

${ }^{353}$ Ibídem.

${ }^{354}$ Ibídem.

${ }^{355}$ Ibídem.

${ }^{356}$ Ibídem.
} 


\section{SEBASTIÁN JUSTO COSOLA}

superioridad de ningún, y desde aquí el clásico ejemplo que reconoce que la posesión corresponde al ladrón, en tanto no pueda ostentarla el arrendatario, pues considera la cosa como ajena ${ }^{357}$.

La teoría de Ihering en cambio, se analiza y justifica desde otro punto de vista $^{358}$. Desde esta perspectiva, la protección de la posesión es un complemento necesario de la protección de la propiedad, que facilita la prueba para al propietario y de la que también se aprovecha necesariamente el no propietario ${ }^{359}$. Ni la protección a la persona ni la reacción ante la violencia constituyen el fundamento de la tutela posesoria, que únicamente puede encontrarse en la propiedad ${ }^{360}$. Según la opinión de Hernández Gil es este un punto débil en la tesis de Ihering, ya que nadie duda acerca de que la posesión ofrece matices de un poder cualificado sobre las cosas en general, que supera la mera tenencia y que no equivale a la relación de propiedad ${ }^{361}$. Se vuelve entonces difícil justificar a la posesión como imagen y sombra de la propiedad ${ }^{362}$, y así, Ihering terminará por justificar, con el transcurso de los años, la fundamentación de la protección posesoria, postergando el propio concepto de propiedad al momento de combatir el animus domini

\footnotetext{
${ }^{357}$ Ibídem.

${ }^{358}$ Ibídem, p. 22. Principalmente, su exposición de motivos encuentra reparo en dos obras cumbres: "El fundamento de la protección posesoria" y "La voluntad en la posesión”. Según lo refiere Hernández Gil, las mismas son la prueba de la evolución que como jurista experimenta el propio Ihering alternando su pasado conceptualismo formalista por un trascendente realismo teológico. El profesor español además aclara que plazo de la publicación entre las obras es de veinte años, de ahí a que pueda advertirse, según su posición, la notable evolución académica.

${ }^{359}$ Ídem, p. 24.

${ }^{360}$ Ibídem.

${ }^{361}$ Ibídem, p. 25.

${ }^{362}$ Ibídem, p. 26.
} 
como elemento distintivo de la posesión ${ }^{363}$. En cierta medida, lo que Ihering persigue es silenciar las motivaciones voluntaristas de la posesión ${ }^{364}$.

De las dos teorías sucintamente consideradas, debe concluirse que la tesis de la función social de la posesión se encuentra acreditada mucho más fuertemente en la tesis de Savigny que en Ihering. De esta manera, mientras que desde el primero la posesión se coloca al servicio de la persona y con la finalidad de alcanzar la paz - prioridad al mundo de las realidades sociales-, en el segundo la institución posesoria prioriza la figura del propietario a los efectos de aplicar una clara defensa al dominio -posición que se aleja de la mejor y ordenada convivencia ${ }^{365}$.

En el final, la mencionada referencia a la tesis del Marqués de Olivart se realza desde una base iusnaturalista en donde la posesión se extiende a todos los derechos ${ }^{366}$. Para el autor, la posesión es el ejercicio intencionado, no momentáneo y exclusivo del cualquier derecho ${ }^{367}$. La posesión se encuentra entonces colocada en función de la propiedad, pero no en el sentido de la propiedad romana, sino en dependencia de lo que es la propiedad en sí misma, como derecho absoluto, exclusivo y transmisible del hombre sobre la cosa, regulado por la ley ${ }^{368}$. Inspirado en el derecho canónico, retoma color el concepto de naturaleza, y el autor termina por considerar que sirve esta concepción canónica para destruir la concepción ruda del derecho positivo, y especialmente materialista del derecho romano ${ }^{369}$. Esta tesis notable presenta algún tipo de dudas iniciales: ¿Cómo algo que emana de la

\footnotetext{
${ }^{363}$ Ibídem. Y así lo considera: "Enviar al poseedor a la escuela, cerca del propietario, para aprender de él como debe poseer, es trastornar la relación que existe entre la posesión y la propiedad. La posesión es más antigua que la propiedad. Puede imaginarse la posesión sin la propiedad, pero no al contrario. En la posesión no encontramos en parte alguna la propiedad, ni en la definición, ni en el nacimiento, ni en la extinción, ni en la protección; pudiendo, si fuere preciso, exponerse toda la teoría de la posesión sin emplear una sola vez la palabra propiedad. Que no se intente hacer lo mismo con la propiedad. No podemos separarnos jamás de la posesión; nos sigue constantemente en toda la teoría de la propiedad".

${ }^{364}$ Ídem, p. 32.

${ }^{365}$ Ídem, p. 33.

366 Ídem, p. 35. Es una tesis es inspirada en Ihering, pero con distintos fundamentos: para el nombrado autor los mismos se encontraban en el derecho romano; Marqués de Olivart la fundamenta desde la filosofia del derecho.

${ }^{367}$ Ibídem.

${ }^{368}$ Ibídem, p. 37.

${ }^{369}$ Ídem, p. 38.
} 
naturaleza misma de las cosas requiere de estímulos del avance social y de la lógica jurídica ${ }^{370}$ ? Entender y comprender sus alcances es, en cierta forma, remitirse a los postulados más profundos del derecho providencial. Así, desde la Summa Theológica $\left(I I^{\circ}-I^{\circ}\right)$ se argumentaba que Dios tiene el dominio principal sobre todas las cosas y que por lo tanto, la comunidad de bienes se atribuye al derecho natural ${ }^{371}$. La propiedad privada $-\mathrm{y}$ conjunta $\mathrm{o}$ separadamente de ella según lo expuesto hasta aquí, la teoría posesoria -es aconsejada tanto por la razón natural como por la utilidad de la vida humana. Sin embargo, se vuelve necesario distinguir lo que es naturalmente común de lo que a nivel institucional conviene que sea particular ${ }^{372}$. Lo segundo se desprenderá de las teorías explicativas referentes a través de los años, originarias de doctrinas y de políticas dedicadas a distribuir según la necesidad o la conveniencia. Lo primero se argumenta desde la contundente frase de Vallet: "Todos somos iguales en esencia, aunque la naturaleza nos enseña que somos, y que es bueno y hasta necesario que así sea, diferentes en circunstancias y accidentes (...) Puede por tanto el hombre utilizar, ordenar y mejorar la naturaleza, pero no puede desconocerla ni sustraerse de ella ${ }^{373}$ ".

2.3.2.1. Proyecciones y justificaciones que determinan la naturaleza jurídica.

La idea de la naturaleza jurídica de la posesión parte de considerar a la misma como un hecho (Savigny) o como un derecho (Ihering) ${ }^{374}$. La

\footnotetext{
${ }^{370}$ Ibídem.

${ }^{371}$ Juan B. VALLET DE GOYTISOLO, Estudio sobre el derecho de cosas, ob. cit., p. 119.

${ }^{372}$ Ídem, p. 120.

${ }^{373}$ Cfr. Juan B. VALLET DE GOYTISOLO, En torno al derecho natural, Organización Sala, Madrid, 1.973, p. 17.

${ }^{374}$ Algunos autores entienden sin embargo, que la mencionada disputa entre los dos grandes maestros del derecho alemán no fue de la magnitud con la que con énfasis de la expone, teniendo en cuenta que eran autores a-contemporáneos, y en la consideración en que se ubica a Savigny en una posición firme de que la posesión es exclusivamente un hecho cuando en realidad no fue esa la realidad de sus exposiciones. Cfr. Domingo C. CURA GRASSI,
} 


\section{LOS EFECTOS DE LA PUBLICIDAD EN EL DOCUMENTO NOTARIAL}

posesión como hecho intenta demostrar que si se atiene a las consecuencias, la relación real que se proyecta se asemeja a un derecho, en esencia, porque es motivo de protección lega $l^{375}$. El derecho positivo protege a la posesión de toda turbación, sea o no sea violenta, que afecta la relación establecida con fines de preservar el orden social y evitar la justicia por mano propia, no dejando nunca de tener en cuenta que la violencia siempre es contraria al derecho $^{376}$. Aceptar esta tesis importa asumir ciertas cuestiones interesantes:

a) La primera es la que comprueba que la especie de relación real proyectada hacia el mundo exterior puede aun ser adquirida de manera ilegítima, y así, la protección al poseedor, aun vicioso, “no puede convertir la posesión en un derecho ${ }^{377 " ;}$

b) Otra consecuencia es la que refiere a la adquisición del derecho real por medio de la usucapión, ya que si se entendiera que la posesión es un derecho, no habría motivos para volver a adquirirlo mediante la mencionada institución ${ }^{378}$. De ahí es que se considere a la posesión como base de la usucapión ${ }^{379}$, y de ahí que algunos aportes de la escuela platense del derecho clarifiquen que para esta situación ocurra, es necesario detentar la posesión a titulo de dueño, que la misma sea continua y no interrumpida, y que sea además pública y pacifica $^{380}$.

Desde otro lado, la posesión como un derecho considera que si la misma se encuentra tutelada por diversas acciones es porque se trata de un derecho que merece el amparo legal, dando lugar a las llamadas acciones posesorias que

Derechos Reales. Posesión, Ad-Hoc, Buenos Aires, 2.009, p. 37.

${ }^{375}$ Lilian GURFINKEL DE WENDY, Derechos Reales, $\mathrm{t}^{\circ}$ I, ob. cit., p. 165.

${ }^{376}$ Ibídem.

${ }^{377}$ Ibídem.

${ }^{378}$ Ibídem.

${ }^{379}$ Cfr. Manuel J. FERRO, Práctica de la usucapión, Ediciones Jurídicas, Buenos Aires, 2.012, p. 89.

${ }^{380}$ Cfr. Pablo María CORNA, Prescripción adquisitiva, ob. cit., págs. 47-48. Sobre este tema, recuerda Mariani de Vidal que con ciertos matices, también Mackeldey y Windscheid se enrolaban en este pensamiento, y es importante destacarlo, por cuanto Vélez sigue la posición de Mackeldey según se encuentra expuesto en el libro pertinente de los derechos reales. Marina MARIANI DE VIDAL, Curso de derechos reales, t $^{\circ}$ I, ob. cit., p. 119. 


\section{SEBASTIÁN JUSTO COSOLA}

vienen a representar la defensa de la posesión independientemente de la prueba de la propiedad ${ }^{381}$. Desde ciertos puntos de vista, esta concepción es coherente con el propio pensamiento de Ihering acerca del derecho subjetivo, al que consideraba como un interés jurídicamente protegido ${ }^{382}$. En el derecho comparado y desde otras perspectivas, algunos autores mexicanos exponen que la verdadera naturaleza jurídica de la posesión es la de ser considerada un jus ad rem, esto es, un derecho personal con la vocación suficiente de convertirse más adelante, ya sea en propiedad, usufructo o servidumbre, todo dependiendo del derecho real que se esté poseyendo ${ }^{383}$, ya que en última instancia, los efectos jurídicos de la posesión que fundamentan su valor y existencia son la posibilidad de usucapir, la correspondencia de frutos y el otorgamiento de los medios de defensa contra todo aquel que no tenga un mejor derecho para poseer ${ }^{384}$. Con mayor profundidad que la posición referida se alza la teoría que llega a considerar la verdadera naturaleza real de la posesión. De esta manera, se parte de considerar que la persona que ejerce un poder de hecho frente a un bien o un derecho sin facultad suficiente brindada por el ordenamiento jurídico, hace emerger para sí un derecho con facultades subjetivas suficientes para consolidar en él la fuerza de los derechos reales ${ }^{385}$. En ese país, la

${ }^{381}$ Lilian GURFINKEL DE WENDY, Derechos Reales, $\mathrm{t}^{\circ}$ I, ob. cit., p. 165.

${ }^{382}$ Marina MARIANI DE VIDAL, Curso de Derechos Reales, T I, ob. cit., p. 119. Según la opinión de la autora, del articulado del Código Civil Argentino pareciera desprenderse el criterio que afirma que la posesión es un hecho, mientras que del análisis de sus notas, se afirma categóricamente lo contrario. Sobre este tema, un estudio profundo del conflicto entre las normas y las notas puede estudiarse en la obra de Domingo Cura Grassi, a la que remito en la medida en que se pretenda alcanzar una mayor medida en la justificación expositiva: Domingo CURA GRASSI, Derechos Reales. Posesión, ob. cit., págs. 37 y ss.

${ }^{383}$ Cfr. Felipe DE LA MATA PIZAÑA y Roberto GARZÓN JIMÉNEZ, Bienes y derechos reales, Porrúa, México, 2.013, p. 428.

${ }^{384}$ Ibídem, p. 429.

${ }^{385}$ Cfr. Miguel ALESSIO ROBLES, Temas de derechos reales, Porrúa, México, 2.015, p. 95. Más adelante el autor confirma: "Ciertamente la realidad y la práctica jurídica enseña que normalmente las personas poseen bienes en concepto de propietario; pero nada impide que se posean bienes en concepto de titular de otros derechos absolutos, bien sea como consecuencia de un derecho aparente, como sucede en el caso del heredero aparente, o como consecuencia de un derecho derivado de un acto anulado. En ambos supuestos, el heredero aparente o el titular del derecho distinto de la propiedad respecto de un bien, puede alegar la usucapión ganada en el transcurso del tiempo. En este caso, la característica de que la posesión debe ser realizada en concepto de dueño, debe entenderse como titular del derecho poseido". 
LOS EFECTOS DE LA PUBLICIDAD EN EL DOCUMENTO NOTARIAL

confluencia de teorías dispares que en todo caso, se justifican por la interpretación que se realiza de los Códigos Civiles de cada Estado miembro -y desde ellos, los más cercanos y los más alejados al sistema de Commonlaw-, no dejan de poner evidencia que en última instancia, las diferencias que existen entre la propiedad como derecho real y como poder jurídico inmediato que tiene el titular sobre la cosa -con efecto hacia todo el mundo-, y la posesión como un poder de hecho que confiere al poseedor la facultad de tener la cosa bajo su voluntad -sin tomar en cuenta si ese poder se deriva o no de una situación contemplada de derecho- deben seguir siendo mantenidas y en todo caso, profundizadas y actualizadas ${ }^{386}$.

\subsubsection{La posesión desde la exposición de Carnelutti: armonía} entre la seguridad jurídica y la justicia.

El tratamiento de la posesión que presenta Francesco Carnelutti desde una teoría general del derecho ${ }^{387}$, con todo lo que ello implica, es comprensiva de todos los elementos provenientes de una estructura elemental del derecho, $\mathrm{y}$ en este espacio sin duda alguna merece destacarse ${ }^{388}$. Para el autor italiano, el

${ }^{386}$ Cfr. Javier TAPIA RAMIREZ, Bienes. Derechos reales, derechos de autor y registro público de la propiedad, Porrúa, México, 2.016, p. 374.

${ }^{387}$ Cfr. Francesco CARNELUTTI, Teoría general del derecho, trad. de Francisco Javier OSSET, Revista de Derecho Privado, Madrid, 1.955, p. 25.

${ }^{388}$ Siempre he asumido que el derecho, debatido muchas veces desde la especialidad, debe siempre argumentarse desde la generalidad. Una teoría general del derecho puede proyectar todos los elementos encadenados y ordenados para que ciertos elementos del derecho puedan verificar algunos valores que el jurista se impone en obtener, tales como la seguridad y la justicia. Es en la teoría del derecho en donde la seguridad jurídica y la justicia conviven y se armonizan, proyectando el máximo alcance de sus expresiones y finalidades, erigiéndose como dos baluartes esenciales de argumentación jurídica. En general los autores suelen contraponer a estos valores. Si la justicia es dirimida en los Tribunales, no puede entonces existir la seguridad jurídica previa, que precisamente quita al juez la potestad de decir "que es lo justo". Esta tesis se esfuerza por demostrar que de la unión de estos valores con la verdad, se obtiene la paz, que es el valor más buscado y perseguido por el ser humano, y que por su especial singularidad, esos valores se advierten también en el seno del documento notarial. De ahí quizás que Kelsen haya adscripto a ese valor, y de ahí la necesidad de consolidar una estructura del documento notarial que permita hacer vislumbrar el contenido esencial del mismo (Reglas + valores+ normas + principios). 


\section{SEBASTIÁN JUSTO COSOLA}

fin del derecho parte de una consideración del interés: todos tenemos intereses, y los intereses de un mismo hombre pueden determinar en ese sujeto una toma de posición de preeminencia o de indiferencia ${ }^{389}$. Descartada la indiferencia y configurada la preeminencia, la única consecuencia posible es o la solidaridad o el conflicto ${ }^{390}$.

Las nociones de interés y solidaridad aumentan en importancia cuando además se las considera desde la perspectiva de varios hombres ${ }^{391}$. Y uno de estos temas específicamente cobra relevancia al analizar el derecho de dominio $^{392}$. La naturaleza provee así a todo hombre de bienes, siendo el primero de ellos el propio cuerpo ${ }^{393}$, para que por medio de éste el mismo pueda procurar otros bienes ${ }^{394}$, y de esta manera, el conjunto de bienes de cada uno para lograr la satisfacción de las necesidades se llama dominio; un concepto estrictamente económico y por ende, pre-jurídico ${ }^{395}$.

Como el dominio se encuentra fundado en la distribución de los bienes que existen en la naturaleza de los hombres, su finalidad es la de satisfacer sus necesidades. Pero la distribución es un hecho casual ${ }^{396}$. Si por el contrario la consecuencia es el conflicto, la justificación del mismo es la limitación de los bienes ${ }^{397}$. Ese conflicto se agrava cuando se manifiesta entre hombres diversos, dando lugar a la guerra con disgregación de la sociedad -invasión del dominio de uno o más hombres por parte de otro o de otros ${ }^{398}$ - o al

\footnotetext{
${ }^{389}$ Francesco CARNELUTTI, Teoría general del derecho, ob. cit., p. 25.

${ }^{390}$ Ibídem.

${ }^{391}$ Ibídem, p. 26.

${ }^{392}$ Ibídem, p. 27.

${ }^{393}$ Ibídem.

${ }^{394}$ Ibídem, p. 28.

395 Ibídem. En estas palabras lo expresa Carnelutti: "Ya se verá más veces que, al constituirse el derecho, asume importancia jurídica (el dominio); pero su valor puro y original es independiente del derecho. En otras palabras: que aun sin el derecho la cosa que le corresponde al dominio existe".

${ }^{396}$ Ibídem. Para el autor, es necesario aun ir más lejos en el análisis, para remitirse a los orígenes de la riqueza y de la pobreza: "El dominio es como la sombra de cada hombre proyectada por sus intereses sobre la tierra; se la podría denominar por eso la proyección económica del hombre".

${ }^{397}$ Ibídem, p. 29.

${ }^{398}$ Ibídem.
} 


\section{LOS EFECTOS DE LA PUBLICIDAD EN EL DOCUMENTO NOTARIAL}

mismo problema sin disgregación de la sociedad, como una composición espontanea, que es la posesión ${ }^{399}$.

Para el maestro italiano, la posesión "consiste en que por iniciativa de uno de los sujetos se hace prevalecer uno de los intereses en conflicto, y por la tolerancia del otro sujeto queda sin satisfacer el otro interés ${ }^{400 " . ~ E l ~ p r i m e r o ~}$ es el poseedor, que goza de los bienes, mientras que el segundo es el poseído o sujeto pasivo, que permanece a la sombra siendo su figura esencial para completar la noción de la posesión ${ }^{401}$.

¿Qué es entonces los que persigue la posesión? Tranquilidad ${ }^{402}$. De esta manera, la tranquilidad puede ser turbada de un momento a otro ${ }^{403}$, y por ello para garantizar esa tranquilidad interviene el derecho. Por ello es que el jurista concluye al finalizar el comentario: "Solo hemos de notar aquí que la sociedad no puede contentarse con obtener la tranquilidad, sino que tiene necesidad de la paz ${ }^{404}$ ". Para ello recurre a la explicación de la composición ética del conflicto, comprensiva de una paz entre los hombres referida a un modo de composición espontánea de sus conflictos, cuya existencia se encuentra demostrada por la observación de la realidad ${ }^{405}$. Así, si el conflicto se soluciona por caridad o por bondad de un hombre respecto de otro hombre, esa composición conduce a la paz. Y esa composición pacífica del conflicto, en la mente de cada hombre, será reflejada como lo que a cada uno le parecía justo.

Así se presenta la justicia en el desarrollo de la posesión, virtud trascendente a la que me referiré oportunamente para justificar como la misma se desenvuelve en el documento notarial. En especial, no puede dejar de adelantarse aquí, que según la visión del genial maestro italiano, la justicia es conformidad con el orden del universo, que no es lo mismo que conformidad y adecuación a la regla o a la ley ${ }^{406}$. En este punto como en

\footnotetext{
${ }^{399}$ Ibíd., p. 32.

${ }^{400}$ Ibídem, p. 33.

${ }^{401}$ Ibídem.

402 Ibídem. Tranquilidad que no puede confundirse con la paz, porque el defecto de la tranquilidad es la precariedad.

${ }^{403}$ Ibídem.

${ }^{404}$ Ibídem.

${ }^{405}$ Ibídem.

${ }^{406}$ Ibídem, p. 34.
} 
tantos otros, la similitud con el pensamiento de Vallet de Goytisolo ya referido en el presente capítulo, es sustancial y admirable.

\section{4. ¿Cuáles son los fundamentos de la protección posesoria?}

Concretados de manera sucinta los análisis correspondientes relativos al desarrollo del instituto de la posesión y su proyección publicitaria -que vienen a determinar y explicar de qué manera se ha proyectado la misma en el ordenamiento jurídico y en la doctrina, y además a proyectar cuáles han sido sus principales inconvenientes-, resulta conveniente destacar los fundamentos de la protección posesoria. Esto es así porque si hay problema que la jurisprudencia ha tenido que solucionar en sendos casos absolutamente paradigmáticos es la referencia al conflicto que se origina entre quien tiene un documento que lo vuelve propietario y quien carece de él, o lo presenta viciado, pero es quien definitivamente ejerce el hecho posesorio $^{407}$.

Con todo lo que hasta aquí he referido en relación al derecho de propiedad, el derecho de dominio y las referencias a la institución posesoria, ¿Cómo es posible que un documento privado tenga más fuerza en el derecho si se lo acompaña y justifica conjuntamente con la posesión, que un documento público que reúne todos los requisitos del nacimiento del derecho real a favor de quien oficia de adquirente de buena fe? ¿Y en los casos en donde ni siquiera existe el instrumento pero si existe el hecho exterior posesorio, cual es la circunstancia que legitima al poseedor? ¿La apariencia pública genera en su persona un derecho que merece ser protegido?

407 Ya Alberto Molinario había oportunamente presentado unas ideas rectoras acerca de la protección posesoria, teniendo en cuenta la evolución de la historia interna de nuestro país, de indudable relevancia si se pretendiera acudir a un panorama de la evolución histórica legislativa hispano-argentina en esta materia. Cfr. Alberto D. MOLINARIO, Interpretación de la protección posesoria actual en función de la historia interna, Separata de AFCJSUNLP, La Plata, 1.963, 62 p. 


\section{LOS EFECTOS DE LA PUBLICIDAD EN EL DOCUMENTO NOTARIAL}

Con todo lo antedicho, es preciso señalar con Jorge Alterini, que en la protección posesoria se encuentra en juego el propio Estado de derecho ${ }^{408}$. Con esto se reconoce que se suele brindar la mayor importancia a la protección de la posesión, elevando sus efectos por sobre las teorías de Savigny y de Ihering citadas que advertían que el fundamento de la protección mencionada cobraba especial relevancia, ya sea porque protegía a la persona del poseedor, ya sea porque funcionaba como una tutela del derecho de propiedad respectivamente ${ }^{409}$.Se encuentra en juego entonces el Estado de Derecho porque al monopolizar naturalmente el uso de la fuerza, las defensas privadas o las que se hallan fuera del poder judicial tienen un campo de aplicación muy acotado ${ }^{410}$.

Teniendo en cuenta que el monopolio de la fuerza del Estado debe ejercitarse de acuerdo con el derecho, se determina la protección posesoria judicial y se brega además por su eficacia ${ }^{411}$. En esta orientación, sostiene Manuel Albaladejo, la protección de la posesión se alcanza a través de un juicio oportuno que se realiza para que quien ostenta la posesión sin derecho sea privado de ella y para que la misma sea conferida, de acuerdo a la justicia, a quien verdaderamente corresponda ${ }^{412}$.

Así puede inferirse que la protección posesoria consiste en el establecimiento de los medios judiciales y extrajudiciales que la ley viene arbitrando para la defensa de la posesión, en atención exclusiva al carácter del poseedor ${ }^{413}$. El Código Civil y Comercial de La Nación regula este tema, y parte de un principio general ya establecido con anterioridad en la legislación y en la doctrina, que advierte que un título válido no da la

\footnotetext{
${ }^{408}$ Cfr. Jorge Horacio ALTERINI, Protección posesoria, en Carlos Gustavo VALLESPINOS (Dir.), Cuestiones Esenciales en derechos reales, LexisNexis, Buenos Aires, 2.002, p. 9.

${ }^{409}$ Ibídem.

${ }^{410}$ Ibídem, p. 10.

${ }^{411}$ Ibídem.

${ }^{412}$ Cfr. Manuel ALBALADEJO, Compendio de derecho civil, José María Bosch Editor, Barcelona, 1.997, p. 317. Y continúa el autor: "Tal protección se apoya en que la ley no debe permitir que una situación, aun de hecho, como la posesoria, sea atacada ni por el que persigue un fin justo (como el de hacerse de una posesión que le corresponde), y menos por quien pretende despojar injustamente al poseedor. El ordenamiento que rija cualquier comunidad medianamente organizada, lo primero que ha de prohibir es que nadie se tome la justicia por su mano".

${ }^{413}$ Cfr. Julio César BENEDETTI, La posesión. Teoría y práctica de su amparo, Astrea, Buenos Aires, 1.976, p. 1. (TD)
} 


\section{SEBASTIÁN JUSTO COSOLA}

posesión (...), sino un derecho a requerir el poder sobre la cosa; quien no tiene sino un derecho a la posesión (...) no puede tomarla, y debe demandarla por las vías legales ${ }^{414}$.

Sobre esto, es bueno recordar que Vallet de Goytisolo alcanza a demostrar que el derecho presupone a la sociedad y que ésta, en cierta manera, necesita del derecho y del poder para poder cumplir con su cometido ${ }^{415}$. El maestro español enseñaba así que el concepto de derecho mismo oscila entre dos polos, los del amor y los de la fuerza $a^{416}$ y así alcanza a determinar que la sociedad y el derecho preexisten al Estado: "Antes de existir el Estado, existió la Sociedad, y desde que hubo Sociedad, existió el Derecho ${ }^{417}$ ". Desde esta posición, el derecho tiene por fin realizar la justicia ${ }^{418}$ : la misma debe imponerse allí donde lo justo sea violentado ${ }^{419}$. Consecuentemente, la justificación de la protección posesoria debe ubicarse en modo general, también en ese sentido.

\subsubsection{Excursus: El valor y la fuerza emergentes de la publicidad} posesoria.

Las teorías y los análisis anteriormente realizados sirven para alcanzar a comprender que en definitiva, la verdadera fuerza de la publicidad posesoria se encuentra en el comportamiento externo del poseedor y no tanto en su ánimo $^{420}$. Un comportamiento que, entre tantas otras herramientas, otorga 
LOS EFECTOS DE LA PUBLICIDAD EN EL DOCUMENTO NOTARIAL

claros y concretos fundamentos jurídicos tanto judiciales como extrajudiciales de protección, que se pondrán en funcionamiento ante cualquier ataque que sufra el titular del mismo ${ }^{421}$. En el Código Civil y Comercial de La Nación en vigencia, se establecen ciertas pautas derivadas de este principio que demuestra la fuerza del hecho posesorio entendido como relación de poder ${ }^{422}$. Así, a través de la común y adecuada publicidad la posesión se presume:

a) En favor de quien ejerce el poder de hecho sobre la cosa;

b) En favor de la fecha si la relación de poder se muestra en un título, y

c) Desde el inicio de la causa en la relación de poder que se esgrime y que se presumen legítimas y de buena fe -salvo supuestos determinados especialmente previstos-.

Debe además tenerse especialmente en cuenta que quien ejerce el hecho posesorio no tiene obligación de producir el titulo de la posesión (...) sino en el caso en el que deba exhibirlo como obligación inherente a la relación de poder $^{423}$. Sencillamente, y como lo prescribía nuestro anterior Código Civil: el poseedor posee porque posee ${ }^{424}$. Todas estas circunstancias determinan las distintas funciones que cumple la posesión en nuestro derecho, entendida como contenido o modo de ejercicio de los derechos reales -salvo en las servidumbres negativas y en la hipoteca-, o como un medio para la adquisición de los derechos reales que se ejercen por ella misma $^{425}$.

Por esta razón es que la importancia del tema posesorio y su vinculación con la institución notarial viene siendo referenciada por algunos autores que de

\footnotetext{
${ }^{421}$ Marina MARIANI DE VIDAL y Adriana N. ABELLA, Derechos reales, $\mathrm{t}^{\circ}$ I, ob. cit., $\mathrm{p}$. 69 .

${ }^{422}$ Arts. 1911 (presunción de poseedor o servidor de la posesión); art. 1914 (presunción de fecha y extensión); Art. 1916 (presunción de legitimidad de la posesión); Arts. 1917 y 1918 respectivamente (presunción de buena fe) entre otros análogos del CCCN.

${ }^{423}$ Art. 1917 CCCN.

${ }^{424}$ Art. 2363 CCA: "El poseedor no tiene obligación de producir su titulo a la posesión, sino en el caso que deba exhibirlo como obligación inherente a la posesión. El posee porque posee".

${ }^{425}$ Liliana ABREUT de BEGHER, Derechos reales, ob. cit., p. 102.
} 


\section{SEBASTIÁN JUSTO COSOLA}

manera simple y sencilla han advertido lo verdaderamente relevante a tener especialmente en cuenta de la posición notarial ${ }^{426}$ en un tema tan complejo y dificultoso. En efecto, desde el Código Civil de Vélez Sarsfield se infería que para que la tradición traslativa de la posesión hiciera adquirir el dominio de la cosa que se entregaba, debía ser hecha por un propietario con capacidad para enajenar y además, ser recibida por alguien con capacidad para adquirir $^{427}$. También se aceptaba que el dominio se adquiría por la tradición $n^{428}$, que hay ciertos actos que, para ser y valer como tales ${ }^{429}$, requerían esencialmente de la escritura pública -erigida ésta por aquel entonces como especie principal del instrumento público ${ }^{430}$ - ya que por contrario -y entre otros considerandos-, el dominio se perdía por la enajenación de la cosa en los inmuebles luego de firmado el instrumento público de enajenación, seguido de la tradición ${ }^{431}$. Desde allí y desde otros

${ }^{426}$ Cfr. Élida Sara ARDISSONI, Tradición de bienes inmuebles y muebles registrables, Universidad, Buenos Aires, 1.987, p. 87 y ss.

${ }^{427}$ Art. 2601 del CCA: "Para que la tradición traslativa de la posesión haga adquirir el dominio de la cosa que se entrega, debe ser hecha por el propietario que tenga capacidad para enajenar, y el que la reciba ser capaz de adquirir".

${ }^{428}$ Art. 2524 del CCA (Parte pertinente): "El dominio se adquiere: $4^{\circ}$ Por la tradición (...)"

${ }^{429}$ Art. 1184 del CCA: "Deben ser hechos en escritura pública, con excepción de los que fuesen celebrados en subasta pública: $1^{\circ}$ Los contratos que tuvieren por objeto la transmisión de bienes inmuebles, en propiedad o usufructo, o alguna obligación o gravamen sobre los mismos, o traspaso de derechos reales sobre inmuebles de otro; $2^{\circ}$ Las particiones extrajudiciales de herencias, salvo que mediare convenio por instrumento privado presentado al juez de la sucesión; $3^{\circ}$ Los contratos de sociedad civil, sus prórrogas y modificaciones; $4^{\circ}$ Las convenciones matrimoniales y la constitución de dote; $5^{\circ}$ Toda constitución de renta vitalicia; $6^{\circ}$ La cesión, repudiación o renuncia de derechos hereditarios; $7^{\circ}$ Los poderes generales o especiales que deban presentarse en juicio, y los poderes para administrar bienes, y cualesquiera otros que tengan por objeto un acto redactado o que deba redactarse en escritura pública; $8^{\circ}$ Las transacciones sobre bienes inmuebles; $9^{\circ}$ La cesión de acciones o derechos procedentes de actos consignados en escritura pública; $10^{\circ}$ Todos los actos que sean accesorios de contratos redactados en escritura pública; $11^{\circ}$ Los pagos de obligaciones consignadas en escritura pública, con excepción de los pagos parciales, de intereses, canon o alquileres".

${ }^{430}$ Art. 979 del CCA (Parte pertinente): "Son instrumentos públicos respecto de los actos jurídicos: $1^{\circ}$ Las escrituras públicas hechas por escribanos públicos en sus libros de protocolo, o por otros funcionarios con las mismas atribuciones, y las copias de esos libros sacadas en la forma que prescribe la ley; $2^{\circ}$ Cualquier otro instrumento que extendieren los escribanos ofuncionarios públicos en la forma que las leyes hubieren determinado (...)”

${ }^{431}$ Art. 2.609 del CCA: "Se pierde igualmente el dominio por enajenación de la cosa, cuando otro adquiere el dominio de ella por la tradición en las cosas muebles, y en los inmuebles, después de firmado el instrumento público de enajenación, seguido de la tradición”. 
LOS EFECTOS DE LA PUBLICIDAD EN EL DOCUMENTO NOTARIAL

sólidos fundamentos, se venía a plantear que el sistema de los derechos reales del Código Civil conformaba ni más ni menos que la piedra angular sobre la que debía reposar el notariado latino, ya que el escribano, a través de su poder esencialmente fideifeaciente, debía regular la prueba de la posesión y la constitución de los derechos reales ${ }^{432}$.

La fuerza publicitaria de la posesión trae aparejado varios conflictos relevantes; entre otros, el que puede suscitarse entre la publicidad que la misma otorga y la distinta que pueda otorgar, con identidad de objeto, la publicidad registral ${ }^{433}$. Esta situación se vuelve aun más interesante para el análisis, teniendo en cuenta que para el ordenamiento jurídico actual que rige nuestra vida privada, la prioridad del comprador de buena fe mediando boleto de compraventa sobre los terceros que hayan gravado con medidas cautelares sobre el inmueble oportunamente vendido, se prueba, entre otras tres cuestiones, si la adquisición ha tenido publicidad suficientes, sea registral sea posesoria. Entre la equiparación de las dos publicidades se encuentra librada la suerte del adquirente que pretenda demostrar su buena fe.

\footnotetext{
${ }^{432}$ Élida Sara ARDISSONI, Tradición de bienes inmuebles y muebles registrables, ob. cit., p. 17.

${ }^{433}$ Cfr. René A. PADILLA, Derecho civil y registral inmobiliario, Ediciones El Graduado, Buenos Aires, 1.995, p. 81.
} 
SEBASTIÁN JUSTO COSOLA 


\section{Capitulo 3.}

\section{Los conflictos que desde la posesión importan al derecho notarial. El impacto en la teoría documental.}

\subsection{De nuevo sobre la relación entre los derechos reales y personales.}

Si se trata de argumentar que la fuerza publicitaria del documento notarial, comprensiva de herramientas técnicas y axiológicas determinantes, proyecta todos los elementos para ser considerada como rectora o modelo frente a las demás publicidades jerarquizadas, dentro de los efectos que plantea la fuerza publicitaria de la posesión -inclusive, mediando boleto de compraventa- no puede dejar de exponerse en los aspectos que a esta tesis importa. Es en ésta realidad donde pueden encontrarse algunos de los principales conflictos que presenta el ejercicio publicitario de la posesión, muchas veces con fuente en un instrumento endeble que cuando acontece el conflicto se enfrenta al documento notarial auténtico. De esta manera, tanto la interpretación del boleto de compraventa como la manifestación de entrega o no entrega de la posesión, la designación de tiempos o métodos para su concreción, el hecho de la ocupación provisoria, precaria, anterior o posterior a la suscripción del instrumento, entre otras cuestiones fundamentales, son quizás los casos sobresalientes a tener en cuenta en el ejercicio de la adecuada función notarial relacionada con la confección de una escritura destinada a consolidar el derecho de dominio con causa, en el ejemplo, en una compraventa.

Lo antedicho importa admitir la exposición de un tema relativamente complejo, de preocupación constante tanto para el jurista como para la 


\section{SEBASTIÁN JUSTO COSOLA}

sociedad necesitada de protección. Es que a estas alturas, aun puede decirse que muy a pesar de los esfuerzos jurisprudenciales y académicos consolidados a lo largo del tiempo - y sobre todo los que acontecieron luego de las reformas legislativas posteriores a la sanción del Código Civil Argentino-, ciertas inconsistencias siguen emergiendo de las diferentes interpretaciones de los institutos referidos ${ }^{434}$. Queda absolutamente establecido que los diferentes puntos de vista brindados como posibles caminos para la adecuada interpretación no persiguen otro camino que alcanzar la consolidación de los criterios jurídicos mínimos y necesarios para alcanzar la solución a muchos de los conflictos que se generan a partir de la confluencia de la posesión con el boleto -relación de poder +derecho personal-, y con ellos, de todos los temas que pueden de ahí derivar como la cuestiones que ya he expuesto relativas a la consolidación del derecho real de dominio (derecho privado) y el acceso al derecho de propiedad entre otras. Sin embargo, algunas precisiones merecen tenerse en cuenta. Al presente desarrollo corresponde únicamente la referencia a las relaciones que se generan entre el instituto de la posesión y el boleto de compraventa ${ }^{435}$.

\footnotetext{
${ }^{434}$ Desde la vigencia de la ley 17.711/68 y su reforma mediante ley $17.940 / 68$, los conflictos que se originan entre los adquirentes mediando entre ellos boleto de compraventa; o los que importan una decisión del conflicto entre quienes ostentan un boleto con posesión frente a otro que tiene la escritura pública; los que emergen a partir de la defensa que realiza un adquirente de la cosa inmueble por boleto con posesión frente a los acreedores del enajenante, entre otros casos relevantes, han encontrado una infinidad de respuestas a partir de los argumentos legales, jurisprudenciales y académicos que se han venido sucediendo en la última media centuria.

${ }^{435}$ Especialmente me refiero a la cuestión de las medidas cautelares y la oponibilidad, tema que tratado extensamente puede inclusive generar otra tesis doctoral. A modo de ejemplo, puede consultarse la obra de Eduardo N. de LAZZARI, Medidas Cautelares, II t ${ }^{\circ}$, Librería Editora Platense, La Plata, 1.997 ( $\mathrm{t}^{\circ}$ I) y 2000 ( $\mathrm{t}^{\circ}$ II). Para tomar dimensión del tema y de su posible incidencia en el tema del Boleto de Compraventa, ver especialmente el tomo segundo de la obra, que cuenta con la colaboración de Carlos E. CAMPS, Francisco A. HANKOVITS y Carlos A. VALLEFÍn, y allí, el tratamiento bajo el acápite las medidas cautelares y el derecho registral, p. 525 y ss.
} 
LOS EFECTOS DE LA PUBLICIDAD EN EL DOCUMENTO NOTARIAL

\subsection{La figura del boleto de compraventa $y$ las primeras interpretaciones académicas. Los primeros problemas originarios.}

La figura del boleto de compraventa en nuestro medio provocó innumerables interpretaciones durante un largo tiempo. Por un lado, el régimen jurídico lo consideraba como un contrato preliminar e incompleto -por falta de forma legal-, mientras que por el otro, las partes lo entendían como un contrato adecuado y definitivo ${ }^{436}$. De manera clara y concisa se ha explicado lo siguiente: "Esta división entre la ley y la costumbre llevó a posturas formalistas y realistas, que intentaron mantener la seguridad jurídica que surgía de aplicar la legislación vigente, o sacrificarla con la intención de despejar el fantasma de una legislación, no sólo inaplicable, sino contraria a las costumbres, a sus propias finalidades y a la justicia del caso ${ }^{437}$ ".

Desde aquí es que se haya insistido con cierta vehemencia, que el Código Civil de Vélez, a pesar de la reforma instaurada por ley 17.711/68 no define al boleto de compraventa, muy a pesar que a partir de ella la figura se reconoce como instituto jurídico portante de determinados efectos ${ }^{438}$. Esa es la razón por la cual las discusiones acerca de su naturaleza jurídica aun hayan seguido en vigencia. La incorporación mencionada se debía, entre otras cosas, a la necesidad de despejar las dudas y los problemas originados frente al adquirente de buena fe, para que el mismo pudiera llegar a alcanzar la concreción de la operación mediante un título idóneo; y por ello el legislador, apoyado en la doctrina y en la jurisprudencia referida, decidió dotar al boleto de una cierta y normal legalidad ${ }^{439}$.

Claudio Kiper se refiere a que la práctica de la compraventa de inmuebles en general se concreta en diferentes pasos, porque el otorgamiento final de la escritura lleva cierto tiempo, ya que el escribano actuante debe realizar las verificaciones necesarias antes del otorgamiento del acto ${ }^{440}$. Al recordar que

${ }^{436}$ Cfr. Ricardo Luis LORENZETTI, Tratado de los contratos, $\mathrm{t}^{\circ}$ I, Rubinzal Culzoni, Santa Fe, 1.999, p. 331.

${ }^{437}$ Ibídem.

${ }^{438}$ Cfr. Lilian GURFINKEL de WENDY, Escrituración, La Ley, Buenos Aires, 2.007, p. 136.

${ }^{439} \mathrm{Cfr}$. Gabriel B. VENTURA, El boleto de compraventa frente al embargo del vendedor, http://www.acaderc.org.ar/doctrina/articulos/el-boleto-de-compraventa-frente-al-embargodel ,p. 2. (Último acceso: 20/08/2017).

${ }^{440}$ Cfr. Claudio M. KIPER, Juicio de escrituración (Conflictos derivados del boleto de compraventa), Hammurabi, Buenos Aires, 2.004, p. 53. 


\section{SEBASTIÁN JUSTO COSOLA}

la compraventa es un contrato consensual, el autor se refiere a que el boleto en realidad no es indispensable, precisamente porque el acuerdo de voluntades se podría concretar inclusive a través de un acuerdo verbal que permitiría exigir -aunque con las dificultades probatorias consecuentes- el otorgamiento de la escritura ${ }^{441}$. Al final de las referencias a la tradición, la posesión y el boleto de compraventa, el autor deja en claro dos supuestos relevantes a considerar en el desarrollo del presente capítulo:

a) Por un lado, afirma que el boleto de compraventa no es título suficiente para adquirir el dominio, ni siquiera en el caso en que se haya hecho tradición al comprador -que será poseedor, pero no dueño-.

b) Por el otro, y como consecuencia de no ser titulo suficiente, salvo en algún caso de excepción, el boleto no tiene publicidad registral ${ }^{442}$.

También se encuentra entre nosotros los aportes de Jorge Mosset Iturraspe y Norberto Novellino, que dieron en algún tiempo algo de claridad al complicado panorama del boleto de compraventa, partiendo de la premisa de admitir que el boleto de compraventa importa en definitiva, una situación nueva que tiene que ser considerada ${ }^{443}$. Los autores se inclinaron por enseñar que desde su perspectiva, el boleto se asimila a la compraventa definitiva ${ }^{444}$. Pero dadas las explicaciones, desde allí entonces advierten: " $L a$ contratación inmobiliaria directamente por escritura pública-buscando, a la vez, celebrar el contrato obligacional y hacer el título al dominio- tiene la dificultad de los certificados sobre subsistencia del dominio y libre

\footnotetext{
${ }^{441}$ Ibídem, p. 54.

${ }^{442}$ Ídem, p. 56. En la actualidad, el Registro de la Propiedad de La Provincia de Buenos Aires, mediante la DTR 2/2013, permite el ingreso de inscripción de los Boletos de Compraventa. Es facultativo de alguna de las partes contratantes su realización.

${ }^{443}$ Cfr. Jorge MOSSET ITURRASPE y Norberto J. NOVELLINO, La obligación de escriturar, La Rocca, Buenos Aires, 2.001, p. 36.

${ }^{444}$ Ibídem, p. 39. Llama la atención sin embargo, la explicación que los autores realizan en las páginas siguientes, relacionada con la facilidad con la que la gente accede al boleto a través de una instrumentación privada y no directamente inspirada en una escritura pública. Desde esa posición, no dudan en considerar la seguridad que emana de la escrituración y de la presencia del oficial público (así lo denominan) y aconsejan, en torno a la seguridad, la certificación notarial de las firmas.
} 


\section{LOS EFECTOS DE LA PUBLICIDAD EN EL DOCUMENTO NOTARIAL}

disponibilidad del bien que, aunque los plazos de obtención se hayan acortado, significa siempre una cierta espera, la necesidad de un tiempo, que las partes no siempre están dispuestas a aguardar, en la pretensión de asegurar el negocio ${ }^{45}$ ". No es posible advertir cual es el sentido final y práctico de las mencionadas enseñanzas. En efecto, las certificaciones notariales - y exclusivamente aquellas que gozan de prioridad-, están destinadas precisamente, a otorgar seguridad a la contratación, razón por la cual si hay algo que no harán las partes en defensa de su negocio al obviar este paso, porque esa es la manera más segura y sensata de asegurarlo. En el ejercicio práctico habitual, la solicitud de certificados o informes se impone como obligatoria -es ésta una muestra de la fuerza de la costumbre-, inclusive antes de la firma del boleto de compraventa e independientemente de considerar cualquier naturaleza que lo considere como contrato, como precontrato, etcétera. El sistema de solicitud de certificados en sede notarial, cuya presentación en el Registro guarda y protege la debida prioridad, es una garantía de la seguridad del tráfico inmobiliario, y su valoración es frecuente tanto en nuestro país como a nivel internacional ${ }^{446}$. Es precisamente el argumento de la buena fe el que obliga a que las partes estén al tanto de los posibles o probables problemas relacionados con la contratación que van a realizar, antes de suscribir los instrumentos, antes de entregar el dinero, antes de transmitir la posesión, entre otras cuestiones ${ }^{447}$. La consolidación actual del deber de buena fe en modo diligencia no ofrece ninguna duda acerca de la necesidad de su implementación.

El tema quizás se tenga que relacionar con la seguridad jurídica estática (del propietario) y dinámica (del tráfico) según lo veremos más adelante. Pero es bueno remarcar que la actuación jurídica notarial destinada a resguardar la seguridad $-\mathrm{y}$ que también pueden realizar otros profesionales a través de la solicitud de informes respectivos antes de la firma o suscripción del instrumento aunque sin reserva de prioridad-, posiciona a los contratantes frente al principio de la buena fe, de la referida buena fe diligencia, razón por la cual será mucho más difícil encontrarse en la situación de sorpresa

\footnotetext{
${ }^{445}$ Ibídem, p. 47 (n. 19).

${ }^{446}$ Cfr. Jorge Horacio ALTERINI, Certificados registrales. Reserva de prioridad y medidas judiciales, $\mathrm{RN}^{\circ}{ }^{\circ}$ 949, La Plata, 2.004, p. 619.

${ }^{447}$ Ibídem, p. 623 y ss.
} 


\section{SEBASTIÁN JUSTO COSOLA}

ante cualquier inconveniente que surgiera en el transcurso de la operación realizada. Buena fe, que según las recientes expresiones de Jorge Alterini, se construye en el Código Civil y Comercial de La Nación sobre la idea de rectitud y honradez que se corresponde con las enseñanzas de los romanos que postulaban el principio de vivir honestamente ${ }^{448}$. No debe nunca olvidarse que en realidad, como lo ha enseñado Juan Carlos Rezzónico, en materia de contratación, la adecuación de los principios mencionados, conjuntamente con otros que le sirven de antecedente como los de realidad jurídica, autodeterminación y autorresponsabilidad, autonomía privada, libertad contractual y efecto relativo, determinan el buen fin de la operatoria, que no es otra cosa que la justicia en la equivalencia de las prestaciones ${ }^{449}$.

En suma, la doctrina general mayoritaria ha tratado los supuestos, y ha brindado las respuestas pertinentes, generalmente avaladas por la jurisprudencia, que si bien no son enteramente coincidentes, todos reflejan la preocupación del jurista en la búsqueda de las soluciones que alejen a los hombres de los problemas que se generan cuando hay conflicto entre dos instituciones del derecho tan importantes, y que además, pertenecen inclusive a ámbitos diferentes de tutela. Sí hubiera que afirmar que existe relevancia en el tratamiento de los conflictos entre los derechos reales y los derechos personales, es por el tema de que tratan estas líneas.

\subsubsection{Teoría del boleto de compraventa en el Código Civil.}

En un clásico libro ya próximo a cumplir media centuria de vida, el inolvidable Augusto Mario Morello aclaraba que para la ley, la doctrina y la jurisprudencia vernáculas el boleto de compraventa no conforma ni un título traslativo del dominio ni crea una obligación de dar la cosa al comprador, ya que su ser, más modesto, tipifica un anteacto o antecontrato no traslativo de

\footnotetext{
${ }^{448}$ Cfr. Jorge Horacio ALTERINI, Claves para tener en cuenta, Supl. Empresa, negocios y el nuevo Código Civil y Comercial, Thomson Reuters-La Ley, Diario La Nación, 30/08/2015, p. 3.

${ }^{449}$ Cfr. Juan Carlos REZZÓNICO, Principios fundamentales de los contratos, Astrea, Buenos Aires, 1.999, 604 págs.
} 


\section{LOS EFECTOS DE LA PUBLICIDAD EN EL DOCUMENTO NOTARIAL}

la propiedad, que sólo acuerda el derecho de exigir una determinada obligación de hacer: el otorgamiento de la escritura pública de adquisición de dominio ${ }^{450}$. En aquella oportunidad, el eminente jurista advertía que con el boleto no se instrumenta sino una obligación de hacer ${ }^{451}$, y por el otro lado, que múltiples son las ventajas utilizar esta figura, ya que le permite y posibilita la libertad de utilizarlos hasta que puedan proceder a la ejecución del contrato definitivo (escritura pública de compraventa traslativa del dominio $^{452}$ ).

Ya luego de la referida reforma instaurada a fines de la década del sesenta del pasado siglo, el boleto de compraventa cobra particular atención del jurista ya que el mismo pasa a conformar parte del articulado del por entonces Código Civil vigente, con alusión expresa a ciertas situaciones de duda que se planteaban desde su propia naturaleza ${ }^{453}$. Al decir de Morello, el boleto de compraventa presentaba una notoria fuerza sociológica, a la vez que solicitaba una necesidad cualificada de tutela efectiva ${ }^{454}$. Comenzaban por aclararse y determinarse entonces algunos alcances de esta figura, y considerado como un instrumento público o privado que detalla el contenido del contrato de compraventa de inmueble estableciendo al menos los elementos esenciales de la misma ${ }^{455}$, la doctrina esencialmente se divide

\footnotetext{
${ }^{450}$ Cfr. Augusto Mario MORELLO, El boleto de compraventa inmobiliaria, Editora Platense, La Plata, 1.966, p. 9.

${ }^{451}$ Ibídem, p. 26.

${ }^{452}$ Ibídem, p. 40.

${ }^{453}$ Como ha quedado expuesto, el boleto de compraventa cobró mayor trascendencia a partir de la reforma del Código Civil efectuada por la comisión de reformas encabezada por Guillermo Borda. Su figura, aun sin ser definida, fue tenida en cuenta de manera expresa incorporándose al cuerpo general del articulado tanto en la parte general de los contratos como en materia de derechos reales, en la parte dedicada a la posesión. De aquí que haya sido una figura que haya abarcado el análisis de los derechos personales y reales, y que haya suscitado los conflictos ya analizados.

${ }^{454}$ Cfr. Augusto Mario MORELLO, El boleto de compraventa inmobiliaria: su fuerza sociológica y la necesidad cualificada de tutelarlo, JA 1994-IV-182, en Cristina Noemí ARMELLA (Dir.) Mariano ESPER (Inv.), Summa de Contratos, t II, Abeledo Perrot, Buenos Aires, 2012, pág. 1853.

${ }^{455}$ Cfr. Jorge E. LAVALLE COBO, De las obligaciones que nacen de los contratos, en César A. BELlUSCIO (Dir.) y Eduardo A. ZANNONI (Coord.), Código Civil y leyes complementarias. Comentado, anotado y concordado, $t^{\circ}$ 5, Astrea, Buenos Aires, 2.007, p. 834.
} 


\section{SEBASTIÁN JUSTO COSOLA}

en dos al considerar su naturaleza jurídica. Dentro de estas dos vertientes, existen los bemoles correspondientes:

a) Por un lado, aquellos que sostienen que el boleto de compraventa es un precontrato en el cual las partes se obligan a celebrar mediante escritura pública y en el futuro, el verdadero contrato de compraventa ${ }^{456}, \mathrm{y}$

b) Por el otro, aquellos que opinan que el boleto es el verdadero contrato de compraventa con todas las consecuencias salvo la transferencia del dominio que se obtiene por el otorgamiento posterior de la escritura pública ${ }^{457}$.

Desde el notariado, Etchegaray se inclina por considerar al boleto como un verdadero contrato de compraventa, ya que en él se encuentran todos los elementos esenciales tipificantes ${ }^{458}$, aunque no sea el requisito formal para transmitir el dominio, ya que el mismo se conforma con la escritura pública $^{459}$. En igual sentido se expresa Rubén Lamber ${ }^{460}$, quien además considera, desde la reforma de 1968 que realza la figura del boleto desde dos perspectivas diferentes:

a) Los boletos provisorios, que son aquellos que quedan condicionados a la celebración del definitivo, por alguna causal relevante, como la falta de ratificación del propietario, el

\footnotetext{
${ }^{456}$ Acerca de este punto, ver Fallos: 273:57, "Sociedad en Comandita Lunan Inmobiliaria y Financiera y otras c. Dirección Nacional de Industrias del Estado (D.I.N.I.E) y CIFEN E.N", y el interesante comentario que realizan Esteban Javier ARIAS CAU y Matías Leonardo NIETO, El contrato de compraventa, en Cristina Noemí ARMELLA (Dir.) y Mariano ESPER (Inv.), Máximos precedentes-Corte Suprema de Justicia de La Nación, t ${ }^{\circ}$ II, La Ley, Buenos Aires, 2.014, págs. 101 y ss.

${ }^{457}$ Jorge E. LAVALLE COBO, De las obligaciones que nacen de los contratos, ob. cit., p. 835.

${ }^{458}$ Cfr. Natalio Pedro ETCHEGARAY, Boleto de compraventa. Marcelo DE HOZ (Col.), Astrea, Buenos Aires, 2.009, p. 3.

${ }^{459}$ Ibídem, p.6.

${ }^{460}$ Cfr. Rubén Augusto LAMBER, Derecho civil aplicado, Colección Función Notarial, t ${ }^{\circ} 3$, Astrea, Buenos Aires, 2.010, p. 218.
} 


\section{LOS EFECTOS DE LA PUBLICIDAD EN EL DOCUMENTO NOTARIAL}

asentimiento conyugal o la autorización judicial de los actos que así lo requiera, como aquellos en los que intervienen menores de edad entre otros ${ }^{461}, \mathrm{y}$

b) Los boletos definitivos, que pueden crearse directamente reunidos los requisitos faltantes, o bien las partes reunirse para confeccionar la escritura pública traslativa del dominio como ejecución directa de la obligación anteriormente asumida en relación a la determinación de la $\operatorname{cosa}^{462}$.

El tratamiento de estas figuras y de otros presupuestos del boleto se encuentra además, descripto en otras obras y ensayos del autor ${ }^{463}$, siendo estas clasificaciones recogidas y receptadas por una parte de la jurisprudencia ${ }^{464}$. También María Acquarone advierte que el boleto de compraventa es útil y ágil para quien tiene en mente concluir una compraventa inmobiliaria, y por lo tanto, es un medio para formalizar el acuerdo de voluntades a partir de la firma de un instrumento privado en el que constan los elementos esenciales de la operación ${ }^{465}$. En un extenso trabajo, la autora recoge las opiniones mayoritarias acerca de la naturaleza del boleto ${ }^{466}$, esto es, si el mismo es un contrato de compraventa definitivo y perfecto (Morello), un pre-contrato, un contrato definitivo con efecto de generar la obligación de celebrar la compraventa forzosa (Gatti-Alterini), contrato preliminar con efectos de conversión en razón de tener el boleto una naturaleza bifronte (López de Zavalía) y demás posturas intermedias. Sobre esto, la profesora también aclara que la doctrina y la jurisprudencia en este tema han sido heterogéneas a la hora de decidir la naturaleza, así existen diferentes pronunciamientos sustentados según la situación y el criterio del juzgador ${ }^{467}$. Finalmente, Adriana Abella también contribuye a la teorización

${ }^{461}$ Ibídem, p. 219.

${ }^{462}$ Ibídem, p. 220.

${ }^{463}$ Rubén Augusto LAMBER, La escritura pública, $\mathrm{t}^{\circ}$ III y IV respectivamente, ob. cit., p. 15 y ss ( $\left.\mathrm{t}^{\circ} \mathrm{III}\right)$ y p. 11 y ss $\left(\mathrm{t}^{\circ} \mathrm{IV}\right)$.

${ }^{464}$ C.Nac. Civ., Sala A, 24/12/1959: "Ramírez, Francisco J. v. Breccia, Guillermo”; C. Nac. Civ., Sala A, 23/8/1960: "Auneau de Petit, Magdalena v. Citymar S.R.L".

${ }^{465}$ Cfr. María Teresita ACQUARONE (Dir.) y AA.VV, Derecho Inmobiliario, Di Lalla, Buenos Aires, 2.010, p. 133.

${ }^{466}$ Ibídem, p. 134 y ss.

${ }^{467}$ Ídem, p. 136. 


\section{SEBASTIÁN JUSTO COSOLA}

del tema, exponiendo también las teorías que difieren la naturaleza del boleto $^{468}$, destacando un punto de coincidencia entre la doctrina y jurisprudencia no pacífica, que es el que aduce que con la firma del boleto se está en presencia de los derecho personales, que autoriza a demandar el cumplimiento de las obligaciones que de él emanen, esencialmente la obligación de realizar la escritura pública ${ }^{469}$.

De acuerdo con lo antedicho, pareciera acertada la posición que advierte que en definitiva, al hablar de boleto de compraventa se hace mención a un contrato vinculante que obliga a otorgar el definitivo si se dan las condiciones $^{470}$, ya que en última instancia, el boleto no es titulo suficiente y carece de eficacia traslativa del dominio en tanto no sirve de causa suficiente a la tradición ${ }^{471}$. Sobre estos postulados, cabe decir que la jurisprudencia considera que el boleto contiene todos los elementos del contrato definitivo ${ }^{472}$.

\subsubsection{Boleto de compraventa en el Código Civil y Comercial de}

\section{La Nación.}

El Código Civil y Comercial de la Nación contempla la figura en la parte final del análisis del contrato de compraventa. La nueva normativa referida al boleto de compraventa lo presenta como una figura también inquietante, que recoge en cierta manera, algunos desarrollos académicos que se han brindado a lo largo del tiempo, en relación a las leyes que le servían como antecedente ${ }^{473}$. Para algunos autores, el cuerpo jurídico en vigencia no decide

\footnotetext{
${ }^{468}$ Adriana Nélida ABELLA, Derecho inmobiliario registral, ob. cit., págs. 173-174.

${ }^{469}$ Ibídem, p. 175.

${ }^{470}$ Claudio M. KIPER, Juicio de escrituración, ob. cit., p. 62.

${ }^{471}$ Cfr. Adriana Nélida ABELLA y Sebastián E. SABENE, El boleto de compraventa. Acuerdos previos. Aspectos y consecuencias, en Adriana Nélida ABELLA (Dir.), Estudios de derecho inmobiliario, Zavalía, Buenos Aires, 2.012, p. 302.

${ }^{472}$ Ibídem. Los autores citan al fallo de la SCBA Tabani, Oscar $H \mathrm{c}$ Girard, Leonor, ac. 24.109, ED 12/07/79, fallo 32.012.

473 Cfr. Mariano ESPER, Boleto de Compraventa, en Julio César RIVERA y Graciela MEDINA (Dir.)-Mariano ESPER (Coord.), Código Civil y Comercial de La Nación comentado, $\mathrm{T}^{\circ}$ III, La Ley, Buenos Aires, 2.014, p. 892 y ss.
} 


\section{LOS EFECTOS DE LA PUBLICIDAD EN EL DOCUMENTO NOTARIAL}

sin embargo, acerca de las cuestiones que han tenido en vilo a la doctrina nacional de los últimos cincuenta años, muy a pesar que desde los fundamentos del entonces último anteproyecto de unificación del código civil y comercial hoy en vigencia bien se advertía que era necesario contar con una regulación y tutela de los derechos de los adquirentes de inmuebles por instrumento privado (...) $)^{474}$.

Lo cierto es que no se deja relucir la idea de la naturaleza del boleto, es decir, si es este un contrato preliminar de venta, si es un contrato definitivo, o si tiene o cumple alguna otra función ${ }^{475}$, perdiéndose quizás una buena chance de eliminar dudas que al respecto pueden llegar a generarse (si el boleto es un contrato preliminar, habrá que estarse a los dispuesto por los artículos relativos a los contratos preliminares, por ejemplo ${ }^{476}$ ). Recordemos entonces que tampoco existe una doctrina clara al respecto en la jurisprudencia de la Corte Suprema de Justicia Nacional. En efecto, aun teniendo la posibilidad de hacerlo, el máximo tribunal no se ha expedido acerca de la naturaleza de los boletos de compraventa -en el caso como justificación de un boleto de compraventa de tipo provisorio ${ }^{477}$-. Otros autores en cambio se inclinan por considerar que el código actual, al regular la figura del boleto dentro del contrato de compraventa claramente le atribuye esa naturaleza, diferenciándolo del contrato preliminar ${ }^{478}$, lo que viene a ser ratificado desde otras posiciones que además de ello, argumentan que muy a pesar que pueda sostenerse con sólidos argumentos que la figura en estudio puede ser considerada como un ante-contrato en virtud de lo

\footnotetext{
${ }^{474}$ V. Anteproyecto de Código Civil unificado con el Código de Comercio 2012, Ediciones Códice, 2.012, págs. 730-731.

${ }^{475}$ Mariano ESPER, Boleto de Compraventa, en Julio César RIVERA y Graciela MEDINA (Dirs.)-Mariano ESPER (Coord.), Código Civil y Comercial de La Nación comentado, $\mathrm{T}^{\circ} \mathrm{III}$, ob. cit., p. 893.

${ }^{476}$ Ibídem.

477 CSJN Fallos 273:57. "Sociedad en comandita Lunan Inmobiliaria y financiera y otras. Dirección Nacional de Industrias del Estado (D.I.N.I.E) y CIFEN E.N. V. excelente nota crítica de Javier ARIAS CAU y Matías Leonardo PRIETO, El contrato de compraventa, en Cristina Noemí ARMELLA (Dir.) y Mariano ESPER (Coord.), Corte Suprema de Justicia de la Nación. Máximos precedentes. Contratos, tº II, La Ley, Buenos Aires, 2.014, p.103.

${ }^{478}$ Cfr. María Florencia CULASSO y Julieta C. TABARES, Compraventa y permuta, en Noemí L NICOLAU y Carlos A. HERNÁNDEZ (Dir.)- Sandra A. FRUSTAGLI (Coord.), Contratos en el Código Civil y Comercial de La Nación, La Ley, Buenos Aires, 2016, p. 546.
} 


\section{SEBASTIÁN JUSTO COSOLA}

establecido en la parte general de la teoría contractual ${ }^{479}$, lo cierto es si los tribunales habitualmente resuelven que quien compra por instrumento privado tiene derecho a exigir el cumplimiento del contrato de compraventa y la firma de la escritura pública por el vendedor y en caso de negativa, por el juez, no existen motivos suficientes para considerar al boleto como una simple promesa y no como un contrato definitivo ${ }^{480}$.

Finalmente y desde otras perspectivas, se destaca con verdadero énfasis que el verdadero problema del boleto de compraventa sigue siendo el relativo a la oponibilidad o inoponibilidad de los derechos de quien es titular o cesionario de un determinado boleto frente a los demás acreedores del vendedor ${ }^{481}$. De los artículos implicados en el Código Civil y Comercial de La Nación se desprende entonces que el derecho que tiene el comprador de buena fe gozará de prioridad sobre los terceros que hayan trabado cautelares sobre el inmueble vendido en tanto y en cuanto ${ }^{482}$ :

a) El comprador haya contratado con el titular registral o que haya podido subrogarse en la posición jurídica de quien lo haya hecho mediante un perfecto eslabonamiento con los adquirentes sucesivos;

b) Haya pagado como mínimo el veinticinco por ciento del precio con anterioridad a la traba de la medida cautelar;

c) Que haya fijado en el boleto, la fecha cierta;

d) La adquisición detente una publicidad suficiente, sea registral $o$ posesoria.

\footnotetext{
${ }^{479}$ Arts. 1017 y $1018 \mathrm{CCCN}$. En el primer supuesto se refiere a lo que se ordena en torno a que deben ser hechos en escritura pública los contratos que tienen por objeto la adquisición de derechos reales sobre inmuebles. Eso implica referirse en el segundo artículo a la situación en la que se encuentra el otorgamiento pendiente de un instrumento a la forma indicada, lo que constituye una obligación de hacer; en definitiva, implica reconocer que si el contrato requiere de la escritura pública el mismo no quedará concluido mientras no se otorgue mediante esa forma. Una adecuada comprensión de los artículos en referencia desde mi visión puede consultarse: Lidia GARRIDO CORDOBERA, Incidencias del Código Civil y Comercial. Contratos en general, Hammurabi, Buenos Aires, 2.015, págs- 131-133.

${ }^{480}$ Cfr. Alejandro BORDA, Contratos, en Alejandro BORDA (Dir.), La Ley, Buenos Aires, 2.016 , p. 376

${ }^{481}$ Cfr. Ernesto C. WAYAR, Boleto de Compraventa, en Ricardo L. LORENZETTI (Director)- Miguel F. DEL LORENZO y Pablo LORENZETTI (Coord.), Código Civil y Comercial de La Nación Comentado, Rubinzal Culzoni, Santa Fe, 2.015, p. 445.

${ }^{482}$ Art. $1170 \mathrm{CCCN}$.
} 
LOS EFECTOS DE LA PUBLICIDAD EN EL DOCUMENTO NOTARIAL

Un segundo artículo cierra el tema dentro de la normativización especial del boleto de compraventa en el código ${ }^{483}$. En efecto, el artículo prevé la oponibilidad del boleto (con fecha cierta) de adquirentes de buena fe al concurso o la quiebra del vendedor habiéndose abonado al menos, el veinticinco por ciento del precio, debiendo el juez autorizar el otorgamiento y autorización de la escritura pública. Si la obligación fuere a plazo, puede el comprador cumplirlas en el plazo estipulado; y si la prestación a su cargo fuera también a plazo, debe sobre el bien constituirse una hipoteca de primer grado en garantía del saldo del precio. Sin duda alguna, esta redacción encuentra su vinculación y antecedente con el articulado de la ley de Concursos y Quiebras $^{484}$, donde además se requiere que el comprador sea de buena fe $e^{485}$.

\subsubsection{La adquisición de la posesión de inmuebles de buena fe} mediante el boleto de compraventa.

Jorge Alterini expone que si en esta materia se piensa en los efectos de la transmisión de la posesión es porque en definitiva, se acepta que una de las

\footnotetext{
${ }^{483}$ Art. $1171 \mathrm{CCCN}$.

${ }^{484}$ Cfr. Atilio Aníbal ALTERINI, Código Civil Sistematizado, La Ley, Buenos Aires, 2.010, pág. 782. Dice el Art. 146 de la Ley 24.522: "Promesas de contrato. Las promesas de contrato o los contratos celebrados sin la forma requerida por la ley no son exigibles al concurso, salvo cuando el contrato puede continuarse por éste y media autorización judicial, ante el expreso pedido del síndico y del tercero, manifestado dentro de los TREINTA (30) dias de la publicación de la quiebra en la jurisdicción del juzgado. Los boletos de compraventa de inmuebles otorgados a favor de adquirentes de buena fe, serán oponibles al concurso o quiebra si el comprador hubiera abonado el VEINTICINCO POR CIENTO (25 \%) del precio. El juez deberá disponer en estos casos, cualquiera sea el destino del inmueble, que se otorgue al comprador la escritura traslativa de dominio contra el cumplimiento de la prestación correspondiente al adquirente. El comprador podrá cumplir sus obligaciones en el plazo convenido. En caso de que la prestación a cargo del comprador fuere a plazo deberá constituirse hipoteca en primer grado sobre el bien, en garantía del saldo de precio".

${ }^{485}$ Cfr. Marcelo J. HERSALIS, Boleto de compraventa, en Alberto J. BUERES, Código Civil y Comercial de La Nación analizado, comparado y concordado, T ${ }^{\circ}$ I, Hammurabi, Buenos Aires, 2.017, p. 665.
} 


\section{SEBASTIÁN JUSTO COSOLA}

consecuencias más importantes y elementales del contrato de compra y venta es la de generar, en la persona del vendedor, la obligación de hacer la entrega de la posesión para transferir la propiedad ${ }^{486}$. Recordemos que para el autor -en opinión compartida con Edmundo Gatti-, el boleto de compraventa era una promesa de venta que genera una compraventa forzosa, en virtud de su recepción en el código velezano que prescribía -dentro de varios supuestos previstos de ventas forzosas-, el que refiere a que por convención se obliga a vender alguna cosa a una persona determinada ${ }^{487}$. Forzosamente la persona obligada debe llevar adelante la venta, ya que recién habría venta con la escritura pública ${ }^{488}$.

En aquella relevante obra y en lo que a este estudio respecta ${ }^{489}$, los autores comenzaban a plantear la metodología de tratamiento comparativo entre el Código Civil de Vélez y la reforma efectuada por la Ley 17.711/68 -corregida por Ley 17.940/68-, aduciendo en una primera parte la protección legal de los titulares de boletos de compraventa ${ }^{490}$, el análisis de los nuevos términos de la posesión ${ }^{491}$, la naturaleza de los boletos de compraventa ${ }^{492}, \mathrm{y}$ las consecuencias que se derivaban del sistema expuesto ${ }^{493}$.Más allá de las interpretaciones y que hoy estemos en presencia de una obra que en cierta manera proyecta el análisis de un derecho positivo histórico, es importante destacar que Jorge Alterini planteaba la problemática del boleto desde la posesión, o lo que es similar: la posesión incluida o no incluida en el cuerpo del boleto de compraventa ${ }^{494}$.

${ }^{486}$ Cfr. Jorge Horacio ALTERINI, Boleto de compraventa. Efectos de la entrega de la posesión entre las partes, $\mathrm{RdN}^{\circ}{ }^{\circ} 796$, Buenos Aires, 1.984, p. 882.

${ }^{487}$ Ibídem, p. 884.

${ }^{488}$ Ibídem.

489 Cfr. Edmundo GATTI y Jorge Horacio ALTERINI, Prehorizontalidad y boleto de compraventa, Fedye, Buenos Aires, 1.973, 299 p.

${ }^{490}$ Ibídem, p. 13.

${ }^{491}$ Ibídem, p. 15.

${ }^{492}$ Ibídem, p. 19.

${ }^{493}$ Ibídem, p. 25 y ss.

${ }^{494}$ Jorge Horacio ALTERINI, Boleto de compraventa. Efectos de la entrega de la posesión entre las partes, ob. cit., p. 883. Allí advertía que en los boletos de compraventa en general, se pactaba -como en la actualidad en una infinidad de casos-, la entrega de la posesión con anterioridad al acto escriturario. Y también afirmaba que si los boletos nada expresaran acerca de la mencionada posibilidad de entrega, si la misma no estuviese pactada, no sería posible efectivizarla, precisamente en razón de que desde esa visión, el boleto no era considerado el contrato, y por ello ni siquiera era idóneo para generar la obligación de entrega de la 
La reforma en referencia había introducido cambios relevantes en ciertos artículos medulares de la parte general de los derechos reales, que implicaba en cierta manera comenzar a analizarlos desde una lectura conjunta con los derechos personales. Así, por ejemplo, el criterio que consideraba legítima la adquisición de la posesión de inmuebles de buena fe, mediando boleto de compraventa ${ }^{495}$. Indudablemente, este agregado colocaba al comprador que obraba con esa fe en una mejor situación, no solo respecto del vendedor sino también frente a terceros ${ }^{496}$. De esta manera, mientras que la posesión cumplía una función exteriorizadora ${ }^{497}$, la tradición hacía producir el desplazamiento de la potestad del transmitente hacia el adquirente ${ }^{498}$. En consecuencia, la posesión y los actos posesorios realizados por quien tenía una relación de señorío sobre una cosa se tornaban públicos ${ }^{499}$. Muchas fueron las opiniones académicas que se vertieron a partir de esta consolidación de la realidad a nivel legislativo, y algunas de las posiciones fueron las que campearon durante muchísimo tiempo.

Así, hay quienes sostuvieron que trasladado el principio de buena fe al adquirente de la posesión, él mismo debe apreciarse en el momento de hacerse efectiva la adquisición, tomando en cuenta los recaudos de prudencia y diligencia que el derecho postula y protege ${ }^{500}$. Si esto era así, el boleto de compraventa no era título suficiente para adquirir el dominio pues le falta el requisito de la escritura pública, y por todo lo expuesto, sería ilegitima la posesión ejercida por quien adquirió oportunamente de un modo insuficiente para adquirir derechos reales ${ }^{501}$. Es en esta inteligencia que la reforma había introducido el párrafo aludido al antiguo código civil,

\footnotetext{
posesión.

${ }^{495}$ Art. 2355 CCA.

${ }^{496}$ Lilian GURFINKEL de WENDY, Escrituración, ob. cit., p. 147.

497 Ídem, p. 149.

${ }^{498}$ Ibídem, p. 148.

${ }^{499}$ Ibídem. Más adelante la autora expresará que la posesión presentaría así la clasificación de legítima e ilegítima. En lo que aquí interesa, la posesión legítima -el ejercicio de un derecho real de conformidad con las disposiciones del código- hacía concluir que únicamente el titular de un derecho real que se ejerce por la posesión pueda ser calificado de poseedor legitimo

${ }^{500}$ Cfr. Domingo C. CURA GRASSI, Contratación Inmobiliaria: Aspectos notariales y registrales. Recaudos previos, ED 261, nro. 13696, 27/03/2015.

${ }^{501}$ Lilian GURFINKEL de WENDY, Escrituración, ob. cit., p. 149.
} 


\section{SEBASTIÁN JUSTO COSOLA}

estableciendo que la adquisición de la posesión de inmuebles de buena fe mediante boleto de compraventa se consideraba legítima; y aunque su interpretación no era pacífica en la doctrina ${ }^{502}$, cierta jurisprudencia relevante lo comenzaba a avalar ${ }^{503}$.

En similar dirección, también se exponía acerca de las posiciones que consideraban al supuesto como relativo a la adquisición de un dominio imperfecto, como así también otras que negaban todo tipo de consecuencias jurídicas por ser considerada la cláusula como anodina ${ }^{504}$. Para algunos, era ésta postura la que debería predominar en doctrina, por cuanto no puede considerarse la posibilidad del dominio imperfecto porque la tradición posesoria no es suficiente para constituir un derecho real, y el boleto de compraventa es un contrato preliminar en el cual las partes se obligan a elevarlo a escritura pública y por ello "si la posesión adquirida es ilegítima al no ser el ejercicio de algún derecho real, no es sostenible que esa posesión configure el contenido de un dominio, ni siquiera imperfecto ${ }^{505}$ ". En similar orientación otro académico ponía de manifiesto que al no haber transmisión del dominio por medio del boleto de compraventa -ni por ende, adquisición del derecho por parte del comprador- mal puede erigirse el comprador como titular de un dominio imperfecto; el dominio, aunque haya

\footnotetext{
${ }^{502}$ Algunos sostienen la consolidación de la legitimidad de la adquisición de la posesión en estos términos mediante boleto de compraventa, mientras que otros llegan a considerar un derecho real de posesión o un dominio imperfecto. V. especialmente Alberto G. SPOTA, Art. 2355 del Cód. Civil (Ref. Ley 17711) y posesión legítima del comprador de buena fe con boleto de compraventa inmobiliaria, ED 98-821.

${ }^{503}$ Cfr. Elena Inés HIGHTON, Propiedad horizontal y prehorizontalidad, Col. Elena C. NOLASCO, Hammurabi, Buenos Aires, 2007, p. 789. La autora trae el fallo CNCiv. Sala C, 21/11/78, LL 1979-B-259: "El boleto de compraventa de fecha cierta es oponible a los acreedores privilegiados o quirografarios, aun a los hipotecarios, si ha mediado desplazamiento de la posesión a favor del adquirente. Ello aun cuando la posesión sea posterior al nacimiento de los créditos privilegiados o quirografarios, salvo los hipotecarios. La primacía del adquirente por boleto de compraventa que fue puesto en posesión del inmueble con posterioridad a los créditos mencionados se justifica ante la carencia de publicidad de esos créditos, lo que demuestra una notable diferencia con los créditos hipotecarios exteriorizados mediante los registros. Es aplicable el triunfo del poseedor por boleto frente a los acreedores en cuestión porque el dueño del inmueble se desprendió de su posesión y el comprador la adquirió legítimamente con apoyo de un titulo suficiente a tales efectos, adquisición posesoria"

${ }^{504}$ Cfr. Emma Adelaida ROCCO, Boleto de compraventa, La Ley, Buenos Aires, 2.009, p. 187.

${ }^{505}$ Ibídem, p. 189.
} 
mediado tradición posesoria, continúa en cabeza del vendedor hasta el otorgamiento de la escritura pública ${ }^{506}$-es el mismo autor que sostiene que la compraventa -si bien puede o no puede quedar perfeccionada con la suscripción del boleto- siempre se refiere a la compraventa circunscripta al ámbito de los derechos personales, mientras que para obrar dentro del campo de los derechos reales la escritura pública es un requisito indiscutido ${ }^{507}$-.

De todo lo antes expuesto es que entonces pueden destacarse al menos, dos supuestos de conflictos interesantes y ya resueltos por la doctrina mayoritaria ${ }^{508}$. En el primer supuesto, se consideran la situación de una adquirente mediante boleto de compraventa frente a otro adquirente también por boleto de compraventa, siendo los posibles supuestos los siguientes:

a) Adquirente mediante Boleto de Compraventa con tradición de la cosa frente a otro adquirente por boleto pero sin tradición de la cosa: tiene prioridad el primero si actúo de buena fe, ignorando la existencia de un boleto anterior ${ }^{509}$;

b) Adquirentes mediante boleto de compraventa a quienes además, se les ha efectuado tradición posesoria: triunfa el primero al que se haya puesto en posesión de la cosa, siempre que haya actuado de buena $\mathrm{fe}^{510}$;

c) Adquirentes mediante boleto de compraventa sin puesta ninguno en posesión, triunfa el que tenga boleto de fecha anterior ${ }^{511}$.

En el segundo supuesto, se exponen con claridad los conflictos que emergen entre el adquirente por boleto de compraventa frente al comprador por escritura pública, siendo los supuestos los siguientes:

a) Adquirente mediante boleto de compraventa frente al comprador mediante escritura pública sin haberse hecho efectiva la tradición

${ }^{506}$ Claudio M. KIPER, Juicio de escrituración, ob. cit., p. 69.

${ }^{507}$ Ibídem, p. 68.

${ }^{508}$ Puedo consultarse sobre este tema: Mariano ESPER, Manual de Contratos Civiles y Comerciales. Parte Especial, Abeledo Perrot, Buenos Aires, 2.011, Pto. VII (VTRP).

${ }^{509}$ Emma Adelaida ROCCO, Boleto de compraventa, p. 193.

${ }^{510}$ Ibídem, p. 194.

${ }^{511}$ Ibídem. 


\section{SEBASTIÁN JUSTO COSOLA}

posesoria del inmueble a ninguno de ellos, se tiene en cuenta como primera medida, la fecha del instrumento, dando absoluta relevancia al tema de la prioridad de las fechas en el instrumento público por imperio de la fe pública; dentro de esto, deben distinguirse los siguientes (sub) temas: 1) Boleto carente de fecha, se prefiere al comprador de buena fe mediante escritura pública, y 2) supuesto de boleto de compraventa con fecha cierta y escritura, prevalece el de la fecha más antigua ${ }^{512}$.

b) Adquirente de buena fe mediante boleto de compraventa con tradición posesoria frente a comprador por escritura sin posesión, es preferido el primero en razón de que al no haberse efectuado tradición posesoria en la escritura no se ha adquirido el dominio y por ello, el comprador se transforma en una acreedor de una obligación de cumplimiento imposible de dar de cosa cierta a fin de que se le transfiera el dominio, por cuanto ya se le ha hecho tradición al tercero ${ }^{513}$.

La doctrina a partir del Código Civil y Comercial de La Nación sigue haciendo referencia concreta a muchas de las opiniones antes referidas, con mayor o menor displicencia. Y teniendo en cuenta que la problemática actual del boleto se circunscribe a la trascendencia de la situación de los terceros embargantes, las soluciones que se ofrecen son las que determinan la prioridad o no de las medidas cautelares esgrimidas con anterioridad o con posterioridad a la elaboración del contrato ${ }^{514}$. Así, las situaciones que pueden ocurrir son las siguientes:

a) triunfo de la medida cautelar efectivizada registralmente con anterioridad a la posesión del adquirente por boleto;

\footnotetext{
${ }^{512}$ Ibídem, p. 195-196.

${ }^{513}$ Ibídem, p. 196.

514 Cfr. Eduardo N. FARINATI, Contrato de compraventa, en Marcelo J. HERSALIS (Coord.), Incidencias del Código Civil y Comercial. Contratos en particular, Hammurabi, Buenos Aires, 2.015, p. 87.
} 
LOS EFECTOS DE LA PUBLICIDAD EN EL DOCUMENTO NOTARIAL

b) triunfo del boleto inscripto registralmente frente al embargo posterior; $y$

c) triunfo del boleto con publicidad posesoria ${ }^{515}$.

\subsubsection{Conclusiones.}

En los dos capítulos precedentes se ha pretendido demostrar, de manera concisa, la importancia de la publicidad posesoria en general, y de modo particular, frente a los documentos que contienen declaraciones que no se condicen con ella - e independientemente de su naturaleza de públicos o privados-. Al ser un estado de hecho que se prueba a través de la exhibición y de la presunción, la posesión es sin duda productora de importantes consecuencias para el derecho, que se resumen, siguiendo a Kiper, de la siguiente manera ${ }^{516}$ :

a) Salvo en los casos puntuales referidos con anterioridad (hipoteca + servidumbres) la misma es el contenido de los derechos reales;

b) Frente a un conflicto entre quien alega ser titular del derecho real y el poseedor, la carga de la prueba le corresponde al primero, salvo frente a quien demuestre tener un mejor derecho ${ }^{517}$;

c) La posesión goza de todas las protecciones que el derecho le brinda y también, de las defensas judiciales y extrajudiciales, por configurar la misma un estado de hecho;

d) Es un elemento esencial en la transmisión de los derechos reales sobre inmuebles (tradición posesoria);

e) Según los casos, permite la adquisición del dominio, por prescripción;

f) Quien posee de buena fe hace suyo los frutos devengados en el tiempo en que poseyó.

${ }^{515}$ Ibídem.

${ }^{516}$ Claudio KIPER, Tratado de derechos reales, ${ }^{\circ} \mathrm{I}$, ob. cit., p. 109 y ss.

${ }^{517}$ Art. 2256 CCCN. 


\section{SEBASTIÁN JUSTO COSOLA}

Los estados de hecho se prueban físicamente e incluso, de manera aparente. Sin embargo, por más que el derecho brinde protección a esas situaciones, debe tenerse presente que el amparo de un determinado abuso en razón de la fuerza o de la oportunidad, muy a pesar de que técnicamente sea recogido por la suposición que realiza la norma, siempre debe ser condenado desde el derecho y desde la justicia. Cierto es que la regulación de la posesión tiende a efectivizar el valor de justicia, lo que no obsta a considerar que en circunstancias a veces más frecuentes que ocasionales, se intente alcanzar la tutela jurídica para la obtención de una consecuencia disvaliosa frente a los verdaderos derechos de quienes en realidad, son los únicos artífices y titulares del derecho que ha estado en discusión.

El problema de la publicidad posesoria no se encuentra en la demostración o en la fuerza que el derecho le otorga; de hecho pienso que han quedado prácticamente consolidados esos presupuestos en el marco de lo antes expuesto. No cabe ninguna duda en reconocer que la misma existe desde el mismo momento en que aquellos que sean terceros interesados hayan conocido o podido conocer la realidad extrarregistral. El tema quizás predominante, novedoso y relevante para una investigación de esta envergadura, es el que proyecta su estudio desde la ponderación de los valores trascendentes en juego, para poder establecer como es su posición frente a los demás medios de publicidad aceptados por el derecho. Desde mi visión, la publicidad posesoria recepta la justicia y recepta la certeza, pero carece de seguridad hasta tanto no se legitime la misma, entre otros bemoles trascendentes de nivel axiológico, a través de la adecuada instrumentación, según tendremos oportunidad de advertir en las líneas que siguen a continuación. 


\section{PARTE SEGUNDA.}

\section{La Inscripción Registral y sus Efectos.}

\section{Capitulo 4: El Registro de la Propiedad Inmueble y la publicidad registral.}

\subsection{Introducción a los registros ${ }^{518}$}

Vistos y analizados los efectos publicitarios de la posesión, se vuelve necesario ahondar en el tema de los registros y de su función para luego poder proyectar el alcance de los efectos de la publicidad registral que de ellos se deriva. Para ello, es preciso comenzar entonces por aceptar que los registros son, en sentido amplio, organismos mediante los cuales se produce la publicidad jurídica $^{519}$. Esa publicidad y sus diversas acepciones y significaciones, deben comprenderse en todas sus direcciones ${ }^{520}$. Más específicamente, puede afirmarse que como primera medida, los registros son instituciones públicas que tienen por objeto la inscripción, anotación y cancelación de actos, contratos, instrumentos y documentos relativos al dominio y todo tipo de derechos reales sobre bienes inmuebles o muebles registrables, siendo públicos sus documentos, libros y actuaciones ${ }^{521}$.

\footnotetext{
${ }^{518}$ Cfr. Sebastián Justo COSOLA, Cuestiones registrales del automotor y reclamo de daños y perjuicios derivados de un accidente, en Marcelo J.LÓPEZ MESA, Responsabilidad por accidentes de tránsito, $\mathrm{t}^{\circ}$ III, La Ley, Buenos Aires, 2.014, p. 234 y ss.

${ }^{519}$ Cfr. Américo Atilio CORNEJO, Derecho registral, Astrea, Buenos Aires, 2.001, p. 6.

${ }^{520}$ René A. PADILLA, Estudios de derecho civil y registral, ob. cit., p. 13 y ss; Luis MOISSET DE ESPANÉS, Publicidad Registral, ob. cit., p. 15 y ss; Raúl R. GARCIA CONI y Ángel A. FRONTINI, Derecho registral aplicado, LexisNexis, Buenos Aires, 2.006, p. 5 y ss; Felipe Pedro VILLARO, Elementos de derecho registral. Colección Función Notarial, $\mathrm{t}^{\circ}$ II, Astrea, Buenos Aires, 2010, p. 9 y ss.
} 


\section{SEBASTIÁN JUSTO COSOLA}

En nuestro país, el objeto de la registración inmobiliaria surge del artículo primero de la Ley Nacional Registral 17.801/68, de donde claramente se deduce que la anotación o inscripción es para la publicidad, oponibilidad a terceros y demás previsiones legales ${ }^{522}$. Algunos autores con atinado criterio inclusive, insisten en que al registro puede calificárselo tanto de acuerdo a su objeto como a la finalidad que le sirve de fundamento ${ }^{523}$ : en este sentido, el mismo puede ser considerado como institución ${ }^{524}$, pero también como oficina $^{525}$, como conjunto de libros ${ }^{526}$, y hasta como un servicio público ${ }^{527}$. En esta dirección, también puede reconocerse al registro una fundamentación sociológica, por cuanto conforma un medio técnico que está destinado a cubrir necesidades del tráfico que interesa a la sociedad: es decir, atiende intereses particulares a la vez que cumple una función de interés público $^{528}$. Esta última fundamentación también permite la realización de la justicia, causa fundamental de todo buen sistema jurídico ${ }^{529}$.

\subsubsection{Funcionamiento, interrelación y adecuación de los registros.}

\footnotetext{
521 Cfr. Nery Roberto MUÑOZ y Rodrigo MUÑOZ ROLDÁN, Derecho registral inmobiliario guatemalteco, Infoconsult Editores, Guatemala, 2.005, p. 57.

${ }^{522}$ Cfr. Felipe Pedro VILLARO y Raúl E. BIDART, Legislación registral inmobiliaria, Editorial Campos S.C.A, Buenos Aires, 1.972, p. 18.

${ }^{523}$ Cfr. Lucila ORTIZ de DI MARTINO, Manual de derecho Registral, Marben, Asunción, 2.009 , p. 137 y ss. entre otros.

${ }^{524}$ Es el caso mediante el cual se persigue alcanzar la seguridad del tráfico jurídico a través de la adecuación coherente del principio de publicidad.

${ }_{525}$ De carácter público, lugar de custodia de los libros y/o asientos registrales.

${ }^{526}$ En razón de su objeto, es un conjunto de libros y asientos, que perfila su aspecto adjetivo.

${ }^{527}$ Si bien la doctrina discute el concepto de servicio público (¿son un servicio público? ¿o simplemente prestan un servicio público?) lo cierto es que se pretende con estas afirmaciones aclarar que los registros se encuentren bajo la regulación y el control del Estado.

${ }^{528}$ Raúl R. GARCIA CONI y Ángel A. FRONTINI, Derecho registral aplicado..., ob. cit., p. 32.

${ }^{529}$ Cfr. Gabriel B. VENTURA, Ley 17.801. Registro de la propiedad inmueble. Comentada. Anotada, Hammurabi, Buenos Aires, 2.009, p. 27.
} 


\section{LOS EFECTOS DE LA PUBLICIDAD EN EL DOCUMENTO NOTARIAL}

Algunos estudios modernos intentan demostrar -a mi juicio con acierto-, la necesaria vinculación que existe entre la función notarial, la registral y la catastral ${ }^{530}$. En nuestro país, un aporte vigente al tema en referencia propone -quizás inspirado en el análisis que en una similar orientación efectuara Raúl Garcia Coni hace más de cuarenta años ${ }^{531}$-, que los regímenes de esta naturaleza en realidad, funcionan en una especie de armonía y complementariedad $^{532}$. De esta manera se argumenta con éxito que el adecuado funcionamiento del régimen inmobiliario reposa sobre tres registros: el registro notarial, el registral y el registro catastra $^{533}$. En efecto, hace tiempo ya que se viene advirtiendo la importancia de proteger la necesaria vinculación entre el registro y el catastro ${ }^{534}$, al mismo tiempo que se insistía en destacar ciertos valores de la escritura pública notarial en el seno de la institución registral ${ }^{535}$. Sin embargo, no hay que dejar de advertir, como quedará demostrado más adelante, que la interrelación y adecuación no implica una confusión de funciones, al menos entre el registro notarial y el registro registral, por cuanto al primer compete la creación y adecuación jurídica, ética y constitucional del documento, y al segundo la inscripción o registración con la consecuente publicidad posterior del acto instrumentado ${ }^{536}$.

\subsubsection{Tipos de Registro.}

\footnotetext{
${ }^{530}$ Cfr. Adolfo CALATAYUD SIERRA, La obligación notarial de suministrar datos al catastro, RJN n ${ }^{\circ} 33$, Madrid, 2.000, p. 225 y ss.

${ }^{531}$ Raúl R. GARCIA CONI, Derecho Registral aplicado..., ob. cit., p. 44 y ss.

${ }^{532}$ Cfr. Sebastián E. SABENE, Registro Catastral, Zavalía, Buenos Aires, 2.013, p. 15.

${ }^{533}$ Ibídem.

${ }^{534}$ Cfr. Alberto D. MOLINARIO, Del derecho registral y del derecho registral inmobiliario, en Curso de derecho registral inmobiliario, Ediciones Pannedille, Buenos Aires, 1.971, p. 32.

535 Cfr. Manuel ADROGUÉ, La escritura pública y el derecho registral, en Curso de derecho registral inmobiliario, Ediciones Pannedille, Buenos Aires, 1.971, p. 381 y ss.

536 Cfr. Ramiro VILLARROEL CLAURE, Fundamentos de derecho notarial y registral inmobiliario, Alexander, Cochabamba, 2.005, p. 322.
} 


\section{SEBASTIÁN JUSTO COSOLA}

Los registros suelen ser clasificados de diferente manera. Para algunos autores $^{537}$, los registros pueden ser de hechos ${ }^{538}$, de derechos ${ }^{539}$, de títulos ${ }^{540}$, de $\operatorname{contratos}^{541}$, pueden ser registros $\operatorname{reservados}^{542}$, publicitarios ${ }^{543}$, legitimadores $^{544}$, personales ${ }^{545}$, reales ${ }^{546}$, de trascripción $^{547}$, de incorporación ${ }^{548}$ o de inscripción ${ }^{549}$. Algunas de estas características de los registros, que en última instancia denotan una forma de organización y de trabajo del organismo en estudio, es desarrollada por la doctrina de acuerdo al nombre de sistemas registrales ${ }^{550}$, donde no solo se analizan las cuestiones de criterios geográficos y orgánicos ${ }^{551}$, sino que se incluye frecuentemente la cuestión de las técnicas de folio real o personal, de inscripciones o transcripciones, entre otras ${ }^{552}$. Para otros autores en cambio, existen -aunque con matices concretos y críticas al respecto- solo los registros personales, los reales y los causales $^{553}$. Finalmente, se considera la clasificación de registros de publicidad completa y de publicidad incompleta, los convalidantes y los no convalidantes, los abstractos o sustantivos, los

${ }^{537}$ Raúl R. GARCIA CONI, Derecho Registral Aplicado..., ob. cit., p. 80.

${ }^{538}$ Ibídem.

${ }^{539}$ Ídem, p. 81.

${ }^{540}$ Ídem, p. 82.

${ }^{541}$ Ídem, p. 83.

${ }^{542}$ Ibíd.

${ }^{543}$ Ídem, p. 84.

${ }^{544}$ Ibíd.

${ }^{545}$ Ídem, p. 85.

${ }^{546}$ Ibídem.

${ }^{547}$ Ibídem.

${ }^{548}$ Ídem, p. 86.

${ }^{549}$ Ibíd.

${ }^{550}$ Américo Atilio CORNEJO, Derecho registral..., ob. cit., p 17 y ss, entre muchos otros autores.

${ }^{551}$ Raúl R. GARCIA CONI y Ángel A FRONTINI, Derecho registral aplicado..., ob. cit., p. 69 y ss.

${ }^{552}$ Felipe Pedro VILLARO, Elementos de derecho registral inmobiliario, Scotti Editora, La Plata, 2.003, p. 31, entre muchos otros. En materia de registro de automotores, puede advertirse en algún autor un desarrollo amplio de las técnicas registrales utilizadas: v. Fernando F. PRÓSPERI, Régimen legal de automotores, La Rocca, Buenos Aires, 1.997, p. 141 y ss.

${ }^{553}$ Luis MOISSET DE ESPANÉS, Publicidad registral..., ob. cit., p. 88 y ss. 
LOS EFECTOS DE LA PUBLICIDAD EN EL DOCUMENTO NOTARIAL

centralizados y los descentralizados, los facultativos, los obligatorios, y entre otros, los que tienen fe pública registral ${ }^{554}$.

\subsection{La publicidad registral de los derechos sobre las cosas con independencia de su naturaleza ${ }^{555}$.}

En el derecho argentino, la discusión acerca de la cuestión de la publicidad registral en general, sus modos y naturaleza, y especialmente, los alcances que pueda ésta determinar, reconoce ya una larga historia, la que estimo inclusive puede analizarse en comparación con otros institutos de jerarquía similar o superior, dentro del estudio del derecho y que han precedido notablemente a su debate (distinción entre los derechos reales y personales, la teoría de la posesión y sus conflictos incluso permanentes como las cuestiones de la publicidad que de ella emerge y la publicidad registral ${ }^{556}$, la cuestión del documento notarial, etcétera). Si bien es cierto que el derecho registral justifica su fortaleza con la agrupación de todos los registros, que son muchos, lo cierto es que el tratamiento de los temas de cada registro es tan dispar, tan diferente, que no pueden ser considerados con ciertos principios elementales que determine un mismo tronco común. La doctrina nacional especializada mayoritaria coincide con estas apreciaciones ${ }^{557}$, y en

${ }^{554}$ En resumen, además de todos los autores referenciados en el presente ensayo, se recomienda la lectura de: Cristina Noemí ARMELLA (Dir.), Tratado de Derecho Notarial, Registral e Inmobiliario, Ad-Hoc, Buenos Aires, T ${ }^{\circ}$ III, 1998; Argentino I. NERI, Tratado teórico y práctico de derecho notarial, Vol. VI, Depalma, Buenos Aires, 1973; Jorge Horacio ALTERINI (Dir.)-Ignacio Ezequiel ALTERINI (Coord.), Derecho Notarial, Registral e Inmobiliario-Doctrinas Magistrales 1897-2012, $\mathrm{T}^{\circ}$ III, ob. cit. Los tomos referidos se dedican al análisis del derecho registral.

${ }^{555}$ Cfr. Sebastián Justo COSOLA, Cuestiones registrales del automotor ..., ob. cit., p. 223 y SS.

${ }^{556}$ V. Mario J. CAPON FILAS y Pedro ETCHEVERS, La publicidad registral en las VIII Jornadas Nacionales de Derecho Civil, ED 98-827.

${ }^{557}$ Cfr. Adriana Nélida ABELLA, Derecho Inmobiliario Registral, ob. cit., p. 66 y ss; Luis O. ANDORNO y Marta MARCOLÍN, Ley Nacional Registral Inmobiliaria 17801, Comentada y Anotada, Hammurabi, Buenos Aires, 1999, p. 33 y ss; Antonio R. COGHLAN, Teoría general de derecho inmobiliario registral, Abeledo Perrot, Buenos Aires, 1995, p. 7 y ss; Américo Atilio CORNEJO, Derecho Registral, ob. cit., p. 1 y ss; Gabriel DE REINA TARTIÉRE, Manual de derecho Registral Inmobiliario, La Ley, Buenos Aires, 2.004, p. 3 y ss, y Principios Registrales, Heliasta, Buenos Aires, 2009, p. 295 y ss; Marta E. FAZIO de 


\section{SEBASTIÁN JUSTO COSOLA}

general suele estarse de acuerdo en afirmar que dentro de análisis de la registración, es el derecho registral inmobiliario el que opera como referente de los demás registros ${ }^{58}$. De esta manera, se llega a reconocer el inigualable prestigio del ordenamiento argentino en el universo del derecho registral inmobiliario, hecho que lo ubica como un sistema de vanguardia inclusive frente al derecho comparado ${ }^{559}$. Desde el análisis de la parte general del registro inmobiliario, comprensivo de normas, principios, reglas y disposiciones técnico-registrales se originan entonces todas las discusiones y

BELLO, Actos jurídicos y documentos inscribibles, La Rocca, Buenos Aires, 1998, p. 163 y ss; Raúl R. GARCIA CONI, Derecho Registral Aplicado, Ediciones Librería Jurídica, La Plata, 1.972, p. 68 y ss, y Registración Inmobiliaria Argentina, Depalma, Buenos Aires, 1.983, p. 17 y ss; Raúl R. GARCIA CONI y Ángel A. FRONTINI, Derecho Registral Aplicado, ob. cit., p. 7 y ss; Fernando LOPEZ DE ZAVALIA, Curso Introductorio al Derecho Registral, Víctor P. de Zavalía, Buenos Aires, 1.983, p. 47 y ss; Alberto D. MOLINARIO (Coord.), Curso de derecho Registral Inmobiliario, Pannedille Ediciones, Buenos Aires, 1.971 [NdA: Todo el texto reúne reflexiones interesantes acerca de la cuestión de la publicidad]; Luis MOISSET DE ESPANÉS, Publicidad Registral, ob. cit.,; Luis MOISSET DE ESPANÉS y Horacio VACCARELLI, Sistema Registral Inmobiliario Argentina-Paraguay, Zavalía, Buenos Aires, 1.994, p. 9 y ss; René A. PADILLA, Estudios de derecho civil y Registral Inmobiliario, ob. cit., p. 13 y ss; José Luis PEREZ LASALA, Derecho Inmobiliario Registral, Depalma, Buenos Aires, 1.965, p. 9 y ss; Sebastián E. SABENE, Registro Catastral, ob. cit., p. 15 y ss; Edgardo SCOTTI, Derecho Registral Inmobiliario, Universidad, Buenos Aires, 1980 (Ver exposición de motivos del libro escrita por el autor); Gabriel B. VENTURA, Ley 17801. Registro de la Propiedad InmuebleComentada y Anotada, ob. cit., p. 28 y ss; Felipe Pedro VILLARO, Elementos de derecho registral Inmobiliario, ob. cit., p. 9 y ss; Felipe Pedro VILLARO, Derecho Registral Inmobiliario, ob. cit., p. 3 y ss; entre otros.

${ }^{558}$ Fernando LOPEZ DE ZAVALIA, Curso introductorio..., ob. cit., p. 12: Afirma el autor: "Piensen que dentro del derecho registral, el derecho registral inmobiliario es el derecho rey, el más finamente elaborado, y que de alli deben partir todos los estudios".

${ }^{559} \mathrm{Cfr}$. Marcelo Eduardo URBANEJA, Relevancia de la posesión en el régimen jurídico del automotor, Diario El Derecho, UCA, Buenos Aires, 05/07/2011, p. 2. El innegable hecho de ser un modelo referente, determina que el tratamiento del derecho registral no sea sólo una preocupación exclusiva del ámbito notarial. De ahí que entre tantos otros autores, Aída Kemelmajer presente un estudio formidable del derecho inmobiliario argentino, que permite avizorar los puntos de contacto y especialmente las diferencias con el tratamiento que la misma autora presenta en materia de registración de automotores. V. Aída KEMELMAJER de CARLUCCI, Registro de la Propiedad Inmueble. Ley 17.801, en Eduardo A. ZANNONI (Director) y Aída KEMELMAJER de CARLUCCI (Coordinadora), Código Civil y Leyes Complementarias. Comentado, Anotado y Concordado, t ${ }^{\circ} 13$, Astrea, Buenos Aires, 2.012, p. 1-420, y Aída KEMELMAJER de CARLUCCI, La calificación registral en materia de automotores (Diferencias con el sistema inmobiliario, Revista de Derecho Privado y Comunitario 2009-2, T I, Rubinzal Culzoni, Santa Fe, 2009, p. 21. 
todos los frecuentes debates ${ }^{560}$. Sin embargo, otras posiciones se encuentran en la doctrina nacional. En efecto, no debe dejar de tenerse en cuenta, como también se advierte entre nosotros, que el fenómeno de la registración trajo consigo la necesidad de la generación de un derecho registral de dudoso desarrollo autónomo ${ }^{561}$.

Independientemente de todas las diversas valoraciones, la importancia de la publicidad registral es un hecho absolutamente relevante para el estudio del derecho tal como lo ejercemos, lo sentimos y lo percibimos. Por mi parte, siempre he sostenido que el derecho registral es un derecho de naturaleza procesal, que a través de una pléyade de principios proyectados en la ley madre, en el ordenamiento civil y comercial unificado y en las diversas disposiciones técnicas, justifica su misión describiendo los procesos, las maneras y las formas de anotación e inscripción de todos los documentos que tengan vocación registral ${ }^{562}$.

\subsection{Situación del derecho registral en la República Argentina.}

\footnotetext{
${ }^{560}$ Hay autores que enseñan que desde los primeros tiempos se comprueba que la función del notario, si bien noble y reconocida, no era suficiente, y reclamaba la existencia de funcionarios e instituciones que ejercieran además el control de la legalidad de las adquisiciones en el ámbito inmobiliario extrajudicial con la finalidad de producir publicidad registral de los negocios con efectos respecto de terceros. Cfr. Lilia Noemí DIEZ, La función del registrador de la propiedad; distinta de la del escribano, RdN-ER n ${ }^{\circ} 170,2.001, \mathrm{p} .15$.

${ }^{561}$ Cfr. Gabriel B. VENTURA, El régimen registral del automotor, publicación de la Academia Nacional de Derecho y de Ciencias Sociales de Córdoba, http://www.acaderc.org.ar/el-regimen-registral-del-automotor. (Ultimo acceso: 21/08/2017). Un derecho registral que pretende ser autónomo, pero que en realidad no es más que, en palabras del autor, una pseudo rama jurídica con relativa autonomía didáctica.

${ }_{562}$ Así como los profesionales de la abogacía recurren a los códigos procesales para probar y justificar la valoración de los derechos de sus representados, el notario encuentra en el derecho registral el procedimiento adecuado para cumplir con las inscripciones de los títulos y documentos, que a través de la prioridad, realza el concepto de seguridad jurídica dinámica.
} 


\section{SEBASTIÁN JUSTO COSOLA}

Suele haber acuerdo general en la doctrina en aceptar que Vélez Sarsfield ${ }^{563}$ -un codificador hostil a los registros ${ }^{564}$-, se inclinó por la publicidad posesoria $^{565}$, con una postura clara y concreta acerca de la innecesaridad e inconveniencia de la creación de registros en el territorio nacional ${ }^{566}$. De esta forma, el creador del hoy histórico Código Civil Argentino -y según he analizado líneas atrás- no dudó en adoptar como medida de publicidad a la tradición, salvo para el derecho real de hipotecas, contrariando decididamente al sistema de publicidad registral ${ }^{567}$. Esta determinación permite la realización de una clara distinción entre los sistemas de adquisición de los derechos reales que convivían en nuestro país muy a pesar de las normas prescriptivas vigentes ${ }^{568}$.

${ }^{563}$ Una postura diferente a la que esgrime la generalidad de la doctrina argentina puede leerse en Héctor LAFAILLE y Jorge H. ALTERINI, Derecho Civil-Tratado de los derechos reales, $\mathrm{T}^{\circ} \mathrm{V}$, ob. cit., p. 221 y ss.

${ }^{564}$ Guillermo 1. ALLENDE, Panorama de derechos reales, ob. cit., págs. 228 y ss.

${ }^{565}$ Con excepción de las hipotecas, en donde no quedo alternativa posible que la de establecer la publicidad registral. El artículo 3934 del Código Civil Argentino establecía que la preferencia hipotecaria se gozará desde la fecha de la toma de razón; el artículo 3137 fijaba el plazo de seis días desde el otorgamiento de la escritura para presentar la hipoteca al Registro. En fin, el artículo 3149 disponía que el efecto de la hipoteca presentada en término se computase desde la fecha de la escritura.

${ }^{566}$ Vale la pena nuevamente, en el cuerpo de esta tesis, la transcripción del siguiente párrafo memorable: "En un país como el nuestro, donde el dominio de los inmuebles no tiene en la mayor parte de los casos títulos incontestables, la necesidad del registro público crearía un embarazo mas al crédito hipotecario (...) Hoy en las diversas provincias de la República sería dificil encontrar personas capaces de llevar esos registros...". Con esa vehemencia el codificador se refería a la situación, en la nota al artículo 3.203 del CCA.

${ }^{567}$ Cfr. Miguel Ángel LUVERÁ, Sistemas de constitución y transmisión de derechos reales sobre inmuebles en Latinoamérica, ANDCSC, p. 2. http://www.acaderc.org.ar/doctrina/articulos/sistemas-de-constitucion-y-transmision-dederechos (Último acceso: 21/08/2017).

${ }^{568}$ Fernando LÓPEZ DE ZAVALIA, Adquisición de derechos reales, en Carlos Gustavo VALLESPINOS (Director), Cuestiones esenciales en derechos reales, ob. cit., p. 61. Así, hace tiempo que el autor nos enseñaba los sistemas registrales desde la siguiente comprensión ya analizada en el cuerpo de esta tesis: a) La familia dilecta (teoría del título y el modo); b) La familia rebelde (se refiere a las excepciones a la exigencia del título y del modo: 1) En la cesión de créditos y la consecuente teoría de la cesión de derechos, que se traspasa solo por la fuerza del consentimiento (el jurista tucumano considera que debería haberse previsto que "antes de la notificación de la cesión, ningún derecho queda trasmitido), y 2) en la hipoteca, para lo cual quedó prevista la publicidad registral) y c), la familia adoptiva (Se refiere a la publicidad registral exigida por las provincias, con una fuerte crítica en razón de su inconstitucionalidad). 
En materia de derecho inmobiliario, las exigencias de la inscripción en ciertos registros estaduales como constitutiva de los derechos reales fue un tema trascendente en la práctica jurídica argentina, lo que produjo incertidumbre y no pocos planteos de inconstitucionalidad durante un tiempo determinado ${ }^{569}$, y que felizmente se vio normalizado a través de la publicación de dos normas nacionales referentes: me refiero a las leyes 17.711/68 y 17.801/68, reforma notablemente discutida en torno a este tema ${ }^{570}$. Aun así, desde esa fecha, la discusión sobre el tema de la función y la importancia de la publicidad en los registros se ha acrecentado notoriamente $^{571}$, e incluso ha ido mucho más lejos desde la sanción del decreto ley 6582/58 ${ }^{572}$, de Registro Nacional de la Propiedad del Automotor, que de antemano impuso un régimen de inscripción constitutiva, verdadera innovación jurídica y de notable impacto sociológico en relación al valor de las inscripciones o anotaciones, que sin embargo no ha tenido la repercusión académica que tuvo el régimen declarativo en el registro de la propiedad inmobiliaria a partir de la puesta en vigencia del artículo 2.505 del Código Civil $^{573}$. Muy a pesar de la influencia del mencionado decreto del automotor y su impacto en el derecho patrio, su traslación al régimen inmobiliario no fue posible. En efecto, a poco de haber sido publicada la ley de reforma del Código Civil, la Suprema Corte de la Provincia de Buenos Aires, en un trascendente fallo, despejó todo tipo de dudas planteadas por quienes argumentaban un nuevo sistema constitutivo de inscripción registral ${ }^{574}$.

\footnotetext{
${ }^{569}$ Héctor LAFAILLE, Tratado de los derechos reales, $\mathrm{T}^{\circ} \mathrm{V}$, ob. cit., p. 226 y ss.

${ }^{570}$ Cfr. Manuel A. LAQUIS, La reforma del artículo 2505, en Examen y crítica de la reforma del Código Civil, Augusto Mario MORELLO (Coord.), t 3: Contratos-Reales, Editora Platense, La Plata, 1.974, p. 437.

${ }^{571}$ Dando lugar incluso a que puedan perpetuarse para siempre en la discusiones del derecho civil y notarial argentino cuestiones tales como la del alcance y los efectos del título suficiente y del modo suficiente; las bondades y las posibles observaciones de los títulos con sus consecuentes técnicas de saneamiento, entre otros temas de interés.

${ }^{572}$ Texto ratificado mediante ley 14.467, ordenado en la actualidad por el decreto 1114/97.

${ }^{573}$ Cfr. Guillermo A. BORDA, La reforma de 1968 al Código Civil, ob. cit., p. 376 y ss; Alberto G. SPOTA, Curso sobre temas de derecho civil, ob. cit., p. 240 y ss.

574 "Al reformar la ley 17.711 el art. 2505 del Cód. Civ., no modificó las otras normas que constituyen el fundamento de los requisitos para la adquisición del derecho real de dominio. Se limitó a agregar a aquellos la formalidad de la inscripción en el registro pertinente". SCBA, 14/04/1970, ED to 33, p. 47. Fuente: Manuel OSSORIO Y FLORIT, Código Civil y Leyes Complementarias. Anotados, Comentados y Actualizados, t IV, Ediciones Librería Jurídica, La Plata, 1.973, p. 13.
} 


\section{SEBASTIÁN JUSTO COSOLA}

No debe dejar de advertirse a título de curiosidad que, como lo expone autorizada doctrina, la ley registral $17.801 / 68$, viene a ser una de las pocas leyes con entrada de vigencia retroactiva en nuestro país ${ }^{575}$, ya que la misma, posterior a la ley 17.711/68, rige desde el mismo momento de la vigencia de la última mencionada. Y así es que para una enorme cantidad de autores, la ley del registro de la propiedad inmobiliaria se presentaba como un complemento, casi un reglamento, del antiguo y ya referido artículo 2.505 del Código Civil, que venía a ordenar no sólo la incertidumbre acerca del carácter de la inscripción en los registros inmobiliarios, la que sin duda, se imponía como declarativa, sino además el desorden legislativo que imperaba en las provincias en contradicción con la legislación nacional. En esta materia, la referencia a lo declarativo implica siempre afirmar que la registración reconoce la preexistencia del derecho real, al que le otorga diversos efectos, pero el único que no le otorga es el de ser el elemento esencial de constitución ${ }^{576}$. Esto significa que la falta de registración no impide el nacimiento del derecho real, sino que lo que se obtiene es una limitación de los efectos en cuanto a los sujetos y en cuanto a su intensidad $^{577}$. En definitiva, así se comenzaba y se iniciaba un camino que era necesariamente oportuno de recorrer, en razón de las exigencias del tráfico jurídico y de la necesidad de contar con una forma de publicidad más certera que la mera apariencia ${ }^{578}$.

${ }^{575}$ Luis MOISSET DE ESPANÉS y Horacio VACCARELLI, Sistema registral..., ob.cit, p. 36: Dicen los autores: “...(El carácter declarativo) quedo plenamente reafirmado por la ley que -como consecuencia de esta reforma, y para reglamentarla- se dicto sobre el momento mismo de entrar en vigencia la ley 17.711; nos referimos a la ley 17.801, que lleva como fecha de sanción el día 28 de Junio de 1.968, y de la que recién se tuvieron noticias el día 3 de Julio, es decir, dos días después de su propia entrada en vigencia, fijada para el día 1 de Julio, pese a que su publicación en el Boletín Oficial no se efectuó hasta el día 10 de Julio de $1.968^{\prime \prime}$.

576 Zulma Aurora DODDA y Marcelo Eduardo URBANEJA, Principio de inscripción. Rogación. Documento inscribible. Publicidad previa y sus efectos en la seguridad jurídica, ob. cit., p. 2.

${ }^{577}$ Ibídem. En este sentido, Jorge Alterini recuerda en estudio formidable, que de la literalidad del hoy derogado artículo 2505 puede extraerse que ni el titulo ni el modo se perfeccionan con la inscripción, sino que el perfeccionamiento se refiere a la adquisición o transmisión, ya que tales adquisiciones y transmisiones no son factibles si no se conjugan ambas exigencias del título y el modo. v. Jorge H. ALTERINI, Gravitación de la reforma al artículo 2505 del Código Civil..., ob. cit., p. 1185.

${ }^{578}$ Gabriel B. VENTURA, Ley 17.801. Registro de la Propiedad Inmueble ..., ob. cit., p. 26. 
LOS EFECTOS DE LA PUBLICIDAD EN EL DOCUMENTO NOTARIAL

\subsubsection{La publicidad inmobiliaria en el Código Civil y Comercial} de La Nación.

Analizados ya los efectos y alcances de la comprensión del título suficiente, el derecho vigente establece que dentro de los modos suficientes establecidos para la adquisición de los derechos reales se encuentran previstos tanto desde la tradición posesoria como desde la inscripción registral. Esta última conforma el modo suficiente ya sea para transmitir o constituir derechos reales sobre cosas registrales únicamente en los casos legalmente previstos, de la misma manera que sobre las cosas no registrales cuando el tipo de derecho asi lo requiera ${ }^{579}$. Asimismo, se establece que la adquisición y transmisión de los derechos reales constituidos de conformidad con las disposiciones emergentes del Código no son oponibles a terceros interesados de buena fe mientras no cuenten con publicidad suficiente. Es publicidad suficiente la inscripción registral o la posesión según sea el caso de que se trate, salvo que el modo consista, de manera excepcional y legalmente prevista, en un tipo de inscripción constitutiva, donde sin duda alguna la registración será el único modo suficiente ${ }^{580}$.

Considerando además que el nuevo ordenamiento prescribe que no es posible la invocación de prevalencia de falta de publicidad a quienes participaron del acto, conocían o debieron conocer la existencia del título al derecho real, debe decirse que la normativa vigente mejora la redacción y las interpretaciones del sistema de publicidad inmobiliaria en el Código Civil y Comercial de La Nación, cuestión que lamentablemente ha quedado plasmada de manera confusa en la exposición relativa a los efectos de la publicidad en la ya analizada figura del boleto de compraventa ${ }^{581}$.

${ }^{579}$ Art. 1892 CCCN (Parte Pertinente).

${ }^{580}$ Art. 1893 CCCN.

${ }^{581}$ Art. 1170 inc. d), CCCN. El precepto alude a los supuestos en donde la prioridad del comprador de buena fe se impone por sobre quien haya trabado medidas cautelares sobre el inmueble que ha sido objeto e instrumentación de un boleto de compraventa. El inciso aludido hace lugar a la interpretación que advierte que tiene prioridad si la adquisición tiene 
SEBASTIÁN JUSTO COSOLA

\subsubsection{Génesis del derecho registral y sustento de los otros} $\operatorname{derechos}^{582}$.

Resulta necesario reconocer $-\mathrm{y}$ hasta paradójicamente- que la disciplina que se presenta como Derecho Registral tiene, tanto en nuestro país como en el derecho comparado ${ }^{583}$, una breve historia, si se la somete a comparación con otras instituciones que le sirven de sustento ${ }^{584}$. Es que el derecho registral contiene, resguarda, protege, asimila, facilita la inscripción o anotación de documentos e instrumentos por derivación, que necesariamente tienen que pasar por el procedimiento de creación y argumentación jurídica integrada tanto material -creación del documento- como formal -documento tipo formulario-. Por ello es necesario reconocer que no hay derecho registral posible $-o$ técnica registral posible, para aquellos que no consideran a la disciplina en el pleno de su autonomía- sin el ejercicio y la determinación de un derecho fuerte, antecedente, que le sirva de sustento ${ }^{585}$.

publicidad suficiente sea registral, sea posesoria. Si la adquisición se juzga sobre la cosa, es una clara referencia al derecho real; si en cambio, es analizada desde el derecho, la referencia es hacia los derechos personales. Este artículo debió interpretarse en su total magnitud con la posibilidad originaria de atribuirle a la registración de los inmuebles, el carácter constitutivo. Al no haberse concretado el anhelo de la comisión redactora, pareciera ser que esta mención viene a confundir la verdadera valoración del modo suficiente en el sistema de publicidad declarativa.

${ }^{582}$ Sebastián Justo COSOLA, Cuestiones registrales..., ob. cit., p. 227 y ss.

583 Cfr. Nery Roberto MUÑOZ y Rodrigo MUÑOZ ROLDÁN, Derecho registral inmobiliario guatemalteco, ob.cit., p. 57 y Lucila ORTIZ de DI MARTINO, Manual de derecho Registral, ob. cit., p. 137.

${ }^{584}$ Inclusive aun en esta época algunos autores niegan a esta disciplina el carácter de autonomía. V. Nery Roberto MUÑOZ y Rodrigo MUÑOZ ROLDAN, Derecho registral Inmobiliario Guatemalteco, ob. cit., p. 4.

${ }^{585}$ Sobre esto, al introducir uno de los temas centrales del derecho registral - la calificación-, Aida Kemelmajer enseña: “(...) Interesa destacar que, sea cual sea el origen del título, casi nunca hay una sola calificación: por el contrario, cuando el registrador se encuentra con el titulo, ha habido una calificación anterior. El escribano controla lo que hace (suponemos), el juez controla el oficio que firma (también suponemos). O sea que, antes del que el titulo haya llegado al registro hay otro sujeto, sea la autoridad administrativa, sea la autoridad judicial, sea el escribano interviniente que hizo una primera calificación del título que expidió; 
LOS EFECTOS DE LA PUBLICIDAD EN EL DOCUMENTO NOTARIAL

Los autores en general tratan el tema a través de las relaciones que el registro mantiene con el derecho notarial y con el derecho civil, procesal y administrativo, entre otros ${ }^{586}$. En este sentido, tanto el derecho notarial como el derecho judicial -éste último, en relación a las inscripciones que ordena como resultado de un determinado procedimiento sujeto a comprobación y valoración judicial- contribuyen a consolidar las pretensiones publicitarias registrales. Por ello es que un análisis de los fundamentos de la función de los registros que no sea el originado para plantear su propia naturaleza, tiene como principales componentes la actuación notarial y la judicial destinada a alcanzar las respectivas inscripciones o anotaciones. En este sentido, debe tenerse en cuenta, como bien lo enseñaba Carnelutti en el tratamiento del cavere, responderé y postulare, que la función judicial y la notarial sólo se asimilan en un solo y único hecho: tanto el juez como el notario juzgan. Pero el juez juzga sobre un inconveniente que ya se ha verificado, y el notario juzga para que el inconveniente no surja ${ }^{587}$. Desde la disciplina registral, ese juzgamiento es denominado calificación.

\subsubsection{Fundamentos del funcionamiento del Registro Inmobiliario (I): La función notarial.}

En un trabajo que ya tiene sus buenos años, Miguel Ángel Ciuro Caldani advertía desde la ius-filosofía que el notario debe hacer funcionar las normas

después llega al registro donde se hace una segunda calificación”. Cfr. Aída KEMELMAJER de CARLUCCI, Calificación registral de instrumentos de origen judicial, en Carlos Gustavo VALLESPINOS (Dir.), Cuestiones esenciales en derechos reales, LexisNexis, Buenos Aires, 2002, p. 35.

${ }^{586}$ Cfr. Luis CARRAL Y DE TERESA, Derecho Notarial y Derecho Registral, Porrúa, México, 2.007, p 289 y ss. En nuestro país, son Garcia Coni y Frontini quienes han propuesto a la fecha la mayor cantidad de relaciones existentes entre el derecho registral y las disciplinas tanto jurídicas como no jurídicas que sirven tanto a su cometido como a su sustento. Incluso resaltan la importancia de las ciencias auxiliares y de los métodos que recurren al auxilio del derecho registral, como las microfilmaciones, la informática, el muestreo, la planimetría, etc. v. R. GARCIA CONI y Ángel A. FRONTINI, Derecho registral aplicado..., ob. cit., p. 40 y ss.

${ }^{587}$ Cfr. Francisco CARNELUTTI, La figura jurídica del Notario, IER, Madrid, 1954, p. 21. 


\section{SEBASTIÁN JUSTO COSOLA}

constitucionales y legales para asegurar la eficacia del instrumento ${ }^{588}$. Para ello debe interpretarlas, determinarlas, elaborarlas y aplicarlas a la luz de una función conjetural respecto a las decisiones que adoptaran las autoridades en los casos en donde se requiera su intervención. Con esto, el jurista santafesino quería argumentar que el notario, en su opus cotidiano, debe en definitiva satisfacer el valor predecibilidad ${ }^{589}$; consecuentemente, teniendo especialmente en cuenta que parte relevante del trabajo del notario se dirige como fin hacia la institución registral -que toma razón suficiente de los derechos reales que nacen en el seno de la escritura pública-, si bien la registración puede reconocer diversas finalidades, en un sistema como el que rige en nuestro país, quizás la más trascendente sea la que se refiere a la publicidad patrimonial $l^{590}$.

La institución notarial sirve de base y fundamento para el funcionamiento general de la institución registral. Desde esta concepción institucional, se afirma con razón suficiente que el notariado es una de las más antiguas que el hombre ha conocido ${ }^{591}$. Su nacimiento obedece a un sin número de causas

${ }^{588}$ Cfr. Miguel Ángel CIURO CALDANI, Valores de la actividad notarial, GdN n ${ }^{\circ} 7$, Rosario, 1.979, p. 13.

${ }^{589}$ Ibídem.

${ }^{590}$ Miguel Ángel CIURO CALDANI, Notas trialistas sobre la filosofía del derecho registral, Investigación y Docencia Vol. VIII, Rosario, 1.988, p. 73.

${ }^{591}$ Diversos autores y tratadistas iberoamericanos concuerdan con esta afirmación, remitiendo a estudios del génesis notarial o tan solo comentando las respectivas evoluciones históricas de los notariados que se ejercen en sus países de origen. A modo de ejemplo y a titulo simplemente informativo pueden traerse algunos de ellos, sin pretender de ninguna manera en acabar con la lista: Eduardo Bautista PONDÉ, Origen e Historia del notariado, Depalma, Buenos Aires, 1.967; Argentino I. NERI, Tratado Teórico y Práctico de Derecho Notarial, $\mathrm{T}^{\circ}$ I, Depalma, Buenos Aires, 1.968; José A. NEGRI, Obras completas, $\mathrm{T}^{\circ}$ II, Colegio de Escribanos de la Capital Federal, Buenos Aires, 1.966; José María MENGUAL Y MENGUAL, Elementos de derecho notarial, T ${ }^{\circ}$ I, Librería Bosch, Barcelona, 1.931; Nery R. MUÑOZ, Introducción al estudio del derecho notarial, Guatemala C.A, Guatemala, 2.004; Antonino E. SOARES, El escribano y la fe pública, Imprenta San Martin, Buenos Aires, 1.915; Bernardo Pérez FERNANDEZ DEL CASTILlO, Derecho Notarial, Porrúa, México, 2.007; Leonardo B. PÉREZ GALLARDO e Isidoro LORA TAMAYO RODRÍGUEZ, Derecho Notarial, $\mathrm{T}^{\circ}$ I, Ediciones Félix Varela, Cuba, 2.006; Nelson Rudys CASTILLO OGANDO, Derecho notarial, T ${ }^{\circ}$ I, Trajano Potentini Editorial, Santo Domingo, República Dominicana, 2.007; Ramiro VILLARROEL CLAURE, Fundamentos de derecho notarial y registral inmobiliario, ob. cit.,; Lucila ORTIZ de DI MARTINO, Manual de derecho notarial, Marben, Asunción, Paraguay, 2.007; Rufino LARRAUD, Curso de derecho notarial, Depalma, Buenos Aires, 1.966 [NdA: Texto del autor uruguayo concordado por el IACN]. 


\section{LOS EFECTOS DE LA PUBLICIDAD EN EL DOCUMENTO NOTARIAL}

que directamente han estado ligadas desde siempre con su actuar en comunidad. Entre todas ellas, quizás la que sobresale es la que ubica y afirma la necesidad de base comunitaria que tenían todas las personas que vivieron en cualquier tiempo y lugar de conocer, de asegurarse o de documentar todo lo que a su alcance podrían llegar a realizar. Y si bien resulta importante recordar aquí que la doctrina no ha sido pacífica en reconocer los antecedentes inmediatos de la figura del notario actual ${ }^{592}$, lo cierto e indubitable es que desde siempre se le ha exigido a la persona del escriba $^{593}$, o logógrafo ${ }^{594}$, o tupsarru $^{595}$, o tabelio $^{596}$, o tabularii ${ }^{597}$, o notarius $^{598}$, o escribano ${ }^{599}$ o notario $^{600}$, entre otras tantas denominaciones, el cumplimiento de un cierto comportamiento, de una determinada conducta,

\footnotetext{
${ }^{592}$ Basta con tomar algunos libros para notar que hay autores que refieren los antecedentes remotos que vinculaban al notario del hoy con el escriba egipcio, otros encuentran su antecedente en los tabeliones o notarios romanos, para muchos el prototipo notarial nace con la Escuela de Bologna, en donde se destacan Rolandino, Irnerio y Salatiel, y en donde ve la luz el "ars notarie", para quien finalmente considera que nuestro antecesor directo es el notario de tipo francés, nacido en épocas de napoleón con la ley del ventoso, entre otras opiniones minoritarias.

593 El notario argentino Tomas Diego BERNARD manifiesta: "Resulta dificil dar una definición genérica del "escriba", pues su institución varía según los países y aun, dentro de estos, según las épocas". Cfr. Tomás Diego BERNARD en Enciclopedia Jurídica OMEBA, voz escriba, Editorial Driskill S. A, Buenos Aires, Tomo X, 1.993, p. 579. Aun así, lo asimila con Egipto y Grecia, reconociendo la etimología en el latín scriba, que significaba copista, amanuense, estudioso, que era un funcionario público. En este orden: Eduardo Bautista PONDÉ, Origen e historia del notariado, ob. cit., p. 6; Eduardo Bautista PONDE, Tríptico Notarial, Depalma, Buenos Aires, 1.977, ps. 22 y 227; José María MUSTAPICH, Tratado Teórico y Práctico de Derecho Notarial, T ${ }^{\circ}$ II, Ediar, Buenos Aires, 1.955, p. 22.

${ }^{594}$ Tomas Diego BERNARD, Escriba, ob. cit., p. 582. Explica el autor que en Grecia, si bien no se expandió la figura del escriba, los logógrafos (De Logo: palabra, y grafo, grabar, escribir) hacían las veces de escritores y redactores de los documentos más importantes, discursos y alegatos de los acusados, quienes se los aprendían de memoria para recitarlos frente al Tribunal el día de la audiencia.

${ }^{595}$ Denominación que el escribano adquiere en el derecho Asiririo-Babilonio, en donde se encuentran testimonios de la contratación escrita. V. José María MUSTAPICH, ob. cit, p.10

${ }^{596}$ La denominación se remonta a la época de Justiniano, y se menciona por vez primera en La novela XLIV de Justiniano I de Bizancio. V. Eduardo Bautista PONDÉ, Tríptico notarial, ob. cit., p. 338.

${ }^{597}$ Denominación que se menciona en la segunda mitad del siglo IX, por el emperador León VI, que escribe la Constitución numero XXV, estudiando la función del tabularii. V. Bernardo PÉREZ FERNANDEZ DEL CASTILLO, Derecho Notarial, ob. cit., p. 6.

${ }^{598}$ Se refiere a un secretario de consejo, que era el que redactaba la actas que tenían como único y especial requisito el ser autenticas y verídicas. Cfr. José María MENGUAL Y MENGUAL, Elementos de derecho notarial, $\mathrm{t}^{\circ} \mathrm{I}$, ob. cit., p. 100.
} 


\section{SEBASTIÁN JUSTO COSOLA}

acorde con la ley aplicable en un momento determinado, y de acuerdo con la importancia de la función que este debía de $\operatorname{prestar}^{601}$.

Resulta ser así que en torno a la consideración de la función notarial en el tiempo -y siempre teniendo en consideración la conducta en evolución permanente-, se pueden leer y asimilar posturas de estudiosos del derecho que indican que el antecedente de quien hoy reviste la posición de notario, oscila desde un funcionario estatal dependiente del poder faraónico ${ }^{602}$, religioso o del estado, hasta un jurista ${ }^{603}$, un consejero, o simplemente un sabedor del arte de escribir ${ }^{604}$. En definitiva, desde la más remota antigüedad, la función notarial, interpretada con los alcances

${ }^{599}$ Denominación que se hace fuerte principalmente en el derecho español antiguo, y que aparece primeramente en las grandes obras de la literatura medieval. V. Enrique GIMÉNEZ ARNAU, Derecho Notarial, EUNSA, Universidad de Navarra, S.A, Pamplona, 1.976, ps. 102 y ss.

${ }^{600}$ Cfr. Juan Francisco DELGADO DE MIGUEL, Código Notarial de la Unión Europea, $\mathrm{t}^{\circ} \mathrm{I}$, CGN, Madrid, 2.003, p. 501 y ss. Denominación que introduce la Ley de 25 de Ventoso del año XI. Además de introducir el concepto de notario, hace lo propio con el de funcionario público, influyendo en todos los países europeos e hispanoamericanos. Por los problemas que ha causado la denominación de funcionario público, la propia ley lo ha sabido reformar, intercambiando el concepto de "fonctionnaires publics" para hablar de "officiers publics", en el año 1.945 Hoy, derogada en prácticamente todos sus artículos, reformada y actualizada por leyes modernas posteriores, la histórica Ley de ventoso sigue en pie en poco más de quince artículos.

${ }^{601}$ Como he intentado demostrar en alguna otra ocasión, la evolución notarial en este tema fue de tal magnitud que se ha pasado desde la exigencia ética y deontológica, hasta alcanzar en la actualidad la responsabilidad por los deberes éticos notariales. V. Sebastián Justo COSOLA, Perfiles ético-jurídicos de los principios de legalidad notarial y registral (armonía y complementariedad), en Estudios de Derecho Notarial Iberoamericano (Homenaje al Prof. Dr. Nery Roberto MUÑOZ), Infoconsult Law, Guatemala, 2.013, págs. 187-236.

${ }^{602}$ En la magistral organización religiosa Egipcíaca Thot era el escriba considerado como una persona Divina, y su reino era el del intelecto y la sabiduría. Su mano es la que escribe las preceptivas divinas emanadas de la autoridad de los dioses tal cual fueron encomendadas. De ahí surge la confianza del pueblo en el escriba. Eduardo Bautista PONDÉ, Origen e historia del notariado, ob. cit., ps. 7 y ss.

603 Juan B. VALLET DE GOYTISOLO asegura que la consolidación del notariado románico o latino se produce cuando a un ars dictandi, conjunto de conocimientos gramaticales lógicos y retóricos, se le añaden los conocimientos jurídicos, y así ese ars dictandi se convierte en ars notariae. Si a todo esto se le considera el reconocimiento de la fides pública a los documentos autorizados por el notario, pasa a convertirse este en nuestro más lejano antecedente, habiendo cobrado autorictas con mas la potestas de la jerarquía civil o eclesiástica de la cual derivaba su designación. V. Juan B. VALLET DE GOYTISOLO, Orígenes del notariado latino en Italia y en España, RJN n 47, Madrid, 2.003, p. 306. 
LOS EFECTOS DE LA PUBLICIDAD EN EL DOCUMENTO NOTARIAL

correspondientes, ${ }^{605}$ contribuyó a brindar seguridad y previsibilidad a las relaciones entre las personas, aun cuando no existía la registración.

\subsubsection{Fundamentos del funcionamiento del Registro Inmobiliario (II): La función judicial.}

Algo similar ocurre con el derecho judicial ${ }^{606}$, que desde la perspectiva procesal proyecta los principios del derecho de fondo para acceder al registro y así, dar reflejo a las verdades de los procesos concluidas de acuerdo a la justicia. La función judicial actual, mucho más amplia y compleja que la que primaba en otras épocas, integra la esfera del reconocimiento de los derechos integrados con las disciplinas que ayudan a determinar las causas de los acontecimientos que posicionan al hombre frente al juez. De esta manera, todas las disciplinas jurídicas, si bien reconocen principios y fuentes que brindan argumento a su existencia, en circunstancias necesitan del derecho judicial para poder alcanzar una determinada proyección. De ahí que existan obras que se refieran a la constitucionalización y a la judicialización del derecho ${ }^{607}$, como así también las que vienen a justificar el ejercicio de los poderes implícitos de los máximos organismos de justicia ${ }^{608}$. Es que como con acierto refiere Abelardo Rossi, la función judicial no se resume en la vertiente legalista de su problemática, sino que ahonda en sus raíces filosóficas, éticas,

\footnotetext{
604 "Escribano tanto quiere decir como ome que es sabidor de escribir", Ley $1^{\circ}$, Titulo XVIII, Partida Tercera, de la ley de las Partidas.

${ }^{605}$ Para profundizar el tema de las posiciones notariales en la historia, v. Jorge A. LATINO, Ora pro nobis notarii. En torno a san Ginés y a la Cofradia Porteña, RdN 925, Jul-Sep (2016), Buenos Aires, 2.017. http://www.revista-notariado.org.ar/2017/01/ora-pro-nobisnotarii-en-torno-a-san-gines-y-a-la-cofradia-portena/ (Último acceso: 21/08/2017).

${ }^{606}$ Para advertir los alcances del moderno derecho judicial confrontar la obra de Rodolfo Luis VIGO y María GATTINONI de MUJÍA (Dir.), Tratado de derecho judicial, Abeledo Perrot, Buenos Aires, 2013.

607 Cfr. Rodolfo Luís VIGO, Constitucionalización y judicialización del derecho, Porrúa, México, 2.013.

${ }^{608}$ Cfr. Carlos S. FAYT, Los poderes implícitos de la Corte Suprema de Justicia de La Nación, La Ley, Buenos Aires, 2.006, p. 104.
} 
sociológicas e históricas ${ }^{609}$. De esta manera, también la indispensable función judicial es fuente directa de la registración, situación innegable que esgrime con los más fuertes fundamentos.

\subsubsection{Fundamentos del funcionamiento del Registro Inmobiliario (III): La profesión del abogado y de otros profesionales que tienen acceso a la información.}

Finalmente, debe destacarse que la eficacia de la publicidad registral también se justifica a partir de la solicitud de información del contenido de los asientos registrales, a los efectos de anoticiar algún supuesto desconocido por la parte interesada, como para cumplir con algún requisito formal del procedimiento judicial (presentación de informes determinados). Tanto los abogados como otros profesionales matriculados como los martilleros $y$ corredores públicos $^{610}$ tienen acceso a la información registral de las personas interesadas, aquellas que requieren de sus servicios para cumplir con un objetivo determinado. La información registral así se vuelve imprescindible para alcanzar los cometidos que entraña el derecho, siempre partiendo del supuesto, hoy elevado a categoría de principio, de la buena fe.

\subsubsection{El contenido del derecho registral y la actuación del} registrador.

609 Cfr. Alejandro GUZMAN BRITO, Carlos I. MASSINI CORREAS, Bernardino MONTEJANO, Julio SOLER MIRALLES y Rodolfo Luis VIGO, La función judicial, Prólogo de Abelardo ROSSI, Depalma, Buenos Aires, 1.980, p. VII y ss.

${ }^{610}$ Cfr. Eduardo L. LAPA, Manual del martillero público y del corredor, Abeledo Perrot, Buenos Aires, 2.009, p. 47 y ss. 


\section{LOS EFECTOS DE LA PUBLICIDAD EN EL DOCUMENTO NOTARIAL}

En razón de lo antedicho, estoy seguro de afirmar que el contenido del derecho registral puede advertirse desde dos orientaciones tan disímiles como complementarias:

a) La sustantiva o material, comprensiva de la finca y su inmatriculación, de los actos y derechos inscribibles, de los principios registrales y de las anotaciones y sus efectos, $\mathrm{y}$

b) La adjetiva, formal u orgánica, relacionada directamente con los asientos registrales, al proceso de registración y a la organización de los registros ${ }^{611}$.

Es por ello que la actuación del registrador -siempre posterior a la que realizan los notarios, los abogados o los jueces-, encuentra esencial fundamento en la recepción y calificación de los documentos que recibe para su anotación o inscripción. Su responsabilidad es analizada desde el mismo momento en que el documento ingresa al Registro ${ }^{612}$, lugar en donde deben cumplirse todos los procedimientos establecidos, para que la publicidad que desde el organismo emerja a modo de noticia -con o sin prioridad-, y los documentos que requieran de anotación o inscripción se logren adecuar a derecho. De manera que esta responsabilidad únicamente puede analizarse en razón de su intervención temporal; y así, podría intentarse el siguiente paradigma: "Cuanto más perfecta y cuidada sea la elaboración de los documentos, formularios o instrumentos que emanen de la función notarial $o$ de la función judicial en su versión procesal (proyectando todos los derechos), menor posibilidad de error".

Desde aquí sí que puede entonces cumplirse con la verdadera función registral de control o ennoblecimiento de los documentos e instrumentos que ingresan al registro ${ }^{613}$, inclusive hasta llegar a considerar, como lo ha

${ }^{611}$ Aída KEMELMAJER de CARLUCCI, Registro de la Propiedad Inmueble, ob. cit., p. 3.

${ }^{612} \mathrm{Se}$ acepta que la responsabilidad registral recepta la teoría de la recepción, pero en circunstancias especiales, también el Registro tiene responsabilidad en la emisión de los documentos registrales (supuesto de fuga registral).

613 Sebastián Justo COSOLA, Perfiles ético-jurídicos de los principios de legalidad notarial y registral (armonía y complementariedad), ob. cit., p. 187-235. 
referido Alberto Molinario -aunque a mi juicio exageradamentefundamento registral relacionado con el poder de policía $a^{614}$.

\subsubsection{La cuestión de las normas y de los principios registrales.}

La Carta de Buenos Aires es el documento que nace como resultado de la celebración del I Congreso Internacional de Derecho Registral celebrado en Buenos Aires hace ya algo más de cuatro décadas. En ella se establece que el derecho registral integra el sistema jurídico con normas y principios propios de derecho público y privado que coexisten y funcionan en armonía ${ }^{615}$.

La referencia a las normas nos motiva a pensar esencialmente, tanto en las leyes que regulan el funcionamiento del registro, y también aquellas que prescriben cómo deben de efectuarse o rogarse las anotaciones $\mathrm{o}$ inscripciones en el organismo, de rango eminentemente inferior. Bajo la denominación de normas registrales ubicamos entonces en nuestro país tanto a la ley nacional registral y las normas implicadas en el Código Civil y Comercial de La Nación, como a todas las leyes provinciales que en virtud de la autonomía legislativa estadual argentina se presentan como válidas y vigentes y complementarias de la ley madre -aunque en su mayoría todas hayan sido publicadas con anterioridad a la sanción de la ya referida ley registral 17.801/68-. Pero también se deben tener en cuenta todo ese universo interminable de disposiciones técnico-registrales, cartas $u$ órdenes de servicios especiales y normas afines ${ }^{616}$, todas de rango inferior $\mathrm{y}$ de naturaleza eminentemente administrativa, que muchas veces se imponen como normas de procedimiento obligatorias hasta que una sentencia las

${ }^{614}$ Alberto MOLINARIO, Del derecho registral y del derecho registral inmobiliario..., ob. cit., p. 18.

${ }^{615}$ Aída KEMELMAJER de CARLUCCI, Registro de la propiedad inmueble, ob. cit., p. 4.

${ }^{616}$ En la provincia de Buenos Aires: v. Zulma A. DODDA y María Florencia FRANCHINI, Digesto de disposiciones técnico Registrales, III tomos, FEN, La Plata, 2.011. 
declara inconstitucionales o la fuerza de las costumbre las aleja del sistema de funcionamiento por desuso o vetustez.

Contamos en nuestro país entonces al menos con tres tipos de normas, de disímil jerarquía, que se encuentran interrelacionadas y referidas especialmente tanto al derecho registral como al funcionamiento interno de la institución, y que vale la pena designar nuevamente:

a) La norma nacional rectora y los artículos consolidados en el Código Civil y Comercial de La Nación;

b) Las normas provinciales que consolidan y apoyan a la norma rectora $\mathrm{y}$ a las normas generales del mismo rango ${ }^{617}$, y,

c) Las disposiciones técnico-registrales, cartas de servicio y directivas registrales diversas cuya finalidad es estandarizar criterios y pautas para la inscripción de los documentos o instrumentos que ingresan al registro.

Sobre esto, la idea de trabajo adecuada es la que obliga al jurista a interpretar e integrar a las mismas siempre en procura de alcanzar la excelencia en la búsqueda de la publicidad adecuada. Esto significa que el orden descripto no puede de ninguna manera alterar el funcionamiento del derecho tal cual lo conocemos y lo aplicamos, y por ello es necesario y conveniente aclarar que el orden de jerarquía registral descripto tendrá validez y vigencia siempre y cuando no altere las normas, las reglas y los principios del derecho en general, planteadas como baluartes que se encuentran muy por arriba de la clasificación en estudio. De manera que no puede, de ninguna manera,

\footnotetext{
${ }^{617}$ A modo de ejemplo, puede recordarse que el artículo 24 de la Ley Nacional 17801/68 no permite que los plazos allí establecidos de validez de los certificados para el cómputo de la prioridad $-15,25$ o 30 días- sean disminuidos por las normas inferiores. Si en cambio pueden los mismos ampliarse, en beneficio de quien pretende inscribir algún título o documento, y por ello, el Decreto Ley 11643/63 bonaerense (ratificado por la Ley 6736) y reglamentado por el Decreto 5479/65, pionero en materia de legislación registral inmobiliaria en Argentina y fuente indirecta de la Ley 17801, permite en los artículos respectivos que los escribanos de la localidad de Carmen de Patagones tengan una ampliación del plazo inscriptorio para inmuebles de otras demarcaciones de 35 días en lugar de los 30 establecidos en la ley nacional. Por ello debe reafirmarse que las leyes locales, deben ser consideradas en su total magnitud y esplendor cuando de las mismas emergen derechos superiores a los establecidos en la ley madre.
} 


\section{SEBASTIÁN JUSTO COSOLA}

imponerse una norma de inferior por sobre la de jerarquía superior, muy a pesar que se invoque para justificar su nacimiento, que viene a cumplir una tarea de orden y acomodamiento. Las normas de jerarquía inferior deben acompañar a las de mayor jerarquía; facilitar su concreción y aplicación; clarificar el alcance ante alguna oscuridad propia de la ley, pero de ninguna manera imponerse ni en el rango ni en la valoración y argumentación final del derecho destinado a inscribirse o anotarse.

Muy por el contrario, la referencia a los principios nos posiciona frente a un panorama de argumentación superior. No se trata ya de complementar las normas para que todas, en su conjunto, puedan interpretarse de la mejor manera posible, evitándose así los inconvenientes propios de la redacción humana, desencadenantes de los conflictos y determinantes, en infinidad de situaciones concretas, de la intervención judicial. De lo que se trata es de comprender que éste derecho registral, de eminente naturaleza procesal, reconoce como fuente principal a una serie de baluartes que, repetidos y reiterados en el tiempo y en todas las legislaciones comparadas, consolidan a la institución a través de la similar proyección de su finalidad. Sin embargo en esta materia, algunos autores vienen advirtiendo que el problema de los principios registrales es precisamente el que reconoce que los mismos carecen de vigencia universal, no siendo asimilados ni siquiera uniformemente por los ordenamientos positivos receptivos de los diversos sistemas registrales ${ }^{618}$. De ahí entonces es que en la actualidad, algunos autores sostengan que en nuestro país, los principios registrales son criterios básicos establecidos por tradición, que conforman el sistema de publicidad jurídica inmobiliaria, y que se definen como auténticas normas jurídicas ${ }^{619}$, considerándose como propios del registro de la propiedad inmueble ${ }^{620}$.

Por ello es que los principios registrales son, para cada Estado y Provincia, paradigmas de naturaleza sectorial, y no son principios universales o valores que se captan por evidencia y que sirven para entender cuál es la finalidad de la institución, cual es su motivo de existencia, que pretende para la sociedad y como resguarda y reconoce su naturaleza primaria. Cada Estado o cada

${ }^{618}$ Cfr. Antonio R. COGHLAN, Teoría general de derecho inmobiliario registral, ob. cit., p. 11.

${ }^{619}$ Cfr. Gabriel DE REINA TARTIÈRE, Principios registrales..., ob. cit., p. 31.

${ }^{620}$ Ídem, p. 45. 
provincia entonces explica sus principios a través de su legislación, de sus normas complementarias, y de las demás ya referidas normas o reglas inferiores de funcionamiento, y por ello, los principios registrales explican el contenido y la función del Registro Público de la Propiedad ${ }^{621}$; desde aquí entonces que la doctrina sea pacífica en reconocer a los principios como fuente primaria del derecho registral ${ }^{622}$.

Realizadas las necesarias cuestiones introductorias, corresponde ahora continuar con el análisis estricto del principio de publicidad registral.

${ }^{621}$ Cfr. Bernardo PEREZ FERNÁNDEZ DEL CASTILLO, Derecho Registral, Porrúa, México, 2.013, p. 77.

${ }^{622}$ Es fundamento de esta tesis el desarrollo del principio de publicidad registral -quizás comprensivo de todos los demás principios ya que todo sistema registral es de publicidad-, por cuanto de lo que se intenta es de advertir que la misma es un sostén, un control formal y una contribución a la seguridad que emana del documento. No corresponde en cambio a esta tesis el desarrollo de todos los demás principios reconocidos y aceptados por la doctrina mayoritaria, tan bien elaborados y considerados por los muchos autores consultados para la confección del presente capitulo. Sin embargo, muchos de ellos serán referenciados tan siquiera indirectamente como complemento del mencionado principio de publicidad registral. Para analizar la ubicación del principio de publicidad registral como contenedor de todos los demás principios: Gabriel DE REINA TARTIÈRE, Principios registrales ..., ob. cit., p. 295. 
SEBASTIÁN JUSTO COSOLA

$\cdot 172 \cdot$ 


\section{Capitulo 5:}

\section{El principio de publicidad registral.}

\subsection{Introducción a su tratamiento.}

Enseñaba el maestro Alfredo Di Pietro que en el mundo antiguo, existían dos líneas nítidamente perfiladas en relación a la publicidad: los derechos grecoorientales, sensibles por dotar a las operaciones inmobiliarias de cierta publicidad, y el derecho romano, que se mantenía al margen de todo tipo de publicidad $^{623}$. En sintonía con estas apreciaciones, se suele aducir que el origen de la publicidad registral comprende el derecho antiguo, el derecho romano y el derecho germánico, aunque con razón suficiente también se advierte que nuestro derecho actual reconoce influencias tanto del derecho francés como del español ${ }^{624}$. Y también existen algunos autores que inclusive llegan aun más lejos en relación a los orígenes y los primeros precedentes de la publicidad registral en el mundo antiguo, situando a los mismos en los últimos años del siglo XII A.C $C^{625}$.

Independientemente de las mencionadas argumentaciones, es el profesor hispano José Antonio Álvarez Caperochipi quien transmite la idea que confirma que el principio de publicidad registral es el fuerte fundamento de los denominados registros germánicos de la propiedad ${ }^{626}$, lugar en donde la publicidad oficia como garantía de los derechos reales inscriptos, con la

${ }^{623}$ Cfr. Alfredo DI PIETRO, Evolución histórica de la publicidad inmobiliaria, en Curso de derecho registral inmobiliario, Ediciones Pannedille, Buenos Aires, 1.971, p. 44.

${ }^{624}$ Marta E. FAZIO de BELLO, Actos jurídicos y documentos inscribibles, ob. cit., p. 25.

${ }^{625}$ Cfr. Antonio LINAGE CONDE, Un precedente de la publicidad registral en el mundo antiguo, RDN n ${ }^{\circ}$ LXXVI, Madrid, 1.972, p. 395.

${ }^{626}$ Cfr. José Antonio ÁLVAREZ CAPEROCHIPI, Derecho inmobiliario registral, Est. Prel. Gunther GONZÁLES BARRÓN, Ediciones Legales, Lima, 2.012, p. 563. 


\section{SEBASTIÁN JUSTO COSOLA}

única finalidad de causar una presunción de veracidad o integridad del Registro $^{627}$. Esta situación empero, no es la aplicable a nuestro derecho.

Otro autor español, José María Chico y Ortiz advertía hace tiempo -en sintonía con la tesis de Ehremberg- que el principio de publicidad se erige a partir de la puesta en consideración de la importancia de la seguridad del tráfico ${ }^{628}$, o sea de una perspectiva o derivación de la seguridad jurídica, pero no el valor en su total esplendor. En la visión de Juan Vallet de Goytisolo, muchos de los problemas que sufrieron los españoles a la hora de tener que armonizar la ley hipotecaria con los usos, costumbres y el propio derecho hispano, fue que la primera se inspiró en un sistema germánico que daba a la publicidad un tinte que en países de otras tradiciones no cumple, como es el caso de todos aquellos que, reconociendo una raigambre romana, dan a la posesión un fuerte sentido publicitario orientado hacia la seguridad $^{629}$. Así, los países de influencia germánica trasladaron, en materia de inmuebles, los efectos de la antigua Gewere ${ }^{630}$, que mostraba su cometido en sociedades donde las relaciones jurídicas eran simples y de fácil visibilidad, pero de imposible protección hacia instituciones más complejas como las hipotecas, los fideicomisos, las vinculaciones y los censos entre otros ejemplos, hacia el Registro de la Propiedad ${ }^{631}$. Es por esta razón que el fin esencial del mencionado registro fue el brindar publicidad a las limitaciones del dominio no dotadas intrínsecamente de visibilidad ${ }^{632}$; pero de ninguna manera fue la de eliminar la posesión como modo de publicidad, situación que ocurre en España al pretenderse que el Registro la elimine definitivamente ${ }^{633}$.

\footnotetext{
${ }^{627}$ Ibídem.

${ }^{628}$ Cfr. José María CHICO Y ORTÍZ, Teoría, práctica y formula de la calificación registral, Marcial Pons, Madrid, 1.977-1978, p. 17.

${ }^{629}$ Juan Berchmans VALLET DE GOYTISOLO, Estudio sobre el derecho de las cosas, ob. cit., p. 330 .

${ }^{630}$ Ibídem, p. 331.

${ }^{631}$ Ibídem.

${ }^{632}$ Ibídem.

${ }^{633}$ Ídem, p. 332. En este sentido, argumenta Isabel Hernando que esta situación se comprueba a través del tratamiento que el Tribunal Supremo Español viene dando, desde hace muchísimo tiempo, a lo que allí se conoce como principio de legitimación registral, comprensivo de los preceptos de presunción de exactitud registral (sentido positivo), de presunción de extinción
} 


\section{LOS EFECTOS DE LA PUBLICIDAD EN EL DOCUMENTO NOTARIAL}

En nuestro país, autores como Luis Moisset de Espanés aseguran que la publicidad registral, tanto en materia de inmuebles como de bienes muebles registrables, ha presentado en los últimos tiempos, una notable evolución, sobre todo y más rápidamente en el campo inmobiliario ${ }^{634}$. En sintonía con todo lo anteriormente referenciado, el autor advierte que la publicidad, en sentido vulgar, es una actividad dirigida a hacer notorio un hecho, una situación o una determinada relación jurídica, mientras que en materia de derechos reales, es también una actividad dirigida a hacer cognoscible una situación jurídica real, que persigue la protección del crédito y la seguridad del tráfico ${ }^{635}$. A estas caracterizaciones, se agrega con razón suficiente la búsqueda de la realización efectiva del valor justicia ${ }^{636}$.

Esto hace pensar que el principio de publicidad está orientado a entender una cierta y precisa posibilidad de cognocibilidad desde aquellas personas que no intervienen en la conformación del derecho real en base al título y al modo $^{637}$, y que por ende no tienen otra alternativa que la posibilidad de conocer. En esta orientación, no caben dudas entonces que la publicidad, como primera medida, procura una cognocibilidad general en razón de poder acceder al conocimiento de situaciones jurídicas relevantes para el interés de la comunidad $^{638}$. En definitiva, en materia de publicidad, la palabra cognocibilidad implica posibilidad de conocer y no (efectivo) conocimiento $^{639}$. Todo esto implica reconocer una vez más que el derecho real nace fuera del Registro, con la tradición del inmueble, con la suscripción

frente a la cancelación del asiento (sentido negativo), y la salvaguarda de los asientos registrales por parte de los tribunales. V. Isabel HERNANDO COLLAZOS, El principio de legitimación registral y su tratamiento jurisprudencial, Civitas, Madrid, 1.990, págs. 11-12.

${ }^{634}$ Luis MOISSET DE ESPANÉS, Publicidad registral, ob. cit., p. 15.

${ }^{635}$ Ídem, p. 275.

${ }^{636}$ Cfr. Karen M. WEISS y Gastón A. ZAVALA, Eficacia ofensiva de la publicidad registral inmobiliaria, $\mathrm{RN} \mathrm{n}^{\circ}$ 965, La Plata, 2.010, p. 307.

${ }^{637}$ Luis O. ANDORNO y Marta MARCOLÍN de ANDORNO, Ley Nacional registral inmobiliaria 17.801, ob. cit., p. 350.

${ }^{638}$ Cfr. Jorge Horacio ALTERINI, La buena fe y la publicidad inmobiliaria registral y extrarregistral. Con una armonización entre la tradición y la inscripción registral, L.L AR/DOC/497/2012, p. 1.

${ }^{639}$ Marta E. FAZIO de BELLO, Actos jurídicos y documentos inscribibles, ob. cit., p. 116. 


\section{SEBASTIÁN JUSTO COSOLA}

de la escritura y con un contrato causal necesario ${ }^{640}$; es ésta la posición que dirige inclusive el rumbo de la jurisprudencia ${ }^{641}$.

Pero la publicidad cobra su importancia, por un lado, en razón de la oponibilidad, nota característica de los derechos reales vinculada esencialmente con esa posibilidad de conocer $^{642}$, y por el otro, por su estrecha relación con las certificaciones y por ende, con el principio de prioridad $^{643}$.

\subsection{Publicidad formal y publicidad material.}

La publicidad presenta dos elementos que se unen y que son inescindibles ${ }^{644}$, precisamente porque todo hecho publicitario presenta aspectos formales y materiales o sustantivos que justifican su misión ${ }^{645}$. Dentro de los primeros aspectos se encuentran la información emergente de la expedición de los certificados, informes y copias -siempre a solicitud de parte con interés-, mientras que la exhibición de los asientos registrales conforma la publicidad de tipo material $^{646}$. Desde aquí entonces que la publicidad formal sea particular, oponible únicamente a quien la hubiera solicitado y que opera a rogación de parte $^{647}$, mientras que la publicidad material implica una

${ }^{640}$ Cfr. Cristina Noemí ARMELLA, La función notarial y los Registros de la Propiedad, RNCNL n ${ }^{\circ}$ 12, Lima, 2.002, p. 30.

641 “(...) se afirma que el derecho real inmobiliario nace y se constituye extra-registralmente y que el documento portante del título ingresa al registro a los efectos de la publicidad y consiguiente oponibilidad respecto de terceros" Cam. Nac. Civ., Sala J, 5/03/2008, Departamento técnico y jurídico administrativo v. Registro de la Propiedad Inmueble, JA 2008-IV-500.

${ }^{642}$ Aída KEMELMAJER de CARLUCCI, Registro de la propiedad inmueble, ob. cit., p. 46.

${ }^{643}$ Cfr. Francisco I. J. FONTBONA, Estudio de cuestiones. Principio de publicidad. Certificaciones, en Jorge Horacio ALTERINI (Dir.) e Ignacio Ezequiel ALTERINI (Coord.), Derecho Notarial, Registral e Inmobiliario. Doctrinas Magistrales (1897-2012), t ${ }^{\circ}$ IV, La Ley y CECBA, Buenos Aires, 2.012, p. 349 y ss.

${ }^{644}$ Luis MOISSET DE ESPANÉS, Publicidad registral, ob. cit., p. 275.

${ }^{645}$ Ibídem, p. 276.

${ }^{646}$ Aída KEMELMAJER de CARLUCCI, Registro de la propiedad inmueble, ob. cit., p. 293.

En igual sentido, Américo Atilio CORNEJO, Derecho registral, ob. cit., p. 146.

${ }^{647}$ Marta E. FAZIO de BELLO, Actos jurídicos y documentos inscribibles, ob. cit., p. 124. 
presunción de que lo inscripto es una situación conocida por todos ${ }^{648}$. Estas apreciaciones además, permiten reconocer que la publicidad en sentido formal es la que se identifica con el papel, con el instrumento, desde el momento en que una persona accede al Registro solicitando un informe o certificación que el Registro expide si se cumplen los requisitos de legitimación pertinentes, mientras que la publicidad en sentido material está orientada a la cognocibilidad legal del contenido de los asientos ${ }^{649}$.

Otros autores en cambio, ponen un manto de duda sobre la clasificación y el alcance de la publicidad antes referido. Al afirmar que la publicidad registral se cumple tanto mediando la exhibición de los asientos como a través de la expedición de constancias, se argumenta que la doctrina registral mayoritaria considera que la exhibición de los asientos y la expedición de las constancias aludidas conforman la publicidad en sentido formal ${ }^{650}$. Por ello es que se insiste en que la publicidad formal se alcanza tanto por manifestación o exhibición en el momento en que el interesado tiene la posibilidad de leer directamente los libros del Registro como la información que resulta de una constancia que se entrega al interesado con la información requerida extraída de los asientos registrales ${ }^{651}$. Así, el régimen vigente de publicidad registral inmobiliaria en nuestro país se exterioriza únicamente a través de la exhibición de la documentación registral, el pedido y emisión de las certificaciones, y la expedición de copias auténticas de la documentación registral solicitadas en conformidad con las disposiciones locales respectivas $^{652}$.

De todas formas, y a pesar de las clasificaciones que dividen a la doctrina que discrepa en razón de las actividades que se encasillan dentro de ambos tipos de publicidad, debe reconocerse que en materia de publicidad estamos en definitiva en presencia de una posición posiblemente originada en la doctrina germánica, que si bien resulta útil desde el punto de vista didáctico, no deja ni afecta el verdadero sentido de la publicidad. De aquí la contundencia en las enseñanzas de Moisset de Espanés: "La exhibición de

${ }^{648}$ Ibídem, p. 123.

${ }^{649}$ René A. PADILLA, Estudios de derecho civil y registral inmobiliario, ob. cit., p. 17.

650 Raúl GARCIA CONI y Ángel Agustín FRONTINI, Derecho registral aplicado, ob. cit., p. 98.

651 Adriana Nélida ABELLA, Derecho inmobiliario registral, ob. cit., p. 66.

${ }^{652}$ Ibídem. 


\section{SEBASTIÁN JUSTO COSOLA}

los libros de Registro, los informes y los certificados, en cuanto son herramientas de la publicidad, integran la llamada publicidad formal; y en cuanto producen un efecto sustantivo (como la prioridad o la oponibilidad) son parte de la publicidad material ${ }^{653}$ ". Esto explica que la noción de publicidad material encuentra asiento sustantivo en la fe pública registral que gozan algunos registros de la propiedad en otros países ${ }^{654}$, pero que no es el caso del nuestro.

En definitiva, es útil para esta tesis admitir únicamente, que las dos nociones resultan ser inescindibles, por cuanto no cabe ninguna duda que las características dominantes del sistema registral publicitario inmobiliario argentino se resumen en la referencia a la publicidad con efecto declarativo, no convalidante, y el principio de inscripción necesaria ${ }^{655}$. Sobre estas características existe prácticamente unanimidad de opiniones en el mismo sentido y orientación.

\subsubsection{La relación de la publicidad con la seguridad jurídica.}

La mayor parte de los autores consultados para la conformación del presente tema reconocen que el principio de publicidad es absolutamente imprescindible para conformar tanto el favorecimiento del tráfico negocial especialmente de los inmuebles- como así también para consolidar lo que

${ }^{653}$ Luis MOISSET DE ESPANÉS, Publicidad registral, ob. cit., p. 276-277.

${ }^{654}$ Ídem, p. 278.

${ }^{655}$ Cfr. Marta G. VARGAS de VALLANIA, Marta S. BENJAMÍN de RUIZ y Ángela V. BONETTO DE CIMA, La inexactitud registral y su proyección negocial, Depalma, Buenos Aires, 1.985 , p. 43. Las autoras se refieren a las tres características que también considero, son las que emergen del sistema registral publicitario inmobiliario argentino. Sin embargo, es mi deseo referirme a la característica de la inscripción necesaria en lugar de la denominación por ellas utilizada en origen -inscripción obligatoria-, para alejarme de las discusiones acerca de si es o no es obligatorio el principio de inscripción, que no cuenta en la ley con la positividad necesaria, situación que ya no se discute en la doctrina actual. La referencia a lo necesario deriva la atención a aquellos casos a los que la publicidad registral les otorga la debida protección a los terceros interesados y además los que proyectan, en todo caso, la debida y real publicidad, alejando las cuestiones relacionadas a las inexactitudes registrales de los asientos respectivos. 


\section{LOS EFECTOS DE LA PUBLICIDAD EN EL DOCUMENTO NOTARIAL}

denominan, precisamente, la seguridad jurídica del tráfico ${ }^{656}$. Tendremos ocasión de analizar teóricamente a la seguridad jurídica más adelante, y en esencia, como valor intrínseco del documento notarial; pero corresponde ahora mismo hacer las menciones necesarias para poder alcanzar a determinar, de la mejor manera que sea posible, cual es la verdadera relación que existe entre la publicidad registral y la seguridad jurídica así comprendida, ya que nos encontramos en presencia de una de las consecuencias de la aplicación formal del valor seguridad, que en este caso se dirige a alcanzar la protección del aspecto registral inmobiliario ${ }^{657}$.

Por eso es bueno dejar en claro que la referencia a la seguridad del tráfico es significativa únicamente a la aplicación del valor seguridad jurídica al tráfico inmobiliario, que comprende la seguridad sobre los títulos y las registraciones, sobre los datos allí contenidos -implicancias de las calificaciones notariales, judiciales y registrales ya aludidas-, y sobre la pretendida correlación entre las verdades registrales y extra-registrales emergentes del mencionado valor ${ }^{658}$. Es que en definitiva, la razón de ser del derecho registral inmobiliario es precisamente, ser un instrumento de seguridad, porque el fin del derecho registral es brindar seguridad jurídica al tráfico inmobiliario ${ }^{659}$.

A poco que se medite, puede fácilmente notarse por un lado, una seguridad jurídica que protege la existencia de derechos individuales, y por el otro otra vertiente, casi enfrentada, la que viene a proteger la seguridad del tráfico ${ }^{660}$,

\footnotetext{
${ }^{656}$ Inclusive hay obras consolidadas en el extranjero que orientan toda la investigación registral en ese único sentido. Cfr. Alberto ORDOÑEZ ORTIZ y Germán IZQUIERDO DAVILA, Derecho registral y seguridad jurídica, Cuenca, Ecuador, 2.006, 140 págs.

${ }^{657}$ El tratamiento de la seguridad jurídica se deriva también especialmente hacia otros estudios interesantes, como los relacionados a la protección de la economía y las finanzas, de los aspectos vinculados a las inversiones, a las diversas titulaciones del mercado financiero, entre otros aspectos que si bien se refieren a la seguridad, no componen ni su eje central ni su teoría general. Al decir de Vallet, debe distinguirse (por ejemplo) la seguridad jurídica propiamente dicha de la seguridad económica, subsidiaria de aquella. V. Juan Berchmans VALLET DE GOYTISOLO, Seguridad jurídica estática y seguridad jurídica dinámica, ob. cit., p. 209.

${ }^{658}$ Así lo justifican los autores inclusive, en el resto de Iberoamérica, según iré citando a lo largo del presente capítulo.

${ }^{659}$ Nery Roberto MUÑOZ y Rodrigo MUÑOZ ROLDÁN, Derecho registral inmobiliario guatemalteco, ob. cit., p. 3.

${ }^{660}$ René A. PADILLA, Estudios de derecho civil y registral inmobiliario, ob. cit., p. 29.
} 


\section{SEBASTIÁN JUSTO COSOLA}

lo que implicaría en cierta manera poner un aviso acerca de la posible existencia de un conflicto en el seno de la propia naturaleza de la seguridad jurídica así conformada y determinada. Es que es cierto: el derecho debe tender a proteger la seguridad primera (estática), emparentada con la relación de un sujeto y la cosa frente a las turbaciones de terceros, y también a la seguridad segunda (dinámica), directamente conectada con la necesidad de proteger a las personas que desarrollan el tráfico y que además se involucran en la circulación de la riqueza ${ }^{661}$. Pero no lo es menos la realidad que pone de manifiesto que en realidad, pareciera ser que existiera un conflicto en el seno del derecho privado, entre dos exigencias absolutamente contrapuestas: la seguridad del derecho subjetivo (interés individual) y la seguridad del tráfico jurídico (interés de la comunidad ${ }^{662}$. Al decir de Vallet de Goytisolo, podría decirse que la seguridad de un derecho de propiedad está ajustada al derecho de propiedad mismo, y se enfrenta a la otra seguridad de una adquisición determinada que se ajusta al denominado derecho subjetivo del adquirente $\mathrm{y}$ al derecho objetivo que determina su protección ${ }^{663}$. Si así fuera entonces, ¿Qué es lo que debe primar entonces? ¿La protección individual o la protección del tráfico? ¿Pueden ambas convivir en armonía? El tratamiento de la publicidad registral y la referencia a sus posibles derivaciones y ámbitos de tutela efectiva plantea estos interrogantes, que pueden analizarse desde el desarrollo de las diferentes perspectivas que de ella emergen con fuerza y vigor, resaltando la importancia de la teoría de la publicidad inmobiliaria registral.

\subsubsection{La seguridad jurídica estática y la seguridad jurídica}

\section{dinámica.}

\footnotetext{
${ }^{661}$ Karen M. WEISS Y Gastón A. ZAVALA, Eficacia ofensiva de la publicidad registral inmobiliaria, ob. cit., p. 307.

${ }^{662}$ Marta G. VARGAS de VALLANIA, Marta S. BENJAMÍN de RUIZ y Ángela V. BONETTO DE CIMA, La inexactitud registral y su proyección negocial, ob. cit., p. 1.

${ }^{663}$ Juan Berchmans VALLET DE GOYTISOLO, Seguridad jurídica estática y seguridad jurídica dinámica, ob. cit., p. 208.
} 


\section{LOS EFECTOS DE LA PUBLICIDAD EN EL DOCUMENTO NOTARIAL}

Juan Vallet de Goytisolo ha contribuido a conformar la clasificación de la seguridad jurídica en estática y dinámica, y según lo expresa, no se siente demasiado feliz por el planteamiento de la diferenciación que oportunamente ha formulado ${ }^{664}$. La seguridad jurídica en su faz estática plantea el supuesto de que nadie puede ser privado de su propiedad por un acto traslativo que él mismo no haya otorgado. De esta manera, la seguridad jurídica emergente del derecho de propiedad incluye la seguridad de que otro, no facultado debidamente por el mismo propietario, no lo pueda privar de su propiedad ${ }^{665}$.

El ámbito de tutela jurídica de la seguridad jurídica en perspectiva dinámica es totalmente diferente. Muchos de los sistemas transmisivos de los derechos reales de muchos de los ordenamientos modernos, permiten reconocer lo que Vallet considera como determinados signos visibles de titularidad. Los mismos proyectan, mediante una adecuada publicidad, quién es el titular del bien objeto de la transmisión, asegurando la adquisición con algunos requisitos especiales como la actuación de buena fe, muy a pesar que sea el caso que confirme que la titularidad del transmitente no sea real sino sólo aparente. Ocurre así también la adquisición ajustada a derecho para el adquirente que obra de tal manera o de tal forma, y para él también se consolida la seguridad jurídica, pero en su faz dinámica ${ }^{666}$.

Dados los alcances y ocurridas las interpretaciones, es el propio Vallet quien decide precisar los conceptos, en razón de poner a consideración de la crítica ciertos ajustes que piensa como necesarios para alcanzar la perfección de los conceptos antes descriptos ${ }^{667}$. Y, muy a pesar de seguir utilizando las mismas denominaciones -en razón del conocimiento público que habían adquirido-, el maestro enseña que la correcta opción de la denominación de la seguridad jurídica estática es la de seguridad jurídica del propietario poseedor, mientras que la denominación de la seguridad dinámica debería

${ }^{664}$ Ibídem, p. 211.

${ }^{665}$ Ibídem.

${ }^{666}$ Ibídem.

${ }^{667}$ Ibídem, p. 212. Dice el autor: "El ejercicio de la propiedad por el propietario que no enajena no puede, hablando con precisión y exactitud, calificarse de estático si cultiva su predio, lo mejora, construye en él o realiza alguna otra actividad minera, industrial o incluso comercial. Y la seguridad de la adquisición por un comprador que no se preocupa de conocer la situación posesoria de una finca no poseída por el titular registral, sólo muy impropiamente podemos calificarla de dinámica". 


\section{SEBASTIÁN JUSTO COSOLA}

ser considerada como seguridad jurídica de quien de buena fe adquiere de un titular aparente ${ }^{668}$.

En nuestro medio, Moisset de Espanés también recoge esta diferenciación, inclusive haciéndola extensiva a todos los supuestos registrables donde pueda llegar a incidir ${ }^{69}$. En sintonía a lo planteado por Vallet, advierte que el derecho protege al derecho-habiente o a la relación entre un sujeto y una cosa de las turbaciones o ataques de terceros a través de la seguridad estática, mientras que desde la seguridad dinámica -a la que también denomina seguridad del tráfico- se procura brindar protección a los terceros involucrados en la circulación de la riqueza, tanto a los acreedores del enajenante como de los adquirentes que no deben exponerse a la sorpresa de las anotaciones o gravámenes del bien que se les transmite ${ }^{670}$. En este sentido, Jorge Alterini afirma que mientras que la seguridad jurídica estática se conecta con los derechos adquiridos con el fin de que se clarifiquen las situaciones jurídicas y exista la certeza en la vida comunitaria, la seguridad del tráfico o de la apariencia-seguridad dinámica- sirve para ajustarse a su creencia, para aquella persona que en su buena fe, crea que es verdadero lo que aparece como tal, independientemente de que pueda o no pueda ser falso ${ }^{671}$.

Todo esto explica la razón por la cual existen algunos planteos académicos que dan a la inscripción y a la fe pública registral el valor que no les otorga ni el ordenamiento ni las costumbres negociales. Los mismos intentan fundamentar a la publicidad registral desde la necesidad de protección del

\footnotetext{
${ }^{668}$ Ibídem, p. 211.

${ }^{669}$ Luis MOISSET DE ESPANÉS, Publicidad registral, ob. cit., p. 18 y ss. El autor se refiere a los muebles, buques, aeronaves y derechos intelectuales.

${ }^{670}$ Ibídem, p. 19.

${ }^{671}$ Cfr. Jorge Horacio ALTERINI, La seguridad jurídica. Notariado y Registros, LL Temas Doctrinarios, 2 2007, 01/01/2007, 53- LLO, cita: AR/DOC/495/2012, p. 2. La tesis de la apariencia viene en auxilio, entre otras cosas, de ciertas figuras esenciales en el desarrollo del derecho notarial como la del heredero aparente, que se encuentra tutelado por la seguridad dinámica. En nuestro país, es Alberto Spota quien destaca la situación del heredero aparente como persona que tiene notables legitimaciones para influir en el patrimonio de los auténticos señores de la herencia. Dice entonces Spota: “ (...)de tal manera que el adquirente de buena fe y a título oneroso de un bien que forma parte del acervo hereditario, es un adquirente que tiene seguridad, porque ha adquirido el bien. Lo único que la ley le pide es que adquiera a titulo oneroso y tenga buena fe". v. Alberto Gaspar SPOTA, Curso sobre temas de derecho civil, ob. cit., p. 246.
} 
LOS EFECTOS DE LA PUBLICIDAD EN EL DOCUMENTO NOTARIAL

tráfico jurídico y de su contribución a la circulación de la riqueza, frente a la insuficiencia (supuesta) de la protección publicitaria de la posesión. Sin embargo, el panorama del problema de esta forma expuesto es absolutamente incompleto, si no se atiene al hecho que marca que en circunstancias no menos relevantes, se echa mano a la registración para hacer conocer quién es el titular del derecho de propiedad, o de otros derechos subjetivos, en la necesidad de obtener un dato cierto pero inseguro $^{672}$. Quizás por ello se enseña que propiedad y crédito son dos caras del mismo fenómeno, por cuanto la certeza de la propiedad favorece a la certeza del crédito $^{673}$. Y quizás también por ello es que autores argentinos postulen que al hablar de seguridad jurídica y más precisamente, de publicidad posesoria y de publicidad registral, nos encontramos frente a dos modos de publicitar los derechos que no son excluyentes sino por el contrario, verdaderamente concurrentes ${ }^{674}$. Es éste el sentido que pretendo sea el que oriente la presente investigación.

\subsubsection{1 ¿Resulta necesario seguir insistiendo en la clasificación de seguridad jurídica estática y dinámica?}

Autores contemporáneos como Gonzales Barrón no dejan de sostener que en realidad no existe una seguridad jurídica estática y otra dinámica, sino que lo que existe es una seguridad jurídica general o en todo caso, una seguridad dinámica que se fundamenta en la estática ${ }^{675}$. El autor se encuentra convencido de que en forma ingenua se sostiene entonces que el registro favorece a los terceros (seguridad dinámica) en lugar de los verdaderos propietarios (seguridad estática) en razón de que los primeros resultan ser inversionistas, productores o creadores de riqueza que contribuyen a la economía, y que se enfrentan a la realidad del propietario

\footnotetext{
${ }^{672}$ Luis MOISSET DE ESPANÉS, Publicidad Registral, ob. cit., p. 20.

${ }^{673}$ José Antonio ÁLVAREZ CAPEROCHIPI, Derecho inmobiliario registral, ob. cit., p. 102.

674 Cfr. Domingo C. CURA GRASSI, Derechos reales: reflexiones en torno a la ansiada seguridad jurídica. Publicidad posesoria y registral: seguridad dinámica vs. Seguridad estática, ED 234-816.

${ }^{675}$ Cfr. Gunther GONZALES BARRÓN, Derecho registral y notarial, to I, Jurista Editores, Lima, 2.012, p. 116.
} 


\section{SEBASTIÁN JUSTO COSOLA}

actual que resulta ser un sujeto improductivo, rentista, que no acrecienta la economía y que no le brinda a la riqueza una verdadera utilidad social ${ }^{676}$. En realidad, quien antes ofició como adquirente -seguridad dinámica-, una vez realizado el acto, resultará ser un propietario actual -seguridad estática-. De esta manera, todos los adquirentes se convierten inmediatamente en propietarios, y en razón de ello, su posición como propietario lo vuelve débil y vulnerable frente a un futuro y potencial tercer adquirente ${ }^{677}$. En palabras del autor: "En suma, la seguridad dinámica no sirve para nada si no existe seguridad estática, pues resulta irracional que hoy ganes algo y mañana lo pierdas (...) la seguridad dinámica y la estática, por separado, simplemente no existen; pues la protección del adquirente no acaba en ese momento temporal, sino que requiere protección en cuanto se convierte en

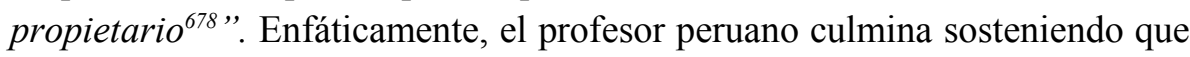
la protección de la apariencia no puede considerarse como un principio general ${ }^{679}$.

\subsubsection{Un ejemplo de conflicto entre seguridad jurídica estática} y seguridad jurídica dinámica (o proyección de los conflictos entre la propiedad registrada y la posesión).

Dadas las explicaciones antecedentes, corresponde ahora realizar la exposición de un conflicto, sobre el ejemplo de un caso real, que termine por identificar como en la práctica común y cotidiana pueden producir los diferentes efectos del planteamiento teórico efectuado ${ }^{680}$. La situación que

\footnotetext{
${ }^{676}$ Ibídem, p. 117.

${ }^{677}$ Ibídem, p. 119.

${ }^{678}$ Ibídem.

${ }^{679}$ Ibídem, p. 120.

${ }^{680}$ Son estos temas que se suscitan y que demuestran la importancia de haber traído a esta tesis los temas esenciales del tratamiento de la posesión, de la propiedad, del registro y de los documentos. No habría manera entonces de comprender los conflictos que se plantean en el seno de cada una de las instituciones mencionadas, si no se parte de un desarrollo general o expositivo de los elementos esenciales que le son innatos, inherentes a cada figura. En efecto, cada una de ellas alberga en su más íntimo seno ciertos principios que no solo las erigen como instituciones, sino que además son los fundamentos que justifican su existencia milenaria
} 
LOS EFECTOS DE LA PUBLICIDAD EN EL DOCUMENTO NOTARIAL

planteo, sustentada en un ejemplo brindado por Vallet, enfrenta al propietario de la tierra que no la utiliza (propiedad y seguridad jurídica estática registral) y al poseedor que pretende utilizarla y comportarse como dueño (posesión y seguridad jurídica dinámica registral).

De esta manera, ocurre en España una determinada circunstancia: unos titulares registrales intentan expulsar a los poseedores de sus tierras que las cultivaban inmemorialmente (utilización del Registro de la Propiedad para probar la titularidad, pero como un instrumento con fines de despojo). Del otro lado, unos titulares aparentes de la propiedad por cultivar la tierra desde toda la vida (poseedores), pero sin propiedad y sin la debida registración. Según lo anteriormente analizado, existen frente al caso dos únicas soluciones posibles:

a) Si se pondera el triunfo de la seguridad estática, la misma haría primar el derecho de los propietarios con la sola información registral, para que los mismos, aun desde la total inutilización de los predios, puedan expulsar con herramientas jurídicas a quienes ostentan violentar sus derechos relacionados con la propiedad;

b) Si en cambio, se postulara como mejor opción la que tutela la seguridad dinámica, primaría, por sobre todo, la teoría de la apariencia, la circunstancia de la circulación de la riqueza y con ella, de la buena fe de los cultivadores de la tierra.

La registración es sólo un elemento más que ayuda a desarrollar el valor seguridad jurídica: en su faz dinámica, referida al grado o certeza de los contratantes, y en faceta estática, referida exclusivamente a la protección y reconocimiento de los derechos registrados ${ }^{681}$. En el caso real planteado ocurre que la seguridad estática se impone; pero llamativamente no a favor de los propietarios registrales, sino a favor de los cultivadores de la tierra. Al decir de Vallet, el cambio de paradigma en el caso operó como un hecho de justicia. Y la decisión se fundamenta en un hecho innegable que ocurre, que es la desviación del efecto normativo cuando frente a él existe una

desde el origen mismo del estudio del derecho.

${ }^{681}$ Gabriel B. VENTURA, Ley 17.801. Registro de la Propiedad inmueble..., ob. cit., p. 27. 


\section{SEBASTIÁN JUSTO COSOLA}

valoración justa del derecho. Ante estos conflictos, siempre pondera mejor el poseedor que cultiva la tierra, comprometiendo su acción con la economía del país y además, proyecta un fin social de la cosa que posee ${ }^{682}$. En fin, las nociones de seguridad jurídica estática y dinámica son supuestos generales que plantean una determinada regla a la hora de juzgar la conveniencia o no conveniencia de la defensa de cada una de ellas en el caso en que se trate (entre esas conveniencias actuales, se imponen con mayor frecuencia las reglas que imponen los mercados de consumo, que siempre intentan sobrevalorar la seguridad jurídica dinámica). Sin embargo, esas nociones viran de acuerdo a los valores en juego que, estando implicados, deseen sobrevalorarse (en el caso, las relacionadas con los fines sociales de las instituciones en referencia). Así las normas y las reglas quedan de lado, definitivamente, cuando desde la decisión se pondera lo que es justo para cada uno.

En el caso planteado, justa era la apariencia y la cultivación memorial de los terrenos con producción de alcance nacional, frente a la pretensión injusta del despojo por el sólo hecho de la registración. Las lagunas en la interpretación de las mencionadas calificaciones son validas y además, necesarias; al no determinarse que es lo cierto con precisión matemática, la búsqueda de los valores esenciales a tutelar se vuelve imprescindible. En definitiva, como bien lo argumenta Vallet de Goytisolo: "El ejercicio de la propiedad por el propietario que no enajena no puede, hablando con precisión y exactitud, calificarse de estático si cultiva su predio, lo mejora, construye en él o realiza alguna otra actividad minera, industrial o incluso comercial. Y la seguridad de la adquisición por un comprador que no se preocupa en conocer la situación posesoria de una finca no poseída por el titular registral, sólo muy impropiamente podemos calificarla de dinámica $^{683}$,

\footnotetext{
${ }^{682}$ Cfr. Juan B. VALLET DE GOYTISOLO, La buena fe en las transmisiones inmobiliarias a non domino, en Marcos M. CÓRDOBA (Dir.). Lidia M. GARRIDO CORDOBERA y Viviana KLUGER (Coord.), Tratado de la buena fe en el derecho, $\mathrm{t}^{\circ}$ II, La Ley, Buenos Aires, 2.005, págs. 274-275.

${ }^{683}$ Juan B. VALLET DE GOYTISOLO, Seguridad jurídica estática y seguridad jurídica dinámica, ob. cit., p. 212.
} 
LOS EFECTOS DE LA PUBLICIDAD EN EL DOCUMENTO NOTARIAL

\subsubsection{Las consideraciones axiológicas que necesariamente} deben ser asumidas.

Lo expuesto hace reflexionar acerca de los valores que intenta tutelar la posesión y los propios que persigue el Registro de la Propiedad a partir de la inscripción con efectos publicitarios. ¿Cuáles son esos valores y como se desenvuelven en cada una de las instituciones mencionadas? Mientras que algunos autores consideran que las dos figuras son antagónicas, -ya que fundadas en un mismo principio ambas persiguen la legitimación de la propiedad-, otros en cambio prefieren valorar las diferentes funciones desde la propia noción de la ya analizada función social de la propiedad. Si la sociedad sobrepusiera la verdadera función de la propiedad -siempre constituyente del suelo nacional y asiento de la familia- se posicionará de mejor forma la seguridad jurídica estática, mientras que si la misma procediera a valorar la protección de la transmisión de las propiedades en razón del tráfico mercantil, no queda otra alternativa que dirigirse a tutelar con mayor rigor el lado dinámico de la seguridad. Dicho de otro modo, puede decirse que mientras que el valor justicia es el que se impone desde la posesión, el valor seguridad es el que se sobrepone en la institución registral. Valores que persiguen quizás una misma finalidad, y que en situaciones, pueden tener que enfrentarse, para que la valoración jurídica pondere uno sobre el otro, pero en interrelación y no desde el descarte, ya que el conflicto por los valores -similares a los conflictos entre principios-, no se soluciona con la eliminación, sino con la ponderación.

Lo relevante de lo expuesto tiene que dirigir la atención hacia la comprensión de las diferentes actuaciones jurídicas del notario y de los registradores respectivamente. Cada una persigue una necesidad elemental que es la que fundamenta su ejercicio, siendo las mismas relevantes en igual grado de importancia y además, en la necesidad de tener que ser complementarias. Como bien se refiere en la doctrina nacional, en la lucha por la consolidación de la justicia y de la paz, a veces se advierte que los mismos son valores complementarios, pero en otras ocasiones suelen ser antagónicos, lo que explica enfrentar muchas veces los intereses individuales 


\section{SEBASTIÁN JUSTO COSOLA}

con los intereses sociales ${ }^{684}$. Eso obliga a que cada profesional del derecho establezca con precisión su aporte, en la búsqueda de la composición de los valores expuestos. $\mathrm{Y}$ es aquí donde cobra relevancia el verdadero sentido de lo que conocemos y estudiamos a partir del término calificación. Es que todo aquel que oficia de jurista desempaña su función calificando ${ }^{685}$ :

a) El juez, al dirimir una controversia, califica jurídicamente el hecho, centrando el análisis central en el concepto de razonabilidad para que la sentencia sea efectivamente, fundada de manera razonable.

b) El abogado califica al actuar, y esa actuación lo presenta como un defensor de los derechos de su cliente, que orienta su trabajo a interpretar que tipo de derecho es el que verdaderamente le asiste para así obtener la mejor solución al problema de su representado;

c) El profesor de derecho califica, al tomar una posición determinada destinada a crear doctrina;

d) El notario califica, y al hacerlo su función se convierte en un cavere, relacionado con la precaución, con el deber ético de prevenir, a partir de la aplicación de una autorictas ( $f e$ ) -que se erige como una singularidad propia de la función notarial ${ }^{686}$-, que es lo que permite dar previsibilidad y seguridad a las relaciones jurídicas, desenvolviéndose toda la actividad en un ámbito de paz, sin conflicto y sin controversias ${ }^{67}$

e) El registrador califica, sobre la creación de un ejercicio jurídico previo, la concreción de la legalidad de las formas extrínsecas de los documentos o instrumentos que ingresan al Registro.

Todas las calificaciones están destinadas a obtener la prueba o el reconocimiento de un determinado derecho, siendo en sí, absolutamente

\footnotetext{
${ }^{684}$ Raúl R.GARCIA CONI y Ángel A. FRONTINI, Derecho registral aplicado, ob. cit., p. 3.

${ }^{685}$ Cfr. Fernando M. TOLLER, Sistema de citas y redacción en derecho, Marcial Pons, Buenos Aires, 2.016, pág. 34.

${ }^{686}$ Ver la interesante argumentación que antecede a la explicación que sobre el término en cuestión realiza Enrique Horacio DEL CARRIL, en el Prólogo a mi libro Fundamentos del Derecho Notarial I- La concreción del método, Ad Hoc, Buenos Aires, 2.013.

${ }^{687}$ Cfr. Juan Berchmans VALLET DE GOYTISOLO, Manuales de metodología Jurídica, ${ }^{\circ}$ III, CGN, Madrid, 2.004, p. 231.
} 


\section{LOS EFECTOS DE LA PUBLICIDAD EN EL DOCUMENTO NOTARIAL}

diferentes ${ }^{688}$. Sin embargo, la calificación notarial y la calificación registral vienen amparándose históricamente y en esencia, en el deber jurídico y ético de legalidad. De todos los profesionales que ofician de juristas, son sólo estas dos disciplinas las que han optado por someterse de manera rigurosa al concepto que emerge únicamente de la ley, mientras que las otras actividades, si bien reconocen la fuerte impronta legal, han recurrido, para argumentar o para decidir el derecho a todo tipo de fuentes jurídicas.

La función notarial y la actividad registral se encuentran emparentadas en razón de la necesidad, pero en sí, son absolutamente diferentes, lo que lleva a Jorge Alterini a advertir, que el notario atiende especialmente a la seguridad estática, mientras que el registrador se ocupa de la seguridad de la apariencia, de la seguridad del tráfico o dinámica ${ }^{689}$.

En el caso de Vallet la visión es diferente, ya que opta por analizar la seguridad jurídica desde la función notarial y desde la función registral ${ }^{690}$, diferenciando originariamente a ambos protagonistas:

${ }^{688}$ Como en alguna anterior oportunidad he expresado: "En efecto, si bien todas las profesiones jurídicas reconocen un mismo tronco común -el estudio del derecho-, creo poder defenderme con sólidos argumentos al concluir afirmando que la aplicación del derecho que realiza un juez, en poco puede relacionarse con la argumentación notarial, mucho menos, con la interpretación que de los hechos realizan quienes ejercen la abogacía, y desde ya, mas lejos aun desde el análisis lógico deductivo o decimonónico, metafísico, crítico o analítico que pueda presentar quien ejerce académicamente el derecho, únicamente desde el ars o la cientiae, pero sin reflejo en la praxis, y lógicamente, sin tecné. Como hemos afirmado en alguna oportunidad, tanto el juez, como el abogado, el escribano y el profesor de derecho conforman los cuatro pilares donde se asienta firme, la balanza de la justicia .Esa fue una afirmación que entiendo, hemos rescatado de Vallet cuando afirmaba: "El instrumento adecuado para la justicia no es el silogismo, sino la balanza”. Sin embargo, las argumentaciones jurídicas de esos cuatro juristas -por la propia naturaleza de las diferentes funciones- pueden ser absolutamente dispares frente al análisis de un mismo hecho, de cuyas consecuencias pueden derivar una sentencia, una demanda, una escritura pública notarial o una doctrina general. Mientras que la sentencia judicial dirime razonablemente el litigio y la demanda fundada inicia el reclamo potencial de un derecho que se creé, ha sido vulnerado, la escritura pública notarial se erige como un baluarte de la magistratura del derecho en la paz a través de la aplicación directa del principio de seguridad jurídica preventiva. En el medio, una doctrina o posición académica intentará alcanzar la consagración científica y así, lograr las reformas pertinentes en las instituciones politicas especializadas. De un mismo tronco común surgen cuatro diferentes $-y$ felizmente, diferentes- perspectivas de la argumentación jurídica lo que vuelve en cierta forma, más rico, más polémico y más apasionante el curso que sigue el estudio del derecho". v. Sebastián Justo COSOLA, Fundamentos del derecho notarial. La concreción del método, Ad-Hoc, Buenos Aires, 2.013, p. 36 y ss.

${ }^{689}$ Jorge Horacio ALTERINI, La seguridad jurídica. Notariado y Registros, ob. cit., p. 2. 


\section{SEBASTIÁN JUSTO COSOLA}

a) La institución notarial, por un lado, integrada por profesionales que prestan un servicio social, y que a través de la aplicación de la función notarial logran el resultado esperado: el instrumento público, razón por la cual la institución notarial se fundamenta entonces en la persona del notario ${ }^{691}$;

b) La institución del Registro o Registral, como un instrumento de publicidad que cumplen los registradores a través del control legal de los documentos presentados denominado calificación. Desde aquí entonces en que la institución registral se esmere por instrumentar el registro de la propiedad y la publicidad que emerge de éste ${ }^{692}$.

Si así se consideran las diferencias, podrá advertirse que la actividad notarial relacionada con el tráfico inmobiliario no solamente no es excluyente de otras actividades periódicas que realiza el fedatario, sino que además ocurre antes de la redacción del documento, momento en el cual el notario hace primar el ejercicio de la función notarial a través de la concreción de los deberes éticos notariales aplicados. La actividad notarial entonces, luego de ocurrida la labor de información, asesoramiento y consejo, de la aplicación de la imparcialidad y, eventualmente, de la independencia, y en especial, de la concreción del deber ético de legalidad integrada (argumentación a través reglas + normas + valores + principios), alcanza como resultado la creación del mejor documento que pueda nacer a la vida jurídica creado por el hombre, teniendo en cuenta especialmente la libertad y la autonomía de la voluntad de los requirentes y los fines y metas que éstos mismos se han propuesto a la hora de optar por la contratación. Y sobre el resultado obtenido, se alcanza aun un efecto absolutamente relevante: el producto de la labor notarial, exhibido en ese documento público, que goza de la presunción de veracidad que le otorga el imperio de la fe pública. De ahí entonces que sea la misión esencial del Registro la de publicitar el resultado documental

\footnotetext{
${ }^{690}$ Juan Berchmans VALLET DE GOYTISOLO, Seguridad jurídica estática y seguridad jurídica dinámica, ob. cit., p. 216.

${ }^{691}$ Ibídem.

${ }^{692}$ Ibídem.
} 
en cuanto este proyecte la trascendencia real de la labor notarial ${ }^{693}$. Por ello siempre será el objetivo del Registro el de salvaguardar esencialmente, a través de la publicidad, a la seguridad jurídica dinámica: la seguridad propia del tráfico inmobiliario a favor de los terceros adquirentes ${ }^{694}$. La importancia del Registro se advierte absolutamente consolidada tanto en el momento anterior a la adquisición como en el momento posterior a la inscripción de la misma, en donde se anoticia acerca de la posibilidad de protección del tercer adquirente de buena fe. Como refiere Vallet: "Es evidente, pues, que ambas instituciones, en su respectiva función, no cubren en el mismo ámbito la seguridad jurídica ${ }^{695}$ ". Desde aquí entonces que el concepto de tercero o de tercero interesado sea absolutamente trascendente en el estudio del derecho registral.

Dadas las premisas expuestas, se vuelve preciso entonces ahondar en el tema de la calificación notarial y de la calificación registral, teniendo especialmente en cuenta que es un tema esencial en la literatura notarial y registral, que hace tiempo se viene desarrollando, con aciertos y estrategias de un lado y desde el otro, todos emergentes del análisis de los fundamentos que esgrime cada cual para justificar su exposición metodológica.

Por mi parte, no puedo dejar de adelantar que, al coincidir con Vallet en que ambas actividades son notoriamente diferentes, la discusión acerca de la superioridad o inferioridad de una calificación sobre la otra conforma una labor o tarea que carece radicalmente de sentido y que además, daña notablemente a todas las disciplinas jurídicas implicadas en el cuerpo de esta investigación. El mejor aporte que puede hacerse al universo de la seguridad jurídica es demostrar que ambas actividades, si bien diferentes, se complementan en procura de la protección y salvaguarda del mencionado valor. Por eso mismo, desde mi perspectiva también diré que la clasificación entre la seguridad jurídica en estática y dinámica carece de sentido. Las mismas, con sus respectivos alcances y cuando no existe el conflicto situación que ocurre en la mayoría de los casos-, deben enmarcarse sin conflicto dentro de lo que se denomina seguridad jurídica preventiva. Como ya ha quedado expuesto, si el conflicto emergiera, la argumentación del

${ }^{693}$ Ídem, p. 217.

${ }^{694}$ Ibídem.

${ }^{695}$ Ibídem. 
SEBASTIÁN JUSTO COSOLA

derecho de quien sea el juzgador deberá ir en la búsqueda del valor justicia, situación donde los alcances de cada una de las seguridades aludidas se vuelven absolutamente relativos, pudiendo inclusive -como se ha también referido-, mutar y hasta exageradamente de perspectiva. 


\section{Capitulo 6:}

\section{El deber de calificar.}

\subsection{Justificación de tratamiento.}

La publicidad cartular notarial y la publicidad registral exhiben el resultado de una calificación previa. $\mathrm{O}$, dicho de otro modo, son el resultado de una actividad compleja, efectuada por personas que dirigen su actuar en la búsqueda de una misma finalidad, pero con diversos y diferentes fundamentos de tutela efectiva. De esta forma, mientras que el documento notarial destinado a transmitir formalmente el dominio persigue la finalidad de dar seguridad y previsibilidad a los derechos personales y reales que en su seno se relacionan a través de una teoría de los valores trascendentes, el asiento registral intentará alcanzar el reflejo exacto tal cual del documento lo recibe para poder cumplir acabadamente con la proyección de la publicidad formal en el mismo. Ninguna de las publicidades descriptas se deben a de la naturaleza. Son el resultado de una creación humana, componiendo así el amplio mundo del derecho entendido como objeto cultural ${ }^{696}$. El acceso a los diferentes objetos que el derecho exhibe y demuestra, aun siendo diversos, hacen presuponer una cierta actividad interpretativa o argumentativa, que en el plano jurídico, varían según sea la visión o

696 Quienes asumen que el derecho es un objeto cultural, advierten dos elementos fundacionales: un cierto substrato y la existencia, sobre él, de un determinado sentido. De ahí que el derecho como objeto cultural sea considerado como un producto de la actividad humana, que se desprende de ella misma, en la búsqueda de substratos y contenidos lógicos. Cfr. María Teresa LÓPEZ, Introducción al derecho, tº I, CED-UNLP, 1.996, p. 73. 


\section{SEBASTIÁN JUSTO COSOLA}

perspectiva que se tenga acerca del objeto a estudiar y descifrar ${ }^{697}$. En los casos en referencia, adelanto mi posición diciendo que el notario argumenta el derecho que se vuelca en el documento, mientras que el registrador interpreta el documento para crear el asiento registral.

De manera que la cuestión de la calificación es relevante en este punto de tratamiento de la tesis, precisamente porque desde su adecuada implementación emergerá el mejor concepto de publicidad que sea posible obtener desde la creación humana del derecho. Por eso mismo se plantean los alcances y las proyecciones de la calificación notarial y registral respectivamente; para poder advertir sobre y desde ellas, la marca que cada una establece y fija en la materia objeto de trabajo (documento y asiento) dando así impulso a las publicidades que emergen de cada una de las mencionadas actuaciones.

\subsection{La calificación notarial (principio de legalidad integrada)}

La calificación notarial actual comprende un abanico infinito de actividades que diariamente cumple el notario en el ejercicio de la función fedante ${ }^{698}$. Desde tiempos inmemoriales se viene advirtiendo que la primera directiva en este tema emerge de la necesidad de que el escribano, al momento de confeccionar el documento, cumpla con la ley ${ }^{699}$. Pero en los tiempos actuales no alcanza con cumplir la ley, sino que además hay que cumplir con el derecho, que puede coincidir con la ley, que puede sustentarse en otra fuente jurídica de jerarquía para la argumentación o interpretación, o

\footnotetext{
${ }^{697}$ Cfr. Carlos E. PETTORUTI, Conocimiento, interpretación y aplicación del derecho en la perspectiva del proyecto del Código Civil y Comercial de La Nación, RN n 977, 2.014, p. 539.

${ }^{698}$ Cfr. los siguientes autores: Adriana Nélida ABELLA, Derecho Notarial, Zavalía, Buenos Aires, 2.005; Sebastián Justo COSOLA, Los deberes éticos notariales, Ad Hoc, Buenos Aires, 2.008, p. 478; Juan Francisco DELGADO DE MIGUEL, Deontología Notarial, Junta de Decanos de los Colegios Notariales de España, Madrid, 1.992, p. 759; Carlos Emérito GONZÁLEZ, Derecho Notarial, Fedye, La Plata, 1.971, p. 202. La enumeración no pretende ser taxativa.

${ }^{699}$ Cfr. Oscar GARCIA RUA, El proceso disciplinario del escribano, Ábaco, Buenos Aires, 2.003, p. 158.
} 


\section{LOS EFECTOS DE LA PUBLICIDAD EN EL DOCUMENTO NOTARIAL}

inclusive que puede llegar a oponerse a la primera cuando la misma resulte ser o absurda o extremadamente injusta. Como en ningún otro momento de la historia de nuestro país, derecho y ley únicamente pueden ser términos intercambiables, si la segunda proyecta o prescribe acciones o conductas que son compatibles con los valores y principios que conforman los pilares fundacionales de donde el propio derecho emerge encontrando justificación. El Código Civil y Comercial de la Nación, ordenamiento que recepta las opiniones académicas y jurisprudenciales mayoritariamente consolidadas de los últimos treinta años en nuestro medio, otorga vida e impulso a un derecho privado integrado, consolidado, positivizado y codificado, que comienza por estudiarse en simultáneo por primera vez en la historia, conjuntamente con los postulados constitucionales -lo que importa admitir la influencia del derecho público en su seno-. Los tres primeros preceptos del cuerpo normativo vigente son claros y contundentes, al ordenarle a quienes componen el oficio del jurista -jueces, abogados, escribanos, procuradores, profesores de derecho, legisladores, registradores, entre otros- que tengan en cuenta tanto las fuentes de que se sirve el nuevo derecho ${ }^{700}$ como las nuevas reglas de interpretación jurídica ${ }^{701}$ desde una visión o posición esencialmente razonable $e^{702}$. Ya no hay mas aplicación directa del precepto, o interpretación decimonónica, literal o exegética; lo que existe en la actualidad es un notable campo de argumentación jurídica que permite resolver los posibles conflictos dentro de un margen de apreciaciones jurídicas generales y especiales que se originan en la Constitución Nacional, siguen su camino hacia el derecho de fondo, para culminar en una sentencia judicial, en un documento notarial, en un laudo arbitral, o en un dictamen de un Consejo Consultivo que se expide acerca de una determinada conducta acaecida, de dudosa interpretación.

Frente a este panorama, y a través de la creación del documento, el notario se transforma en un protagonista singular del mundo jurídico. Su actuación directamente relacionada con la $f e$ (que para el derecho no es otra cosa que

\footnotetext{
${ }^{700}$ Art. 1 CCCN.

${ }^{701}$ Art. 2 CCCN.

${ }^{702}$ Art. 3 CCCN. Para ver el alcance el criterio de aplicación del principio de razonabilidad notarial consultar mi ensayo La capacidad, la minoridad y el principio de razonabilidad notarial (Argumentación de la teoría de la personalidad humana a partir del art. 3 del Código Civil y Comercial de La Nación), RNC n 94, Córdoba, 2.016, pág. 471-533.
} 
la certeza y la verdad), debe dirigir la atención hacia la tarea de análisis jurídico especial, que necesariamente lo debe derivar hacia una solución justa para quienes requieran de su servicio. Pero además esa solución justa que asume la certeza presuponiendo la verdad, debe resguardar el valor relativo a la seguridad que viene a consolidar, desde una trilogía esencial, el valor referido a la paz. Expresado en forma de definición, el actual aporte notarial al derecho a través de la creación del documento, entonces, debería estar contenido en estas líneas: "La aplicación y concreción del derecho notarial sustantivo y formal, está destinado a volcar en el documento la tutela de lo justo como valor singular en el ámbito negocial y privado; lo garantiza a través de la fe (verdad) allí consolidada (certeza), y lo hace prosperar en el tiempo a través de la aplicación del valor seguridad, todo lo que en conjunto determina la paz".

De ahí que el notario no pueda en los tiempos actuales, calificar únicamente la letra de la ley, sino que debe de orientar su argumentación a todas las fuentes formales y materiales que hoy provee el moderno ordenamiento, para alcanzar en la creación jurídica documental el mejor derecho que sea posible alcanzar. Consecuentemente, el esmero máximo tiene que estar dirigido a proyectar sobre el mismo objeto de su creación, la mejor publicidad cartular que le sea posible alcanzar ${ }^{703}$. En suma, la calificación notarial excede el cumplimiento de la ley, para alcanzar el cumplimiento del derecho, en donde además debe de estarse al cumplimiento efectivo de los principios generales básicos, insustituibles, que se captan por evidencia ${ }^{704}$.

\subsubsection{El alcance académico de la calificación notarial.}

Hace tiempo que la doctrina nacional tradicional tuvo la oportunidad de aportar reflexiones que indican que es lo que significaría entender como una

\footnotetext{
${ }^{703}$ Para ampliar: v. Rodolfo Luis VIGO, La injusticia extrema no es derecho (de Radbruch a Alexy), La Ley, Buenos Aires, 2006.

${ }^{704}$ Cfr. Sebastián Justo COSOLA, Interpretación iusfilosófica de los principios notariales, Revista Telemática de filosofía del derecho 11, Madrid, 2008, p. 7-14.
} 
adecuada actuación notarial conforme a derecho ${ }^{705}$. Opiniones sumamente valiosas ocurrieron en general, todas referidas a lo que se consideraba el adecuado cumplimiento de la calificación notarial sumida esencialmente por aquellos tiempos, en el deber de adecuación de la voluntad de las partes al sistema legal previsto en los ordenamientos jurídicos referentes y respectivos. Desde estas perspectivas, también se argumentó lo que se conoció -a mi juicio equivocadamente- como función social notarial, por cuanto las partes concurren a la notaría para que sea el notario quien alcance a interpretar su voluntad de acuerdo a la ley y así, alcanzar la creación instrumental, la máxima obra del notario ${ }^{706}$. Lo mismo que las líneas directrices del análisis de la legalidad desde la función interpretativa ${ }^{707}$, la configuradora $^{708}$, la autenticante ${ }^{709}$ o la de reproducción ${ }^{710}$. Todos adjetivos comunes para describir esta tarea, tan desarrollada en el ámbito académico, que es fruto de la asimilación del trabajo notarial a la ley, pero de ninguna manera a las perspectivas sociales que emergen de su función ${ }^{711}$.

Pero también en este tema la doctrina española ha sido por demás de elocuente. De la misma se desprende, en torno al alcance de la calificación notarial:

${ }^{705}$ Cfr. Carlos Alberto VILLALBA WELSH, El derecho notarial a la luz de la teoría egológica, Ediciones de la Universidad Notarial Argentina, 1.967; José María MUSTAPICH, Tratado de derecho notarial, $\mathrm{T}^{\circ} \mathrm{I}$, ob. cit., p. 17.

${ }^{706}$ Carlos Emérito GONZÁLEZ, Derecho Notarial, ob. cit., p. 160; también del mismo autor Teoría General del Instrumento público, Ediar, Buenos Aires, 1.953. Además: Cristina Noemi ARMELLA y AAVV, Función notarial y responsabilidad, RN no 886 -887, La Plata, 1.986; María Carla ZATTA, Deberes y Derechos, en Tratado de Derecho Notarial, Registral e Inmobiliario, Cristina N. ARMELLA (Directora), $\mathrm{T}^{\circ} \mathrm{I}$, Ad-Hoc, Buenos Aires, 1.998, p. 261.

707 Cfr. Francisco MARTíneZ SEGOVIA, Función Notarial, Delta Editora, Entre Ríos, 1.997, p. 198.

${ }^{708}$ Cfr. Natalio Pedro ETCHEGARAY, Escrituras y actas notariales, Astrea, Buenos Aires, 2.016 , p. 39.

${ }^{709}$ Francisco MARTÍNEZ SEGOVIA, ob. cit., p. 211.

${ }^{710}$ Natalio Pedro ETCHEGARAY, Escrituras y actas notariales, ob. cit., p. 39.

${ }^{711}$ La función social notarial debe estar enfocada hacia lo que considero se debe denominar en nuestros días como sociología del derecho notarial. La temática no se refiere a la actividad tendiente a la calificación notarial del derecho, sino muy por el contrario, a la actividad notarial tendiente a crear el derecho con las herramientas que los requirentes cuentan a la hora de hacer valer sus derechos. En todo caso, la calificación notarial se encuentra aquí vinculada únicamente con la búsqueda del valor justicia, sin mayores argumentos que un análisis certero y adecuado de la realidad. 


\section{SEBASTIÁN JUSTO COSOLA}

a) Actividad de formación del instrumento público, como consecuencia de la función pública y privada del notario, que no desconoce el imperio de la ley ni la voluntad jurídica de las partes ${ }^{712}$;

b) Calificación como poder o facultad notarial consistente en la valoración normativa del ordenamiento ${ }^{713}$, que se presenta como un juicio personal $^{714}$, necesario ${ }^{715}$, autónomo ${ }^{716}$, de obligada alternativa ${ }^{717}, y$ normativamente reglado ${ }^{718}$;

c) Calificación como potenciación de los deberes de información, asesoramiento y concejo, para que la voluntad de los requirentes se ajusten a derecho ${ }^{719}$;

d) Calificar para no discriminar el trabajo en razón de la cuantía económica (el notario debe estar preparado para recibir todo tipo de labor en la notaría que merezca ser vertida como contenido de un documento público ${ }^{720}$ );

\footnotetext{
${ }^{712} \mathrm{Y}$ agrega el autor, refiriéndose a la importancia de reconocer en el documento la voluntad de las partes: “(...) sin la cual la fe pública resultaría verdaderamente peligrosa, se convertiría en una trampa tendida a la buena fe de las partes". Cfr. Antonio RODRÍGUEZ ADRADOS, Sistemas notariales existentes en el mundo. Características del notariado latino, Escritos Jurídicos, Vol. II, CGN, Madrid, 1.996, p. 20. Sobre el mismo tema se citan también de mismo autor las siguientes obras: La seguridad jurídica sustancial de los actos jurídicos; El notario: función privada y función pública: su inescindibilidad; El notario y el documento notarial; Necesidad social de la imparcialidad del redactor del contrato, ensayos publicados en el mismo tomo de la Colección citada que en seis tomos, compila todos sus trabajos.

${ }^{713}$ Cfr. José Antonio MOLLEDA FERNANDEZ LLAMAZARES, Deber de servicio y juicio notarial de legalidad, AAMN n ${ }^{\circ}$ XXI, Madrid, 1.978, p. 445 y ss.

${ }^{714}$ Ídem, p. 485. Y agrega: "Por lo tanto indelegable".

715 Ídem, p. 486. "Pues resulta imprescindible, no se puede escapar a él".

716 Ídem, p. 487. "Porque nadie puede imponérselo al notario, ni siquiera La dirección General de los Registros y del Notariado".

717 Ídem, p. 487. "Pues ofrece solo dos caminos: o autoriza o deniega el documento".

${ }^{718}$ Conf. Art. 1 de la Ley Orgánica del Notariado Español: "El notario es el funcionario público autorizado para dar fe, conforme a las leyes, de los contratos y demás actos extrajudiciales”. También el Art. 145 del Reglamento Notarial Español, de donde surge un "deber de enjuiciar o calificar previamente".

${ }^{719}$ Cfr. Isidoro LORA-TAMAYO RODRÍGUEZ, La seguridad jurídica del contrato, RDN n ${ }^{\circ}$ CXVI, Madrid, 1.982, p. 69.

${ }^{720}$ Cfr. Juan Francisco DELGADO DE MIGUEL, La integridad de la prestación del servicio notarial, RJDN n ${ }^{\circ} 38$, CGN, Madrid, 2.001, p. 410.
} 


\section{LOS EFECTOS DE LA PUBLICIDAD EN EL DOCUMENTO NOTARIAL}

e) Calificación como concreción del principio de equidad ${ }^{721}$;

f) Calificación como actividad aplicada al orden multicultural e internalizado del derecho documental ${ }^{722}$;

g) Calificación analizada a partir de los juicios notariales en materia de representación ${ }^{723}$

h) Calificación destinada a resguardar el derecho y la voluntad de cada compareciente, a partir de la adecuada conformación del derecho documental ${ }^{724}$, que proyecta los fundamentos de la noble tarea de análisis notarial ${ }^{725}$.

\footnotetext{
${ }^{721}$ Cfr. Isidoro LORA-TAMAYO RODRÍGUEZ, Aplicación por el notario de la equidad, Revista Jurídica del Notariado No 53, Consejo General del Notariado Español, 2.005, P. 192.

${ }^{722}$ Cfr. Juan BOLAS ALFONSO, El papel del notariado europeo en el nuevo espacio jurídico y económico, Revista Escritura Pública, Secc. "Ensayos de Actualidad”, Consejo General del Notariado Español, Madrid, 2.004.

${ }^{723}$ Cfr. Juan ÁLVAREZ SALA-WALTHER, La representación y la calificación notarial, Revista Escritura Pública, Secc. "Ensayos de Actualidad", Consejo General del Notariado Español, Madrid, 2.003. Este escrito es sumamente importante pues introduce al estudio la problemática introducida a través de la publicación del artículo 98 de la Ley 24/2001, de Acompañamiento de los Presupuestos Generales del Estado, que obliga a los notarios a realizar una reseña identificativa del documento auténtico aportado para acreditar la representación en una escritura, a la vez que debe expresar que a su juicio son "suficientes" las facultades representativas acreditadas. Todo ello y el juicio de valor del notario es lo que hace a la fe pública.

${ }^{724}$ Cfr. Pedro GARRIDO CHAMORRO, La Función Notarial, sus costes y sus beneficios, ob. cit.

${ }^{725}$ En igual sentido, pueden consultarse las conclusiones del VIII Congreso Notarial Español, que al tratar "El suelo y la vivienda en el siglo XXI", refiere en el tema 1 al deber de legalidad que debe respetar el notariado. Ver especialmente ponencias de Pilar De Prada Solaesa, José Luis Fernández Lozada y José María Segura Zurbano. Edición a cargo del Consejo General del Notariado Español, Madrid, 2.005.
} 


\section{SEBASTIÁN JUSTO COSOLA}

Similares orientaciones se recogen en el derecho comparado, en países como Italia $^{726}$, Guatemala ${ }^{727}$, Perú ${ }^{728}$ y México ${ }^{729}$ respectivamente.

En definitiva, puede decirse que los mencionados aportes reconocen un elemento común: el que sostiene que la calificación notarial es un poder o facultad que abarca esencialmente, el análisis de la voluntad particular para así poder ubicarla dentro de los cánones legales. Sin embargo, y de acuerdo a todo lo antes expresado, el deber de calificación no puede en la actualidad reconocer esa única fuente fáctica. Debe entonces recurrirse a otras fuentes relevantes, que relacionan los deseos de las personas relacionados también con los usos, las costumbres y los principios provenientes de las tradiciones familiares; en ellos, la necesidad de concreción los deseos de justicia, las finalidades, los motivos que cada uno tiene a la hora de poner en juego el patrimonio personal y familiar. La noción de ley, referida por toda la doctrina citada, hoy además debe analizarse como si estuviera la misma

\footnotetext{
${ }^{726}$ D'Orazi Flavoni intentaba demostrar que el notario es un consejero jurídico y también alguna cosa más y distinta. Fueron sólo esas palabras las que le bastaron para crear la magnífica teoría de la adecuación, que logra por primera vez unir la voluntad de los requirentes con lo exigido por la ley vigente. Así lo afirmaba el autor: "Adecuar, también en las particularidades el supuesto de hecho concreto (querido por las partes) a uno de los posibles paradigmas abstractos previstos por las normas positivas". Otro autor, Satta, resume la calificación en estas palabras: "La asunción publica de la voluntad privada en el valer de esta como voluntad general", para afirmar lo siguiente: "el juicio notarial consiste propiamente en la asunción de esta voluntad como la voluntad del ordenamiento, de donde fuera de esta voluntad no hay nada, no puede haber juicio, solo hay falsedad". D'ORAZI FLAVONI, Riflessioni su una Scuola di Notariato, trad. de Antonio RODRÍGUEZ ADRADOS, en El notario: Función privada y función pública. Su inescindibilidad, Escritos Jurídicos, Vol. II, CGN, Madrid, 1.996, p. 269 y ss; y Salvatore SATTA, Poesía e verità nella vita del notaio, Rivista di Diritto Processuale, Biblioteca del Ilustre Colegio de Notarios de Madrid, 1.955, p. 264.

${ }^{727}$ Nery Roberto Muñoz se esmera por enseñar la función modeladora que cumple el notario, en cuanto dicha función ocurre cuando el notario esta adecuando mentalmente la voluntad de las partes, y a las normas que regulan el negocio que se pretende celebrar antes de plasmarlo en el instrumento. Y también con otro alcance nos remite al control de legalidad notarial: "El notario debe ajustarse a la ley y por lo tanto no debe prestar sus servicios cuando el hecho que se desee documentar sea contrario a la ley o a la moral". Nery Roberto MUÑOZ, Introducción al Estudio del Derecho Notarial, ob. cit., p. 66; y también del mismo autor: El instrumento público y el documento notarial, Ediciones Guatemala, C.A, Guatemala, 2.004 , p. 61.

${ }^{728}$ Cfr. Gunther GONZÁLEZ BARRÓN, Derecho Notarial, Jurista Editores, Lima, 2.016, p. 51.

${ }^{729}$ Cfr. Luis A. AGUILAR BASURTO, La función notarial, Ubijus, México, 2.015, p. 185.
} 
LOS EFECTOS DE LA PUBLICIDAD EN EL DOCUMENTO NOTARIAL

integrada, contenida, protegida y amparada por los principios y por el derecho, y así entonces debe de argumentarse e interpretarse al momento de originarse la calificación notarial.

\subsubsection{El alcance actual de la calificación notarial.}

La exposición de los aportes mencionados persigue el fin de demostrar que las teorías acerca de la calificación asumidas y resguardadas por el notariado en su plenitud en el inicio del estudio del derecho notarial son las que sirvieron para dar inicialmente fuerza al desarrollo de la disciplina y especialmente, del documento notarial como hoy lo conocemos: en el impulso de la ciencia (cientiae) y con un amplio desarrollo en la técnica (tecné). Por ello las estudiamos oportunamente, y por ello hoy las celebramos. Pero si tan solo esas teorías fueran lo suficientemente fuertes como para acompañar la evolución del derecho proyectada en nuestro país y en el extranjero, con la instauración y puesta en vigencia del Código Civil y Comercial de La Nación que normativamente constitucionaliza el derecho privado actual, esta tesis doctoral destinada a dar fuerza y vigor a los valores emergentes en el documento notarial no tendría razón suficiente ni para ser ni para nacer.

Me refiero a que hay que definitivamente asumir que la indudable mutación que el derecho ha producido, en donde claramente existe una especie de traslación cada vez más frecuentemente en materia de argumentación e interpretación, que se dirige desde el paradigma científico que el notariado ha venido asumiendo desde siempre, hacia el paradigma artístico, más cercano a consolidar los valores en general y en especial, el valor referido a la justicia.

La cientificidad del derecho relacionada con la seguridad indubitable de la norma, ha sido puesta en jaque en los últimos tiempos en nuestro país al menos, desde cuatro puntos de vista: 


\section{SEBASTIÁN JUSTO COSOLA}

a) La reforma constitucional del año 1.994 y la incorporación de la teoría del los derechos humanos al ámbito local como principios y no de cómo mera fuente del derecho;

b) La publicación, en sintonía, de leyes trascendentes de derechos humanos que dieron positividad a los temas propuestos genéricamente en los tratados y sobre los cuales siempre existieron dudas de aplicación formal ( Protección integral de las Niñas, Niños y adolescentes; Salud mental, lavado de activos, entre tantas otras);

c) Las sentencias de la Corte Suprema de Justicia de La Nación y también las de los tribunales inferiores, al menos de los últimos treinta años, que desconocen la seguridad de la norma cuando la misma, en el caso concreto, colisiona con los derechos humanos fundamentales;

d) La puesta en vigencia del Código Civil y Comercial de la Nación, definido como un código de principios, destinado a posicionar los grandes principios y valores del derecho privado, a través del dialogo de fuentes ${ }^{730}$.

El derecho científico (ciencia del derecho) afirma paradigmas rígidos de contemplación de situaciones inamovibles y suficientes para los casos allí contemplados. No requiere de análisis de casos puntuales y específicos, sino que requiere de aplicación legal directa cuando los casos se encuadran en determinada situación jurídica existente (o preexistente). La seguridad de la ley así, desconoce la situación puntual de los hombres o de las mujeres implicadas en el asunto para poder así considerar todos los casos como comunes o similares. Esa seguridad, propia del iluminismo y de la escuela de la exégesis, está lejos de ser considerada por el nuevo tratamiento del derecho y con él, con el nuevo paradigma jurídico que nos rige ahora normativamente.

¡Esto no significa que el jurista debe desconocer la ley! Sino que debe comprender que en la actualidad, el objeto del derecho es tan heterogéneo e

${ }^{730}$ Ricardo Luis LORENZETTI, Presentación del Proyecto, en Código Civil y Comercial de La Nación (Proyecto del Poder Ejecutivo de la Nación redactado por la Comisión de Reformas designada por decreto 191/2011), ob. cit., p. 12. 
indeterminado, que el mismo ya no es sólo una ciencia o una técnica ${ }^{731}$. El mismo carece de algo sustancial que le da razón de ser y de existencia, y es eso precisamente el arte del derecho, la creación del derecho fundada en las fuentes y en la justicia, que el jurista crea o debe crear para alcanzar un óptimo, y más que ello, el mejor resultado que le sea posible alcanzar.

En resumen: esa perspectiva acerca del derecho -en donde el jurista intérprete no debía de preocuparse por la justicia del caso concreto, sino únicamente por el cumplimiento de la ley ${ }^{732}$ - es absolutamente diferente a la que hoy se debe de tener a la luz de las declaraciones de defensa de la humanidad que constantemente promulgan y aconsejan respetar las naciones del mundo. Finaliza entonces la comprensión y aprehensión de jurista a la noción de sistema rígido que se corporaliza, se hace código, para autoabastecerse a sí mismo a través de las fuentes y del principio de analogía, porque el sistema de derecho actual reconoce que toda esa aplicación rígida, si bien en apariencia más organizada, ha causado fisuras esenciales en materia de justicia. Parafraseando a Renato Rabbi-Baldi Cabanillas, podría decirse lo siguiente: “...ningún sistema, por más perfecto que se pretenda, está ni definitivamente concluido, ni al abrigo de la sinrazón humana ${ }^{733}$ ".

De ahí que el derecho artístico (arte del derecho) postule una solución diferente y acorde a los tiempos actuales. Al analizar los casos puntuales, el

\footnotetext{
${ }^{731}$ Cfr. Enrique DEL CARRIL, Interpretación, neoconstitucionalismo y ética profesional, en Sebastián J. COSOLA, Enrique H. DEL CARRIL, Luis MONTESANO y Santiago FINN, Ética de las profesiones jurídicas (Abogados, jueces, notarios), Ad Hoc, Buenos Aires, 2.010, p. 55.

${ }_{732}$ Para advertir los alcances de ese derecho y consecuentemente, de la seguridad emanada de la ley: v. Jean-Etienne PORTALIS, Discurso preliminar sobre el proyecto de Código Civil presentado el primero de pluvioso del año IX por la comisión designada por el gobierno consular, Abeledo Perrot, Buenos Aires, 1.959, 60 p.

${ }^{733}$ Cfr. Renato RABBI-BALDI CABANILLAS (Coord.), Las razones del derecho naturalEstudio introductorio a la segunda edición, Ábaco, Buenos Aires, 2.008, p. 26.
} 


\section{SEBASTIÁN JUSTO COSOLA}

jurista recurre a la búsqueda de la solución a un amplio abanico de fuentes (no solamente la ley), y con ello, la prevalencia se centra no tanto en cumplir con el postulado científico sino con cumplir lo justo para cada uno. El jurista ya no interpreta la norma, la voluntad del legislador, la historia del derecho, sino que argumenta el caso con todas las fuentes que a su lado tiene para alcanzar un resultado justo: Constitución y Tratados con jerarquía, Constituciones Provinciales, tratados sin jerarquia, leyes nacionales, leyes estaduales, ordenanzas municipales, sentencias judiciales, sistemas formularios, fuentes menores de procedimiento -en nuestro caso, las disposiciones técnico-registrales o las ya referidas órdenes de servicio-, opiniones académicas y consultivas, entre otras.

Este es el nuevo ámbito del derecho. Este derecho es el que ha incorporado el moderno cuerpo de leyes unificado. Desde un análisis más general, diríamos en sintonía con Rodolfo Vigo que el cambio en esencia radica en una clara mutación desde la ley hacia el derecho ${ }^{734}$, o más precisamente en el traspaso desde el Estado de Derecho Legal hacia el Estado de Derecho Constitucional $^{735}$. El Estado de Derecho Legal postulaba algunas descripciones y características propias, afirmando que ${ }^{736}$ :

a) El derecho estaba solamente contenido en la ley y en los códigos;

b) Que los jueces -por analogía el notario- solamente debían aplicar la ley a partir del silogismo deductivo, bajo amenaza de incurrir en el delito de prevaricato -el notario, también por analogía, violentaría notoriamente los deberes de legalidad, independencia, asesoramiento, información y consejo ${ }^{737}$;

c) Se debe imponer tanto el método gramatical y lógico como los medios interpretativos de excelencia para desentrañar el sentido de la ley;

\footnotetext{
${ }^{734}$ Cfr. Rodolfo Luis VIGO, De la ley al derecho, Porrúa, México, 2.005, 258 p.

${ }^{735}$ Cfr. Rodolfo Luis VIGO, Prólogo a la obra de Alfonso SANTIAGO (h), En las fronteras entre el derecho constitucional y la filosofia del derecho, Marcial Pons, Buenos Aires, 2.010, p. 9 y ss.

${ }^{736}$ Cfr. Rodolfo Luis VIGO, Iusnaturalismo y neoconstitucionalismo. Coincidencias y diferencias, Educa, Buenos Aires, 2.015, p. 232 y ss.

${ }^{737}$ Sebastián Justo COSOLA, Los deberes éticos notariales, ob. cit., p. 466 y ss.
} 
d) Y que no hay lagunas en la ley -por eso explica el autor que el Code no contempla mecanismos de integración-,

Desde otra posición, el Estado de Derecho Constitucional, propio de los tiempos en los que nos toca vivir y sentir el derecho viene a postular lo siguiente $^{738}$ :

a) El derecho no es solo la ley, sino también las Constituciones y los Tratados que reconocen derechos humanos;

b) La voluntad legislativa debe ser controlada y es posible que los jueces las invaliden por razones jurídicas formales y sustanciales;

c) Los jueces - por analogía, también el notario- deben procurar la justicia y la equidad por medio del derecho, asumiendo los casos concretos y dando valor a sus decisiones;

d) El jurista debe recurrir a una inagotable categoría de fuentes del derecho y además debe recurrir a otros saberes no estrictamente jurídicos (como el prudencial y él filosófico);

e) Para comprender el funcionamiento del derecho, necesariamente debe de recurrirse al estudio de la filosofía jurídica en general;

f) La Constitución es la norma fundamental de un Estado, y obliga a los jueces - por analogía, también al notario- a velar por la sujeción de los ciudadanos a su cumplimiento y para que la misma no sea vulnerada ${ }^{739}$.

En definitiva, sobre estas nuevas y elementales consideraciones, con la base de los aportes realizados anteriormente -y de tantos otros que se han ido brindando a lo largo del tiempo-, puede afirmarse que la calificación notarial actual:

a) Se relaciona con el principio de legalidad que comprende a las normas, las reglas y los principios, desde la misma Constitución

${ }^{738}$ Rodolfo Luis VIGO, Iusnaturalismo y neoconstitucionalismo..., ob. cit., p. 275.

${ }^{739}$ Rodolfo Luis VIGO, Prólogo a la obra de Alfonso SANTIAGO (h), ob. cit., p. 13. 


\section{SEBASTIÁN JUSTO COSOLA}

hasta la última norma inferior;

b) Se refiere a la función que cumple el notario en toda su labor, que comienza en la primera audiencia y finaliza con la autorización del documento, extendiéndose también a la labor post escrituraria como los deberes legales de inscripción o de conservación, entre otros deberes funcionales;

c) La función calificadora notarial se encuentra establecida en prácticamente todos los artículos de las leyes estaduales e internacionales que hacen referencia a los deberes de los mismos. Pero si no lo estuviera, vale como principio general de la función fedante;

d) Coadyuva a reforzar el principio de adecuación de la voluntad de las partes con la legalidad (integrada) exigida para instrumentar ese fin, en donde se destaca la protección de instituciones tan importantes como la teoría de la causa y su consecuente frustración del fin del contrato $^{740}$.

e) Se debe tener una concepción globalizadora de la misma, ya sea a través del control de toda la documentación pertinente, ya sea exigiendo la totalidad de la documentación necesaria para crear cualquier tipo de acto;

f) La calificación también permite apartarse de la autorización del negocio cuando el mismo no se ajuste a derecho, y le impone al notario hacer docencia para que el mismo pueda configurarse de la manera adecuada;

g) Dada la adecuada implementación de la calificación en el negocio, se vuelven visibles desde la publicidad cartular los valores de fe (verdad), justicia y seguridad, determinantes de la paz.

En la redacción del documento se cumple formalmente con el presupuesto de la calificación notarial ${ }^{741}$. Desde allí que consolidados los valores en el

740 Cfr. Karl LARENTZ, Base negocial e incumplimiento contractual, Comares, Madrid, 2.003; Rubén STIGLITZ, El objeto y la causa en los contratos, Depalma, Buenos Aires, 1991.

${ }^{741}$ Cfr. Antonio DOMINGUEZ MENA, El notario y los Registros. Registros Inmobiliarios, mercantiles, de anotaciones personales y otros. La función calificadora del notario en la 


\section{LOS EFECTOS DE LA PUBLICIDAD EN EL DOCUMENTO NOTARIAL}

documento, los actos realizados por el notario estén dirigidos a asegurar el derecho de una persona cuyo deseo es precisamente, hacerlo valer en el núcleo social en el que pretenda desarrollarse. Al concretar el deber de legalidad integrada, el notario contribuye a evitar conflictos posteriores en todos los actos en que sea necesaria su presencia ${ }^{742}$. De manera que la calificación notarial de la legalidad integrada genera en la sociedad una singular presunción de certeza, sobre lo hecho en el documento que presupone la verdad, amparando lo justo de cada uno, y brindando seguridad $^{743}$ ".

\subsubsection{La trascendencia de la calificación notarial.}

Para justificar el valor de la función notarial en los tiempos actuales Vallet de Goytisolo se apoya en Figa Faura ${ }^{744}$, en el intento por demostrar que la misma es una verdadera protección frente a las pretensiones de la mentalidad capitalista que intentan multiplicar el valor de la economía dejando en el camino, desechos, los verdaderos valores que sustentan la paz en el mundo de relación. Figa enseñaba que lo esencial no es la circulación rápida de las fincas, sino el arraigo del hombre a la tierra, porque lo fundamental de la tierra no es su valor monetario sino su aptitud para satisfacer de manera directa las necesidades humanas en lugar de las conveniencias comerciales $^{745}$. Algo similar a lo que ocurre aquí en Argentina, pero en

elaboración documental, RJN n ${ }^{\circ}$ VI (Extraordinario), Madrid, 2.004, p. 224.

${ }^{742}$ Cfr. Dominique SAVOURÉ, Benjamin DUMONTET y Lionel GALLIEZ, Ponencias del notariado francés, CINL-UIN, de BUSSAC-Clermont-Ferrand, París, 2.010, 206 págs.

${ }^{743}$ Cfr. Santiago Raúl DEIMUNDO, Pensamiento y sentimiento sobre el notariado, Depalma, Buenos Aires, 1.989, p. 39. Dice el autor: “"Los actos notariales tienen intrínsecamente aptitud de certeza y gozan socialmente, además, de una presunción genérica de legalidad, no solo por la capacidad jurídica de su autor, sino también, y en especial, por el respeto que él inspira".

${ }^{744}$ Juan Berchmans VALLET DE GOYTISOLO, Seguridad jurídica estática y seguridad jurídica dinámica, ob. cit., p. 213.

${ }^{745}$ Ibídem. ¿Qué fantásticas enseñanzas y que útiles y provechosas para el notario actual! España tiene esa grandeza con la que muy pocos países cuentan, que es la cultura arraigada en los hombres y mujeres que ejercen la función fedante, y que es proveniente de la enseñanza de 


\section{SEBASTIÁN JUSTO COSOLA}

relación al ejercicio de la abogacía, que cuenta con las palabras siempre vivas de Augusto Morello, en este caso, cuando ordenaba a la congregación abogadil insuflar a todas las relaciones humanas de un definido carácter ético, con la única finalidad de evitar que el derecho privado concluya por ser cerradamente materialista ${ }^{746}$, regla que por analogía también debe hacerse eco el notariado en su conjunto. Es que todo lo dicho es absolutamente cierto: existe una creencia extendida que advierte que el valor económico domina el obrar real de los hombres ${ }^{747}$, y por ello, la consolidación de un notariado preparado para conformar y estructurar los valores en el documento en aras de la justicia, la verdad, la certeza y la seguridad es tan oportuna como necesario.

Por lo expuesto es que hace tiempo vengo sosteniendo con humildad y firmeza que el fundamento del derecho notarial se encuentra más allá de la fe pública ${ }^{74}$, de la teoría general de las formas ${ }^{749}$, de la teoría general del instrumento público ${ }^{750}$, entre otras manifestaciones de importancia que nuestra doctrina ha ido aportando, y que quizás deba buscárselo en el ejercicio de una función justa que claramente se sostiene por imperio de la fe, y únicamente a través de una conducta basada en el cumplimiento estricto de una teoría general de los deberes éticos notariales, que tiene y debe de mantener incólume el notariado ${ }^{751}$. Si se conforman estas apreciaciones, se contribuye hacia la fortaleza del fin social de la institución notarial, que en la búsqueda de la protección del requirente y luego de la

los grandes maestros del derecho notarial.

${ }^{746}$ Cfr. Augusto Mario MORELlO, El abogado, el juez y la reforma del Código Civil, Librería Editora Platense, La Plata, 1.969, p. 24.

${ }^{747}$ Cfr. Raúl ALFONSÍN, Fundamentos de la República Democrática. Curso de Teoría del Estado, Eudeba, Buenos Aires, 2.006, p. 43.

${ }^{748}$ Se recomienda la lectura de Eduardo COUTURE, El concepto de Fe Pública. Introducción al estudio del derecho notarial, Fas, Rosario, Argentina, 2.005. Este trabajo fue publicado originariamente en Buenos Aires, $\mathrm{RdN} \mathrm{n}^{\circ}$ 546, 1.947, págs. 5-76.

${ }^{749}$ Muy especialmente se cita aquí a Alberto VILLALBA WELSH, Hacia una teoría Egológica del Derecho notarial, UNA, La Plata, 1.967.

${ }^{750}$ Carlos Emérito GONZÁLEZ, Teoría General del Instrumento Publico, ob. cit.

${ }^{751}$ Cfr. Eduardo Justo COSOLA, Ser éticos, RE-Colescba, La Plata, 1.999, p. 11; Juan Francisco DELGADO DE MIGUEL, La esencia deontológica de la función notarial, Deontología Notarial, Consejo General del Notariado Español, Madrid, 1.992, p. 27; Juan Berchmans VALLET DE GOYTISOLO, Manuales de Metodología Jurídica, T ${ }^{\circ}$ III, ob. cit., p. 231 y ss y José María MUSTAPICH, Tratado de Derecho Notarial, T I, ob. cit., p. 58. 


\section{LOS EFECTOS DE LA PUBLICIDAD EN EL DOCUMENTO NOTARIAL}

tarea conformadora y creadora del derecho, entrega al registrador el documento para que el mismo lo inscriba como auténtico y genuino. Nunca más precisas entonces, las presentes palabras: "Por eso, nos atrevemos a decir que si los notarios se limitan a dar fe pública, posiblemente en el futuro serán sustituidos por "simples" funcionarios, pero si los notarios entran en las cuestiones morales y deontológicas, en las cuestiones de justicia y legalidad, y realizan autenticas labores de asesoramiento, (acorde a la ley) entonces el modelo de notariado latino que tenemos será una gran aportación a la sociedad ${ }^{752}$ ".

\subsection{En torno a la calificación registral.}

El principio de calificación registral es medular y en nuestro país, la doctrina y la jurisprudencia ${ }^{753}$ se esfuerzan por orientan al intérprete hacia el convencimiento de su notable importancia no sólo proyectada en la ley marco y en cada una de las leyes registrales locales o provinciales ${ }^{754}$, sino también en el ámbito internacional. La misma redacción del artículo pertinente de la ley nacional registral, en la parte pertinente referida al análisis de la legalidad de las formas extrínsecas ${ }^{755}$, permite advertir que las

${ }^{752}$ Cfr. Francisco Javier DE LA TORRE DIAZ, Ética y deontología jurídica, Dykinson, Madrid, 2.000, p. 410.

753 "Nadie discute que la función calificadora es limitada pues no abarca todos los aspectos del titulo inscribible. Pero explicitar hasta que donde se extiende es cuestión que depende del sistema adoptado por el legislador. En algunos ordenamientos, la calificación es mínima (por ej., el francés); en otros, es más amplia (por ej., el español). Pero de que legislador se está hablando en Argentina ¿el nacional o el provincial? (...) La ley 17.801 respetuosa de las autonomías locales, remite reiteradamente a las legislaciones provinciales. Sin embargo, tratándose de función calificadora, contiene disposiciones expresas, por lo que indubitablemente hay que ceñirse a ellas, salvo que fueran inconstitucionales..." Sup. Corte Mendoza, sala $3^{\circ}, 9 / 8 / 1991$. Lucena Cabello, Jorge R. v. Dirección de Registros Públicos y Archivo Judicial de la Provincia de Mendoza, JA 1992-IV-656.

754 "Es de buena hermenéutica interpretar las leyes sistemáticamente, o sea, en todo su contexto” Sup. Corte Mendoza, sala 3, 20/05/1992, Iturbide Abel R, JA 1993-II.286.

755 Art. 8 LNR: "El Registro examinará la legalidad de las formas extrínsecas de los documentos cuya inscripción se solicite, ateniéndose a lo que resultare de ellos y de los asientos respectivos". 


\section{SEBASTIÁN JUSTO COSOLA}

interpretaciones sucedidas son de tal alcance que a veces resulta difícil encontrar un justo medio que pueda determinar cuál es su verdadero alcance. Pero precisemos que en nuestro país -y probablemente en el resto de los países que adoptan el sistema de calificación registral relacionado con el principio de legalidad- existen básicamente dos posiciones en torno a este conflictivo y debatido tema -a mi juicio innecesariamente-:

a) Por un lado, aquellos que piensan que los análisis del registrador sobre los documentos que ingresan al registro son únicamente aquellos que se refieren a las mencionadas formas extrínsecas;

b) A la par, otros opinan que la función calificadora registral se extiende más allá de las formas extrínsecas, para tener incidencia en otras cuestiones relevantes internas del documento ${ }^{756}$.

Todas las voces registrales relacionan el deber de legalidad con la calificación registral, aunque advierten al lector de las consecuencias de la calificación del registrador. En este sentido, el maestro Chico y Ortiz claramente detalla, expone y defiende los caracteres de la función de calificación registral, al transmitir que la misma es una función jurídica ${ }^{757}$, que reconoce independencia en su ejercicio ${ }^{758}$, de ejercicio eminentemente unipersonal $^{759}$, que acarrea serias consecuencias al registrador en materia de responsabilidad $^{760}$, y que es absolutamente necesaria ${ }^{761}$, ya que el registrador interpreta, califica y decide ${ }^{762}$. Desde los fundamentos planteados en el anteproyecto de la ley nacional registral 17.801/68, en materia de calificación, se sugiere: "La calificación consiste en la atribución que tiene

\footnotetext{
${ }^{756}$ Cfr. Lilia Noemí DIEZ, Ley Nacional Registral Inmobiliaria: Una mirada a treinta años de su vigencia ..., $\mathrm{RdN} \mathrm{n}^{\circ}$ 856, Ciudad Autónoma de Buenos Aires, 1.999, págs. 90-91.

${ }^{757}$ José María CHICO Y ORTÍZ, Teoría, práctica y fórmula de la calificación registral, ob. cit., p. 61.

${ }^{758}$ Ibídem.

${ }^{759}$ Ibídem, p. 63.

${ }^{760}$ Ibídem.

${ }^{761}$ Ibídem.

${ }^{762}$ Ibídem, p. 65. Más adelante dice: "lo que permite inferir que la función calificadora tiene una labor constructiva similar a la desarrollada por el notariado".
} 


\section{LOS EFECTOS DE LA PUBLICIDAD EN EL DOCUMENTO NOTARIAL}

el registrador de examinar el documento cuya inscripción o anotación se solicite a los efectos de verificar si reúne los presupuestos legales necesarios para poder ingresar al Registro ${ }^{763}$ ". El tratamiento del tema inclusive se traslada hacia las consecuencias de la calificación, que la doctrina en general considera al tratar el principio de presunción registral ${ }^{764}$. Hay presunción registral de exactitud, precisamente porque los documentos que ingresan al registro, sin bien declarativo y no convalidante, tienen un examen previo (calificación) que los depura ${ }^{765}$.

De aquí en mas, autores como López de Zavalía ${ }^{766}$ realizan un extenso análisis del principio de legalidad, considerándolo tanto en su faz pública como en la privada -desde el momento en que las partes someten el ejercicio pleno de la voluntad como a las reglas que impone la ley misma ${ }^{767}$-. Para el profesor tucumano, el concepto de calificación se relaciona con la referencia legislativa de la legalidad de las formas extrínsecas" ${ }^{768}$ : "Calificar es encuadrar un objeto de conocimiento en una determinada categoría. El que controla realiza una doble calificación, pues autocalifica su conducta para decidir si obra y como lo hará y califica la conducta ajena. Así entendida (reservas aparte ${ }^{769}$ ) la función calificadora en los registros de recepción existe siempre". También Moisset de Espanés acuerda con lo antedicho ${ }^{770}$; la consideración de las formas extrínsecas son las referidas a los requisitos propios que deben poseer todos los instrumentos públicos ${ }^{771}$, y no sobre el

\footnotetext{
${ }^{763}$ Edgardo O. SCOTTI, Derecho Registral inmobiliario, ob. cit., p. 29.

${ }^{764}$ Marta E. FAZIO de BELLO, Actos jurídicos y documentos inscribibles, ob. cit., p. 142.

${ }^{765}$ Ibídem.

${ }^{766}$ Fernando LOPEZ DE ZAVALIA, Curso introductorio al derecho registral, ob. cit., p. 393.

${ }^{767}$ Ibídem, p. 388.

${ }^{768}$ Ídem, p. 83. En una brillante argumentación de las teorías de la forma en el Código Civil de Vélez explica el significado de las formas extrínsecas interpretando el artículo 2072 del Código Civil (Contrato Oneroso de Renta Vitalicia).

${ }^{769}$ Ídem, p. 386. No está el autor muy de acuerdo con estas definiciones, es por ello que inicia su explicación al principio de legalidad hablando de una mutilación y una distorsión del mismo, basando la legalidad en el principio de razonabilidad jurídica.

${ }^{770}$ Luis MOISSET DE ESPANES, Publicidad Registral, ob. cit., p. 175.

771 Ídem, p. 178-9. Reduce el significado de las formas extrínsecas "al acto instrumental, es decir, en este caso, a los requisitos propios del instrumento publico de que se trate, como son la competencia territorial del oficial público, su idoneidad con relación al acto, la existencia de las firmas del oficial público y de los otorgantes, etc. ".
} 


\section{SEBASTIÁN JUSTO COSOLA}

contenido del mismo acto, por ello es que el profesor cordobés difiere con algunas sentencias judiciales que acuerdan en que las limitaciones a la capacidad de disponer establecidas en el asentimiento conyugal son formas extrínsecas $^{772}$. En este sentido, se encuentra convencido que los creadores de la ley tuvieron "la intención de reducir al mínimo las facultades del registrador, procurando que sólo analizara las formas extrínsecas ${ }^{773,}$, precisamente porque otra serie de normas en la norma nacional amplían tal función calificadora en manos del registrador ${ }^{774}$, aumentando el panorama de análisis de los documentos que entran al registro con la pretensión de ser inscriptos.

Sin embargo, autores como García Coni advierten que las facultades de calificación del registrador, frente a lo minúsculo del análisis de las formas extrínsecas que ofrece el artículo referente a la legalidad, deben ir más allá del análisis de la mera formalidad: “(...) el registrador tendrá que ir más allá del examen relativo a las formas extrínsecas, para incursionar en el negocio jurídico ${ }^{775 " . ~ E s t e ~ c r i t e r i o ~ t a m b i e ́ n ~ e s ~ e l ~ r e c e p t a d o ~ p o r ~ a l g u n a ~}$ jurisprudencia $^{776}$. Américo Cornejo ${ }^{777}$ explica el alcance de la calificación

\footnotetext{
${ }^{772}$ Passim. Cita la sentencia de la Sala E de la Cámara Nacional Civil de la Capital Federal que ordena: "la exigencia del consentimiento hace a la faz extrínseca del documento, o sea tiene por base la ley".

773 Luis MOISSET DE ESPANES y Horacio VACARELLI, Sistema Registral Inmobiliario ..., ob. cit., p. 60.

774 Ídem, págs. 66-67: dicen los autores: "Si la función registradora se contrajese al análisis de las formas extrínsecas, su ámbito seria minúsculo y no cumpliría con la tarea que la propia ley le fija...la redacción del artículo $8^{\circ}$ no traduce lo que el legislador pretendia; en parte por la subsistencia de otras normas en el cuerpo legal que se vinculan con la función calificadora del registrador y cuyo cumplimiento es inexcusable".

${ }^{775}$ Cfr. Raúl GARCIA CONI, ¿Que inscriben los registros inmobiliarios?, Libro Homenaje al Profesor L. M. E., Universidad, Buenos Aires, 1.980, p. 245.

776 "El principio de legalidad se traduce en que los documentos cuya inscripción se persigue reúnan todos los requisitos exigidos por las leyes a tal efecto, para lo cual, será necesario efectuarles un examen previo de calificación que asegure su validez. De esta formal el cuidado de la legalidad constituye un elemento integrativo de la función calificadora, y ésta implica siempre un juicio de valor que amerita las condiciones de lo que se examina. Ahora bien, la función del registrador, si bien no debe exceder los limites que la ley establece, ni invadir esferas reservadas a otros poderes del Estado, no es meramente pasiva. En efecto, no cabe duda que deberá analizar el acto jurídico..." Cam. Nac. Civ., Sala J, 5/03/2008, Departamento técnico y jurídico administrativo v. Registro de la Propiedad Inmueble, JA 2008-IV-500.

${ }^{777}$ Américo Atilio CORNEJO, Derecho Registral, ob. cit., p. 201.
} 
refiriendo las mencionadas doctrinas, la naturaleza jurídica del instituto en cuestión $^{778}$, los caracteres ${ }^{779}$ y límites ${ }^{780}$ de la calificación, y además la comparación de la potestad calificadora del registrador argentino con la de otros registradores pertenecientes a otros sistemas de registración inmobiliaria ${ }^{781}$. Al considerar la función calificadora registral, comparte con Scotti ${ }^{782}$ la definición del principio de legalidad: "Principio de legalidad es aquel por el cual se impone que los documentos que se pretenden inscribir o anotar en el Registro de la Propiedad reúnan los requisitos exigidos por las leyes para su registración, a cuyo fin es necesario someter los a un previo examen, verificación o calificación que asegure su validez o perfección ${ }^{783}$ ". Otros autores reconocen una diferenciación entre los registros administrativos y los jurídicos, para desde allí considerar la doble dimensión del principio de legalidad ${ }^{784}$; la primera se refiere a la necesidad de la documentación pública o titulación para que pueda efectivizarse una inscripción, mientras que la segunda se refiere a la labor de calificación en cuanto al fondo y forma que realiza el registrador. Para Felipe Villaro ${ }^{785}$ la calificación es "el examen que el registrador hace del documento presentado a inscribir, para determinar si reúne los requisitos exigidos por

\footnotetext{
778 Ídem, págs. 203-204. Cita a doctrina extranjera, refiriendo que en España los autores en su mayoría consideran que la función calificadora registral tiene naturaleza judicial, "pues resulta obligatorio, independiente, limitado a su propio contenido y con alcance de cosa juzgada". También considera los autores que ubican la función calificadora dentro de los actos de "jurisdicción voluntaria".

${ }^{779}$ Ídem, págs. 204-205. La considera como función independiente, completa, integra y obligatoria para el registrador.

${ }^{780}$ Menciona a la doctrina dividiendo entre los que consideran la función calificadora en la concepción de Moisset que analizamos anteriormente, y una teoría amplia, que reconoce su fundamento mayor en un fallo de la Suprema Corte Mendocina, Sala III, del 9 de Agosto de 1.991, que en materia de amplitud de la calificación del registrador sentenció: "Cualquier nulidad manifiesta del documento -sea que afecte las formas extrínsecas o al contenido del acto instrumentado- tendrá que ser observado por el registrador". Publicado en J.A, 1992IV-656.

${ }^{781}$ Ídem, p. 202. Refiere aquí que por ejemplo, en el sistema australiano Torrens, la amplitud y el exceso en la calificación es abrumadoramente desmesurado, acorde con el funcionamiento general del sistema.

${ }^{782}$ Edgardo O. SCOTTI, Derecho Registral Inmobiliario, ob. cit., p. 18.

${ }^{783}$ Américo Atilio CORNEJO, Derecho Registral, ob. cit., p. 202.

${ }^{784}$ Gabriel DE REINA TARTIERE, Manual de Derecho Registral Inmobiliario, ob. cit., p. 8.

${ }^{785}$ Pedro Felipe VILLARO, Elementos de Derecho Registral Inmobiliario, ob. cit., p. 59.
} 


\section{SEBASTIÁN JUSTO COSOLA}

la ley, y en consecuencia, practicar su registración ${ }^{786 " . ~ F i n a l m e n t e ~ L u i ́ s ~}$ Andorno ${ }^{787}$ argumenta el sentido de la calificación considerándola como "una actividad que desarrolla el registrador para evitar el acceso al registro de títulos nulos o insuficientes, para garantizar la seguridad jurídica"; en sintonía con lo sostenido por Chico y Ortíz, la considera como una función creadora, porque alcanza las denominaciones de calificación control y también de calificación creación ${ }^{788}$.

Hasta aquí, el análisis de algunas de las innumerables definiciones que se han brindado, como así también de la descripción y el alcance que las mismas han proyectado. A nivel jurisprudencial el reconocido plenario Mauricio Feidman -frente a un caso de necesidad o no necesidad de que la publicidad cartular refleje el asentimiento conyugal en un acto dispositivo-, termina por considerar que existen en la ley argumentos significativos que permiten extender la calificación del registrador mas allá de las formas extrínsecas para penetrar en cierta medida en el contenido del acto, sin detenerse en su continente ${ }^{789}$. En suma, en la búsqueda de un denominador común puede sostenerse lo siguiente:

a) La función de calificación se relaciona exclusivamente con el principio de legalidad y con la función que la ley le otorga al registrador.

b) Esta dirigida hacia y por el registrador, que debe evitar que títulos defectuosos $^{790}$ se inscriban en el registro ${ }^{791}$, con escasas posibilidad de aplicar la argumentación jurídica;

\footnotetext{
${ }^{786}$ Ibídem. Más adelante el autor enfatizará: "El autor analiza extensamente el tema, considerando que el fundamento del mismo se apoya "no solamente en el principio de legalidad, al menos no en el únicamente, sino en una exigencia lógica derivada del sentido y finalidad de la publicidad registral".

${ }^{787}$ Cfr. Luis ANDORNO, Publicidad Registral. Principios Registrales, en Cuestiones esenciales en derechos reales", Gustavo VALLESPINOS (Director), Lexis Nexis- AbeledoPerrot, Buenos Aires, 2.002, p. 24.

${ }^{788}$ Ibídem, p. 24 y ss.

${ }^{789}$ CNCiv en pleno, 27-07-1977 ( $\mathrm{RdN} \mathrm{n}^{\circ}$ 754, p. 1007).

${ }^{790}$ Con el alcance que cada autor brinda aquí, que resulta de imposible tratamiento: ANDORNO habla de títulos nulos o insuficientes; MOISSET y VACARELLI se refieren a los documentos que presenten fallas o defectos groseros", entre otros lógicamente.

${ }^{791}$ Con el análisis respectivo acerca de la función no convalidante de nuestro registro, que también merece otro estudio.
} 
LOS EFECTOS DE LA PUBLICIDAD EN EL DOCUMENTO NOTARIAL

c) En sentido amplio, la función calificadora se encuentra contenida en todo el articulado de la ley registral ${ }^{792}$, pero siempre es una tarea limitada a lo que la ley ordena ${ }^{793}$;

d) Coadyuva a valorizar el principio de conservación de los títulos y documentos que pueden o no encontrar una semejanza con la realidad extra-registral.

\subsubsection{La necesaria separación de roles que implican ambas} funciones. Auxilio de la cuestión terminológica.

La Real Academia Española de Letras enseña que el término calificar, del latín qualificare, significa, en su primera acepción, apreciar o determinar las cualidades o circunstancias de alguien o de $\operatorname{algo}^{794}$. En torno a la definición propuesta y su relación con el espacio temporal en la consideración de la producción de los hechos, la apreciación o la determinación de las cualidades de las circunstancias de alguien le corresponde al notario, que tiene el primer y único contacto con los otorgantes del acto; mientras que la apreciación o determinación de las cualidades de las circunstancias de algo le corresponde al registrador, que tiene el documento en sus manos para realizar la tarea de control que debe éste legalmente realizar al final de la cadena transmisora, que se observa desde el otorgamiento primero, recurriendo a la suscripción en caso que la ley haya requerido testigos para instrumentar el acto en cuestión, para finalmente arribar al acto de autorización o autenticación notarial . Únicamente desde esta primera aproximación se advierte una diferencia sustancial entre la calificación notarial y la calificación registral:

\footnotetext{
${ }^{792}$ Fernando LÓPEZ DE ZAVALÍA, Curso introductorio..., ob. cit., p. 397.

${ }^{793}$ Luis MOISSET DE ESPANÉS, Publicidad Registral, ob. cit., p. 177; V. también Felipe VILLARO, Elementos de derecho registral..., ob. cit., p. 66.

${ }^{794}$ http://lema.rae.es/drae/?val=calificar (Último acceso: 21/08/2017).
} 


\section{SEBASTIÁN JUSTO COSOLA}

a) La función calificadora notarial se relaciona con lo que el escribano puede conocer a través del estudio de las fuentes, del dialogo con los requirentes, del normal desenvolvimiento de los hechos, de lo que resulte del deber de asesoramiento y consejo, de la aplicación de la imparcialidad y la independencia, de la conformación del negocio jurídico en base a la voluntad y al derecho, del acto de instrumentación formal que confirma ese acuerdo que las partes han realizado y finalizado con total seguridad, frente a la constatación con fe pública notarial;

b) La función calificadora registral se encuentra en una posición bastante diferente, pues ya el acto y la instrumentación han sido realizadas, es decir, ya se ha concluido el acto jurídico y el titulo que lo contiene se ha convertido en suficiente, no teniendo nunca el registro forma posible de tener la plena certeza de que lo que inscribe se ajusta realmente a la realidad extra-registral ${ }^{795}$.

La jurisprudencia ha sido determinante a la hora de marcar las diferencias de las calificaciones, haciendo en ocasiones responsable al registrador que haya excedido de sus funciones calificadoras ${ }^{796}$. Desde mi posición, la calificación registral reúne en la actualidad requisitos especiales que la

${ }^{795}$ Este tema, por demás controvertido, ha sido tomado en gracia por el genial López de Zavalia que advierte: "(considerando el control de legalidad) los registradores tienen razón, porque cuatro ojos ven mejor que dos; dos cabezas piensan mejor que una. Pero esa explicación tendría su razón de ser si los cuatro ojos vieran juntos, si las dos cabezas pensaran juntas, no se ven y piensan sucesivamente. Porque entonces la posición del registrador es muy cómoda. Le traen el pastel hecho, y dice: no me gusta, agréguele azúcar, o agréguele una yema de huevo". Fernando LOPEZ DE ZAVALIA, Curso introductorio..., ob. cit., págs. 77-78.

796 "No desconoce el tribunal que la calificación registral es distinta de la que realiza el funcionario autor del documento, ya que esta última tiene al notario interviniente autorizando el acto en el limitado ámbito de las partes. La calificación registral -mientras tanto- se extiende hacia aspectos fundamentales de las constancias del propio registro, a efectos del tracto sucesivo y de las prohibiciones o limitaciones del derecho del disponente. Pero esto no significa que el registrador pueda volver hacia los mismos aspectos que el notario ya calificó en ejercicio de su potestad calificante”. CNCiv., Sala I, 22/04/2010, D 'Alessio, Carlos Marcelo v. Registro de la Propiedad Inmueble, en Cristina Noemí ARMELLA (Dir.) y Mariano ESPER (Inv.), Summa notarial, Registral e inmobiliaria, t ${ }^{\circ}$ IV, Abeledo Perrot- UNA, Buenos Aires, 2.013, p. 5625. 


\section{LOS EFECTOS DE LA PUBLICIDAD EN EL DOCUMENTO NOTARIAL}

vuelven una función valorable, pero no debe dejar de notarse que la misma siempre llega a configurarse, parafraseando a López de Zavalía, después que todo ha sido ya previamente elaborado. Por ello no creo acertada las posiciones esgrimidas por Chico y Ortíz o Andorno, que consideran a la función de calificación registral como una función creadora ${ }^{797}$. No hay creación ni puede haberla sobre el documento elaborado, suscripto y consolidado; en todo caso, la importancia de la función de calificación registral radica en la de ser una función de contralor, como bien se ha advertido $^{798}$, de ennoblecimiento del documento si se me permite la expresión, teniendo en cuenta las acepciones que brinda la Real Academia Española de Letras. Indubitadamente debe de estar el registrador preparado científica y técnicamente para coadyuvar a que la tarea primera de calificación que hiciera el notario cumpla con la finalidad inscriptoria. La determinación de lo justo para las partes; lo justo negocial, corresponde únicamente al notario, y por esta razón, considerar que el documento carece de aspectos jurídicos sustanciales y no meramente formales, conforma un exceso en una tarea que es exclusivamente de control.

En relación a lo antedicho, Aída Kemelmajer de Carlucci enseña: "La calificación es una tarea de control (esto nadie lo puede dudar) que opera a la manera de un tamiz (algunos títulos se quedarán y otros pasarán) que impide el acceso al registro de títulos cuya publicidad se opone algún obstáculo ${ }^{799 " .}$. Desde allí es que se destaque la necesidad de evitar conflictos que perjudiquen a los particulares por cuanto debe bregarse por tener registros dirigidos por personas de altísima profesionalidad ${ }^{800}$. Para la autora, dentro de las características de la función calificadora, se debe asumir que la misma resulta ser patriarcal ${ }^{801}$. Esto último se justifica porque en

${ }^{797}$ Luis ANDORNO, Publicidad registral. Los principios..., ob. cit., ps. 24-25; José María CHICO Y ORTIZ, Teoría, práctica y fórmula ..., ob. cit., p. 66.

${ }^{798}$ Cfr. Saúl F. GUZMÁN FARFÁN, Derecho notarial y registros públicos, ColorgrafRodríguez, Cochabamba, 2.000, p. 416.

${ }^{799}$ Cfr. Aida KEMELMAJER DE CARLUCCI, Calificación Registral de instrumentos de Origen judicial, ob. cit., p. 35.

${ }^{800}$ Ídem, p. 36.

${ }^{801}$ Ibídem, p. 38. Marcando la diferencia existente con la función judicial, expresa la autora: "cuando presentamos un escrito judicial que no corresponde...el juez dice "por improcedente, no ha lugar"...; del Registrador, se espera, que como un buen padre nos diga que es lo que a ese título le falta y de qué manera podemos subsanar el problema. Por 


\section{SEBASTIÁN JUSTO COSOLA}

definitiva, esa función es la clave para alcanzar a comprender la naturaleza de la calificación registral. El Registro de la Propiedad es una institución administrativa, que debe encargarse de prestar un servicio público consistente únicamente en brindar publicidad oficial sobre el estado jurídico de la propiedad ${ }^{802}$. Por ello inclusive parte de su actividad está destinada a hacer docencia acerca de las reglas registrales, y siempre teniendo en cuenta, que la calificación registral no es de ninguna manera una actividad que se enmarque dentro de la función jurisdiccional, ni por lo tanto causa la misma cosa juzgada, porque además, carece de conflicto ${ }^{803}$. La misma es una actividad que forma parte de la función pública, pero de una naturaleza que excede los alcances de la función eminentemente administrativa, porque además del control se encuentra frente a la tutela de los intereses privados, teniendo como fin alcanzar la seguridad jurídica de los derechos reales inmobiliarios mediante la proclamación pública de los derechos privados acreditados como legítimos ${ }^{804}$. Quizás por esta razón, autores como el mencionado Chico y Ortiz concluyan en que la actuación del registrador al momento de calificar es una actuación especial, que tiene y guardo contacto con la actividad jurisdiccional, administrativa y con la denominada jurisdicción voluntaria, pero que la misma presenta caracteres propios ocupando lugares especiales ${ }^{805}$.

En definitiva, con lo expuesto hasta aquí se encuentra absolutamente comprobado que ambas funciones de calificación se encuentran delimitadas tanto funcional como temporalmente. $\mathrm{Y}$ es por esta razón que pienso que mientras que el notario argumenta el registrador interpreta. Tal como lo he adelantado en el inicio del presente capitulo, pienso que la tarea de argumentación implica una tarea de intelección del caso, para luego proceder la deducción de las normas, las reglas y los principios implicados

ejemplo dirá "falta el plano", "falta el asentimiento conyugal". El registrador debe detallar las razones por las que no inscribe, para que el interesado sepa como presentar el título la próxima vez, de modo tal que se pueda inscribir".

${ }^{802}$ Bernardo PÉREZ FERNÁNDEZ DEL CASTILLO, Derecho registral, ob. cit., p. 61.

${ }^{803}$ Cfr. Gilberto MENDOZA DEL MAESTRO, Responsabilidad civil del registrador público, Gaceta Notarial, Lima, Perú, 2.011, p. 124.

${ }^{804}$ Ibídem, p. 125.

${ }^{805}$ José María CHICO Y ORTIZ, Teoría, práctica y fórmula de la calificación registral, ob. cit., p. 60. 
LOS EFECTOS DE LA PUBLICIDAD EN EL DOCUMENTO NOTARIAL

en lo que el notario tiene que aplicar respetando la voluntad, en el marco de la fe y con los efectos propios esgrimidos por la seguridad. La argumentación notarial del derecho se consolida en la teoría de los valores que se relacionan proyectando el contenido del documento, según tendré ocasión de demostrar. Por el contrario, la tarea del registrador es una tarea interpretativa; la misma consiste en desentrañar el sentido del documento, aplicando la observación y en todo caso, dando por cumplidos ciertos hechos que son para el absolutamente incomprobables porque derivan de lo escrito en el documento y que ya es un hecho del pasado (por ejemplo la declaración de la posesión). En sede registral la declaración de la posesión y con ella, de la tradición recibida funciona como lo que es: una declaración. En sede notarial los efectos son diferentes, porque esa declaración, según tendré ocasión de demostrar, funciona como una confesión.

\subsubsection{Los problemas que no observamos de la disputa por el} alcance de cada calificación ${ }^{806}$.

Fuera de todo lo antes referido, pienso que el problema de la cuestión acerca del alcance, método y control de las calificaciones notariales y registrales se genera únicamente en el ámbito de la política institucional. Es que los términos y argumentos -no solo a la luz de las prerrogativas de cada institución- sino desde su presentación como un método conceptual, empírico y comparativo, son bastante claros y precisos, no necesitan de mayor justificación que la propia que surge de la ley y de la interpretación de los principios del derecho. Así, funciona perfectamente la función notarial de calificación de acuerdo a la ley y de acuerdo al derecho, y también funciona la calificación registral como medio de control de las formas extrínsecas. No se trata de analizar las incumbencias que se alcanzan a partir de la calificación, sino de admitir que las funciones notariales y registrales

\footnotetext{
${ }^{806}$ Cfr. Mariano COSTANZO y Sebastián Justo COSOLA, La inexactitud registral a partir del significado de calificación. Premisas normativas y principistas para la determinación de la naturaleza y solución del conflicto, $29^{\circ}$ Jornada Notarial Argentina, $\mathrm{t}^{\circ}$ I, FEN, La Plata, 2.010, págs. 117-148.
} 


\section{SEBASTIÁN JUSTO COSOLA}

son diferentes, que -al menos en este sentido- nada tienen que ver la una con la otra, y es por ello que tanto la calificación que ofrece el notario -incluso también el juez- son notoriamente diferentes a la que ofrece el registrador.

Es que ya no debe resultar relevante el análisis de las diferencias estructurales de ambas tareas, de ambas funciones, si una es más importante que la otra, o si realmente una de ellas es esencial y sirve de punto de partida de la otra o viceversa ${ }^{807}$; por ello que a la hora de establecer criterios contundentes en torno al alcance de la calificación notarial y de la calificación registral, estimo que lo bueno, lo interesante y lo positivo solamente podría construirse sobre la base de una propuesta sumamente alentadora, que sepa distinguir y a su vez entrelazar temporalmente ambas funciones; que pueda delimitar el alcance de cada una, persiguiendo por siempre la unión de ambas instituciones representadas por profesionales del derecho, siempre en esfuerzo común orientado exclusivamente en la búsqueda de alcanzar el autoabastecimiento pleno de las necesidades sociales.

De aquí entonces es que sea oportuno que nos preguntemos: ¿Qué bien se pretende tutelar a partir de la calificación? Sin duda alguna, tanto notarios como registradores proponen una tutela efectiva al sistema de intercambio de bienes a partir de una potenciación de la seguridad jurídica. Los fines se unen en este aspecto, precisamente porque ambas tareas están destinadas a brindar seguridad ${ }^{808}$. Cualquier institución de la república democrática se vuelve plena cuando cumple su cometido, que es la obtención de una acreditada representación a partir de dos premisas fundamentales: una proyección social de excelencia y un eficiente control del ejercicio profesional/funcional de los matriculados. Si esto se advirtiera, no habría mayores problemas a la hora de realizar aportes de envergadura que consoliden ambas tareas dentro de lo que a cada profesional o institución corresponde.

\footnotetext{
${ }^{807}$ La temática, como resulta lógico, lejos de ser de importancia nacional, se verá reflejada en otras jurisdicciones estaduales a nivel dualista.

${ }^{808} \mathrm{Si}$ en cambio, se plantea la controversia cuando se pretenden determinar los alcances de la calificación, lo que genera una reacción de los cuerpos institucionales que se esmeran por defender las incumbencias desde las políticas propias y específicas desde posiciones criticables tanto jurídica como moralmente. Una vez más se impone el deber de insistir en lo desacertado de los caminos elegidos.
} 
LOS EFECTOS DE LA PUBLICIDAD EN EL DOCUMENTO NOTARIAL

\subsubsection{Punto de acuerdo acerca de las calificaciones (desde la} noción de seguridad jurídica).

Se visualiza la máxima virtud del sistema inmobiliario argentino desde dos vertientes diferentes pero que se justifican en igual grado de importancia:

a) La voluntad de las partes que reconocen una causa (fin) en sus proyecciones;

b) La calificación que realiza tanto un funcionario (juez) como un profesional del derecho en ejercicio de una función pública (notario), de ese fin determinante, adecuándola in extremis al principio de legalidad.

Dado que las partes pueden querer realizar sus proyecciones a partir de esquemas poco claros, confusos o en circunstancias, contrarios al orden jurídico, es deber del jurista el de adecuar esas voluntades de acuerdo al derecho actual imbuido de principios, con los alcances antes justificados, aun en reconocimiento de sus ventajas, riesgos y prevenciones ${ }^{809}$. Este hecho fáctico ocurre así, naturalmente. No es un capricho institucional. En este sentido, únicamente los jueces y los notarios tienen la posibilidad de adecuar esas voluntades al derecho, porque solo ellos quienes tienen las posibilidades de las instancias, de las audiencias, de las consultas antes de que un hecho le importe al derecho. Son además, quienes tienen la opción de saber la verdad de los acontecimientos antes o después de que sean o hayan sido realizados, y por eso se acrecienta su responsabilidad y su deber de obrar con prudencia. De ahí que sea acertado referir a una calificación judicial y una calificación notarial de títulos y documentos. Se complementan los institutos mencionados con un sistema especial de protección que presenta un registro

${ }^{809}$ Cfr. Rodolfo Luis VIGO, Constitucionalización y neoconstitucionalismo: Riesgos y prevenciones, Acerbo de la Biblioteca Jurídica Virtual del Instituto de Investigaciones jurídicas de la Universidad Nacional Autónoma de México, en www.juridicas.unam.mx 


\section{SEBASTIÁN JUSTO COSOLA}

único de la propiedad local que tiende a resguardar los derechos adquiridos a partir de la publicidad de las acciones realizadas por los hombres y las mujeres libres.

Posicionados en la actividad notarial, debe argumentarse que del ejercicio de la función notarial, con la aplicación especial de los deberes éticos notariales aplicados de información, asesoramiento consejo, imparcialidad, independencia y legalidad integrada, emerge el instrumento público que, en los documentos destinados a consolidar formalmente el dominio, tiene dos destinos:

a) El registro de la propiedad en primer lugar y

b) El de conservación de las matrices antes, durante y luego de haberse inscripto el testimonio.

La creación del instrumento público se encuentra lógicamente circunscripto a normas legales que cuidan en esencia, la forma exigida por el derecho para determinado tipo de actos solemnes. Pero esas normas están destinadas únicamente a establecer exigencias de tipo mínimo para que ese producto documentado tenga la consideración de un instrumento público ${ }^{810}$. Pero de ninguna manera afectan la libertad creativa de los otorgantes que guiados por el notario intentan alcanzar sus finalidades personales ${ }^{811}$. En fin, de lo que se intenta es de alcanzar la realización del valor justicia como fin de toda disposición u ordenación jurídica, a través del respeto absoluto de las normas delimitadoras de la autonomía de la voluntad, que se cubren a través de la aplicación notarial de un mínimo formal que asegure su trascendencia ${ }^{812}$.

De ahí que se sostenga con acierto que toda la realización del negocio jurídico desde su génesis hasta su concreción calificada y autenticada queda fuera del ámbito funcional del registro, y es parte de la calificación notarial; por ello el documento cronológicamente es obra anterior a la tarea registral, razón que justifica y comprueba que en el sistema notarial de tipo latino el registro únicamente reconoce eficacia convalidatoria a los documentos en

\footnotetext{
${ }^{810}$ Juan Berchmans VALLET DE GOYTISOLO, Seguridad jurídica estática y seguridad jurídica dinámica, ob. cit., p. 216.

${ }_{811}$ Ibídem, p. 217.

${ }^{812}$ Ibídem.
} 
favor de los terceros de buena fe y a titulo oneroso ${ }^{813}$. De aquí que, como ya he referido, se afirme que con el Registro de la Propiedad se encuentra salvaguardada la seguridad jurídica dinámica ${ }^{814}$, la que será efectiva si se concreta sobre la exactitud del título y la adecuada conformación del derecho en el documento, teniendo en cuenta la voluntad de las partes y el control y aplicación notarial del deber integrado de legalidad.

La calificación registral entonces, no es ni más ni menos que una actividad destinada a confirmar que el documento que se califica está de acuerdo con la $l e y^{815}$, y ello con todos los complementos por mí sustanciados con anterioridad. Desde esta posición entonces, el cierre le pertenece al inolvidable Vallet: "Por eso, para que un registro este verdaderamente al servicio de la plena seguridad jurídica, debe ser un registro de títulos auténticos, y de títulos auténticos válidos, que incorporen fielmente negocios jurídicos justos y bien configurados ${ }^{816 " .}$

\subsubsection{Registro inmobiliario, publicidad y calificación registral:}

\section{fin instrumental declarativo al servicio de la justicia.}

Se vuelve oportuno que en el epílogo del presente capítulo pueda destacarse con énfasis cual es la función primordial del registro inmobiliario y cuál es la finalidad que éste persigue a través de la proyección de la publicidad, resultado directo de la calificación registral. Todo esto debe hacerse con el máximo de objetividad, y precisamente por ser un tema tan influenciado por la cuestión política, la respuesta argumentativa debe llegar amparada de la verdad.

El notariado y el registro encuentran precisamente su fuerza en el estudio de los fundamentos que en algún tiempo, les permitieron nacer y consolidarse como instituciones indispensables que sirven a que la sociedad pueda realizar y continuar su infinito acontecer. Existen fundamentos para

\footnotetext{
${ }^{813}$ Ibídem, p. 218.

${ }^{814}$ Ibídem, p. 219.

${ }^{815}$ Cfr. Lucila ORTIZ de DI MARTINO, Manual de Derecho Registral, ob. cit., p. 67.

${ }^{816}$ Juan Berchmans VALLET DE GOYTISOLO, Seguridad jurídica estática y seguridad jurídica dinámica, ob. cit., p. 220-221.
} 


\section{SEBASTIÁN JUSTO COSOLA}

comprender porque las instituciones perduran en el tiempo, y a ellos tenemos que acudir para encontrar en el caso, la función registral de publicidad, ya que en referencia a la institución notarial, cuento con una opinión formada al respecto, la que en cierta forma he podido proyectar - tan siquiera parcialmente- en las líneas antecedentes ${ }^{817}$.

El registro inmobiliario es uno de los más grandes adelantos de técnica jurídica, que persigue como finalidad esencial que toda propiedad inmueble se encuentre debidamente inscripta, que cada finca tenga su número correlativo en los libros registrales, para que haya efectivamente un perfecto paralelismo entre el registro y la realidad ${ }^{818}$. Sin embargo, en el transcurso de los dos últimos siglos, a medida que se fue atenuando la publicidad de la tradición con origen en el derecho romano y esencialmente por causas demográficas, el Registro pretendió extenderse mucho más allá de lo que reclamaban las necesidades que provocaron su existencia ${ }^{819}$. A tal fin, se intentó eliminar la tradición para que la inscripción sea el único medio de publicidad $^{820}$. Casi al mismo tiempo, la propiedad inmobiliaria pasa a conformar parte esencial del sistema capitalista, lanzándose los inmuebles $a$ la voracidad de la usura y especulación ${ }^{821}$. Todas las condiciones entonces estaban dadas para que la inscripción sustituyera a la referida tradición.

En nuestro país, esta situación viene siendo estudiada al menos desde que a fines del siglo XIX se haya por vez primera planteado la posibilidad de agregar un último artículo al entonces vigente Código Civil de Vélez que estableciera que en todos los casos en que en ese código se exija la tradición en la constitución o transmisión de derechos reales sobre inmuebles, la misma solamente se juzgará hecha mediante la inscripción de los instrumentos respectivos en el Registro de la Propiedad ${ }^{822}$. Desde allí hasta el presente, diversos proyectos han intentado lo mismo: sustituir el sistema

\footnotetext{
${ }^{817}$ Sebastián Justo COSOLA, Fundamentos del derecho notarial..., ob. cit. En Perú: La prudencia notarial, Gaceta Notarial, Lima, 2.014.

${ }^{818}$ Juan Berchmans VALLET DE GOYTISOLO, La buena fe, la inscripción y la posesión en la mecánica de la fe pública, en Estudios sobre derecho de cosas, ob. cit., p. 327.

${ }^{819}$ Ibídem, p. 331.

${ }^{820}$ Ibídem, p. 332.

${ }^{821}$ Ibídem.

${ }^{822}$ Ricardo Luis LORENZETTI, Elena Inés HIGHTON y Aída KEMELMAJER DE CARLUCCI, Código Civil y Comercial de la Nación, Proyecto del Poder Ejecutivo de la Nación redactado por la comisión de reformas..., ob. cit. p. 679.
} 


\section{LOS EFECTOS DE LA PUBLICIDAD EN EL DOCUMENTO NOTARIAL}

traditivo por el sistema inscriptorio, en alusión, más o menos similar, de lo antes afirmado: la protección y la seguridad del tercer adquirente, siempre de buena fe (seguridad jurídica dinámica) $)^{823}$.

De todas las diferentes exposiciones de fundamentos que oportunamente se han elevado a las autoridades con el objeto de modificar al hoy histórico Código Civil, debe destacarse con firmeza la que efectuara el Instituto de Derecho Civil del Ministerio de Justicia de La Nación, entonces a cargo de Jorge Joaquín Llambias. De la parte pertinente de las argumentaciones esgrimidas, y en defensa del método inscriptorio (sin acto abstracto, reconociendo al contrato como causa fundacional del derecho del transmitente), puede leerse lo siguiente: "La publicidad equívoca y rudimentaria que significa la tradición, unida a la regla del artículo 3270 del código vigente y sus numerosas aplicaciones concretas, debe ser abandonada para obtener una adecuada firmeza y seguridad en el régimen inmobiliario $^{824 "}$.

Así se llega a la solución que se brinda en la trascendente reforma del año mil novecientos sesenta y ocho, donde se confirma que la transmisión de los derechos reales sobre inmuebles únicamente se juzgará perfeccionada mediante la inscripción de los títulos en el Registro, pero sin alternar la estructura de los derechos reales sobre inmuebles, que hacen consolidar el derecho de dominio a través del título suficiente (titulo notarial) y del modo suficiente (tradición). Tal cual oportunamente lo expresara Miguel Falbo casi en sintonía con la publicación de la reforma: “(...) el grado de perfección que se obtiene con la inscripción de los títulos en los registros, es conferirles publicidad para su oponibilidad a terceros, pero no agrega ninguna perfección ni aumenta la eficacia con relación a los sujetos titulares del derecho real ${ }^{825}$ ".

La inscripción entonces, perfecciona la mencionada transmisión, por cuanto favorece a los terceros de buena fe en la publicidad noticia que pueden llegar a tener al momento de acceder al registro con acreditado interés legítimo,

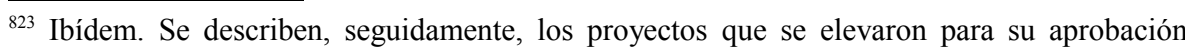
desde 1899 a los tiempos actuales.

${ }^{824}$ Ibídem, p. 680.

${ }^{825}$ Cfr. Miguel Norberto FALBO, Las reformas al código civil y su significación con relación a la función notarial, COLESCBA, La Plata, 1.968, p. 38.
} 


\section{SEBASTIÁN JUSTO COSOLA}

para saber el estado de una propiedad, y si en definitiva, este se condice o no se condice, por ejemplo, con el dato esgrimido desde la realidad. De aquí entonces es que en nuestro derecho impere, en materia de inmuebles, el régimen registral declarativo, porque precisamente declara el estado del inmueble a través de la incorporación de lo que emerge del documento notarial, pero que no se erige como modo suficiente para conformar el derecho real de dominio (régimen constitutivo).

El Código Civil y Comercial de La Nación mantiene el régimen actual, por el cual los derechos reales se adquieren, se transmiten o se extinguen según he bosquejado en el primer capítulo de la presente tesis, a través de la teoría del título suficiente (contrato causal + escritura pública) y modo suficiente (tradición efectiva). Y se establece, para ciertos casos determinados y específicos (similares a los actuales) la inscripción de tipo constitutiva, como en el caso de los automotores -con normas y leyes especiales ${ }^{826}$-. Acerca de esto último, siempre es bueno recordar que la inscripción es constitutiva cuando es requisito necesario, sine qua non para que se produzca la transmisión del dominio ${ }^{827}$. Esto significa que el Registro interviene como elemento esencial para que la transmisión efectivamente se considere realizada $^{828}$. Como lo explica Aída Kemelmajer, casi como si fuera un principio: sin inscripción registral, como elemento intrínseco que hace existente el derecho real, no hay transmisión ${ }^{829}$.

Desde aquí entonces es que puede concluirse, que tanto en el régimen velezano como en el actual, la publicidad suficiente puede considerarse desde la tradición seguida de la posesión, reflejada en el documento, o desde la inscripción registral con los alcances que correspondan. Frente a los terceros adquirentes de buena fe, la publicidad registral actúa como una causa justa; causa que protege a quienes de buena fe acceden a la base registral para realizar actos jurídicos o simplemente para obtener información. Los nuevos alcances de la buena fe contractual remiten a

\footnotetext{
826 Ricardo Luis LORENZETTI, Elena Inés HIGHTON y Aída KEMELMAJER DE CARLUCCI, Código Civil y Comercial de la Nación..., ob. cit., p. 681.

827 Aída KEMELMAJER de CARLUCCI, La calificación registral en materia de automotores (Diferencias con el sistema inmobiliario), ob. cit., p. 23.

${ }^{828}$ Ibídem.

${ }^{829}$ Ibídem.
} 
LOS EFECTOS DE LA PUBLICIDAD EN EL DOCUMENTO NOTARIAL

considerar, según surge de la propia norma, los alcances en que razonablemente se habría obligado un contratante cuidadoso y previsor. $\mathrm{Si}$ los derechos se suponen ejercidos de buena fe, en materia de derechos contractuales y reales para el derecho vigente actual, además deben suponer una cierta diligencia ${ }^{830}$. Precisamente para ello se encuentra previsto desde siempre y mucho mas, en los tiempos actuales, el principio de publicidad registral. Eso justifica entre otras cosas, ciertas actividades que en el ejercicio práctico se realizan de manera habitual y permanente; así, en la conformación de un derecho personal como el boleto de compraventa, no existe cumplimiento de la obligación sin antes tener la información registral del estado de los bienes inmuebles que se transmiten. El estudio de los títulos antecedentes, la proyección de las medidas precautorias con anterioridad y las que emergen de los certificados administrativos, que entre otras cuestiones vienen a informar la vigencia de obligaciones propter rem otrora incumplidas, son todas acciones tendientes a consolidar la buena fe diligencia del adquirente, que hoy conforman el verdadero valor y sentido de la publicidad registral.

\subsubsection{El desarrollo de la función notarial en el momento donde} opera la transmisión del dominio y el necesario complemento registral.

De acuerdo a todo lo antedicho, puede afirmarse que tanto posesión como la inscripción son apariencias legitimadoras de publicidad formal ${ }^{831}$. Sin embargo, al estudiar la tradición, se advierte con que la misma es una institución que a través de la historia jurídica ha intentado desde siempre dar tanto efectividad como publicidad a la transmisión ${ }^{832}$. En nuestro país se ha coincidido con las mencionadas apreciaciones ${ }^{833}$. Todo esto sin dejar de recordar que para nuestros sistemas, la tradición compone un sistema

\footnotetext{
${ }^{830}$ Conf. Arts. 9 y 961 CCCN.

${ }^{831}$ Juan Berchmans VALLET DE GOYTISOLO, La buena fe, la inscripción y la posesión en la mecánica de la fe pública, ob. cit., p. 338.

${ }^{832}$ Ibídem, p. 349.

${ }^{833}$ Marta E. FAZIO de BELLO, Actos jurídicos y documentos inscribibles, ob. cit., p. 112.
} 


\section{SEBASTIÁN JUSTO COSOLA}

vertebral constitutivo condicionante de los derechos reales ${ }^{834}$. De esas dos vertientes, Vallet opta por escoger como preponderante - y junto a la más autorizada doctrina española- a la forma natural del contrato transmisivo, a la efectividad en el dar y recibir el cuerpo mismo de la $\cos a^{835}$. Y ahí mismo, se pregunta: “¿Cómo, pues, puede la inscripción ser la forma más adecuada para hacer efectiva la adquisición? Podrá ser una más, entre tantas formas ficticias, pero jamás podrá eliminar a las demás, y deberá inclinarse siempre ante la superioridad de la entrega efectiva del señorio. La ficción puede auxiliar a la realidad, pero nunca eliminarla ni borrarla ${ }^{836}$ ".

En este delicado tema, hay que tener en cuenta ciertas circunstancias que ocurren habitual y cotidianamente en el momento mismo en donde opera la transmisión del dominio de un inmueble, que es el momento en donde se suscribe la escritura pública frente a un notario que presencia el acto, que da lectura y que autoriza la misma a través del imperio de la dación de fe. Es un momento especial, donde las voluntades de las partes -comprendidas como causas-, se entrelazan unas a otras de la mejor forma y manera posible en el convencimiento de que el acto al que asisten, el que oyen por la lectura notarial, el que se encuentra ya instrumentado listo para ser suscripto por las mismas, es producto de una elaboración notarial del derecho que se ha esmerado por reflejar la voluntad querida y esperada (justicia), en el marco de la ley y del derecho (legalidad integrada), que goza de fe (certeza) sobre lo que realmente ha ocurrido (verdad) para que los efectos dañosos no perturben el documento desde ese momento y hacia el futuro (seguridad jurídica). El hecho físico de la firma frente al notario -tanto en su faz interna como externa- no es un dato menor, y mucho menos la recepción de las llaves o la conformidad de la declaración de entrega de la posesión leída y asentida por los requirentes -en general, mientras el transmitente declara que entrega la posesión, el adquirente declara que la recibe y que la acepta-, siempre recordando que el acto viciado por violencia o fraude, simulación o lesión, no tiene cabida en sede notarial, porque frente a él es deber ético

\footnotetext{
${ }^{834}$ Élida Sara ARDISSONI, Tradición de bienes inmuebles y muebles registrables, ob. cit., $\mathrm{p}$. 25 .

${ }^{835}$ Juan Berchmans VALLET DE GOYTISOLO, La buena fe, la inscripción y la posesión en la mecánica de la fe pública, ob. cit., p. 350.

${ }^{836}$ Ibídem.
} 


\section{LOS EFECTOS DE LA PUBLICIDAD EN EL DOCUMENTO NOTARIAL}

inexcusable el de independencia, que impone al mismo tanto el abstenerse como el apartarse.

En este sentido, existen autores que destacan con razón suficiente y sentido coherente que los efectos de la transmisión inmobiliaria son eficaces cuando son realizados por sujetos capaces, mediante actos materiales y existiendo posesión vacua, sin contradictores ${ }^{837}$. En razón de los efectos materiales, se refieren a la entrega de llaves, y allí advierten que al realizarse la misma en presencia del notario autorizante la misma adquiriría los efectos probatorios propios de la fe pública ${ }^{838}$. En cierta manera, se quiere con esto argumentar una posición que conduce al conflicto con aquellos que opinan, en sintonía con el derogado artículo 2378 del Código de Vélez, que la sola declaración del tradente de darse por desposeído o de dar al adquirente la posesión no suple las formas legales ${ }^{839}$.

La solución quizás provenga de la pluma de Salvat, cuando en torno a este tema, advertía que al menos las declaraciones de las partes tienen la prueba de la confesión ${ }^{840}$. Es que en definitiva, como recientemente lo expone Rodolfo Vigo con toda claridad, “... hay hechos de la vida humana que el derecho y los juristas siempre han asumido en el ámbito de su competencia, y que no pueden dejar de hacerlo si pretenden ser reconocidos como tales y se proponen la subsistencia de la vida social ${ }^{841}$ ". Participo de éste último criterio, y aun teniendo en cuenta que los efectos de la confesión solo hacen frente a los reclamos entre partes y no frente a potenciales terceros interesados $^{842}$. En este tema tan particular, la investigación realizada me obligada a intentar consolidar los criterios desde otros enfoques que permiten advertir que hoy, más que en ninguna otra época en la historia, el

\footnotetext{
${ }^{837}$ Marcelo Eduardo URBANEJA, Tradición ..., ob. cit., p. 768.

${ }^{838}$ Ibídem.

${ }^{839}$ Ibídem, p. 769.

${ }^{840}$ Ibídem.

${ }^{841}$ Cfr. Rodolfo Luis VIGO, Interpretación (Argumentación) jurídica en el Estado de Derecho Constitucional, Rubinzal Culzoni, Santa Fe, 2.015, p. 162.

${ }^{842}$ Norma Elena CIURO DE CASTELLO y Laura GARATE (Compil.), Jornada Notarial Bonaerense. Colegio de Escribanos de la Provincia de Buenos Aires, ob. cit., p. 234. Allí se refiere el siguiente despacho: "Que no obstante el carácter de acto jurídico formal de la tradición, la manifestación en la escritura de que la tradición existió, implica prueba de confesión de quien se desprendió de la cosa a favor del accipiens que tiene plena eficacia entre las partes, creando una presunción iuris tantum de su veracidad".
} 
derecho es como ya he adelantado, una disciplina que oscila entre el amor y la fuerza, que se ejerce con poder, y que se interpreta de manera multicultural.

\subsubsection{Las declaraciones de las partes en el documento y la prueba} de confesión.

Impacta gratamente el aporte del genial Michel Foucault en relación al tema de las declaraciones y de las confesiones ${ }^{843}$. Si bien la idea de confesión remite a considerar un tipo de declaración escrita $\mathrm{u}$ oral mediante la cual alguien reconoce haber dicho o haber hecho algo, lo cierto es que la sola declaración no basta para constituir una confesión ${ }^{844}$. Lo que marca la diferencia entre una declaración y una confesión es lo que se denomina costo de enunciación; costo que asumen los individuos que afirman haber realizado hechos o actos en absoluta, total y plena libertad. En palabras del propio Foucault: "En sentido estricto la única confesión que puede haber es la confesión libre ${ }^{845 ",}$

El tema de la confesión ha sido determinante en el estudio del derecho procesal, y por ello en obras consolidadas de nuestro país pueden estudiarse fácilmente los alcances de la misma, considerada como prueba, dentro del marco del proceso ${ }^{846}$. En ellas se afirma que la confesión es una declaración de ciencia o de conocimiento, de naturaleza procesal, que oficia como medio de prueba ${ }^{847}$. Lógicamente estaré por la afirmativa de trasladar los conceptos citados hacia el ámbito notarial. Los hombres y mujeres que declaran en escritura, absolutamente libres, sin vicios de la voluntad frente a un notario ya no declaran, sino confiesan. Ante la confesión entendida en estos

${ }^{843}$ Cfr. Michel FOUCAULT, Obrar mal, decir la verdad (La función de la confesión en la justicia), Siglo XXI Editores, Buenos Aires, 2.014, p. 24.

${ }^{844}$ Ibídem.

${ }^{845}$ Ibídem, p. 25 y ss.

${ }^{846}$ Cfr. Hernando DEVIS ECHANDÍA, Compendio de la prueba judicial, $\mathrm{t}^{\circ} \mathrm{I}$, Rubinzal Culzoni, Santa Fe, 2000, p. 249 y ss.

${ }^{847}$ Ibídem, p. 283. 
LOS EFECTOS DE LA PUBLICIDAD EN EL DOCUMENTO NOTARIAL

términos, libres de vicios posibles o patentes (dados los vicios el notario se excusa de actuar en razón de los ya referidos deberes éticos de imparcialidad e independencia), no hay más motivaciones para no darle el valor que se merece a la entrega de llaves o demás confesiones frente a un notario que brinda dación de fe.

\subsubsection{Misión de la función calificadora registral (publicidad) y el} aporte de la función notarial.

Los inconvenientes que pueden presentarse a la hora de considerar a la inscripción con el carácter constitutivo de los derechos reales no son menores. Por más profundo que sea el alcance de lo que puede encuadrarse dentro del concepto de función calificadora registral, jamás la misma podrá extender su accionar hacia la constatación de la realización de actos materiales de tradición; de esta manera, podemos hablar de una realidad extra-registral y de una realidad registral; no existiendo un vaso comunicante entre tradición y registro, es posible hoy igualmente, inscribir un título que no constituya un derecho real, aunque le falte la tradición ${ }^{848}$. Esta única situación explica la importancia que reviste la función notarial en el sistema de transmisión de los derechos reales, y su valoración no puede de ninguna manera ser desconocida o ignorada. Es necesario que exista un tutor del documento con las facultades emergentes de la fe que delega el Estado, porque es necesario dotar de certeza y verdad a las transmisiones libres (justas) destinadas a inscribirse (seguridad).

¿Por qué motivo entonces, buscar que el sistema milenario y actual de transmisión sea entonces alternado por el sistema inscriptorio, que por principio general elemental no puede cubrir de mejor manera a cada uno de esos supuestos? Definitivamente, el Registro cumple una acertadísima y necesaria función publicitaria, pero la misma debe ser la que originariamente se le ha impuesto: la de dar publicidad a los hechos jurídicos de transmutación de las fincas o de las propiedades, para que las mismas se

${ }^{848}$ Marta E. FAZIO de BELLO, Actos jurídicos y documentos inscribibles, ob. cit., p. 172. 


\section{SEBASTIÁN JUSTO COSOLA}

adecuen, de a poco y en orden, a la realidad que opera fuera del registro y hoy, además, como fuente de información para el ejercicio del derecho diligente y adecuado. Para ello es necesario remarcar que el Registro de la Propiedad es una institución necesaria, útil para el propietario, útil para el adquirente de buena $\mathrm{fe}^{849}$, y en nuestro país, mucho más teniendo en cuenta la reserva de prioridad, que permite que las operaciones sean seguras y efectivas, en todo el mayor esplendor que sea posible. Así, también el Registro es útil para el interés nacional y para el interés social, desde el mismo momento en que sanea la propiedad, aumenta la prosperidad pública, y facilita el conocimiento ${ }^{850}$ (o la posibilidad de conocer). Estos fines -en forma alguna menores o intrascendentes-, son los que tiene el Registro de la Propiedad Inmueble en nuestro medio, y su misión entonces, más clara que nunca, debe configurarse respetando los fundamentos para los cuales fue concebido por la sociedad en su conjunto; aquellos que le sirven de sustento para que en los tiempos actuales, sea una institución avalada y respetada por la comunidad jurídica en general.

De esta manera, si hiciéramos caso a la clasificación antes esbozada de la seguridad jurídica -seguridad estática y seguridad dinámica-, podría argumentarse que la seguridad jurídica dinámica se protege con la actuación publicitaria registral, pero no debe nunca confrontar con la seguridad jurídica estática que es la que legítimamente le pertenece al propietario. La prosperidad nacional no es óbice para que se le otorgue al registro una fuerza excesiva y antinatural, productora de injusticias aun mayores ${ }^{851}$; y así lo refiere Vallet de Goytisolo en posición que enteramente comparto: "No es lícito sacrificar a la especulación el cuidado secular de la tierra. A Dios lo que es de Dios y al César lo que es del César ${ }^{852 " . ~ E n ~ s u m a, ~}$ en España el registro es y será siempre un fin instrumental en el campo del derecho, que está y deberá estar (también por siempre) al servicio de la justicia y subordinado a ella ${ }^{853}$. Al igual que en nuestro país, por cuanto la registración constituye un elemento más que coadyuva a la seguridad

${ }^{849}$ Juan Berchmans VALLET DE GOYTISOLO, La buena fe, la inscripción y la posesión en la mecánica de la fe pública, ob. cit., p 386.

${ }^{850}$ Ibídem, p. 388.

${ }^{851}$ Ibídem.

${ }^{852}$ Ibídem.

${ }^{853}$ Ídem, p. 327. 
jurídica, esta última eficaz para arribar a la justicia, entendida como causa fundamental de todo buen sistema jurídico ${ }^{854}$.

Debo no obstante dejar en claro que otros reconocidos autores han sostenido que el Registro, destinado a brindar publicidad y a informar acerca de la oponibilidad y de la legitimación, alberga la tarea de resguardar a través de los operadores del derecho los valores de justicia -jueces, abogados y procuradores- $\mathrm{y}$ de $p a z$-notarios y registradores ${ }^{855}$. Cierto es que al notariado siempre se ha sido asimilado al valor que lo acerca a la paz, al menos desde que en España, hace ya más de cien años, Monasterio haya advertido, a través de su ensayo referido a la declaración biológica de los derechos en la normalidad, que al notario compete magistralmente el magisterio de este valor. Los demás operadores jurídicos en cambio, han siempre sido asimilados al valor de justicia, como si éste ultimo fuera un valor que puede emerger únicamente de la decisión razonable que pone fin al conflicto o a la controversia.

Estamos en nuestro país en presencia de un nuevo derecho; un derecho que persigue que lo justo sea alcanzado, a través de los principios, y de su valoración como estándares de argumentación. La teoría de la argumentación exige que los todos aquellos que ofician de juristas tengan que tener en cuenta, esencialmente, cuando una ley positiva es de aplicación adecuada, y cuando es de aplicación extremadamente injusta o absurda. Para ello debe recurrirse a su posicionamiento dentro de un esquema que comprenda no sólo lo prescripto, sino lo que da a esa prescripción el valor de derecho; el ámbito, el uso y la costumbre, lo multicultural, lo que se advierte desde el referido prisma constitucional. $\mathrm{Si}$ el derecho es lo justo analógicamente comprendido, si está unido a la justicia de manera absoluta y perpetua, resulta absolutamente ilógico desligar a la función notarial de tan preciado valor. Sin duda alguna, su desvinculación ronda con la insensatez. La posibilidad de concreción de lo justo antes del conflicto es un valor que en las sociedades problematizadas como las nuestras debe defenderse, valorarse e imitarse.

\footnotetext{
${ }^{854}$ Gabriel B. VENTURA, Ley 17.801 ..., ob. cit., p. 27.

${ }^{855}$ Raúl R. GARCIA CONI y Ángel Agustín FRONTINI, Derecho registral aplicado, ob. cit., p. 4.
} 
SEBASTIÁN JUSTO COSOLA

Según intentaré demostrar en los capítulos venideros, sólo se trata de configurar la función notarial creadora del documento adecuadamente, para que pueda apreciarse en su total magnitud y esplendor, y así descubrir, como la misma contribuye a dar valor y vigor, a partir de la certeza y verdad (fe), tanto a la justicia (voluntad) como a la seguridad (previsibilidad). 


\section{PARTE TERCERA}

\section{Los efectos del título notarial.}

\section{Capítulo 7:}

\section{La proyección del documento Notarial.}

\subsection{Introducción al estudio del documento notarial.}

El tratamiento de la teoría general del documento y/o del instrumento viene ocupando un lugar altamente trascendente en el desarrollo académico del derecho notarial tanto en su faz formal como sustantiva. Sin temor puede afirmarse que el análisis del documento conforma la piedra angular del desarrollo de la ciencia notarial. Sobre la creación y elaboración del documento ocurre, incluso para la mayor parte de la doctrina actual, la más importante e incuestionable tarea notarial, porque en definitiva es el documento elaborado de acuerdo a pautas éticas y legales específicas, el que servirá al final como medio de prueba de un prácticamente incuestionable valor probatorio ${ }^{856}$.

Esta orientación del pensamiento alcanza varios fines, que son las que en definitiva conforman el fundamento elemental de esta tesis, y también algunas específicas, de naturaleza eminentemente histórica, originariamente defendidas por el notariado. De esta manera, si resultara cierta la aseveración

${ }^{856}$ Natalio Pedro ETCHEGARAY, Escrituras y Actas, ob. cit.; Rubén A. LAMBER, La escritura pública, ob. cit.; Carlos A. PELOSI, El documento Notarial, Astrea, Buenos Aires, 1.987. 


\section{SEBASTIÁN JUSTO COSOLA}

de Michel Foucault cuando afirmaba que no existe ningún tipo de duda en reconocer que el surgimiento histórico de cada una de las ciencias humanas aconteció en ocasión de un problema, de una exigencia o de un obstáculo teórico o práctico ${ }^{857}$, en el caso notarial se debe remarcar la importancia que para la sociedad en su total comprensión reviste el resguardo auténtico de las verdades ocurridas en su seno ${ }^{858}$.

Lo antedicho no puede dejar de comprenderse armónicamente dentro de la porción de historia que al notariado legítimamente corresponde. Es que sin duda alguna, el notariado es una de las instituciones más antiguas que el hombre ha conocido, y su creación obedece a una necesidad social, de amplia raigambre en los pueblos, de contar con personas que a través de determinado imperium puedan resguardar el paradigma de la siempre referida seguridad jurídica, propia de las naciones que privilegian y resguardan la autonomía de la voluntad por sobre cualquier otro medio de decisión jurídica intervenida o causada. La doctrina en general está de acuerdo con estas apreciaciones ${ }^{859}$.

En razón de ello es que se haya procedido a enseñar que la historia de las diferentes formas primitivas de las convenciones privadas no significa ni implica otra cosa que la historia de los orígenes del notariado ${ }^{860}$. Desde tiempos inmemoriales, el ejercicio del notariado ha tenido, con ciertos y determinados matices, una tarea esencialmente documentadora, pues históricamente y dentro de los profesionales del derecho al escribano le correspondió la función de configurar el instrumento público ${ }^{861}$. Es así que

\footnotetext{
${ }^{857}$ Cfr. Michel FOUCAULT, Las palabras y las cosas (Una arqueología de las ciencias humanas), Siglo XXI Editores, Buenos Aires, 2.012, p. 358.

${ }^{858}$ En palabras de Ignacio Allende: "El documento auténtico y fijativo de los hechos y actos jurídicos configurado por persona idónea fue una preocupación de los gobernantes como consecuencia de una necesidad jurídica: en definitiva fijar y salvaguardar la verdad de los hechos de la deformación, consecuencia del transcurso del tiempo o de la deshonestidad". V. Ignacio M. ALLENDE, La institución notarial y el derecho, Abeledo Perrot, Buenos Aires, 1.969, p. 27.

${ }^{859}$ La doctrina argentina siempre ha encontrado fundamentos justificatorios en los aportes españoles, y la situación también ha sido proporcionalmente inversa. La idea académica de un derecho notarial presenta una fuerza esencial en estos dos países, a los que luego se le sumarían otros hoy absolutamente relevantes, como México y Perú.

${ }^{860}$ José María MENGUAL y MENGUAL, Elementos de derecho notarial, to II-Vol. IIIntroducción y Parte General (Continuación), ob. cit. El autor cita a Michot.

${ }^{861}$ Ignacio M. ALLENDE, ob. cit., p. 92.
} 
LOS EFECTOS DE LA PUBLICIDAD EN EL DOCUMENTO NOTARIAL

desde ésta línea argumentativa, siempre se destacó que el origen fundamental de la función notarial responde a la necesidad social de efectuar una constatación de los hechos para que sobre los mismos, se pueda configurar el elemento de la perpetuidad ${ }^{862}$.

Desde allí y hasta el presente más próximo, los aportes académicos consolidados nos ponen al tanto de una situación que se comprueba sencillamente por la evidencia: a través de los tiempos, los países necesitaron de personas que ejercieran una función de manera saludable y competente, que pudieran centrar su tarea en la redacción gramatical de los documentos que contienen negocios jurídicos adecuados a derecho, para así, poder dotarlos de autenticidad y fuerza probatoria ${ }^{863}$. De esta manera, recordados autores como Otero y Valentín han podido comprobar que los notarios, como magistrados consagrados de manera exclusiva para recoger y sancionar los hechos y relaciones de interés privado en formulaciones solemnes, sean dueños de una verdadera función autorizante instrumental ${ }^{864}$. La función notarial de los últimos cien años ha crecido notablemente. Y pienso que no exageraría ni un gramo a la verdad si en este espacio afirmara que, a partir de las formidables presentaciones de Juan Vallet de Goytisolo referidas a la descripción de la determinación notarial negocial del derecho, el ejercicio profesional dentro del marco de aplicación del derecho notarial sustantivo y formal no deja de proyectar su valor y su trascendencia.

\subsection{Los orígenes científicos y las razones actuales.}

Todo lo antedicho se comprueba desde los estudios históricos acerca del documento que crea el escribano ${ }^{865}$, el notario -o una persona con la misma

${ }^{862}$ Cfr. Eloy ESCOBAR DE LA RIVA, Tratado de derecho notarial, Marfil, Valencia, 1.957, p. 35 .

${ }^{863}$ Juan Berchmans VALLET DE GOYTISOLO, Manuales de metodología jurídica, $\mathrm{t}^{\circ}$ III, ob. cit., p. 231.

${ }^{864}$ Cfr. Julio OTERO Y VALENTÍN, Sistema de la función notarial, Artes Gráficas :: N. Poncell, Barcelona, 1.933, p. 4.

${ }^{865}$ Inclusive estos estudios históricos del documento son absolutamente relevantes para el análisis de la historia de los estados o países miembros de la Unión Internacional del 


\section{SEBASTIÁN JUSTO COSOLA}

función pero designada de forma diversa o diferente ${ }^{866}$-, siempre recordando que en cuestión de designación de quien oficia de fedatario, las cuestiones consuetudinarias regionales tienen una notable influencia ${ }^{867}$. De los mismos se deduce que la doctrina iberoamericana especializada inmejorable e insuperablemente concuerda en que existen pruebas concretas de actuaciones notariales a través del tiempo que han quedado perpetuadas en instrumentos, minerales, objetos materiales, cuero, papel, arcilla, piedra y todo tipo de material cuya composición haga frente a la marcha de los $\operatorname{siglos}^{868}$. La prueba que une el ejercicio de la función con el concepto de documento es absolutamente relevante y no ofrece en la doctrina ningún tipo de duda. Pero la elaboración formal del documento notarial comienza a desarrollarse en la denominada Escuela de Bolonia ${ }^{869}$, sobre los aportes de los glosadores y post glosadores medievales, durante los primeros tiempos del siglo XII d.C $\mathrm{C}^{870}$.

Notariado. A modo de ejemplo, puede citarse en México el muy buen aporte de Fernando TRUEBA BUENFIL y Jorge Claudio IBARROLA MURO, El arte de la memoria notarialLos trabajos y los días de los notarios del Estado de México: 1808-1937, Foem, México, 2.013, $414 \mathrm{p}$. Asimismo, puede leerse también el aporte de Silvia MONDRAGÓN FIESCO, La pluma y el papel (Semblanza histórica del notariado mexiquense), Foem, México, 2013, $340 \mathrm{p}$.

${ }^{866}$ En una sencilla ojeada retrospectiva, se encuentran las voces escriba, logógrafo, tupsarru, tabelio, tabularii, notarius, escribano y notario, entre otras denominaciones. Es sumamente trascendente en contenido la evolución nominativa notarial, principalmente en Roma, interpretada a través de los diferentes periodos del imperio. A la persona del escriba, con similares y diferentes atribuciones en Roma, se la conocío, entre otras, con las siguientes denominaciones: Notarii, scribal, tabelione, tabularii, schola, chartularii, actuari, librrari, amanuenses, logrographi, refrandarii, cancelarii, diastoleos censuales libelenses, numerarii, scriniarii. comicularii, exceptores, epistolares, consiliarri y congnitores. V. Sebastián Justo COSOLA, Los deberes éticos notariales, ob. cit., p. 55 y ss.

${ }^{867}$ En Argentina se intenta académicamente imponer la voz notario/a, pero eso no se condice con la terminología habitual de los habitantes de nuestro país. Así surge del diccionario del habla de los argentinos, que reconoce las voces escribano/a y escribanía, pero no la de notario/a ni la de notaría. V. Academia Argentina de Letras, Diccionario del habla de los argentinos, La Nación, Buenos Aires, 2.008, p. 329.

${ }^{868}$ Cfr. Roberto Mario ARATA, Estudios para una historia del documento notarial, Colescba, La Plata, 1.980; Eduardo Bautista PONDÉ, Origen e historia del notariado, ob. cit.;; Bernardo PÉREZ FERNANDEZ DEL CASTILLO, Origenes e historia del notariado en México, Porrúa y A.N.N.M, México, 2009; Julio Antonio CUAUHTÉMOC GARCIA AMOR, Historia del derecho notarial, Trillas, México, 2.000.

${ }^{869}$ Eduardo B. PONDÉ, Origen e historia del notariado, ob. cit., p. 151 y ss.

${ }^{870}$ Ver especialmente el ensayo de Rafael NUÑEZ LAGOS, El documento Medieval y Rolandino, Edic. UNA, La Plata, 1.968. En absoluta sintonía, los autores concuerdan en que 


\section{LOS EFECTOS DE LA PUBLICIDAD EN EL DOCUMENTO NOTARIAL}

Mucho más cerca de los tiempos en lo que vivimos, se reconoce en España a Rafael Núñez Lagos como el encargado de dar inicio formal al desarrollo cientifico del derecho notarial tal cual hoy lo conocemos, desde una sólida base legal planteada a instancias de la teoría documental ${ }^{871}$, situación que según he referido, confirmaría mucho más profundamente Juan Vallet de Goytisolo, desde la metodología de la determinación del derecho ${ }^{872}$. En nuestro país, el reflejo de la teoría inicial lleva impreso el nombre de Carlos Emérito González, que fuera quien formalmente diera inicio al desarrollo del instrumento público como objeto legal destacable de la función notarial, en reconocimiento de que la tarea esencial del escribano tiene como principal misión la de proceder a la estructuración del documento ${ }^{873}$. No nos encontramos tan lejos de estos acontecimientos: me refiero tan sólo a siete décadas atrás del tiempo presente.

Pero existe una razón jurídica relevante que termina por explicar porque para la doctrina general, el momento de creación del documento notarial siempre se encuentra asimilado a los postulados de la ley entendida esta como única fuente válida para el ejercicio funcional. En este sentido, de todas las profesiones o funciones que ofician el derecho, la institución notarial ha sido la que prácticamente ha hecho valer a la ley como única fuente jurídica en su expresión más pura y concreta. El principio de legalidad notarial sobre el documento se concreta a partir del cumplimiento de la ley en cualquiera de sus expresiones. Prácticamente no existen antecedentes relevantes que permitan hacer inferir que el notario ha recurrido, en el momento de creación del documento, al auxilio de otras fuentes auxiliares del derecho que no sea la ley escrita válida y vigente. La ley positiva, sea como fuere su incidencia

el derecho notarial sustantivo y formal, tal cual nosotros hoy lo conocemos, comienza por estas épocas a desarrollarse y a potenciar todo su esplendor documental-instrumental. Cfr. Carlos Enrique BECERRA PALOMINO, El honor de dar fe. Ensayos de Derecho Notarial, Editorial Jurídica del Perú, Lima, 2.015, págs. 31 y ss.

${ }^{871}$ Solía decir el autor: "Los notarios hacemos documentos. Es nuestro oficio. Hablar de documentos debiera ser nuestro gozo. Sin embargo, se habla más del oficio. Y aunque del oficio vivimos, la honra del oficio está en su dignidad de arte" Cfr. Rafael NÚÑEZ LAGOS, Hechos y derechos en el Documento Público, Instituto Nacional de Estudios Jurídicos, Madrid, 1.950, p. 1.

${ }^{872}$ Juan B. VALLET DE GOYTISOLO, Manuales de Metodología Jurídica, $\mathrm{t}^{\circ}$ III, ob. cit., p. 233 y ss.

${ }^{873}$ Carlos E. GONZÁLEZ, Teoría General del Instrumento Público..., ob. cit., p. 22. 
jerárquica, ha sido hasta la fecha la única fuente de consulta al servicio del derecho notarial, inclusive sin distinción alguna de su proyección jerárquica o normativa ${ }^{874}$.

Pero esta situación que hasta nuestros días carecía de relevancia, se proyecta como una de las esenciales para demostrar cual es efectivamente, el verdadero aporte notarial al derecho a través de su creación principal: el documento. La clave en la interpretación de las fuentes del derecho ha cambiado para el jurista actual; ya no se considera a la ley como única fuente formal obligatoria, sino que la misma es tan relevante como otras fuentes que sirven al derecho, comenzando con la primaria, que es la Constitución, con los tratados y los principios y valores que de ella se desprenden.

Para llegar a ello, se me impone presentar un esquema de tratamiento acabado, que termine por explicar las razones actuales de justificación del derecho por parte del notario y su utilización y concreción final proyectada en el documento, lo que permitirá exponer la importancia del documento y de sus valores tanto extrínsecos como intrínsecos, como así también la justificación de su existencia, en los tiempos presentes, con similar estructura a la histórica y con el apoyo de los componentes esenciales que la sustentan.

\subsubsection{Desarrollo de la teoría del documento notarial: incidencias} e influencias de acuerdo al momento histórico de su desarrollo académico.

La teoría general del documento notarial viene siendo extensamente referenciada por la doctrina general tanto nacional como extranjera, desde

\footnotetext{
${ }^{874} \mathrm{Si}$ se atiene al criterio que consolida la inscripción del documento como causa final de su creación, una determinada Disposición Técnico Registral (DTR) puede tener un impacto mayor que el propio derecho de fondo. El problema no se advierte en la utilización del procedimiento notarial de inscripción en base a lo que una norma de inferior jerarquía disponga. La verdadera preocupación radica en utilizarla, para los fines inscriptorios, cuando la misma se encuentra en desacuerdo con las exigencias del derecho de fondo.
} 


\section{LOS EFECTOS DE LA PUBLICIDAD EN EL DOCUMENTO NOTARIAL}

el mismo instante en que el notariado comienza por ser considerado un destacado baluarte para el desarrollo habitual del derecho destinado a resguardar los principios de fe (verdad) y seguridad jurídica preventiva ${ }^{875}$. Los métodos empleados para la argumentación del tema siguen en general, las pautas concretas del derecho privado y sus reminiscencias al derecho público implicado -el acto de dación de fe- y es así que contamos, en la actualidad, con obras consolidadas y de referencia obligatoria que han publicado los más ilustres profesores de todos los tiempos en cualquier formato -ensayos, manuales o tratados-. No importa ni la magnitud ni las correlaciones entre derechos análogos y correspondientes: cualquier obra de derecho notarial argentino o comparado contiene un análisis pormenorizado del documento que confecciona el escribano, y quizás por ello, en épocas del desarrollo del derecho notarial por fuera del ámbito del derecho civil $y$ procesal -coincidente con el notable y persistente desarrollo de las escuelas de pensamiento jurídico explicativas del positivismo- éste haya sido analizado dentro de esa escuela y desde una concepción sistemática del derecho, configurada a partir del análisis de la letra de los códigos y de las leyes especiales, siempre con la firme pretensión de que sean ellas las que conformen el objeto central de estudio de lo que luego se denominaría ciencia del derecho notarial ${ }^{876}$.

\subsection{2. ¿Por qué la búsqueda de un objeto científico como} contenido del derecho notarial?

El desarrollo científico del derecho notarial cobra vigor iniciada la segunda mitad del siglo pasado, ya que antes de ese tiempo las primeras voces se atinaban únicamente a clamar por la libertad notarial como sinónimo de ejercicio profesional independiente ${ }^{877}$. Muchos fueron los factores decisivos

875 Para advertir el desarrollo de la autonomía científica del derecho notarial ver especialmente el ensayo de Carlos A. PELOSI, El derecho notarial como derecho autónomo, en Los anales del notariado argentino, Vol. VII t ${ }^{\circ}$ 2, IACN, Buenos Aires, 1.975, p. 46.

${ }^{876}$ Carlos N. GATTARI, El objeto de la ciencia del derecho notarial, ob. cit.

${ }^{877}$ Cfr. Luis MARTINEZ URRUTIA, Libertad notarial, Palacio del Libro, Buenos Aires, 1.931 , pág. 5 y ss. 


\section{SEBASTIÁN JUSTO COSOLA}

para que esto ocurriera, en donde deben destacarse con verdadero entusiasmo al menos tres de ellos:

a) Las declaraciones de los primeros Congresos Internacionales del Notariado Latino ${ }^{878}$

b) Un desarrollo académico de excelencia iniciado en España ${ }^{879}$ y en la República Argentina ${ }^{880}$, y lo más trascendente: una marcada

${ }^{878}$ Durante el transcurso del Primer CINL, celebrado en Buenos Aires en el año 1.948, se estableció la siguiente declaración: "El notario latino es el profesional del derecho encargado de una función pública consistente en recibir, interpretar y dar forma legal a la voluntad de las partes, redactando los instrumentos adecuados a ese fin y confiriéndoles autenticidad, conservar los originales de estos y expedir copias que den fe de su contenido". Por su parte, una de las conclusiones más trascendentes para el notariado, provienen del Tercer CINL, celebrado en París en el año 1.954: "El derecho notarial, derecho autónomo de la forma, es el conjunto de disposiciones legislativas, reglamentarias, usos, decisiones jurisprudenciales y doctrinas que rigen la función notarial y el instrumento publico notarial". V. Libro Memorias del cincuentenario 1948-1998- Unión internacional del Notariado Latino- XXII Congreso Internacional del Notariado Latino, Buenos Aires, 1.998, Bogotá, Colombia, 1.998, p. 113.

${ }^{879} \mathrm{Al}$ menos siete son las obras esenciales del derecho notarial español de lectura obligatoria: Antonio BELLVER CANO, Principios de régimen notarial comparado, Librería General de Victoriano Suarez, Madrid, no cita año de edición (Aunque se la reconoce editada en la década de 1930); Eloy ESCOBAR DE LA RIVA, Tratado de Derecho Notarial, ob. cit.; Enrique GIMÉNEZ ARNAU, Introducción al derecho notarial, ob. cit.; José GONZÁLEZ PALOMINO y Enrique GIMÉNEZ ARNAU , Instituciones de Derecho Notarial, II Tomos, IER, Madrid, 1.945; José María MENGUAL y MENGUAL, Elementos de derecho notarial, IV Volúmenes, ob. cit.,; Rafael NUÑEZ LAGOS, Estudios de derecho notarial, II Tomos, Instituto de España, Madrid, 1.986, y José María SANAHUJA Y SOLER, Tratado de derecho notarial, II Tomos, ob. cit.; En las mencionadas obras encuentran los más precisos fundamentos para la conformación de los aportes de grandes maestros del derecho notarial contemporáneo, como Juan Berchmans VALLET DE GOYTISOLO, Antonio RODRIGUEZ ADRADOS, Isidoro LORA-TAMAYO RODRIGUEZ y Juan Francisco DELGADO DE MIGUEL entre otros.

${ }^{880}$ Nombro aquí las obras trascendentes del derecho notarial en nuestro país: Carlos Emérito GONZÁLEZ, Teoría General del Instrumento Público (Introducción al derecho notarial argentino y comparado), ob. cit.; Carlos Emérito GONZÁLEZ, Derecho Notarial, ob. cit.; Rufino LARRAUD, Curso de derecho notarial, ob. cit.; José María MUSTAPICH, Tratado de Derecho Notarial, ob. cit.; José Adrián NEGRI, Obras completas, ob. cit.; Argentino I. NERI, Ciencia y arte notarial, IV tomos, Editorial Ideas, Buenos Aires, 1.945; Argentino I. NERI, Tratado teórico y práctico de derecho notarial, ob. cit.; Eduardo Bautista PONDÉ, Origen e historia del notariado, ob. cit.; y Alberto VILLALBA WELSH, El derecho notarial a la luz de la teoría egológica, ob. cit. En las mencionadas obras encuentran los más precisos fundamentos para la conformación de los aportes de los referentes del derecho notarial contemporáneo, como Miguel FALBO, Edgardo SCOTTI, Natalio Pedro ETCHEGARAY, 


\section{LOS EFECTOS DE LA PUBLICIDAD EN EL DOCUMENTO NOTARIAL}

vocación doctrinaria por eternizar para la prosperidad una acertada identidad de ideas y de pensamiento ${ }^{881}$.

c) Los aportes esenciales de juristas de indudable referencia, tres de ellos ajenos a la función notarial: José Castán Tobeñas (tesis de la función notarial creadora de derecho ${ }^{882}$, Francesco Carnelutti (tesis del notario como hombre de buena fe en el mundo del derecho) ${ }^{883}$, Eduardo J. Couture (tesis de la fe pública como contenido introductorio al estudio del derecho notarial) ${ }^{884}$ y Juan Berchmans Vallet de Goytisolo [concreción de una metodología en la determinación notarial del derecho (cavere)].

Sin embargo, no debe pasarse por alto que por aquellos entonces, los académicos en su gran mayoría, se interesaban por alejar del análisis del derecho todo tipo de interpretación que resultara, a fin de cuentas, vaga o ambigua en razón de sus contenidos, o que se fundamentara en paradigmas o

\footnotetext{
Rubén Augusto LAMBER, José Carlos CARMINIO CASTAGNO y Cristina Noemí ARMELLA entre otros.

${ }^{881} \mathrm{Al}$ establecer el Congreso de París el hecho de la existencia del derecho notarial sin objeto científico definido aunque sí teledirigido -el instrumento-, la necesidad instó a los académicos de esos años a intentar fundamentar la nueva rama del derecho. No deben quedar dudas a este respecto, pues no es casualidad que de acuerdo a los años en los que nos ubiquemos, las temáticas y su consecuente desarrollo jurídico hayan sido coincidentes en la mayoría de la doctrina mundial. España entera ve florecer en máxima medida a la teoría general del instrumento público con Enrique Giménez Arnau, casi al mismo tiempo que en la República Argentina el desarrollo lo ocupaba Carlos Emérito Gonzalez. Rafael Nuñez Lagos resaltaba la teoría de la forma, igual que aquí en la Argentina lo hacían Villalba Welsh y Mustapich. Al plantear las problemáticas que aquejaban al notariado de la época en la búsqueda de sus fines, pueden leerse las planteadas por José María Mengual y Mengual en España, que las clasificaba en causas internas propias y externas, entre muchas otras, de la misma manera que aquí en Argentina las planteaba como causas propias y externas, también entre otras, Francisco Cerávolo. En la actualidad, hay más de un centenar de obras de derecho notarial laureadas y reconocidas en los países miembros de la Unión. Muchas de ellas son citadas en esta tesis, como ejemplo de la lucha por el triunfo de las ideas en identidad de pensamiento natural.

${ }^{882}$ Cfr. José CASTAN TOBEÑAS, Función notarial y elaboración notarial del derecho, Reus, Madrid, 1.946.

${ }^{883}$ Francesco CARNELUTTI, La figura jurídica del notariado, ob. cit.

${ }^{884}$ Eduardo J. COUTURE, El concepto de fe pública. Introducción al estudio del Derecho Notarial, ob. cit.
} 


\section{SEBASTIÁN JUSTO COSOLA}

principios -generalmente de origen metafísico- que si bien empezaban nuevamente a consolidarse, eran ampliamente debatidos en el seno de las academias en razón de su confuso alcance, aplicación o concreción ${ }^{885}$. Es que desde Savigny y hasta transcurridos algunos años de la finalización de la segunda guerra mundial, se había instaurado en los foros académicos, en las universidades, y en toda institución dedicada a la enseñanza y comprensión del derecho, la noción del derecho como un sistema jurídico cerrado, esto es, el planteamiento de la disciplina como si ésta fuese un cuerpo inaccesible de normas que cubre todas las lagunas y alcanza la máxima completitud, autoabasteciéndose a sí mismo. Así comienza por considerarse la noción de sistema y de sistematización del derecho ${ }^{886}$.

Sin lugar a dudas, en esta concepción jurídica, no hay lugar a una concreción del derecho a través de la argumentación de los principios que le resultan inherentes e inseparables ${ }^{887}$.La teoría de la argumentación jurídica, tal cual hoy la conocemos y valoramos, dificulta su expansión dentro de una noción de objeto y ciencia desarrollados en el marco de un sistema jurídico cerrado -en nuestro caso, el notarial-. Si así fuera, el documento notarial no debería ser más que un resultado, -de naturaleza instrumental- de la aplicación y concreción de las leyes que regulan sus fundamentos. De esta forma, la teoría del derecho notarial comienza por desarrollarse potencialmente en estas épocas, en esplendor de teorías de autores de la magnitud de Hans Kelsen, Herbert L.A Hart, Alf Ross y de Carlos Cossio, entre tantos otros y solo por citar algunos ejemplos, y de ahí entonces los primeros aportes teóricos que comenzaron a servirle de sustento.

Un ius-filósofo de ese entonces, Héctor Rojas Pellerano ${ }^{888}$, fue especialmente convocado por el entonces Colegio de Escribanos de la

\footnotetext{
${ }^{885}$ La intervención en el mundo académico de Rudolf Stammler fue esencial para que la filosofía del derecho vuelva a recobrar la necesidad de debatir, entre otras cosas, el sentido de lo justo. V. Alfred VERDROSS, La filosofia del derecho del mundo occidental, CEF-UNAM, México, 1.962, págs. 285-286.

${ }^{886}$ Cfr. Marcelo Urbano SALERNO, Derecho civil profundizado, Ciudad Argentina y UMSA, Buenos Aires, 1.998, págs. 15-19.

${ }^{887}$ De hecho, es Rodolfo Vigo quien aduce que en todo caso, la teoría de la argumentación o el nuevo modo de razonamiento jurídico han sido desarrollos esenciales para contribuir al desgaste y fractura de la teoría decimonónica a partir de la segunda mitad del siglo pasado. $\mathrm{V}$. Rodolfo Luis VIGO, Iusnaturalismo y neoconstitucionalismo. Coincidencias y diferencias, ob. cit., p. 553.
} 


\section{LOS EFECTOS DE LA PUBLICIDAD EN EL DOCUMENTO NOTARIAL}

Capital Federal - hoy Colegio de Escribanos de La Ciudad Autónoma de Buenos Aires-, para realizar una teoría general del derecho notarial que logre comprender toda la realidad normativista ${ }^{889}$. De esta forma, el autor planteaba las disquisiciones que existen entre la ciencia y su objeto ${ }^{890}$, precisando que el normativismo crítico es una posición tridimensional desarrollada bajo el telón de fondo de la teoría egológica que intenta alcanzar lo que denomina una egología normativa ${ }^{891}$. Dentro de esa pretendida lógica formal normativa, se refiere a las tesis que niegan que el derecho notarial sea un derecho autónomo de la forma ${ }^{892}$ ubica al derecho notarial como una especialidad y una técnica ${ }^{893}$, y desde allí, define al mismo como la conducta del notario en cuanto realiza una norma individual ${ }^{894}$. Desde esta teoría, el núcleo central del problema notarial se centra en determinar la norma individual, por cuanto el notario, al ligar el hecho con el derecho, no puede hacerlo de otro modo que no sea mediante normas individuales. Éste es entonces su aspecto creador, juntamente con las partes en el otorgamiento del documento notarial del derecho, y jurídicamente está obligado a incursionar en todos los campos del derecho ${ }^{895}$.

\footnotetext{
${ }^{888}$ Cfr. Héctor F. ROJAS PELLERANO, Temas de la teoría general del derecho notarial, $\mathrm{RdN}$ on line $\mathrm{n}^{\circ} 734,1.974$.

${ }^{889}$ Ibídem, p. 2 y ss.

${ }^{890}$ Ibídem, p. 3.

${ }^{891}$ Ibídem, p. 6.

${ }^{892}$ Ibídem, p. 16: Afirma el autor: "La posición lógico - formal o dogmática tradicional es aquella que parte del conjunto de normas que constituyen un sector del ordenamiento jurídico y, aplicando un método inductivo a través de una serie de abstracciones, de situaciones particulares, extrae la idea rectora que presidirá toda esa construcción jurídica. Por este camino sólo podrán ser autónomas las ramas del derecho que constituyan una construcción sistemática, completa y cerrada".

${ }^{893}$ Ibídem, p. 18. Y fundamenta: "La ciencia jurídica de nuestro tiempo, en este aspecto, sigue elaborando construcciones jurídicas, sólo que no las encara como un ejercicio lógico, de espaldas a la vida, sino como una tarea a realizar teniendo en mira la concreta experiencia jurídica y ateniéndose a las valoraciones vigentes en un momento determinado. En rigor, toda construcción jurídica, aunque se pretenda ver en ella una categoría puramente lógica, alberga ingredientes históricos - contingentes e importa, quiérase o no, una concreta toma de posición axiológica frente a la experiencia jurídica".

${ }^{894}$ Ibídem, p. 28.

${ }^{895}$ Ibídem. Y Continua: "Como no hay parte - agrega -de la norma jurídica que pueda más o menos a sabiendas prescindir de la evolución de las instituciones, de las cuales somos (refiriéndose a los escribanos) más que testigos, los artifices".
} 
Con lo expuesto se intentaba alcanzar una definición o concepto que abarcara toda la realidad funcional, a través de teorías o tesis en boga en aquellos tiempos, muchas de las cuales siguen adelante en el intento por descubrir apoyos en los foros académicos actuales, más preocupados por sostener lo habitual que por proyectar y defender lo verdaderamente importante. Y como este aporte, varios existieron con orientación similar.

\subsubsection{La cuestión espacial: el paradigma científico vigente al} momento del desarrollo del documento como objeto del derecho notarial.

Al mismo tiempo del desarrollo del derecho notarial científico, autores como Hessen $^{896}$ enseñaban que toda disciplina, para ser firme y poder consolidarse, debería de por sí tener aptitud suficiente para conformar una verdadera teoría del conocimiento tendiente a comprender la significación objetiva del pensamiento humano, y la referencia de éste a sus objetos ${ }^{897}$. Las enseñanzas de Hessen fueron receptadas en las cátedras de introducción al derecho en nuestro país, lo que implica advertir que el inicio de la formación jurídica presenta una notable incidencia formal y positiva del estudio del derecho ${ }^{898}$, inclusive con derivaciones hacia la política sumamente relevantes ${ }^{899}$. De ahí que entre nosotros, fuera Marcelo López Mesa quien oportunamente haya realizado sólidos aportes en esta disciplina y desde esa cátedra, al considerar con Hessen los postulados del conocimiento genérico y los del conocimiento científico aplicados y concretados por y para el derecho ${ }^{900}$.

\footnotetext{
${ }^{896}$ Cfr. Johannes HESSEN, Teoría del conocimiento, Losada, Buenos Aires, 1.954.

${ }^{897}$ Ibídem, p. 126 y ss. Aquí afirma el autor: "La referencia de todo pensamiento a los objetos es el objeto formal de la teoría del conocimiento".

${ }^{898}$ Especialmente en la cátedra de Introducción al derecho de la Facultad de Ciencias Jurídicas y Sociales de la Universidad Nacional de La Plata, que dirigió durante tantísimos años la recordada profesora María Teresa López.

${ }^{899}$ Cfr. Duncan KENNEDY, La enseñanza del derecho como forma de acción politica, Siglo Veintiuno Editores, Buenos Aires, 2.012, p. 16 y ss.

${ }^{900}$ Cfr. Marcelo J. LÓPEZ MESA, El conocimiento y el conocimiento jurídico, Ediciones del Centro de Estudiantes de Derecho, FCJS-UNLP, La Plata, 1.996 (Reimp.) El aporte data del año 1.985 .
} 


\section{LOS EFECTOS DE LA PUBLICIDAD EN EL DOCUMENTO NOTARIAL}

Algunos años después, Mario Bunge comenzaría por introducir sus primeros pensamientos -luego formalizados en obras de referencia indudable-, tendientes a delimitar los objetos de la ciencia ${ }^{901}$, afirmando que todos los objetos científicos son componentes o partes de un sistema ${ }^{902}$, y también aclarando los problemas y desvíos de una ciencia sin ética ${ }^{903}$. En cierta manera, Bunge terminará por plantear, desde una posición filosófica, que las ciencias sociales se encuentran en discusión ${ }^{904}$. Todo esto sin dejar de recordar la verdadera revolución que causó el aporte de Thomas Kuhn ${ }^{905}$, verdadero arquetipo de la ciencia y sus paradigmas, que inspiró a alguno de los autores argentinos a referirse lisa y llanamente a una estructura del conocimiento científico ${ }^{906}$.

En el ámbito jurídico una verdadera revolución fue la promovida por el ya mencionado Hans Kelsen, a partir de las posiciones efectuadas en sus notables estudios, de donde surge que el derecho es un orden de la conducta humana; orden que se entiende como un conjunto de normas que tienen el tipo de unidad que refiere a la noción de sistema ${ }^{907}$. De aquí que sea necesario resaltar que desde el punto de vista científico, libre de toda clase de juicios de valor, el derecho sea solo un problema de técnica social y no un problema ético ${ }^{908}$. Por ello el autor vienés no duda en considerar al verdadero derecho como el positivo, por cuanto es una ordenación válida obligatoria e inmanente, independiente de cualquier relación con el derecho natural ${ }^{909}$. Así, desde la teoría pura del derecho, el profesor se referirá

${ }^{901}$ Cfr. Mario BUNGE, La ciencia. Su método y su filosofia, Sudamericana, Buenos Aires, 2.009, p.15.

${ }^{902}$ Cfr. Mario BUNGE, Sistemas sociales y filosofia, Sudamericana, Buenos Aires, 1.999, p. 11.

${ }^{903}$ Cfr. Mario BUNGE, Ética y ciencia, Siglo Veinte, Buenos Aires, 1.985.

${ }^{904}$ Cfr. Mario BUNGE, Las ciencias sociales en discusión,, Sudamericana, Buenos Aires, 1.999 .

${ }^{905}$ Cfr. Thomas S. KUHN, La estructura de las revoluciones cientificas, Fondo de Cultura Económica, México, 2.013.

906 Cfr. César Julio LORENZANO, La estructura del conocimiento cientifico, Zavalía, Buenos Aires, 1.995, 278 p.

${ }^{907}$ Cfr. Hans KELSEN, Teoría General del derecho y del Estado, trad. Eduardo GARCIA MAYNEZ, Imprenta Universitaria, México, 1.949, p. 3.

${ }^{908}$ Ídem, p. 5.

909 Cfr. Hans KELSEN, La idea del derecho natural y otros ensayos, Editorial Losada, Buenos Aires, 1.946, p. 19. 


\section{SEBASTIÁN JUSTO COSOLA}

explícitamente al derecho y a la ciencia, considerando que el objeto de la ciencia del derecho se encuentra conformado por las normas jurídicas y la conducta humana, ésta ultima solo en la medida en que la misma se encuentre determinada en las normas jurídicas como efecto o condición $n^{910}$. Los contenidos de la revolución jurídica kelseniana -quizás bastante bien resumidos en la frase que antecede- fueron ampliamente debatidos, criticados y aplaudidos en idénticas proporciones. Por ello quizás, en la defensa que realiza de la teoría pura -en clara respuesta a $\operatorname{Ross}^{911}$-, el notable jurista vuelve a afirmar que la norma no es un hecho del ser sino una prescripción del deber ser ${ }^{912}$; se diferencia, entonces, la ciencia empírica de la ciencia metafísica. Para ser empírica, la ciencia del derecho no debe tentar lo imposible, o sea, describir normas del deber ser con proposiciones del $\operatorname{ser}^{913}$. La teoría del derecho adquiere entonces la calificación de empírica si sólo se limita a describir las normas que son el sentido de los actos empíricos, realizados por hombres en tiempo y espacio, sin referencia a normas que emanan de instancias sobrehumanas ${ }^{914}$. Desde su última obra póstuma conocida ${ }^{915}$, Kelsen se refiere a las normas como designaciones de reglamentaciones o de un orden, para que algo deba ser o deba suceder ${ }^{916}$. Norma como imperativo de lo que debe ser, que se genera tanto en el ámbito volitivo como en la propia costumbre ${ }^{917}$. Y norma que además debe ser positiva, porque es el resultado de la imposición de una acto volitivo humano, que le genera a la misma la característica de ser deliberada, ya que cualquier comportamiento querido o pretendido puede ser impuesto por la misma como debido ${ }^{918}$.Por ello es que, entre tantos otros argumentos, las normas del derecho científico se separan de las normas del derecho natural,

${ }^{910}$ Cfr. Hans KELSEN, Teoría pura del derecho, trad. Roberto J. VERNENGO, Porrúa, México, 2.007, p. 83.

${ }^{911}$ Cfr. Alf ROSS, Sobre el derecho y la justicia, Eudeba, Buenos Aires, 1.963.

912 Cfr. Hans KELSEN, Contribuciones a la teoría pura del derecho, Centro Editor de América Latina / Buenos Aires, 1.969, p. 11.

${ }^{913}$ Ibídem, p. 15.

${ }^{914}$ Ibídem.

${ }^{915}$ Cfr. Hans KELSEN, Teoría General de las normas, Trillas, México, 1.994, p. 19.

${ }^{916}$ Ibídem, p. 20.

${ }^{917}$ Ibídem.

918 Ídem, p. 22. 


\section{LOS EFECTOS DE LA PUBLICIDAD EN EL DOCUMENTO NOTARIAL}

que responden a la voluntad en la naturaleza ${ }^{919}$ o la voluntad de Dios en la naturaleza ${ }^{920}$.

Al mismo tiempo en Argentina, Carlos Cossio trasmitía que la ciencia del derecho, como ciencia de la realidad, considera el ser de la conducta en su deber ser positivo o ideal real ${ }^{921}$. Al referirse a la comparación entre la sociología y a la axiología jurídica con la ciencia del derecho, el maestro argentino afirmaba desde una clara posición científica, que el jurista entonces se encuentra siempre frente a una experiencia de libertad que lo dirige a recurrir a las normas ${ }^{922}$. Sólo por no redundar en mayores detalles, únicamente recordaré que autores como Rojas Pellerano ${ }^{923}$, Ambrosio Gioja $^{924}$, Carlos Nino ${ }^{925}$, Carlos Alchourrón, Eugenio Bulygin ${ }^{926}$ y Ricardo Guibourg ${ }^{927}$ entre tantísimos otros, comenzaban a postular coherentes teorías del conocimiento jurídico, con objetos específicamente determinados y asumidos de la moderna ciencia jurídica. De hecho, los conceptos jurídicos fundamentales del derecho de esa época eran los relacionados con la dogmática y la técnica; objetivamente, con todo aquello que pueda ser motivo de análisis y estudio científico: obligación jurídica, personas físicas y jurídicas en relación a la posición kelseniana, entre otros ${ }^{928}$.

Los temas actuales de estricto desarrollo, tan diferentes a los que se argumentaban en la biblioteca jurídica de aquel entonces, referidos a los

\footnotetext{
${ }^{919}$ Ibídem.

${ }^{920}$ Ibídem, p. 23.

${ }^{921}$ Cfr. Carlos COSSIO, La teoría egológica del derecho y el concepto jurídico de libertad, Editorial Losada, Buenos Aires, 1.944, p. 114.

${ }^{922}$ Ibídem.

${ }^{923}$ Cfr. Héctor F. ROJAS PELLERANO, Introducción al derecho, Centro Editor Argentino, Buenos Aires, 1.984, p. 27 y ss.

${ }^{924}$ Cfr. Ambrosio L. GIOJA, Ideas para una filosofía del derecho, t II, Sucesión de Ambrosio L. Gioja, Buenos Aires, 1.973, p. 9 y ss.

925 Cfr. Carlos S. NINO, Algunos modelos metodológicos de la ciencia jurídica, Oficina Latinoamericana de investigaciones jurídicas y sociales, Universidad de Carabobo, Venezuela, 1.979, p. 97.

926 Cfr. Carlos E. ALCHOURRÓN y Eugenio BULYGIN, Sistemas normativos, Astrea, Buenos Aires, 2.012, p. 11 y ss.

927 Cfr. Ricardo A. GUIBOURG, Alejandro M. GHIGLIANI y Ricardo V. GUARINONI, Introducción al conocimiento científico, Eudeba, Buenos Aires, 1.993, p. 82.

${ }^{928}$ Cfr. Norberto GRIFFA y Eduardo Ángel RUSSO, Los conceptos jurídicos fundamentales del derecho, en Héctor F. ROJAS PELLERANO, Introducción al derecho, Centro Editor Argentino, Buenos Aires, 1.984, p. 237 y ss.
} 


\section{SEBASTIÁN JUSTO COSOLA}

valores, a los principios, a los derechos humanos y esencialmente a la justicia, no encontraban casi reparo en el debate jurídico científico, ni ameritaban siquiera una reflexión intimidante. Por aquellos entonces, hubiera sido imposible lograr un planteo de tipo científico del derecho con fundamentos en conceptos considerados metafísicos, y mucho más difícil hubiera sido justificar el desenvolvimiento justo del derecho desde una perspectiva de los derechos sociales fundamentales ${ }^{929}$, que parten desde el más fino análisis de los derechos subjetivos ${ }^{930}$ para proyectarse en todos aquellos conceptos que importan al derecho simplemente por ser innatos al hombre ${ }^{931}$.

Ese era el panorama del desarrollo del derecho por aquellos entonces: elevar al cientificismo a su máximo esplendor para evitar la alusión a conceptos considerados -creo que injustamente- abstractos. Por ello mismo, tampoco faltaron aquellos autores que se preguntaban si realmente existía la ciencia del derecho o si efectivamente lo que existía era una crisis en su seno por no poder dar cientificidad formal a la misma ${ }^{932}$. En estos tiempos nacía el desarrollo científico del derecho notarial tal cual hoy lo conocemos, lo estudiamos y lo aprendemos, y por ello mi insistencia en plantear seguidamente, una nueva posición fundada en los valores que definitivamente, hay que comenzar por proyectar en el documento notarial actual.

Ésta explosión científica y positivista de la ciencia no ocurría únicamente en la disciplina jurídica; se extendía en general, hacia todas las disciplinas humanísticas. Si nos apartamos por un instante del tratamiento científico del derecho para recurrir a otras actividades científicas con objeto y método propio, podremos advertir en sintonía con lo antes afirmado, que desde la medicina, Nerio Rojas argumentaba que toda ciencia busca su síntesis en ciertos principios concretos ${ }^{933}$. De ahí que su célebre tratado de medicina

${ }^{929}$ Cfr. Rodolfo ARANGO, El concepto de derechos sociales fundamentales, prol. Robert ALEXY, Universidad Nacional de Colombia-Legis, Bogotá, 2.005.

${ }^{930}$ Ibídem, p. 7 y ss.

${ }_{931}$ Ídem, p. 238 y ss.

${ }^{932}$ Cfr. Julio E. LOPEZ LASTRA, Que es el derecho, Editora Platense, La Plata, 1.972, p. 138 y ss.

${ }^{933}$ Cfr. Nerio ROJAS, Medicina Legal, Librería El Ateneo Editorial, Buenos Aires, 1.958, p. 15. De ahí que su célebre tratado de medicina legal haya tenido al menos una docena de 


\section{LOS EFECTOS DE LA PUBLICIDAD EN EL DOCUMENTO NOTARIAL}

legal haya tenido al menos una docena de reimpresiones, y correspondientemente, que se hayan considerado verdades absolutas las descripciones de sus capítulos, que eran graficados, luego de exposición teórica, con una foto del perfil del delincuente, para que científicamente pueda comprenderse al criminal en toda su magnitud, de acuerdo a sus facciones y expresiones, repetidas y reiteradas objetivamente según el delito que correspondiere imputar. Esto explica que las concepciones científicas del delincuente encuentren en la psicología pautas concretas de comportamiento y de castigo ${ }^{934}$, o que desde la antropología se postule que además del estudio filosófico del hombre, sea centro de atención el mismo en su comportamiento objetivo cultural ${ }^{935}$. Todas las ciencias denominadas humanísticas se encontraban frente al mismo desarrollo, en la misma situación.

Todos estos movimientos se explican en el notable ensayo de Ernesto Sábato, Uno y el universo ${ }^{936}$; al relatar de manera exquisita los desavíos de la ciencia, nuestro inolvidable referente enseñaba que la ciencia no es poderosa a pesar de su abstracción sino justamente por ella ${ }^{937}$; de esta manera, teniendo en cuenta sus referencias al dogmatismo imperante ${ }^{938}$, la geometrización de la novela ${ }^{939}$ y el planteo del método científico ${ }^{940}$, en definitiva, la idea de lo que pretendo se desarrolle en este punto de la tesis es la siguiente: "De este modo, el mundo se ha ido transformando paulatinamente en un conjunto de piedras, pájaros, arboles, sonetos de Petrarca, cacerías de zorro y luchas electorales, en un conglomerado de

reimpresiones, y correspondientemente, que se hayan considerado verdades absolutas las descripciones de sus capítulos, que eran graficados, luego de exposición teórica, con una foto del perfil del delincuente, para que cientificamente pueda comprenderse al criminal en toda su magnitud, de acuerdo a sus facciones y expresiones, repetidas y reiteradas objetivamente según el delito que correspondiere imputar.

${ }^{934}$ Cfr. Michel FOUCAULT, Vigilar y castigar. Nacimiento de la prisión, Siglo Veintiuno Editores, Buenos Aires, 2.015, 359 p.

935 Cfr. Guillermo P. BLANCO, Curso de antropología filosófica, Educa, Buenos Aires, 2.002, p. 21.

${ }^{936}$ Cfr. Ernesto SÁBATO, Uno y el universo, Obra Completa, Seix Barral, Buenos Aires, 2.009, p. 15.

${ }^{937}$ Ibídem, p. 28.

${ }_{938}$ Ídem, p. 37.

${ }^{939}$ Ibídem, p. 57.

${ }^{940}$ Ibídem, p. 69. 
sinusoides, logaritmos, letras griegas, triángulos y ondas de probabilidad. Y lo que es peor: nada más que eso. Cualquier cientifico se negará a hacer consideraciones sobre lo que podría estar más allá de la mera estructura matemática ${ }^{941}$ ".

\subsection{Necesidad de destacar al documento notarial como} un objeto de tipo científico dentro del positivismo. Lógica cuestión antecedente.

En este panorama científico positivo comienza a desarrollarse el documento como objeto o elemento esencial del derecho notarial. La propia lógica devenida de las teorías jurídicas en esplendor académico de la época hizo que los autores de aquel entonces justificaran la atención del notario en la propuesta de consolidación de un objeto del derecho notarial -el documentomarcadamente científico y técnico, que pudiera precisar todos sus extremos en una ley, en un reglamento o en algo que estuviera científicamente reconocido. Toma así el notariado como postulado un verdadero resabio de las primeras interpretaciones del derecho nacional argentino, que en adecuada y cierta interpretación, toma al positivismo como teoría y metodología jurídica ${ }^{942}$. Y esta realidad inclusive se encuentra descripta en investigaciones de juristas extranjeros ${ }^{943}$, que han concluido en sus estudios que los civilistas hispanoamericanos, si bien creaban doctrina sobre códigos hechos por codificadores que respetaban los postulados del derecho natural, han estado considerablemente influenciados por el positivismo jurídico ${ }^{944}$. En definitiva, la disciplina notarial se desarrolla en épocas en donde la lógica

${ }^{941}$ Ídem, p. 30.

${ }^{942}$ Cfr. Fernando MARTINEZ PAZ, Introducción al Derecho, Ábaco, Buenos Aires, 2.005, p. 253.

${ }^{943}$ Cfr. José María CASTÁN VAZQUEZ, Las bases iusnaturalistas del derecho privado hispanoamericano, ACADERC. http://www.acaderc.org.ar/doctrina/articulos/las-basesiusnaturalistas-del-derecho-privado (Ultimo acceso: 22/08/2017)

${ }^{944}$ Ibídem, p. 25. 


\section{LOS EFECTOS DE LA PUBLICIDAD EN EL DOCUMENTO NOTARIAL}

se erige como la herramienta y el fundamento determinante de todo tipo de conocimiento $^{945}$.

Sobre esto y hasta hace no demasiado tiempo, autores como Eduardo Russo exponían con convencimiento notorio que el iusnaturalismo no podía de ninguna manera subsumirse dentro del esquema que plantea la moderna ciencia del derecho ${ }^{946}$. Si el derecho es una ciencia con objeto y método propio no puede adoptar como objeto una entidad que sea dependiente de valoraciones, y mucho menos, de considerar como objeto a la propia noción de justicia con los alcances propuestos por Santo Tomás de Aquino (lo justo es lo que no se opone al derecho natural ${ }^{947}$ ). Para el autor, los principios iusnaturalistas no son verificables, no tienen sentido empírico sino supraempírico, porque tienen naturaleza metafísica ${ }^{948}$, y por ella razón propone que en el esquema científico del derecho la única posibilidad de inserción es la que presenta el positivismo ${ }^{949}$.

Sea como fueren las opiniones y las teorías respectivas, el notariado ha seguido las orientaciones positivistas desde su nacimiento como disciplina ${ }^{950}$.Desde aquí entonces que no puedan sorprender las manifestaciones de los primeros notarialistas argentinos, como el recordado Alberto Villalba Welsh ${ }^{951}$ : "En este estudio (El derecho notarial a la luz de

${ }^{945}$ Cfr. Lucía M. ASEFF, Argumentación jurídica y semiosis social, Juris, Rosario, 2.003, p. 95. (TD)

${ }^{946}$ Cfr. Eduardo Ángel RUSSO, Teoría general del derecho, LexisNexis- Abeledo Perrot, Buenos Aires, 2.004, p. 193.

${ }_{947}$ Ibídem, p. 194.

${ }^{948}$ Ibídem, p. 195.

${ }^{949}$ Ibídem.

${ }^{950}$ Muestra suficientemente clara de lo antedicho es el simposio sobre teoría general del derecho organizado por la Facultad de Ciencias Jurídicas y Sociales de la Universidad Nacional de La Plata y el Colegio de Escribanos de la Provincia de Buenos Aires, con el auspicio del Instituto de Cultura Jurídica y la Revista Notarial, que en las personas de Juan Carlos Smith y Martha Elvira Yorio respectivamente, dejaron como resultado un trabajo de indudable valor académico publicado en un número especial y correlativo de la Revista Notarial. Esto es solo una firme muestra de que los escribanos -en este caso, los bonaerensesno han estado ajenos a las deliberaciones acerca de los conceptos jurídicos fundamentales propios de cada época, pero lógicamente dedicadas al movimiento positivista. De esta manera, los resabios de los aspectos científicos del derecho se trasladaron a la sede del Colegio de Escribanos bonaerense, oportunidad maravillosa para que los fedatarios de ese entonces buscaran el sentido de su quehacer jurídico en las sendas propias del derecho de la época. Cfr. Simposio sobre teoría general del derecho, $\mathrm{RN} \mathrm{n}^{\circ}$ 853, número especial, La Plata, 1.980.

${ }^{951}$ Alberto VILLALBA WELSH, El derecho notarial a la luz de la teoría egológica, ob. cit. 


\section{SEBASTIÁN JUSTO COSOLA}

la teoría egológica) estamos tratando de captar al notario como notario, vale decir, despojándolo de las otras funciones que la tradición latina le impone y que son de gran importancia pero ajenas a la normatividad típica del notario como autor de la forma. Así, dejamos conscientemente de lado al jurista y al asesor que hay en todo escribano porque tales funciones no encajan, como decimos, en el cuadro de las normas jurídicas connotariales $^{952 ",}$

Entonces el documento, desde su ubicación como objeto esencial del derecho notarial, logra su posicionamiento consolidándose como una institución jurídica que reconoce todos sus postulados en criterios específicos y sistemáticos, habitualmente descriptos en los códigos de fondo $\mathrm{y}$ en las leyes que regulan el ejercicio notarial. Por ello es que las primeras doctrinas esclarecedoras de los primeros conceptos del documento notarial no se han apartado de las leyes en vigencia ${ }^{953}$, y es por esta razón que los primeros estudios de la institución en referencia se presentan bajo la denominación de ciencia como principal exponente del desarrollo del derecho notarial. De esta manera los primeros conceptos por nosotros aprehendidos no son más que representaciones mentales, de las cuales asumimos una representación psicológica que alojamos en un lugar particular ${ }^{954}$.

Deberán pasar los años desde aquellas enseñanzas, prácticamente hasta nuestros días, para poder advertir que lo que importa de las instituciones es destacar ya no sólo y únicamente su objeto científico, sino su posición dentro del saber jurídico, esto es, de qué modo o manera completa podemos llegar a conocer una cosa para saber lo que verdaderamente ésta es ${ }^{955}$. Desde aquí es

\footnotetext{
${ }^{952}$ Ibídem, p. 24.

${ }^{953}$ En la República Argentina, al gran civilista Raymundo SALVAT es uno de los primeros juristas argentinos en afirmar la importancia jurídica que reviste para la comunidad la labor diaria y extensa que cumple el escribano. Afirmaba el maestro: "Persuadidos de que el derecho civil no está en todo entero contenido en el Código Civil, hemos agregado el estudio de las leyes que organizan el notariado, indispensable para completar el conocimiento de las escrituras públicas ".

${ }^{954}$ Cfr. Joseph RAZ, Robert ALEXY y Eugenio BULYGIN, Una discusión sobre la teoría del derecho, Marcial Pons, Madrid, 2.007, p. 15. La significación aludida pertenece al estudio preliminar realizado por Hernán BOUVIER, Paula GAIDO y Rodrigo SÁNCHEZ BRIGIDO.

${ }_{955}$ Cfr. Abelardo F. ROSSI, Algunos modos del saber humano, El Derecho, Buenos Aires, 2.003, p. 11.
} 
que la función notarial y con ella, el fruto de su creación, el documento notarial, merezcan en esta tesis como ya he dicho, un tratamiento diferente al que los vio y los justificó al nacer, de acuerdo con los desarrollos jurídicos actuales, teniendo en cuenta a la institución como un saber práctico (filosófico), un saber científico, y un saber prudencial ${ }^{956}$.

\subsubsection{El estudio del derecho notarial y del documento en la} actualidad.

Resulta absolutamente incomprensible que desde allí hasta los tiempos actuales las presentaciones que se realizan sigan priorizando el elemento de positividad lógico formal y deductivo de la actuación notarial como por sobre el análisis de la actuación notarial antes y durante la conformación del documento. La misma está destinada, más que en ninguna otra época, a consolidar y perpetuar los derechos esenciales humanos básicos e insustituibles relativos al tema que ocupa a la función. En el tratamiento del derecho notarial, y consecuentemente, del documento, la pretensión de los autores sigue siendo precisamente, alcanzar una concepción científica del derecho a través de la valoración de postulados positivizados de la más diversa naturaleza -comprensivo esencialmente de normas y reglas del derecho civil y comercial, pero también del derecho tributario o financiero; disposiciones técnico registrales, normativa del registro del automotor y de los diversos organismos de control de disímil naturaleza- todo bajo el mismo prisma y con la misma fuerza de análisis, lo que desde mi posición es considerado como un total desacierto. Motivados por la búsqueda incesante de la seguridad jurídica entendida únicamente como un elemento y valor del mercado de intercambio, se confunden grave $y$ notablemente las valoraciones, las jerarquías y los fines de las normas y del derecho; y así, la tarea notarial documental se aparta de los principios que la vieron emerger

956 Cfr. Gabriel LIMODIO y Javier BARBIERI, Introducción al saber jurídico, Educa, Buenos Aires, 2.006, págs. 26 y ss. 


\section{SEBASTIÁN JUSTO COSOLA}

para posicionarse como una verdadera miscelánea de normas que recogen declaraciones de la más absoluta intrascendencia y lo que es aun más grave: en varias circunstancias, contradictorias entre sí.

Es importante destacar en este punto lo que significa la expresión positivismo jurídico. Como expresión no univoca ${ }^{957}$ indica prevalentemente -y de un modo no exclusivo- una teoría que reconoce con carácter jurídico a todo aquello que haya sido puesto por una autoridad soberana, y siempre se refiere a un plano formal de creación de la norma por un ente que se atribuye el poder de generar derecho ${ }^{958}$. Una posición netamente positivista, si bien presenta diferentes concepciones doctrinales, se dirige a reivindicar una postura jurídica monista, entendiendo por ello que solo se admite la existencia de un solo derecho: el positivo ${ }^{959}$. De ahí que el análisis deba de referirse a los rasgos más característicos a esta doctrina ${ }^{960}$ :

a) Un acercamiento al derecho que es -y no el que debería ser o el que nos gustaría que sea-;

b) Una ubicación del mismo dentro de un sistema y que desde el punto de vista lingüístico ${ }^{961}$ sea válido y vigente independientemente de valoraciones axiológicas, y finalmente

c) Un reconocimiento a una fuente estatal que posibilite el ejercicio de la coacción.

No debe dejar de destacarse que la realidad específica del derecho no se manifiesta en la conducta real de los individuos sometidos al orden jurídico, ya que la misma puede hallarse o no hallarse de acuerdo al orden cuya existencia constituye la realidad en cuestión. Participo de los que opinan que

\footnotetext{
${ }^{957}$ Cfr. Genero CARRIO, Notas sobre lenguaje y derecho, LexisNexis, Buenos Aires, 2.006, p. 213 y ss.

${ }^{958}$ Cfr. Ariel ÁlVAREZ GARDIOL, Pensamiento jurídico contemporáneo, Fundación para el desarrollo de las ciencias jurídicas, Rosario, Santa Fe, 2.009, p. 23.

959 Cfr. Antonio Enrique PÉREZ LUÑO, Trayectorias contemporáneas de la filosofía y la teoría del derecho, Palestra, Lima, Perú, 2.005, p. 47 y ss.

${ }^{960}$ Ariel ÁLVAREZ GARDIOL, ob. cit., p. 26-7.

961 Sobre este tema, cercano a la Escuela Analítica, ver el excelente trabajo de Ricardo GUIBOURG, Una concepción analitica del derecho, en Andrés BOTERO BERNAL (Coordinador), Filosofía del derecho Argentina, Temis, Bogotá, Colombia, 2.008, p. 3-37.
} 
LOS EFECTOS DE LA PUBLICIDAD EN EL DOCUMENTO NOTARIAL

el orden jurídico determina como debe ser la conducta de los hombres, mientras que el comportamiento de los individuos tal como es, se encuentra determinado por las leyes de la naturaleza, de acuerdo con el principio de causalidad -comportamiento de realidad natural-. La elección de una corriente con matices iusnaturalistas no implica desconocer en ningún modo, ni en forma alguna, la importancia del derecho positivo. Se necesita imperiosamente conocer, aceptar y aplicar la ley positiva; en nuestro caso, la notarial de cada provincia, de cada Estado, de cada nación, porque sin dudas es la ley escrita la fuente esencial del derecho en cada país. Solo que también hay que considerar ciertos tipos de herramientas que sean útiles para alcanzar resultados justos, que muchas veces se encuentran fuera del perímetro legal, y que comprendan además las otras fuentes elementales de la actual teoría de la argumentación jurídica (Constitución Nacional, usos y costumbres, jurisprudencia, equidad, principios, valores, diversos comportamientos, etc.). Por ello le asiste razón al recordado profesor Abelardo Rossi cuando afirmaba que nadie puede dejar de tener en cuenta la necesidad del derecho positivo y su consecuente importancia. Así lo expresaba: "La positividad, al derecho, le es consubstancial 962 ". Sin embargo, su dura réplica que realiza es contra el positivismo jurídico, al que considera una degeneración de la positividad, por cuanto en la soberbia de querer construir toda la esfera del ordenamiento jurídico, descuidó aquel derecho que el creador de la naturaleza había ubicado en las condiciones personales y sociales del hombre ${ }^{963}$.

Es así entonces que en la medida en que la regla del derecho positivo se torne injusta, por haberla creado alguien que no esté facultado para ello incompetencia-, o por no haber distribuido las cargas sin igualdad proporcional entre los miembros de la sociedad; o por apartarse o no adaptarse a las exigencias del bien común, será considerada como una regla inequitativa, que pondrá en jaque al jurista, que debe soslayar prudentemente su aplicación y procurar un cambio según los requerimientos del bien de la comunidad política.

962 Cfr. Abelardo F. ROSSI, Aproximación a la justicia y a la equidad, EDUCA, Buenos Aires, 2.000, p. 159.

${ }^{963}$ Ibídem. 
SEBASTIÁN JUSTO COSOLA

\subsubsection{Una adecuada interpretación del título preliminar del} Código Civil y Comercial de la Nación y la elaboración notarial del derecho documental.

Lo que intento plantear es la consolidación del arte notarial que, de acuerdo al paradigma del moderno derecho codificado, se debe desde mi visión reflejar en el documento. El arte que admite, en consonancia con los tiempos actuales, la existencia y en todo caso, también la preexistencia de derechos y principios relacionados o no relacionados con cualquier tipo de legislación, cuestión que no es aceptada por el positivismo jurídico ${ }^{964}$, y que es esencial para el ejercicio de la función notarial. Antes de elaborar el documento, el notario crea el derecho que en él va a proyectar, acatando el principio de legalidad comprensivo no sólo de normas, sino también de reglas, valores y principios que consolidan un derecho justo y seguro con sustento y fundamento en la certeza y en verdad. Sólo en el ejercicio del asesoramiento y el consejo, y más importante que ello, en la puesta en práctica de la imparcialidad e independencia, el escribano actual puede concretar la aplicación de los principios notariales que se captan por evidencia en el documento, con el fin de cumplir, más que con la ley, con el derecho mismo.

La actuación notarial sobre el documento debe respetar los que ordena el título preliminar del Código Civil y Comercial de La Nación. En primer lugar, debe respetar la separación definitiva del concepto de ley con el concepto de derecho, tal cual lo he dejado expuesto líneas atrás. El profesor Rodolfo Vigo ha explicado con claridad y precisión este importante artículo primero del título preliminar ${ }^{965}$ del código unificado vigente, destacando las indudables circunstancias históricas que determinaron su concreción ${ }^{966}$, y

${ }^{964}$ Cfr. Donald DWORKIN, Los derechos en serio, Ariel-Derecho, Barcelona, 2.002, p. 36.

965 Cfr. Rodolfo Luis VIGO, Comentarios al capítulo I del título preliminar, Biblioteca Digital de la UCA. www.pensamientocivil.com.ar/system/files/2015/01/Doctrina463.pdf (Último acceso: 22/08/2017)

${ }^{966}$ Ibídem. Afirma el profesor: "La distinción entre Derecho (capitulo 1) y la Ley (capítulo 2) parece un acierto frente a la estructura originaria del Código Civil que las asimilaba, 


\section{LOS EFECTOS DE LA PUBLICIDAD EN EL DOCUMENTO NOTARIAL}

reafirmando lo siguiente: "El desafio para la teoría jurídica y los juristas es controlar sustancialmente a toda ley más allá de las formas, para de ese modo constatar racionalmente si ha logrado emerger o no al derecho, dado que frente a esa contradicción solo corresponde hacer prevalecer el derecho $y$ declarar inválida a la ley ${ }^{967, "}$

Es esta, definitivamente, la primera oportunidad real en el tiempo con la que el notario cuenta para demostrar el alcance y la importancia de su singular modo de ver y de argumentar el derecho. La argumentación notarial del derecho debe contener y abarcar, en cada caso en el que toque prestar el ministerio, los postulados teóricos y prácticos consolidados en la ley y en los principios generales del derecho. Inclusive puede el notario recurrir a una regla de argumentación aun más extensa. Muy a pesar que en el ordenamiento privado codificado actual exista una particular ausencia de fuentes jurídicas relevantes como la doctrina o la equidad, pueden ellas argumentarse desde las aquellas fuentes que si están enumeradas en el título preliminar y que en definitiva, son las que comprenden a todas las existentes. Esto permitirá que el derecho que se concrete en el documento notarial pueda tener una cercana vinculación con la Constitución, con los principios emergentes de los derechos humanos, en definitiva, a todo lo que he venido designando y sosteniendo con anterioridad.

Como jurista, el notario muchas veces también se enfrenta a postulados jurídicos rígidos que impiden visualizar la tan ansiada concreción del derecho justo. Muchas veces en la norma inflexible el derecho a encontrado cierta razón de seguridad; sin embargo, esa seguridad que presume que las personas de similares características merecen aceptar siempre las mismas consecuencias, hoy se enfrenta con la justicia. Frente a la notable evolución de los derechos relacionados con las minorías, o aquellos emergentes de las nuevas instituciones desarrollaras como la minoridad, la ancianidad, las que

aunque - como ampliaremos en las críticas - en el desarrollo de los artículos de ambos capítulos esa distinción queda en buena medida diluida. Es que esa diferenciación fue decisiva en la gestación del nuevo Estado de Derecho Constitucional con posterioridad a la condena de Núremberg contra los criminales nazis por haber cumplido la "ley" y violado el “derecho”. Será la ley fundamental de Bonn del 49 la que consagrará en Europa continental esa crucial y decisiva distinción, dejando atrás la sinonimia proclamada por la revolución francesa y sus códigos".

${ }^{967}$ Ibídem. 


\section{SEBASTIÁN JUSTO COSOLA}

asisten a las personas con capacidades limitadas o restringidas -y que en ocasiones, necesitan de un apoyo para la realización de un acto jurídico determinado-; aquellas relacionados con la protección del hogar familiar o del derecho de vivienda -independientemente de la conformación de la familia a través de nupcias o de uniones de hecho, ensamblada o monoparental-, entre otros planteos esenciales de las necesidades jurídicas actuales, si el notario no interpreta decididamente determinadas leyes que en la actualidad violentan el reconocimiento de esos derechos proclamados por la comunidad jurídica mundial, puede ser que cumpla con la ley, pero decididamente incumplirá también con el derecho.

Concretar en el documento el derecho notarial justo es una tarea de indudable actualidad y relevancia ${ }^{968}$, y por ello mi interés por replantear la teoría general del instrumento o documento notarial para luego, una vez estructurada sobre los cánones justos, se pueda apreciar que tipo de publicidad se desprende del mismo. Sólo a través de una reformulación de los postulados esenciales que alberga desde antaño podrá el documento demostrar su importancia, y con ella, la demostración que confirma que dentro de las publicidades jerarquizadas, es el único que puede albergar y proyectar para la comunidad en general, todos los valores jurídicos necesarios para que la misma se desarrolle en paz.

Hechas las aclaraciones pertinentes, corresponde ahora ahondar en los primeros conceptos acerca del documento, el análisis de la cuestión terminológica -determinante de un necesario concepto unívoco-, y los diferentes tópicos que propugnan las disciplinas jurídicas que lo estudian desde diferentes ángulos. Eso permitirá obtener un denominador común sobre el cual proyectar una definición de documento notarial omnicomprensiva de todos sus características y elementos, para luego poder sobre y desde ellos concretar una estructura que pueda destacar la relevancia de la publicidad cartular, configuradora de los efectos y de la validez que le importa al derecho.

${ }^{968}$ Sebastián Justo COSOLA, Fundamentos del derecho notarial, ob. cit. 
LOS EFECTOS DE LA PUBLICIDAD EN EL DOCUMENTO NOTARIAL

\subsection{Los primeros conceptos acerca del objeto esencial del derecho notarial.}

La definición de documento en nuestro derecho no estaba plasmada en el Código Civil de Vélez Sarsfield ${ }^{969}$ ni lo está actualmente en el Código Civil y Comercial de la Nación ${ }^{970}$. Tampoco el Código Civil Español -de tanta influencia notarial entre nosotros- define al documento, y por ello Antonio Rodríguez Adrados insiste en que si bien el cuerpo de normas no tiene por qué dar el concepto, eso no es una excusa de la necesidad y conveniencia de intentar averiguar la definición que subyace a sus preceptos ${ }^{971}$.

Es obra de la doctrina absolutamente coincidente la de conceptualizar de manera genérica al documento atendiendo a la descripción de su contenido: así se lo describe entonces, como un acto escrito ${ }^{972}$, que presenta a la forma, al contenido y a la firma como elementos esenciales $^{973}$. La finalidad de la unión de esos tres elementos es la obtención de la prueba de algún hecho o relación jurídica relevante. Por ello se sobreentiende que es documento aquello que sirve para justificar un derecho, asegurar una acción, y probar todo aquello en lo que una persona tenga interés ${ }^{974}$.

La teoría general del documento presenta determinados niveles de interés que son estudiados desde diferentes perspectivas de acuerdo a la disciplina jurídica que se intente tanto desarrollar como justificar. De esta manera, cada disciplina potencia algún elemento del documento y sobre él, se desarrolla toda una hipótesis con su consecuente conclusión. Esto ocurre porque el desarrollo de la teoría documental es verdaderamente compleja, y

\footnotetext{
${ }^{969}$ Cfr. Cristina N. ARMELLA, De los instrumentos públicos, en Alberto J. BUERES (Dir.) y Elena I. HIGHTON (Coord.), Código Civil y Normas Complementarias. Análisis doctrinario y jurisprudencial, $\mathrm{T}^{\circ}$ 2C, Hammurabi, Buenos Aires, 1.999, p. 2.

${ }^{970}$ Cfr. Sebastián J. COSOLA, Instrumentos públicos, en Julio C. RIVERA y Graciela MEDINA (Dir.) y Mariano ESPER (Coord.), Código Civil y Comercial de La Nación, T ${ }^{\circ}$, La Ley, Buenos Aires, 2.014, p. 664.

971 Cfr. Antonio RODRIGUEZ ADRADOS, El documento en el Código Civil, Escritos Jurídicos, T III, CGN, Madrid, 1.996, p. 27.

${ }^{972}$ Ibídem.

${ }^{973}$ Carlos A. PELOSI, El Documento Notarial, ob. cit., p. 32.

${ }^{974}$ Ibídem.
} 


\section{SEBASTIÁN JUSTO COSOLA}

los temas de interés académicos, si bien intentan brindar tutela a los mismos temas dentro de una teoría general (concepto + naturaleza + elementos del documento + efectos), se bifurcan ni bien se alejan de los primeros análisis de los mencionados postulados. Consecuentemente, se viene afirmando que hasta la fecha, los intentos de los autores para lograr establecer un concepto de documento que sea aplicable a todos los supuestos y modalidades con validez en todos los campos del derecho, no ofrecen como resultado una solución suficientemente acabada, omnicomprensiva y satisfactoria ${ }^{975}$. De aquí que se considere, desde cada análisis específico, algún tema de especial atención por sobre otro, dando a la cuestión terminológica y sus bemoles, un valor meramente referente ${ }^{976}$.

Es en razón de ello que existen ciertas vicisitudes, tanto iniciales como naturales en el tema en estudio que deben ser aclaradas definitivamente, para que no se llegue a confundir la conformación y estructuración formal del documento con la composición y función de sus elementos esenciales, y mucho menos desde la actuación del autor que imprime sobre él un determinado contenido. Esas vicisitudes iniciales, que yo prefiero considerar desde la parte dogmática del derecho notarial, se refieren a la cuestión conceptual, desde la cual se designa como natural algún objeto del derecho cuya impronta no se adecúa a la denominación que se sugiere.

\footnotetext{
${ }^{975}$ Cfr. Pablo A. CARRICA, Derecho Documental, La Ley, Buenos Aires, 2.003, p. 1.

${ }^{976}$ No puede dejar de resaltarse en un estudio de esta magnitud ciertas cuestiones que si bien, pueden parecer elementales a la luz del ejercicio funcional notarial, requieren de atención permanente de la doctrina, en procura de afirmar y sostener de manera correcta, el resultado de la interpretación de las bondades del documento notarial. Es que cada vez más frecuentemente emergen a la luz opiniones totalmente falaces y desacertadas, inclusive efectuadas fuera del contexto adecuado en ámbitos políticos o mal considerados como de gremio, y no en la Academia, ámbito en el cual en honor a lo ético y a lo jurídico deberían nacer, y bregar por su consolidación. Las mismas, muy lamentablemente, impactan de manera absolutamente negativa en el derecho en general, desprotegiendo a las personas, y si no fuera por la notable recepción jurisprudencial del valor del documento notarial, de sus valores y de sus efectos, la seguridad jurídica en las transacciones periódicas y habituales se perdería tanto en desde la celebración como en la duración y permanencia de la misma proyectada hacia el futuro.
} 
LOS EFECTOS DE LA PUBLICIDAD EN EL DOCUMENTO NOTARIAL

\subsubsection{El tema de la cuestión terminológica.}

Uno de esos temas esenciales de la problemática jurídica en general y de muy escasa difusión entre los autores del derecho nacional, es el referente a la preocupación por el análisis de la cuestión terminológica de los conceptos jurídicos ${ }^{977}$. Una adecuada metodología de tratamiento del tema conceptual se dirige en primer término a delimitar el ámbito de aplicación de la palabra para poder determinar su dominio; se advierte así, cuando la misma denota un género, y cuando, por ejemplo, se refiere a una especie ${ }^{978}$. El tema del lenguaje en el derecho, abordado por la escuela analítica dentro del desarrollo de las escuelas de pensamiento jurídico, requiere de especial cuidado y atención, ya que como advierte Ricardo Guibourg, un lenguaje claro y positivo desalienta lecturas inadecuadas de terceros relativamente desinteresados, contribuyendo a que la seguridad jurídica se vea fortalecida cuando más precisas y llanas sean las clausulas de la ley ${ }^{979}$.

En el estudio general del derecho notarial el análisis del tema no conforma la excepción, y por ello opino que el inicio del desarrollo del documento notarial requiere en principio, establecer un cierto esclarecimiento de conceptos, que permita obtener un determinado resultado elaborado que pueda sólidamente respaldarse con criterios argumentativos suficientes. Esto trae aparejado un repaso de los estudios académicos antecedentes, que en el intento por designar o denotar ciertas palabras, introducen cuestiones etimológicas, conceptuales, terminológicas y lexicográficas, que merecen ser aclaradas. Potenciar el adecuado concepto es precisar el alcance y la atención que una determinada figura merece ${ }^{980}$.

\footnotetext{
977 Recordemos que en nuestro país fue Rafael Bielsa uno de los tantos maestros que enseñaron que lo esencial a tener en cuenta a la hora de realizar algún tipo de apreciación que pueda llegar a influir en las posteriores opiniones, es atender a la problemática de los conceptos jurídicos: "La palabra bien formada tiene un derecho propio, y si se le niega el derecho, la equidad justifica la admisión de ellas (otras palabras)" Cfr. Rafael BIELSA, Los conceptos jurídicos y su terminología, Depalma, Buenos Aires, 1.961, p. 21.

${ }_{978}$ Ibídem.

${ }^{979}$ Cfr. Ricardo GUIBOURG, Una concepción analítica del derecho, en Andrés BOTERO BERNAL (Coord.), Filosofia del Derecho Argentina, Temis, Bogotá, 2.008, p. 10 y ss.
} 


\subsubsection{Documento, instrumento o escritura pública notarial: la} cuestión conceptual en el derecho notarial argentino.

Los términos usuales de instrumento, documento y escritura, en soledad o con todos sus adjetivos, han sido utilizados como términos intercambiables. Muy a pesar que los autores puedan tener algún criterio asumido con respecto de la cuestión terminológica -incluso yo mismo tengo una opinión formada al respecto ${ }^{981}$-, lo cierto es que pueden hacerse un sinnúmero de deducciones al efecto acerca de las razones por las cuales siempre los conceptos han sido utilizados como términos intercambiables.

En nuestro país, Carlos Emérito González advertía que en la materia de instrumentos $\mathrm{y} / \mathrm{o}$ documentos, son pocos los vocablos que presentan acepciones diferentes $^{982}$. El autor fue quien fundamentó la existencia del derecho notarial formal a través de una novedosa presentación que por primera vez en nuestro país sistematizó la teoría general del instrumento público, estudio desde donde enseñó que las denominaciones escritura, escritura pública, instrumento, instrumento público, instrumento publico notarial, documento y documento notarial son voces que se utilizan de manera intercambiable en los países que profesan el notariado latino ${ }^{983}$. Otro inolvidable autor argentino, Carlos Pelosi, confirmaría lo argumentado por

${ }^{980}$ El tema viene llamando la atención. En el desarrollo del derecho notarial, determinados objetos de análisis como la fe pública y la deontología y/o los deberes éticos notariales, cuentan con estudios especializados. V. Eduardo J. COUTURE, El concepto de fe pública (Introducción al estudio del derecho notarial), ob. cit., págs. 16 y ss, y Sebastián Justo COSOLA, Los deberes éticos notariales, ob. cit., págs. 355 y ss.

${ }^{981}$ Siempre he creído que el desarrollo de la teoría del instrumento público como objeto esencial del derecho notarial respondía a una cuestión de conveniencia: eran los momentos claves en donde el notariado se separaba del derecho civil. Obtener una teoría desarrollada ampliamente a lo largo de los países de tradición occidental, e impulsarla hacia la categoría de "objeto esencial" de una determinada nueva disciplina científica como la notarial, daba fuerza y vigor al derecho madre. Luego se potenciarían las teorías acerca del documento, en razón de las cuestiones terminológicas, y de la escritura pública como el instrumento público más relevante.

${ }^{982}$ Cfr. Carlos Emérito GONZALEZ, Teoría general del instrumento público..., ob. cit., p. 35 . 
LOS EFECTOS DE LA PUBLICIDAD EN EL DOCUMENTO NOTARIAL

González, aunque al momento de efectuar el intenso estudio acerca de las cuestiones etimológicas implicadas ${ }^{984}$, se ocuparía por resaltar que aunque sea mínima, la diferencia entre el significado de documento y de instrumento existe y es indudablemente, una realidad. Decía por aquel entonces Pelosi: “...estimo que la primera (instrumento) es más expresiva cuando se quiere hablar de prueba. En la base de la noción de documento está la idea de docencia, y en la de instrumento, la de prueba ${ }^{985 " .}$. Argentino Neri por su parte adelantaba que la voz instrumento hace referencia al escrito con que se justifica o se prueba un hecho o un derecho, y en el sentido jurídico, es lo que sirve para instruir una causa, o lo que conduce a la averiguación de la $\operatorname{verdad}^{986}$. En un aparente camino de similar interpretación parecen también orientarse los aportes de José María Mustapich ${ }^{987}$, quien a partir de señalar que la voz documento es de naturaleza procesal, argumenta que el documento es una representación objetiva e idónea para reproducir una cierta manifestación del pensamiento, mientras que los instrumentos llevan en si la prueba de su procedencia ${ }^{988}$. En una orientación análoga, también los legados de Rufino Larraud ${ }^{989}$.

Ya más cerca en el tiempo Cristina Armella advierte que el propio concepto de instrumento público motiva a análisis desde diferentes disciplinas del

\footnotetext{
${ }^{983}$ Así, el inolvidable autor de la primera tesis doctoral de derecho notarial defendida en la Facultad de Derecho de la Universidad de Buenos Aires, de excelente rigor científico, dio tratamiento de manera indistinta a los términos instrumento, escritura y documento. La tesis, con el mismo nombre que el citado anteriormente, fue defendida el 19/12/1952.

http://www.derecho.uba.ar/academica/posgrados/doc tesis aprobadas tabla_1952.php (Último Acceso: 23/08/2017). Será más adelante en el tiempo el momento en que González se ocupe de precisar ciertos conceptos, inclinándose por admitir que mientras el instrumento público es el género, la escritura pública es su principal especie, aunque aclarando nuevamente que muchas veces se admite la designación de la especie por el género al igual que la sinécdoque. Cfr. Carlos Emérito GONZÁLEZ, Constitución de Sociedades Anónimas, Abeledo Perrot, Buenos Aires, 1.958, p. 20.

${ }^{984}$ Cfr. Carlos A. PELOSI, El documento notarial, ob. cit., págs. 12 y ss.

${ }^{985}$ Ibídem, p. 16. El autor se inclina finalmente por la designación documento notarial, en lugar de instrumento notarial, pues la considera más dotada de precisión en la lexicografía notarial como así también la que mejor se ajusta a la cuestión académica del momento. Ídem, p. 18. También el autor se refiere a la voz documento en la obra de su autoría, Estudios jurídicos notariales, Abeledo Perrot, Buenos Aires, 1.965, p. 15.

${ }^{986}$ Argentino I. NERI, Tratado teórico y práctico de derecho notarial, Vol. II, ob. cit., p. 4.

${ }^{987}$ José María MUSTAPICH, Tratado teórico y práctico de derecho notarial, $\mathrm{t}^{\circ} \mathrm{I}$, ob. cit.

${ }^{988}$ Ibídem, págs. 90 y ss.

${ }^{989}$ Rufino LARRAUD, Curso de Derecho Notarial, ob. cit., págs. 197 y ss.
} 


\section{SEBASTIÁN JUSTO COSOLA}

derecho, como la civil, la penal, la administrativa, la comercial y la procesal ${ }^{990}$, y se suma a considerar que la voz documento implica una enseñanza mientras que la de instrumento intenta instruirnos o informarnos acerca de un hecho pasado ${ }^{991}$, de la misma manera que José María Orelle presenta un análisis esquematizado y preciso, con profundas connotaciones teóricas ${ }^{992}$. También son relevantes los aportes de Adriana Abella ${ }^{993}$ y de Mario Zinny ${ }^{994}$, que son quienes desarrollan estas teorías que se refieren a operaciones representativas de las declaraciones de voluntad, marcando una notable diferencia entre las voces documento e instrumento con interesantes análisis efectuados desde los aspectos esencialmente históricos y comparativos. En fin, en el intento por presentar un panorama teórico introductorio al estudio del tema, las teorías clásicas referidas, han establecido estas primeras diferencias que dieron y dan lugar en la actualidad para que algún autor pueda optar por la designación que considere apropiada desde lo etimológico, desde lo conceptual y desde lo terminológico.

De esta forma, y sólo por citar algunos ejemplos, puede decirse que en nuestro país adoptan la voz documento notarial Francisco Martínez Segovia ${ }^{995}$, Roberto Mario Arata ${ }^{996}$, Mario Antonio Zinny ${ }^{997}$, Cristina Noemí Armella ${ }^{998}$, Adriana Nélida Abella ${ }^{999}$, Natalio Pedro Etchegaray y Vanina

\footnotetext{
990 Cristina Noemí ARMELLA, De los instrumentos públicos, Alberto BUERES (Dir.) y Elena I. HIGHTON (Coord.), ob. cit., p. 2.

${ }^{991}$ Ibídem, p. 3.

992 Cfr. José María ORELlE, De los instrumentos públicos, en Augusto C. BELLUSCIO (Dir.) y Eduardo A. ZANNONI (Coord.), Código civil y leyes complementarias- Comentado, anotado y concordado, $\mathrm{T}^{\circ} 4$, Astrea, Buenos Aires, 2.001, p. 474 y ss.

${ }^{993}$ Adriana Nélida ABELLA, Derecho notarial..., ob. cit., págs. 305 y ss.

${ }^{994}$ Cfr. Mario Antonio ZINNY, Conocimientos útiles para la práctica del derecho, Ad Hoc, Buenos Aires, 2.007, págs. 147 y ss.

${ }^{995}$ Francisco MARTINEZ SEGOVIA, Función notarial, ob. cit., p. 26.

${ }^{996}$ Roberto Mario ARATA, Estudios para una historia..., ob. cit.

${ }^{997}$ Cfr. Mario Antonio ZINNY, El acto notarial (Dación de fe), Depalma, Buenos Aires, 2.000 , p. 7. El autor remite a la definición de documento brindada por Carnelutti. En referencia a la voz documento, ver también del autor el libro La base de la teoría general del derecho, Ad Hoc, Buenos Aires, 2.010, p. 31.

998 Cfr. Cristina Noemí ARMELLA, Julieta Ema ORIOL y Marta Rosa PIAZZA, El documento notarial. Su valor probatorio, RN n ${ }^{\circ}$ 909, Colescba, La Plata, 1.991, p. 811 y ss.

999 Adriana Nélida ABELLA, Derecho notarial (Derecho documental-responsabilidad notarial), Zavalia, Buenos Aires, 2.010, p. 363.
} 
LOS EFECTOS DE LA PUBLICIDAD EN EL DOCUMENTO NOTARIAL

Leila Capurro ${ }^{1000}$, Rufino Larraud ${ }^{1001}$, Ricardo Javier Saucedo ${ }^{1002}$, y entre tantos otros, Alberto Villalba Welsh ${ }^{1003}$.

En cambio, las voces instrumento, instrumento público o instrumento público notarial -indistintamente- son adoptadas por Carlos Emérito González $^{1004}$, Carlos Nicolás Gattari ${ }^{1005}$, Ignacio Allende ${ }^{1006} y$ entre otros, Santiago Raúl Deimundo ${ }^{1007}$, mientras que la referencia a la fuerza de la escritura pública puede advertirse en algún solitario aporte de José María Mustapich ${ }^{1008}$ y en la consolidada obra de Rubén Augusto Lamber ${ }^{1009}$. En fin, algunos autores también advierten de la utilización de los mencionados términos como sinónimos ${ }^{1010}$ a la vez que otros, sin advertirlo, los utilizan indistintamente ${ }^{1011}$.

1000 Cfr. Natalio Pedro ETCHEGARAY y Vanina Leila CAPURRO, Derecho notarial aplicado, T ${ }^{\circ}$ I, Colección Función Notarial-Natalio Pedro ETCHEGARAY (Coord.), Astrea, Buenos Aires, 2.011, p. 197. También Natalio Etchegaray utiliza la voz Documento Notarial en Escrituras y actas notariales, ob. cit., págs. $25 \mathrm{y}$ ss; y finalmente en su última obra Protocoleando (Notariado y lunfardo), Editorial de la Cultura Urbana, Avellaneda, 2.012, págs. 33 y ss.

${ }^{1001}$ Rufino LARRAUD, Curso de derecho notarial, ob. cit., p. 199.

1002 Cfr. Ricardo Javier SAUCEDO, Régimen del notariado en el Mercosur, Ediciones Jurídicas, Buenos Aires, 1.998, p. 53 y ss.

${ }^{1003}$ Alberto VILLALBA WELSH, El derecho notarial a la luz de la teoría egológica, ob. cit., p. 26.

${ }^{1004}$ Carlos Emérito GONZÁLEZ, Derecho notarial, ob. cit., págs. 299 y ss.

1005 Cfr. Carlos Nicolás GATTARI, El objeto de la ciencia del derecho notarial, Depalma, Buenos Aires, 1.969, págs. 84 y ss.

${ }^{1006}$ Ignacio M. ALLENDE, La institución notarial..., ob. cit., p. 92.

1007 Santiago Raúl DEIMUNDO, Pensamiento y sentimiento sobre el notariado, ob. cit., p. 31.

1008 Cfr. José María MUSTAPICH, Escrituras públicas (En el proyecto de Reformas al Código Civil), Editorial Guillermo Kraft Ltda., Buenos Aires, 1.941, p. 22 y cc.

${ }^{1009}$ Rubén A. LAMBER, La escritura pública, ob. cit.

${ }^{1010}$ Cfr. Marina C. ZUVILIVIA, El notario y la seguridad jurídica, Juris, Rosario, 2.008, p. 177.

1011 Cfr. Susana Violeta SIERZ, Derecho Notarial -Concordado-, Dilalla, Buenos Aires, 2.007 , p. 137. En el capítulo cuarto de la obra, que lleva como título Documentos Notariales, la autora expresa: "La misión documentadora del notario implica la creación y reacción del instrumento, a los efectos de que el mismo sea válido y eficaz". 


\subsubsection{Las otras perspectivas propuestas para el análisis} conceptual.

Otras teorías independientes también intentaron justificar la cuestión terminológica. Eduardo Bautista Pondé, en el ejemplo, fue quien oportunamente ofreció un tratamiento diferente ${ }^{1012}$. Para éste autor, al no haberse desarrollado una teoría profunda sobre la naturaleza jurídica del documento notarial, debe prevalecer lo primero que fuera históricamente tenido en cuenta como relevante en el seno de su estudio: la relevancia de $s u$ valor probatorio como prueba preconstituída ${ }^{1013}$. La designación de documento entonces, cobra sentido con mayor precisión que la de instrumento, por cuanto el mismo históricamente siempre se ha probado a través de cualquier soporte, independientemente de las formas requeridas para conformar lo que luego sería considerado el protocolo. En contra de ello, algunos notarialistas contemporáneos dirigidos por Elena Highton advierten que la noción de documento en la actualidad no se vincula exclusivamente con la prueba, sino que ésta es únicamente su consecuencia refleja, pero para nada determinante de su naturaleza ${ }^{1014}$.

También es particular el análisis que ofrece Rubén Lamber en relación a la diferenciación terminológica ${ }^{1015}$. El autor considera que la enorme variedad de instrumentos públicos que existen -y que exceden claramente a los mencionados en el articulado del Código Civil-, hacen pensar que puede existir una diferencia entre lo que se denomina documento público e instrumento público. Mientras que estos últimos son los limitados a ciertos casos previstos en la ley, la primera definición implicaría una consideración de género, es decir, todos los documentos que puedan tener la característica

\footnotetext{
${ }^{1012}$ Eduardo Bautista PONDÉ, Tríptico Notarial, ob. cit., p. 97.

${ }^{1013}$ Ibídem.

1014 Cfr. Elena HIGHTON, Angélica G.E VITALE, Liliana E. ABREUT y Ricardo J. BLANCO LARA, La función notarial en la comunidad globalizada, Elena HIGHTON (Dir.) y Angélica G.E. VITALE (Codir.), Rubinzal Culzoni, Santa Fe, 2.005, p. 116 y ss.

${ }^{1015}$ Cfr. Rubén Augusto LAMBER, La escritura pública, $\mathrm{t}^{\circ} \mathrm{I}$, ob. cit.
} 
de público ${ }^{1016}$. Este es un tema que aborda en profundidad José María Orelle ${ }^{1017}$ desde diversos enfoques ${ }^{1018}$.

También existen otras posiciones. Carlos Gattari se refiere al instrumento notarial como una de las especies más importante de documento público ${ }^{1019}$; Gastón Zavala afirma que el documento notarial ha sido el concepto originario y matriz del documento público en general y de la autenticidad en especial $^{1020}$, mientras que José Carminio Castagno elabora un interesante planteo de la definición del instrumento público, estableciendo como premisa que lo más trascendente a resaltar de esta figura es tanto la percepción sensorial de los hechos como la declaración coetánea, de manera escrita, de lo percibido ${ }^{1021}$. Aun sin hacer hincapié en distinguir las voces documento e instrumento, el último autor referenciado vuelve a referirse tangencialmente al tema de la prueba del instrumento ${ }^{1022}$.

\footnotetext{
${ }^{1016}$ Ibídem, p. 12.

1017 Cfr. José María R. ORELLE, Actos e instrumentos notariales, La Ley, Buenos Aires, 2.008 , p. 16 y cc. (TD).

${ }^{1018}$ Cfr. José María R. ORELLE, Actos Jurídicos, en Jorge Horacio ALTERINI (Dir. Gen.), José W. TOBIAS (Dir. T ${ }^{\circ}$ Ignacio E. ALTERINI (Coord.), Código Civil y Comercial Comentado. Tratado exegético, $\mathrm{t}^{\circ}$ II, Thomson Reuters-La Ley, Buenos Aires, 2.016, p. 426 y ss.

${ }^{1019}$ Cfr. Carlos Nicolás GATTARI, Manual de derecho notarial, Abeledo Perrot, Buenos Aires, 2.008, p. 11.

${ }^{1020}$ Cfr. Gastón Augusto ZAVALA, La forma notarial, en Anuario Iberoamericano de Derecho Notarial $n^{\circ} 2$, Juan Francisco DELGADO DE MIGUEL (Director), Consejo General del Notariado Español, Madrid, 2.003, p. 400.

${ }^{1021}$ Cfr. José Carlos CARMINIO CASTAGNO, Teoría general del acto notarial y otros estudios, t ${ }^{\circ} \mathrm{I}$, Edición del Autor, Paraná, 2.006, págs. 235-237. El notarialista entrerriano destaca, por sobre todas las cosas, la figura del funcionario que elabora el instrumento, y por ello concluye en lo que considera es un concepto esencial: "El documento que contiene dicha simultanea declaración del funcionario de los hechos por el sensorialmente percibidos es un instrumento público". Su análisis continúa con la consideración del contenido del instrumento, donde no duda en afirmar que si su contenido hace plena fe, "es verdad impuesta".

${ }^{1022}$ En algunos aspectos sobresalientes de esta teoría encuentra José María Orelle algunos fundamentos de su tesis doctoral, pero con otros interesantes fundamentos, y adoptando la voz documento notarial. V. José M. R. ORELLE, Actos e instrumentos notariales, ob. cit., p. 157 y ss.
} 
SEBASTIÁN JUSTO COSOLA

\subsubsection{Teleología legal en la República Argentina ${ }^{1023}$.}

En nuestro país y en general, en todos los países de tradición romanista que adoptan el derecho notarial formal y sustantivo que aquí ejercemos, la presentación para el estudio del documento notarial se predispone siguiendo el correspondiente método de análisis:

a) Código Civil y Comercial de La Nación y leyes especiales : estudio de las instituciones del derecho privado afines al tema -teoría general del instrumento público, teoría del acto jurídico, sus clases y sus modos normales y anormales de conclusión y dentro del acto, en particular, el estudio de la teoría de la forma, como elemento del acto y también desde el instrumento;

b) Las leyes notariales, sean nacionales o provinciales y estaduales: cada ley local presenta una descripción del documento notarial, con sus requisitos, sus efectos y sus alcances, que siguiendo los principios generales establecidos en leyes de mayor jerarquía describen con acierto ciertas cuestiones de técnica notarial que ayudan a alcanzar aun un mayor grado de certeza en la mencionada dación de fe; y

c) Relación con las leyes del procedimiento notarial de inscripción (registración de acuerdo al principio de publicidad registral ya analizado).

Sin lugar a dudas, la denominación que campea en la legislación argentina es la que se refiere al documento notarial. Algunas leyes notariales argentinas exigen que el mencionado documento notarial, para que sea tal, tiene que reunir ciertos requisitos esenciales e ineludibles. Así, es notarial todo aquel documento que reúna las formalidades legales, que sea autorizado por un

${ }^{1023}$ Cristina Noemí ARMELLA (Dir.) y Mariano ESPER (Inv.), Summa Notarial, Registral e Inmobiliaria, $\mathrm{T}^{\circ} \mathrm{VI}$, ob. cit., págs. 7596-8129. 
LOS EFECTOS DE LA PUBLICIDAD EN EL DOCUMENTO NOTARIAL

notario en ejercicio de sus funciones y que el mismo obre dentro de los límites impuestos por su competencia. Dentro de esta dirección se encuentran las legislaciones específicas y vigentes pertenecientes al ejercicio notarial bajo el controlar de los Colegios de Escribanos de las Provincias de Buenos Aires $^{1024}$, Mendoza ${ }^{1025}$, Misiones ${ }^{1026}$, Rio Negro ${ }^{1027}$, San Juan ${ }^{1028}$, San Luis $^{1029}$, Santiago del Estero ${ }^{1030}$, como así también la institución de la actual Ciudad Autónoma de Buenos Aires ${ }^{1031}$.

Otros leyes en cambio se refieren directamente al protocolo, y conjugando éste ultima voz con las competencias de los notarios o escribanos, conforman los requisitos que se deben tener en cuenta a la hora de avizorar las exigencias que requiere la creación del documento notarial. En esta dirección se encuentran las legislaciones respectivas de los escribanos que

${ }^{1024}$ Colegio de Escribanos de la Provincia de Buenos Aires. Decreto-Ley 9020/1978, art. 133: "En el sentido de esta ley es notarial todo documento que reúna las formalidades legales, autorizado por notario en ejercicio de sus funciones y dentro del límite de su competencia".

${ }^{1025}$ Colegio de Escribanos de la Provincia de Mendoza. Ley 3058/1964. Art. 11 "Es notarial todo documento con las formalidades de Ley, autorizado por notario en ejercicio de sus funciones y dentro de los limites de su competencia".

${ }^{1026}$ Colegio de Escribanos de la Provincia de Misiones. Ley 3743/2001. Art. 89: "En el sentido de esta ley, es notarial todo documento que reúna las formalidades legales, autorizado por notario en ejercicio de sus funciones y dentro de los límites de su competencia". Esta norma ha sido consolidada por ley 4526/2010.

1027 Colegio de Escribanos de la Provincia de Rio Negro. Ley 4193/2007. Art. 61: "En el sentido de esta ley, es notarial todo documento que reúna las formalidades legales, autorizado por notario en ejercicio de sus funciones $y$ dentro de los límites de su competencia". Esta ley además, introduce la denominación de "principios" en sus primeros tres artículos para sentar bases acerca del ejercicio de la función notarial, el notario, y el Colegio de Escribanos.

${ }^{1028}$ Colegio de Escribanos de la Provincia de San Juan. Ley 3718/1972. Art. 11: “Es notarial todo documento con las formalidades de ley, autorizado por notario en ejercicio de sus funciones y dentro de los límites de su competencia".

${ }^{1029}$ Colegio de Escribanos de la Provincia de San Luis. Ley 5721/2004 (Consolidada según ley 5781/2004). Art. 55: "En el sentido de esta ley, es notarial todo documento que reúna las formalidades legales, autorizado por notario en ejercicio de sus funciones y dentro de los limites de su competencia".

${ }^{1030}$ Colegio de Escribanos de la Provincia de Santiago del Estero. Ley 3662/1971. Art. 17: "Es notarial todo documento con las formalidades de ley, autorizado por el notario en ejercicio de sus funciones y dentro de los limites de su competencia".

${ }^{1031}$ Colegio de Escribanos de la Capital Federal (Hoy Ciudad Autónoma de Buenos Aires). Ley notarial 404/2000 (T.O), art. 59: "En el sentido de esta ley, es notarial todo documento que reúna las formalidades legales, autorizado por notario en ejercicio de sus funciones $y$ dentro de los límites de su competencia". 


\section{SEBASTIÁN JUSTO COSOLA}

ejercen en las provincias de Chaco ${ }^{1032}$, Chubut ${ }^{1033}$, Córdoba ${ }^{1034}$, Entre Ríos ${ }^{1035}$, Formosa $^{1036}$, Jujuy ${ }^{1037}$ y La Pampa ${ }^{1038}$.

También existen otras legislaciones, como la de Catamarca ${ }^{1039}$, Corrientes ${ }^{1040}$, Neuquén ${ }^{1041}$, que se refieren a las escrituras públicas, y en una larga mención de sus requisitos, formalidades a tener en cuenta y descripción de la competencia, contiene las bases generales planteadas para conformar el

${ }^{1032}$ Colegio de Escribanos de la Provincia de Chaco. Ley Notarial 2212/1977 arts. 1 y 64 respectivamente: "El escribano de Registro a los efectos de esta Ley es el profesional de Derecho a cargo de una función pública instituida por el Estado para hacer constar y garantizar en un registro la autenticidad de los hechos cumplidos por el mismo o pasados en su presencia, en ejercicio de sus funciones así como para dar forma, perfeccionar y autenticar las relaciones jurídicas extrajudiciales. Todo ello en los casos en que su intervención fuera requerida y de conformidad con las leyes, sus reglamentaciones y con las instrucciones particulares que reciba". Art. 64 (Parte pertinente): "El protocolo es la colección ordenada de todas las escrituras matrices autorizadas durante el año, con la documentación anexa a las mismas y con sujeción estricta a las disposiciones del Código Civil y de la presente Ley..."

${ }^{1033}$ Colegio de Escribanos de la Provincia de Chubut. Ley 5055 (Consolidada por ley 5688/2007). Art. 15: "El escribano de registro es el oficial publico facultado para recibir y redactar conforme a las leyes, los actos y contratos que le fueran encomendados y para dar carácter de autenticidad de los hechos, declaraciones y convenciones que ante él se desarrollen, formulen o expongan cuando para ello fuere requerida su intervención"; Art. 67 (Parte Pertinente): "Además de los requisitos establecidos por el código civil y otras leyes, la redacción de las escrituras públicas y documentos notariales se sujetará a las siguientes normas..."

${ }^{1034}$ Colegio de Escribanos de la Provincia de Córdoba. Ley 4183/1975 arts. 10 ,12 y 41: Art. 10: "El escribano de registro es el profesional de derecho y el funcionario público instituido para recibir y redactar conforme a las leyes, los actos y contratos que le fueren encomendados y para dar carácter de autenticidad a los hechos, declaraciones y convenciones que ante él se desarrollaren, formularen o expusieren, cuando para ello fuere requerida su intervención"; Art. 12 (Parte pertinente): "Las escrituras y demás actos públicos de competencia notarial sólo podrán ser autorizados por escribanos de registro y a ello compete también (...) y en general intervenir en todos aquellos actos que no requieren la formalidad de la escritura pública en el modo y forma que determinen las leyes procesales y el reglamento notarial". Art. 41: "Las escrituras públicas deberán extenderse en el protocolo que se formará con la colección ordenada de todos los otorgamientos efectuados durante el año y con los certificados del Registro General en la forma y condiciones establecidas por el Cód. Civil y esta ley"

${ }^{1035}$ Colegio de Escribanos de la Provincia de Entre Ríos. Ley 6200 (T.O). Art. 6 (Parte pertinente): "Son funciones notariales de los escribanos titulares o adscriptos a requerimiento de parte: a) Recibir, interpretar, dar forma legal y conferir autenticidad previo asesoramiento sobre el alcance y efectos del acto- a las declaraciones de voluntad y de verdad de quienes le cometen su instrumentación pública (...); d) Formar, redactar y 


\section{LOS EFECTOS DE LA PUBLICIDAD EN EL DOCUMENTO NOTARIAL}

documento notarial. La legislación de Tucumán ${ }^{1042}$ presenta también una descripción precisa de las escrituras públicas y el protocolo notarial.

Otros cuerpos normativos estaduales presentan algunas características que merecen ser destacadas. Si bien en líneas generales, suelen referirse también al documento en la conjunción de las funciones notariales típicas, tanto La

extender las escrituras públicas, actas y demás documentos mencionados en la presente ley (...); Articulo 39: "Las escrituras deberán ser extendidas en el protocolo, que se formara con la colección ordenada de los folios, indices, documentos extendidos en ellos, y demás que se agreguen por imperio de las leyes, a requerimiento o por decisión del escribano".

1036 Colegio de Escribanos de la Provincia de Formosa. Decreto Ley 719/1979; Ley 1219/1996 y sus modificatorias. Art. 2: “La Provincia de Formosa reconoce a la función notarial como el ejercicio privado de una función pública delegada por el estado en quienes, además del título profesional, se encuentran habilitados para su ejercicio mediante evaluación técnico, profesional y ética y, además, reciban la investidura fedante que le asigna el estado, a través de los mecanismos legales"; Art. 57": "El protocolo es la colocación ordenada de todas las escrituras matrices autorizadas durante el año, con la documentación anexa a las mismas y con sujeción estricta a las disposiciones del Código Civil y de la presente Ley. Los protocolos comprenderán las escrituras matrices de cada año calendario" Art. 70: "Las escrituras públicas se extenderán con sujeción a las disposiciones del Código Civil, otras leyes y sus reglamentaciones y las del presente capítulo. Solo pueden ser asentadas en los cuadernos habilitados de acuerdo con lo dispuesto en el artículo precedente".

${ }^{1037}$ Colegio de Escribanos de la Provincia de Jujuy. Ley 4884/1995. Art. 1 (Parte pertinente): "Compete al notario: 1- La función de recibir, interpretara y adecuar al ordenamiento jurídico las exteriorizaciones de voluntad de quienes requieren su ministerio para la instrumentación fehaciente de hechos, actos y negocios jurídicos (...)”; art. 15 (Parte Pertinente): "Las escrituras públicas y las actas que en esta ley se denominan escrituras actas, como requisito esencial de validez, deberán ser redactadas en el protocolo (...)" y art. 33: "Escritura pública es todo documento matriz que contuviere actos o negocios jurídicos. Su redacción se sujetara a las normas impuestas por las leyes de fondo y la presente".

1038 Colegio de Escribanos de la Provincia de La Pampa. Ley 49/1993. Art. 9 (Parte pertinente): "El Escribano de Registro es el funcionario público instituido para recibir y redactar conforme a las leyes, los actos y contratos que le fueren encomendados y para dar carácter de autenticidad a los hechos, declaraciones y convenciones que ante él se desarrollen, formularen o expusieren, cuando para ello fuere requerida su intervención (...); Art. 58: "Los protocolos son instrumentos públicos del Estado, bajo la custodia del Escribano titular del Registro"; Art. 59 "Las escrituras deben extenderse en el protocolo que se formará con la colección ordenada de los otorgamientos hechos durante el año".

1039 Colegio de Escribanos de la Provincia de Catamarca. Ley 3843/1982. Art. 59: "Los protocolos son instrumentos públicos del Estado provincial bajo custodia del escribano titular del registro"; art. 68: "Las escrituras públicas se extenderán con sujeción a las disposiciones del Código Civil, leyes especiales, sus reglamentaciones y de las del presente 


\section{SEBASTIÁN JUSTO COSOLA}

Rioja $^{1043}$ como Salta ${ }^{1044}$ describen una parte general de suma importancia que presenta al notario como hacedor directo del instrumento público ${ }^{1045}$.

En otro orden, también puede avizorarse de manera tan siquiera llamativa, que legislaciones como las de Santa $\mathrm{Cruz}^{1046}$ y Santa $\mathrm{Fe}^{1047}$ no refieren en ningún capitulo o apartado al documento notarial, como así tampoco a los instrumentos públicos o las escrituras y los requisitos que deben estos conformar para ser válidos, salvo en menciones propias y típicas de la descripción general de la labor notarial.

capítulo" y articulo "El escribano de registro es el funcionario público facultado para recibir, redactar y dar autenticidad, conforme a las leyes y en los casos que ellas autorizan, los actos y contratos que les fueren encomendados".

${ }^{1040}$ Colegio de Escribanos de la Provincia de Corrientes. Ley 1482/89 art. 32 (de amplia descripción de competencia material del escribano); Art. 54 (Parte pertinente). "Las Escrituras Públicas deberán extenderse en el Protocolo que se formará con la colocación adecuada de todos los otorgamientos efectuados durante el año", y art. 87 "Sin la habilitación por autoridad competente no hay protocolos. Es nula toda actuación hecha en cuadernos sin haber llenado esa formalidad".

${ }^{1041}$ Colegio de Escribanos de la Provincia de Neuquén. Ley 1033/1977. Art. 43: "Las escrituras serán autorizadas por los escribanos a cargo de registros, con sujeción a las disposiciones del Código Civil y las del presente capitulo". Art. 11: "El escribano de registro es el funcionario público instituido para recibir, redactar y dar autenticidad conforme a las leyes y en los casos en que ellas determinen los actos y contratos que le fueran encomendados. Solo a él compete el ejercicio del notariado".

1042 Colegio de Escribanos de la Provincia de Tucumán. Ley 5732/1985. Art. 47: "Las escrituras públicas, como requisito esencial de validez, deben ser extendidas en el protocolo. Las actas y demás documentos notariales pueden formar o no parte del protocolo, salvo que por su carácter y fines o por disposición de la ley requieran facción protocolar"; Art. 65: "A los efectos de esta ley, escritura pública es todo documento matriz autorizado por los escribanos de registro, con sujeción a las normas vigentes".

${ }^{1043}$ Colegio de Escribanos de la Provincia de La Rioja. Ley 6071/ Art. 13: "El Escribano de Registro es el profesional de derecho a cargo de una Función Pública, investido de la facultad dar Fe de los actos pasados ante él y dar carácter de autenticidad a los hechos, declaraciones y convenciones que ante él se desarrollaren, formularen o expusieren, cuando para ello se requiera su intervención; y en tal carácter quedan asimilados a los Magistrados en cuanto atañe al respeto y consideración que debe guardárseles"; Art. 68 (Parte Pertinente): "Además de los requisitos establecidos por el Código Civil y otras Leyes, la redacción de las Escrituras Públicas se sujetará a las siguientes normas (...)”.

${ }^{1044}$ Colegio de Escribanos de la Provincia de Salta. Ley 6486/1987. Art. 24 (Parte pertinente): "La competencia de los escribanos, por las razones de la materia se extiende a todos los hechos, actos y contratos de naturaleza privada extrajudiciales que se les confieren voluntariamente, con el objeto de perfeccionarlos jurídicamente y darles fuerza probatoria mediante la garantía de autenticidad". Art. 61: "Las escrituras y demás actos públicos sólo podrán ser autorizados por los escribanos de registro y a ellos les compete, en forma exclusiva, certificar la autenticidad de firmas personales o sociales, de impresiones digitales, 


\section{LOS EFECTOS DE LA PUBLICIDAD EN EL DOCUMENTO NOTARIAL}

Finalmente, debe destacarse con verdadero énfasis la existencia de legislaciones que introducen el tema de los principios, paradigmas o fundamentos del notariado como parte general introductoria, siempre referidos al ejercicio de la función notarial, al concepto de escribano y la significación de la colegiación, como es el caso de la Ciudad Autónoma de Buenos Aires ${ }^{1048}$, Chubut ${ }^{1049}$, Misiones ${ }^{1050}$, Rio Negro ${ }^{1051}$, Salta ${ }^{1052}$, San Luis $^{1053}$ y Tucumán ${ }^{1054}$. Es que una parte general introductoria a los principios que son origen de la función notarial permiten una argumentación solida e inequívoca del resto del articulado, que se consolida reconociendo los baluartes establecidos ab initio del ejercicio funcional. Y en esta sintonía, destaco que quizás la legislación de Tierra del Fuego sea la que mejor se ubica a la hora de describir la labor notarial de argumentación en el presente. La misma, sin posicionar al documento, la escritura, el protocolo o el instrumento como elemento esencial del quehacer cotidiano, presenta un artículo que reúne la función y labor notarial documentadora, entre

de copias y en general intervenir en todos aquellos actos que no requieran la formalidad de la escritura pública, en el modo y forma que determine la presente ley y el Reglamento Notarial".

1045 Art. 61: "Los Escribanos redactarán los instrumentos públicos en idioma castellano, empleando en ellos claro y preciso, sin términos oscuros ni ambiguos, evitando repeticiones inútiles". Colegio de Escribanos de la Provincia de Salta: Art. 62: "Los escribanos redactaran los instrumentos públicos en idioma castellano empleando en ellos estilo claro y preciso, sin términos oscuros o ambiguos".

${ }^{1046}$ Colegio de Escribanos de la Provincia de Santa Cruz. Ley 1749/1985. Art. 8: "El Escribano de Registro es el profesional de Derecho a cargo de una función pública, investido de la facultad de dar fe de los actos pasados ante él y dar carácter de autenticidad de los hechos, declaraciones y convenciones que ante él se desarrollaren, formularen o expusieren, cuando para ello fuera requerida su intervención"

1047 Colegio de Escribanos de la Provincia de Santa Fe. Ley 6898/1973. Art. 10: "El escribano es el funcionario público instituido para recibir y redactar conforme a las Leyes, los actos y contratos que le fueran encomendados y para dar carácter de autenticidad a los hechos, declaraciones y convenciones que ante él se desarrollaron, formularan o expusieron, cuando para ellos fuera requerida su intervención".

${ }^{1048}$ Arts. 1 a 6 inclusive.

${ }^{1049}$ Art. 1.

${ }^{1050}$ Arts. 1 y 2

${ }^{1051}$ Arts. 1 a 3 inclusive.

${ }^{1052}$ Arts. 1 a 5 inclusive.

${ }^{1053}$ Arts. 1 a 4 inclusive.

${ }^{1054}$ Arts. 1 a 5 inclusive. 


\section{SEBASTIÁN JUSTO COSOLA}

interpretación de leyes y argumentación de principios, digna de elogio y consideración ${ }^{1055}$.

\subsection{La cuestión de los conceptos en España proyectada}

\section{hacia el derecho comparado.}

Uno de los primeros autores del notariado español, Miguel Fernández Casado, advertía que es común utilizar las voces documento, instrumento y documento como si las mismas tuviesen la misma fuerza y los mismos resultados de aplicación ${ }^{1056}$. Otro autor, José María Mengual ${ }^{1057}$ aportaría notables teorías para conformar la autonomía científica del derecho notarial, y al considerar al derecho notarial como sustantivo, público y objetivo, tuvo la idea de someterlo a un test de universalidad que le permitió inferir que es posible alcanzar un código internacional de conceptos del derecho notarial $^{1058}$, dentro de los cuales los conceptos aludidos son intercambiables. Es Mengual quien comienza por acercar al notariado a José Castán

${ }^{1055}$ Colegio de Escribanos de Tierra del Fuego, Antártida e Islas del Atlántico Sur. Ley 285/1995 (observada por decreto 47/1996). Art. 4: “(El escribano) En ejercicio de la función y fe pública instrumental deben interpretara la voluntad de los requirentes, dándole forma legal, cuidando de la exactitud de lo que pueden ver, oír o percibir y de la eficiente estructuración jurídica del instrumento publico notarial cumpliendo las normas y los principios del derecho notarial respecto de los instrumentos públicos, a los efectos de obtener legitimación y autenticidad plena de todos los actos y contratos que ante él se formalicen"

${ }^{1056}$ Cfr. Miguel FERNÁNDEZ CASADO, Tratado de la notaría, $\mathrm{t}^{\circ} \mathrm{I}$, Imprenta de la viuda de M. Minuesa de Los Ríos, Madrid, 1.895, p. 349. El autor describe así, los documentos e instrumentos no definidos y descriptos en los códigos españoles de aquellos entonces.

1057 José María MENGUAL Y MENGUAL, Elementos de derecho notarial, t ${ }^{\circ}$ I (Preliminares), Librería Bosch, Barcelona, 1.931; t t $^{\mathrm{II}}-1$ (introducción y parte general), Librería Bosch, Barcelona, 1.932; $\mathrm{t}^{\circ} \mathrm{II}-2$ (Introducción y parte general-Continuación) y t $\mathrm{II}^{\circ}-3$ (Introducción y parte general-Conclusión), ob. cit.

1058 José María MENGUAL Y MENGUAL, Elementos..., tº I, ob. cit., p. 452. 
LOS EFECTOS DE LA PUBLICIDAD EN EL DOCUMENTO NOTARIAL

Tobeñas ${ }^{1059}$-reacio a separar el derecho notarial del derecho civil $^{1060}$-, hecho de notable trascendencia que termina por concretar tiempo después el ya recordado Rafael Núñez Lagos $^{1061}$, y por ello es harto probable que la designación de instrumento público en el derecho español y su influencia a los países latinoamericanos haya sido por aquellos entonces todavía más fuerte. En fin, de todo lo mucho escrito por los autores mencionados sin embargo, no existen mayores referencias al tema en estudio, salvo algunas menciones del notario como creador del documento ${ }^{1062}$. Tampoco existen referencias en el estudio de Antonio Bellver Cano tantas veces referido por notarialistas de la segunda mitad del siglo pasado ${ }^{1063}$.

1059 José CASTÁN TOBEÑAS, Prólogo de la obra de José María MENGUAL Y MENGUAL, Elementos de derecho notarial, t ${ }^{\circ}$ I (Preliminares), Librería Bosch, Barcelona, 1.931, p. VI y ss.

${ }^{1060}$ Ibídem, p. XI. Afirma CASTÁN TOBEÑAS en el prólogo: “Aplaudamos el interesante ensayo de sistematización y construcción cientifica del derecho notarial, tan valientemente acometido por el señor Mengual y que abre sus cauces al natural y progresivo desenvolvimiento de las normas que rigen la institución de la fe pública. En el campo del derecho, como en el de todas las ciencias, es ley biológica la división del trabajo, con sus secuelas de especialización y formación de nuevas disciplinas. Pero quizás el señor Mengual va demasiado lejos en la determinación del ámbito que corresponde al derecho notarial, como disciplina propia e independiente. Nosotros limitariamos la substantividad y la autonomía del derecho notarial al que nuestro autor llama derecho notarial formal. No negamos que no sea conveniente, para fines didácticos y profesionales, agrupar, como lo hace él, las normas de ese derecho notarial formal con las del derecho notarial material o contractual. Más esto no autoriza, a nuestro juicio, para reconocer a favor de estas últimas una rigurosa autonomía científica. ¿Cómo atribuir a los preceptos que rigen la capacidad y la validez intrínseca de los distintos actos notariales, principios propios, diversos de los principios del derecho civil, el mercantil o el administrativo que sean aplicables a cada uno de dichos actos, según su naturaleza? No exageremos la tendencia de diversificar y disgregar las materias jurídicas. Bueno es que se desenvuelvan el derecho laboral, el derecho agrario, el hipotecario, el notarial y tantas otras disciplinas juridicas que están hoy en periodo de formación; pero que no sea a costa de romper los vínculos que les ligan a las grandes formaciones cientificas clásicas -el derecho público y el civil o privado- sembrando la confusión y la desarmonía en la ciencia jurídica".

${ }^{1061}$ No dudo en afirmar que el planteo de Mengual ha sido quizás el que más me haya impactado de todos los libros a los que he recurrido en búsqueda de respuestas. A este grandioso autor español, la muerte lo alcanzó en su plenitud científica, y su obra, muy lamentablemente, quedo inconclusa.

1062 José María MENGUAL Y MENGUAL, Elementos..., tº II-1, ob. cit., p. 21.

${ }^{1063}$ Cfr. Antonio BELLVER CANO, Principios de régimen notarial comparado, ob. cit. De manera llamativa, el libro no tiene impresa ninguna fecha ni de edición y aun contando con la excelente introducción de Mateo AZPEITIA y el epílogo de Rafael de AZPITARTE, no hay referencia a fecha alguna. Todo indica que ha sido redactado entre 1932 y 1944, por las 


\section{SEBASTIÁN JUSTO COSOLA}

Otro gran referente del derecho notarial español, Enrique Giménez-Arnau cuya doctrina encuentra tan fiel reflejo aquí en nuestro país a través del mencionado Carlos Emérito González-, relaciona toda significación y alcance de la función notarial con el instrumento público ${ }^{1064}$. El autor insiste en que los fundamentos del instrumento público se remiten a un indiscutible origen probatorio $^{1065}$, para concluir que los fines del instrumento público son probar, dar forma y dar eficacia legal ${ }^{1066}$. José María Sanahuja y Soler, explica que el instrumento público es una de las clases de documento público, específicamente, el autorizado por notario ${ }^{1067}$. Nos advierte que los valores etimológicos de las voces documento e instrumento son exactamente los mismos ${ }^{1068}$, y que el Código Civil Español, como también la ley orgánica del notariado utilizan los términos dándoles un valor de equivalencia ${ }^{1069}$. En toda la obra, el autor utiliza los términos indistintamente ${ }^{1070}$. También el referido Castán Tobeñas se refiere a la voz instrumento como a la especie del género documentos que autoriza el notario ${ }^{1071}$.En una orientación similar a la referida en nuestro medio por Carminio Castagno, Eloy Escobar de la Riva advierte que el documento no es más que una exteriorización del pensamiento perceptible con la vista ${ }^{1072}$. Sobre estos conceptos, presenta un análisis del articulado del código civil de ese país que sirve para que pueda esbozar una propia clasificación instrumental. Es que el código español

diferentes citas dentro del libro a sentencias o fallos judiciales respectivamente.

${ }^{1064}$ Cfr. Enrique GIMENEZ-ARNAU, Introducción al derecho notarial, Revista de Derecho Privado, Madrid, 1.944, p. 183.

${ }^{1065}$ Ibídem, p. 189. Más adelante y sobre análisis histórico-jurídicos, el autor afirma que debe diferenciarse de género a especie las locuciones documento público e instrumento público, diferenciándose las mismas a partir de la intervención notarial en la confección del instrumento: "Queda asi perfilado el concepto: cuando un documento público es autorizado por un notario se convierte en un instrumento público”. V. págs. 207-208.

1066 Ídem, p. 122.

${ }^{1067}$ Cfr. José María SANAHUJA Y SOLER, Tratado de Derecho Notarial, to I, ob. cit., p. 421.

${ }^{1068}$ Ibídem. Dice el autor: "El valor etimológico de las palabras documento e instrumento es el mismo, no revelando relación de género a especie; así, la primera se deriva del verbo doceo, es, ere, igual a enseñar; y la segunda, de intruo, es, ere, equivalente a instruir".

${ }^{1069}$ Ibídem.

1070 Ídem, p. 422.

${ }^{1071}$ José CASTÁN TOBEÑAS, Función notarial y elaboración notarial del derecho, ob. cit., p. 59.

${ }^{1072}$ Cfr. Eloy ESCOBAR DE LA RIVA, Tratado de Derecho Notarial, ob. cit., p. 252. 
LOS EFECTOS DE LA PUBLICIDAD EN EL DOCUMENTO NOTARIAL

permite la interpretación de un concepto genérico y otro especifico de documento, y es el ultimo mencionado el documento notarial, que según sus propias palabras: "(es) conocido genéricamente como instrumento público $^{1073}$ ". También distingue a los documentos públicos en general del instrumento público en razón de su autor: para la obtención de un instrumento público se requiere la presencia notarial, mientras que para los documentos públicos en general basta con que sea autorizado por empleado público competente ${ }^{1074}$. Finalmente, enseña que para que el instrumento público pueda alcanzar los fines previstos por la ley debe estar dotado de permanencia y seguridad, para lo cual necesariamente será indispensable relacionarlo con el protocolo ${ }^{1075}$.

Otro gran aporte acerca del tema en estudio es promovido por Antonio Rodríguez Adrados. El maestro del notariado recuerda que el articulado específico del Código Civil Español utiliza las voces documento público e instrumento público indistintamente, y así, es considerado notarial el que sea autorizado por notario competente, con las solemnidades requeridas por ley ${ }^{1076}$. En otro estudio, adelanta que se identifica al documento con la cosa mueble, a la que le es incorporada una grafía, en principio escrito y expresivo del pensamiento jurídicamente relevante de su autor ${ }^{1077}$. También presenta un análisis histórico comparativo que termina por demostrarnos que en el Reino de España, las voces instrumento, escritura y documentos son consideradas como sinónimas, a pesar de reconocer, todas esas acepciones, fuentes diversas en el tiempo y en el significado etimológico ${ }^{1078}$. En el Código Civil Español -nos aclara el autor-, el documento funciona tanto como medio de prueba como vehículo de las declaraciones de voluntad cuando las mismas se realizan por escrito ${ }^{1079}$, hecho éste ultimo que da lugar a la producción de efectos sustantivos o negociales "que van mucho más

\footnotetext{
${ }^{1073}$ Ibídem.

1074 Ídem, p. 253.

${ }^{1075}$ Ibídem, p. 505.

1076 Cfr. Antonio RODRIGUEZ ADRADOS, El notario y el documento notarial, Escritos Jurídicos, Vol. II, CGN, Madrid, 1.996, p. 361.

1077 Cfr. Antonio RODRIGUEZ ADRADOS, Documento, Escritos Jurídicos, Vol. III, CGN, Madrid, 1.996, p. 11.

1078 Antonio RODRIGUEZ ADRADOS, El documento en el código civil, ob. cit., p. 27.

${ }^{1079}$ Ibídem, p. 30.
} 


\section{SEBASTIÁN JUSTO COSOLA}

allá de los estrechos límites de los negocios solemnes ${ }^{1080 " .} \quad$ Finalmente, a los fines del análisis del presente acápite, destaca que la fuente de seguridad del documento notarial radica en la existencia del protocolo ${ }^{1081}$.

En total sintonía, Juan Vallet de Goytisolo se refiere a los documentos notariales, a los que denomina genéricamente documentos públicos ${ }^{1082}$. El gran maestro siempre se refiere a la voz documento para referirse al creado por el notario ${ }^{1083}$. Isidoro Lora-Tamayo Rodríguez utiliza de manera indistinta las voces documento notarial ${ }^{1084}$ e instrumento publico notarial ${ }^{1085}$ para designar a aquellos que son creados por el notario, de la misma manera en que lo hacía Juan Francisco Delgado de Miguel $^{1086 .}$

La ley notarial española de mil ochocientos sesenta y dos fue modelo para Europa y para América. Por esta razón en muchos de los temas notariales y específicamente en el que ahora ocupa mi atención, debo decir que las voces instrumento público, instrumento publico notarial, instrumentos notariales o documentos notariales son en general utilizadas indistintamente en diversos

\footnotetext{
${ }^{1080}$ Ibídem.

${ }^{1081}$ Cfr. Antonio RODRIGUEZ ADRADOS, El documento notarial y la seguridad jurídica, Escritos Jurídicos, Vol. III, CGN, Madrid, 1.996, p. 107.

1082 Juan Berchmans VALLET DE GOYTISOLO, Panorama de derecho civil, ob. cit., p. 110.

1083 Juan Berchmans VALLET DE GOYTISOLO, Manuales de metodología jurídica, $\mathrm{t}^{\circ}$ III, ob. cit., p. 235; y también el ensayo Función autenticadora de las relaciones jurídicas, estudiada por el derecho notarial formal o técnico, en Derecho Notarial, Leonardo B. PEREZ GALLARDO e Isidoro LORA-TAMAYO RODRIGUEZ (Coord.), t ${ }^{\circ}$ I, ob. cit., p. 51.

${ }^{1084}$ Cfr. Isidoro LORA-TAMAYO RODRIGUEZ, Aplicación por el notario de la equidad, en Derecho Notarial, Leonardo B. PEREZ GALLARDO e Isidoro LORA-TAMAYO RODRIGUEZ (Coord.), $t^{\circ}$ I, ob. cit., p. 232 y ss.

${ }^{1085}$ Cfr. Isidoro LORA-TAMAYO RODRIGUEZ y Leonardo B. PEREZ GALLARDO, Estructura del instrumento publico notarial: una aproximación desde el derecho español y el derecho cubano, en Derecho Notarial, Leonardo B. PEREZ GALLARDO e Isidoro LORATAMAYO RODRIGUEZ (Coord.), $\mathrm{t}^{\circ}$ II, ob. cit., p. 227 y ss.

${ }^{1086}$ Cfr. Juan Francisco DELGADO DE MIGUEL, Principios generales de deontología notarial, en Derecho Notarial, Leonardo B. PEREZ GALLARDO e Isidoro LORATAMAYO RODRIGUEZ (Coord.), $\mathrm{t}^{\circ}$ II, ob. cit., p. 79 y ss y en La deontología notarial frente a los clientes, a los colegas y al estado, Gráficas Summa, Asturias, 1.998.
} 
LOS EFECTOS DE LA PUBLICIDAD EN EL DOCUMENTO NOTARIAL

países del notariado latino como Bolivia ${ }^{1087}$, Costa Rica ${ }^{1088}$, Cuba ${ }^{1089}$, Guatemala $^{1090}$, México ${ }^{1091}$, Paraguay ${ }^{1092}$, Perú ${ }^{1093}$, República Dominicana ${ }^{1094}$ y Uruguay $^{1095}$. No sin antes advertir que también en general, algunos autores en países como Colombia y Perú presentan ciertos análisis correspondientes bajo el único nombre de documento ${ }^{1096}$, mientras que ciertas obras específicas iberoamericanas de indudable importancia, realizan sus aportes aduciendo a nombres diferentes como los de acto jurídico notarial ${ }^{1097}$.

\footnotetext{
${ }^{1087}$ Saúl F.GUZMAN FARFÁN, Derecho notarial y registros públicos, ob. cit., págs. 93 y ss; Ramiro VILLARROEL CLAURE, Fundamentos de derecho notarial y registral inmobiliario, ob. cit., págs. 107 y ss; Álvaro Héctor OQUENDO LOPEZ, Compilaciones de derecho notarial para Bolivia, Cadena Editora, Sucre, 2.007; Juana Aidee MARIACA VALVERDE, Teoría y técnica notarial, ob. cit., págs. 82 y ss. Es de destacar que la ultima autora citada, en la misma obra se refiere a Documento electrónico -y no a instrumento electrónico- como podía suponerse teniendo en cuenta la terminología adoptada en toda la obra. Finalmente, una obra consolidada del notariado boliviano se refiere a la voz escritura pública, dentro del género instrumento publico notarial: Maria Luisa LOZADA BRAVO, María Silvia AGUILAR TARDÍO y Lilia Gladys FLORES MEDINA, De la escritura pública notarial, El País, Santa Cruz de la Sierra, 2.011, p. 44.

${ }^{1088}$ Cfr. Herman MORA VARGAS, La función notarial, Editorial Investigaciones Jurídicas S.A, San José De Costa Rica, 2.013, págs. 257 y ss.

${ }^{1089}$ Cfr. Pedro C. VERDEJO REYES, Derecho notarial, Editorial Pueblo y Educación, La Habana, 1.990, p. 61; Leonardo B. PEREZ GALLARDO, Diligencias y notas en el instrumento público notarial: un acercamiento a su estudio, en Estudios de derecho notarial Iberoamericano (Libro homenaje al prof. Dr. Nery Roberto MUÑOZ), Infoconsult Law, Guatemala, 2.013, p. 335, y Josefina CHINEA GUEVARA, La función notarial como garante de la seguridad jurídica contractual en el ordenamiento jurídico cubano, en Derecho Notarial, Leonardo B. PEREZ GALLARDO e Isidoro LORA-TAMAYO RODRIGUEZ (Coord.), $\mathrm{t}^{\circ} \mathrm{I}$, ob. cit., p. 364 y ss.

${ }^{1090}$ Nery Roberto MUÑOZ, El instrumento público y el documento notarial, ob. cit., págs. 1 y ss.

${ }^{1091}$ Bernardo PEREZ FERNÁNDEZ DEL CASTILLO, Derecho notarial, ob. cit., págs. 87 y ss; Luis CARRAL Y DE TERESA, Derecho notarial y derecho registral, ob. cit., págs. 125 y ss; y César Eduardo AGRAZ, Derecho notarial comparado en la República Mexicana, Porrúa e Instituto Internacional del Derecho y del Estado, México, 2.011.

1092 Lucila ORTIZ de DI MARTINO, Manual de derecho notarial, ob. cit., p. 37 y ss; Ana María DI MARTINO, Derecho notarial, Marben, Asunción, 2.009, p. 69 y ss.

${ }^{1093}$ Gunther GONZÁLES BARRÓN, Derecho registral y notarial, T $\mathrm{II}$, ob. cit., págs. 1175 y ss; Oswaldo ARIAS MONTOYA, Comentarios a la actualidad notarial peruana, Gaceta Notarial, Lima, 2.011; Carlos Ricardo TITO PUCA, Decreto del notariado, Gaceta Notarial, Lima, 2010; Pedro Germán NUÑEZ PALOMINO, Comentarios a la ley del notariado, Gaceta Notarial, Lima, 2.014, entre otros.

${ }^{1094}$ Cfr. César PINA TORIBIO, Temas notariales, Corripio, Santo Domingo, 1.993; y Rhadys I. ABREU de POLANCO, Lecciones de derecho notarial, Servicios Gráficos Integrados,
} 
SEBASTIÁN JUSTO COSOLA

\subsection{El documento y una construcción académica sobre}

\section{la idea de los principios.}

Es preciso advertir que la regulación del documento notarial en países del notariado latino, guarda absoluta sintonía con los principios del documento que en Argentina resultan ser tan esenciales como innegables. El notariado latino justifica su misión sobre la idea de la aplicación de los principios elementales de su ejercicio, idénticos en todos los países que conforman la Unión Internacional, siendo uno de ellos el que dirige a consolidar firmemente al documento notarial. Sin embargo, los países miembros enfrentan ciertas circunstancias propias de los momentos históricos que circunstancialmente les toca transitar. Y es por ello que no debe considerarse como sobreabundante la profusa difusión de informes que las naciones vienen aprobando acerca de la función notarial, intentando que las modernas fronteras del derecho internacional no invadan ni limiten el ejercicio de los principios notariales esenciales ${ }^{1098}$.

Analizadas entonces la teorías explicativas de la cuestión de la parte general del documento notarial, y visto el alcance que las mismas proyectan desde la teleología legal, corresponde analizar las diversas valoraciones que la

Santo Domingo, 2.005.

1095 Eduardo J. COUTURE, El concepto de fe pública..., ob. cit.; y Julio R. BARDALLO, Relaciones jurídicas notariales, $\mathrm{RdN} \mathrm{n}^{\circ} 717,1.971, \mathrm{p} .785$ y ss.

${ }^{1096}$ Cfr. Manuel CORREDOR PARDO, Falsedad documental: ficción social del autor, UEC, Bogotá, 2.007. En Perú: Víctor TINAGEROS LOZA, Naturaleza jurídica del notario, Gaceta Notarial, Lima, 2.013.

${ }^{1097}$ Nelson Rudys CASTILLO OGANDO, Derecho notarial, t ${ }^{\circ}$ I, ob. cit., págs. 149 y ss. En Argentina, José María R. ORELLE, Actos e instrumentos notariales, ob. cit.

${ }^{1098}$ A modo de ejemplo, el informe de la Comisión de asuntos jurídicos y de derechos de los ciudadanos sobre la situación y la organización del notariado en los Estados miembros de la Comunidad Europea, publicado en la sesión del parlamento europeo del 9 de diciembre del año 1993, consolida los principios de la Unión internacional, y en el punto veinticinco, establece: "El documento notarial tiene carácter de documento público y autentico, goza de eficacia especial como medio de prueba, tiene fuerza ejecutiva, y el original es siempre conservado por el notario. Este documento debe poder surtir todos sus efectos en todos los estados miembros". Fuente: Juan Francisco DELGADO DE MIGUEL, Código Notarial de la Unión Europea, $\mathrm{t}^{\circ}$ I, ob. cit., p. 32. 
LOS EFECTOS DE LA PUBLICIDAD EN EL DOCUMENTO NOTARIAL

doctrina realiza desde las diferentes disciplinas que lo ubican -e inclusive sin ahondar en cuestiones terminológicas con el instrumento o el documento público-, como elemento regular del tratamiento teórico y práctico. El análisis permitirá obtener, además de la precisión en la cuestión conceptual, la descripción de los elementos que pueden o no pueden ser considerados como indispensables, y de ahí que el corolario del análisis podrá dejar bosquejada tanto la estructura como los componentes que permiten que la publicidad cartular extrínseca e intrínseca que del documento se desprenda pueda proyectar los valores y la fuerza y potencia respectivamente, que de él emana. 
SEBASTIÁN JUSTO COSOLA

$\cdot 284$. 


\section{Capítulo 8}

\section{EI documento y las disciplinas que resultan afines a su desarrollo.}

La cuestión etimológica se refiere al estudio del origen de la palabra, a la averiguación de la razón de su existencia, de su significado y de su forma ${ }^{1099}$. La cuestión terminológica, relacionada con el empleo de la terminología, se dirige hacia la comprensión del conjunto de términos y vocablos propios utilizados en determinadas profesiones, ciencias y materias ${ }^{1100}$. La mención de la lexicografía implica un reconocimiento de una actividad técnica de composición de léxicos o diccionarios, estudiosa de los primeros principios y fundamentos teóricos ${ }^{1101}$. Lo conceptual, relacionado al concepto, es una idea concebida, una forma de entendimiento, una representación mental asociada a un determinado significado lingüístico, y también es un juicio y una opinión ${ }^{1102}$; formar un concepto es una actividad de determinación mental luego de que fueran examinadas las circunstancias ${ }^{1103}$.

Puede reconocerse entonces que, desde el desarrollo antes expuesto de la teoría general del derecho notarial, las tres cuestiones iniciales se encuentran corroboradas y acreditadas: el origen, la utilización en el ámbito específico y su fundamentación teórica. De lo que puede deducirse que las diferencias entre las voces instrumento $y$ documento son las que posicionan, elementalmente, los fundamentos históricos, probatorios o de docencia del uno sobre el otro. Cuestiones académicas de relevancia que deben aun seguir desprendiendo precisiones para poder generar, de una buena vez, un concepto realmente descriptivo del elemento esencial de justificación de la labor notarial. Para poder llegar a proyectar los alcances de la publicidad

1099 DRAE: http://dle.rae.es/?id=H48BwrZ (Último Acceso: 23/08/2017).

${ }^{1100}$ DRAE: http://dle.rae.es/?id=ZZ3RfMj (Último Acceso: 23/08/2017).

${ }^{1101}$ DRAE: http://dle.rae.es/?id=ND4v8oL (Ultimo Acceso: 23/08/2017).

${ }^{1102}$ DRAE: http://dle.rae.es/?id=A7Kk6Zz (Ultimo Acceso: 23/08/2017).

${ }^{1103}$ Ídem. 


\section{SEBASTIÁN JUSTO COSOLA}

cartular es preciso definir el elemento central objeto de la tutela, y por ello el concepto debe nutrirse de los elementos contenidos tanto en el documento como en el instrumento, que además destacan particulares visiones -según lo advertido por Cristina Armella ${ }^{1104}$,, de acuerdo a cual es la disciplina jurídica que los contiene y que procede a describirlos. En la búsqueda de la cuestión conceptual, las líneas que continúan ayudaran a aportar mayor claridad en la búsqueda de la adecuada designación del elemento en estudio.

\subsection{Proyección del documento en el derecho civil.}

El tratamiento parte de la distinción entre documento (enseñar) e instrumento (algo destinado a instruirnos e informarnos del pasado) ${ }^{1105}$. De aquí que se afirmen tres tesis doctrinarias:

a) Una amplia, que advierte que existe el instrumento cuando interviene un funcionario público;

b) Otra restringida, que sostiene que solo hay instrumento público cuando la ley -tanto material como formalmente- confiere una facultad especial para su autorización, y finalmente,

c) La tesis intermedia, que indica que el documento público abarca tanto al instrumento como a las meras actuaciones administrativas $^{1106}$.

Sobre lo antedicho, consideremos que la teoría del documento y/o del instrumento encuentra tratamiento académico especialmente, en la parte general del derecho civil $^{1107}$. Desde allí se destacan inclusive algunos interesantes aportes, como los que diferencian a los documentos (género

${ }^{1104}$ Cristina Noemí ARMELLA, De los instrumentos públicos, Alberto BUERES (Dir.) y Elena I. HIGHTON (Coord.) ob. cit., p. 2.

${ }^{1105}$ Cristina N. ARMELLA, De los instrumentos públicos, ob. cit., p. 3.

${ }^{1106}$ Ibídem, p. 4.

1107 Julio C. RIVERA, Instituciones de Derecho Civil. Parte General, to II, ob. cit., p. 433; Jorge J. LLAMBÍAS, Tratado de Derecho Civil. Parte General, t ${ }^{\circ}$ II, ob. cit., p. 430. 
+ cosa mueble + carácter representativo) e instrumentos (que únicamente escritos conforman la especie) con los monumentos (inmuebles) $)^{1108}$.

Pero también algunos autores hacen referencia a la misma en el transcurso del desarrollo de la teoría general del contrato ${ }^{1109}$, y otros dentro de ella -en consonancia con el tratamiento sustancial ofrecido por el derecho de procedimientos- también en materia de prueba $^{1110}$. Todo esto sin dejar de advertir que desde los derechos reales se advierten referencias notables a los documentos que contienen hechos y actos inscribibles. Esta rama del derecho civil se empeña por describir de manera específica las cualidades y requisitos que deben reunir los títulos calificables para la inscripción en los registros respectivos ${ }^{1111}$. Así, resulta de utilidad, por ejemplo, el tratamiento de la voz documento y al uso frecuente de la expresión título ${ }^{1112}$.

También desde el derecho de familia, la consideración del tema cobra relevancia si se lo presenta desde un análisis formal. Al hablar de titulo de

${ }^{1108}$ Cfr. Luis F. P. LEIVA FERNANDEZ, Hacia una nueva concepción de la forma a través del Código Civil, en Ensayos de Derecho Civil y Técnica Legislativa, La Ley, Buenos Aires, 2.007, p. 72.

${ }^{1109}$ Cfr. Francesco MESSINEO, Doctrina General del Contrato, T ${ }^{\circ}$ I, Ejea, Buenos Aires, 1.986, p. 39 y ss.

1110 Cfr. Georges RIPERT y Jean BOULANGER, Tratado de Derecho Civil, Las Obligaciones, $\mathrm{T}^{\circ} \mathrm{IV}$, La Ley, Buenos Aires, 1.964, p. 233 y ss;

${ }^{1111}$ Cfr. Luis A. PEÑA GUZMÁN, Derecho Civil-Derechos Reales, t ${ }^{\circ}$ I, ob. cit., p. 160; Héctor LAFAILLE y Jorge H. ALTERINI, Derecho Civil-Tratado de los derechos reales, $\mathrm{t}^{\circ}$ V, ob. cit., p. 233; Marina MARIANI DE VIDAL, Curso de derechos reales, $\mathrm{t}^{\circ}$ 3, ob. cit., $\mathrm{p}$. 394; Ricardo J. PAPAÑO, Claudio M. KIPER, Gregorio A. DILLON y Jorge R. CAUSSE, Derecho Civil- Derechos Reales, to 2 , ob. cit., p. 570; Guillermo A. BORDA, Manual de Derecho Civil-Derechos Reales, ob. cit., p. 673. En el derecho comparado: Carlos LASARTE, Derechos Reales y Derecho Hipotecario, ob. cit., p. 255; Felipe DE LA MATA PIZAÑA y Roberto GARZÓN JIMÉNEZ, Bienes y derechos reales, ob. cit., págs. 455 y ss.

1112 Cfr. Ricardo J. SAUCEDO, Publicidad Registral, en Lilian N. GURFINKEL de WENDY, Derechos Reales, t II, Abeledo Perrot, Buenos Aires, 2.010, págs. 1624-1625. El autor advierte que el Registro Inmobiliario inscribe títulos y no derechos, y que la ley registral se refiere genéricamente a los documentos inscribibles. A la vez, enseña que la vos título presenta dos acepciones: una de ellas, vinculada al negocio jurídico real que opera como causa eficiente para la transmisión, adquisición, modificación y extinción de los derechos subjetivos, y la otra relacionada con la forma que debe revestir el acto que opera como causa fuente en las mutaciones reales (instrumento publico notarial judicial, administrativo, incluso el documento privado con cierta vocación registral). En una adecuada interpretación de los artículos $2^{\circ}$ y $3^{\circ}$ de la Ley Nacional Registral 17801/68, expone cuando la ley se refiere a documentos lo hace en sentido amplio, incluyendo la noción de título implicando por igual la cuestión interna y la externa o de forma. 


\section{SEBASTIÁN JUSTO COSOLA}

estado en sentido formal, hacemos expresa alusión al instrumento público o conjunto de ellos de los cuales surge el estado de familia de una persona ${ }^{1113}$. El tratamiento del derecho sucesorio permite hacer alusión a los documentos e instrumentos en relación a las características que deben resguardar ciertas instituciones formales, como por ejemplo el testamento ${ }^{1114}$, para que en el momento oportuno, pueda a éste otorgársele validez y vigencia formal (cumplidas las solemnidades sustanciales absolutas ${ }^{1115}$ ). De hecho es en este tema en el cual autores como Eduardo Zannoni presentan análisis singulares del documento y del instrumento, que hacen referencia puntual a los supuestos en donde se sustraigan, se pierdan, se destruyan o se alteren el/los instrumento/s que contiene/n la última voluntad del testador ${ }^{1116}$. Finalmente, digamos que también hay alusiones indirectas a los documentos en obras de derecho de las obligaciones, en donde cierta doctrina extranjera consolidada hace referencia a ellos en el análisis de la forma de los actos y contratos ${ }^{1117}$. Es quizás por esta magnitud y esta dispersión de tratamiento que algunos autores advierten que es preciso que se establezca el derecho documental como disciplina autónoma del derecho, con objeto y método propio,

${ }_{1113}$ Cfr. Eduardo A. ZANNONI, Derecho Civil-Derecho de Familia, T 1 , Astrea, Buenos Aires, 2.006, p 87.

1114 Cfr. Eduardo A. ZANNONI, Derecho Civil-Derecho de las Sucesiones, T ${ }^{\circ} 2$, Astrea, Buenos Aires, 2.001, p. 297.

1115 Ibídem.

${ }^{1116}$ Ibídem, p. 298. Afirma ZANNONI: "Esta identificación entre la expresión formal o solemne de la última voluntad y el instrumento que la contiene no existe, aunque habitualmente pueda parecer que existe. Es cierto que cotidianamente parece obvio que el testamento es el instrumento mismo, por cuanto las formas o solemnidades instrumentales, entre ellas la escritura, muestras su corporalidad. Pero pueden presentarse verdaderos casos limite que ponen en duro trance a esta identificación. En efecto, si el instrumento que contiene la última voluntad del testador expresada conforme a todas las solemnidades prescriptas por la ley, se pierde, se sustrae, se destruye o acaso se altera ¿desaparece con el instrumento el testamento mismo?. Esta es la pregunta crítica. Si respondemos afirmativamente es porque reputamos que el instrumento es constitutivo del acto mismo, de suerte que perdido el instrumento se extingue o queda aniquilado éste. Creemos que no es así. Reputamos que cabe aqui la distinción clásica entre el "documento" y lo "documentado", o si se prefiere, entre el "instrumento" y lo "instrumentado". Lo que habitualmente, y por comodidad de lenguaje se denomina "el testamento" es, en realidad, el instrumento o documento que contiene uno o más declaraciones de última voluntad de su autor. Pero son ellas -las declaraciones- la esencia del testamento como tal. El trozo de papel es el continente, el documento".

${ }_{117}$ Cfr. Ernesto GUTIERREZ Y GONZÁLEZ, Derecho de las obligaciones, Porrúa, México, 2.014 , p. 284 y ss. 
destinada a analizar y comparar los documentos y los instrumentos a la luz de la normativa, la doctrina y la jurisprudencia ${ }^{1118}$. No participo de ese criterio.

En fin, más allá de las mencionadas interpretaciones, precisemos que la doctrina civilista es prácticamente pacífica en reconocer que son instrumentos o documentos públicos los otorgados con las formalidades que la ley establece, con la presencia de un oficial público que tiene la facultad de autorizar o autenticar el documento, otorgándoles plena $\mathrm{e}^{1119}$.

\subsection{Proyección del documento en el derecho de procedimientos.}

$\mathrm{Al}$ derecho procesal le incumbe el documento esencialmente como medio de prueba, y de ahí que desde este punto de vista pueda distinguirse en el mismo tanto al autor (a quien jurídicamente el documento le es atribuido) como al destinatario (el juez, cuando se presenta como prueba en un proceso, y el sujeto pasivo, quien extraprocesalmente resulta obligado por él) ${ }^{1120}$. Es común entonces que para los procesalistas, la palabra instrumento y documento conlleve el adjetivo de hábil, precisamente porque es la que le otorga la autosuficiencia de ser apto en la vía ejecutiva ${ }^{1121}$.

Dentro del proceso, la prueba documental se ofrece y produce a los efectos de formar la convicción del tribunal acerca de la veracidad del acto que

\footnotetext{
${ }^{1118}$ Pablo A.CARRICA, ob. cit., p. IX.

${ }^{1119}$ Sin embargo existen excepciones a estos generalizados criterios. Autores como Guillermo Borda, advierten que afirmar que instrumento público es el otorgado con intervención de un oficial público y con las formalidades que la ley establece es un concepto equivocado, ya que hay varios instrumentos en los que no interviene un oficial público y a los cuales la ley les reconoce expresamente este carácter (se refiere específicamente a los asientos de libros de corredores, a las acciones de compañías autorizadas especialmente y emitidas en conformidad a sus estatutos, y a los billetes, libretas, cedulas emitidas por los bancos autorizados para tales emisiones). El recordado maestro sostenía que en verdad lo que confiere a un instrumento la calidad de público es su autenticidad, que es la que les otorga fuerza ejecutiva, una fecha cierta, entre otras características importantes, cualidad o característica que es captada y analizada muy enérgicamente la doctrina del derecho notarial.

${ }^{1120}$ Hernando DEVIS ECHANDÍA, Compendio de la prueba judicial, t ${ }^{\circ}$ II, ob. cit., p. 174.

${ }^{1121}$ Cfr. Norberto J. NOVELLINO, Ejecuciones. Judicial-Bancaria-Notarial, Astrea, Buenos Aires, 2.011, p. 1.
} 


\section{SEBASTIÁN JUSTO COSOLA}

conforma su contenido ${ }^{1122}$. Así, se explica que la presunción de verdad de los hechos lícitos afirmados en la demanda no descarta que deba surgir con precisión la existencia de documentos acompañados ${ }^{1123}$. Para algunos autores, existe esa doble conceptualización de los documentos que refiere por un lado, a la tesis amplia, entendida como toda representación objetiva del pensamiento humano y que se resuelve mediante la materialización mediantes signos, y por el otro, a la tesis más restringida, que se refiere a los documentos escritos o instrumentos, a la que dan mayor relevancia ${ }^{1124}$. Otros en cambio, siguen la jurisprudencia en sentido amplio que advierte que no solo son documentos lo que llevan signos de escritura, sino también aquellos que presentan como objeto alguna cosa susceptible de representar una manifestación del pensamiento (planos, dibujos, mapas, contraseñas, fotografías, discos, cintas magnetofónicas, películas, video tape, hoy los instrumentos particulares no firmados, etc. $)^{1125}$. Finalmente, están aquellos que además incluyen el análisis de los documentos electrónicos ${ }^{1126}$. Desde aquí es que se presentan las clasificaciones que ubican a los mismos atendiendo a su contenido, a su función y al carácter en que actúan los sujetos que intervienen ${ }^{1127}$.

\subsection{Proyección del documento en el derecho penal.}

El análisis del documento desde el derecho penal se proyecta de manera diferente. Un análisis del documento desde la óptica de lo falso, se esmerará

${ }^{1122}$ Cfr. Carlos E. FENOCHIETTO, Código Procesal Civil y Comercial de la Provincia de Buenos Aires, Astrea, Buenos Aires, 1.999, p. 460.

${ }^{1123}$ Cfr. Enrique M. FALCÓN, Comentario al Código Procesal Civil y Comercial de la Nación y leyes complementarias, $\mathrm{t}^{\circ} \mathrm{I}$, Abeledo Perrot, Buenos Aires, 1.998, p. 667.

${ }^{1124}$ Carlos E. FENOCHIETTO, ob. cit., p. 460.

${ }^{1125}$ Cfr. Augusto M. MORELLO, Guadalberto L. SOSA, Roberto O. BERIZONCE y Alberto TESSONE, Manual de códigos procesales en lo civil y comercial de la Provincia de Buenos Aires y de La Nación, Librería Editora Platense-Abeledo Perrot, Buenos Aires, 1.997, p. 446.

${ }^{1126}$ Cfr. Jorge L. KIELMANOVICH, Código Procesal Civil y Comercial de la Nación. Comentado y Anotado, to II, La Ley, Buenos Aires, 2.013, Art. 333 (VTRP).

${ }^{1127}$ Cfr. Lino Enrique PALACIO, Manual de derecho procesal civil, La Ley, Buenos Aires, 2.014, pto. 213 (VTRP) 
por destacar esencialmente en ellos una función probatoria destinada a cumplir los efectos legales previstos en el tráfico jurídico ${ }^{1128}$. Efectos que podrán ser de los más variados: emergentes de la representación formada por un autor cierto, o documento que destina su nacimiento a la prueba de un hecho en el futuro (prueba predeterminada), o documento que exponga un contenido sin finalidad en el origen pero elaborado con un propósito puramente individual, entre otras ${ }^{1129}$. En este sentido se destaca que documento es un objeto mueble de comunicación de hechos jurídicamente relevantes, formado por el hombre, que incorpora una representación o declaración con significado autónomo, que objetivamente reconoce aptitud para ser empleado como medio de prueba en el tráfico, y que fundamenta la actuación de terceros que en interacción social enfrenten hipotéticamente al contenido del documento, en donde aparece un autor cierto responsable de la vida social ${ }^{1130}$. En relación directa con las referidas descripciones, autores del derecho penal argentino ${ }^{1131}$ enseñan que la definición y alcance del documento en materia penal excede a la propia del derecho civil, por cuanto para analizar la configuración de los delitos propios documentales, debe entenderse por documento todo el que con significación de constancia atinente a una relación jurídica, es observador de las formas requeridas por el orden jurídico como presupuestos para asignar un valor de acreditación del hecho o acto que le da vida, modifica o extingue ${ }^{1132}$. De allí que muchas de las características descriptas por los autores sean coincidentes con la teoría general. De esta forma, los documentos escritos ${ }^{1133}$ (que reconozcan una forma de idioma) presentan:

a) Función de perpetuación ${ }^{1134}$, por cuanto son fijados en soportes destinados a permanecer en el tiempo;

${ }^{1128}$ Manuel CORREDOR PARDO, Falsedad documental: ficción social del autor, ob. cit., p. 299.

${ }^{1129}$ Ibídem.

${ }^{1130}$ Ibídem, p. 309.

${ }^{1131}$ Cfr. Carlos CREUS y Jorge E. BUOMPADRE, Falsificación de documentos en general, Astrea, Buenos Aires, 2.004, p. 14.

${ }^{1132}$ Ibídem, p. 15.

${ }^{1133}$ Ibídem, p. 20.

${ }^{1134}$ Ibídem, p. 17. 


\section{SEBASTIÁN JUSTO COSOLA}

b) Función probatoria ${ }^{1135}$, esencial en el derecho penal, por cuanto tiene que tener capacidad para servir como prueba objetiva de hechos $\mathrm{y}$ relaciones jurídicas;

c) Función de garantía ${ }^{1136}$, supuesto que nace cuando el documento es expresión del pensamiento de alguna persona, por cuanto sin autor no hay documento; así, la función de garantías implica una imputación de responsabilidad a quien es garante de la declaración contenida en el documento.

Para advertir el delito de falsedad documental, son documentos jurídicos aquellos que resultan idóneos o aptos para configurar el sector del tráfico jurídico que está dotado de fiabilidad objetiva por parte del Estado ${ }^{1137}$. El bien jurídico protegido es "la fiabilidad objetiva conferida estatalmente a determinado sector del tráfico jurídico ${ }^{1138 "}$. De esta manera, el derecho penal no aporta un concepto de documento, sino que delimita cuales son los documentos que deben protegerse jurídicamente, estableciendo las condiciones necesarias que deben ocurrir para que pueda entablarse la mencionada tutela ${ }^{1139}$.

Dentro de esta disciplina, se impone recordar con Carnelutti ${ }^{1140}$ que la moderna teoría del documento purifica aun más su comprensión desde la historia y a través de todos los años de estudio de la enigmática figura en referencia ${ }^{1141}$. Así, es documento cualquier cosa idónea para la representación de un hecho, que se identifica con la prueba histórica real $^{1142}$. De ahí que considere la categoría de documentos directos,

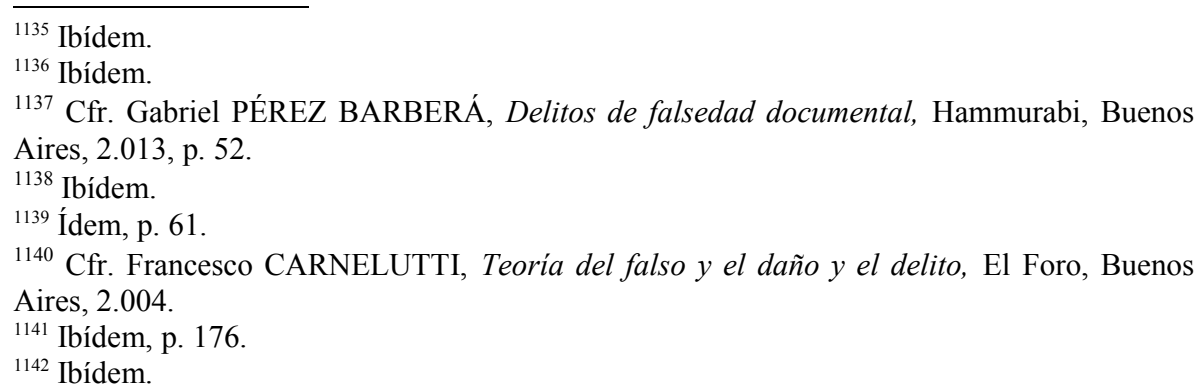


relacionando las cosas producidas por la técnica de representación reciente que transportan de manera directa imágenes o sonido (documento fotográfico, cinematográfico y fonográfico $)^{1143} \mathrm{y}$ los documentos indirectos, que son por un lado, los escritos, y por el otro, los figurativos (pintura, escultura $)^{1144}$. Sobre estas nociones el maestro italiano plantea su teoría del objeto del falso documental, restringiendo todas las apuntadas para referirse únicamente al documento escrito ${ }^{1145}$, al que contribuye agregando una nueva subdivisión a la tradicional doctrinaria de actos públicos y escrituras privadas $^{1146}$ : actos públicos en sentido amplio $^{1147}$, y actos públicos estricto sensu ${ }^{l 148}$. Recordemos que las nuevas teorías representativas en el documento, en la visión del autor, advierten acerca de las modernas técnicas de reproducción mecánica, que prescinden del autor del documento, ya que consideran que debe entenderse por documento toda cosa idónea para representar un hecho. En este sentido, el Código Penal Argentino, al referirse a la significación de los conceptos utilizados en el cuerpo normativo, establece lo siguiente:

a) El término documento comprende toda representación de actos o hechos, con independencia del soporte utilizado para su fijación, almacenamiento, archivo o transmisión;

b) Los términos firma y suscripción comprenden la firma digital, la creación de una firma digital o firmar digitalmente.

c) Los términos instrumento privado y certificado comprenden el documento digital firmado digitalmente.

Alguna doctrina notarial no deja de destacar sin embargo que la fuerza probatoria del documento consiste en su imputabilidad a un autor y en su

\footnotetext{
${ }^{1143}$ Ibídem, p. 177.

${ }^{1144}$ Ibídem, p. 178.

${ }^{1145}$ Ibídem, p. 178.

${ }^{1146}$ Ibídem, p. 179.

${ }^{1147}$ Ibídem, p. 180. Se refiere a los documentos que se forman únicamente como resultado del ejercicio de una actividad pública.

1148 Ibídem. Se refiere a los documentos cuya formación representa el ejercicio de una actividad pública dirigida a la documentación, que tiene como finalidad atribuir a los actos la fe pública (pública función documentaria).
} 


\section{SEBASTIÁN JUSTO COSOLA}

consiguiente responsabilidad, mientras que la pretendida fuerza probatoria de los hechos sin autor depende exclusivamente "de la exacta correspondencia de lo producido y lo reproducido que a su vez, depende de la calidad del aparato $y$ de la habilidad del artista... ${ }^{1149 ",}$. Independientemente de estas apreciaciones, lo importante es destacar la relación notarial actual con el documento desde el punto de vista informático, que permite desde el derecho penal, admitir que el fedatario puede proceder a constatar un hipertexto de una página web y a documentarlo desde lo que aprecia desde los sentidos, sin incurrir en ningún supuesto de falsedad ${ }^{1150}$, y muy a pesar que no se refiera en el cuerpo del instrumento el lugar donde se efectuó la conexión o la calidad del aparato electrónico entre otras cuestiones para nada relevantes ${ }^{1151}$.

Finalmente, dejemos establecido que son prácticamente asimilables a estos desarrollos las obras o tratados de documentología, propias de comisarios o de peritos de la policía, que se refieren a los documentos desde la identidad y desde la escritura, en explicación de la anormalidad que sobre ellos acontece por ser objeto de un acto delictual ${ }^{1152}$.

\subsection{Proyección del documento en el derecho administrativo.}

El principio de juridicidad estatal cobra relevancia a partir del concepto de potestad jurídica. Desde el estudio de nuestras disciplinas más afines, parte de la deuda al desarrollo de la teoría de la potestad es debida al profesor Alberto Molinario, quien desde un ensayo singular, enseñó que la misma venía a tutelar una determinada relación existente entre una persona y otra, o una persona y un objeto, o una persona y toda una comunidad, que quedan

\footnotetext{
${ }^{1149}$ Pablo A. CARRICA, Derecho documental, ob. cit., p. 11. EL autor cita los fundamentos brindados por el eximio notarialista español José GONZALEZ PALOMINO.

${ }^{1150}$ CNCiv., Sala A, 21/05/2008, Biggest Bank S.A c. Corporate Business Solutions S.R.L s/ Daños y Perjuicios, ED 229-14.

${ }^{1151}$ V. Luis R. CARRANZA TORRES, El hipertexto, la página web y su constatación por escribano público, ED 229-17.

${ }^{1152}$ Cfr. Carlos E. BONILLA, Tratado de documentología, La Rocca, Buenos Aires, 2.014, $591 \mathrm{p}$.
} 


\section{LOS EFECTOS DE LA PUBLICIDAD EN EL DOCUMENTO NOTARIAL}

sometidos en forma total o parcial a la acción y a la voluntad de la primera $^{1153}$. Nuestra aprehensión de la potestad jurídica así descripta significaba entender que la misma conformaba un conjunto de poderes, facultades y atribuciones que un sujeto de derecho tiene sobre una cosa o sobre un determinado bien ${ }^{1154}$. Pero es importante tener en cuenta ese concepto desde el derecho administrativo, disciplina que difiere del derecho civil, ya que según los fundamentos esgrimidos oportunamente por Miguel Marienhoff, además de ser disciplinas que tutelan aspectos diferentes de la ciencia jurídica, mientras que en el derecho público administrativo las normas se consolidan a partir de la idea de subordinación, en el derecho privado las normas se caracterizan a partir del esquema de la coordinación ${ }^{1155}$.

Este esquema separatista sin embargo -compartido por la totalidad de la doctrina clásica-, hoy pierde el efecto descripto, por cuanto el derecho público y el derecho privado, si bien con diferencias regulatorias históricas y vigentes, se acercan notablemente a partir de la nueva codificación de derecho privado argentino. En efecto, esta situación se explica a través de la argumentación de los principios jurídicos del derecho privado que pueden aplicarse en el derecho privado, entre otros bemoles interesantes ${ }^{1156}$.

La teoría de la potestad jurídica tuvo un desarrollo notable en la obra del profesor Bartolomé Fiorini. Desde el derecho administrativo, la potestad general del Estado es suprema porque está creada por el poder normativo constituyente que actúa como una manifestación de la voluntad soberana del pueblo $^{1157}$, y que nace para crear relaciones que regulan a toda la comunidad

\footnotetext{
${ }^{1153}$ Cfr. Alberto D. MOLINARIO, La enseñanza de las potestades y relaciones jurídicas, ensayo visible en la página del profesor Dr. Luis F.P. LEIVA FERNÁNDEZ, quien considera en la actualidad esta temática en la primer bolilla del estudio de los contratos civiles y comerciales en las cátedras a su cargo de la Facultad de Derecho de la UBA y de Ciencias $\begin{array}{llllll}\text { Jurídicas } & \text { y } & \text { Sociales la } & \text { del }\end{array}$ http://www.leivafernandez.com.ar/Molinario ens potest.pdf (último acceso: 23/08/2017).

${ }^{1154}$ Alberto D. MOLINARIO, Derecho patrimonial y derecho real, ob. cit., p. 48.

${ }^{1155}$ Cfr. Miguel S. MARIENHOFF, Tratado de Derecho Administrativo, $\mathrm{t}^{\circ} \mathrm{I}$, Abeledo Perrot, Buenos Aires, 1.965, p. 169.

1156 Cfr. Carlos F. BALBÍN, Impacto del Código Civil y Comercial en el derecho administrativo, Astrea y DPI Cuántico, Buenos Aires, 2.016, p. 173.

${ }^{1157}$ Cfr. Bartolomé A. FIORINI, Manual de Derecho Administrativo, t I, La Ley, Buenos Aires, 1.968, p. 223.
} 


\section{SEBASTIÁN JUSTO COSOLA}

en forma incondicionada ${ }^{1158}$. Entendida desde esta óptica, la potestad no es otra cosa que la atribución jurídica que se imputa a un órgano o a un sujeto, y que sirve para crear relaciones que de manera unilateral e imperativa vienen a reglar conductas de terceros ${ }^{1159}$. Las potestades son un reflejo cualificado emergente del poder del Estado, que incluso pueden clasificarse según las necesidades de la administración pública ${ }^{1160}$.

La actuación del Estado con potestad implica un claro reconocimiento a los principios de juridicidad, legalidad administrativa y de discrecionalidad emergentes de esa actuación, con verdadero impacto en la teoría del acto y del hecho administrativo ${ }^{1161}$, que por lo expuesto se presumen legítimos y con fuerza ejecutoria ${ }^{1162}$. El acto administrativo, entendido como declaración, disposición, o decisión de la autoridad estatal en ejercicio de sus propias funciones administrativas y productora de un efecto jurídico, es un acto jurídico que puede ser general o individual, unilateral o bilateral, que puede consistir en una manifestación de la voluntad expresa o implícita, proveniente de una autoridad estatal en ejercicio de funciones propias administrativas $^{1163}$.

La validez de esos actos administrativos ${ }^{1164}$ depende del cumplimiento de los elementos esenciales, dentro de los cuales se encuentra el tratamiento de la

\footnotetext{
${ }^{1158}$ Ibídem.

${ }^{1159}$ Ídem, p. 222.

${ }^{1160}$ Miguel S. MARIENHOFF, Tratado de Derecho Administrativo, to I, ob. cit., p. 574. El autor cita y describe las siguientes: potestad reglamentaria, imperativa o de mando, ejecutiva o de gestión, jurisdiccional y sancionadora.

${ }^{1161}$ Bartolomé A. FIORINI, Manual de Derecho Administrativo, t I, ob. cit., págs. 269 y ss. ${ }^{1162}$ Ídem, págs. 292 y ss.

${ }^{1163}$ Cfr. Miguel S. MARIENHOFF, Tratado de Derecho Administrativo, $\mathrm{t}^{\circ}$ II, Abeledo Perrot, Buenos Aires, 1.965, págs. 263-264.

1164 Ídem, págs. 223-224. Enseña Marienhoff que los actos administrativos conforman sólo una manera de expresión de la voluntad de la Administración Pública -como el acto de administración, el acto de gobierno y el acto institucional, todos de distinta naturaleza-, y comprende también según sean las circunstancias, actos emitidos por los órganos Legislativo y Judicial como por ejemplo, el dictado de sus reglamentos de funcionamiento interno.
} 
forma ${ }^{1165}$, que dentro de esta teoría conforma un elemento de garantía ${ }^{1166}$. La misma es configurativa de la validez del acto, y así, el instrumento que lo exhibe como objeto es tanto el título como la prueba que demuestra los efectos de la relación en él contenida ${ }^{1167}$. La palabra forma, en el derecho administrativo, se asimila a la palabra titulo e instrumento, aunque las diferentes formalidades surjan con posterioridad a la instrumentación formal del acto, porque hacen a la exigibilidad y no a su objeto o contenido ${ }^{1168}$, y de ahí que el acto administrativo pueda instrumentarse de muchas maneras: escrita, verbal, simbólica, implícita y tácita ${ }^{1169}$. En paralelo al mencionado tratamiento, debe decirse también que las descripciones de las formalidades propias del acto administrativo presentan un análisis prácticamente similar al descriptivo de las partes en las que se puede estudiar un documento o un instrumento (Fecha, firma, foliatura, membrete, sellos que designan al servidor público autorizante del acto, expedición de copias o testimonios, entre otras descripciones) $)^{1170}$.

La visión administrativa del acto jurídico notarial cobra relevancia en nuestro medio en los aportes de José Carlos Carminio Castagno, para quien el acto notarial público -consecuencia de la potestad autenticadora- permite demostrar que el escribano o notario es un verdadero funcionario público ${ }^{1171}$, y de José María Orelle, que comprueba que el acto notarial es un acto administrativo, evidenciando que la función notarial es pública, precisamente porque es contenedora de una parte del poder estatal, atribuida a un órgano que actúa como entidad abstracta e impersonal, y que oficia con competencia específica, porque integra una determinada estructura de

\footnotetext{
1165 Ídem, p. 305. La forma en el acto administrativo tiene una doble acepción: a) de manera restringida, se refiere a la manera que debe observarse al emitir el acto; y b) de manera amplia, se comprende no solo la manera de emisión, sino también el conjunto de formalidades que deben respetarse para llegar a emitir el acto. Así se distingue la forma de las formalidades del acto jurídico, que implica reconocer en lo primero, un proceso de formación de la voluntad y lo segundo un proceso de formación del propio acto administrativo (procedimiento).

${ }_{1166}$ Ídem, p. 309.

${ }^{1167}$ Bartolomé A. FIORINI, Manual de Derecho Administrativo, t $^{\circ}$ I, ob. cit., p. 335

1168 Ídem, p. 337.

${ }^{1169}$ Ibídem.

${ }^{1170}$ Miguel S. MARIENHOFF, Tratado de Derecho Administrativo, to II, ob. cit., p. 313.

1171 José Carlos CARMINIO CASTAGNO, Teoría General del Acto Notarial y otros estudios, $\mathrm{t}^{\circ} \mathrm{I}$, ob. cit., p. 38 .
} 


\section{SEBASTIÁN JUSTO COSOLA}

función, competencia y procedimiento, que emana directamente de la ley ${ }^{1172}$. Desde la opinión de los últimos autores mencionados, la estructura de los actos públicos como emanaciones del poder del Estado presentan ciertos tratamientos de indudable importancia como los referidos a la función, al órgano, a la potestad y al agente comprendido en el esplendor de sus atribuciones, y que son los que explican la naturaleza pública del acto notarial ${ }^{1173}$. De esta manera, el acto privado de las partes se integra al acto público notarial, conformándose así una subclase de actos que en lugar de colocarse frente al ciudadano se colocan a su lado ${ }^{1174}$, evitando generar una tensión exceso-garante, y produciendo, en palabras de José María Orelle un fenómeno de homologación, de adjunción de garantías, que confiere efectos "reforzados" que permiten comprobar que los actos públicos y los instrumentos públicos gozan de credibilidad oponible en la sociedad ${ }^{1175}$. Antes del desarrollo de estas teorías, Carlos Gattari presentaba un esquema de tratamiento comparativo entre el instrumento notarial y el documento administrativo digno de elogio, que dedicaba a Eduardo Pondé, a quien reconocía como pionero en el desarrollo del tema ${ }^{1176}$.

\subsection{El documento y el derecho notarial.}

Mientras que el derecho civil se dedica a analizar los postulados teóricos del documento y su función en el derecho privado, el derecho notarial añade a esto tanto el análisis del aspecto formal como el de la función notarial que el autor ejerce al crearlo, lo que implica en cierta manera, una ampliación del análisis que excede el mero marco de análisis elemental ${ }^{1177}$. En opinión de Castán, la instrumentación notarial no solamente ofrece un tinte meramente

\footnotetext{
1172 José María R. ORELLE, Actos e instrumentos notariales, ob. cit., p. 95.

1173 José Carlos CARMINIO CASTAGNO, Teoría General del Acto Notarial y otros estudios, $\mathrm{t}^{\circ} \mathrm{I}$, ob. cit., p. 107 y ss; José M.R. ORELLE, Actos e instrumentos notariales, ob. cit., págs. 174 y ss.

${ }^{1174}$ Cfr. José M. R. ORELLE, Impuesto de sellos y autenticación notarial de firmas, RN 963, 2.009 , p. 913.

${ }^{1175}$ Ibídem, p. 914.

${ }^{1176}$ Cfr. Carlos N. GATTARI, Instrumento notarial y documento administrativo, en Práctica Notarial $\mathrm{n}^{\circ}$ 5, Depalma, Buenos Aires, 1.988, p. 147.
} 
adjetivo o probatorio. Lo que además intenta es la consolidación de un aspecto sustantivo y civil, que persigue como finalidad, además de la demostración del acto o negocio, darle al mismo una "forma que ha de ser base a su eficacia ${ }^{1178}$,. El documento es el resultado de una creación, que en esta disciplina se estudia bajo el nombre de creación notarial del derecho. Entendido de esta manera, el documento es el elemento final de una cadena de ejercicio del derecho que precisamente se encuentra establecida por el ordenamiento jurídico para alcanzar la efectiva y máxima protección y certeza en las declaraciones y modificaciones que impactan en los atributos de la persona. Los deberes éticos notariales aplicados entonces son herramientas esenciales para llegar a conformar al auténtico documento notarial. Sobre el análisis hecho desde el derecho civil, en razón de todas sus divisiones y bajo todos los postulados que hemos ya analizado, el derecho notarial agrega el tratamiento exhaustivo de:

a) La función de los deberes éticos notariales aplicados (información, asesoramiento, consejo; imparcialidad, independencia y deber integrado de legalidad);

b) El concepto y el alcance de la fe pública;

c) El significado y la proyección de la autenticidad formal y la legitimación sustancial;

d) Una proyección de los derechos es estado biológico (estado de normalidad) dentro de las relaciones privadas sin conflicto;

e) Un análisis de la justicia sustantiva y de la seguridad jurídica en su faz preventiva.

\footnotetext{
${ }^{1177}$ Expresa PELOSI: "Se puede hablar de distintas nociones del documento, según se trate del derecho civil, del derecho procesal, del derecho penal, etcétera. El derecho penal estudia el documento ya sea en su noción amplia o restringida como objeto material de la falsedad documental o documentaria. Para el derecho civil interesa el aspecto sustantivo o derecho material del documento, en tanto que el aspecto formal es el punto de vista del derecho notarial. A su vez el derecho procesal considera al documento como medio de prueba". Carlos A. PELOSI, El documento notarial, ob. cit., p. 33.

1178 José CASTÁN TOBEÑAS, Función notarial..., ob. cit., p. 55.
} 
Las declaraciones de las XIII Jornadas Nacionales de Derecho Civil, celebradas en la Universidad Notarial Argentina, se refieren a estos supuestos en sus considerandos, y especialmente al de la fe pública ${ }^{1179}$.

\subsection{Conclusión de la cuestión conceptual: El documento notarial} auténtico.

He presentado hasta aquí las exposiciones que del documento realizan algunas de las diferentes disciplinas del derecho, profundizando los elementos que se creen destacables desde cada óptica. La finalidad expositiva del presente capitulo se relaciona con la necesidad de alcanzar cierta claridad conceptual a la hora de designar el objeto sobre el cual se proyectará la publicidad cartular rectora. De esta manera se han expuesto las teorías específicas para que se puedan advertir, dentro de todo lo referido, los principios y elementos comunes al documento, que le sean intrínsecos y que sirvan para presentar definitivamente un tratamiento elemental. De esta manera, tal como lo refiriera Rodríguez Adrados "es más significativo determinar lo que el documento es... que aquello para lo que el documento

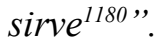

¿Por qué es relevante destacar estos elementos y principios comunes en el documento? Porque de su adecuada configuración depende en notoria medida el grado de validez y eficacia que surjan de los mismos. La conformación estructural de los documentos consolida los derechos en ellos asumidos y distribuidos y además, permite tener una lectura clara y ordenada de su contenido, cuestión que permite obtener un sentido real de valoración de la publicidad cartular.

También he podido exponer un panorama de las cuestiones terminológicas, etimológicas y lexicográficas del documento notarial, que abarca todas sus

${ }^{1179}$ Conf. Libro Congresos y Jornadas Nacionales de Derecho Civil, La Ley, Buenos Aires, 2.005, p. 107-109.

${ }^{1180}$ Antonio RODRIGUEZ ADRADOS, El documento en el código civil, ob. cit., p. 28. 
denominaciones, en donde no dejo de advertir que la doctrina clásica en general no ha tenido en cuenta ciertas cuestiones especiales de tratamiento, que desde mi visión colaborarían con la obtención de una necesaria unidad de criterio al momento de denominar al producto hecho y realizado.

Quizás este análisis no haya sido relevante en el transcurso de todos estos años, porque en definitiva lo que es relevante de la creación notarial en el documento o instrumento es el resultado que ofrece: una prácticamente indudable fuerza probatoria y una inigualable fuerza ejecutiva. Sobre esos postulados ha trabajado denodadamente la citada doctrina notarial mundial, y el fruto de ese esfuerzo nos enorgullece desde la jurisprudencia dominante que siempre se orienta a dar a los documentos notariales la máxima certeza y previsibilidad.

Tampoco debe dejar de tenerse en cuenta que el análisis que se ha presentado se realizó en base a la genérica denominación de las voces documentos e instrumentos. Me he abstenido de considerar las denominaciones más específicas como las de escritura pública o protocolo, salvo en alguna referencia de rigor, por cuanto no todos los actos que documenta el notario se formalizan en esa especie de instrumentos o documentos, típica notarial, pero ni única ni excluyente ${ }^{1181}$. Es que también el notario crea documentos que no están destinados a consolidarse en el protocolo, y les adhiere a ellos la autenticidad formal que requieren para poder cumplir con determinados fines específicos, como las certificaciones de fechas, de firmas, de fotocopias y de contenido, siempre en procura de resguardar la seguridad jurídica formal.

Por ello en este tema el concepto de autenticidad, como cualidad de lo auténtico $^{1182}$, es absoluto y determinante. Sobre la voz auténtico ${ }^{1183}$, se reconocen ciertos adjetivos que nos ayudan a comprender la fuerza que esta

\footnotetext{
1181 Así se explica que una vez cumplidos los deberes éticos notariales aplicados de información, asesoramiento y consejo notarial, la parte documental siga a la suerte de aquél, en respeto de la voluntad de los requirentes, pudiendo conformarse bajo la forma pública o privada reconocida en las legislaciones positivas de manera indistinta. Es que no puede pasarse por alto que aunque no sea un opus principal y específico notarial, existen un sinnúmero de documentos privados que son también creados y certificados por el notario, y no por ello debe asegurarse que en la creación de las escrituras públicas se encuentra únicamente justificada la propia función notarial.

$1182 \mathrm{http}: / /$ dle.rae.es/?id=4Qiute4 (Último Acceso: 23/08/2017).

$1183 \mathrm{http}: / /$ dle.rae.es/?id=4QjqWMu (Último Acceso: 23/08/2017.
} 


\section{SEBASTIÁN JUSTO COSOLA}

palabra denota: a) acreditado de cierto y positivo por los caracteres, requisitos o circunstancias que en ello concurren; b) Honrado, fiel a sus orígenes y convicciones; c) Certificación con que se testifica la identidad y verdad de algo; d) Copia autorizada de alguna orden o carta y e) Algo que se muestra tal cual es.

Estas descripciones nos acercan a la valoración definitiva del documento notarial, y no precisamente referida a los valores intrínsecos del documento -que son el eje central de su importancia-, sino a la propia valoración extrínseca: valoración que la sociedad en su conjunto, de manera recíproca con la tradición, devuelve al notariado consolidándolo como una institución de confianza y certeza. Y es desde aquí que se comprende, como lo ha venido haciendo la doctrina especializada, en que lo socialmente relevante a tener en cuenta es la seguridad en el resultado final que determina una adecuada confección del documento.

Por lo demás, pienso que no resulta jurídicamente relevante en estos tiempos, volver a traer doctrinas que se enfrenten desde estudios históricos o comparativos. Si en cambio es importante prestar atención a los efectos principales que se obtienen una vez que el documento revestido de las formalidades notariales nace a la vida jurídica para perpetuar su contenido. Por ello es que pretendo desde la cuestión conceptual que en lo sucesivo, se considere al documento notarial auténtico, haciendo alusión al resultado de la máxima creación notarial del derecho, con fuerza probatoria y fuerza ejecutiva, que reviste de seguridad jurídica preventiva a todo negocio, hecho o acto jurídico destinado a cumplir un cometido buscado, esperado, alcanzado por las partes que tengan interés en su efectiva valoración. Por cuanto el documento notarial auténtico viene a exteriorizar la representación de los derechos privados en la normalidad o sin contienda ${ }^{1184}$, la función autenticadora y legitimadora notarial recae sobre actos, negocios y hechos jurídicos ya sean humanos o naturales ${ }^{1185}$. En definitiva, por documento auténtico se entiende a aquel que se encuentra autorizado o legalizado ${ }^{186}$. Al anteponer el adjetivo de auténtico a la reconocida alocución documento

${ }^{1184}$ José CASTÁN TOBEÑAS, Función notarial y elaboración notarial del derecho, ob. cit., p. 42.

${ }_{1185}$ Ibídem, p. 43.

1186 http://dle.rae.es/?id=E4EdgX1 (Último acceso: 23/08/2017). 
LOS EFECTOS DE LA PUBLICIDAD EN EL DOCUMENTO NOTARIAL

notarial, se diferenciará indudablemente a aquellos documentos que aun creados en sede notarial, no gocen de la autenticidad formal y material que impone el principio de seguridad jurídica preventiva, aunque si estén bajo el manto de la tutela notarial.

\subsubsection{Innecesaridad de otras perspectivas clasificatorias.}

Desde este lugar si será entonces tarea relativamente sencilla presentar clasificaciones académicas que cumplan con su finalidad didáctica ${ }^{1187}$. Así, por ejemplo, podría decir que dentro de una categoría, la que contiene a los documentos notariales auténticos, se encuentran las escrituras y las actas, que brindan protección integral a todo el contenido que resulta de la elaboración notarial del derecho, mientras que en la que se refiere a los documentos generales con tutela notarial, se encuentran aquellos documentos que contienen un trabajo notarial destinado a investir con seguridad jurídica las bondades del mismo, como la autenticidad sobre las firmas o la que se imprime sobre las fotocopias argumentando que son fieles al original que se tiene a la vista. Es cierto que sobre estas actividades se demuestra la existencia de dos actos jurídicos diferentes; por un lado el del requirente que decide solicitar al notario la actividad de autenticación, y por el otro el del notario que acepta y la realiza. Dos actos jurídicos diferentes que reconocen una causa común, lo que hace en definitiva una combinación de $\operatorname{actos}^{1188}$. Pero luego de realizado, el mismo goza de tutela notarial, ya

${ }^{1187}$ Las clasificaciones académicas pueden ser tan notables y evidentes, como superfluas y disparatadas. No estoy de acuerdo en presentar una extensa clasificación como lo viene haciendo la doctrina en general del documento notarial cuando lo que pretendo transmitir es un valor de la institución en estudio que sirve para generar en ella confianza y certeza. No todas las instituciones están sujetas a interminables clasificaciones y lo que es más relevante: no todas las instituciones necesitan presentar clasificaciones para demostrar determinada importancia. Tal es el caso del documento notarial. Así, no creo adecuado en lo más mínimo admitir que una presentación de una clasificación del documento autentico notarial de acuerdo a su contenido, su función, o su método de elaboración, pueda llegar a enaltecer técnicamente a esta tesis, ya que en la actualidad esas clasificaciones únicamente son útiles a los fines comparatistas con postulados históricos tanto del derecho nacional como del proyectado que en este caso, pierden total vigencia e interés.

${ }^{1188}$ Cfr. José María R. ORELLE, La autenticación de firmas en la República Argentina, Academia Nacional del Notariado, Buenos Aires, 2.007, p. 40. El autor se refiere a la 


\section{SEBASTIÁN JUSTO COSOLA}

que no es posible proceder a la autenticación sobre algún documento que sea contrario a la ley o a los principios generales del derecho. La certificación de firmas o la certificación de fotocopias son un claro ejemplo de la necesidad de confianza en la extrínseca del documento. El valor de la autenticidad externa se visualiza con los sellos y la firma notarial. Una publicidad cartular que supone que el contenido del documento es adecuado al ordenamiento y a los principios, porque existe una valoración sobre la actuación fedante que ordena creer al hombre o a la mujer portante del documento únicamente tanto porque la ley lo impone como porque la costumbre así lo indica. En los ejemplos referenciados se evidencia, de manera sustancial, el valor de la publicidad cartular exterior, la que inclusive se imprime con fuerza en documentos privados o particulares que no fueron originariamente creados por el notario, que únicamente procedió a solicitud de parte, a registrar sobre el mismo una actividad de autenticación. La publicidad cartular exterior, de esta manera, se conforma con elementos esenciales que permiten apreciar su valor.

\subsubsection{Los elementos formales externos del documento notarial}

\section{auténtico.}

El documento auténtico notarial presenta dos elementos formales externos que acompañan a nivel cartular, la conformación del valor seguridad jurídica: ellos son la firma y el sello notarial. La firma como impresión de la autorización, similar a la que el notario registra en el colegio profesional y en las instituciones públicas con las que compartirá el trabajo cotidiano. Y el sello, que viene a representar un signo material a través del cual se exterioriza una declaración intelectiva o volitiva ${ }^{1189}$, con la finalidad de dotar de solemnidad y autenticidad, esencial o complementariamente, a un

autenticación de las firmas, que por analogía es trasladable a la actividad de certificación de fotocopias, no sin antes dejar de advertir como bien se aclara en el texto, que el acto notarial de autenticación es complejo porque todo su desarrollo exhibe diferentes etapas.

${ }^{1189}$ Cfr. Manuel ANDRINO HERNÁNDEZ, El sello notarial, AIDN 2, CGN, Madrid, 2.003, p. 22. 
documento ${ }^{1190}$, de una manera figurativa utilizable y perceptible incluso por iletrados, por cuanto su vía de percepción es básicamente sensitiva ${ }^{1191}$. No debe dejar de recordarse que el sello ha sido y sigue siendo uno de los elementos de la solemnidad del documento notarial ${ }^{1192}$. Su estampa conforma un acto elemental que potencia y tanto la solemnidad como la autenticidad del instrumento, a la vez que lo reviste de mayor autoridad y fiabilidad ${ }^{1193}$. Esta afirmación puede felizmente corroborarse por la última jurisprudencia ${ }^{1194}$, que admite un tema tan trascendente como la fuerza ejecutiva del documento notarial a partir de una copia certificada de una escritura pública ${ }^{1195}$. Es por estas nuevas situaciones que a menudo ocurren en la práctica cada vez más frecuente del derecho documental es que creo necesario y oportuno comenzar por prescindir de clasificaciones innecesarias y obsoletas -propias de tiempos en donde la justificación del derecho notarial únicamente se priorizaba desde la técnica documental- para conformar una verdadera teoría del documento auténtico notarial.

Si hay firma y sello notarial, significa que ese documento emerge del poder notarial ${ }^{1196}$. Son elementos que en definitiva, acreditan la autoridad de quien está investido para actuar sobre el documento ${ }^{1197}$. Y es una obligación inherente a la función notarial la de crear o autenticar documentos que revistan las propias características de legalidad. No puede un notario autenticar hechos o actos ilícitos. Por lo demás, son estos elementos los que ayudan a comprender y a dar por ciertos los primeros principios que emergen desde la consideración formal de la publicidad instrumental; en

\footnotetext{
${ }^{1190}$ Ibídem, p. 23.

${ }^{1191}$ Ibídem, p. 24.

1192 Ídem, p. 39.

${ }_{1193}$ Ídem, p. 140.

${ }^{1194}$ CNCiv., Sala F, 21/10/1996, Vijnovich, Boris c. Benmaman, León y otros s/ ejecución hipotecaria, ED 177-363.

${ }^{1195}$ Cfr. Jorge H. PALMIERI, La fuerza ejecutiva de la copia certificada de una escritura pública. Comentario Breve, ED 177-363.

${ }^{1196}$ En otros países como en España, además de la firma y el sello existe lo que se conoce como signo, que es una señal manuscrita que el notario extiende antes de realizar la firma y que otorga un determinado carácter "especial" a la autorización que la distingue de la que realizan otros funcionarios. Cfr. Pedro ÁVILA ÁlVAREZ, Estudios de Derecho Notarial, Ediciones Nauta S.A, Barcelona, 1.962, p. 259.

${ }^{1197}$ Cfr. Roque J. PICHETTO, Comentarios históricos y jurídicos del notariado, Talleres Gráficos D’Accurzio, Mendoza, 1.947, págs. 181 a 185.
} 
efecto, claramente podrá advertirse desde la firma y el sello, quienes han conocido el documento, quienes han tenido contacto con él y quienes debieron conocerlo por imperio legal. Siendo así, determinar si la autenticidad es total o parcial, absoluta o relativa, si lo es sobre la fecha, las firmas, o todo el contenido, no requiere más que una remisión a los postulados históricos del derecho civil y del derecho notarial, generalmente considerados taxativamente en las leyes generales o especiales respectivas.

\subsection{La clasificación de la estructura y de los componentes del documento notarial auténtico.}

Desde mi visión, el documento notarial auténtico presenta, como elementos formales relacionados a la estructura:

a) La descripción y ubicación temporal de la corporalidad;

b) El análisis decisorio del autor: fe pública objetiva (relativa con la certeza);

c) La proyección general del contenido (reglas + normas + principios).

La referida estructura se nutre y conforma de manera sustancial con los componentes que hacen a su esencia y determinan la finalidad y los efectos del documento. Ellos son:

a) En la corporalidad, los componentes materiales (forma + prueba);

b) En el autor, el componente personal [función + competencias + virtudes notariales + fe pública subjetiva (relativa a la verdad)];

c) En el contenido, el componente relacional libre (voluntad tutelada) + valores del documento (intrínsecos y extrínsecos).

La conformación de los componentes dentro de la estructura y especialmente desde el contenido, permite corroborar los valores emergentes de la fe 
pública en sus dos vertientes -objetiva, relativa a la certeza, y subjetiva, referida a la verdad-, la justicia y la seguridad, todos determinantes de la paz. Para ello, es fundamental comprender la doble perspectiva que emerge del valor relativo a la fe pública:

a) El primer aspecto, analizado desde la estructura, permite observar al notario desde un ejercicio legal de la función, absolutamente objetivo, tendiente a consolidar la certeza del acto que redacta o percibe a través de la dación de fe pública con que lo ha investido el Estado;

b) El segundo aspecto, analizado como un componente, se relaciona con el aspecto subjetivo de la fe pública, que dirige a comprender que lo que se realiza frente a un notario goza de verdad, erigiendo a la figura notarial dentro de la concepción de jurista, autor y magistrado de la paz y del cavere en la elaboración del documento, debiendo destacarse esencialmente la naturaleza de la función, el régimen de competencias y las virtudes notariales que lo comprometen con ese aspecto esencial de tutela de la verdad ${ }^{1198}$.

Dada o supuesta la certeza a través de la norma jurídica, queda dilucidar si esa certeza es definitivamente la verdadera.

En el fin, todos los documentos restantes, que cuentan únicamente con la tutela notarial respectiva, podrán alcanzar a la justicia en ellos prevista a través de los valores de seguridad y verdad que imprime el notario al momento de aceptar la actividad de autenticación.

\footnotetext{
${ }^{1198}$ Para analizar los alcances de esta diferenciación pero relacionada con la función notarial y no desde el documento, v. Argentino I. NERI, La función notarial en su doble aspecto: subjetivo y objetivo, en Jorge H. ALTERINI (Dir.)-Ignacio E. ALTERINI (Coord.), Derecho Notarial, Registral e Inmobiliario. Doctrinas Magistrales 1897-2012, t ${ }^{\circ}$ I, La Ley, Buenos Aires, 2.012, p. 223-237.
} 
SEBASTIÁN JUSTO COSOLA

$\cdot 308$. 


\section{Capítulo 9:}

\section{La estructura del documento notarial.}

\subsection{Palabras iniciales.}

Asumida la clasificación propuesta y una vez internalizados los conceptos hasta ahora referidos, corresponde advertir en primer término la estructura elemental del documento notarial para que desde aquí puedan entonces ubicarse ordenadamente los componentes sustanciales que terminan por demostrar la posición del documento frente a las demás publicidades jerarquizadas, situación que se comprueba desde la proyección intrínseca y extrínseca de la publicidad cartular. Pero es preciso referirse a la cuestión de la intangibilidad de la estructura y de los componentes del documento para poder comprender como es que en tiempos de cambios absolutos asumidos por el jurista, aun quedan al resguardo del derecho ciertas instituciones rectoras del derecho histórico que prefiero denominar tradicionales.

\subsection{Los aspectos intangibles del documento notarial: Justificación y} propuesta.

El concepto de intangibilidad es -y debería ser- totalmente ajeno al nuevo derecho, mucho más en estos tiempos en donde las cuestiones inherentes a los derechos de las personas inciden de manera constante en las decisiones y reflexiones jurídicas por más fuertes y seguras que demuestren ser. Doctrinas magistrales fundadas en el espíritu de la ley e inclusive, en el 


\section{SEBASTIÁN JUSTO COSOLA}

orden público $^{1199}$, han dejado de existir o han relativizado sus proyecciones porque las mismas atentaban contra el espíritu del hombre libre, cada vez más atento a posicionar su voluntad por sobre las exigencias dirigidas del derecho formal o decimonónico, esto es, la presencia de un hombre cada vez más preocupado por alcanzar al máximo, su verdadero y único estado de plenitud $^{1200}$. Esta situación se prueba en nuestros días desde la concreción normativa de la distinción entre ley y derecho en el Código Civil y Comercial de La Nación, que desarticula definitivamente cualquier resabio legalista y formalista provenientes de los legados del derecho de la escuela histórica o de la exégesis ${ }^{1201}$, para permitir la entrada y vigencia de un verdadero código fundado en valores y principios ${ }^{1202}$. Esta circunstancia demuestra los cambios significativos en la comprensión jurídica, que merecen la atención del jurista ${ }^{1203}$, en especial aquellas mutaciones que ya venían siendo advertidas desde hace mucho tiempo por la filosofía del derecho ${ }^{1204}$.

Es indudable que el cambio de paradigma en la comprensión y aplicación del ordenamiento se compadece con la realidad y además, es sano para el derecho como disciplina que debe siempre priorizar la protección del

1199 V. Agustín GORDILLO, Orden público como principio no general del derecho argentino, LL 2015-F, 1041. AR/DOC/3877/2015. El autor intenta demostrar que el orden público es una "vieja muletilla del derecho" carente de contenido y significación autónoma. Por mi parte, sigo creyendo que el orden público sigue siendo un principio general, al menos desde el derecho privado, los artículos 12 y 2600 del CCCN así parecen establecerlo. Traigo esta opinión aquí por lo reveladora y trascendente. No obstante existen corrientes de opinión que de de algún modo relativizan -no sin cierta razón- los alcances del orden en materias como el derecho de familia. V. Aída KEMELMAJER de CARLUCCI, La autonomía de la voluntad en el derecho de familia argentino, en Derecho de las familias, de la infancia y de la adolescencia, Portal Infojus, Buenos Aires, 2.015, y Marisa HERRERA, Manual de derecho de las familias (Col. Natalia DE LA TORRE y Silvia E. FERNÁNDEZ), Abeledo Perrot, Buenos Aires, 2.015, p. 20 y ss.

${ }^{1200}$ Cfr. Eduardo L. TINANT, El hombre y su búsqueda, SL año $1 \mathrm{n}^{\circ}$ 5, La Plata, 1.997, p. 2.

${ }^{1201}$ Cfr. Amós A. GRAJALES y Nicolás J. NEGRI, Interpretación y aplicación del Código Civil y Comercial, Astrea, Buenos Aires, 2.016, p. 24.

1202 Cfr. Ricardo L. LORENZETTI, Fundamentos de derecho privado. Código Civil y Comercial de la Nación Argentina, Thomson Reuters-La Ley, Buenos Aires, 2.016, p. 11 y ss. ${ }^{1203}$ Hubiera sido impensado plantear hace no mucho tiempo atrás, por ejemplo, que el orden publico del derecho civil general y específicamente del derecho de familia iba a ceder frente al desarrollo del principio de autonomía en una enorme cantidad de casos.

${ }^{1204}$ Cfr. Carlos I. MASSINI CORREAS, La prudencia jurídica, LexisNexis-Abeledo Perrot, Buenos Aires, 2.006, p. 91 y ss. 


\section{LOS EFECTOS DE LA PUBLICIDAD EN EL DOCUMENTO NOTARIAL}

hombre y de la mujer en la realidad y en la cotidianeidad. Así, tan perjudicial es el derecho absurdo como el injusto, inclusive aun siendo vigente, si desconoce las prioridades de los principios filosóficos, jurídicos y sociológicos en esplendor. De acuerdo a lo afirmado, pocas son las instituciones en la nueva codificación que no han sufrido prácticamente variaciones de sustancia y de forma en épocas de mutaciones interesantes y de rotundos cambios de paradigmas. Una de ellas es la notarial, y esencialmente desde ella, la conformación del documento. Dicho de otro modo, el impacto en la manera de implantar el nuevo derecho dentro del documento notarial no ha variado en demasía. Es cierto que los derechos humanos fundamentales encuentran protección en el documento, como en ninguna otra época conocida desde sus orígenes hasta la fecha ${ }^{1205}$. Pero no es menos comprobable que la conformación estructural del documento y la teoría de las formas sobre él proyectada no ha variado bajo ningún concepto, y en este tema, tanto el Código Civil de Vélez como el Código Civil y Comercial de La Nación son prácticamente idénticos en su redacción, salvo en algún caso puntual y específico y a nivel exclusivamente técnico o formal-formulario.

Debo reconocer que durante algún tiempo relativamente prolongado he estado reflexionando sobre esta situación, relacionando preguntas dudosas con respuestas poco claras, en especial, aquellas que me dirigían hacia una total incomprensión lógica: ¿porque razón la modificación total de un cuerpo de leyes tan significativo para un Estado como el código que regula el derecho privado -hoy mas público que nunca a partir de la incorporación positiva de los principios constitucionales-, con la recepción una herramienta tan valiosa y necesaria para el desenvolvimiento justo del derecho como la teoría de la argumentación jurídica -en reemplazo de la añeja teoría de la interpretación-, no se había preocupado por modificar, tan siquiera formalmente, la estructura de un quehacer histórico funcional? Razones y justificaciones para hacerlo existían en demasía ${ }^{1206}$, sin embargo

${ }^{1205}$ En el ejemplo, la derogación de leyes usuales de práctica notarial como la de bien de familia es una rotunda prueba de lo antedicho.

${ }^{1206}$ Tan sólo imaginar el impacto del documento electrónico y la firma digital; la reproducción inacabable y desmesurada de los documentos públicos del Estado y los más politizados, como las escrituras de la escribanía de Gobierno, que no reúnen los recaudos formales y materiales de las escrituras realizadas con intensa labor notarial, sobre todo en la etapa de trámites pre- 


\section{SEBASTIÁN JUSTO COSOLA}

el legislador optó por incorporar las innovaciones esperadas a través de leyes especiales, pero de ninguna manera en el cuerpo del código ${ }^{1207}$.

Es que el nuevo cuerpo legal acomoda sus instituciones de acuerdo al derecho actual y tengo para mí, que sólo una notable reforma como la que nos asistió en los últimos tiempos puede ofrecer como resultado tres tipos de instituciones, que desde mi visión pueden ser clasificadas de la siguiente manera: a) Las nuevas instituciones; b) Las instituciones antiguas $u$ obsoletas, y c) Las instituciones tradicionales. En alguna de ellas debe de ubicarse y fundamentarse el documento notarial, que como sabemos, recepta una regulación normativa en el moderno cuerpo en los artículos específicos, que no deben porque presentarle al escribano o notario mayores problemas que los que emerjan de su estudio profundo y meditado ${ }^{1208}$. De esta manera:

a) Las nuevas instituciones merecen ser estudiadas y argumentadas en profundidad, para que su utilización comience cuanto antes y ayude al hombre a alcanzar de la mejor manera el fin del derecho que siempre es y será la justicia, independientemente de que ahora se ofrezcan vías de acceso a la misma con algunos excesos que pretenden encontrar asidero en una nueva y confusa visión -o extensión- del concepto de libertad ${ }^{1209}$;

escriturales; la función de la robótica en el derecho (por ejemplo, para multiplicar y duplicar los documentos), en fin, un sinnúmero de casos que podría tranquilamente hacer prever una mutación de sistema de conformación de la estructura del documento tal cual la conocemos y apreciamos.

${ }^{1207}$ Por los tiempos actuales la ley de apoyo al capital emprendedor -LN 27.349/2017introduce la figura novedosa denominada protocolo notarial electrónico. El artículo 59 se refiere expresamente a que "El estatuto de la SAS, sus modificatorios y los poderes y revocaciones que otorguen sus representantes podrán ser otorgados en protocolo notarial electrónico. Aun habiéndose otorgado en soporte papel, su primera copia deberá expedirse en forma digital con firma digital del autorizante. En dichos casos, la inscripción en el Registro Público que corresponda será exclusivamente en forma electrónica". Esta "novedad" podría haberse incorporado al $\mathrm{CCCN}$, sin embargo - y a mi juicio, acertadamente- se optó por no hacerlo.

${ }^{1208}$ Resulta verdaderamente ilustrativa la conferencia de Gabriel VENTURA denominada $L a$ Actividad Notarial en el nuevo Código Civil y Comercial, en https://www.youtube.com/watch?v=memG2MXdDig (Último Acceso: 28/08/2017).

${ }^{1209}$ Debe siempre tenerse en cuenta que no pueden reclamarse los derechos si no se presenta de antemano, la prueba del cumplimiento de los deberes humanos básicos. 
LOS EFECTOS DE LA PUBLICIDAD EN EL DOCUMENTO NOTARIAL

b) Las instituciones antiguas, aquellas obsoletas o en desuso son las que dejarán de existir naturalmente. No obstante, la ausencia del escenario principal no es ni será óbice para restarles la debida importancia. Las mismas servirán entonces para estudios históricos y comparativos, de fundamentación de nuevas naturalezas jurídicas y de contenidos, como parte de evoluciones o involuciones que el derecho ha tenido al plantearlas originariamente desde el derecho positivo; $y$ finalmente,

c) Las instituciones tradicionales, que son aquellas que aún se mantienen en pleno vigor, precisamente porque lo tradicional trae consigo la noción de seguridad en la continuidad y de justicia en lo que se asimila como natural, y porque además sigue las ideas, las normas, las costumbres y los principios sostenidos desde antaño, mereciendo la subsistencia en razón de su conveniencia para el hombre y de su trascendencia para el derecho.

La teoría del documento notarial claramente se relaciona con la noción de tradición. Cierto es que la propia denotación de la palabra nos posiciona relacionándola a la negativa asimilación de lo obsoleto. Pero también es cierto que esa tradición es la que en la actualidad y frente a temas esenciales de la vida de relación -frente a tantos cambios repentinos que justifican su accionar invocando mejorías para la vida de la persona preocupada por atender lo urgente en lugar de lo importante-, es la que aleja al hombre de la noción de lo temporario para posicionarlo dentro de lo que es considerado como perpetuo. La consolidación de los derechos humanos básicos e insustituibles ocurre en el seno del documento a partir de las declaraciones de las partes y de la justificación jurídica notarial que otorga validez y vigencia a los acuerdos o deseos privados. Si lo temporario es lo que se esfuma, la perpetuidad es precisamente lo que no nunca perece. Lo que siempre se encuentra presente, con mayor o menor grado de intensidad, pero siempre vigente, precisamente porque debe tener el valor de soportar los cambios en procura de la protección de los derechos que nacen para vivir en 


\section{SEBASTIÁN JUSTO COSOLA}

el tiempo, salvo que en algún tiempo, la voluntad decida torcer ese destino. La única justificación que existe para explicar porque las modernas tendencias aun aceptan como presente y vigente a algo tradicional y perpetuo como el documento notarial, es tanto por la necesidad como por lo indispensable de su prestación. El documento entonces es tradicional y necesario para la sociedad, tanto como la investidura que ejerce quien lo crea y lo realiza. Tradición, documento, notariado y deberes éticos aplicados, todo llega a unirse en la justificación de su trascendencia.

Las instituciones tradicionales fundadas en innegables necesidades sociales, persisten en el tiempo precisamente porque nacieron para asumir el deber de encontrarse siempre alistadas, en guardia, preparadas, para auxiliar al hombre y la mujer problematizados, y mucho más, cuando la imposición de una nueva institución simplemente fundada en la modernidad, atenta contra cualquier libre ejercicio de la voluntad o contra la violencia de cualquier derecho humano fundamental.

Justificados los alcances de la clasificación propuesta, queda entonces la necesidad de proyectar al documento en el moderno derecho dentro de la noción jurídica de tradición ${ }^{1210}$, respetando dentro de él tanto la estructura como la conformación en su seno de ciertos componentes esenciales.

\subsubsection{Los elementos de la estructura.}

Desde la estructura ${ }^{1211}$, el documento presenta dos cuestiones relevantes, que son el tratamiento de la materia y del contenido. La grafía se incorpora a la

\footnotetext{
${ }^{1210}$ Para obtener una opinión sociológico de la tradición y su relación con la estructuración social de los cuerpos intermedios en contra la tecnocracia, V. Juan B. VALLET DE GOYTISOLO, Ideología, praxis y mito de la tecnocracia, Montecorvo, Madrid, 1.975, p. 305 y ss. Existe también una edición reducida, publicada con el mismo nombre, que puede consultarse, perteneciente a la editorial Escelicer de Madrid, publicación del año 1.971. Para una comprensión acabada del término tradición en Juan Vallet, ver la obra Sociedad de Masas $y$ derecho, Taurus, Madrid, 1.968, págs. 237 y ss. Es que en definitiva, la tradición encuentra fundamentos en la vida de los hombres para poder hacer frente a los cambios en resguardo de los conceptos elementales con los que las sociedades avanzan hacia el desarrollo.

${ }^{1211}$ Antonio RODRIGUEZ ADRADOS, Documento, ob. cit., p. 11.
} 
LOS EFECTOS DE LA PUBLICIDAD EN EL DOCUMENTO NOTARIAL

materia, formando parte integrante de la corporalidad documental desde el aspecto estático. En un aspecto dinámico, la expresión del pensamiento del hombre jurídicamente relevante (autor) integra el contenido ${ }^{1212}$. Por ello, los elementos que conforman la estructura del documento notarial son:

a) Corporalidad: Soporte [Efectos publicitarios externos (autenticidad extrínseca)+ grafía en sentido estático];

b) Autor: Notario (argumentos de la verdad objetiva);

c) Contenido: Creación notarial del derecho [Efectos publicitarios internos (autenticidad intrínseca) + grafía en sentido dinámico].

\subsubsection{Primer elemento: La corporalidad.}

La corporalidad se encuentra compuesta por dos elementos. La cosa en sí misma (que en la actualidad es el papel $^{1213}$ ) y la grafia, palabra que habitualmente es utilizada para referir a la escritura ${ }^{1214}$. Sobre esto, debe recordarse que el proyecto de Codificación Civil y Comercial del año 1998 dejaba abierta a la ley local la posibilidad de establecer los recaudos a tener en cuenta a la hora de estampar el texto escriturario en el soporte, dando lugar a que incluso pueda ser electrónico, cosa que como pude advertir anteriormente, se evitó proyectar en el Código Civil y Comercial de La Nación vigente ${ }^{1215}$.

${ }^{1212}$ Ibídem.

${ }^{1213}$ Antes que esto, y en relación a la historia notarial, puede referirse a la cosa en sentido de cuerpo a los ladrillos, los biblos, las tablillas, los papiros y pergaminos, las pieles, el metal en ocasiones, etc.

1214 Cfr. Rafael NUÑEZ LAGOS, Concepto y clases de documentos, en Los esquemas conceptuales del instrumento público, Estudio preliminar de Sebastián Justo COSOLA, Gaceta Notarial, Lima, 2.013, p. 81-82.

1215 Cfr. Art. 277 Proyecto de Código Civil y Comercial del año 1998 (Parte pertinente). "Requisitos. El escribano debe recibir por sí mismo las declaraciones de los comparecientes. Las escrituras públicas, que deben extenderse en un único acto, pueden ser manuscritas o 


\section{SEBASTIÁN JUSTO COSOLA}

Mucho se ha discutido acerca de si la grafía es únicamente el escrito presentado por medios alfabéticos, grabados y pinturas, o si puede también dársele naturaleza documental a las reproducciones mecánicas ${ }^{1216}$. En razón de ello, se enseñaba que la representación del hecho en el documento ocurre mediante la incorporación de signos gráficos a una $\cos ^{1217}$. A esa cosa, la consideraba con la denominación de soporte físico, sustancia o cuerpo apto para la representación $n^{1218}$.

\subsubsection{La $\cos a$ (el soporte).}

¿Qué puede referirse en relación a la cosa que no haya sido ya expresado con anterioridad, para evitar un exceso ritual inútil y sobreabundante? Un adecuado análisis de la actualidad documental notarial tanto en la Argentina como en el resto de los países que profesan el notariado latino, nos dirige a referirnos a los folios de actuación notarial -comúnmente denominados sellados- que son adecuadamente reglamentados en las leyes orgánicas respectivas ${ }^{1219}$, expedidos y contabilizados por las autoridades pertinentes habitualmente los Colegios Notariales- que son quienes llevan adelante sobre los mismos un estricto sistema de contralor -control de producción, control de expedición, control de venta, control de entrega, entre otros-. Los folios, numerados generalmente con sistemas alfa-numéricos de identificación y elaborados con extremas medidas de seguridad -sellos de agua, textura y cuerpo inalterable-, realzan la seguridad del documento notarial por sobre todo otro documento de carácter público. Están destinados y preparados, como en ninguna otra época de esplendor documental en la historia del notariado, a garantizar los efectos emergentes de la autenticidad externa.

mecanografiadas, pudiendo utilizarse mecanismos electrónicos de procesamiento de textos, siempre que en definitiva el texto resulte estampado en el soporte exigido por las reglamentaciones, con caracteres fácilmente legibles".

${ }^{1216}$ Pablo A. CARRICA, Derecho documental, ob. cit., p. 11.

${ }^{1217}$ Carlos A. PELOSI, El documento notarial, ob. cit., p. 36.

${ }^{1218}$ Ibídem, p. 39.

${ }^{1219}$ Cfr. Adriana Nélida ABELLA, Documento notarial, RN n 941, La Plata, 2002, p. 87. 


\section{LOS EFECTOS DE LA PUBLICIDAD EN EL DOCUMENTO NOTARIAL}

El documento como cosa, es mueble; puede desplazarse, y esa es la nota que lo diferencia del monumento, muy a pesar que ambos elementos sirvan al proceso como medio probatorio ${ }^{1220}$. Esto no obsta lógicamente a que la doctrina nacional mayoritaria acuerde que los instrumentos públicos donde constare la adquisición de derechos reales sobre inmuebles sean inmuebles por su carácter representativo. Esta alusión no quita las características de las cosas muebles, como por ejemplo, la posibilidad de desplazamiento ${ }^{1221}$. Además, esta naturaleza determina que el documento pueda ser objeto de apropiación y por lo tanto, de lugar a la discusión en torno a su propiedad ${ }^{1222}$.

\subsection{El protocolo.}

Toda existencia reflejada en el documento es advertida a través de una realidad con trascendencia jurídica denominada protocolo $^{1223}$. El estudio del protocolo va unido a la historia de la documentación y más precisamente, de la documentación notarial. El mismo ha mutado a través de los tiempos, y de ser una simple anotación conservada por el escribano sobre el documento redactado en pergamino, se erigió como documento original que el notario conserva ordenadamente ${ }^{1224}$. En nuestro país, como en el resto de los países del notariado romano germánico, el uso, cuidado y resguardo del protocolo se presenta como uno de los pilares de la función notarial ${ }^{1225}$. Según la acertada opinión de Rubén Lamber, el estudio y elaboración del protocolo debe ser abordado desde dos aspectos diferentes: uno de tipo particular, dirigido a conocer sobre las características y elementos externos configuradores del sustrato papel donde se redacta el documento notarial, y otro general, que se aprecia a la distancia, cuando el protocolo deja de ser un cuaderno compuesto por folios con numeración correlativa en el margen

\footnotetext{
${ }^{1220}$ Carlos A. PELOSI, El documento notarial, ob. cit., p. 36.

${ }^{1221}$ Ibídem, p. 38.

${ }^{1222}$ Cfr. Antonio RODRIGUEZ ADRADOS, El instrumento público. Requisitos de forma y fondo, Escritos jurídicos, $\mathrm{t}^{\circ}$ III, CGN, Madrid, 1.996, p. 140.

${ }^{1223}$ Rubén A. LAMBER, La escritura pública, $\mathrm{t}^{\circ} \mathrm{I}$, ob. cit., p. 214.

${ }^{1224}$ Ibídem.

${ }^{1225}$ Ídem, p. 213.
} 


\section{SEBASTIÁN JUSTO COSOLA}

superior y logos que identifican al Colegio Notarial o institución emisora ${ }^{1226}$, para convertirse en los tomos anuales que con nota de apertura y de cierre, reúnen los documentos, la documentación incorporada, las notas marginales y el índice entre otros elementos de relevancia ${ }^{1227}$.

\subsubsection{La publicidad cartular y la autenticidad externa.}

Enseñaba Rafael Núñez Lagos que el mundo jurídico se divide en atención a la cuestión de las normas y la cuestión de los hechos, siendo únicamente relevantes los mencionados en último término si sirven de fuente para acreditar cualquier tipo de atribución de derechos subjetivos ${ }^{1228}$. Es por ello que al derecho le importa que el hecho revele una existencia cierta, una persistencia o prueba, y una determinada valoración y eficacia. La correlación de cada una de estas fases hace producir la forma ${ }^{1229}$. El hecho es jurídico a través de las forma, y las formas le imprimen al mismo el grado de eficacia ${ }^{1230}$. A partir de la forma, la fuerza de la publicidad cartular externa -motivada desde el propio concepto de autenticidad externa-, se fundamenta desde situaciones absolutamente comprobadas por la doctrina notarial, que son las que confirman que la presunción de veracidad del documento, derivada de la expresión formal externa o exterior de un negocio jurídico, se capta y se recibe como válida tanto para lo probado como para lo expresado

\footnotetext{
${ }^{1226}$ Ibídem, p. 214.

${ }^{1227}$ Ídem, p. 213.

${ }^{1228}$ Cfr. Rafael NÚÑEZ LAGOS, Documento público y autenticidad de fondo, en Jorge H. ALTERINI (Dir.)-Ignacio E. ALTERINI (Coord.), Derecho Notarial, Registral e Inmobiliario. Doctrinas Magistrales 1897-2012, t ${ }^{\circ}$ I, La Ley, Buenos Aires, 2.012, p. 747. Afirma categóricamente el autor: "El hecho es el reactivo de la norma. La eficacia en potencia de la norma se convierte inactu gracias al hecho. Se podría decir que el hecho es el despertador de la eficacia dormida de la norma. O mejor aún, que la norma es fecunda por el hecho".

${ }^{1229}$ Ibídem. Más adelante explica el autor que la diferencia entre forma de ser y forma de valer se relaciona con la ponderación que de las mismas realiza el orden jurídico a través de la jerarquía establecida para los valores jurídicos receptados en el ordenamiento de que se trate, y por ello, hay una imposibilidad que el hecho jurídico exista por sí. ${ }^{1230}$ Ídem, p. 754.
} 
LOS EFECTOS DE LA PUBLICIDAD EN EL DOCUMENTO NOTARIAL

o declarado ${ }^{1231}$. La autenticidad externa, entonces, relacionada históricamente con la selladura o el sellado realizado por autoridad pública y otros signos o símbolos externos, imprime una seguridad cartular visible y palpable a ese hecho convertido en jurídico. Por ello, lo que decido en denominar publicidad cartular extrínseca no puede ser otra que la que se advierte, a simple vista, tanto de los textos matrices como de las primeras o ulteriores copias o testimonios y también, de los documentos anexos a las matrices. La misma entonces puede ser analizada dentro del continente que comprende al contenido, o en el caso de los documentos matrices también fuera de la cosa pero sobre los instrumentos anexos a la misma.

A estos fines, debe entenderse como documentos matrices aquellos producidos por la actividad fedante notarial directa e inmediata, que evidencia coetáneamente los hechos que ocurren en presencia del notario, que el mismo percibe por sus sentidos, procediendo a su narración ${ }^{1232} \mathrm{y}$ luego a su guarda y custodia, hasta el momento oportuno -legal o consuetudinario-, del depósito en el archivo que sea correspondiente. El principal de ellos es el denominado protocolo-cosa-, que una vez redactado queda en poder del notario, además de su guarda para que pueda sobre el mismo expedir copias $^{1233}$. Son documentos protocolares entonces las escrituras constitutivas, las de reconocimiento de relaciones jurídicas, las de "elevación a escritura pública de documento privado" y las de protocolización de instrumentos privados ${ }^{1234}$.

La actividad también comprende a los documentos que se denominan copias $o$ testimonios, independientemente del grado que detenten, que la doctrina considera como documentos reproducidos directos (desde los originales o matrices) e indirectos (desde una reproducción) ${ }^{1235}$. La diferencia central entre las matrices y las copias o testimonios radica en la inmediación. Mientras que las matrices se realizan coetáneamente al hecho que se procede a autenticar, los testimonios y copias vienen a representar el hecho

${ }^{1231}$ Cfr. Enrique GIMENEZ-ARNAU, Derecho notarial español, Vol. I, UN, Pamplona, 1.964, p. 252.

${ }^{1232}$ A los documentos matrices Carlos Pelosi los denomina originales. v. Carlos A. PELOSI, El documento notarial, ob. cit., p. 245.

${ }^{1233}$ Natalio P. ETCHEGARAY, Escrituras y actas notariales, ob. cit., p. 53.

1234 Ídem, p. 32 y ss.

1235 Ídem, p. 28. 


\section{SEBASTIÁN JUSTO COSOLA}

documento y no el hecho natural y humano que da origen al documento matriz, por ello es que se advierte de la conveniencia de llamarlos indistinta y genéricamente como reproducciones ${ }^{1236}$. Las copias o testimonios notariales, explica Natalio Etchegaray, tienen elementos y requisitos que permiten identificarlas de acuerdo a su naturaleza; así se dice que existen requisitos documentales, como los materiales (papel + grafía) los formales ( cláusula que identifica para quien se expide la copia + rubrica de cada hoja + mención del carácter + subsanación de errores), los elementos reales (exactitud + integridad) y los requisitos personales ( competencia del notario que expide la copia), y también existen requisitos extra-documentales (notas de expedición colocadas en el protocolo + agregación al mismo de órdenes judiciales o requerimientos de las partes) ${ }^{1237}$. Dada la descripción anterior, se acuerdan diferentes alcances en cuanto la referencia sea a las copias $o$ testimonios $^{1238}$, a las copias simples ${ }^{1239}$ y a las simples $\operatorname{copias}^{1240}$, estas últimas en carencia de las cualidades de la propia copia ${ }^{1241}$. Finalmente, la referencia a otros documentos anexos hace alusión a aquellos que se agregan a las matrices, esencialmente al protocolo, de naturaleza administrativa, fiscal-tributaria o registral, de los que emergen también notas o rasgos relevantes de publicidad cartular.

\subsection{Casos más frecuentes de publicidad cartular} extrínseca.

${ }^{1236}$ Cfr. Carlos A. PELOSI, Estudios jurídicos notariales, Abeledo Perrot, Buenos Aires, 1.965 , p. 202.

${ }^{1237}$ Natalio P. ETCHEGARAY, Escrituras y actas notariales, ob. cit., p. 64 y ss.

${ }^{1238}$ Ídem, p. 65. Se refiere a los documentos que reúnen los requisitos documentales y extradocumentales descriptos.

${ }^{1239}$ Ibídem. Se refiere a la que presenta una autenticidad perfecta en relación al original, pero que carece de los elementos materiales porque no existe intención de expedición de copia o testimonio.

${ }^{1240}$ Ibídem. Es la que únicamente informa la existencia de la escritura, sin veracidad ni fe notarial que relacione la exactitud e integridad en relación al documento original

${ }^{1241}$ Carlos A. PELOSI, Estudios Jurídicos Notariales, ob. cit., p. 235. 
Existe un sinnúmero de casos ejemplificativos que sirven para comprobar la importancia del principio de autenticidad externa que se analiza sobre la $\cos a$ (protocolo + primer testimonio y ulteriores copias + otros documentos anexos). Sin duda alguna, la primera publicidad cartular emergente del documento es la que se deduce de la lectura pausada y coherente de un acto o un hecho jurídico que en él se contiene, el que -si aduce una buena técnica de conformación- permitirá distinguir en partes bien diferentes, el acto de la comparecencia, las declaraciones pertinentes y las legitimaciones notariales, o la comparecencia y el cumplimiento de la diligencia, si es que fuera necesario para comprobar el hecho requerido, todo a rogación de parte que cuente con un determinado interés legitimo al obrar o al justificar su actuación ${ }^{1242}$. Pero además de ello se encuentran al servicio de la publicidad cartular:

a) Las notas marginales en el protocolo o en los testimonios $o$ primeras copias -también denominadas anotaciones $^{1243}$-, entendidas en sentido amplio, como toda constancia asentada en el protocolo vinculada o no al contenido de la escritura, y también en sentido estricto, como atestaciones o constancias hechas fuera del texto escriturario, al margen o al pie del mismo ${ }^{1244}$, relacionadas con hechos que se relacionan con el contenido, y con las obligaciones notariales determinadas ${ }^{1245}$. Las notas comprendidas desde todas sus

${ }^{1242}$ Cfr. Carlos N. GATTARI, El protocolo notarial, en Jorge H. ALTERINI (Dir.) e Ignacio E. ALTERINI (Coord.), Derecho Notarial, Registral e Inmobiliario. Doctrinas Magistrales 1897-2012, to I, ob. cit., p. 1293.

${ }^{1243}$ Es la denominación de origen que reciben en otros países como España. v. Julio OTERO Y VALENTÍN, Sistema de la función notarial, Artes Gráficas :: N. Poncell, Igualada (Barcelona), 1.933, p. 225 y ss.

${ }^{1244}$ Cfr. Carlos A. PELOSI, Las notas en el protocolo, en Jorge H. ALTERINI (Dir.) e Ignacio E. ALTERINI (Coord.), Derecho Notarial, Registral e Inmobiliario. Doctrinas Magistrales 1897-2012, t I, ob. cit., p. 1366-1367. Dentro de las notas descriptas en sentido amplio, se encuentran las notas de apertura y cierre, y las referencias a documentos incorporados al protocolo.

${ }^{1245}$ Cfr. Carlos N. GATTARI, El protocolo notarial. Corporalidad. Contenido. Valores, en Jorge H. ALTERINI (Dir.) e Ignacio E. ALTERINI (Coord.), Derecho Notarial, Registral e Inmobiliario. Doctrinas Magistrales 1897-2012, to I, ob. cit., p. 1308 y ss. El autor ejemplifica las siguientes: el destino y la fecha de la copia expedida; la inscripción registral y las citas de rectificación, inclusive aquellas que sirven para declarar nulidades, rescisiones, resoluciones, revocaciones o actos de similar naturaleza ordenados por autoridad competente. 


\section{SEBASTIÁN JUSTO COSOLA}

clases $^{1246}$, como parte constitutiva del protocolo, pueden integrar además la parte funcional de la escritura para superar omisiones y/o dificultades, pero de ninguna manera pueden alterar las declaraciones de voluntad plasmadas en el documento ${ }^{1247}$ ni las comprobaciones realizadas coetáneamente con el acto o el hecho instrumentado. En caso de corresponder, para la eficacia hacia los terceros, la nota marginal deberá ser realizada tanto en la escritura matriz como en el testimonio ${ }^{1248}$;

b) Las denominadas notas de corrección o subsanación, relacionadas teóricamente con las notas marginales, que se originan en el documento debido a los errores que se producen al momento de la proyección notarial del derecho sobre él, y que son aquellas que al pie del documento y antes de la suscripción del mismo, salvan y enmiendan errores, tachaduras o entrerrenglonaduras ${ }^{1249}$. También se las suele denominar enmiendas y salvados, y su utilización están reguladas en general, por las leyes notariales especiales ${ }^{1250}$. Bajo la denominación de defectos de forma en la sección de instrumentos

A esto se agrega las aclaraciones y demás correcciones de similar naturaleza.

${ }^{1246}$ Cfr. Ricardo J. SAUCEDO, Notas de subsanación, RN n 943, La Plata, 2002, p. 891. Dentro de las clases de notas, el autor considera de una manera enunciativa, las siguientes: notas de apertura y cierre del protocolo notarial, de expedición de primeras o ulteriores copias, las que consignan la inscripción de los documentos en diversos registros públicos; notas de advertencia sobre la existencia de actos notariales otorgados en el propio registro o en otro que tienen incidencia en el contenido o efectos de un determinado documento matriz; notas que consignan la existencia o el otorgamiento de otros documentos; notas indicativas de los motivos por los cuales algún documento no se pudo concluir de redactar, no se otorgo o fue oportunamente desistido; notas que referencian sentencias o actos que emanan de autoridades competentes que restan eficacia a los documentos en cuestión (declaración judicial de nulidad, inexistencia o inoponibilidad de un acto instrumentado); notas que demuestran el cumplimiento de diligencias encomendadas a la tarea notarial (por ejemplo, una notificación), y las notas de subsanación.

${ }^{1247}$ Cfr. Carlos A. PELOSI, Las notas en el protocolo, en Jorge H. ALTERINI (Dir.) e Ignacio E. ALTERINI (Coord.), Derecho Notarial, Registral e Inmobiliario. Doctrinas Magistrales 1897-2012, t ${ }^{\circ}$ I, ob. cit., p. 1389.

1248 Cfr. Gastón A. ZAVALA, Subsanación de los documentos notariales, en Cristina N. ARMELlA (Dir.), Tratado de Derecho Notarial, Registral e Inmobiliario, t ${ }^{\circ}$ III, Ad-Hoc, Buenos Aires, 1.998, p. 225.

${ }^{1249}$ Herman MORA VARGAS, La función notarial, ob. cit., p. 380.

${ }^{1250}$ José M.R. ORELLE, Actos e instrumentos notariales, ob. cit., p. 156. 


\section{LOS EFECTOS DE LA PUBLICIDAD EN EL DOCUMENTO NOTARIAL}

públicos y en el análisis del contenido de la escritura aparecen reguladas las mencionadas notas de corrección en el Código Civil y Comercial de La Nación ${ }^{1251}$. A modo de directivas generales, además de ser realizadas con anterioridad a las firmas, es recomendable que sean realizadas de puño y letra -aunque ello no es excluyente de otra técnica aprobada jurídicamente-, de manera legible, clara y precisa, respetando el interlineado especial y a través de una técnica que brinde certezas en lugar de incertidumbre ${ }^{1252}$;

c) Las que actualmente podríamos denominar notas de información, dentro del régimen de notas marginales, que no se originan en errores o correcciones, sino que emergen a partir de la toma de conocimiento de una determinada situación jurídica que ha ocurrido luego de la autorización del documento y que es relevante para advertir los nuevos efectos que genera (por ejemplo la nota de revocación o sustitución en los poderes generales o especiales cuando los mismos son otorgados como actos jurídicos unilaterales y recepticios desde la voluntad del poderdante/representado hacia el ejercicio del apoderado/representante ${ }^{1253}$ ).

${ }^{1251}$ Arts. 294 y 305 inc. e) del CCCN respectivamente.

${ }^{1252}$ José M.R. ORELLE, Actos Jurídicos, en Jorge Horacio ALTERINI (Dir. Gen.), José W. TOBIAS (Dir. del T.), Ignacio E. ALTERINI (Coord.), Código Civil y Comercial Comentado. Tratado Exegético, t ${ }^{\circ}$ II, ob. cit., p. 454 y ss.

${ }^{1253}$ Al estar prevista normativamente la teoría de la representación en el cuerpo del Código Civil y Comercial de la Nación y adecuadamente, dentro de la teoría del acto jurídico, corresponde avizorar la representación de esta manera y no dentro del contrato de mandato, salvo en el caso en la que la misma forme parte de lo que nosotros aceptamos como contrato de mandato con representación. Mientras que el mencionado contrato únicamente focaliza sus intereses en el desarrollo de los deberes y las obligaciones de las partes, la teoría de la representación -comprensiva de la representación voluntaria, de la orgánica y de la que emerge de una regla de derecho-, se refiere exclusivamente a la relación jurídica que le permite a un determinado sujeto actuar en nombre de otro. De esta manera, se admite que la revocación en el mandato -siempre unilateral, en cabeza del mandante, y motivada esencialmente en la pérdida de la confianza-, supone el conocimiento de la misma por ambas partes una vez que acontece y comienza a surtir los efectos previstos en la ley. Sin embargo, desde el acto y ejercicio de la representación, esto no ocurre o no debería ocurrir de la misma manera. La realización de un contrato de mandato con representación en escritura pública requiere de la voluntad de ambas partes contratantes, mientras que el acto de apoderamiento que da origen a la representación es solo suscripto por quien decide dar poder. Por ello, la revocación del poder de representación (voluntaria) o la sustitución cuando no existe 


\section{SEBASTIÁN JUSTO COSOLA}

d) Las constancias tributarias incorporadas al protocolo, producto de la legitimación impositiva que tiene y resguarda el notario ${ }^{1254}$, las que desde su carácter inicial - analizadas dentro de los límites del derecho tributario entendido como conjunto de normas y principios relativos a todos los tributos ${ }^{1255}$-, se caracterizan por ser obligaciones "trasladadas" al notariado como consecuencias de una comprensión del mismo como agente del órgano público ${ }^{1256}$, o más precisamente en su carácter de agente de recaudación, tarea que realiza frente a los tributos debidos por los contribuyentes para que los mismos pueden ingresar debidamente a las arcas fiscales ${ }^{1257}$.

e) Las constancias fiscales, tan relevantes por los tiempos actuales, relacionadas esencialmente con la actividad notarial colaboradora con el Estado frente a los delitos penales relevantes para nuestro tiempo, como los provenientes de operaciones sospechosas que pueden de algún modo, justificar el lavado de activos. En este sentido, las informaciones que resultan de las registraciones o noticias instrumentales provenientes de los organismos especialmente creados al efecto, se vuelven absolutamente

liberación del sustituido, salvo en las demarcaciones donde exista un registro de mandatos y poderes, únicamente adquiere publicidad noticia ante un estudio de antecedentes, en el texto matriz del acto de apoderamiento. La claridad de las normativas actuales -ya que desde el Código de Vélez se infería y estudiaba la representación desde el contrato de mandatopermite el razonamiento en este sentido, y desde mi perspectiva, la necesaria puesta en práctica de estas notas de información, destinadas a dar publicidad sin que sea necesaria una corrección, aclaración o rectificación.

${ }^{1254}$ Cfr. Carlos N. GATTARI, Manual de derecho notarial, Abeledo Perrot, Buenos Aires, 2.008 , p. 118. Para el autor, la legitimación impositiva consiste tanto en la comprobación como en la retención de fondos realizados por el notario que justifican con el pago la libre deuda de impuestos, tasas y contribuciones que gravan a los actos notariales.

${ }^{1255}$ Cfr. Héctor B. VILLEGAS, Curso de finanzas, derecho financiero y tributario, Astrea, Buenos Aires, 2.016, p. 159.

${ }^{1256}$ Carlos E. GONZÁLEZ, Derecho Notarial, ob. cit., p. 684. Sin embargo el autor no está de acuerdo con esta obligación trasladada a los notarios, y más profundamente, propone que se la elimine, teniendo en cuenta entre otras cosas, la no pertenencia del notario a la administración pública, que es la única que puede a través de sus reparticiones cumplir tal finalidad.

1257 Cfr. Viviana C. DI PIETROMICA, Régimen tributario de la actuación notarial, LexisNexis, Buenos Aires, 2.008, p. 99. 


\section{LOS EFECTOS DE LA PUBLICIDAD EN EL DOCUMENTO NOTARIAL}

relevantes, exhibiendo una publicidad especial que brinda un alerta a través de la información suministrada. En nuestro país, la normativa específica del lavado de dinero se encuentra tanto en artículos determinados del Código Penal ${ }^{1258}$ como en leyes especiales de la misma naturaleza. Al margen de ello, es conveniente señalar que las denominadas acciones neutrales, entendidas como conductas realizadas bajo el amparo de una actividad socialmente adecuada concretada en aportes que realiza alguien que posee algún nivel de conocimiento -en el caso, escribano-, y que es utilizado por un tercero con finalidad ilícita ${ }^{1259}$, no generan responsabilidad penal notarial -en el caso, delito de participación-, si el mismo adecua su actuar a la ley y es engañado, salvo que la actuación notarial se aparte de las exigencias normativas vigentes y el profesional fedatario no las haya efectivamente cumplido ${ }^{1260}$.

f) Las constancias administrativas, producidas por los organismos públicos o privados que cuentan con la colaboración notarial para la ejecución de las obligaciones a cargo de la ciudadanía, como las que emergen de las informaciones municipales acerca del estado constructivo de los inmuebles, las deudas u obligaciones propter rem, o aquellas que derivan de organismos privados que han tercerizado los servicios especiales (obra de gas natural, agua corriente, realización de pavimentación o construcción del cordóncuneta, entre otros ejemplos);

g) Las constancias registrales, que son las que solicita el notario y las personas autorizadas a pedido de parte (principio de rogación), y las que emite el Registro de la Propiedad inmueble, a través de la expedición de certificados e informes de todo tipo (prioridad directa + prioridad indirecta o retroprioridad en el primer caso, publicidad noticia en el segundo), modo de hacer efectivo el principio de

\footnotetext{
${ }^{1258}$ Conf. Arts. 303, 304 y cc. CP; Arts. 17 inc. 12, 20 y cc. ley 25.246/2000.

${ }^{1259}$ Cfr. Leónidas A. QUINTELA, Las acciones neutrales en el ámbito profesional de los escribanos, IJ Editores, Buenos Aires, 2.013, p. 78.

${ }_{1260}$ Ídem, p. 209. El autor considera que no puede la mera infracción de un deber profesional generar responsabilidad penal notarial.
} 


\section{SEBASTIÁN JUSTO COSOLA}

publicidad material (emergente de la exhibición de los asientos registrales) y la publicidad formal (la que surge a partir de la referida expedición de los informes y certificados). De las mismas debe resultar el perfecto encadenamiento de los sujetos transmitentes principio de tracto, considerando en el las debidas modalidades-, y especialmente, el principio de especialidad en cuanto al objeto.

h) Las constancias catastrales, que conforman en definitiva un documento cartográfico compuesto de los elementos que componen la parcela, expedido por un registro de hechos, que tiene como finalidad la designación de la ubicación, límites, dimensiones, superficie y linderos de los inmuebles; la publicidad del denominado estado parcelario; la registración y publicitación de cualquier otro objeto territorial de naturaleza legal y finalmente, la incorporación de las sucesivas mejoras determinantes de las actualización de las valuaciones fiscales ${ }^{1261}$. Emitidas por el Registro de Catastro, estas constancias persiguen varias finalidades: fines fiscales o tributarios, fines económicos, fines políticos, sociales y estadísticos ${ }^{1262}$; su inclusión al protocolo resulta de notable importancia.

i) Los instrumentos anexos a los documentos matrices aptos para la legitimación o para la prueba, de naturaleza notarial (actas, poderes que acreditan la legitimación, estatutos y demás actos y hechos que puedan anexarse al protocolo); judicial (sentencias, órdenes judiciales necesarias para la autorización debida del acto y demás documentos afines), administrativo-institucional (certificados e informes emitidos por el Registro del Estado Civil y Capacidad de las Personas o de otros registros afines); financiera (emisiones de cuenta y depósitos bancarios que ayudan a comprobar que los actos que se autorizan no incurren en la calificación de actos meramente sospechosos en razón de la acreditación de los fondos); contable (balances, certificaciones de contadores o de los Colegios

${ }^{1261}$ Sebastián E. SABENE, Registro Catastral, ob. cit., p. 26.

${ }^{1262}$ Cfr. Beatriz AREÁN de DÍAZ DE VIVAR, Tutela de los derechos reales y del interés de los terceros, Abeledo Perrot, Buenos Aires, 1.979, p. 173. 
LOS EFECTOS DE LA PUBLICIDAD EN EL DOCUMENTO NOTARIAL

Profesionales de Ciencias Económicas, rendiciones de cuenta, justificación del ingreso o egreso de los fondos, y entre otros, acreditación del cumplimiento de la carga de los tributos a través de la utilización de la clave fiscal del compareciente desde su rol de contribuyente) y personales (documentos privados que los requirentes deseen aportar o anexar, rogando al notario interviniente la mencionada incorporación al protocolo).

\subsection{Acceso a la publicidad cartular extrínseca.}

El estudio y la comprensión de la publicidad cartular en primer término, está dirigida hacia las personas a quienes el documento notarial se encuentra dirigido o destinado. Como ya he adelantado en el primer capítulo, esta situación relativa al valor de la publicidad cartular fue ya tenida en cuenta en el Código Civil originario, argumentada por el codificador en materia de dominio revocable ${ }^{1263}$. Y como advertía desde allí también, el valor de la publicidad emergente del documento respondía definitivamente a cuestiones relacionadas con la lógica jurídica y no tanto con la buena fe; así el codificador originario dio valor a la publicidad emergente del documento. El paradigma de la incolumidad formal confirma que no pueden ni el escribano ni los testigos del acto instrumentado contradecir, variar o alterar su contenido, lo que implica en cierta manera aceptar, por sobre todas las cosas, el conocimiento acabado que tienen $-\mathrm{O}$ deben tener- del mismo ${ }^{1264}$. El

1263 Artículo 2663 del CCA (Parte Pertinente): “...Sea cual fuere la lógica de la jurisprudencia, no puede oponerse razón alguna para que las partes que contratan la enajenación de una cosa no puedan poner condiciones o plazos resolutorios de dominio que transmite la una y adquiere la otra. Esas cláusulas revocatorias debiendo estar en el mismo instrumento público por el cual se hace la enajenación, no pueden dejar de ser conocidas por el tercer adquirente, pues constan del mismo instrumento que crea el dominio del que lo transmite. Hablamos de escrituras públicas, porque sólo por ese medio puede transferirse el dominio de los bienes raices, pues respecto de los muebles, el dominio sólo será revocable en el caso que se determina en uno de los artículos de este título".

1264 Para ver los alcances de la incolumidad formal en el código unificado, con ciertos bemoles interesantes: Adriana N. ABELLA y Ariel REGIS, De los instrumentos públicos, en Eduardo G. CLUSELLAS (Coord.), Código Civil y Comercial..., t ${ }^{\circ}$ I, ob. cit., p 754 y ss; 


\section{SEBASTIÁN JUSTO COSOLA}

principio general a tenerse en cuenta en materia de publicidad cartular es el que ordena que el protocolo y los demás documentos notariales relevantes son públicos - de hecho las voces registro y protocolo muchas veces fueron utilizadas como intercambiables-, pero solo para aquellos que tienen sobre ellos un determinado y especifico interés. Es así que el documento notarial se convierte en una notable fuente de conocimiento tanto para quienes en él intervienen otorgando, asintiendo, consintiendo o suscribiendo en carácter de testigos instrumentales; también para aquellos a quienes directa o indirectamente les es dirigido, y finalmente para aquellos que, en razón del acontecimiento de ciertos hechos jurídicos imprevistos o indeterminados en su origen y autorizados por la ley (fallecimientos, concursos o quiebras) necesaria o involuntariamente deben alcanzar la información de su contenido.

Indudablemente también cuenta con el acceso a la publicidad cartular el notario interviniente, y el personal de la notaría, sobre todo los denominados protocolistas, que actúan sobre el protocolo y cuya órbita de actuación se encuentra legitimada a través del sistema de responsabilidad notarial (el notario responde por el hecho de todos sus dependientes). Pero además tiene acceso a la información del documento la autoridad judicial, que debe requerir al notario la vista, guarda o custodia del protocolo y demás libros o documentos que considere relevantes. Y también el cuerpo de inspectores notariales, que son los encargados de tutelar el ejercicio disciplinar de la forma notarial que, cumpliendo con los requisitos legales, moldea la actuación en sintonía con los preceptos legales.

Mucho más discutible es la solicitud de vista por los organismos administrativos o dependientes de la administración, y ni que mencionarlo, de aquellos de naturaleza fiscal o tributaria sin sustento jurídico suficiente o sin facultades expresamente previstas para la actuación sobre los

Carlos M. D'ALESSIO, Hechos y actos jurídicos, en Ricardo L. LORENZETTI (Dir.). Miguel F. DE LORENZO y Pablo LORENZETTI (Coord.), Código Civil y Comercial de La Nación comentado, $\mathrm{t}^{\circ}$ II, Rubinzal-Culzoni, Santa Fe, 2.015, p. 154 y ss; José M.R. ORELLE, Actos jurídicos, en Jorge H. ALTERINI (Dir. Gen.). José W. TOBÍAS (Dir. $\mathrm{T}^{\circ}$ ), Código Civil y Comercial..., $\mathrm{t}^{\circ}$ II, ob. cit., p. 486; Gabriel V. VENTURA, Hechos y actos jurídicos, en Alberto J. BUERES (Dir.), Código Civil y Comercial de La Nación y normas complementarias, $\mathrm{t}^{\circ} 1 \mathrm{~B}$, Hammurabi, Buenos Aires, 2.016, p. 262, y Sebastián J. COSOLA, Instrumentos públicos, en Julio César RIVERA y Graciela MEDINA (Dir.). Mariano ESPER (Coord.), Código Civil y Comercial..., ob. cit., p. 684. 
documentos notariales. La exhibición del protocolo o de documentos esenciales que quedan en resguardo del notario a estas instituciones, sin la debida tutela judicial, se encuentra reposando sobre el hilo fino que determina si la actuación notarial violenta o no violenta el deber de secreto profesional y mucho más trascendente que ello, el principio constitucional de habeas data.

Fuera de estos casos especiales, en la actualidad también el interés se justifica para acreditar la debida diligencia, que en ámbito negocial, se advierte desde la concreción de la buena fe diligencia, situación jurídica que se concreta con el denominado estudio de títulos.

\subsection{El estudio de los títulos antecedentes.}

Si existen tres momentos del título notarial, el primero de ellos corresponde al denominado examen de los titulos antecedentes ${ }^{1265}$. La referencia al denominado tracto sucesivo de los títulos, tiene absoluta relevancia tanto desde el confronte de títulos y titulares, como del computo del plazo para alcanzar la prescripción, y por ello el examen de los títulos abarca cuestiones relacionadas con el sujeto, con el objeto y con los títulos ${ }^{1266}$.

Enseña Emilio Betti que en la teoría del negocio jurídico, el tema del estudio de los títulos antecedentes ocupa un espacio en el estudio de la legitimación de la parte como presupuesto del negocio, que ayuda a determinar quién y frente a quien puede correctamente concluir el negocio para que éste pueda desplegar los efectos jurídicos conforme a su función ${ }^{1267}$. Pareciera ser que en nuestro país Santos Cifuentes ${ }^{1268}$ y Rubén Compagnucci ${ }^{1269}$ se orientan hacia el mismo sentido, y más dudosa es en cambio, la posición de Federico

1265 Cfr. Rafael NUÑEZ LAGOS, Tres momentos del título notarial, en Rafael NUÑEZ LAGOS, Los esquemas conceptuales del instrumento público, (ob. com.), por Sebastián Justo COSOLA, Gaceta Notarial, Lima, 2.013, p. 215. Los otros momentos son la redacción del nuevo documento y el momento de inmunidad del nuevo título.

1266 Ídem, p. 217.

${ }^{1267}$ Emilio BETTI, Teoría General del Negocio Jurídico, ob. cit., p. 203.

${ }^{1268}$ Cfr. Santos CIFUENTES, Negocio Jurídico, Astrea, Buenos Aires, 2.004, p. 181. 


\section{SEBASTIÁN JUSTO COSOLA}

de Castro y Bravo, quien pareciera ubicar el tema dentro del análisis de la declaración de voluntad negocial ${ }^{1270}$.

El estudio de títulos es una tarea compleja que requiere de solventes conocimientos jurídicos. Se trata del análisis de los antecedentes jurídicos que legitiman el dominio que se alega; las referencias alcanzan tanto a las escrituras como a los expedientes de origen judicial y/o administrativo, y desde allí se analizan de manera exhaustiva y críticamente a los titulares anteriores, y todas las circunstancias que le son imputables, hasta llegar al último título traslativo que permita determinar el trascurso del tiempo adecuado a los efectos del computo de la prescripción ${ }^{1271}$. Desde la función notarial, el mismo conforma una de las operaciones de ejercicio, destinada a analizar en los títulos antecedentes la inexistencia de vicios ostensibles ${ }^{1272}$ que puedan generar algún tipo de inconveniente en la titulación que se pretende llevar adelante.

La recepción de la figura expresamente en el Código Civil y Comercial de La Nación, a simple lectura, pareciera dejar en claro que no existen dudas al respecto no ya sólo de la conveniencia de su realización, sino además de su efectiva concreción. Dado el principio general de la responsabilidad que ordena que cuanto mayor es el deber de obrar con prudencia y conocimiento de las cosas, mayor es la diligencia exigible a quien obra de determinada forma -debiendo considerarse además las situaciones de confianza especial y la valoración de las conductas en los contratos en donde se suponga una confianza especial entre las partes ${ }^{1273}$-, otras normas aisladas hacen hincapié en la importancia de la buena fe diligencia. De esta manera, mientras que la figura encuentra recepción expresa en el contrato de compraventa -

${ }^{1269}$ Cfr. Rubén H. COMPAGNUCCI DE CASO, El negocio jurídico, Astrea, Buenos Aires, 1.992 , p. 161.

${ }^{1270}$ Cfr. Federico DE CASTRO Y BRAVO, El negocio jurídico, Civitas, Madrid, 2.002, p. 58.

${ }^{1271}$ Cfr. Atilio A. ALTERINI, Estudio de titulos, en Jorge H. ALTERINI (Dir.) e Ignacio E. ALTERINI (Coord.), Derecho Notarial, Registral e Inmobiliario. Doctrinas magistrales 1897-2012, t II, La Ley, Buenos Aires, 2.012, p. 495.

${ }^{1272}$ Karina V. SALIERNO, La adquisición legal del derecho real del subadquirente de buena fe..., ob. cit., p. 885. La autora señala que frente al estudio de los antecedentes se debe verificar la efectiva matricidad, su coincidencia con la realidad registral, la inexistencia de vicios o cláusulas que determinen una posible ineficacia.

${ }^{1273}$ Art. 1725 CCCN. 


\section{LOS EFECTOS DE LA PUBLICIDAD EN EL DOCUMENTO NOTARIAL}

obligación del vendedor de asumir los gastos de su realización ${ }^{1274}$-, no es posible el amparo de buena fe del subadquirente a titulo oneroso si el acto se realiza sin intervención del titular del derecho ${ }^{1275}$. Fuera de estos casos, la obligación de actuar de buena fe es un principio general del derecho que cuenta en la actualidad con recepción positiva ${ }^{1276}$, y por esa razón las menciones al obrar con prudencia y diligencia se distribuyen en todo el cuerpo codificado ${ }^{1277}$. De ahí que lo que impere en el derecho actual es el concepto de buena fe diligencia y no ya el de buena fe creencia, salvo cuando esta última pueda llegar a comprobarse desde la visibilidad de algún vicio de la voluntad como la lesión.

No obstante lo dicho, pienso que la diferenciación esencial que ordena comprender si el estudio de títulos puede o no puede advertir las falencias de los actos internos debe seguir estimándose de la misma manera en que la doctrina y la jurisprudencia lo vienen realizando ${ }^{1278}$. De esta manera, hay que diferenciar el caso en que el estudio de los antecedentes es idóneo o no lo es para comprobar las causas de invalidez. Si lo es -o lo fuera- queda probada la buena fe diligencia del adquirente; y si no lo fuera, también queda probada su buena fe, ya sea por haberlo realizado o inclusive, por omitir su realización, precisamente porque la misma jamás hubiera podido advertir los posibles defectos generadores de la invalidez (esencialmente, los vicios de la voluntad que no pueden advertirse desde el análisis material de los documentos matrices sin tener el apoyo de peritajes externos).

A través del estudio de títulos entonces, se accede a los casos enunciados de publicidad cartular externa, en todos los supuestos en donde la ley o la costumbre lo admitan, además de aquellos que tienen acceso directo a la facción protocolar.

\footnotetext{
${ }^{1274}$ Art. 1138 CCCN.

${ }^{1275}$ Art. $392 \mathrm{CCCN}$.

${ }^{1276}$ Art. 9 CCCN.

${ }^{1277}$ Art. 362 CCCN.

${ }^{1278}$ Atilio A. ALTERINI, Estudio de títulos, ob. cit., p. 497 y ss. En este trabajo se encuentran citadas una larga nómina de doctrina y jurisprudencia en el sentido indicado.
} 


\subsection{El estudio de los antecedentes y la defensa de la} seguridad jurídica. Casos detectables.

Para los notarios en ejercicio, la exposición académica de la seguridad jurídica dinámica es en definitiva, una defensa del movimiento escriturario; relevante sí, pero de ninguna manera determinante de la misión notarial. En la protección de la seguridad jurídica estática se encuentra el principal desarrollo y fundamento de la actividad notarial, su principal misión; al nadie poder ser privado de su propiedad por un acto traslativo que el mismo no haya voluntariamente otorgado, se consolida así en el documento, el valor de la justicia.

Desde las estadísticas se advierte que los documentos notariales mayormente valorados por la sociedad en su conjunto son aquellos que concretan la ilusión de la adquisición de la primera vivienda ${ }^{1279}$. Inclusive desde esta posición de la seguridad jurídica puede advertirse claramente como las publicidades registrales, posesorias o provenientes del mercado inmobiliario pueden resultar ciertamente insuficientes para solucionar alguna controversia que haya ocurrido entre partes, y por esta razón desde el notariado se responde acudiendo al documento matriz para decir lo que en definitiva allí se encuentra planteado -decir el derecho justo-, proyectando los errores, subsanando los defectos, y brindando garantías a la nueva y jurídicamente apta transmisión. Esta es la manera de solucionar los temas cotidianos más habituales que escasos emergentes del estudio de los títulos, como la cuestión de los límites de la medianería, o de anotación inadecuada o inusitada de clausulas que indisponen al inmueble y que no reconocen sustento en el documento notarial, entre otros casos relevantes. Es decir, que

\footnotetext{
${ }^{1279}$ Para advertir el alcance de la vivienda en el nuevo derecho ver: Adriana N. ABELLA y Sebastián E. SABENE, Vivienda, en Eduardo G. CLUSELLAS (Coord.), Código Civil y Comercial. Comentado, Anotado y Concordado, t ${ }^{\circ}$ I, Astrea-FEN, Buenos Aires, 2.015, p. 619 y ss., y Leopoldo L. PERALTA MARISCAL, Vivienda, en Julio César RIVERA y Graciela MEDINA (Dir.), Mariano ESPER (Coord.), Código Civil y Comercial de La Nación Comentado, $\mathrm{t}^{\circ}$ I, La Ley, Buenos Aires, 2.014, p. 543 y ss.
} 
frente a los problemas de la publicidad posesoria ${ }^{1280}$, de la publicidad registral ${ }^{1281}$ y de la publicidad emergente del mercado inmobiliario ${ }^{1282}$ debe recurrirse al estudio meditado del documento para dirimir las dudas y por ende, para neutralizar -si ya no se han instaurado- las posibles controversias.

\subsection{La grafía.}

El segundo elemento que conforma la corporalidad, dado sobre una cosa mueble creada por el hombre a la que se le ha incorporado un medio de expresión ${ }^{1283}$, es comúnmente conocido con el nombre de grafia. La misma, como puente entre el espíritu humano y la cosa, es el medio de expresión que se incorpora por su amor a la cosa para que ésta alcance definitivamente la condición de documento ${ }^{1284}$. La grafía, en palabras de Núñez Lagos, es el enlace entre una realidad del espíritu y una realidad de la naturaleza ${ }^{1285}$. Un enlace que encuentra tutela jurídica, y que para la mayoría de la doctrina notarial mundial, se constituye mediante la escritura ${ }^{1286}$, por cuanto dota al documento de expresividad ${ }^{1287}$.

${ }^{1280}$ ¿Están bien establecidos los límites que demarcan el terreno? ¿Son las medidas tomadas las adecuadas? ¿están rectificados en el documento las diferencias de mediciones con las escrituras antecedentes y que no han sido tomadas en cuenta por el adquirente o su colindante? ¿Qué parte o porcentaje de la cosa indivisible se adquirieron definitivamente? ¿Se ha adjudicado de buena fe a través de un documento adjunto una parte determinada del condominio? ¿Consta en el documento el constituto posesorio o la traditio brevi manu?

${ }^{1281}$ ¿Consta alguna indisponibilidad en el titulo? ¿Se ha asumido el embargo o las medidas cautelares? ¿Costa expresa constancia de la situación de indisponibilidad del inmueble? ¿Constan los derechos asumidos de respeto a los derechos de servidumbre, a las limitaciones del Reglamento de Propiedad que en razón de una fuga registral no se han publicitado desde los asientos registrales?

${ }^{1282}$ ¿Es apto para el crédito el departamento en el que deseo vivir? ¿Tiene alguna restricción proveniente del derecho público que merezca o deba conocerse?

${ }^{1283}$ Antonio RODRIGUEZ ADRADOS, El instrumento público. Requisitos de forma y fondo, ob. cit., p. 140. El autor hispano nos recuerda que no existen los documentos naturales.

${ }^{1284}$ Rafael NUÑEZ LAGOS, Concepto y clases de documentos, ob. cit., p. 86-87.

${ }^{1285}$ Ibídem.

${ }^{1286}$ Antonio RODRIGUEZ ADRADOS, El instrumento público. Requisitos de forma y fondo, ob. cit., p. 140 .

${ }^{1287}$ Ibídem, p. 141. 


\section{SEBASTIÁN JUSTO COSOLA}

Es que debe recordarse hasta el cansancio que desde la visión valletiana que tan bien le hace a la argumentación negocial (notarial) de la metodología jurídica, el derecho no es más que una parcela de la vida social del hombre que se ubica entre el amor por un lado, y el poder o la fuerza por el otro ${ }^{1288}$. Por ello sin la fuerza o sin el poder o los poderes necesarios para imponer $l o$ que es justo coactivamente, no puede alcanzarse como resultado más que la anarquía. Y si la única manera de imponer al derecho fuese a través del poder o de la fuerza, el mismo poder podrá vencer al derecho en cuanto no sean convenientes sus reglas ${ }^{1289}$. Por ello también el amor es importante como balanza de equilibrio en la permanente búsqueda de lo justo concreto y, como virtud, -recordaría Josef Pieper ${ }^{1290}$-, el amor se refiere a Dios, a la patria, al prójimo, al deber y a la justicia ${ }^{1291}$. Una fantástica coincidencia de pensamiento. ¡De cuanta fuerza se nutre la grafía en la concepción de estos inigualables autores contemporáneos!

\subsubsection{Tipos de grafía.}

Hay una grafía considerada como elemento físico de la corporalidad documental, y es la grafía en sentido estático ${ }^{1292}$. Esta grafía se adhiere fisicamente a la $\cos a^{1293}$, y en la historia esa adhesión fue a través del

\footnotetext{
1288 Juan Berchmans VALLET DE GOYTISOLO, El orden natural y el derecho- En torno al derecho natural, ob. cit., p. 7.

${ }^{1289}$ Ibídem.

${ }^{1290}$ Cfr. Josef PIEPER, Las virtudes fundamentales, Rialp, Madrid, 2.003, págs. 415-551.

${ }^{1291}$ Juan VALLET DE GOYTISOLO, El orden natural y el derecho- En torno al derecho natural, ob. cit., p. 7.

${ }^{1292}$ Rafael NUÑEZ LAGOS, Concepto y clases de documentos, ob. cit, p. 87. El maestro PELOSI sigue esta descripción incluso ampliando los conceptos. V. Carlos A. PELOSI, El documento notarial, ob. cit., p. 54 y ss.

${ }^{1293}$ Ibídem.
} 
LOS EFECTOS DE LA PUBLICIDAD EN EL DOCUMENTO NOTARIAL

calamus $^{1294}$ y el incausto $^{1295}$. En la actualidad el documento puede ser manuscrito, impreso o mecanografiado ${ }^{1296}$, y en general, su impresión se realiza mediante métodos informáticos. Por ello es que tanto las leyes notariales, sus respectivos reglamentos, como así también las frecuentes resoluciones de los Colegios Notariales imponen como debe ser la impresión del documento, que calidad de tinta debe utilizarse para ello, que tipo de impresora se adecúa a las exigencias propias de la autenticidad externa del documento, entre otras directivas de importancia. De esta manera se determinan con rigurosa precisión las condiciones que requiere la grafía para perdurar en el tiempo indeleble, legible e inalterable ${ }^{1297}$, sin que la humedad, cualquier tipo de temperatura ambiente o la propia degradación del elemento utilizado puedan borrar los textos que deben ser rigurosamente conservados en sede notarial ${ }^{1298}$.

Pero también hay una grafía que reconoce un aspecto biológico, y es la que se denomina grafía en sentido dinámico ${ }^{1299}$. De esta forma, el pensamiento humano se vuelca hacia la grafía del documento, y por ello el pensamiento del autor se vuelve grafía de tipo sensible ${ }^{1300}$. Al hablar de grafía en este sentido, nos referimos especialmente a la incorporación del pensamiento del autor: una incorporación de autenticidad interna ${ }^{1301}$. La misma es dada únicamente en el documento original exclusivamente, por cuanto a la copia solo se traslada el contenido ideológico del documento ${ }^{1302}$.

Hay entonces, dos direcciones. Por un lado, el pensamiento humano que se dirige hacia la grafía del documento. Por la otra, el documento devuelve el

\footnotetext{
${ }^{1294}$ Ibídem. Se refiere a la utilización del punzón cuneiforme, la caña afilada, la pluma de ave y luego, la pluma de metal.

${ }^{1295}$ Ibídem, p. 88. Se refiere a los ingredientes utilizados para escribir. La tinta no fue usada hasta el nacimiento del papiro y el pergamino.

${ }^{1296}$ Ibídem.

${ }^{1297}$ Adriana N. ABELLA, Documento notarial, ob. cit., p. 87

${ }^{1298}$ Rubén A. LAMBER, La escritura pública, t ${ }^{\circ}$ I, ob. cit., p. 218.

${ }^{1299}$ Rafael NUÑEZ LAGOS, Concepto y clases de documentos, ob. cit., p. 88.

${ }^{1300}$ Ibídem.

${ }^{1301}$ Carlos A. PELOSI, El documento notarial, ob. cit., p. 59.

1302 Ibídem. Dice PELOSI: “Así, por ejemplo, si se reproduce una escritura matriz o se obtiene fotocopia de ella, el ante mi Fulano de Tal de la matriz no tiene ningún valor. En tanto no se agregue la cláusula de suscripción o "concuerda" la copia no será instrumento público y carece de autenticidad".
} 
pensamiento pero ya no a su autor, sino al destinatario ${ }^{1303}$. Sin este doble pensamiento humano, afirma Rafael Núñez Lagos, no hay documento ${ }^{1304}$.

\subsubsection{Notas de grafía.}

Las notas sirven para que la grafía tenga carácter documental. Dentro de la doctrina notarial del último siglo, las mencionadas notas fueron originariamente desarrolladas por Rafael Núñez Lagos $^{1305}$ y receptadas en nuestro país por Carlos Pelosi ${ }^{1306}$. Así, se acuerda que la grafía debe tener las notas de visibilidad, expresividad y recognoscibilidad. Por cuanto ha de ser perceptible a la vista y ser la expresión objetiva del pensamiento humano, la misma puede existir como escritura o como otras formas gráficas, fotográficas, planos, dibujos, esquemas, con tal que reúnan todos los demás requisitos del documento ${ }^{1307}$.

\subsection{Segundo elemento: El autor.}

El segundo elemento de la corporalidad es el referido a la persona que crea y argumenta el derecho notarial sustantivo y formal. El análisis del autor es quizás el determinante del documento, porque es quien lo condiciona y le da vida $^{1308}$, y por ello el problema del autor del documento está siempre orientado a indagar acerca de su paternidad ${ }^{1309}$. En nuestro país, es el referido Pelosi quien sigue a Núñez Lagos ${ }^{1310}$ recogiendo las opiniones

\footnotetext{
${ }^{1303}$ Rafael NUÑEZ LAGOS, Concepto y clases de documentos, ob. cit., p. 88

${ }^{1304}$ Ibídem.

${ }^{1305}$ Ibídem, p. 90 y ss.

${ }^{1306}$ Carlos A. PELOSI, El documento notarial, ob. cit., p. 59.

${ }^{1307}$ Ibídem.

${ }^{1308}$ Carlos A. PELOSI, El documento notarial, ob. cit., p. 62.

${ }^{1309}$ Ibídem.

${ }^{1310}$ Rafael NUÑEZ LAGOS, Concepto y clases de documentos, ob. cit., p. 97 y ss.
} 
mayoritarias acerca de la naturaleza jurídica del tema en referencia. El autor argentino expone que para explicar el alcance de la autoría documental, la doctrina ha presentado diversas teorías sin llegar a ponerse en un todo de acuerdo. Consecuentemente, se sostiene que hay una teoría de la firma ${ }^{1311}$, una teoría corporal ${ }^{1312}$, una teoría de la compilación $^{1313}$, una teoría de la causa $^{1314}$, una teoría de la imputación ${ }^{1315}$, una teoría de la ley ${ }^{1316} \mathrm{y}$ finalmente, una teoría del autor del pensamiento ${ }^{1317}$.

De manera mucho más simple y sencilla, Francisco Martínez Segovia enseña que el notario es el único autor del documento, y que esa autoría se explica naturalmente a través de la responsabilidad por realización de la totalidad de la obra y la originalidad ${ }^{1318}$. De aquí entonces es que se deriva que no son ni las partes ni los terceros interesados los autores del documento, ya que el escribano es el único responsable por amoldar la voluntad de las partes al negocio jurídico y así, poder revestirlo de certeza, validez y eficacia ${ }^{1319}$. Para el autor entrerriano, en la originalidad del acto notarial se encuentra la clave para considerar la categoría del autor. En efecto, la función notarial permite que una siempre nueva relación jurídica voluntaria cobre vida e impulso a través de su adecuación al negocio jurídico que le sea determinado. Nace a la vida por vez primera, a diferencia de las demás funciones públicas estatales, como el acto administrativo, que no

\footnotetext{
${ }^{1311}$ Carlos A. PELOSI, El documento notarial, ob. cit., p. 62. Esta teoría sostiene que es autor quien firma o suscribe el documento, aunque se encuentra frente al problema que demuestra que hay documentos que no requieren firma.

1312 Ídem, p. 69. Doctrina que entiende que el autor del documento es quien lo redacta materialmente, y que no tiene éxito, según Pelosi, porque "el que escribe es un trabajador, creador material del documento; otra cosa es el que lo forma o redacta en el aspecto intelectual. El documento es, en definitiva, una obra cultural, un opus".

${ }^{1313}$ Ibídem. Para esta teoría el autor es quien forma o hace jurídicamente al documento. Teoría próxima a la teoría corporal, que excluye al simple amanuense o mecanógrafo.

${ }^{1314}$ Ibídem, p. 70. Teoría que postula que es autor del documento el causante de su formación.

${ }^{1315}$ Ibídem. 71. Autor del documento es aquel a quien el mismo le es imputable (variante de la teoría de la causa).

${ }^{1316}$ Ibídem. Para esta teoría, expuesta por CARNELUTTI, autor del documento es por cuenta de quien el mismo se ha formado.

1317 Ídem, p. 72. Es la teoría denominada sustancial, que advierte que es autor del documento quien le imprime su pensamiento. El documento tiene que expresar el pensamiento de su autor.

${ }^{1318}$ Francisco MARTÍNEZ SEGOVIA, Función Notarial, ob. cit., p. 221.

${ }^{1319}$ Ibídem, p. 222.
} 


\section{SEBASTIÁN JUSTO COSOLA}

pretende originalidad sino abarcar el mejor interés de la comunidad; como el acto judicial, que reconstituye intereses, y como el acto registral que es el simple reflejo de una realidad que permanece intacta ${ }^{1320}$. Así, el notario se constituye en autoridad jurídica, como perito del derecho, ya que a nivel documental, brinda el mayor valor jurídico al documento que autoriza ${ }^{1321}$.

Quizás sea por lo expuesto, que autores como Núñez Lagos hayan adelantado que hay que distinguir entre el autor del documento y autor de la declaración ${ }^{1322}$. En el análisis del autor del documento, mientras que en el documento público notarial el único autor es el notario ${ }^{1323}$, en el instrumento privado se reconoce como autor de la declaración al particular que lo suscribe $^{1324}$. Sin embargo, posicionados desde el análisis del autor de la declaración, podría sostenerse que en los documentos públicos con contenido de derecho privado, el autor de la declaración es un particular que, en la escritura, entra por los ojos del notariado, como hecho evidente de la audiencia $^{1325}$. La paternidad de la declaración se produce entonces, en las entrañas de un acto público, constituyéndose en una paternidad endógena y por consiguiente, auténtica. En el documento privado, por el contrario, la pretendida paternidad es neutra, y totalmente ineficaz ${ }^{1326}$.

Ese es entonces el valor agregado del documento notarial, y por ende, de la función notarial. No pueden entonces albergarse ningún tipo de dudas al afirmar categóricamente que el escribano es el creador intelectual - y generalmente, también material- del documento, del que se desprenderá el carácter público y la fuerza fedante que el mismo presenta en razón de la mencionada intervención notarial ${ }^{1327}$. Para ello, es indispensable, previo a

\footnotetext{
${ }^{1320}$ Ibídem, p. 223.

${ }^{1321}$ Ibídem, p. 224.

${ }^{1322}$ Rafael NUÑEZ LAGOS, Concepto y clases de documentos, ob. cit., p. 99.

${ }^{1323}$ Ibídem. Afirma el autor categóricamente: "En el documento público, autor del documento -sea su contenido de derecho público o de derecho privado-, es exclusivamente el funcionario público que lo autoriza. Es siempre una imputación auténtica, una paternidad legitima solo atacable por falsedad".

${ }^{1324}$ Ibídem. "El autor del documento privado es siempre el particular que lo suscribe. Es una imputación inauténtica, una paternidad neutra, pero ulteriormente legitimable por el reconocimiento legal".

${ }^{1325}$ Ídem, p. 101.

${ }^{1326}$ Ibídem, p. 102.

${ }^{1327}$ Rubén A. LAMBER, La escritura pública, t I, ob. cit., p. 159.
} 


\section{LOS EFECTOS DE LA PUBLICIDAD EN EL DOCUMENTO NOTARIAL}

que ocurra la regla abstracta de investidura notarial $^{1328}$, que su actuación esté determinada por las reglas específicas de competencia funcional, a las que remito en razón de conveniencia, a estudios ya realizados ${ }^{1329}$.

\subsubsection{Los comparecientes en el documento.}

Presentado el análisis del autor, debe referirse, tan siquiera mínimamente, a los sujetos intervinientes en el documento notarial, que se presentan en la audiencia, objeto esencial de la comparecencia ${ }^{1330}$. En él entonces intervienen las partes interesadas, que en el derecho notarial se denominan comparecientes. Son comparecientes, porque están presentes en el acto, y están referidos en el instrumento, coincidan o no coincidan con los sujetos negociales. La idea del compareciente se encuentra ligada inexorablemente al hecho material de la presencia física ${ }^{1331}$. Gran razón entonces le asiste a Rafael Núñez Lagos cuando sostiene que es incorrecto referirse a parte en materia de documentación notarial, por cuanto las mismas pertenecen al mundo del derecho, mientras que el compareciente pertenece al mundo de los hechos ${ }^{1332}$. De ahí que el autor clasifique a los comparecientes como aquellos que actúan en nombre propio y ajeno, tomando como referencia la relación con la parte; a los comparecientes simples, que son quienes prestan la conformidad a la narración, y finalmente al otorgante, que es quien presta

\footnotetext{
${ }^{1328}$ Ibídem, p. 165. Dice el autor: "La investidura notarial es un verdadero acto de autoridad del Estado que pone en ejercicio de la función pública fideifaciente a un escribano para ejercerla como titular o adscripto de un determinado registro. Mediante la investidura, el escribano graduado es introducido en el notariado activo y accede al ejercicio de la función con todos los derechos y obligaciones propios de la institución”. De ahí que generalmente se refiera a los escribanos a aquellos que son poseedores del título universitario, y notarios a los que tengan investidura, esto es, a los que puedan estar en ejercicio de la función fedante. Es esta una categorización meramente teórica, que se debe a ciertas interpretaciones de artículos y postulados históricos recogidos por las leyes positivas vigentes. En ciertas provincias, como la de Buenos Aires, los colegiados en ejercicio pertenecen al Colegio de Escribanos de la Provincia de Buenos Aires.

${ }^{1329}$ Sebastián J. COSOLA, Los deberes éticos notariales, ob. cit., p. 162 y ss.

${ }^{1330}$ Rafael NUÑEZ LAGOS, Los esquemas conceptuales..., Gaceta Notarial, ob. cit., p. 179.

${ }^{1331}$ Ídem, p. 141.

${ }^{1332}$ Ídem, p. 140.
} 


\section{SEBASTIÁN JUSTO COSOLA}

un concreto consentimiento, especial y notarial, tanto al negocio como al instrumento ${ }^{1333}$.

\subsubsection{La cuestión de los testigos instrumentales en sede notarial.}

La cuestión de los testigos en los instrumentos públicos - y en especial en las escrituras públicas- no debe ni puede traer ningún tipo de complejidad. En efecto, los testigos en los instrumentos públicos son un requisito o un elemento de forma, por cuanto no declaran ni testifican ningún hecho del pasado ${ }^{1334}$, como los testigos que son analizados desde la óptica del derecho de procedimientos. Tal como se afirma, el testigo del proceso realiza una declaración formal en el curso del proceso sobre lo que pueda llegar a conocer a través de la percepción de sus sentidos, sobre hechos relevantes que puedan contribuir a la reconstrucción de una verdad histórica ${ }^{1335}$. Pero la verdad es que los testigos a los que hace referencia el presente artículo, y los anteriores designados, son testigos de forma, y por ello Emérito González los denomina instrumentales ${ }^{1336}$.

¿Por qué son tan importantes? Precisamente, por ser un elemento de forma indispensable para la validez del acto. No por su presencia, sino por la exigencia de la forma que se considera adecuada para ciertos actos de la vida a los que el hombre recurre quizás no con tanta frecuencia, pero si necesitado y esperanzado de cierta protección ${ }^{1337}$.

\footnotetext{
${ }^{1333}$ Ibídem, p. 142.

${ }^{1334}$ Lo que no implica que algún testigo comparezca en las actas notariales para realizar alguna declaración de algún hecho pasado que haya podido ser percibido por sus sentidos, y que pueda ser trascendente y significativo para los fines que el requirente de la diligencia pretenda para sí al solicitarle al notario la realización del documento.

${ }^{1335}$ Cfr. Maximiliano HAIRABEDIÁN, Prueba testimonial. En el sistema acusatorio y adversarial, Astrea, Buenos Aires, 2.016, p. 17. El autor se refiere a la prueba testimonial en el proceso penal.

${ }^{1336}$ Carlos Emérito GONZÁLEZ, Teoría General del instrumento público..., ob. cit., p. 247 y ss.

1337 "No es viable la prueba testimonial para destruir los efectos de una escritura pública, pues toda modificación o alteración de un contrato que la ley exige en forma determinada, no puede ser probada sino mediante otro instrumento de igual clase, salvo la nulidad por fraude
} 
LOS EFECTOS DE LA PUBLICIDAD EN EL DOCUMENTO NOTARIAL

\subsection{Tercer elemento: El contenido.}

La doctrina ha considerado, desde dos extremos visiblemente diferentes, que el contenido documental puede estar compuesto tanto por las declaraciones que el mismo contenga, como por el hecho mismo que represente. Dentro de esta ultima teoría, hay quienes además especifican que el contenido está compuesto por la propia representación del hecho y no por el hecho en si ${ }^{1338}$. Si el contenido entonces es la representación del hecho -o hecho representativo-, el objeto de la representación el objeto mismo de la percepción ${ }^{1339}$.

Antonio Rodríguez Adrados reniega de esta última concepción. Sostiene el gran autor que se logra debilitar al documento en relación a la seguridad jurídica que del mismo se desprende, por cuanto el contenido del documento ya no sería la propia declaración de voluntad, sino su representación, que se consigue por la mente humana, muy cercana a la prueba testimonial ${ }^{1340}$. Las propias declaraciones de voluntad son elemento dinámico y constitutivo del negocio jurídico. Conforman un texto auténtico, con nota de exactitud de fe pública, porque en este sentido, las declaraciones son reproducidas tal cual las partes las han producido ${ }^{1341}$. Y por ello es que en principio, las propias declaraciones de las partes no necesitan ser probadas entre ellas ni respecto de terceros, ya que se han incorporado a través de la grafía de manera permanente a la materia documental, siendo directamente cognoscibles por cualquier destinatario ${ }^{1342}$. A esto hay que agregar las manifestaciones

y simulación”. CNCiv, 19/12/1963, JA, 1964-IV-195.

${ }^{1338}$ Rufino LARRAUD, Curso de derecho notarial, ob. cit., p. 242.

${ }^{1339}$ Carlos A. PELOSI, El documento notarial, ob. cit. p. 76: "El objeto de la representación es, pues, el objeto mismo de la percepción: un hecho, es decir, una actitud concreta (determinada en el espacio y en el tiempo) del mundo exterior. Lo que no es un hecho, es decir, lo que no tiene existencia concreta, no se representa".

${ }^{1340}$ Antonio RODRIGUEZ ADRADOS, El documento notarial y la seguridad jurídica, ob. cit., p. 117.

${ }^{1341}$ Ibídem, p. 119.

${ }^{1342}$ Ibídem. 


\section{SEBASTIÁN JUSTO COSOLA}

notariales del derecho, que son las que el notario percibe por sus propios sentidos ${ }^{1343}$. Y de aquí que se advierta que en el documento convivan tanto las declaraciones de las partes como las del propio notario, y que las mismas sean merecedoras de la fuerza que les corresponda ${ }^{1344}$.

Por lo expuesto, parece más que evidente que lo que el documento contiene en realidad, es el pensamiento del notario: el hecho histórico, pero tal como él lo aprehende y piensa ${ }^{1345}$. El hecho entonces es el contenido de ese pensamiento, destinado a revelar hechos jurídicos ${ }^{1346}, \mathrm{y}$ el concepto del autor resulta elemental para conformar el contenido del documento, porque en última instancia, "el documento merece la fe de su autor ${ }^{1347 "}$. Y el documento no es ya una mera representación, sino que es la expresión escrita del pensamiento de un hombre (el escribano o notario) que se erige como su autor ${ }^{1348}$. Por ello la declaración notarial del derecho conforma el contenido inmediato del documento, mientras que el hecho histórico referido se convierte en el contenido mediato o indirecto ${ }^{1349}$.

El contenido así representa el pensamiento del autor ${ }^{1350}$. Y el documento contiene el pensamiento del notario (como autor del documento) y el pensamiento sobre o acerca del propio pensamiento de los otorgantes ${ }^{1351}$. De aquí que se considere al escribano como exclusivo autor del documento sin

\footnotetext{
${ }_{1343}$ Ídem, p. 128.

${ }^{1344}$ Ibídem.

${ }^{1345}$ Rufino LARRAUD, Curso de derecho notarial, ob. cit., p. 242.

${ }^{1346}$ Carlos A. PELOSI, El documento notarial, ob. cit. p. 79.

${ }^{1347}$ Antonio RODRIGUEZ ADRADOS, El instrumento público. Requisitos de forma y fondo, Escritos Jurídicos, ob. cit., p. 141.

1348 Antonio RODRIGUEZ ADRADOS, El documento notarial y la seguridad jurídica, ob. cit, p. 128. Dice el autor: "El autor de la escritura pública es el notario, que presenta su pensamiento en parte como propio y en parte como ajeno; hay pues que distinguir entre autor del instrumento, que es siempre el notario, y autor o autores de las manifestaciones o declaraciones contenidas en el documento, que puede ser el notario, pero que también pueden ser los particulares".

${ }^{1349}$ Rufino LARRAUD, Curso de derecho notarial, ob.cit, p. 242. Aclara el autor: "Cuando de un documento notarial se trata, y el hecho documentado es un negocio jurídico, la declaración del escribano es su contenido inmediato; y el otorgamiento de la parte, su contenido mediato. De este modo, el instrumento notarial, que es forma de la declaración del notario, simultáneamente representa la declaración de la parte que lo otorga".

${ }^{1350}$ Carlos A. PELOSI, El documento notarial, ob. cit, p. 75.

${ }^{1351}$ Ídem, p. 81.
} 
LOS EFECTOS DE LA PUBLICIDAD EN EL DOCUMENTO NOTARIAL

que se desvíen los principios a los que se encuentra sometida su conformación ${ }^{1352}$.

Finalmente, recordemos que la adecuación del contenido del documento notarial debe enmarcarse en los requisitos de forma y de fondo que el mismo prevé para adecuada conformación, muchos de los cuales hemos ya estado analizando en tratamiento que anteceden a estas líneas ${ }^{1353}$.

En cuanto a los primeros, la doctrina se refiere a la materia escriptoria (papel); a la grafía, que debe ser en letra clara, legible, perfeccionada de corrido sin guarismos, abreviaturas ni espacios en blanco; el idioma - que debe ser el nacional-. Finalmente, los requisitos de forma ordenan consignar en el instrumento el lugar y la fecha de otorgamiento, la designación del notario como autor del documento y la autorización notarial del derecho que se desprende del mismo ${ }^{1354}$.

Los requisitos de fondo son analizados desde la autoría del documento notarial exclusivamente ${ }^{1355}$, y sin duda alguna, se explican a través de la teoría general de la función notarial ${ }^{1356}$.

\subsubsection{La publicidad cartular y la autenticidad interna.}

La historia del documento notarial es la historia de su lucha por la autenticidad interna ${ }^{1357}$. La misma, referida exclusivamente al contenido del documento y a su autenticidad en la esfera de los hechos, hace notar la existencia de tres grados de eficacia:

a) La verdad impuesta, compuesta de las narraciones que realiza y comete el notario captadas por sus sentidos, todas sus actuaciones y

\footnotetext{
1352 Ibídem, p. 82.

${ }^{1353}$ Antonio RODRIGUEZ ADRADOS, El instrumento público. Requisitos de forma y fondo, ob. cit, p. 146

${ }^{1354}$ Ibídem.

1355 Ídem, p. 147.

${ }^{1356}$ Sebastián Justo COSOLA, Los deberes éticos notariales, ob. cit., págs. 173 y ss.

${ }^{1357}$ Rafael NUÑEZ LAGOS, Documento público y autenticidad de fondo, ob. cit., p. 761.
} 
diligencias ${ }^{1358}$, determinantes de la fe pública como realidad evidente y como acto de $f e^{1359}$;

b) La verdad supuesta, compuesta por los hechos afirmados por el notario que no son evidencias indirectas, y las declaraciones de voluntad de las partes ${ }^{1360}, \mathrm{y}$

c) La verdad puesta, relacionada con el principio de prueba por escrito, son las declaraciones de verdad realizadas por las partes y las enunciativas ${ }^{1361}$.

Es evidente que el tema de la autenticidad interna gira en torno a la cuestión de la fe, y dentro de ella al desarrollo de la fe pública. Desde mi visión, el tema debe exceder notablemente el análisis de ese valor, para extenderse hacia otros valores esenciales que además, forman parte de la comprensión de la autenticidad a nivel interno. A la fe pública, analizada desde la certeza y desde los efectos del valor verdad, debe agregarse tanto el análisis de la justicia, referida al reflejo de la autonomía de la voluntad negocial vertida en el documento y tutelada notarialmente en el mismo momento de argumentación y creación documental, como la proyección de la seguridad jurídica, entendida como fuente de valoración de los efectos del documento que emana de la actuación notarial. La suma de los tres valores en el documento, consolidan la paz, que es el cuarto valor resultante de la adecuada concatenación de los tres anteriores mencionados, según demostraré en la parte tercera de esta investigación.

\footnotetext{
${ }^{1358}$ Ídem, p. 762.

${ }^{1359}$ Ibídem, p. 763. El acto de fe (evidencia) que es el que alguien realiza sobre un objeto evidente, mientras que el razonamiento sobre el acto de fe, puede determinar un acto de juicio, que no se percibe sino a instancias de otra persona. El autor trae el caso de la creencia sobre el átomo: "creo en el átomo, para mi inevidente porque unos sabios, dignos de todo crédito me lo han testimoniado. Para ellos ha sido un objeto evidente, y sobre ese objeto han formulado un juicio de razón".

${ }^{1360}$ Ídem, p. 768.

${ }^{1361}$ ídem, p. 770.
} 
LOS EFECTOS DE LA PUBLICIDAD EN EL DOCUMENTO NOTARIAL

\subsubsection{Los temas de la publicidad cartular intrínseca.}

Los análisis de los temas que componen la publicidad cartular intrínseca se relacionan exclusivamente con los aspectos valorativos y axiológicos contenidos y resguardados en el documento. Mientras que la publicidad cartular extrínseca tiene como misión el análisis de los efectos inmediatos de la publicidad (palpables y visibles), la publicidad cartular intrinseca persigue una cuestión diferente: analizar cómo es que se van o se han proyectado los valores en el documento; si los mismos se encuentran presentes o ausentes, si han sido adecuadamente ponderados por las partes $\mathrm{y}$ tutelados por el notario, y que efectos se desprenden de su adecuada implementación.

Para alcanzar a consolidar lo intrínseco de la publicidad en el documento, no es posible conformarse con un análisis meramente externo de los antecedentes, sino que aquí se desarrolla en plenitud la tarea pre-documental notarial, relacionada con los deberes de información, el asesoramiento y el concejo notarial, de imparcialidad, independencia y aplicación y concreción del principio de legalidad integrada, que permiten alcanzar la adecuada comprensión de lo que realmente los comparecientes quieren realizar. No es el efecto regular de los negocios jurídicos, con la consecuente muestra de eficacia (inscripciones en término, prioridades, entre otros temas técnicos) lo que debe primar en este tipo de autenticidad, sino los efectos que compadecen la realidad, el deseo verdadero de las partes con el acto o negocio a instrumentar.

Este tema es quizás el más relevante a la hora de analizar el contenido del documento. En ocasiones cada vez más frecuentes se suele considerar a la instrumentación como una cuestión meramente técnica, que sí reúne todos los requisitos extrínsecos relativos a la forma se transforma en apta para consolidar el tráfico económico del mercado. El verdadero notario creador del derecho dirige su actividad hacia un fin mucho más amplio y relevante: adecuar la voluntad real de las partes que a él acuden en búsqueda de respuestas al derecho, procurando generar la plena satisfacción de cada una de ellas -y en lo que a cada cual le corresponda-, aunque esa actuación ni siquiera concluya en la creación misma del documento. Por ello, la 


\section{SEBASTIÁN JUSTO COSOLA}

autenticidad interna jamás podrá consolidarse en el documento ya realizado o finalizado, y por ello excede ampliamente la justificación de la autenticidad externa. La única posibilidad de concretar en un documento lo intrínseco es a través de la ponderación y de la tutela de cada valor comprometido antes de que los mismos sean definitivamente creados, y además, destinados a vivir, por el tiempo que sea, deseado o necesario, en un continente.

¿Por qué razón entonces el documento notarial puede entonces erigirse como rector frente a todas las demás publicidades jerarquizadas? Porque, de todos los medios conocidos de publicidad que ofrece el derecho, es el único que puede lograr los valores proyectados instrumentalmente en el momento de la creación, los que justificados, alcanzaran la máxima satisfacción de la voluntad jurídicamente tutelada (justicia), equivalente tanto a la certeza como a la verdad (fe), con la protección de la autenticidad externa aparente, que no es otra cosa que ver consolidada en él la libre y adecuada circulabilidad (seguridad).

\subsubsection{El acceso a la publicidad cartular intrínseca.}

Para acceder de manera técnica a este tipo de conocimiento, inicialmente bastará con analizar en el documento las cuestiones centrales de las manifestaciones notariales -aquellas cumplidas por el notario-, las propias de los comparecientes -aquellas que los mismos advierten en el documento-, y las relativas a los símbolos o signos exteriores, su orden y especialmente, el análisis del cumplimiento de cuestiones inherentes a un normal desarrollo del derecho documental (vigencia y cumplimiento de los plazos, solicitudes formales anexas al protocolo, la cuestión del otorgamiento y de la autorización, y demás cuestiones relacionadas). No hay diferencia, desde estas perspectivas, con el acceso a la autenticidad externa.

Sin embargo, de acuerdo a lo antes expuesto y desde el máximo nivel sustancial, el análisis de la publicidad cartular intrínseca cobra relevancia en el momento de creación del documento. Por ello el primer acercamiento 
LOS EFECTOS DE LA PUBLICIDAD EN EL DOCUMENTO NOTARIAL

corresponde a las partes o comparecientes que exponen sus deseos una vez acordada la voluntad, mientras que el acceso directo a la misma corresponde al notario que moldea esas intenciones, procediendo ubicarlas en el documento donde formalmente corresponde, protegiendo la voluntad y el derecho a través de la conformación real de los valores esenciales del documento. El elemento contenido se convierte hoy a lo que se denomina elaboración y creación notarial del derecho. Captadas las voluntades claramente expresadas, se crea y elabora el documento con la adecuada proyección de la autenticidad interna.

\subsubsection{En torno a lo extrínseco e intrínseco de la autenticidad.}

Desde la posición que decido plantear y sostener, puede claramente advertirse que el ámbito de la tutela efectiva de autenticidad varía de acuerdo a que la misma se proyecte a nivel extrínseco o a nivel intrínseco. La primera entonces, dedicada al análisis de lo que efectivamente se palpa y advierte con el sentido de la vista y del tacto en el documento -cosa-, y la segunda, más preocupada por asegurar cierto cumplimiento de determinados valores que son los que efectivamente terminan por corroborar la esencia rectora de la publicidad cartular notarial.

Ya he advertido que esta investigación no está dirigida a posicionar la importancia y preponderancia de uno por sobre otro medio de publicidad receptado por el derecho sino, en todo caso, de demostrar efectivamente porque la publicidad emergente del documento es la que puede alcanzar el máximo grado de tutela jurídica elemental. En este espacio, el camino hacia la consolidación de lo que afirmo comienza a demostrar su justificación. Para ello, es preciso determinar primeramente que en forma alguna puede aceptarse que la autenticidad interna tiene mayor valor, trascendencia o importancia que la autenticidad externa. En todo caso, el concepto de autenticidad es uno solo, y su bifurcación en dos vertientes responde a una cuestión de análisis de los casos que hasta los tiempos actuales, doctrina y jurisprudencia vienen considerando con diferentes argumentaciones, 


\section{SEBASTIÁN JUSTO COSOLA}

interpretaciones y proyecciones. Sin embargo, existen algunas particularidades que merecen ser traídas a modo de reflexión. Del análisis del concepto que refiere lo extrínseco surge que es referido a lo externo, lo no esencial ${ }^{1362}$. Por el contrario, del análisis conceptual de lo intrínseco, hace referencia a aquello que es íntimo, esencial ${ }^{1363}$. Sea una particularidad o quizás, una curiosidad, lo cierto es que bien merece la pena destacar en este punto la referida cuestión conceptual, para poder enfrentar con mayor entusiasmo, y en la parte pertinente de este estudio, la cuestión de los valores que proyecta el documento notarial.

\subsubsection{Derecho comparado.}

El desarrollo de los elementos del documento es generalmente compartido por la doctrina mayoritaria internacional, pero a diferencia del tratamiento realizado en nuestro país y en España, -que diferencia los elementos del documento de las partes integrantes del contenido- lo que se presenta es un esquema general que abarca tanto la mención de los elementos como las clasificaciones de ciertas partes esenciales del mismo, como las referidas a los tipos de clausulas que conforman el contenido, o la redacción como actividad propia de la grafía, el protocolo y la escritura como análisis del soporte, la diferenciación entre escritura y acta, entre otros análisis relevantes que tanto en Argentina como en España se presentan desde el estudio independiente de la escritura pública. Es como si los dos países que ofician de originarios en el desarrollo académico del derecho notarial presentaran una parte general del documento notarial, que se refiere al análisis de los elementos referidos a la corporalidad, al autor y al contenido, y una parte especial, dirigida a definir y precisar el alcance de la especie principal, la escritura pública y en ella, el desarrollo de todas sus partes componentes. Ya sea por mera casualidad o por alguna razón fundada en cuestiones de practicidad jurídica, la mayoría de los países del notariado

${ }^{1362}$ RAE: http://dle.rae.es/?id=HQB90tU (Último acceso: 28/08/2017)

${ }^{1363}$ RAE: http://dle.rae.es/?id=M03Jhd5 (Último acceso: 28/08/2017). 


\section{LOS EFECTOS DE LA PUBLICIDAD EN EL DOCUMENTO NOTARIAL}

latino presentan obras que desarrollan el tema de manera integrada. Digamos también que en algunos casos, las presentaciones comparadas de alto rigor científico y de marcado carácter pedagógico, vuelven más ameno el estudio del documento notarial, hecho que no ocurre con ciertas obras consagradas, repletas de clasificaciones y formulas, que proyectan una lectura bastante dificultosa.

Así se advierte un buen tratamiento de los elementos integrados con las partes de la escritura en determinadas obras de jerarquía de Bolivia ${ }^{1364}$, Brasil $^{1365}$, Costa Rica ${ }^{1366}$, Cuba ${ }^{1367}$, Guatemala ${ }^{1368}$, México ${ }^{1369}$, Panamá ${ }^{1370}$, Paraguay ${ }^{1371}$, Perú ${ }^{1372}$, República Dominicana ${ }^{1373}$ y Uruguay ${ }^{1374}$.

${ }^{1364}$ Saúl F.GUZMAN FARFÁN, Derecho notarial y registros públicos, ob. cit., págs. 93 y ss; Ramiro VILLARROEL CLAURE, Fundamentos de derecho notarial y registral inmobiliario, ob. cit., págs. 107 y ss; Álvaro Héctor OQUENDO LOPEZ, Compilaciones de derecho notarial para Bolivia, ob. cit.; Juana Aidee MARIACA VALVERDE, Teoría y técnica notarial, ob. cit., págs. 82 y ss; María Luisa LOZADA BRAVO, María Silvia AGUILAR TARDÍO y Lilia Gladys FLORES MEDINA, De la escritura pública notarial, ob. cit., págs. 41 y ss.

${ }^{1365}$ Cfr. Leonardo BRANDELLI (Coordenador), Ata Notarial, Sergio Antonio Fabris Editor, Sao Paulo, 2.004, págs. 15 y sig.

${ }^{1366}$ Herman MORA VARGAS, La función notarial, ob. cit., págs. 257 y ss.

${ }^{1367}$ Pedro C. VERDEJO REYES, Derecho notarial, ob. cit., págs.61; Leonardo B. PEREZ GALLARDO, Diligencias y notas en el instrumento público notarial: un acercamiento a su estudio, ob. cit., págs. 335; Josefina CHINEA GUEVARA, La función notarial como garante de la seguridad jurídica contractual en el ordenamiento jurídico cubano, ob. cit., págs. 364 y ss.

${ }^{1368}$ Nery Roberto MUÑOZ, El instrumento público y el documento notarial, ob. cit., págs. 1 y ss.

${ }^{1369}$ Luis CARRAL Y DE TERESA, Derecho Notarial y Derecho Registral, ob. cit., págs. 125 y ss; Bernardo PEREZ FERNANDEZ DEL CASTILLO, Derecho Notarial, ob. cit., págs. 87 y ss, y César Eduardo AGRAZ, Derecho notarial comparado en la República Mexicana, ob. cit., págs. 173 y ss.

${ }^{1370}$ Cfr. Boris BARRIOS GONZÁLEZ, Derecho notarial panameño, Cultural Portobelo, Panamá, 2.006, págs. 175 y sig.

${ }^{1371}$ Lucila ORTIZ de DI MARTINO, Manual de derecho notarial, ob. cit., p. 37; Ana María DI MARTINO, Derecho notarial, ob. cit., págs. 69 y ss.

${ }^{1372}$ Gunther GONZALES BARRÓN, Derecho registral y notarial, t ${ }^{\circ}$ II, ob. cit., págs. 1175 y ss; Oswaldo ARIAS MONTOYA, Comentarios a la actualidad notarial peruana, ob. cit., (Parte general introductoria).

${ }^{1373}$ César PINA TORIBIO, Temas notariales, ob. cit., (Introducción); Rhadys I. ABREU de POLANCO, Lecciones de derecho notarial, ob. cit.

${ }^{1374}$ Eduardo J. COUTURE, El concepto de fe pública (introducción al estudio del derecho notarial), ob. cit., (Parte propedéutica). 
SEBASTIÁN JUSTO COSOLA

$\cdot 350$. 


\section{Capitulo 10.}

\section{La conformación de los componentes en la estructura del documento \\ notarial.}

\subsection{Palabras iniciales.}

Asumida la estructura del documento propuesta, es preciso entonces afirmar dentro de ella los componentes esenciales o primarios del documento notarial $^{1375}$. Es que como enseñaba Rafael Núñez Lagos, el documento es una figura jurídica absolutamente relevante para presentar el más vasto y notorio tratamiento de los hechos y de los derechos reflejados en un mismo continente. Necesariamente debe existir entonces una cierta tutela de la consideración formal y material de los hechos y del derecho en el documento público ${ }^{1376}$. Pero es oportuno también destacar que esas enseñanzas no hubieran alcanzado a tener una amplia trascendencia, si no fuera porque casi en sintonía espacial y temporal con la elaboración científica del documento, José Castán Tobeñas ${ }^{1377}$ daba inicio a una novedosa perspectiva de elaboración notarial del derecho, que comenzaría por justificar en España y en el resto de los países que asumen el notariado latino, la trascendencia del

\footnotetext{
${ }^{1375}$ La misma se inspira en la que fuera oportunamente bosquejada por nuestros más grandes maestros del derecho notarial, pero necesariamente adecuada y conformada de acuerdo a los tiempos actuales. La creación de nuevas perspectivas en las que creo hay que insistir para consolidar la nueva estructura del documento notarial, se advierten claramente desde el estudio meramente comparativo.

${ }^{1376}$ Rafael NUÑEZ LAGOS, Hechos y derechos en el documento público, ob. cit., p. 3.

1377 José CASTÁN TOBEÑAS, Función notarial y elaboración notarial del derecho, ob. cit. En la dedicatoria, dice CASTÁN: "A Rafael Núñez Lagos, que fue un dia mi mejor discípulo, y que hoy, por su gran pericia en Derecho Privado y Notarial, me orienta en uno y otro campo como verdadero maestro".
} 


\section{SEBASTIÁN JUSTO COSOLA}

ejercicio de la función fedante sobre el documento notarial $^{1378}$. Ese fantástico aporte venía a comprobar que al notario - a diferencia del juez-, no le basta con aplicar una regla elaborada e inflexible a los hechos que ocurren antes de un pleito y que son probados en un determinado litigio. Su tarea es modeladora ab initio de los actos jurídicos, para que los mismos se ajusten a la ley y para que las consecuencias que produzcan sean favorables tanto al interés de las partes como al supremo interés de pública prosperidad ${ }^{1379}$. Para el ejercicio de la función notarial no alcanza entonces la acción de aplicar el manejo hábil de las reglas lógicas en forma de silogismo, ya que "se hace visible en ella (la función) un método de hallar soluciones justas poniendo los textos legales en comunicación con la vida, con la naturaleza de las cosas y con la utilidad social, fuente y objeto del derecho ${ }^{1380 " . ~ A ~}$ partir de esas primeras doctrinas, es relativamente corto el tiempo que transcurre para que Juan Vallet de Goytisolo desarrolle ampliamente el concepto de elaboración y la concreción notarial del derecho sobre el documento en estudios hasta hoy insuperables ${ }^{1381}$. En definitiva, fueron aportes analizados desde un prisma poco común, que pueden alcanzar a comprobar la verdadera utilidad actual del análisis de los componentes que fortalecen de manera notable, los valores que emergen de la publicidad cartular. Parte de esas enseñanzas conforman algunos de los cimientos que sirven de guía a la presente tesis doctoral, y que son aquí descriptos con la idea de poder profundizarlos, adecuarlos y ampliarlos hacia ciertos nuevos conceptos y horizontes del derecho que actualmente nos rige.

\footnotetext{
${ }^{1378}$ Ibídem, p. 59. Sobre esto, Castán argumentaba lo siguiente: "Los efectos de la función notarial se sintetizan y resumen en la producción del instrumento público". El gran civilista hispánico no dejaba de advertir sin embargo, que los efectos del instrumento público suelen ser muy complejos, y por ello es que decide agruparlos en tres grupos diferentes. Así se explican desde ese entonces los efectos sustantivos o civiles, los efectos probatorios y los efectos ejecutivos de los instrumentos o documentos notariales.

1379 Ídem, p. 96.

${ }^{1380}$ Ibídem.

${ }^{1381}$ Juan B. VALLET DE GOYTISOLO, Manuales de metodológica jurídica, $\mathrm{t}^{\circ} \mathrm{III}$, ob. cit., p. 233 y ss.
} 
LOS EFECTOS DE LA PUBLICIDAD EN EL DOCUMENTO NOTARIAL

\subsection{Los componentes materiales.}

Si la estructura es el aspecto exógeno del documento, los componentes conforman el aspecto endógeno de la misma. Es la misma relación que en medicina tiene el cuerpo humano con las células que dentro de él, se dirigen hacia lugares específicos buscando cumplir con una determinada finalidad que les es naturalmente atribuida ${ }^{1382}$. La estructura tiene que ver con el análisis de las causas externas del documento, mientras que los componentes se relacionan con las causas internas que el mismo tiene y posee. Aludir a las causas del derecho significa aprehender en profundidad la realidad que es el derecho; alcanzar un mejor saber acerca del objeto ${ }^{1383}$, en este caso, del documento notarial.

De esta manera, en la esfera de los hechos, el documento notarial presenta el análisis de doble perspectiva que se comprende desde una doble efectividad, la forma y la prueba ${ }^{1384}$ :

a) La forma, en sentido amplio como la exteriorización o expresión del hecho -en donde no es posible reconocer un origen histórico autónomo ${ }^{1385}$-, mientras que en un sentido más restringido es una fórmula mágica, que sí reconoce antecedentes en la vida primitiva

\footnotetext{
${ }^{1382}$ La referencia a la ciencia de la medicina reconoce la comparación que efectuara Mario ZINNY entre el estudio de la anatomía para el joven aspirante a médico y la comprensión de la secuencia "situación-hecho-situación" para el joven abogado. Esos son los troncos comunes que dan inicio a la comprensión y el conocimiento de cada una de las ciencias implicadas. Cfr. Mario A. ZINNY, La base de la teoría general de derecho, ob. cit., p. 75 y ss; y del mismo autor, La enseñanza del derecho y los estudios comparados, Nova Tesis, Rosario, 2.014, p. 83 y ss.

${ }^{1383}$ Cfr. Rodolfo L. VIGO, Las causas del derecho, Abeledo Perrot, Buenos Aires, 1.983. p. 53.

${ }^{1384}$ Rafael NUÑEZ LAGOS, Hechos y derechos en el documento público, ob. cit., p. 33. Dice el autor: "La forma y la prueba son dos planos paralelos y superpuestos en estratos (existir y persistir). El mismo hecho jurídico en dimensión tiempo".

${ }^{1385}$ Ibídem, p. 17. Dice el autor: "En este sentido (acepción amplia), la forma no tiene origen histórico autónomo, porque se confunde con el origen de la expresión social de hechos diversos, de los que los hechos jurídicos no son más que una parte. La forma como lenguaje es un medio de expresión y comunicación. Lo que la palabra es a la idea, es la forma al hecho jurídico".
} 


\section{SEBASTIÁN JUSTO COSOLA}

tales como los nacimientos, los matrimonios, y hasta la propia muerte, que se subrayan con ritos sacramentales ${ }^{1386}$.

b) La prueba, que permite que el hecho documentado sea directamente sometido a la percepción judicial; "El documento se comporta a la evidencia del juez como cosa material ${ }^{1387}$ ". Es prueba en sentido vulgar cuando la misma es sometida a la libre apreciación judicial $^{1388}$, mientras que es prueba en sentido técnico cuando esa apreciación se aleja de estimaciones admisibles desde el punto de vista de la filosofía de valores ${ }^{1389}$, en los casos en que el documento público no es un hecho por probar, sino una fuente de prueba en cuanto a su contenido ${ }^{1390}$.

En el campo de los hechos entonces, la relación entre forma y prueba no demuestra ni más ni menos que una correlación de conceptos en distinto plano: la intervención, en el plano de la forma, y la narración, en el plano de la prueba ${ }^{1391}$. Emérito González fue en nuestro país quien advirtió oportunamente que forma y prueba son dos planos paralelos y superpuestos en estratos: existir y persistir ${ }^{1392}$ : "Con la forma el negocio existe, con la prueba, persiste ${ }^{1393}$ ". Desde aquí que se haya planteado entre nosotros la construcción de una teoría introductoria de la voluntad determinante de los efectos del documento, esto es, de la forma y de la prueba, digna de toda atención ${ }^{1394}$ : La forma y la prueba en el seno del documento se conforman entonces, a partir de una declaración de la voluntad libre y espontánea,

\footnotetext{
1386 Ídem, p. 18.

1387 Ídem, p. 55.

${ }^{1388}$ Ídem, p. 54.

${ }^{1389}$ Ibídem.

1390 Ídem, p. 55.

${ }^{1391}$ Ibídem, p. 35.

${ }^{1392}$ Carlos Emérito GONZÁLEZ, Teoría General del Instrumento Público..., ob. cit., p. 154. ${ }^{1393}$ Ibídem.

${ }^{1394}$ Rubén A. LAMBER, La escritura pública, t II, ob. cit., p. 13. Dice el autor: "Si bien el solo estar de las personas en el mundo implica situaciones jurídicas (de las personas con las cosas o con otras personas de los que derivan los derechos al igual que las obligaciones reales y personales) su voluntad es altamente significativa para comprender y calificar las situaciones y relaciones jurídicas derivadas de ello".
} 
precisamente porque la voluntad comprensiva del hecho voluntario implica tanto el estar como el hacer (estar siendo), debe exteriorizarse y debe ser atrapada por el régimen jurídico que le fija a la misma las consecuencias previstas $^{1395}$. Clarificando las teorías al respecto, puede afirmarse que la declaración libre y espontánea en el documento determina tanto la forma como la prueba que en él se reflejan.

\subsubsection{El derecho notarial como derecho formal.}

Al afirmar reiteradamente que el derecho notarial es un derecho formal, la doctrina clásica mayoritaria intenta precisar el alcance de dos elementos fundacionales del derecho notarial: la forma notarial hacia el derecho, y el desarrollo del instrumento o documento público notarial.

Julio Otero y Valentín advertía hace ya algún tiempo que la soberanía jurídica se le presenta al notariado como un poder ético-social; un poder de obrar y de hacerse respetar según la razón justa ${ }^{1396}$. En la práctica jurídica y cotidiana, las personas no actúan por libre determinación subjetiva, sino que utilizan su voluntad dentro de los límites que impone la legalidad y que les permite alcanzar la máxima perfección de las conductas justas ${ }^{1397}$. Para ello, se necesitaba que las personas tengan competencia o capacidad para comerciar y que las mismas alcancen a obrar dentro de los cánones que marca la forma adecuada. Así, como el derecho es la garantía de la vida práctica y tiene que acreditarse con relación al tiempo, la realización jurídica se logra autenticando los actos de los particulares, momento en donde el notario presencia y consagra directamente los hechos y las conductas jurídicas, autorizándolas a base de observar formalidades y solemnidades. De esta manera se hacen las conductas justas y respetables ${ }^{1398}$. Por cuanto lo justo es verdadero y lo útil es lo provechoso para todos $-\mathrm{y}$ no para unos

\footnotetext{
${ }^{1395}$ Ibídem.

1396 Julio OTERO Y VALENTÍN, Sistema de la función notarial, ob. cit., p. 5.

${ }^{1397}$ Ibídem.

${ }^{1398}$ Ibídem, p. 6.
} 
pocos- ${ }^{1399}$, con acierto se afirmaba que forma es escritura pública ${ }^{1400}$, porque "forma es el freno que detiene las tentativas de los que arrastran la libertad hacia la licencia ${ }^{1401}$ " $\mathrm{o}$, en palabras de Ihering, "Enemiga jurada de la arbitrariedad, la forma es hermana gemela de la libertad ${ }^{1402}$ ".

\subsubsection{La forma notarial.}

Al mismo tiempo que se postulaba la referida teoría de Otero y Valentín, Antonio Bellver Cano admitía que si el fenómeno ético y social de la exteriorización de la voluntad es realmente permanente y necesario, es preciso que tenga sus reglas biológicas y fisiológicas adecuadamente establecidas $^{1403}$. La doctrina que postula este criterio formal del derecho notarial tiende a argumentar que el objeto del derecho notarial es el instrumento público en relación con la idea de forma ${ }^{1404}$. Dicho de otro modo: La forma notarial se erige entonces como una forma de tipo funcionarista, para llegar al resultado del instrumento público ${ }^{1405}$.

También se refirió al tema Enrique Giménez-Arnau: "Toda la significación $y$ alcance de la función notarial puede resumirse en el instrumento público. Si al hombre se le conoce por sus obras, a las instituciones se las identifica por su resultado ${ }^{1406 " . ~ Y ~ p o s t e r i o r m e n t e, ~ l o ~ t r a n s m i t i o ́ ~ e l ~ r e c o r d a d o ~ J o s e ́ ~}$ González Palomino: "Lo característico de la función notarial es que se desenvuelve en la esfera de los hechos (Hechos, actos y negocios, como hechos) para darles forma ${ }^{1407}$ ".

${ }^{1399}$ Carlos Emérito GONZÁLEZ, Constitución de Sociedades Anónimas, ob. cit., p. 9.

${ }^{1400}$ Ibídem, p. 10.

${ }^{1401}$ Ibídem.

${ }^{1402}$ Ibídem.

${ }^{1403}$ Antonio BELLVER CANO, Principios de régimen comparado, ob. cit., p. 16.

${ }^{1404}$ Eloy ESCOBAR DE LA RIVA, Tratado de derecho notarial, ob. cit., p. 30.

${ }^{1405}$ Rafael NUÑEZ LAGOS, Los esquemas conceptuales del instrumento público, Gaceta Notarial, ob. cit., p. 117. Con estas palabras lo decía Núñez Lagos: "Toda la atención del notario esta conversivamente orientada hacia el instrumento público".

${ }^{1406}$ Enrique GIMENEZ-ARNAU, Introducción al derecho notarial, ob. cit., p. 183.

${ }^{1407}$ José GONZÁLEZ PALOMINO, Instituciones de derecho notarial, tº I, ob. cit., p. 14. 
LOS EFECTOS DE LA PUBLICIDAD EN EL DOCUMENTO NOTARIAL

Sobre estas primeras ideas directrices, José María Sanahuja y Soler puso de resalto que el documento añade a la forma tanto las ventajas de la prueba como las del impulso del comercio jurídico, aunque estos criterios cobran absoluta certeza si son realizados en la forma jurídica notarial por oposición a la forma privada ${ }^{1408}$. En la actividad notarial, la finalidad de la forma instrumental viene a fijar el carácter jurídico de las relaciones que se contraen en la escritura ${ }^{1409}$. Con ella se especifica el tipo de negocio jurídico que se contrae y se da a su contenido el nombre adecuado a derecho ${ }^{1410}$, a la vez que se constituye en una prueba que no necesita del apoyo de otras ${ }^{1411}$. El acto se presenta en el instrumento publico con todos los elementos esenciales, naturales y accidentales y se perpetuán en el protocolo los elementos formales, probatorios y sustanciales expresados ${ }^{1412}$, para finalmente, cumplir dentro de los límites adecuados con los fines de la publicidad inherentes a ciertas relaciones jurídicas ${ }^{1413}$. Sanahuja convence que el instrumento notarial enriquece a la forma jurídica, dotándola de reflejos diversos que operan no solo en la sustancia del derecho, sino también en su ejercicio, cumplimiento y pública exteriorización ${ }^{1414}$. Esto hace que la forma notarial, como elemento del documento y en el sentido argumentado por Vallet, pueda ser sustento primario de la presentación de una función social del notario de tipo latino con doble vertiente: conformadora y autenticadora ${ }^{1415}$.

\subsubsection{Derecho notarial formal argentino.}

\footnotetext{
1408 José María SANAHUJA Y SOLER, Tratado de derecho notarial, t ${ }^{\circ}$ I, ob. cit., p. 98.

${ }^{1409}$ Ibídem.

${ }^{1410}$ Ídem, p. 99.

${ }^{1411}$ Ibídem.

${ }^{1412}$ Ibídem.

${ }^{1413}$ Ibídem.

${ }^{1414}$ Ídem, p. 100.

${ }^{1415}$ Cfr. Juan Berchmans VALLET DE GOYTISOLO, La función notarial de tipo latino, en Juan Francisco DELGADO DE MIGUEL (Compilador), Deontología Notarial, Junta de Decanos de los Colegios Notariales de España, Madrid, 1.992, p. 456.
} 


\section{SEBASTIÁN JUSTO COSOLA}

En nuestro país José María Mustapich enseñaba que el derecho notarial era el derecho autónomo de la forma ${ }^{1416}$. Su fundamento era el desarrollo del concepto y alcance de la autenticidad, posición desde donde infería lo indispensable del desarrollo de una teoría que organice y regule eficientemente el instrumento público ${ }^{1417}$ para que luego operen sobre él los registros de inscripción de derechos ${ }^{1418}$. También Alberto Villalba Welsh consideraba al escribano como autor de la forma notarial ${ }^{1419}$, a la que consideraba -acorde con su pensamiento egológico- como un acto de creación volitiva del escribano dirigido a crear y estructurar el documento $^{1420}$. Ya algunos años después de estas manifestaciones, sería Argentino Neri quien postularía a la forma como uno de los principios del derecho notarial, conjuntamente con la fe pública y la autenticación ${ }^{1421}$.

En el presente, Rubén Lamber se refiere a la forma como cuerpo que contiene la voluntad exteriorizada, de lo que se deduce que los actos jurídicos siempre tienen forma, porque si no sería imposible calificarlos como tales ${ }^{1422}$. Y también Carminio Castagno presenta un particular

${ }^{1416}$ José María MUSTAPICH, Tratado teórico y práctico de derecho notarial, $\mathrm{t}^{\circ} \mathrm{I}$, ob. cit., $\mathrm{p}$. 48.

1417 "En el estudio del instrumento público, existe una eficiente unidad entre el documento cosa que sirve para representar otra- y el autor del documento -que no es quien materialmente lo hace, sino aquel por cuenta de quien se forma". Ibídem, p. 50.

${ }^{1418}$ Ibídem, p. 49. Mas adelanta, al referirse a la autenticidad, el autor afirmaba que ella está determinada por la apetencia de certeza que requiere el tráfico jurídico, certeza que ayuda a cumplir el fin inmediato del derecho que es la instauración del principio de seguridad jurídica. Y así, expresaba lo siguiente: "El instrumento público, en primer término, y las inscripciones registrales, secundariamente, constituyen la fuerte estructura en que descansa esa necesidad de certeza que fundamenta la existencia misma del derecho". Para el autor, el análisis de la teoría de la forma pone de relieve la eficacia jurídica y social del acto auténtico.

${ }^{1419}$ Alberto VILLALBA WELSH, El derecho notarial a la luz de la teoría egológica, ob. cit., p. 24.

${ }^{1420}$ Ibídem. Afirma el autor: "El escribano es el autor de la forma en cuanto vuelca sobre el protocolo, individualizándolas, las normas jurídicas que configuran la escritura pública. Función ésta en que las partes no tienen ejecutoria alguna, aparte de que ellas no "quieren" la escritura pública; su volición va dirigida a provocar consecuencias jurídicas y no formas, sólo que para conseguir su objeto deben dejar que su voluntad sea exteriorizada bajo la forma notarial". Este recordado escribano llego a postular una nueva rama del derecho, la que según su razón, debería denominarse el derecho de las formas públicas o derecho formal público, lugar del asidero y desarrollo del derecho notarial formal.

${ }^{1421}$ Argentino I. NERI, Tratado teórico y práctico de derecho notarial, $\mathrm{t}^{\circ}$ I, ob. cit., p. 377.

${ }^{1422}$ Rubén Augusto LAMBER, La escritura pública, t ${ }^{\circ}$ I, ob. cit., p. 10. Lamber advierte, en sintonía con otros autores, que el problema de la forma se encuentra en su finalidad, y para 
tratamiento de la forma proyectada en nuestro derecho ${ }^{1423}$, al recordar que la primera verificación en sentido positivo de lo que considera el derecho (reino cultural), es advertir que el mismo es conducta, vida humana viviente $\mathrm{u}$ objetivada, y por tanto exhibe una triple dimensión: sociológica, preceptiva y axiológica, dimensiones que se hallan unidas indisolublemente en relaciones de esencial implicación ${ }^{1424}$. Sin embargo, éste último autor no deja de advertir como la mayoría de los anteriores autores citados, que en derecho, el hecho posee una especial significación jurídica que le resulta inherente $^{1425}$. El derecho tiene una naturaleza social, y fruto de ella es que todas las manifestaciones jurídicamente relevantes tienen que presentar una cierta entidad que las vuelva reconocibles en el medio de desenvolvimiento ${ }^{1426}$. Siendo ya lógica la exigencia de exterioridad, se advierte que el derecho puede contentarse con cualquiera que ella sea o por el contrario exigir una precisa. En el último caso, estamos en presencia de la forma jurídica ${ }^{1427}$. Forma que, en este sentido y como elemento de la declaración jurídica ${ }^{1428}$, presenta cinco categorías en función del factum: forma para $\operatorname{ser}^{1429}$, forma para valer ${ }^{1430}$, forma para transmutar ${ }^{1431}$, forma para trascender ${ }^{1432}$ y forma para aparecer ${ }^{1433}$. En este sentido, sencillo es entonces inferir la naturaleza formal del documento: "si para determinada

ello se refiere a la forma de ser, para valer, para probar y para trascender, clasificación que realiza siguiendo el método del autor José Carlos Carminio Castagno.

${ }^{1423}$ Cfr. José Carlos CARMINIO CASTAGNO, Algunas disquisiciones sobre la forma jurídica, en Teoría General del Acto Notarial y otros estudios, t ${ }^{\circ}$ I, Edición del autor, Paraná, 2.006, p.262.

${ }^{1424}$ Ibídem.

${ }^{1425}$ Ibídem, p. 269.

${ }^{1426}$ Ibídem, p. 275. En palabras del autor: "todo hecho debe tener una forma que lo haga socialmente perceptible, como condición esencial de apreciación jurídica” en razón de ello es que todos los hechos son formales.

${ }_{1427}$ Ibídem, p. 276.

${ }^{1428}$ Ibídem, p. 279.

${ }^{1429}$ Ibídem, p. 283. La forma como requisito de existencia del factum, ya que hace a su esencia y es constitutiva de su ser.

${ }^{1430}$ Ibídem, p. 285. La forma impuesta hace al valor, es requisito de validez del factum.

${ }^{1431}$ Ibídem, p. 289. El autor se refiere al supuesto en donde encuadran casos de conversión substancial por cuanto lo que se altera es la esencia.

${ }^{1432}$ Ibídem, p. 290. Casos en donde la forma es exigida para que a la existencia y validez del factum prosiga la eficacia.

${ }^{1433}$ Ibídem, p. 293. Esta clase de imposición formal se constituye por la hipótesis es la que la forma es exigida para probar un factum. 


\section{SEBASTIÁN JUSTO COSOLA}

declaración se impone legalmente la forma escrita, el papel (corpus) en el que se ha escrito (grafía) la declaración -o sea, el documento- es forma jurídica de aquel factum ${ }^{1434}$ ". Al documento, forzosamente entonces, se le atribuye en tanto forma, un rol integrativo del factum, en inescindible unidad y sincronía temporal ${ }^{1435}$. Tal como lo afirma el autor, sin forma jurídica, cualquier factum será un mero espectro imperceptible ${ }^{1436}$.

En suma, otros autores también han desarrollado de manera espléndida el tema en tratamiento. De lo que se trata es de comprender a la teoría formal notarial dentro del alcance que la ley y la doctrina otorgan a la forma considerada:

a) Como elemento esencial del acto o negocio jurídico, y

b) Como argumento elemental de la instrumentación.

Desde los inicios del tratamiento del derecho notarial, la postulación del documento como su objeto elemental intentó destacar en su seno, la importancia probatoria del mencionado instituto, precisamente porque uno de los fines esenciales del documento notarial es el de servir de medio de prueba. De ahí que como componentes materiales, dentro del primer elemento de estructura (corporalidad), se destaquen la forma y la prueba. Pero éste fundamento no es el único que posee el documento formal, ni siquiera es el más relevante. De hecho, algunos autores se refieren a la preconstitución de la prueba como objeto negativo del documento, por cuanto lo único que se logra con ello es someter el título a un proceso judicial y contencioso $^{1437}$.

En el desarrollo actual del derecho documental se advierte que a su lado, otros fines son propuestos como constitutivos y de allí que se advierta que todos en conjunto son los que logran determinar la realidad, la importancia y el sentido del desarrollo notarial documental. A la eficacia probatoria entonces, habrá que agregarle otros fines relevantes, que se relacionan con la

\footnotetext{
${ }^{1434}$ Ibídem, p. 297.

${ }^{1435}$ Ibídem.

${ }^{1436}$ Ibídem, p. 314.

${ }^{1437}$ Carlos N. GATTARI, El objeto de la ciencia del derecho notarial, ob. cit., p. 51.
} 
forma visualizada como creadora de los negocios que proyecta una fuerte eficacia legal, producto de la calificación notarial del derecho ${ }^{1438}$. De aquí que pueda afirmarse que la forma en la conformación del documento, en su constitución y en su conservación posterior tiene un valor especial, que marca la diferencia práctica con la prueba en la concreción de los hechos jurídicos, porque engloba además una comprensión de valores que dan realce a la publicidad cartular que se desprende del documento elaborado. Este tema no ha sido tratado por la doctrina notarialista tanto nacional como extranjera. Con los desarrollos que continúan a estas líneas pretendo comenzar a integrar lo que hasta ahora se viene afirmando, para poder llegar a consolidar por primera vez en el documento los valores esenciales que lo convierten en un elemento de decisión jurídica.

\subsection{El componente personal.}

La teoría documental suele destacar que la forma solemne viene a postular que un aspecto esencial en ella es la intervención del notario. La misma debe realizarse teniendo en cuenta los alcances que impone la función notarial, el régimen de competencias y las cualidades personales de quien inviste la función ( virtudes notariales) y con ellas, el ejercicio práctico de la responsabilidad disciplinaria del escribano en relación a la forma (consideración y tratamiento de la función + el órgano + el agente ${ }^{1439}$ ). A continuación, la exposición de cada uno de estos parámetros.

1438 José CASTÁN TOBEÑAS, Función notarial y elaboración notarial del derecho, ob. cit., págs. 60-61.

${ }^{1439}$ José María R. ORELLE, Actos e instrumentos notariales, ob. cit., p. XV. Para el autor estos tres componentes son los que hacen la estructura plena del acto notarial. 


\section{SEBASTIÁN JUSTO COSOLA}

\subsubsection{La función notarial.}

La definición del I Congreso Internacional del Notariado Latino (1948) que describe al notario como un profesional del derecho en ejercicio de una función pública ${ }^{1440}$ deja fuera de dudas la importancia que para esta disciplina implica el desarrollo de teorías que determinen el marco conceptual de la denominada función notarial. Desde allí hasta el presente, todas las obras de derecho notarial hacen referencia clara y contundente al tema en estudio, y desde ellas, el análisis de las teorías que se han presentado hasta la fecha, denota un tratamiento de temas absolutamente dispares que proyectan alcances totalmente diferentes ${ }^{1441}$.

Por alguna especial razón, las doctrinas que mas efectos colaterales exhiben son las que se refieren a la discusión acerca de si el notario es un verdadero funcionario público o si únicamente es un profesional a cargo de una función de naturaleza pública. En nuestro país, el tema cobra relevancia a partir de ciertas opiniones puntuales y específicas, que según sospecho, han incluso superado ampliamente las verdaderas expectativas que han tenido los autores al escribirlas. El tema comienza por receptar inquietudes a partir de los planteos iniciales de Antonino Soares ${ }^{1442}$ y de Raymundo Salvat ${ }^{1443}$ respectivamente, que son los indicados por los académicos en general como

\footnotetext{
${ }^{1440}$ La definición exacta dice: "El notario latino es el profesional del derecho encargado de una función pública consistente en recibir, interpretar y dar forma legal a la voluntad de las partes, redactando los instrumentos adecuados a ese fin y confiriéndoles autenticidad, conservar los originales de éstos y expedir copias que den fe de su contenido".

1441 Oportunamente he presentado un panorama de los temas implicados, y allí remito: Sebastián Justo COSOLA, Los deberes éticos notariales, ob. cit., págs. 175-303. En este tema en particular, sigo opinando que existen dos temas relevantes para considerar: a) el primero de ellos, es aceptar que es imposible obtener una definición de la función notarial que abarque efectivamente toda la labor que realiza el notario en su notaría (mucho mas en estos tiempos que agrega al estudio el tema de la argumentación notarial del derecho); b) el segundo, es el que ordena una actualización permanente del alcance de la función notarial. Es decir, sobre la idea de fe pública, de la teoría de las formas y de los ritos sacramentales, y teniendo en cuenta el régimen de competencias, siempre será necesario proyectar los alcances de la función de acuerdo a las necesidades que tanto la sociedad como el derecho justifiquen en el tiempo en que sea necesario definir o redefinir.

1442 Antonino E. SOARES, El escribano y la fe pública, ob. cit., p. 107.

${ }^{1443}$ Cfr. Raymundo M. SALVAT, Tratado de Derecho Civil Argentino, (Act. Víctor M. ROMERO DEL PRADO), tº II, TEA, Buenos Aires, 1.958, p. 413.
} 


\section{LOS EFECTOS DE LA PUBLICIDAD EN EL DOCUMENTO NOTARIAL}

aquellos que originaron el inicio del debate hasta hoy ciertamente interminable. Para los referidos autores, el escribano o notario es sin duda alguna, un verdadero funcionario público esencialmente, porque con su letra así las leyes los designan. Otro enfoque interesante que oficia como notable antecedente es el que conforma la opinión de Enrique Díaz de Guijarro ${ }^{1444}$, uno de los primeros autores en afirmar categóricamente que el escribano no es un funcionario público, porque, además de estar sometidos a un régimen propio legal, no tienen vinculación constante con el Estado en relación con la gestión de la cosa pública, no existe una remuneración estatal al escribano ni representación estatal por él mismo, para finalmente aducir la ausencia de responsabilidad del Estado por los actos realizados por el escribano. Desde esas épocas a la fecha, la polémica más interesante del derecho notarial en nuestro país acerca de la tesis del funcionario público, fue la sostenida por Elena Highton y Eduardo Pondé. Mientras que la primera se inclinaba a favor de la tesis del notario-funcionario con argumentos sustentados desde el derecho público, el segundo negaba categóricamente este carácter con argumentos provenientes del derecho privado notarial ${ }^{1445}$. Ambas posturas no obstante, se encuentran sólidamente argumentadas.

La aparente conciliación académica llega a partir del aporte de Antonio Rodríguez Adrados en España, quien comprueba lo inútil de la discusión acerca de la naturaleza de la función, precisamente porque existen en ella dos componentes que se exhiben tan inherentes como inescindibles; el componente público, relacionado con la potestad fedante, y el componente privado, que se conforma en la tarea asesora, informativa, consultora e investigadora propia también de la función notarial ${ }^{1446}$. Esa posición es la que en nuestro país sostiene Cristina Armella ${ }^{1447}$. El tema puede además

${ }^{1444}$ Cfr. Enrique DIAZ DE GUIJARRO, ¿Son funcionarios públicos los escribanos?, JA, t ${ }^{\circ}$ 31, Compania Impresora Argentina, Buenos Aires, 1.931, p. 256-263.

${ }^{1445}$ Cfr. Elena Inés HIGHTON de NOLASCO, Responsabilidad del estado por los escribanos por quien no es propietario. El caso de enajenación, LL 1977-C, p. 954 y ss; El escribano como tercero neutral, $\mathrm{RdN} \mathrm{n}^{\circ} 875$, p. 87 y ss, 1.999 y La función notarial en la comunidad globalizada, ob. cit., p. 95; Eduardo B. PONDÉ, Tríptico Notarial, ob. cit., p. 227 y ss., y en La función notarial no es función pública, RN n 917, La Plata, 1.994, p. 137-150.

${ }^{1446}$ Antonio RODRIGUEZ ADRADOS, El notario: función privada y función pública: su inescindibilidad, ob. cit., p. 213-321.

${ }^{1447}$ Cristina N. ARMELLA, De los instrumentos públicos, Alberto J. BUERES (Dir.) Elena I. HIGHTON (Coord.), Código Civil y normas complementarias. Análisis doctrinario y 


\section{SEBASTIÁN JUSTO COSOLA}

profundizarse si se atiene a la cuestión terminológica. Las primeras confusiones para determinar la naturaleza de la función notarial llegan con Lisandro Segovia ${ }^{1448}$, que intercambiaba los términos escribano y secretario (judicial), lo que causó que algunos autores dieran a la función notarial la naturaleza de jurisdiccional y desde allí, la también interminable polémica acerca de los temas relativos tanto a la jurisdicción contenciosa como a la voluntaria.

El Código Civil y Comercial de La Nación hace mención, de manera indistinta, a las voces: escribano, escribano público, escribano de registro, notario y funcionario. La referencia al funcionario público es muy confusa, y precisamente por la unión de conceptos -escribano o funcionario autorizado- pareciera ser que son términos sinónimos o que el ordenamiento unificado los utiliza, o pretende utilizarlos como términos intercambiables. Es doctrina consolidada el hecho de considerar a la denominación referida a los escribanos y a los notarios como equivalente, muy a pesar que las mismas reconozcan, diferencias etimológicas, históricas y de acceso al ejercicio fedante ${ }^{1449}$. Inclusive puede extenderse este criterio equiparador a la voz tabelión, utilizada en Portugal y por su influencia, también en Brasil. Pero la cuestión de la equiparación con la tesis del funcionario público no es coincidente, y requiere de un análisis más profundo y cuidadoso, sobre todo teniendo en cuenta la incidencia de la responsabilidad que emerge de una actuación que puede considerarse o pública o privado de acuerdo al momento de ejecución del acto que acarrea el daño.

Opino que con la última reforma que instaura el código unificado, se ha esfumado una clara oportunidad de diferenciar a los funcionarios, a los oficiales y/o profesionales en ejercicio de una función pública como lo viene haciendo la doctrina y jurisprudencia mayoritaria de al menos, los

\footnotetext{
jurisprudencial, $\mathrm{t}^{\circ} 2 \mathrm{C}$, ob. cit., p. 67.

${ }^{1448}$ Cfr. Lisandro SEGOVIA, El Código Civil de la República Argentina (Con su explicación y crítica bajo la forma de notas), $\mathrm{T}^{\circ}$ Primero, Imprenta de Pablo E. Coni Editor, Buenos Aires, 1.881, p. 263 y ss; v. además: Lisandro SEGOVIA, El Código Civil Argentino Anotado, Félix Lajouane Editor, Buenos Aires, 1.984, p. 156.

${ }^{1449}$ Carlos E. GONZÁLEZ, Teoría general del instrumento público..., ob. cit., p. 37; Cristina N.ARMELLA, Instrumentos públicos, Eduardo G. CLUSELLAS (Coord.) Código Civil y Comercial de La Nación. Comentado..., ob. cit., p. 758.
} 
últimos cuarenta años ${ }^{1450}$. Lejos de polemizar, debe advertirse que en el cuerpo legal unificado hace referencia a los escribanos o notarios, en el mismo sentido que lo hace en torno al funcionario. Asimismo, la expresión "escribano publico o de otro funcionario autorizado... ${ }^{1451}$ " no es lo suficientemente clara como para advertir la verdadera naturaleza de ambas funciones, que según la opinión mayoritaria, en mucho no se asimilan en sus notas esenciales.

Algunos autores nacionales han quizás aportado trascendentes obras al desarrollo del derecho patrio, pero quizás no cuidando las expresiones, y por esa razón la confusión de los términos ha sido aun más notoria ${ }^{1452}$.Como ya he advertido en alguna oportunidad, debe pensarse que si se concluye con la doctrina mayoritaria en que el escribano o notario no es funcionario público, una interpretación exegética o literal del artículo referido a la competencia personal del funcionario ${ }^{1453}$-que tacha de nulo el acto donde el funcionario (no dice escribano) otorgue actos dentro del cuarto grado de parentesco- deja fuera de esta importante regla ética al escribano, para lo cual su actuación en estos términos, no comprometería a la imparcialidad.

En torno al tema de los conceptos ya se había expedido la doctrina civilista y notarialista argentina dando acertados pasos acerca de la conformación estructural de la naturaleza jurídica notarial ${ }^{1454}$, como así mismo también la jurisprudencia nacional ${ }^{1455}$. De algunos estudios se desprenden importantísimos análisis de método y de gramática, que inclusive analizaron

1450 "El escribano es un profesional del derecho pero a cargo de una función pública" CNCiv., Sala C, 05/11/1976, La Ley, 1977-B, 174.

${ }^{1451}$ Refiriéndose a aquellos facultados para autorizar escrituras, como los capellanes, oficiales o médicos militares en materia de redacción de testamentos, capitanes de buques, comandantes de aeronaves o cosmonautas de acuerdo a las leyes y tratados positivos y vigentes que dan esas atribuciones.

${ }^{1452}$ Cfr. Manuel OSSORIO Y FLORIT, Código Civil y Leyes Complementarias. Anotados, Comentados y Actualizados, $\mathrm{t}^{\circ}$ II, Ediciones Librería Jurídica, La Plata, 1.972, p. 96.

${ }^{1453}$ Art. 291 CCCN.

${ }^{1454}$ Cfr. María Emilia LLOVERAS DE RESK, La responsabilidad civil del escribano público, El Derecho, Buenos Aires, $\mathrm{n}^{\circ}$ 5825, 23/09/1984; Alberto J. BUERES, Responsabilidad civil del escribano, Hammurabi, Buenos Aires, 1.984; Eduardo Bautista PONDÉ, Tríptico Notarial, ob. cit., y Francisco MARTÍNEZ SEGOVIA, Función notarial, ob. cit.

1455 "Si bien los escribanos cumplen como fedatarios una función pública, no se presentan las notas características de la relación de empleo público” CS 12/11/2002, JA 2003-11-464. 


\section{SEBASTIÁN JUSTO COSOLA}

de manera pormenorizada las fuentes originarias del Código Civil utilizadas por Vélez Sarsfield, de donde se desprende que la utilización de los términos oficial público, escribano público, funcionario público u oficial de registro en el Código Civil pretende significar realmente una identidad funcional, de deberes y acciones, que emanan de la fe pública que se encuentra presente en todos estos protagonistas que labran o redactan instrumentos públicos. Todas esas doctrinas niegan, a mi modo de ver con acierto, que la esencia de las categorías funcionario público- escribano público sea la misma ${ }^{1456}$.

Desde mis ideas, resulta llamativa la abstención de la comisión elaboradora del proyecto de codificación unificada, de definir adecuada y acertadamente este tema de una buena vez por todas, inclusive teniendo en cuenta que en general, los fallos de la Corte Suprema de Justicia de la Nación vienen transmitiendo la idea de que la función notarial se justifica en el mundo del derecho por su especial naturaleza, y que si bien los escribanos cumplen una función pública como fedatarios, no se presentan en ese quehacer las notas características de la relación de empleo público ${ }^{1457}$. Sin embargo, un relativamente reciente estudio permite aceptar que en realidad, si bien esa es la doctrina que emana del máximo tribunal, los fallos en realidad abrieron otros planteos que tienden a posicionar a la función tanto como una función pública, tanto como un servicio público ${ }^{1458}$. En efecto, hay fallos que si bien aplican la regla de la naturaleza especial de la función, en su texto advierten que el notario tiene la función que tiene por la calidad de funcionario de oficio público ${ }^{1459}$.

En resumen, la postura mayoritaria en los tiempos actuales sostiene que el notario es un profesional del derecho a cargo de una función pública. Por mi

\footnotetext{
${ }^{1456}$ Es Alberto BUERES quien advierte en un estudio recomendable, que si se lee con precaución el texto de la nota al artículo 1.112 del Código Civil de Vélez, referido a los supuestos de responsabilidad extracontractual o aquiliana del funcionario público, que dice: "De los jueces y oficiales del ministerio público, de los párrocos en los actos del estado, de los conservadores de los registros de hipotecas, de los escribanos, procuradores y de todos los empleados de la administración del Estado" se nota claramente que por la conjunción copulativa " $y$ ", el Código acepta que el escribano es un funcionario público, pero en tanto integre el cuadro de la administración pública, o sea, es funcionario público solo el escribano de gobierno, ya sea éste del ámbito nacional o estadual. V. Alberto J. BUERES, Responsabilidad civil del escribano, ob. cit., p. 29 y ss.

${ }^{1457}$ CS 12/11/2002, Franco c/ Pcia. De Bs. As, cit.

${ }^{1458}$ Adriana Nélida ABELLA, Derecho notarial, ob. cit., p. 34.

${ }^{1459}$ Ibídem. Cita la autora a Fallos: 321: 2086.
} 
parte, pienso que es preciso ahondar en otros aspectos de la función notarial, que son relevantes para los tiempos en que vivimos, entre ellos, la capacidad argumentativa que proyecta para crear el documento, que permite reflejar en el tanto la autenticidad extrínseca como la intrínseca, que juntas, consolidan la fuerza de la publicidad cartular. Para ello, sigue siendo oportuna la consideración de la función notarial como aquella que realiza el notario al atender los acontecimientos (hechos), equilibrando los deseos, y narrando los hechos, de acuerdo con el derecho ${ }^{1460}$.

\subsubsection{El régimen de las competencias notariales.}

La referencia a las exigencias de los requisitos de validez del instrumento público $^{1461}$ tiene que ver con el análisis de las atribuciones que según la ley le están encomendadas al oficial público y en razón de ello, no puede dejar de cumplirlas. El caso es propicio para analizar el tema de las competencias. Al estudio del derecho, la voz competencia le resulta clara en ocasiones y muy confusa en otras situaciones. El recordado Lino Palacio advertía con verdadero acierto que la competencia es la medida de la jurisdicción ${ }^{1462}$, y con ello, aun más confuso se tornaba el estudio de estas instituciones. Lo que se trata de determinar es que las atribuciones, propias de la idiosincrasia de cada profesión y de las competencias propias provenientes de la ley, son aquellas que describen las actividades generales repartidas a cada una de ellas. El régimen de competencias en general y notarial en especial, está determinado entonces por la ratione materiae, que ordena al notario obrar dentro de los límites de sus atribuciones ${ }^{1463}$. Pero también se destaca en el

\footnotetext{
${ }^{1460}$ Sebastián J. COSOLA, Los deberes éticos..., ob. cit., p. 302.

${ }^{1461}$ Art. 290 CCCN.

${ }^{1462}$ Cfr. Lino Enrique PALACIO, Manual de derecho procesal civil, La Ley, Buenos Aires, 2.014, capítulo VII-La Competencia (VTRP). El maestro define a la competencia como "la capacidad o aptitud que la ley reconoce a un juez o tribunal para ejercer sus funciones con respecto a una determinada categoría de asuntos o durante una determinada etapa del proceso".

${ }^{1463}$ Cristina ARMELLA trae un ejemplo de Jorge Joaquín LLAMBÍAS que es absolutamente clarificador: "Un escribano titular de un registro notarial no puede extender un acta de
} 


\section{SEBASTIÁN JUSTO COSOLA}

análisis la denominada competencia territorial, que significa que las atribuciones encomendadas al notario se deben ejercer en el ámbito o en el espacio asignado por ley ${ }^{1464}$. Cumplida la competencia territorial, el principio es que los instrumentos públicos extendidos de acuerdo con lo que establece el orden jurídico vigente gozan de entera fe y producen idénticos efectos en todo el territorio de la República, cualquiera sea la jurisdicción donde se hayan otorgado ${ }^{1465}$, lo que viene además a ratificar el cumplimiento de una manda de naturaleza constitucional (lo que se ordena es que se atribuyan los mismos efectos a los instrumentos que hubieran de producir en la provincia de donde emanan ${ }^{1466}$ ). La manera de dotar de mayor seguridad a estas circulaciones es a través del sistema de legalizaciones ${ }^{1467}$, mediante las cuales se consolida el tráfico instrumental o escriturario en todo el territorio nacional.

Además de lo expuesto, el ejercicio de la función fedante ocurre en un determinado periodo de duración del ejercicio de las facultades propias del escribano, notario, y de los funcionarios públicos en general, conocida como competencia temporal o en razón del tiempo. En este tema, al notariado nacional no le resulta ajeno lo resuelto por la Corte Suprema de Justicia de la Nación en el caso Franco ${ }^{1468}$, tan trascendente como relevante ${ }^{1469}$. En

matrimonio, asi como un oficial del Registro Civil no puede autorizar un testamento por acto público”. v. Cristina N. ARMELLA, De los instrumentos públicos..., ob. cit., p. 15.

1464 "No existe ninguna disposición que impida otorgar la escritura pública traslativa del dominio en distinta jurisdicción de la del inmueble. Lo que la ley prohíbe es que se suscriba la escritura fuera del territorio que se ha asignado al escribano para el ejercicio de sus funciones o sea, el desplazamiento de este a una jurisdicción ajena invadiendo la de otros" CNCiv, Sala A, 22/11/1978, La Ley, 1979-A, 342.

1465 Art. 293 del CCCN: "Competencia. Los instrumentos públicos extendidos de acuerdo con lo que establece éste Código gozan de entera fe y producen idénticos efectos en todo el territorio de la República, cualquiera sea la jurisdicción donde se hayan otorgado".

${ }^{1466}$ Helio Juan ZARINI, Constitución Argentina ..., ob. cit., p. 44.

1467 "La falta de legalización en la provincia de Córdoba del poder conferido en otra provincia del país, no obsta a su validez y efícacia, pues el artículo 980 del Código Civil -incorporado por la ley 24441- dispone que los instrumentos públicos extendidos de acuerdo a lo que establece el mismo código de fondo, gozan de entera fe y producen idénticos efectos en todo el territorio de la República Argentina, cualquiera sea la jurisdicción en que se hubiesen otorgado" CCiv. Com., Trab. y Flia. Villa Dolores, 18/08/2009, LLC 2010 (Febrero) 115.

${ }_{1468}$ CSJN 12/11/2002- Franco, Blanca T. v. Provincia de Buenos Aires, JA 2003-II-464; Fallos 325:2968.

${ }^{1469}$ Hechos: Teodora Franco era escribana en la localidad de Vicente López en la Provincia de Buenos Aires. Ante el cese funcional por cumplimiento del tope de edad establecido para el 
aquella memorable oportunidad, la Corte Nacional otorgó la razón a la escribana recurrente, priorizando por sobre todas las cosas, el argumento que confirma que el solo hecho de alcanzar la edad de setenta y cinco años no revela la ausencia de condiciones para cumplir la función encomendada, y privar de la actividad a una persona que se encuentra digna y positivamente ejerciendo una función, es contrario a las declaraciones, derechos y garantías que emanan de la Constitución Nacional. En esta línea de pensamiento, debe también tenerse en cuenta que similares fueron los fundamentos vertidos oportunamente, en el caso Fayt ${ }^{1470}$. Similar situación ocurrió tiempo después en el Perú, aunque no llegó a la justicia por invocación de un interesado lesionado, sino que se elevó al mismo momento de la sanción y publicación del nuevo decreto legislativo de ejercicio del notariado ${ }^{1471}$.

No obstante lo referido, debe dejarse planteado en este desarrollo que en los tiempos recientes, la Corte Suprema de Justicia de la Nación ha cambiado por mayoría, el criterio sustentado en el referido caso Fayt, lo que hace suponer que lo resuelto en el caso Franco también podría correr la misma suerte. El fallo conocido públicamente como Schiffrin, alterna el criterio ideológico sostenido desde los mencionados antecedentes hasta los días en que vivimos, sustentando nueva doctrina que confirma que los magistrados mayores de setenta y cinco años no pueden por principio, y salvo casos excepcionalísimos, continuar ejerciendo esa función ${ }^{1472}$.

ejercicio de la función notarial (75 años) la notaria intenta el recurso de queja ante la Corte Suprema de Justicia de la Nación luego de resultar perdidosa en las instancias anteriores, inclusive en la Suprema Corte Bonaerense. Su argumentación se dirige a obtener un pronunciamiento especial: saber si es o no constitucional una norma que obliga al cese funcional de un escribano de registro que alcanza los 75 años de edad, suponiendo que no existen ya las suficientes facultades físicas para poder ejercer una profesión en el modo de apto.

${ }^{1470}$ Cfr. Antonio María HERNÁNDEZ (h), El caso Fayt y sus implicancias constitucionales, ANDCSC-Advocatus, Córdoba, 2.001. Este aporte resulta ser interesante, pues expone una crítica al fallo desde la seguridad jurídica general.

1471 "Colegios de Notarios de Puno, San Martín y Lima contra el decreto legislativo $n^{o}$. 1049" Causa 00009-2009-PI/TC; 00015-2009-PI/TC; 00029-2009-PI/TC (acumulados) del 6/09/2010.

${ }^{1472}$ CSJN 159/2012 (48-S), "Schiffrin, Leopoldo Héctor c/ Poder Ejecutivo Nacional s/ acción meramente declarativa", 28/03/2017. 


\section{SEBASTIÁN JUSTO COSOLA}

Finalmente, la alusión a la competencia en razón de las personas ${ }^{1473}$, que presente desde mi visión, una doble lectura: la jurídica, en referencia a que el interés personal debe considerarse como directo, objetivo y económico, con virtualidad suficiente para afectar la imparcialidad del oficial autorizante; y la ética o deontológica, protectora de la imparcialidad y de la independencia, tantas veces aludidas por la doctrina notarial en general, que opto por desarrollar dentro de las virtudes del autor.

\subsubsection{Las virtudes del autor.}

Las virtudes notariales se explican desde la teoría de los deberes éticos notariales, y más específicamente, de lo que pueden ser considerados los deberes éticos notariales aplicados ${ }^{1474}$. El deber de verdad notarial se cumple desde el mismo momento en que, a partir del acto de investidura notarial, y hasta el cese de ejercicio por las razones de competencia temporal previstas en las legislaciones respectivas, el notario asume la obligación de realización instrumental del derecho de un modo coetáneo con todo aquello que es por él mismo tutelado o captado a través de su presencia. Esa es la explicación por la cual dentro de la estructura, las cualidades del autor del documento son aquellas que lo justifican y avalan desde la fe pública, que no se describe como una determinada atribución de la persona sino como una suma de garantías objetivas que el ordenamiento exige. Sin embargo, desde el análisis de los componentes, esta situación requiere además de un análisis interno de la persona que investida legalmente de función fedante, va a ser quien en nombre del poder público llegue a autenticar, autorizar o legitimar cualquier hecho o acto que le sea encomendado. De ahí que de las virtudes notariales a destacar dentro del componente personal, sean las que el notario desarrolla diariamente para cumplir con los deberes éticos de imparcialidad, independencia, información, asesoramiento, concejo y concreción notarial

${ }^{1473}$ Art. 291 del CCCN: "Prohibiciones. Es de ningún valor el instrumento autorizado por un funcionario público en asunto en que él, su cónyuge, su conviviente, o un pariente suyo dentro del cuarto grado de afinidad, sean personalmente interesados".

${ }^{1474}$ Sebastián J. COSOLA, Fundamentos del derecho notarial, ob. cit., p. 245 y ss. 
del derecho sobre el documento del deber integrado de legalidad, el que, una vez asumida la voluntad de los comparecientes, proyecta en toda su esplendor las reglas, las normas y los principios jurídicos. A este ejercicio virtuoso se le agregan otras acciones, también relacionadas con el concepto, como aquellas que el notario realiza para capacitarse o mejorar su actuación a través del estudio constante y permanente, o las que realizan los notarios con más experiencia cuando recurren al auxilio del joven y novel notario; en definitiva, toda una serie de virtudes que moldean la personalidad hacia un mejor cumplimiento del deber de verdad, siempre justificado desde las previsiones objetivas de la fe pública.

En general, las leyes notariales argentinas exigen y protegen objetivamente este componente personal desde el cuidado de la virtud. De esta manera, la exigencia dirigida hacia el postulante a notario de un acta de comprobación de buena conducta como requisito esencial para acceder al ejercicio fedante se consolida como uno de los baluartes legales indispensables que permiten claramente advertir la singularidad propia del ejercicio de la función notarial $^{1475}$.

\subsection{El componente relacional.}

Una vez analizada la actividad notarial tanto desde el análisis del documento en la esfera de los hechos como desde la proyección de las características del autor, corresponde hacer referencia a la proyección que tiene el derecho dentro del documento. Debe antes tenerse en cuenta que la eficacia del documento notarial en la esfera del derecho -relaciones jurídicas en el tratamiento académico- nunca es independiente de los hechos narrados en el mismo $^{1476}$, por ello no hay derecho sin hecho ${ }^{1477}$.

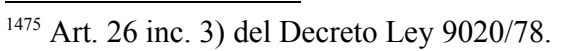

${ }^{1476}$ Rafael NUÑEZ LAGOS, Hechos y derechos ..., ob. cit., p. 76.

${ }^{1477}$ Ibídem. 


\section{SEBASTIÁN JUSTO COSOLA}

La referencia al análisis del derecho dentro el documento implica dirigir la atención más allá de las cuestiones formales. Es preciso alcanzan la comprensión de las relaciones jurídicas que nacen con el documento por consentimiento de las partes, que son quienes efectivamente dan nacimiento y regulación íntegra a su contenido dentro de los límites legales ${ }^{1478}$. De aquí que en este tratamiento se deduzca que la actividad documental del notario, en su posición de jurista, desarrolla su máximo alcance en el ámbito de la autonomía de la voluntad, por cuanto con ella se cumple la obligación legal impuesta naturalmente de redactar los documentos públicos notariales: "Esto significa configurar las declaraciones de voluntad de las partes, dentro de la ley, produciendo el texto del documento, la ley del contrato ${ }^{1479}$ ". La instauración definitiva del principio de autonomía de la voluntad es relativamente reciente, en donde tanto el derecho canónico en primer término como el derecho natural luego, ejercieron toda la influencia sobre el derecho de carácter privado ${ }^{1480}$. Recordemos con Núñez Lagos que en momentos anteriores a los citados, los únicos elementos relevantes en la contratación eran la datio y la forma ${ }^{1481}$. Esta situación impacta también en la historia de la creación notarial del documento, por cuanto no se intentaba por entonces recoger la voluntad y adecuarla a la ley, sino solo de formar instrumentos que reunieran para su validez, los requisitos legales y formales exigidos por el ordenamiento positivo. En torno a lo por mí afirmado, debe tenerse presente que por aquellos entonces, autores como Bartolomé Fiorini argumentaban -desde la concepción imperante del derecho de la época y no sin razón-, que es un grave error identificar al derecho civil con el individuo, ya que el mencionado cuerpo legal no es el estatuto de la voluntad de los mismos sino tan sólo, un cuerpo que contiene un conjunto de normas y principios que sirven para que todos los individuos se coloquen bajo su amparo y cumplan las previsiones normativas sin ninguna mutilación ${ }^{1482}$.

\footnotetext{
${ }^{1478}$ Ibídem, p. 77.

${ }^{1479}$ Ibídem, p. 78.

${ }^{1480}$ En la célebre expresión de Gustav Radbruch: "Para el derecho natural era el contrato el fundamento de todo el derecho, la solución del problema básico de la filosofía jurídica individualista”. Cfr. Gustav RADBRUCH, Filosofia del derecho, Reus, Madrid, 2.008, p. 254.

${ }^{1481}$ Rafael NUÑEZ LAGOS, Hechos y derechos..., ob. cit., p. 169-170.
} 
LOS EFECTOS DE LA PUBLICIDAD EN EL DOCUMENTO NOTARIAL

Bajo esas premisas debe entonces alcanzarse el entendimiento de la proyección histórica notarial del derecho en el documento, sobre una realidad definida y consolidada académica y jurisprudencialmente, pero totalmente ajena a la que impera en los días en lo que vivimos ${ }^{1483}$. En definitiva, se trata de comprender que en el seno del documento notarial auténtico deben coincidir tanto los hechos concretos que sucedan en presencia del notario como las relaciones jurídicas que de la voluntad de las partes puedan llegar a emerger ${ }^{1484}$. Esas relaciones jurídicas lógicamente, comprenden a la tarea notarial tal como la he venido exponiendo hasta aquí: de la ley al derecho, cubriendo toda la teoría de argumentación jurídica suficiente para concretar en el cuerpo del documento, lo verídico, lo cierto, lo justo y lo seguro.

\subsubsection{Situación inicial, (hecho-acto) y situación final (o nueva} situación).

El esquema situación-(hecho-acto)- situación es para Mario Zinny el significado para el derecho de lo que significa la anatomía en el estudio de la medicina. La base de donde surgen todos los estudios posteriores jurídicos es esa secuencia, que no es otra cosa que el comportamiento. El derecho necesita entonces de una situación inicial (estática) que encuentra a dos sujetos frente a frente, inmóviles; un hecho o acto (dinámico) que es el que pone a las personas en movimiento (la celebración y consumación de un

${ }^{1482}$ Cfr. Bartolomé A. FIORINI, Teoría jurídica del acto administrativo, Abeledo Perrot, Buenos Aires, 1.969, págs 43-44.

${ }^{1483}$ Las palabras del Dr. Jorge H. Alterini oportunamente vertidas en la presente investigación, relativas al objeto de tutela de los Códigos Civiles argentinos, no hacen más que confirmar que desde su visión el Código de Vélez era el cuerpo legal de los ricos y de los pobres, mientras que el malogrado proyecto de unificación del año 1998 sería el promisorio código de los consumidores. Yo no albergo ninguna duda en decir además que el Código Civil y Comercial de La Nación vigente es el código de la voluntad. Entre otras cuestiones y como también he referido en el cuerpo de la presente investigación, nunca jamás el orden público se vio tan relativizado como en el presente.

${ }^{1484}$ Rafael NUÑEZ LAGOS, Hechos y derechos..., ob. cit., p. 80. 


\section{SEBASTIÁN JUSTO COSOLA}

acuerdo o de un contrato); y finalmente, una situación final (estática) que posiciona a los dos sujetos originariamente enfrentados pero con los roles invertidos. Si la situación final comienza nuevamente la secuencia, se transforma en nueva situación, que nuevamente da comienzo al esquema medular de la base de la teoría del derecho ${ }^{1485}$. La situación inicial se debe comprender con los tres presupuestos del acto -capacidad y legitimación de los sujetos, e idoneidad del objeto-; en el desarrollo del hecho-acto se deben advertir los tres elementos constitutivos -forma, contenido y causa- y además, el componente subjetivo (volitivo) relacionado con la conciencia del contenido y la intención de la causa, para que en el análisis de la situación final de advierten los efectos, esto es, el análisis de la validez y de las eficacias ${ }^{1486}$. Algunos autores niegan que este esquema sea apto para consolidar la base del derecho, y por ello responden desde lo que consideran es la estructura de la teoría general del derecho, con sólido carácter normativo que es el brinda sustento al derecho para que esa secuencia de comportamiento descripto encuentre verdadero interés ${ }^{1487}$. El esquema propuesto no obstante, es absolutamente apto para alcanzar a visualizar, desde la autenticidad intrinseca, los valores que emergen del documento notarial $^{1488}$, desde una visión eminentemente iusnaturalista ${ }^{1489}$. Solamente desde este esquema es posible analizar la teoría general de las situaciones jurídicas y su proyección especial en el documento notarial.

\footnotetext{
${ }^{1485}$ Mario A. ZINNY, La base de la teoría general de derecho, ob. cit., p. 77; La enseñanza del derecho y los estudios comparados, ob. cit., p. 85.

${ }^{1486}$ Ibídem.

${ }^{1487}$ Cfr. Ariel ÁlVAREZ GARDIOL, La estructura de una teoría general del derecho, Fundación para el Desarrollo de las Ciencias Jurídicas, Rosario, 2.012, p. 144.

${ }^{1488}$ En esta tesis, yo prefiero consolidar la enseñanza expuesta por ZINNY, porque, más allá de las discrepancias, una teoría positivista que considere una determinada estructura normativa no dejará de observar en el documento las cuestiones descriptas en la autenticidad extrínseca, mientras que lo que pretende sea relevante en la presente investigación es en análisis de la publicidad cartular desde la autenticidad intrínseca, que proyecta y realza los valores determinantes de su rectoría frente a las demás publicidades jerarquizadas. Esta vertiente absolutamente novedosa en el análisis del documento únicamente puede alcanzarse a partir de la concepción iusnaturalista.

${ }^{1489}$ Para analizar las contestaciones de Zinny a la "respuesta" de Álvarez Gardiol, v. Mario A. ZINNY, Comentarios a la base de la teoría general del derecho, Ad-Hoc, Buenos Aires, $2.012,46 \mathrm{p}$.
} 
LOS EFECTOS DE LA PUBLICIDAD EN EL DOCUMENTO NOTARIAL

\subsubsection{Las situaciones y relaciones jurídicas.}

Una situación jurídica, enseñaba Carnelutti, comprende en su seno a ciertas cosas; cosas que, desde la ciencia del derecho solemos comúnmente denominar sujetos y objeto, y más allá de ello: lo que hay, lo que existe entre ellos $^{1490}$. Sobre esto, el maestro italiano afirmaba que es ésta una de las tareas más delicadas de la ciencia del derecho, y más aun, de la ciencia de la realidad $d^{1491}$, por cuanto se parte de la idea de intentar aprender que "la separación o intervalo entre dos cosas, en cuanto se piensa como una unión, se llama relación ${ }^{1492}$ ". Es así que al considerar la relación jurídica no hacemos otra cosa que referir a relaciones o uniones establecidas por el derecho ${ }^{1493}$, y por ello la concepción amplia de relación jurídica dice que ésta es la que está constituida por el derecho entre dos sujetos respecto a un objeto $^{1494}$. Oportunamente, también Giorgio del Vecchio ${ }^{1495}$ había ubicado las relaciones jurídicas en el ámbito de la teoría del derecho, a las que definía como vínculos entre personas, en mérito de los cuales una de ellas puede pretender algo a lo que la otra está o se encuentra obligada; por ello es que todas las relaciones jurídicas tiene por los menos dos sujetos, uno activo y uno pasivo ${ }^{1496}$. Esto se condice con lo que ya advertía Carnelutti acerca de las relaciones jurídicas: que existe una noción amplia y sencilla, refiriéndose a la constituida entre dos sujetos respecto de un objeto, y una mucho más específica y dificultosa, que consiste en analizar la relación que el derecho constituye entre partes en orden a un bien, en donde para que ocurra el efectivo goce de ese bien, se impone a una de ellas un deber y se le confiere a la otra un $_{\text {poder }}{ }^{1497}$.

${ }^{1490}$ Cfr. Francisco CARNELUTTI, Teoría General del Derecho, Revista de Derecho Privado, Madrid, 1.955, p. 183 (Reimp. Librería El Foro)

${ }^{1491}$ Ibídem.

${ }^{1492}$ Ibídem.

${ }^{1493}$ Ibídem, p. 184.

${ }^{1494}$ Ibídem.

${ }^{1495}$ Cfr. Giorgio DEL VECCHIO, Filosofia del derecho, Bosch, Barcelona, 1.991, p. 401.

${ }^{1496}$ Ibídem.

${ }^{1497}$ Francisco CARNELUTTI, Teoría General del Derecho..., ob. cit., p. 184. 


\section{SEBASTIÁN JUSTO COSOLA}

Sobre esto, pienso que le asiste razón suficiente a Vallet cuando considera que Carnelutti presenta un enfoque metodológicamente realista de la relación, la institución y los hechos ${ }^{1498}$. A modo de comprobación, el maestro español recuerda el clásico ejemplo de la placa fotográfica y de la cinta cinematográfica ${ }^{1499}$, que si bien son elementos de captación de realidad, no alcanzan sobradamente para obtener cierta certeza del fenómeno del derecho ${ }^{1500}$, y en lo que a nosotros nos interesa, de la propia relación jurídica. El elemento específico del derecho no está fuera, sino dentro de la mente de las personas, por ello el resultado de la manifestación estática de la realidad jurídica para Carnelutti se descompone en tres elementos de diversa naturaleza: física, económica ${ }^{1501}$ y psicológica ${ }^{1502}$. La juridicidad resulta de la combinación de estos tres elementos, y mientras el elemento físico se encuentra constituido por entes, los dos restantes se cobijan constituidos por relaciones $^{1503}$. Esta juridicidad, complementa Vallet, ubicada en la perspectiva del sentido de lo justo, como cualquier sentido para ejercer un

${ }^{1498}$ Juan Berchmans VALLET DE GOYTISOLO, Manuales de metodología jurídica, $\mathrm{t}^{\circ} \mathrm{IV}$, ob.cit., p. 48. Vallet hace notar que en la teoría general del derecho, al momento de efectuar la presentación de la relación entre pensamiento y realidad con la finalidad que ambos términos se correspondan en la búsqueda de la certidumbre como dato de la experiencia, el maestro italiano intentaba asentar el reflejo interior de la realidad.

${ }^{1499}$ Ibídem. Dice VALLET: "El maestro italiano observa que a través de los sentidos, la realidad entra y el pensamiento sale, produciéndose la percepción que capta la realidad y produce la sensación que se asemeja grosso modo a la impresión de una placa fotográfica, y por eso se llama también impresión. Aunque advierte: El hombre escruta la realidad con una mirada, como hace en la noche, sobre el paisaje, un reflector; y por eso cada percepción solo capta la forma de algún aspecto de la realidad"

${ }^{1500}$ Ibídem. Continúa Vallet: "Ciertamente, Carnelutti se da cuenta de que la fotografía de una relación de derecho, por ejemplo, de una compraventa o de un robo, fijará la imagen de dos personas, el vendedor y el comprador, y de una cosa (la cosa vendida o comprada); con esta imagen podríamos también poner de manifiesto la relación simple (de complementariedad) que existe entre cada una de las personas y la cosa, y aun, si se quiere, la relación compleja (conflicto) que, en razón de los intereses respectivos, existe entre las personas. Pero la posibilidad de manifestarse no pasa de aqui y queda fuera lo que constituye el elemento especifico de la situación jurídica. El hecho es que la fotografia puede ser utilizada solo como comparación, y para hallar una manifestación fotográfica de la realidad jurídica deberíamos buscar otra placa, sensible a los fenómenos psíquicos, ya que el elemento especifico del derecho no está fuera, sino dentro de la mente del vendedor o el comprador, del ladrón o del despojado".

${ }^{1501}$ Ibídem. El elemento económico representa un conflicto de intereses entre las personas respecto de la cosa.

${ }^{1502}$ Ibídem. El elemento psicológico es un poder o un deber, respecto de la persona ante la cosa. 
arte cualquiera, requiere de la máxima educación y afinación posible ${ }^{1504}$. Así, es preciso que se observen las relaciones cuando se trata de comprobar su ajustamiento o desajuste de conformidad a la naturaleza de la cosa ${ }^{1505}$. En palabras de Rudolf Stammler adecuadas para lo antedicho: "Habrá que elegir (el notario antes del conflicto) la norma objetivamente justa, aquella que mejor ajuste a las orientaciones de la idea de la comunidad pura ${ }^{1506 " .}$ En este punto, es preciso recordar que la doctrina civilista en nuestro país ${ }^{1507}$ ha captado adecuadamente las mencionadas consideraciones, efectuando un minucioso tratamiento de los elementos esenciales de la relación jurídica, en donde se ven reflejados los sujeto, el objeto y la causa como hecho del cual se deriva la mencionada relación ${ }^{1508}$. En sintonía se transmite que la esfera subjetiva del derecho excede la noción de derechos subjetivos, relacionado con las prerrogativas o facultades que tiene el individuo, para también abarcar el deber jurídico ${ }^{1509}$. La relación jurídica, definida inicialmente como relación de la vida con significación para el derecho que la considera y tutela, contiene tanto al derecho subjetivo como al deber jurídico, lo que no es otra cosa que considerar al igual que Carnelutti, los poderes y deberes ${ }^{1510}$ en interacción antes referidos, en la función específica de la relación

\footnotetext{
${ }^{1503}$ Ibídem, p. 50. Sobre esto, aclara Vallet a modo de advertencia, que los conflictos de los hombres no son solo económicos.

${ }^{1504}$ Ibídem.

${ }^{1505}$ Ibídem. Mucho más adelante y en sintonía con lo aquí sostenido, el genial autor español demostrará que el cavere notarial en la determinación negocial del derecho representa esencialmente a dos funciones propias del notariado latino: unas previas de juicio de legalidad o juridicidad (consejo y asesoramiento, entendidos en el sentido de lo justo) y las propias configuradoras del negocio jurídico y de su traducción documental. Tarea realmente difícil, por cuanto el notario debe atender a una norma objetivamente justa, que se adecúe a la voluntad de las partes y que sirva para alejarlas, a posteriori, de cualquier tipo de interpretación contraria a sus intereses que sirva para iniciar cualquier tipo de conflicto. v. Juan Berchmans VALLET DE GOYTISOLO, Manuales de metodología jurídica, $\mathrm{t}^{\circ}$ III, ob. cit., p. 235.

${ }^{1506}$ Cfr. Rudolf STAMMLER, Tratado de filosofia del derecho, Reus, Madrid, 2.008, p. 500.

1507 Jorge Joaquín LLAMBÍAS, Tratado de Derecho Civil-Parte General, to I, ob. cit., p. 239.

${ }^{1508}$ Ibídem, p. 240. Afirma Llambias: "Toda relación jurídica, todo fenómeno jurídico, lo mismo que cualquier fenómeno del mundo de la naturaleza, está sujeto al principio de razón suficiente, que condice a la investigación de la causa eficiente de la relación o hecho que la produce".

${ }^{1509}$ Julio César RIVERA, Instituciones de derecho civil-Parte general, to I, ob. cit., p. 309.

${ }^{1510}$ Ibídem, p. 314.
} 


\section{SEBASTIÁN JUSTO COSOLA}

jurídica. Para algunos autores, la noción de situación jurídica se corresponde con un determinado modo regulado por el derecho -o una determinada manera- de estar las personas en la vida social ${ }^{1511}$. Su utilización cobra importancia como género o idea marco ${ }^{1512}$. Mientras que la relación jurídica, que en sentido amplio es un vinculo entre dos personas tutelado por el derecho ${ }^{1513}$, requiere para ser marco de deberes y derechos jurídicos de las personas, un concepto elemental mucho más preciso: "Es un vinculo que une a dos o más personas respecto de determinados bienes o intereses, estable y orgánicamente regulada por el derecho, como cauce para la realización de una función social merecedora de tutela jurídica ${ }^{1514}$ ".

\subsubsection{La relación jurídica notarial.}

El tema de la existencia o no existencia de una relación jurídica notarial no ha sido pacífico en el desarrollo académico del derecho notarial. José González Palomino, por ejemplo, renegaba de esta denominación, a la que consideraba dentro de las denominadas teorías procesalistas del derecho notarial, por cuanto son las que intentan encajar a la función notarial dentro del esquema del derecho procesal forzando justamente, los conceptos de jurisdicción y de relación jurídica ${ }^{1515}$. Sin embargo, la doctrina mayoritaria

\footnotetext{
${ }^{1511}$ Ibídem, p. 310.

${ }^{1512}$ Ibídem.

${ }^{1513}$ Ibídem, p. 311.

${ }^{1514}$ Ibídem, p. 312. También para este autor la relación jurídica reconoce como elementos a los sujetos, al objeto y a la causa, advirtiendo que algunos otros autores incluyen en la posición de elemento también a la protección de la relación jurídica, relacionada con las acciones que concede el Estado para que las mismas puedan hacerse valer en justicia.

1515 Cfr. José GONZÁLEZ PALOMINO, Salutación a Carnelutti, en Francisco CARNELUTTI, La figura jurídica del notariado, Colección Biblioteca Notarial I, Lima, 2.011, p. 131. Dice allí el autor: "Aun prevalece en España una doctrina que yo he titulado teoría procesalista del derecho notarial, que ha intentado encajar nuestra función en los esquemas del derecho procesal, forzando los conceptos de jurisdicción y de relación jurídica. Yo la he combatido, hasta con cierta violencia, porque entre la función del juez y la nuestra no caben comparaciones: forman una antitesis. El juez aplica el derecho y rige la conducta ajena. El notario se limita a cumplir el derecho, no rige mas conducta que la propia, y su único acto de voluntad es de aceptar o no el requerimiento que se le haga para que preste sus funciones".
} 


\section{LOS EFECTOS DE LA PUBLICIDAD EN EL DOCUMENTO NOTARIAL}

acuerda en dar tratamiento a la misma dentro del análisis del elemento subjetivo del documento, aunque el tratamiento sea realizado de muy diferentes maneras y formas.

En una primera aproximación, generalmente hay acuerdo en considerar que la mención a la relación notarial alude a la que se genera entre el notario y quienes requieren su actuación profesional ${ }^{1516}$. Así, entienden que es una relación sustancial, de derecho material, que involucra al escribano y a sus requirentes ${ }^{1517}$. Para ello debe establecerse un inicio de la relación, que es el de aceptación notarial del requerimiento que hacen los requirentes, momento en el cual queda trabada la relación ${ }^{1518}$. De esta manera, el notario se convierte en sujeto agente de la relación profesional ${ }^{1519}$, queriéndose significar que al él corresponde la ejecución de la acción más propicia para llevar adelante la relación, ya que es en definitiva quien se encuentra a cargo de la función notarial. Función que, entre sus caracteres primordiales, destaca la confianza por encima de toda otra valoración.

En razón de ello es que la relación notarial es indelegable, y absolutamente personalísima ${ }^{1520}$. En cierta manera, con las presentes doctrinas se pretende captar la atención del lector acerca de temas de relación notarial en cuanto al opus encargado a realizar, analizado quizás desde el desarrollo de la naturaleza jurídica de la relación -tesis contractualistas o de las relaciones legales bilaterales- situación que se explica fácilmente a través de la doctrina y jurisprudencia dominante en materia de responsabilidad notarial $^{1521}$.

Pero desde un enfoque más profundo, en análisis comparativo con la relación preexistente del derecho procesal, la relación jurídica notarial es considerada -a mi juicio acertadamente- como una relación formal que tiene por objeto principal dar vida a la relación sustancial ${ }^{1522}$. De esta manera, los sujetos de la relación sustancial preexistente, recurren (ruegan) al escribano para que éste pueda configurar la voluntad de las partes en el

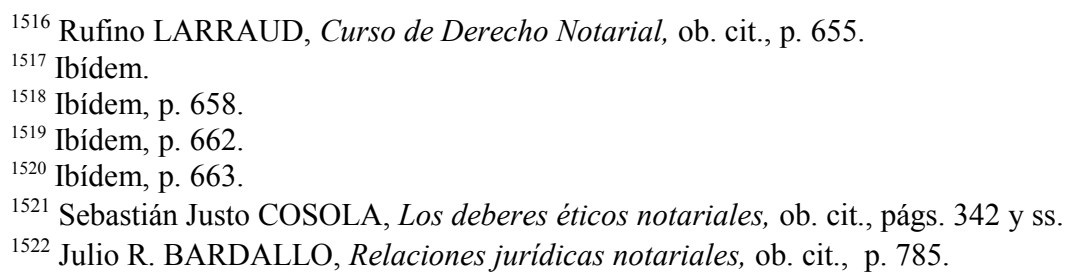




\section{SEBASTIÁN JUSTO COSOLA}

marco de la ley o del derecho que mejor les sea aplicable, para así poder darle forma y autenticidad ${ }^{1523}$, que no son otra cosa que la esencia misma del derecho y de la función notarial ${ }^{1524}$.

El tema del tratamiento de la relación jurídica notarial fue absolutamente relevante en el momento de efectuarse la construcción científica del derecho notarial ${ }^{1525}$, ya que para alcanzarla, se debía recurrir a las instituciones que a la ciencia y arte de la notaría les proporcionan tanto el derecho civil como el derecho de procedimientos ${ }^{1526}$. El primero, posicionando un desarrollo inobjetable de la relación jurídica y del negocio jurídico. El segundo, en una presentación formidable de la relación jurídica formal del derecho ${ }^{1527}$. Se conformaba así una especie de doble base en donde podía reposar el derecho notarial, para que desde allí se construya la primera noción de la ciencia notarial con doble naturaleza y eficacia, sustancial (constitutiva o declarativa) y probatoria del instrumento público, tal cual hasta ahora la he venido explicando y describiendo.

\footnotetext{
${ }^{1523}$ Ibídem, p. 786.

${ }^{1524}$ Ibídem, p. 802. En definitiva, creo que el profesor uruguayo se hizo eco de los impulsos brindados por Castán en este tema, aunque llamativamente no sea citado en su célebre trabajo.

${ }^{1525}$ José CASTÁN TOBEÑAS, Función notarial..., ob. cit., p. 175.

${ }^{1526}$ Ibídem.

1527 Ibídem. Dice CASTÁN en consonancia con el profesor italiano Gaetano DONÁ: "Enlazando el concepto relativo a la documentación del negocio jurídico, bajo forma de acto público autorizado por notario, con el concepto genérico de relación jurídica formal y el específico de la relación procesal, se puede ver de qué modo, análogamente a la relación de naturaleza formal y plurilateral que surge en el proceso civil entre las partes y entre cada una de ellas y el Juez, surge también con ocasión del acto público autorizado por el notario, por encima de la relación de derecho substancial que se produce entre las partes y eventualmente entre éstas y los terceros, una relación jurídica notarial entre el protagonista o los protagonistas del negocio y el notario, asi como entre este y los terceros, tanto en orden a la identidad de las personas, a su capacidad jurídica, a la verdad de la fecha en las declaraciones, de las menciones y de los hechos afirmados con el acto público, como en orden a la conservación, a la exhibición y a la eventual reproducción en copia del acto mismo, a petición de cualquiera".
} 


\section{LOS EFECTOS DE LA PUBLICIDAD EN EL DOCUMENTO NOTARIAL}

\subsubsection{Clases de relaciones jurídicas notariales.}

Sobre lo aprendido, consideremos al menos tres tipos de relaciones jurídicas notariales: a) La relación notarial formal; b) la relación notarial funcional y c) la relación notarial social.

\subsection{La relación notarial formal.}

Se forma entonces una relación notarial formal, que se define como relación legal, onerosa y de confianza, que vincula al notario y a los requirentes, a partir de la rogatio, con la misión de constituir una forma jurídica notarial idónea para alcanzar fines específicos y determinados ${ }^{1528}$. Y conformada por sus elementos, puede advertirse que en la misma hay sujetos $^{1529}$, $_{\text {objeto }}^{1530} \mathrm{y}$ causa $^{1531}$, con la seguridad jurídica preventiva que asegura la protección durante y después de la instrumentación del hecho o derecho de que se trate. Cierto es que la doctrina notarial no es pacifica en considerar la relación notarial formal. Pero creo que la misma es relevante a los fines de considerar una relación jurídica que en última instancia, rescata el valor de la forma y del contenido del documento notarial. En efecto, el verdadero objeto de la relación notarial es la forma jurídica como determinación del acto o negocio jurídico. La forma, como un complejo de elementos constitutivos, que se desprende de los actos de:

a) Calificación ${ }^{1532}$, como determinación formal del derecho aplicable ${ }^{1533}$

\footnotetext{
${ }^{1528}$ Julio R. BARBALLO, Relaciones jurídicas notariales, ob. cit., p. 794.

${ }^{1529}$ Son sujetos el notario y el/los requirentes del hecho o acto jurídico a instrumentarse.

${ }^{1530}$ Es objeto la forma pública notarial que otorga ser y valor al negocio o acto.

${ }^{1531}$ Es la propia rogatio o requerimiento, como compromiso que asume el escribano de ejercer la función notarial que le es encomendada.

1532 Julio R. BARDALLO, Relaciones jurídicas notariales, ob. cit., p. 801.
} 


\section{SEBASTIÁN JUSTO COSOLA}

b) Legalización, referida a la subordinación del acto a la ley y demás fuentes del derecho aplicables ${ }^{1534}$;

c) Legitimación, como respaldo que asegura que sujetos y objeto de la relación material tiene aptitud jurídica necesaria para serlo eficazmente ${ }^{1535}$;

d) Configuración jurídica, referida al conjunto de antecedentes y estipulaciones que estructuran el acto o negocio; una determinación formal "que se ve con los ojos de la inteligencia y se disfruta con el entendimiento, cuando la respalda la técnica depurada de un buen artifice $^{1536 " ;}$

e) Documentación, el sostén físico, el corpus de la forma; y

f) La autorización notarial, que con la con ayuda de la fe pública, importa imponer al conjunto una forma de verdad, un carisma de certeza con el que la comunidad jurídica puede $\operatorname{contar}^{1537}$. La autorización notarial comprende una doble afirmación: la afirmación de veracidad del texto documental y el cumplimiento de los requisitos legales pertinentes y los relativos a la propia suscripción notarial ${ }^{1538}$.

Por ello es que no puede negarse el componente público en el carácter privado de la función notarial, teniendo siempre en consideración la teoría de

${ }^{1533}$ Ibídem. Dice el autor: "Esta determinación formal es quizás, la de más sencilla expresión, pero sin duda la más trascendente. Cuando decimos "compraventa", utilizamos un solo vocablo, pero esta forma está cargada de la más alta significación jurídica".

${ }^{1534}$ Ibídem, p. 802.

1535 Ibídem. Y continúa el autor: "Comprobar que hay una situación jurídica preexistente, que funda eficazmente la nueva situación jurídica, que será consecuencia del acto o negocio, cuya estructura formal realiza el escribano. Más allá de la validez, está la eficacia y ambos valores son los objetivos concretos de la legalización y la legitimación. Esta también implica determinación formal, en cuanto agrega al producto una nueva virtud".

${ }^{1536}$ Ibídem. Y continúa en párrafo memorable: "Ese texto, no son las meras palabras escritas sobre un papel; son las ideas y significados que esas palabras encierran; la armonía del conjunto; la precisión jurídica; la inequivocidad de sus valencias, etc".

${ }^{1537}$ Ibídem.

${ }^{1538}$ Pedro ÁVILA ÁLVAREZ, Estudios de derecho notarial, ob. cit., p. 258. 
LOS EFECTOS DE LA PUBLICIDAD EN EL DOCUMENTO NOTARIAL

las funciones inescindibles ya referida de Antonio Rodríguez Adrados. El poder de la legitimación y de la autenticidad de los hechos y actos jurídicos acercan al notario al desempeño de una función pública. Con ella se atiende al interés general afirmando el imperio del derecho que asegura la legalidad y la prueba fehaciente de los mencionados hechos y actos a los que se sujetan las relaciones privadas ${ }^{1539}$. Ahora, no es la función notarial la que tiene por cometido o única finalidad la de autenticación de hechos y actos relevantes para la comunidad donde el notario desenvuelve sus servicios ${ }^{1540}$. También tiene éste la misión previa de asesorar y aconsejar a quienes requieren su ministerio ${ }^{1541}$, lo que lleva a pensar en una concreción notarial del método de la función notarial previa a la documentación y a la dación de fe, que terminará por consolidad valores esenciales en el contenido sustancial del documento.

\subsection{La relación notarial funcional.}

Es esta relación la que contiene y explica la unión del notario con el Estado $^{1542}$. Al ser el primero un profesional del derecho a cargo o en ejercicio de una función pública, para poder ejercer su actividad necesita de una investidura que solo la autoridad estadual puede brindarle. De ahí que el estado habilite al hombre para el ejercicio de las funciones notariales, para que este pueda luego ser sometido a estrictos regímenes de control ejercidos en general directamente por los Colegios Notariales que actúan por el poder de policía delegado. Hay entonces, entre el Estado y el notario una relación jurídica compleja, relacionada con el ejercicio de la función fedante, que incluye entre otras cosas temas trascendentes del ejercicio como la investidura, el contralor y la disciplina ${ }^{1543}$. Así, la misma se considera de carácter puramente legal, y se define como la relación administrativa, no jerárquica y legal, que tiene por objeto no ya la forma, sino el propio

\footnotetext{
${ }^{1539}$ José CASTÁN TOBEÑAS, Función notarial..., ob. cit., p. 38-39.

1540 Ídem, p. 41.

${ }^{1541}$ Ibídem, p. 42.

1542 Julio R. BARDALLO, Relaciones jurídicas notariales, ob. cit., p. 809.

${ }^{1543}$ Ibídem.
} 
ejercicio de la función notarial ${ }^{1544}$. Sin esta relación trascendente, no es posible asegurar la prestación del servicio a la comunidad, en razón de la necesaria delegación de facultades para el ejercicio de la fe pública en sede notarial $^{1545}$. De esta manera, son sujetos de la relación el notario y el Estado, y el hecho condicionante es la investidura, que implica poseer la situación jurídica para solicitar el nombramiento. El objeto de la relación es, una vez adquirida la facultad de ejercicio de la función notarial, el cumplimiento estricto del derecho aplicable, tanto en el plano de la relación notarial formal como sustancial ${ }^{1546}$. Así, el Estado tiene el deber de habilitar a los escribanos para el ejercicio, y éstos de someterse al control jurídico estatal, pero delegado en los Colegios Notariales. En sintonía con lo hasta aquí argumentado, agreguemos a estas consideraciones la necesidad actual de ejercer y aplicar el derecho de acuerdo a los principios, y no exclusivamente de acuerdo a lo legal cuando de su aplicación resulte un acto injusto o absurdo. Por cuanto el objeto de la mencionada relación se verá necesariamente acotado si se lo ejerciere, en estos tiempos, en relación única a la ley que ordena y ampara la actividad profesional, es importante y relevante tener en cuenta la integración de todas las normas jurídicas, comenzando por la Constitución Nacional y concluyendo en la norma de menor validez, vigencia y jerarquía, que entre nosotros puede ser una disposición técnico registral. En fin, el notario debe considerar al asesorar, aconsejar y documentar, tanto a la ley como a los principios generales del derecho que se capten por evidencia ${ }^{1547}$.

\subsection{Relación jurídica social notarial.}

\footnotetext{
${ }^{1544}$ Ibídem.

${ }^{1545}$ Ibídem, p. 810.

${ }^{1546}$ Ibídem.

${ }^{1547}$ Cfr. Cristina Noemí ARMELLA y Sebastián Justo COSOLA, Abordaje teórico y práctico del adelantamiento de la mayoría de edad-Ley 26.579, Ad-Hoc, Buenos Aires, 2.011, p. 21 y ss.
} 


\section{LOS EFECTOS DE LA PUBLICIDAD EN EL DOCUMENTO NOTARIAL}

Esta relación no presenta nombre propio, pero creo que el más adecuado es el que la vincula directamente con la sociedad. Desde mi visión, la misma encuentra su origen en el primer aporte del notarialista español José María Sanahuja y Soler ${ }^{1548}$, y se amplía en el trascendente ensayo de Julio Bardallo $^{1549}$ en estudio. Recordemos aquí que al tratar la trascendencia de las relaciones jurídicas notariales, Sanahuja parte de considerar un supuesto fáctico sencillo pero de importancia mayúscula: "La relación jurídico notarial se presenta constituida según el siguiente esquema: Si el sujeto a quien compete la fe pública notarial autoriza conforme a las leyes un instrumento público, este tendrá la fuerza auténtica, constitutiva o declarativa y ejecutiva prevenida en la ley (...). Y deduce la consecuencia: dicho instrumento tendrá la fuerza legalmente prevenida. Se traduce en una situación jurídica real, en la cual es sujeto agente el notario y sujeto paciente la comunidad jurídica en general, dado que el valor de la autenticidad se produce con respecto a todos ${ }^{1550 " . ~ A ~ s i m i l a r e s ~ c o n c l u s i o n e s ~}$ llega en nuestro medio Carlos Gattari, aunque desde un análisis absolutamente diferente ${ }^{1551}$. El recordado maestro argentino consideraba la relación jurídica dentro del objeto formal notarial, en el cual desarrollaba el procedimiento como técnica del derecho, siguiendo los conceptos propuestos por Carlos Cossio en su teoría egológica del derecho y dentro del concepto de libertad. Así, el notarialista enseñaba que podía inferirse la existencia de una nueva rama jurídica (se refiere a la notarial) porque en los hechos de la conducta humana en interferencia intersubjetiva se encuentra ese objeto formal propio: "En él se da la estructura, ya que en todos los actos notariales existe bilateralidad jurídica. Su propia relación jurídica fija un efecto que no sólo es inmanente al sujeto que realiza la acción, sino que es trascendente y tiene validez erga omnes ${ }^{1552}$ ". De tal forma puede decirse que en esta relación, se describen dos tipos de sujetos:

a) Uno agente, el notario, siempre unipersonal, y

\footnotetext{
1548 José María SANAHUJA Y SOLER, Tratado..., T $\mathrm{T}^{\circ}$ I, ob. cit., p. 225 y ss.

${ }^{1549}$ Julio R. BARDALLO, ob. cit., p. 813.

${ }^{1550}$ José María SANAHUJA Y SOLER, Tratado..., T ${ }^{\circ}$ I, ob. cit., p. 225-226.

${ }^{1551}$ Carlos N. GATTARI, El objeto de la ciencia del derecho notarial, ob. cit., p. 42.

${ }^{1552}$ Ibídem, p. 43.
} 


\section{SEBASTIÁN JUSTO COSOLA}

b) Otro paciente, la comunidad jurídica considerada en toda su extensión y en su carácter de pluripersonal indeterminada ${ }^{1553}$.

Estos enfoques son verdaderamente significativos, e independientemente de que hayan intentado determinar y fijar posición desde disciplinas tan ajenas al notariado como las que postulan los procesalistas, no puede dejar de advertirse que la finalidad es propia de aquellas doctrinas que intentan hacer prevalecer la seguridad jurídica preventiva. Se intenta dejar en claro que todos los ciudadanos están obligados a reconocer el valor del documento notarial. El hecho condicionante es la propia existencia del instrumento público, lo que genera la estructuración de los deberes y poderes a los que vengo aludiendo: el escribano con derecho a la fuerza legalmente prevenida del instrumento o documento, y la comunidad el deber de reconocimiento de la mencionada fuerza legal notarial ${ }^{1554}$. El objeto de la relación será la fuerza auténtica, constitutiva, declarativa y ejecutiva, una vez realizada la autorización notarial ${ }^{1555}$, es decir, todos los valores jurídicos que le son intrínsecos al documento. Julio Bardallo concluye que no existe un derecho subjetivo ni una obligación correlativa propiamente dicha, por cuanto en el presente caso no existen más sujetos que los requirentes del acto, siendo imposible que sea considerado sujeto la comunidad jurídica ${ }^{1556}$. Asimismo, de considerarse a los sujetos colectivos, no existe la posibilidad, en los hechos, de accionar contra la violación o el desconocimiento de los valores del documento notarial, y esto determina en esencia, su protección jurídica ${ }^{1557}$. Si el juez o la administración desconocieran el valor del documento notarial, lo que alcanzan es simplemente una no aplicación de las normas, pero no conculcan un derecho subjetivo a ese valor, ni incumplen una obligación que merezca sanción ${ }^{1558}$. En palabras del autor: "No existe $n i$ un derecho subjetivo a los valores referidos, ni una obligación correlativa,

\footnotetext{
${ }^{1553}$ Julio R. BARDALLO, Relaciones jurídicas notariales, ob. cit., p. 813.

${ }^{1554}$ Ibídem.

${ }^{1555}$ Ibídem, p. 814.

${ }^{1556}$ Ibídem, p. 819.

${ }^{1557}$ Ibídem.

${ }^{1558}$ Ibídem, p. 820.
} 


\section{LOS EFECTOS DE LA PUBLICIDAD EN EL DOCUMENTO NOTARIAL}

propiamente dicha, a su reconocimiento. No hay, por tanto, una relación jurídica sobre el valor de la forma pública notarial ${ }^{1559}$ ".

La apreciación encuentra reparo lógico, desde el punto de vista formal. Pero cierto es también que ni la magistratura, ni la administración, ni la sociedad desconocen, en los hechos, el valor del documento notarial, por cuanto el mismo ha instaurado, a lo largo del tiempo, una noción absolutamente consolidada de la aplicación de -hasta estos tiempos-, la seguridad jurídica preventiva.

Por mi parte, pienso que le asistía razón a José Castán Tobeñas cuando confirmaba que el documento era el resultado de la aplicación de la función notarial con tres notas que delimitaban su cometido:

a) Autenticación y legitimación que recae sobre hechos y actos humanos o naturales ${ }^{1560}$;

b) Aplicación general de autenticación y legitimación en el ámbito de desenvolvimiento de las relaciones del derecho privado ${ }^{1561}$, con algunas excepciones interesantes ${ }^{1562} \mathrm{y}$

c) Desenvolvimiento de la función en la fase de normalidad del derecho, alejado de lo contencioso o de lo que genere cierta perturbación $^{1563}$.

De esta manera, y ya posicionados desde el aspecto real del ejercicio práctico del derecho notarial, me pregunto con cierta vehemencia si esta relación no es una creación académica que lo único que persigue es dar al documento una especie de trascendencia mas allá de lo que pretendieran las partes interesadas e inmiscuidas en su composición. Así, si yo estuviera en lo cierto, bastará con decir que el documento notarial impone su ministerio en razón de la seguridad jurídica que brinda, siendo desde el aspecto sociológico del derecho una herramienta indubitable que genera confianza,

\footnotetext{
${ }^{1559}$ Ibídem, p. 819.

${ }^{1560}$ José CASTÁN TOBEÑAS, Función notarial..., ob. cit., p. 43.

${ }^{1561}$ Ibídem.

${ }^{1562}$ Ibídem. Por ejemplo la autenticación de hechos de orden político mediante acta de constatación, en el caso de un acto eleccionario; intervención en diversos actos públicos, etc. ${ }^{1563}$ Ibídem, p. 45.
} 


\section{SEBASTIÁN JUSTO COSOLA}

seguridad, certeza y consolidación de los derechos en el contenidos a partir de la autenticidad exterior o extrínseca. Si así fuera, la presente clasificación carece de sentido práctico, pudiendo ser parte de otros desarrollos del derecho notarial -inclusive más profundos y complejos-, como el que se refiere a la función social del notario.

\subsubsection{La estructura y los componentes del documento notarial auténtico: el equilibrio receptivo de los cambios jurídicos y la justificación de las instituciones tradicionales.}

El documento notarial auténtico se consolida sobre dos pilares de esencial trascendencia: el primero, destinado a la consolidación de una estructura, y el segundo, posicionado a favor del análisis de los componentes de esa misma estructura. Así es que mientras que la corporalidad, el autor diferenciado tanto de los comparecientes como de los testigos que intervienen de manera causada en el documento- y el contenido contribuyen para que ocurra una sólida conformación del cuerpo, la fuerza del Estado en la garantía de fe del autorizante, sus virtudes, las relaciones que las partes realizan entre sí, con otros y con el autor del documento, y los efectos probatorios y ejecutivos conforman una garantía de esta estructura destinada a ser perpetua salvo expresa actuación voluntaria de las partes involucradas. Esa intangibilidad a la que hacía referencia al inicio del presente tratamiento, determina entonces la existencia del documento a lo largo del tiempo; lo que permite afirmar que el mismo, como institución tradicional ha recogido todos los derechos que la evolución histórica permita describir. Sólo en nuestro país, esta estructura documental, sostenida por la fuerza de los componentes, ha receptado valor durante mucho tiempo en el Código Civil de Vélez y en el tiempo actual, en el Código Civil y Comercial de La Nación, sin cambios relevantes en la conformación aunque si en su descripción y alcance. De esta manera, la aplicación mecánica del derecho anterior en temas relevantes para el ejercicio notarial como los referidos a la capacidad, 


\section{LOS EFECTOS DE LA PUBLICIDAD EN EL DOCUMENTO NOTARIAL}

la minoridad o la ancianidad, sujeto a reglas rígidas e inflexibles, en nada se relaciona con el actual sistema de argumentación, que además se encuentran tutelados por normas absolutamente flexibles. Sin embargo, tanto la estructura como los componentes han encontrado y encuentran respaldo en el documento notarial.

La estructura y los componentes se interrelacionan en la búsqueda del equilibrio que brinde a la ciudadanía verdad, certeza, justicia y seguridad, determinantes de la paz. Forman una especie de balanza, cuya única misión consiste en mantener en equilibrio tanto la voluntad de los comparecientes como los cambios que necesariamente impone la vida de relación y las necesidades del derecho, receptivo de los cambios, a lo largo de la historia del hombre.

Sólo imaginando el ejercicio jurídico de hace unas décadas atrás podemos concluir que en todas las instituciones jurídicas los cambios han sido relevantes y además, necesarios y oportunos para adecuarlos al ejercicio de la vida de relación. Así nacieron a la vida jurídica las mesas virtuales, las notificaciones por medio de los correos electrónicos, la utilización de internet, la cancelación de deudas por medio de pagos electrónicos, los informes registrales electrónicos, entre tantos otros métodos inimaginables del quehacer jurídico de hace relativamente poco tiempo atrás. Mientras que el documento notarial auténtico sigue manteniendo su original estructura y así se mantiene y se describe. El antiguo derecho notarial y el actual encuentran reposo en la misma estructura, que se proyecta de manera similar sobre los mismos componentes. Pero que para mantener el equilibrio se ha producido un cambio en la fuerza de los platillos de la balanza. La fuerza proyectada a la aplicación e interpretación literal de preceptos rígidos del esquema jurídico anterior merma frente a la actual necesidad de argumentación del autor del documento.

$\mathrm{Si}$ estuviéramos estudiando y analizando cuestiones relativas a la interpretación constitucional, no dudaría en afirmar que el escribano o notario debe, de acuerdo al derecho que nos rige en la actualidad, aplicar la regla de ponderación o balancing test que lo ayude a descubrir cuál es el mejor derecho para ser documentado ${ }^{1564}$. Esto teniendo en cuenta tanto el

1564 Cfr. Pedro SERNA y Fernando TOLLER, La interpretación Constitucional de los Derechos Fundamentales. Una alternativa a los conflictos de derechos, La Ley, Buenos 


\section{SEBASTIÁN JUSTO COSOLA}

esquema ya relacionado de situación -hecho o acto- situación, como además la obligación de ejercicio que impone al profesional fedatario a recurrir a las fuentes que sirvan de origen y de justificación al derecho que se pretende exponer y tutelar desde el documento, que ya no es únicamente la ley escrita, sino la Constitución Nacional y todo valor o principio que de ella emerja.

Lo expuesto permite inferir que en los tiempos actuales, el documento notarial auténtico recepta:

a) Tratamiento constitucional del derecho, en la búsqueda de la revalorización de los valores y principios del derecho privado actual, todo en faz preventiva y sin conflicto o controversia.

b) Tratamiento general del derecho privado unificado, con una amplia y necesaria actitud argumentadora del creador del documento, que reconoce y recepta todo tipo de fuentes del derecho que permitan sustentar el derecho que documentalmente se intenta alcanzar y tutelar;

c) Posicionamiento frente a determinadas leyes especiales de incidencia en la función: me refiero puntualmente a las leyes especiales que ordenan al notario revestir de ciertas precauciones al documento a través de los métodos previsibles por el legislador, como la toma de declaraciones juradas, o la información notarial a los organismos especializados de operaciones que en la notaria se realizan o se van a realizar en el futuro. Todas las cuestiones del más moderno derecho penal, como la que refiere al lavado de activos que sirve para financiar dolores tan incurables en el seno social como el terrorismo, la trata de personas o la solvencia del narcotráfico, impactan directamente en el documento notarial;

d) El impacto de las leyes de naturaleza pública, como las provenientes del derecho tributario. Al ratificar al notario como agente de recaudación de impuestos, tasas, contribuciones especiales y tributos en general $-\mathrm{y}$ en sus diversas modalidades: agente de

Aires, 2.000, p. 10 y ss. 
LOS EFECTOS DE LA PUBLICIDAD EN EL DOCUMENTO NOTARIAL

retención, de percepción y de información- se le impone al mismo tomar ciertas precauciones en el documento que de obviarlas, no se conformaría la justicia notarial tan importante para el normal desarrollo de las instituciones públicas ${ }^{1565}$. Si bien es cierto que el Estado de derecho utiliza varios métodos para obtener recaudación y así, poder solventar, entre otras cosas, el gasto público, lo cierto es que a través del notariado cuenta el Estado con una herramienta recaudatoria precisa, firme, puntual y periódica de indudable trascendencia que se consolida como un baluarte del Estado de Derecho; $y$

e) Las normas o resoluciones de inferior rango, que coexisten diariamente con el ejercicio notarial de confección del documento. Me refiero puntualmente tanto a las disposiciones técnicoregistrales del Registro de la Propiedad Inmueble ${ }^{1566}$ como a las que, en determinadas circunstancias como por ejemplo, la de trasmisión del dominio de inmuebles que cuentan con edificación, requieren la revisión de la planimetría en general, la normalización de la seguridad de las propiedades, entre otras normas inferiores ${ }^{1567}$. La inspección de las propiedades por personas de los municipios encargadas del control de las construcciones, y todas aquellas inspecciones que se realizan en las ciudades, villas o pueblos del país y del extranjero, que se refieren a cuestiones de suma importancia para las personas que adquieren una propiedad, como las relativas a las conexiones de los servicios básicos e insustituibles, o las deudas por servicios públicos como el pavimento, el cordón cuneta, la obra de agua, de gas, entre otras, se vuelve sumamente importante por cuanto deben tener reflejo instrumental para dar seguridad a la transmisión que se realiza y que refleja, en definitiva, el acuerdo de las partes contratantes de buena fe.

\footnotetext{
${ }^{1565}$ Viviana C. DI PIETROMICA, Régimen tributario de la actuación notarial, ob. cit.

1566 Zulma Aurora DODDA y María Florencia FRANCHINI, Digesto de Disposiciones Técnico Registrales, ob. cit.

${ }^{1567}$ V. Luis César MARINELLI, Registro de la Propiedad, Catastro territorial y la actividad notarial, FEN, La Plata, 2.009, 235 p.
} 
SEBASTIÁN JUSTO COSOLA

10.4.4. Corolario: la comprensión y los alcances de la autenticidad externa del documento (Efectos de la publicidad cartular extrínseca).

La descripción general brindada del documento notarial, con los alcances y los fundamentos proyectados, permite visualizar de manera acertada los efectos de la publicidad cartular extrínseca. Todo lo expuesto hasta aquí deja en evidencia la trascendencia que se desprende de la simple lectura del documento en el esfuerzo de captación de todo lo que de él a nivel extrínseco se desprende. Esta es la fuerza derivada de la publicidad cartular, referida por la doctrina y la jurisprudencia siempre en torno a lo visible, lo palpable, lo que verdaderamente se advierte de la lectura del documento a través de los sentidos. Y precisamente porque se dirige a tutelar la cuestión formal instrumental, siempre emergerá de la misma el elemento fuerza.

Pero es necesario comprender que la mencionada fuerza deriva del principio de autenticidad interna, que se proyecta a partir de la publicidad cartular intrínseca, que es la que verdaderamente originara la referida fuerza cartular exterior. Estimo entonces que al análisis del valor de verdad (fe) que la doctrina viene realizando en torno al estudio de la autenticidad interna, debe adicionarse en los tiempos actuales, la proyección en el documento de la justicia y de la seguridad (estática) y no como mera suposición desde los elementos exteriores que exhibe el documento. Es que, si existe en estos tiempos un valor que se encuentra absolutamente relativizado es el valor referente a la verdad, como ya hemos tenido ocasión de analizar algunas líneas atrás. En el documento, ese valor verdad, objetivado desde el ordenamiento a través de la fe pública que ordena al autor a instrumentar de modo coetáneo todo aquello que presencia (certeza), requiere además de otros sustentos, que son los que justifican el valor del derecho en su total magnificencia y amplitud.

Por ello, desde mi visión, la autenticidad interna no solamente incluye el concepto de verdad (fe), sino que debe además incorporar la incidencia de los valores de justicia y seguridad (estática)-unidos y no confrontados o contrapuestos-, que vienen a determinar por un lado, una auditoría y 
colaboración de la voluntad que genera la repartición de lo que a cada cual le pertenece, y por el otro, la demostración que el imperio de la voluntad tutelado y documentado deja de ser una mera probabilidad y conjetura para surgir al mundo jurídico con la máxima certeza de previsibilidad que le es posible alcanzar. Esta es la razón por la cual, la lectura del documento para el análisis de la autenticidad interna deja de ser sencilla, para ser patrimonio del autorizante y de las partes comparecientes o requirentes. Como ya lo he advertido, la garantía de la autenticidad interna alcanza su máximo esplendor en el acto y en el momento de la elaboración notarial del derecho sobre el documento, que incluye los actos preparatorios, las audiencias que sean necesarias, el acto de otorgamiento y autorización, extendiéndose los efectos hacia los actos de conservación y de custodia. Desde aquí que con razón suficiente pueda justificarse que la autenticidad interna será siempre la encargada de proteger la cuestión sustancial del documento, la que en definitiva conforma la voluntad tutela (justicia) amparada por la seguridad y la certeza, y por ello la publicidad cartular intrínseca no puede proyectar otra cosa que la potencia del documento, a partir del análisis de los valores que lo vuelven trascendente. 
SEBASTIÁN JUSTO COSOLA

$\cdot 394$. 


\section{Capítulo 11. La búsqueda conceptual del contenido proveniente de}

\section{la autenticidad interna.}

\subsection{Palabras preliminares.}

La tercera parte de esta tesis en desarrollo, se refiere tanto a la observación del documento como elemento o herramienta tradicional del cuerpo normativo vigente, como así también a los fundamentos axiológicos que del mismo emergen para erigirse como rectores. El documento es el cuerpo que conforma los valores que consolidan la autenticidad interna del mismo y por ende, el que proyecta la potencia de la publicidad cartular intrínseca. Dada la fuerza de la publicidad cartular extrínseca, resta determinar desde donde proviene la mencionada atribución.

En la actualidad, la autenticidad interna aplicada y proyectada como antes he descripto en el documento notarial, permite hacer inferir que del mismo emergen tres valores trascendentes, que desde la posición que deseo con este estudio sustentar, son lo que determinan la verdadera importancia de su justificación actual ${ }^{1568}$. Es decir, la justificación del documento notarial proyectado de manera tradicional en el moderno cuerpo normativo es lo que en definitiva alcanza a demostrar su importancia como elemento fundamental de decisión jurídica destinado a reflejar, de la mejor manera posible, los efectos jurídicos y axiológicos que del mismo se desprenden.

En el marco de una investigación destinada a analizar los alcances de un tema relativamente técnico y complejo como el que se refiere a la cuestión

\footnotetext{
${ }^{1568}$ Es en esta sección donde se advierten los motivos que tuve originariamente al escribir la tesis, y continúa a todo el tratamiento realizado hasta aquí, de los que me fui nutriendo para poder fundamentarla. En esencia, es también aquí más que en ninguna otra parte de la tesis donde podrán advertirse las influencias de la filosofía del derecho en el nuevo derecho y en especial, en el derecho notarial.
} 


\section{SEBASTIÁN JUSTO COSOLA}

de la publicidad jurídica en general, una presentación de estas características no deja de plantear ciertas dudas iniciales que deben ser desechadas desde el inicio. La primera de ellas es la que plantea un resquemor generalizado que alcanza a la duda acerca de si es posible, desde el desarrollo de un tema tan formal y concreto como el referido al documento notarial, poder llegar a proyectar con éxito, ciertas cuestiones abstractas que en temas como este, son las que siempre terminan por generar problemas de envergadura en las diferentes vías de interpretación. Otra duda posible es la que induce a creer que en una disciplina como el derecho notarial, tan ligada a la teoría emergente del ordenamiento jurídico positivo considerado en sus variadas jerarquías, pueda tener lugar o cabida una nueva tesis que vaya mucho más allá de lo que se advierte desde el soporte y la grafía estática; esto es, que intente alcanzar a justificar que el paso previo que determina lo que se advierte por los sentidos no es ya únicamente el resultado de una atribución legal distribuida por el Estado. Así, cierta y relevante es la fuerza determinante de los efectos, y dentro de ellos, los más consagrados a nivel académico, los probatorios y ejecutivos; pero no menos cierta y no menos importante es la tarea actual de determinar porque existen y por qué se causan esos efectos. En épocas de la codificación decimonónica, esta respuesta era sencilla: la fuerza que causa los efectos proviene del Estado, que por imperio de la ley, inviste a ciertas personas de facultad fedante. Hasta esos momentos, las fuentes del derecho era consideradas como los criterios de objetividad que ayudan a alcanzar las respuestas de la vida ${ }^{1569}$; instancias a las que acuden los juristas para imputar consecuencias jurídicas a un determinado hecho acaecido ${ }^{1570}$, donde la ley se erigía como la más importante y relevante fuente del derecho ${ }^{1571}$. Pero en la actualidad una realidad jurídica diferente se impone ${ }^{1572}$. La era de la codificación -en realidad, de descodificación- viene a alterar, de manera sustancial, los criterios interpretativos anteriores. De esta manera, el sistema de fuentes del

\footnotetext{
${ }^{1569}$ Cfr. Julio CUETO RUA, Fuentes del derecho, Abeledo Perrot, Buenos Aires, 1.971, p. 18.

1570 Ídem, p. 20.

1571 Ídem, p. 35.

1572 Para ver el alcance de las nuevas fuentes del derecho: Néstor D. LAMBER, Título preliminar, en Eduardo G. CLUSELLAS (Coord.), Código Civil y Comercial. Comentado, anotado y concordado, $\mathrm{t}^{\circ} 1$, Astrea-FEN, Buenos Aires, 2.015, p. 4 y ss.
} 
LOS EFECTOS DE LA PUBLICIDAD EN EL DOCUMENTO NOTARIAL

derecho tal cual lo conocimos y lo aprehendimos ha cambiado, ha mutado de perspectiva y con él, también los criterios rígidos de valoración jurídica se ven modificados. En efecto, ya no se aplica el criterio único de subsunción de la norma sino que se requiere la herramienta de ponderación como ya he referido, que no es otra cosa que la convocatoria a un diálogo de fuentes a través de una interpretación dialógica ${ }^{1573}$ o más precisamente, la recepción de la teoría de la argumentación jurídica.

$\mathrm{Si}$ esto se comprueba, la autenticidad interna del documento ya no se debe sustanciar únicamente a través de las diversas valoraciones emergentes del problema de la certeza (fe), sino que debe además ocuparse de valorar ponderar- la otra caracterización de la fe (verdad), la seguridad jurídica interna -innata el estudio del documento y por ende, del derecho notarial-, y sin lugar a dudas, también al valor supremo buscado por todos los órdenes normativos y no normativos vigentes: la justicia.

Existe una amplitud indubitable en el campo de argumentación jurídica notarial, y sin duda alguna, la misma se desarrolla desde el fenómeno de la autenticidad interna o de la potencia intrínseca que emerge del documento elaborado por el escribano. En razón de ello es que es el referido profesional quien debe esforzarse por alcanzar, dentro de la función que le fuera encomendada, la consolidación de los derechos fundamentales de las personas en un ámbito de desprotección e inseguridad general -en todo sentido- como el que presenta el desarrollo cotidiano de la vida en la actualidad. El notario, creador del documento, tiene entonces la impostergable tarea de adecuar definitivamente su opus habitual a las necesidades de la sociedad en la que vive y habita. Por ello su tarea esencialmente documentadora debe encontrar fundamento en la protección del hombre y de la mujer de nuestros días, que excede ampliamente las nociones técnicas, formularias y burocráticas a las que se acostumbra a asimilar al quehacer fedatario, para alcanzar una elaboración notarial del derecho a partir de la consolidación de una pléyade de valores de contenido esencial en el seno del documento, todos indispensables para que el derecho ejercido en la paz alcance la plenitud de los efectos esperados. La tarea

${ }^{1573}$ Cfr. Aída KEMELMAJER de CARLUCCI, Pautas para interpretar el Código, en Código Civil y Comercial. Concordado con el régimen derogado y referenciado con legislación vigente, Astrea, Buenos Aires, 2.015, p. 6. 
previa notarial documental cobra entonces, una notable relevancia, como quizás nunca la haya proyectado en todos los años de historia de la institución fedante.

\subsubsection{Una cuestión de elección por la adecuación de la designación de los baluartes esenciales del documento.}

Se me impone entonces justificar si los tres baluartes o elementos con los que pretendo consolidar la potencia de la autenticidad interna y con ello, la elaboración del documento y la parte general de la teoría del derecho notarial contemporánea, pueden ser ubicados bajo el rótulo de valores, de principios, de paradigmas o de virtudes.

Oportuno es recordar que los estudios universitarios relativos a la materia introducción al derecho o teoría general del derecho -y quizás también comprensivas de las nociones de doctrina y práctica jurídica ${ }^{1574}$ - comienzan por generar ciertas inquietudes en los estudiantes para que puedan alcanzar a comprender el desarrollo de los primeros conceptos característicos del mundo del derecho, casi los mismos que luego se profundizan y meditan más profundamente en la disciplina filosofía del derecho. La materia resulta además esencial por cuanto sirve para advertir de antemano, que partir de diferentes definiciones implica en cierta medida, delimitar el campo teórico de aplicación ${ }^{1575}$, con diferentes resultados desde el análisis de los diferentes objetos, lo que producirá diferentes teorías presentadas a través de los más diversos enfoques. En cierta manera, la adscripción a una determinada escuela de pensamiento determina no solo el ejercicio profesional, sino los motivos y los fines que persigue el jurista a la hora de ejercer su trabajo cotidiano. Desde la introducción al derecho se advierten entonces, los primeros conceptos en una disciplina que para algunos autores

1574 Cfr. Enrique ZULETA PUCEIRO, Teoría del derecho. Una introducción crítica, Depalma, Buenos Aires, 1.987, p. 22.

${ }^{1575}$ Eduardo Ángel RUSSO, Teoría general del derecho, ob. cit., p. 20. 
necesariamente debe mostrar al derecho en su total unidad ${ }^{1576}$. Otros en cambio, prefieren entender que la materia proporciona al alumno los mínimos conocimientos sistematizados para acceder a los conceptos primarios de las diferentes ramas del derecho ${ }^{1577}$, negando coherentemente con lo planteado, la autonomía de la mencionada disciplina ${ }^{1578}$.

Más allá de las mencionadas opiniones, coincidamos en que es en ese contenido donde se aprenden y aprehenden para siempre, los primeros conceptos interesantes del estudio del derecho, y sin duda alguna, muchos de ellos me resultan esenciales para este desarrollo de la presente tesis doctoral. Concretamente, al referirnos al campo de la axiología jurídica, hacemos mención obligada a ciertos conceptos cardinales, como el de los valores, los principios, los paradigmas y las virtudes: cuatro conceptos de importancia para la justificación de la trascendencia de la publicidad cartular interna emergente del documento notarial.

\subsubsection{Los valores.}

El concepto de valor refiere a un sentido de cualidad de la cosa; a un alcance de su significación e importancia, a la subsistencia y a la firmeza de algún acto $^{1579}$. No hay cosa en el mundo ante la cual no adoptemos una posición positiva o negativa, es decir, una posición de preferencia ${ }^{1580}$. Observado desde el lado del objeto, no hay cosa alguna que no tenga un valor ${ }^{1581}$.

\footnotetext{
${ }^{1576}$ Cfr. Miguel Ángel CIURO CALDANI, Introducción al derecho, la disciplina de la Unidad del derecho, $2^{\circ}$ Encuentro de Profesores de Introducción al Derecho, UNLP, 2.002.

1577 Cfr. Ariel ÁLVAREZ GARDIOL, Manual de introducción al derecho, Juris, Rosario, 1.995 , p. 22.

${ }^{1578}$ Ibídem, p. 23.

1579 Cfr. Víctor DE SANTO, Diccionario de Ciencias Jurídicas, políticas, sociales y de economía, Universidad, Buenos Aires, 1.996, p. 858.

${ }^{1580}$ Cfr. Manuel GARCIA MORENTE, Lecciones preliminares de filosofia, Losada, Buenos Aires, 1.993, p. 308.

${ }^{1581}$ Ibídem. Dice el autor: "Unas serán buenas, otras malas; unas útiles, otras perjudiciales; pero ninguna absolutamente diferente".
} 


\section{SEBASTIÁN JUSTO COSOLA}

La teoría de los valores es un tema de tratamiento indispensable en la iusfilosofia -relativamente antiguo-, aunque no siempre destinado o dirigido a dilucidar los mismos contenidos ${ }^{1582}$. Desde allí es que consideremos más adecuadamente una clasificación de corrientes acerca de los valores, que optamos por denominar objetivista, que postula que nosotros apreciamos los valores porque los valores valen, y una corriente subjetivista que viene a imponer exactamente lo inverso: en clara posición relativista, sostiene que los valores valen porque el hombre los aprecia ${ }^{1583}$. Todo esto sin dejar de considerar que existen fuertes teorías sociológicas de los valores, de donde surge que ciertos autores plantean que los mismos no son ya producto de un individuo empírico, sino que son algo que debe ser estudiado por la sociedad en su totalidad, ya como expresión de creencias o deseos, ya como productos de la conciencia colectiva ${ }^{1584}$. Por ello es que puede advertirse con mayor docilidad, que los valores están sujetos al criterio de polaridad o bipolaridad $^{1585}$ y también al criterio de jerarquia ${ }^{1586}$ (teorías que entre tantos otros planteos profundiza notablemente Nicolai Hartmann ${ }^{1587}$ al momento

${ }^{1582}$ Cfr. Enrique R, AFTALIÓN, José VILANOVA y Julio RAFFO, Introducción al derecho, LexisNexis- Abeledo Perrot, Buenos Aires, 2.004, p. 683.

${ }^{1583}$ Ídem, p. 691.

1584 Cfr. Miguel REALE, Filosofía del derecho, to I- Introducción filosófica general, Pirámide, Madrid, 1.979, p. 168 y ss.

${ }^{1585}$ Enrique R, AFTALIÓN, José VILANOVA y Julio RAFFO, Introducción al derecho, ob. cit., p. 692-693. Dicen los autores: "Éstos (los valores) se dan siempre en una gradación bipolar, están entre un polo positivo y uno negativo, y entre estos polos hay una gradación de matices imperceptibles, por lo que resulta imposible determinar exactamente cuál es el punto medio entre ambos polos, o sea, cual es el momento en que pasamos del polo positivo al polo negativo. Así, si nos referimos a un valor estético, por ejemplo la belleza, podemos ver que hay un cuadro muy bello, que hay otro que lo es menos y un tercero que es ya bastante menos bello, hasta que caemos en uno que resulta feo. Esta es la idea de bipolaridad. Idea que se da como correcta no solo con los valores estéticos, sino también con los valores morales como la justicia y el bien y en general, con todos los valores.".

${ }^{1586}$ Ibídem. Se refiere a criterios de altura entre los diferentes valores: "Tomemos el caso de la estética: la elegancia es un valor de una jerarquía inferior a la belleza, que es un valor de jerarquía superior. Los valores tienen así una gradación jerárquica que no es dificil advertir. $Y$ esta jerarquía que cada valor tiene esta en relación inversa con la fuerza de ese mismo valor. Se entiende por fuerza la tendencia del valor a su realización: mientras más realización encontremos de él, más fuerza tendrá. Es fácil ser elegante, el valor elegancia tiene bastante fuerza puesto que su tendencia a ser realizado es considerable, pero ya la belleza o la gran belleza de una obra de arte es dificil, se realiza raramente, por lo que la fuerza de la belleza es inferior a la fuerza de la elegancia".

${ }^{1587}$ Cfr. Nicolai HARTMANN, Ética, Encuentro, Madrid, 2.011, 852 p. 
de presentar un inmejorable tratamiento desde la ética, analizado desde un riguroso ontologismo axiológico ${ }^{1588}$ ). Ese gran aporte retorna a los valores a la postura platónica, que resalta a los valores como esencialidades ${ }^{1589} \mathrm{o}$ como principios ${ }^{1590}$, entre otras descripciones, que lógicamente exceden los límites del presente tratamiento introductorio ${ }^{1591}$. En definitiva, la reflexión axiológica no ha encontrado hasta el presente una respuesta concluyente en torno a la objetividad del valor ${ }^{1592}$, afirmación que dentro de la escuela platense del derecho se ratificaba cuando se enseñaba que el valor no es, sino que tiene un modo especial de ser que es el valer ${ }^{1593}$, porque el mismo es un estado psicológico y es una cosa fuera de nosotros; de ahí que el valor o está en las cosas, fuera de nosotros -objetivismo- o en nosotros mismos subjetivismo- ${ }^{1594}$. En los tiempos actuales, la mencionada escuela insiste con verdadero entusiasmo, en que el tema de la axiología es en definitiva, un problema que remite a las conexiones entre el derecho y la moral $^{1595}$.

\subsubsection{Los principios.}

También aprendemos -y aprehendemos- las primeras definiciones de los principios, relacionados especialmente con el principio de analogía en el derecho privado, e identificados de muchas maneras y formas: desde el

\footnotetext{
${ }^{1588}$ Miguel REALE, Filosofia del derecho, ob. cit., p. 172.

${ }^{1589}$ Nicolai HARTMANN, Ética, ob. cit., p. 158.

${ }^{1590}$ Ibídem, p. 198.

1591 Sobre esto, debe reconocerse que algunos profesores del derecho niegan ciertos conceptos precisos y algunos alcances terminológicos en las obras determinadas de autores como Scheler o Hartmann. Es el claro ejemplo de Georges Kalinowski, que opina que no le asiste razón a Hartmann cuando sitúa a los valores en un mundo de las ideas, ni tampoco a Scheler cuando opone el valor al ser. Cfr. Georges KALINOWSKI, El problema de la verdad en la moral y en el derecho, Eudeba, Buenos Aires, 1.979, p. 124.

${ }^{1592}$ Cfr. Juan Carlos SMITH, El desarrollo de las concepciones jusfilosoficas, Abeledo Perrot, Buenos Aires, 1.999, p. 155.

${ }^{1593}$ Cfr. María Teresa LÓPEZ, Nociones de Axiología Jurídica, AFCJS, T XXV, La Plata, 1.966 , p. 167.

${ }^{1594}$ Ibídem.

${ }^{1595}$ Cfr. Carlos Enrique PETTORUTI y Julio César SCATOLINI, Elementos de introducción al derecho, La Ley, Buenos Aires, 2.005, p. 174.
} 


\section{SEBASTIÁN JUSTO COSOLA}

concepto de la naturaleza ${ }^{1596}$; con el derecho natural, con los principios fundamentales de la legislación positiva, con los ideales jurídicos de la comunidad, con las reglas de la equidad, entre otras relaciones ${ }^{1597}$. Desde una posición eminentemente filosófica, los principios presentan tratamientos algo más complejos, como los que intentan por ejemplo, describirlos a partir de divisiones del propio ente ${ }^{1598}$. La filosofía general ha introducido en este tema, en el campo del derecho, todas las proyecciones que se planteaban los antiguos desde los propios orígenes del amor a la sabiduría. Desde entonces, cualquier tratamiento de los principios introduce para la reflexión, en mayor o menor medida, cuestiones jurídicas y filosóficas, y por ello es que en la actualidad campean los análisis de los mismos en relación con la ética y la moral, versionados como autónomos y universales -en la mas intima versión kantiana ${ }^{1599}$-, porque en última instancia, los principios hablan de leyes o esquemas que uno se da a sí mismo con independencia de los promulgados por la autoridad humana.

Existen además determinados análisis que relacionan a los principios, de manera directa, con el valor justicia; los planteos son tan diferentes entre sí, que bien pueden resumirse en aquellos que en toda instancia pretenden imponer que los individuos tienen que tener derecho, entre sí, a una cierta posición relativa de igualdad o desigualdad ${ }^{1600}$. Incluso se advierten tratamientos que ubican a los principios como verdaderos elementos de la argumentación jurídica, porque son los antepuestos al ordenamiento jurídico positivo, situación que les permite brindar al derecho un contenido apropiadamente justo ${ }^{I 601}$. Así, los principios generales del derecho son

${ }^{1596}$ Cfr. Giorgio DEL VECCHIO, El concepto de la naturaleza y el principio del derecho, trad. Mariano CASTAÑO, Hijos de Reus, Madrid, 1.916.

1597 Cfr. Carlos MOUCHET y Ricardo ZORRAQUIN BECU, Introducción al derecho, Editorial Perrot, Buenos Aires, 1.962, p. 241.

${ }^{1598}$ Cfr. Duns SCOTO, Tratado del primer principio, Aguilar, Buenos Aires, 1.964, p.21 y ss.

${ }^{1599}$ Cfr. Carlos Santiago NINO, Introducción al análisis del derecho, Astrea, Buenos Aires, 2.005, p. 403. Dice el autor: "Las leyes morales son, asimismo, universales, puesto que si son los principios que queremos como puros seres racionales con abstracción de nuestras inclinaciones y deseos contingentes que nos diferencian unos de otros, entonces se sigue que cada ser racional querrá la misma ley que querría cualquier otro ser racional, y, por lo tanto, esa ley moral obliga a todos los seres racionales por igual".

${ }^{1600}$ Cfr. Herbert L. A. HART, El concepto de derecho, trad. Genero CARRIÓ, Abeledo Perrot, Buenos Aires, 2.004, p. 198.

${ }^{1601}$ Fernando MARTINEZ PAZ, Introducción al derecho, ob. cit., p. 352. 
LOS EFECTOS DE LA PUBLICIDAD EN EL DOCUMENTO NOTARIAL

elementos originarios del ordenamiento jurídico, y por ello su misión no puede reducirse únicamente a integrar las lagunas del derecho o a brindar una posible solución a los conflictos entre leyes, sino que deben ser siempre tenidos en cuenta para una adecuada y mejor comprensión del ordenamiento jurídico en tu generalidad ${ }^{1602}$. Fundado en estos nuevos criterios, también se argumenta que hoy se habla de una nueva edad de oro de los principios, con absoluta razón y certeza ${ }^{1603}$ : de allí que se alcancen a valorar obras magistrales ${ }^{1604}$, que intentan darle a los principios el lugar que les corresponde en el campo de la moderna y compleja teoría de argumentación jurídica ${ }^{1605}$ en relación directa con la importancia que los mismos ofrecen al ser aplicados en una visión multicultural ${ }^{1606} \mathrm{y}$ analógica.

\subsubsection{Los paradigmas.}

Reconocida la revolución del paradigma de Thomas Kuhn en el campo de las ciencias, también desde la introducción al derecho se habla de paradigma, temática que nos dirige naturalmente a identificar la designación con un determinado ejemplo ${ }^{1607}$. Sin embargo, la importancia de esta palabra en el desenvolvimiento de las ciencias en general y del derecho en particular se advierte desde el mismo momento en que el concepto propio de paradigma viene a relativizar el modelo científico, circunscribiéndolo a un lugar determinado ${ }^{1608}$, para poder brindar la objetividad en función del propio paradigma adoptado ${ }^{1609}$. Así, la importancia de lo que implica el paradigma

\footnotetext{
${ }^{1602}$ Ibídem.

${ }^{1603}$ Cfr. Rodolfo Luis VIGO, Los principios jurídicos. Perspectiva Jurisprudencial, Depalma, Buenos Aires, 2.000, p. 1.

${ }^{1604}$ Cfr. Giorgio DEL VECCHIO, Los principios generales del derecho, Ara Editores, Lima, 2.006 .

${ }^{1605}$ Cfr. Amós Arturo GRAJALES y Nicolás NEGRI, Argumentación Jurídica, Astrea, Buenos Aires, 2.014, p. 331 y ss.

1606 Cfr. Juan CIANCIARDO (Dir.), Multiculturalismo y universalismo de los derechos humanos, Ad-Hoc, Buenos Aires, 2.008, p. 17 y ss.

${ }^{1607}$ http://lema.rae.es/drae/?val=paradigma (Último acceso: 28/08/2017).

${ }^{1608}$ Cfr. Eduardo Ángel RUSSO y Analía Haydee MAS, Introducción al estudio general del derecho, Editorial Docencia, Buenos Aires, 2.000, p. 17.

${ }^{1609}$ Ibídem, p. 19.
} 


\section{SEBASTIÁN JUSTO COSOLA}

se logra advertir cuando en la historia del pensamiento científico se registra un cambio en el modelo utilizado durante un determinado período ${ }^{1610}$, mutando el concepto de ciencia, posicionándolo en el siglo en la cual se desarrolla, separándola de la idea de eternidad ${ }^{1611}$. Este es el sentido en que se puede aplicar la palabra para la justificación de los valores del documento. A la par de esto, digamos que no es menos importante dejar de recordar que tanto desde la introducción al derecho como desde la filosofía del derecho, esta palabra también nos dirige a recordar la creación de Ronald Dworkin, relacionada con el Juez Hércules, que debe construir un esquema de principios que justifiquen, de por sí, su aplicación al caso concreto ${ }^{1612}$. El paradigma herculeano entonces, es una teoría de adjudicación que implica una construcción de un esquema de principios abstractos y concretos que identifican la moralidad presupuesta de las leyes e instituciones de la comunidad $^{1613}$. Se trata entonces de establecer si hay o no respuesta para los casos difíciles que plantea el derecho ${ }^{1614}$, en donde Hércules, juez filosofo dotado de habilidad, erudición, paciencia y perspicacia sobrehumana justificará coherentemente las decisiones jurídicas $^{1615}$, obteniendo la respuesta correcta al caso difícil, ya que el mismo investigará no solo los principios aludidos en las normas particulares, sino también aquellos que se presuponen integrados a todo el ordenamiento jurídico ${ }^{1616}$.

Finalmente, pongamos en advertencia que se suele utilizar también la palabra para desarrollar estructuras de corrientes de pensamiento jurídico. Así, a modo de ejemplo, Enrique Zuleta Puceiro se refiere al paradigma dogmático $^{1617}$, de donde surge que la dogmatica, configurativa del saber jurídico científico, se refiere de modo concreto a una actitud metodológica, que está condicionada por factores de naturaleza científica, histórica, cultural 
LOS EFECTOS DE LA PUBLICIDAD EN EL DOCUMENTO NOTARIAL

y política que resulta necesario poner de manifiesto ${ }^{1618}$. El paradigma de la dogmática supone una aceptación -fundada en la creencia- en ciertos valores generales, que derivan del hecho de la vigencia del ordenamiento jurídico y de la pretendida legitimidad de un saber científico reducido estrictamente a los límites de la descripción empírica ${ }^{1619}$.

\subsubsection{4. $\quad$ Las virtudes.}

Se suele referenciar a la virtud como disposición contenedora de una tendencia que consiste en contrarrestar directamente la limitación de la simpatía humana hacia otros, y cuyo ejercicio es beneficioso para personas diferente del agente ${ }^{1620}$. Referir a la virtud, según Josef Pieper, implica comprometer una cuestión intrínseca del hombre, que no es la honradez y corrección de un hacer, ya que más bien la virtud significa que el hombre es verdadero, y que es considerado en su total dimensión tanto natural como sobrenaturalmente ${ }^{1621}$. Es hombre virtuoso aquel que realiza el bien obedeciendo a sus inclinaciones más íntimas ${ }^{1622}$.

Sobre esto, he planteado con anterioridad que el ejercicio prudente del notariado se conforma a través de la determinación, tanto de lo que es lo justo para cada uno como del ejercicio de las virtudes notariales ${ }^{1623}$. Por cuanto si el acto justo consiste en darle al otro lo suyo, se requiere "determinar lo que es justo o suyo ${ }^{1624}$ ", quien así lo determine debe tener bien definidas el conjunto de virtudes que, en sus muchas manifestaciones y naturalezas cambiantes ${ }^{1625}$, puedan efectivamente enaltecer la función a

\footnotetext{
${ }^{1618}$ Ibídem, p. 14.

1619 Cfr. Enrique ZULETA PUCEIRO, Elementos de teoría del derecho, Abeledo Perrot, Buenos Aires, 2.013, p. 236.

${ }^{1620}$ Carlos Santiago NINO, Introducción al análisis del derecho, ob. cit., p. 375.

1621 Josef PIEPER, Las virtudes fundamentales, ob. cit., p. 15.

${ }^{1622}$ Ibídem.

${ }^{1623}$ Sebastian Justo COSOLA, Fundamentos del derecho notarial..., t ${ }^{\circ}$ I, ob. cit. p. 244-245.

${ }^{1624}$ Cfr. Rodolfo Luis VIGO, Como argumentar jurídicamente, Abeledo Perrot, Buenos Aires, 2.012, p. 135.

${ }^{1625}$ Cfr. Alasdair MacINTYRE, Tras la virtud, Crítica, Barcelona, 2.004, págs. 226-251.
} 


\section{SEBASTIÁN JUSTO COSOLA}

través de su aplicación y de su ponderación ${ }^{1626}$. Nuestro país cuenta con una especie de declaración de virtudes de juez, a través del muy buen aporte que ha realizado la comisión perfil del juez, en el seno del Ministerio de Justicia, de donde surgen las virtudes de los jueces tanto a designar como de aquellos que ya se encuentran en ejercicio ${ }^{1627}$. En analogía y sintonía, las virtudes notariales se describen en el desarrollo del autor dentro de lo que en el marco de la presente tesis he considerado como parte del componente personal del documento notarial, virtudes que unidas y equilibradas entre sí, son las que dan vida, vigor y mayor certeza a los efectos primarios del documento notarial.

\subsubsection{La razón por los valores.}

De la introducción que antecede para alcanzar la justificación de la trascendencia de la publicidad cartular interna, optaré por utilizar la palabra valores para indicar cuáles son, según mi pensamiento, los estándares o baluartes del documento notarial en la actualidad. ¿Por qué razón me inclino por esta denominación y no por otras, quizás con mayor fuerza argumentativa en el tiempo presente, como la que refiere a los principios, al paradigma o a las virtudes? Precisamente porque lo que intento es conformar el documento notarial auténtico desde una teoría sólida que demuestre no solo su jerarquía, sino también el principio de rectoría tanto sobre las demás instituciones aquí consideradas, como también sobre los demás medios técnicos de publicidad formal y material analizados, siempre desde una posición de guía y no de confronte o conflicto. Razón de ello es que no se trata de establecer órdenes de importancia -ya que las tres publicidades en funcionamiento coherente son importantes para el normal desarrollo del derecho- sino ordenes de jerarquía axiológica o simplemente valorativa. La jerarquía puede estar dada por la mayor importancia, pero también por un

${ }^{1626}$ Herbert L.A HART, El concepto..., ob. cit., p. 253.

http://www.lynch-

abogados.com.ar/Publicaciones/Justicia/Humano/PerfilJuez Senado 9Abr03.pdf (Ultimo acceso: $28 / 08 / 2017$ ) 


\section{LOS EFECTOS DE LA PUBLICIDAD EN EL DOCUMENTO NOTARIAL}

análisis medular que se realice desde la institución que es valorada desde su más absoluta objetividad e integridad, lo que en definitiva permite su elevación al rango de rectora dentro de una determinada finalidad prevista por el ordenamiento, que puede ser alcanzada por otras vías adecuadas al derecho formal o consuetudinario.

Ahora bien, muy a pesar de que existan infinidad de doctrinas acerca de los valores que descuiden en los análisis parte de las teorías que explican y fundamentan determinados aspectos de su naturaleza jurídica, yo prefiero limitar la expresión en uso a lo meramente objetivo: los valores así no son únicamente el peso de agrado o desagrado, de placer o de dolor, que queda en mi alma después de la contemplación del objeto ${ }^{1628}$, sino que los valores se descubren tal cual lo hacen las verdades cientificas ${ }^{1629}$. De esta manera, los mismos no se conocen hasta que llegan intuidos al mundo por impulso del hombre en la historia ${ }^{1630}$. No aparecen como algo que antes no era y ahora es, sino como algo que antes no era intuido y ahora lo es ${ }^{1631}$. En definitiva, me propongo aceptar que los valores no son cosas ni tampoco impresiones subjetivas; los valores no son, porque los valores valen ${ }^{1632}$ : valen porque tienen valor, y porque en la primera categoría de la esfera ontológica, lo que tiene valor jamás es indiferente ${ }^{1633}$.

Independientemente de cualquier otra apreciación que pueda postularse, pienso que el principio esencial que ordena al jurista dirimir o presentar el derecho justo, es el que enfatiza que por los tiempos actuales, el derecho actual no puede ser analizado con independencia de los valores a los cuales responde ${ }^{1634}$. Por ello la construcción del ordenamiento jurídico se puede

\footnotetext{
${ }^{1628}$ Manuel GARCÍA MORENTE, ob. cit., p. 309.

${ }^{1629}$ Ibídem.

${ }^{1630}$ Ibídem.

${ }^{1631}$ Ibídem.

1632 Ídem, p. 310.

${ }^{1633}$ Ibídem, p. 311. La segunda categoría se la cualidad de los valores. Finalmente, se habla de la polaridad de los valores como tercera categoría de la esfera ontológica. Todos los valores tienen su contravalor, siempre existe un polo positivo y uno negativo. Por ello más adelante se refiere el autor: "Al valor conveniente, se contrapone el valor inconveniente (contravalor); $s$ bueno se contrapone malo; a generoso se contrapone mezquino; a bello se contrapone feo; a sublime se contrapone ridículo; a santo se contrapone profano. No hay, no puede haber, un solo valor que sea solo, sino que todo valor tiene su contravalor negativo o positivo".

${ }^{1634}$ Cfr. Jorge MOSSET ITURRASPE, Derecho civil constitucional, Rubinzal Culzoni, Santa Fe, 2.011, p. 64.
} 


\section{SEBASTIÁN JUSTO COSOLA}

únicamente realizar a través de la atención de sus fines en relación a la bondad o conveniencia de los principios y de las normas ${ }^{1635}$. Es que considerar la alocución de valores hace referencia a algo que sirve para fundar un sistema del derecho, con gran la mayor parte de las posiciones fundamentadas en el derecho natural, que vienen a ser utilizados con finalidad crítica y orientadora de la producción jurídica, indicando sus fines fundamentales ${ }^{1636}$. De esta manera los valores sirven para fundar decisiones o argumentos, y así, los mismos encuentran un límite axiológico en el campo de la validez material, o pueden conformar el contenido de los principios en el campo argumentativo, o con fines clasificatorios en sentido de categorización de objetos ${ }^{1637}$.

\subsubsection{Los valores que coexisten en el documento notarial.}

Me he referido entonces a los elementos de estructura, a sus características, a la descripción de la misma, a sus efectos y a la consolidación de los componentes del documento notarial. Pero se trata ahora de dar fundamento a la razón principal de este estudio, que posiciona al documento notarial por su especial singularidad-, como otro instituto de jerarquía y decisión jurídica que se suma a la lista de los que cuenta el derecho argentino actual. $\mathrm{Y}$ ello es así porque desde la propia esencia emergente del adecuado ejercicio de la función notarial, el documento se nutre de ciertos valores que lo convierten, lo transforman, lo erigen como un elemento del derecho también indispensable para el desarrollo de la vida jurídica. Valores que desde la filosofía jurídica plantean notables conflictos históricos y permanentes, y sin embargo, en el documento notarial logran convivir sanamente ocupando cada uno el lugar que le es correspondiente. Porque la propia actuación notarial modeladora del derecho desenvuelto en la normalidad los ubica documentalmente en armonía, logrando que los

${ }^{1635}$ Ibídem, p. 66.

1636 Cfr. Ricardo Luis LORENZETTI, Teoría de la decisión judicial. Fundamentos de derecho, Rubinzal Culzoni, Santa Fe, 2.006, p. 145.

${ }^{1637}$ Ibídem, p. 146. 
LOS EFECTOS DE LA PUBLICIDAD EN EL DOCUMENTO NOTARIAL

mismos no tengan otra alternativa que la convivencia pacífica y serena. Y porque además, están destinados a relacionarse precisamente porque los mismos son fundantes o esenciales del derecho notarial. De esta forma, fe (verdad), justicia y seguridad justifican la autenticidad interna del documento, y con ella, el valor intrínseco y extrínseco que del mismo se desprende. 
SEBASTIÁN JUSTO COSOLA

$\cdot 410$. 


\section{Capítulo 12.}

\section{Primer Valor: Fe pública.}

\subsubsection{Una introducción meramente conceptual.}

Referir anteriormente a la cuestión de la autenticidad es en cierta manera, hacer referencia clara y concreta tanto de la causa como de los efectos de la fe pública. El planteo de los efectos internos y externos del documento ha quedado ya consolidado en las líneas antecedentes, y en cierta manera, lo que aquí se desarrolla es el aspecto conceptual, precisamente para elevar la misma a la categoría de valor. Según lo que he referido, la fe pública tiene entonces una doble derivación que vuelve más rico y apasionante el estudio de su contenido. Por un lado, el aspecto objetivo, que viene a ponderar el valor que el ordenamiento jurídico otorga a ciertas realizaciones humanas realizadas por individuos investidos por el Estado para el acto de dación de fe. El derecho entonces reconoce que lo que a través de determinadas personas se percibe coetáneamente con la producción del hecho y que se vuelca en el documento -integridad y exactitud cómo notas de la fe-, tiene efectos de certeza. Es una presunción legal, de carácter absolutamente formal e imperativo, que no deja lugar a dudas que ciertos y determinados hechos para el derecho son prácticamente inalterables, tanto en su nacimiento como en su consolidación posterior a través del paso del tiempo. Pero por otro lado, el estudio del contenido de la fe pública implica el análisis de las cuestiones subjetivas, relacionadas con las virtudes del autor, que en última instancia -y admitida innegablemente la certeza-, vienen a justificar el valor de la verdad en el derecho. En este sentido, opino que en los tiempos actuales, con proliferación de teorías o tesis que advierten la 


\section{SEBASTIÁN JUSTO COSOLA}

notable y decisoria influencia de los valores y los principios en el derecho, un análisis de la fe pública que no comprenda las dos perspectivas de tutela efectiva (certeza y verdad) se presenta como insuficiente. De ahí que definitivamente, mientras que desde la valoración del principio de la autenticidad externa se destaque la fuerza de la certeza, el análisis de la autenticidad interna realizará una profundización de la potencia de la verdad.

Establecidos los alcances sustanciales de la fe pública en el presente estudio, puede comenzar por decirse que la primera aproximación a la fe pública nos posiciona frente al análisis iusfilosófico del derecho, ya que su planteamiento original considera cuestiones iniciales relacionadas con las creencias $^{1638}$. En nuestro país, la más fundada y prevaleciente noción de feinspirada en la ética y la moral- es aquella que le atribuye el sentido de creencia $^{1639}$.

Al notariado la dación de fe pública le resulta absolutamente indispensable. No hay ejercicio del notariado latino sin el imperio de la dación de fe aplicada por el hombre. ¿Qué sentido tendría entonces la función meramente asesora, sino tuviera como parte esencial integrante la función de brindar a su resultado el carácter de indudable? La fe pública se erige como un valor esencial en el desarrollo del documento.

Una cantidad verdaderamente apreciable de autores han promovido la idea que acepta que buena parte del fundamento del derecho notarial y con él, del documento como objeto esencial formal de protección, se encuentra en la noción de fe pública derivada del Estado ${ }^{1640}$. Referentes intelectuales como Eduardo Couture han sido por demás de elocuentes al momento de considerar la eficacia emergente de la autenticidad que el notariado brinda a la comunidad a través de su actuación relacionada con el imperio de dar fe; para él, la $f e$ pública es definitivamente el tema notarial por antonomasia ${ }^{1641}$, y de allí la firmeza de su recordada conclusión: "El

\footnotetext{
${ }_{1638}$ Sebastián Justo COSOLA, Los deberes éticos notariales, ob. cit., p. 279 y ss.

${ }^{1639}$ Argentino I. NERI, Tratado teórico y práctico de derecho notarial, T I, ob. cit., p. 375.

${ }^{1640}$ Carlos N. GATTARI, El objeto de la ciencia del derecho notarial, ob. cit., p. 109 y ss. En el extranjero: Arturo GALLARDO RUEDA, Fe pública y seguridad jurídica, INEJ- ADC, Madrid, 1.949, p. 5 y ss, y entre otros, Carlos E. BECERRA PALOMINO, El honor de dar fe. Ensayos de derecho notarial, ob. cit., p. 233 y ss.
} 


\section{LOS EFECTOS DE LA PUBLICIDAD EN EL DOCUMENTO NOTARIAL}

concepto que se tenga de la fe pública es el concepto que se tenga del derecho notarial ${ }^{1642 "}$.

Desde mi perspectiva, la noción de fe es además la garantía de eficacia de los otros valores trascendente del documento. Analizada desde la perspectiva axiológica -y mucho más allá de ser considerada como un mero tecnicismo documental intrínseco con implicancias extrínsecas-, la misma se erige como valor esencial que admite que la justicia y la seguridad jurídica alcancen, también en el documento, su máxima expresión ${ }^{1643}$. Siempre se ha expresado que técnicamente, la fe pública tiene un límite, y ese límite lo constituyen tanto la verdad ${ }^{1644}$ como también la responsabilidad notarial ${ }^{1645}$. Rufino Larraud lo expresaba claramente hace ya mucho tiempo ${ }^{1646}$, manifestando que el vocablo fe puede tener diferentes acepciones:

a) Creencia o confianza en algo no percibido por los sentidos pero que son aceptados por la autoridad de quien lo afirma;

b) Fe como seguridad o garantía que se brinda en cuanto a la afirmación que se hace acerca de la verdad fiel y exacta de algo, o

c) Fe como calidad o grado de eficacia ${ }^{1647}$.

${ }^{1641}$ Cfr. Eduardo J. COUTURE, La fe pública notarial, en Alberto VILLALBA WELSH y Daniel LARRIQUETA, Temas de Derecho Notarial, Publicación del Colegio de Escribanos de Mendoza, Buenos Aires, 1.948, p.15.

${ }^{1642}$ Eduardo J. COUTURE, El concepto de fe pública, ob. cit., p. 11.

${ }^{1643}$ Muy a pesar de que para el notariado la fe es un valor de indudable importancia, siempre he opinado que técnicamente considerada, la fe notarial no es diferente a la judicial, a la administrativa, a la fe legislativa y a la registral, ésta última, en lo pocos países que la adoptan. Entonces me pregunto si es la fe lo que da valor y vigor al documento, o si son los deberes éticos notariales aplicados los que, respaldados por la fe, brindan la certeza y la seguridad que emana del mismo. A lo mejor es tiempo de pensar que el valor lo otorga la autorización notarial del documento, y que la fe es la necesaria protección que se desprende, de manera histórica y natural del mismo. Precisamente porque en sede notarial, por la fuerza de la costumbre y mucho más que en ninguna otra institución, la fe es asimilada a la verdad.

${ }^{1644}$ Sebastián Justo COSOLA, Los deberes éticos notariales, ob. cit., p. 282.

${ }^{1645}$ Ibídem, p. 289.

${ }^{1646}$ Cfr. Rufino LARRAUD, La fe pública aun, Los anales del Notariado Argentino, $\mathrm{T}^{\circ} \mathrm{III}$, IACN, Buenos Aires, 1.965, p. 39.

${ }^{1647}$ Ibídem. 


\section{SEBASTIÁN JUSTO COSOLA}

Los tres casos, reconocen un elemento común: todos están vinculados a la idea de verdad, y por ello mismo puede afirmarse sin temor que la propia noción material y técnica de la fe constituye un valor, pero además conforma la posesión de la verdad y el impulso hacia ella ${ }^{1648}$.

\subsubsection{Las definiciones y los alcances.}

Un somero análisis del sustantivo $f e$ permite aceptar que quien fe tiene alberga una creencia, una convicción, una persuasión, una certeza o una confianza $^{1649}$. El concepto y el contenido de la fe es presentado desde los más variados matices, inclusive los estudios de la fe pública presentan interesantes conclusiones, muchas diferentes y dispersas entre sí. Pero importa destacar como lo han hecho los autores españoles, que en realidad, todas las formulas que se han venido presentando a lo largo de los años reconocen una virtual sinonimia: la fe pública trata la relación de verdad entre el hecho y el dicho ${ }^{1650}$. De ahí que se advierta que existe una $f e$ individual, relacionada con las creencias, las seguridades y la confianza de la persona en su individualidad ${ }^{1651}$, y la fe pública colectiva, que se presenta de dos maneras diferentes; una vulgar, que implica una creencia o convicción común por una suma de procesos intelectuales, y una jurídica, que supone la existencia de una verdad oficial cuya creencia es impuesta por un imperativo jurídico que obliga a tener por ciertos determinados hechos o acontecimientos y sobre los cuales no puede decidirse sobre su objetiva $v_{\text {verdad }}{ }^{1652}$. Esto también genera que puedan asumirse dos resultados diferentes frente a la dación de fe. Dar fe en sentido vulgar es una actitud pasiva tendiente a prestar crédito a lo que otra persona manifiesta; mientras

${ }^{1648}$ Cfr. Pedro J. BERTOLINO, La verdad jurídica objetiva, Depalma, Buenos Aires, 1.990, p. 36 .

${ }^{1649}$ Enrique GIMENEZ ARNAU, Derecho notarial español, Vol. I, ob. cit., p. 27.

${ }^{1650}$ Ídem, p. 28.

${ }^{1651}$ Ibídem.

${ }^{1652}$ Ídem, p. 29. 
que dar fe en sentido jurídico es una actitud positiva que equivale a un acto de atestiguación solemne ${ }^{1653}$.

La fe pública ha sido así conceptualizada en sentido relativamente amplio ${ }^{1654}$ como la creencia legalmente impuesta ${ }^{1655}$, en íntima y estrecha relación con:

a) La autoría que se desprende de ciertos objeto del tipo de los documentos públicos, monedas, sellos oficiales;

b) La autoría que se desprende de los actos públicos en general , como la sentencia judicial, el acto administrativo o la escritura pública; $\mathrm{y}$

c) La relación con el hecho de haber ocurrido un cierto acontecimiento o comportamiento, que de acuerdo a su importancia ha sido objeto de dación de fe por un notario, o un juez de paz, o un jefe de registro civil, entre otras personas.

En sentido más restringido, se ha considerado a la fe notarial como fe legitimada, poniendo de manifiesto que es la única fe pública regulada por norma legal ${ }^{1656}$. De esta forma puede considerarse la fe pública notarial como un atributo legal especial, que surge de la propia calidad funcional del mismo notario, relacionada íntimamente con lo que éste ha visto, ha oído y ha percibido por sus sentidos, atributo que lega, como principal consecuencia, la autenticidad que éste impone a los documentos que autoriza.

A las primeras manifestaciones desarrolladas, se suman otras posiciones interesantes para el desarrollo. Algunas ubican a la fe notarial dentro de un tríptico que consolida, conjuntamente con la fe de individualización y la tesis que niega naturaleza funcionalista al notario, los baluartes esenciales

\footnotetext{
${ }^{1653}$ Ibídem, p. 30

${ }^{1654}$ Etimológicamente, deriva de fides; indirectamente del griego rey0eiw (peitheio), es decir, yo persuado. Y pública quiere decir notoria, patente, manifiesta, que la ven o la saben todos. Etimológicamente, quiere decir "del pueblo" (populicum).

${ }^{1655}$ Mario Antonio ZINNY, El acto notarial (dación de fe), ob. cit., p. 75.

${ }^{1656}$ Carlos Nicolás GATTARI, Manual de derecho notarial, ob. cit., p. 299.
} 


\section{SEBASTIÁN JUSTO COSOLA}

de la función notarial ${ }^{1657}$. Desde estos estudios se afirma -en sintonía con otros similares ${ }^{1658}$ - que la fe pública es unitaria ${ }^{1659}$ personalísima $^{1660} \mathrm{e}$ indelegable ${ }^{1661}$, ya que jurídicamente supone la existencia de una verdad oficial cuya creencia se impone ${ }^{1662}$. De esta forma, la fe pública no es optativa, sino es imperativa ${ }^{1663}$. Por ello es que en definitiva, no es importante que el ciudadano alcance plena convicción acerca de la $f e$ pública, sino que simplemente hay que admitir que la misma es una imperiosa necesidad jurídica de la organización estatal que ineludiblemente debe obligar a tener como indubitables ciertos hechos que acaecen y algunas situaciones que se producen ${ }^{1664}$. Estos estudios y otros de similar envergadura ${ }^{1665}$ se esmeran por demostrar que la fuerza de la fe pública notarial radica en su origen legal ${ }^{1660}$, lo que permite aseverar que la certeza fedante es plena ${ }^{1667}$, frente a otras situaciones en donde puede existir función pública pero sin ejercicio de la fe pública ${ }^{1668}$. Por ello la fe pública jurídicamente considerada supone la existencia de una verdad oficial cuya creencia se impone ${ }^{1669}$.

Se complementa a lo antedicho la noción de fe asimilada a un poder que compete al escribano para dar vida a las relaciones jurídicas y para constituir sobre las mismas, la garantía de autenticidad ${ }^{1670}$ : esto es, fe pública notarial como resultado de la función de interpretación notarial y la configuración

\footnotetext{
${ }^{1657}$ Eduardo Bautista PONDÉ, Tríptico Notarial, ob. cit., p. 3.

${ }^{1658}$ Carlos Emérito GONZÁLEZ, Derecho Notarial, ob. cit., p. 210.

${ }^{1659}$ Eduardo Bautista PONDÉ, Tríptico Notarial, ob. cit., p. 27.

1660 Ídem, p. 47. Dice el autor: "El notariado, como "cuerpo", como corporación notarial, carece de fe pública. El notario, exclusivamente el notario en su individualidad, es quien la posee".

1661 Ídem, p. 77.

1662 Ídem, p. 29.

${ }^{1663}$ Ibídem, p. 30

${ }^{1664}$ Ibídem.

${ }^{1665}$ Rubén Augusto LAMBER, La escritura pública, T I, ob. cit., p. 17.

${ }^{1666}$ Eduardo Bautista PONDÉ, Tríptico Notarial, ob. cit., p. 70.

${ }^{1667}$ Ibídem, p. 69.

${ }^{1668}$ Ibídem, p. 70. Para el autor, la integración de una convención constituyente, un colegio electoral, ser el presidente de mesa de una mesa escrutadora en procesos electorales o efectuar tareas de censo, entre otras, constituyen funciones públicas sin que su actor asuma el carácter de funcionario público.

${ }^{1669}$ Adriana Nélida ABELLA, Derecho Notarial, ob. cit., p. 106.

${ }^{1670}$ Carlos Emérito GONZÁLEZ, Derecho Notarial, ob. cit., p. 208.
} 
LOS EFECTOS DE LA PUBLICIDAD EN EL DOCUMENTO NOTARIAL

inmediata de las voluntades al instrumento jurídico, que incluso resulta superior a la fe pública administrativa y especialmente a la fe pública judicial, que no capta en el expediente el espiritu de las voluntades que personalmente manifiestan las partes ante el notario ${ }^{1671}$. Con estas palabras lo asimila Carlos Emérito González: "El acto más maravilloso de la actuación notarial es cuando el escribano se siente verdadero representante de la fe, de la verdad, de lo justo, de lo equitativo, que es también verdad del derecho que llamaríamos puro y lo pone al servicio de la colectividad ${ }^{1672, "}$ La fe notarial, fundamento filosófico y jurídico del instrumento público, es en definitiva una orden legislativa que dirige al juez a respetar la valoración legal de un documento público ${ }^{1673}$.

\subsubsection{Las opiniones extranjeras.}

Si bien es cierto que la valoración técnica de la fe pública es similar en todos los países que profesan el notariado latino, algunas posiciones extranjeras resultan ser por demás de interesantes, precisamente porque los ángulos de desarrollo del instituto emergen de valoraciones totalmente diferentes. Como lo hemos advertido hasta aquí, la fe notarial en nuestro país tiene una notable relación con el contenido del documento. Si bien es el notario el que la aplica y la concreta con su actuación, las valoraciones generales tienden a posicionar, por sobre todas las cosas, su valor dentro del documento y con los efectos propios que genera a partir de la autorización del mismo.

La clásica doctrina española de derecho notarial advierte por el contrario y sin reparo alguno, que la fe pública es y debe ser analizada como doctrina o fuente directa de la función notarial y no tanto como valor o cualidad esencial del instrumento. $\mathrm{Y}$ siempre se destaca en su tratamiento, que la misma es necesaria e impuesta para contribuir a la realización normal del derecho como uno de los fines del Estado. De las aseveraciones de Giménez

\footnotetext{
${ }^{1671}$ Ibídem, p. 209.

1672 Ibídem.

${ }^{1673}$ Natalio Pedro ETCHEGARAY y Vanina Leila CAPURRO, Derecho notarial aplicado, ob. cit., p. 29.
} 


\section{SEBASTIÁN JUSTO COSOLA}

Arnau puede concluirse de la manera más clara y concreta que los fundamentos primarios de la fe pública radican en la imperiosa necesidad del grupo social que desarrolla en su seno múltiples relaciones que deben llegar a resultados pacíficos ${ }^{1674}$. En razón de ello es que debe suponerse la instauración de ciertos actos de autoridad y obediencia, de libre comunicación entre los componentes ${ }^{1675}$. Antonio Bellver Cano utiliza la fuerza de la dación de fe para considerar las facultades jurisdiccionales del notariado ${ }^{1676}$. Teniendo en cuenta que la más general facultad del notariado es legitimar, deben tenerse en cuenta en su análisis cuatro aspectos esenciales: el formativo (consejo), el conformativo o formulista (redacción), el fijativo (la constatación) y el sancionador (autorización documental) ${ }^{1677}$. La dación de fe se encuentra en los dos últimos aspectos, de esta manera el acto se vuelve verdadero, fehaciente, válido y eficaz ${ }^{1678}$. Según Otero y Valentín, la fe notarial es un resultado de evolución que surge desde la función hacia la escritura pública, por cuanto se confía a peritos en el arte, cultos o prudentes dando fe de lo notorio y de la bondad de lo que frente a él se ha relatado ${ }^{1679}$. González Palomino en cambio, describe con precisión que el acto de dación de fe es complejo, y se compone de elementos psíquicos, elementos lógicos y objetos reales ${ }^{1680}$. Así, el acto de fe diferencia el acto por un lado y el objeto por el otro ${ }^{1681}$. Es intencional desde lo psíquico; y recae sobre un objeto determinado que no tiene un carácter evidente ${ }^{1682}$. La fe pública se fundamenta en la necesidad de que las personas necesitan creer en ciertos actos para que los mismos sean cumplidos y respetados ${ }^{1683}$, y el

\footnotetext{
${ }_{1674}$ Enrique GIMENEZ ARNAU, Introducción al derecho notarial, ob. cit., p. 27.

1675 Ídem, p. 28.

${ }^{1676}$ Antonio BELLVER CANO, Régimen notarial comparado, ob. cit., p. 27.

1677 Ibídem.

${ }^{1678}$ Ídem, p. 28.

1679 Julio OTERO Y VALENTÍN, Sistema de la función notarial, ob. cit., p. 72.

${ }^{1680}$ José GONZÁLEZ PALOMINO, Instituciones de derecho notarial, t ${ }^{\circ}$ I, ob. cit., p. 60.

${ }^{1681}$ Ibídem.

${ }^{1682}$ Ibídem, p. 61. Dice el autor: “ (...)La evidencia es la presencia integral del objeto ante mí, en mi intuición intelectual, en toda su integridad, sin faltarle nada, sin velos que oculten su estructura intima: conocerlo plenamente, tal cual es, de suerte que no puedo concebir como posible que el objeto no sea y no sea precisamente lo que es. Asentir al objeto evidente, parece un acto inevitable. Aunque yo quisiera no podría dejar de verificarlo".

${ }^{1683}$ Ídem, p. 62.
} 
acto jurídico autorizado con fe, se transforma en acto auténtico ${ }^{1684}$. La fe pública notarial entonces, consiste en la certeza y eficacia que brinda el poder público a los actos y contratos privados por medio del acto de autenticación notarial, en donde actúan los notarios, testigos públicos frente a las posiciones que los hombres realizan y mantienen entre $s i^{1685}$. Sin duda alguna, los actos de fe son indispensables para la vida; pero la fe pública no rige legalmente para estimular a los mismos, sino que sirve para atribuir consecuencias de eficacia ${ }^{1686}$, ya que la vida social sería imposible sin una serie de supuestos legales previos, fijos e indiscutibles ${ }^{1687}$.

Ya un tiempo antes, Sanahuja advertía de antemano que la fe pública es garantía de certidumbre y garantía de legalidad ${ }^{1688}$, obedeciendo a la necesidad general de toda prueba ${ }^{1689}$. La fe notarial debe operar sobre el hecho, y resulta fundamental determinar la propia naturaleza del hecho mismo $^{1690}$, a partir del cumplimiento de cuatro fases que son: a) la norma jurídica, b) el hecho condicionante, c) el hecho condicionado y d) la ejecución ${ }^{1691}$. Así se constituye la función notarial como esencialmente autenticadora de hechos ${ }^{1692}$ apoyada por la fe pública que con distintos grados de desenvolvimiento persigue la clara finalidad de evitar cuestiones litigiosas ${ }^{1693}$. Desde la fe pública entonces puede permitirse hablar de función autenticadora notarial ${ }^{1694}$. Como también lo sostiene Escobar de la Riva, el acto jurídico autorizado con fe pública se tiene por auténtico, palabra esta ultima que significa lo cierto, lo verdadero, lo que ha de ser creído, lo que es fidedigno debiendo consecuentemente afirmarse su certeza ${ }^{1695}$.

\footnotetext{
${ }^{1684}$ Ibídem.

${ }^{1685}$ Ibídem, p. 63.

1686 Ídem, p. 64.

${ }^{1687}$ Ibídem.

${ }^{1688}$ José María SANAHUJA y SOLER, Tratado de derecho notarial, T ${ }^{\circ}$ I, ob. cit., p. 15 y ss.

${ }^{1689}$ Ibídem, p. 17.

${ }^{1690}$ Ibídem, p. 18.

${ }^{1691}$ Ibídem, p. 19.

1692 Ídem, p. 21.

${ }^{1693}$ Ibídem, p. 22.

${ }^{1694}$ Ibídem, p. 27.

${ }^{1695}$ Eloy ESCOBAR DE LA RIVA, Tratado de derecho notarial, ob. cit., p. 26.
} 


\section{SEBASTIÁN JUSTO COSOLA}

En definitiva, desde la función notarial, el instrumento público se diferencia de otros documentos públicos porque se advierte que la fe pública notarial tiene efectos en dos estratos:

a) El de los hechos como manifestación de la realidad y

b) En la del derecho como manifestación de la legalidad ${ }^{1696}$.

Así, la misma presenta una doble eficacia, que parte desde la dación de fe, impactando en la esfera de la verdad y en la esfera de la legalidad ${ }^{1697}$. En la esfera de la verdad, sostiene Núñez Lagos, la existencia del instrumento con fe pública subsistirá hasta una probada declaración de falsedad ${ }^{1698}$, mientras que en la esfera de la legalidad el acto notarial será valido juris tantum hasta que sea declarada su nulidad; nulidad que no afecta a los hechos, sino a las calificaciones que hace el notario como funcionario técnico ${ }^{1699}$.

Desde estas orientaciones podemos seguir definiendo la fe pública, de acuerdo a la concepción de diversos autores hispanos, incluso con algunas que no se compadecen con las propuestas mencionadas ${ }^{1700}$. Podría también extenderse el tratamiento de la misma a sus relaciones con el principio de la buena fe, o considerar el alcance de la plena fe en materia de redargución de falsedad. No es esa la necesidad que tengo en este tiempo. Lo que pretendo es destacar que la fe pública como primer valor del documento es, una consecuencia de la necesidad estatal de imponer una especie de certidumbre de forma coactiva, impuesta ${ }^{1701}$, que contribuye al desarrollo del derecho en paz. El pueblo cree, por que el Estado, dice Couture, le manda a creer; pero no se manda a creer por medio de la autoridad, sino por medio de la ley ${ }^{1702}$. En este mismo sentido, bien vale la pena recordar las conclusiones de la

${ }^{1696}$ Cfr. Rafael NÚÑEZ LAGOS, Estudios sobre el valor jurídico del documento notarial, Academia Matritense del Notariado, Alcalá de Henares, 1.945, p. 68.Ibídem.

${ }^{1697}$ Ibídem.

${ }^{1698}$ Ibídem, p. 69

1699 Ídem, p. 72.

${ }^{1700}$ Así, Esteban AZPEITIA: "La fe pública no es convicción ni creencia sino imposición que coactivamente obliga a todos para estimar con autenticidad y verdad oficial lo que ella ampara", en la obra Legislación Notarial referida por los autores españoles en general, sin cita específica.

${ }^{1701}$ José María SANAHUJA Y SOLER, Tratado de derecho notaria, $\mathrm{t}^{\circ} \mathrm{I}$, ob. cit., p.15. 


\section{LOS EFECTOS DE LA PUBLICIDAD EN EL DOCUMENTO NOTARIAL}

comisión primera de las XIII Jornadas Nacionales de Derecho Civil, organizadas por la Universidad Notarial Argentina, que en relación al tema El documento notarial: su valor probatorio, proyectó la siguiente declaración: "Fe pública es creencia impuesta por la ley. En cuanto tal, ella sujeta a todo el mundo, incluido el juez, a creer en la autenticidad del documento y en la veracidad del notario. O lo que es igual, que puestas las partes, los terceros o el juez ante el documento notarial debe considerarse probado: a) que el documento es obra del notario; b) que lo narrado por el notario ha tenido lugar donde, cuando y como éste lo narra (Código Civil, art. 993) ${ }^{1703}$, .

\subsubsection{Cuestiones técnicas inherentes a la fe pública: Las notas.}

Rafael Núñez Lagos es quien entre nosotros plantea la primera referencia tanto a las notas $^{1704}$ como a las fases ${ }^{1705}$ de la fe pública, y similar orientación siguen los autores en general a partir de los aportes del recordado maestro español ${ }^{1706}$.

Las notas de la fe pública -también denominadas caracteres- son dos: la exactitud y la integridad.

${ }^{1702}$ Dice Antonio RODRIGUEZ ADRADOS al momento de separar las palabras fe y pública para su análisis individual: "Y mas erróneo sería, tomando en otro sentido el adjetivo pública, el pensar que aquella creencia pudiera ser impuesta por la autoridad pública". V. $\mathrm{Fe}$ pública, en Escritos Jurídicos, $\mathrm{t}^{\circ}$ II, CGA, Madrid, 1.996, p. 175. En igual sentido Argentino I. NERI: "La fe pública, en una palabra, es una evidencia de sentido común; por dimanar de la experiencia, su legitimidad ha sido reconocida por el estado e impuesta como "expresión legal" de garantía, de manera de cuño, para imprimir la verdad oficial a la instrumentación pública", en Tratado teórico y práctico..., t ${ }^{\circ}$ I, ob. cit., p. 376.

${ }^{1703}$ Libro Congresos y jornadas nacionales de derecho civil, ob. cit., p. 107.

${ }^{1704}$ Cfr. Rafael NUÑEZ LAGOS, Fe Pública, en Sebastián Justo COSOLA (Comp/Est. Prel.), Colección Biblioteca Notarial n 3, Lima, 2.013, p. 294.

${ }^{1705}$ Ibídem, p. 272 y ss.

${ }^{1706}$ Natalio Pedro ETCHEGARAY y Vanina Leila CAPURRO, Derecho notarial aplicado, ob. cit., p. 30 y ss. En este aporte -una de las últimas obras teóricas del derecho notarial- se brinda relevante tratamiento al tema en referencia, lo que implica considerar no solo la importancia, sino la llamativa actualidad de los conceptos mencionados. 


\section{SEBASTIÁN JUSTO COSOLA}

La exactitud es el hecho histórico en tiempo presente, la imagen en su actualidad, la total adecuación de la narración al hecho (identidad entre el actum y el dictum) ${ }^{1707}$. La misma se da en una dimensión acto (referida a la duración del acto solemne y funcionarista) y en la dimensión papel (referida a la mencionada adecuación de la narración al hecho que acontece) $)^{1708}$. Los efectos de la exactitud son erga omnes, porque la fe pública es absoluta; no ocurre únicamente interpartes, aunque el instrumento público no se presuma conocido por todos y no genere de por sí, fuerza obligatoria en las personas ajenas a su celebración, que podrían eventualmente alegar la ignorancia excusable. Aun así, quien tiene posibilidad de conocer el documento no puede negarle la fuerza probatoria ${ }^{1709}$.

La integridad en cambio, es la exactitud proyectada hacia el futuro ${ }^{1710}$, porque la narración plasmada en el documento fija un tiempo y un lugar determinadores de la fuerza probatoria de los que no supieron o no advirtieron su creación ${ }^{1711}$. Dicen los autores que la integridad es la estatua o la piedra inmóvil de la fe pública ${ }^{1712}$. Desde la integridad surgen los primeros tratamientos del documento como producto corporal, contenedor en su seno de valoraciones oficiales, referidas a los hechos o menciones auténticas que expresan actos propios del escribano o de actos ajenos pero que ocurren frente al mismo, y las valoraciones testimoniales, en referencia a las declaraciones de las partes ${ }^{1713}$. Comúnmente, la doctrina nacional da curso al tratamiento de esta temática al considerar las manifestaciones auténticas y las manifestaciones autenticadas en el documento notarial, en versión

\footnotetext{
${ }^{1707}$ Ibídem. También en Rafael NUÑEZ LAGOS, Fe pública, ob. cit., p. 294. Agregan los autores que la exactitud puede ser de dos clases: a) Natural, referida a la narración completa de un hecho que ocurre en determinados límites de tiempo, esto es, unidad de acto o tiempo de presencia funcionarista, y b) Funcional, ceñida a un hecho determinado que interesa al asunto, como las circunstancias de determinado acto o una inscripción. Es el hecho o acto que ocurre frente a la presencia del funcionario, que es lo que se conoce como unidad de acto.

${ }^{1708}$ Rafael NUÑEZ LAGOS, Fe pública, ob. cit., ps. 294-295.

${ }^{1709}$ Ibídem, p. 296.

${ }^{1710}$ Ibídem.

${ }^{1711}$ Natalio Pedro ETCHEGARAY y Vanina Leila CAPURRO, Derecho notarial aplicado, ob. cit. p. 30.

${ }^{1712}$ Ibídem, p. 31; Rafael NUÑEZ LAGOS, Fe pública, ob. cit., p. 296.

${ }^{1713}$ Rafael NUÑEZ LAGOS, Fe pública, ob. cit., p. 297 y ss.
} 
omnicomprensiva de esos y de muchos otros conceptos escriturales de relevancia ${ }^{1714}$.

\subsubsection{Cuestiones técnicas inherentes a la fe pública (II):}

\section{Las fases.}

Las fases -o requisitos- de la fe pública están dirigidas al documento notarial $^{1715}$; son el medio para dar a las constancias allí contenidas la $f e$ pública correspondiente en virtud del cumplimiento de ciertos pasos de manera armónica, coetánea y sucesiva en la conformación de las declaraciones y hechos que se vierten en su mismo seno ${ }^{1716}$. Así, existen:

a) Una fase de evidencia, que comienza por afirmar que el autor del documento no tiene acto de fe, sino de conocimiento directo. Desde el autor la fe dimana hacia el destinatario, ya que el mismo recibe el acto y da fe de él. Consecuentemente el destinatario no recibe el acto, sino la fe $e^{1717}$.

b) Una fase de solemnidad, que implica que el acto debe reunir las solemnidades exigidas por la ley para adquirir fe pública -es el rigor formal de la fe pública ${ }^{1718}$-;

c) Una fase de objetivación, referida a que el hecho percibido debe materializarse -la dimensión acto debe alcanzar la objetivación en la dimensión papel-. Se emancipa la fe pública de su autor, y alcanza corporalidad a través de la fe escrita, en relación con los supuestos

\footnotetext{
${ }^{1714}$ Pablo Alejandro CARRICA, Derecho documental..., ob. cit., p. 51.

${ }^{1715}$ Rafael NUÑEZ LAGOS, Fe pública, ob. cit., p. 272.

${ }^{1716}$ Natalio Pedro ETCHEGARAY y Vanina Leila CAPURRO, Derecho notarial aplicado, ob. cit. p. 31.

${ }^{1717}$ Ibídem; Rafael NUÑEZ LAGOS, Fe pública, ob. cit., p. 272.

${ }_{1718}$ Natalio Pedro ETCHEGARAY y Vanina Leila CAPURRO, Derecho notarial aplicado, ob. cit. p. 31; Rafael NUÑEZ LAGOS, Fe pública, ob. cit., p. 273.
} 
de grafía que hemos ya analizado, destinada a permanecer como hecho o documento auténtico ${ }^{1719}$.

d) Una fase de coetaneidad: las tres fases anteriores deben ocurrir al mismo tiempo, dando lugar a la unidad de acto ${ }^{1720}$ o unidad de acto formal $^{1721}$.

12.1.4. Función elemental (legal y axiológica) de la fe pública notarial. La remisión constitucional.

La fe pública notarial tiene, según se ha expresado, una enorme misión preventiva de profilaxis jurídica ${ }^{1722}$. Función de preparación y elaboración de la prueba preconstituída es lo que la caracteriza ${ }^{1723}$, dándole al concepto de autenticidad su máxima expresión de valoración. Por cuanto lo auténtico se relaciona con la exactitud y la verdad, la autenticidad jurídica es una virtud que el legislador otorga al documento notarial una vez firmado y sellado por el notario, investido de facultades especiales, que imprime al mismo con una gran presunción de equidad y de efectos ejecutivos ${ }^{1724}$. El valor jurídico de la autenticidad proviene desde las normas y los preceptos constitucionales, de las normas del código único y de todo tipo de norma inferior que permita visualizar a través de sus fines, el imperio de la dación de fe. Desde la apreciación de Bartolomé Fiorini, existe un método constitucional que a través de las normas y los principios dirige la labor del pensamiento en la búsqueda de lo cierto fundamentado sobre un determinado presupuesto causal $^{1725}$, y ese es el que debe imperar al analizar la fuerza de la fe en los

\footnotetext{
1719 Ibídem.

${ }^{1720}$ Rafael NUÑEZ LAGOS, Fe pública, ob. cit., p. 274.

${ }^{1721}$ Natalio Pedro ETCHEGARAY y Vanina Leila CAPURRO, Derecho notarial aplicado, ob. cit. p. 32.

${ }^{1722}$ Enrique GIMENEZ ARNAU, Derecho notarial español, Vol. I, ob. cit., p. 39.

${ }^{1723}$ Ibídem, p. 40.

${ }^{1724}$ Ibídem.
} 


\section{LOS EFECTOS DE LA PUBLICIDAD EN EL DOCUMENTO NOTARIAL}

instrumentos públicos, que nacen a la vida como una superación de garantía de la prueba escrita... que había nacido para superar el olvido ${ }^{1726}$. Por ello es que en esta materia, el principio de reserva constitucional que ordena que ningún habitante de la Nación está obligado a hacer lo que la ley no manda, ni privado de lo que ella no prohibe, es una norma preceptiva y prohibitiva de conducta integral dirigida tanto a los ciudadanos como también a los órganos del Estado -y consecuentemente, a los actos estatales, leyes, sentencias, actos administrativos-. Asimismo, se valora el respeto por la libertad y los derechos humanos sobre la idea de una protección y tutela igualitaria, teniendo en cuenta la jerarquía de la norma primaria por sobre las demás leyes de rangos inferiores ${ }^{1727}$.

\subsubsection{Recepción de la fe pública en el Código Civil y Comercial} de La Nación.

El Código Civil y Comercial de La Nación resguarda la consecuencia de la aplicación de la fe pública: el principio de autenticidad de los instrumentos públicos $^{1728}$. El hombre no cree en los instrumentos o escrituras por nada más que porque así se le ordena creer: es el imperio de la fe pública, una creencia legalmente impuesta. De esta manera, la referencia a la autenticidad, es en definitiva, una remisión al valor probatorio del instrumento público, ya que el mismo goza indudablemente de la presunción de autenticidad que merece la actuación del oficial público interviniente, abonada por su firma y sello ${ }^{1729}$. El instrumento público, -a diferencia del

1725 Cfr. Bartolomé FIORINI, Acto administrativo e instrumento público. El método constitucional, RJLL, $\mathrm{t}^{\circ}$ 146, Buenos Aires, 1.972, p. 1018.

1726 Ídem, p. 1019.

${ }^{1727}$ Ibídem.

${ }^{1728}$ Art. 296 del CCCN. El articulo guarda relación directa con el Código Civil de Vélez en los artículos 993, 994 y 995 respectivamente y notable similitud con el art. 272 del Proyecto de Unificación de 1998, aunque con algunas diferencias en la redacción.

${ }^{1729}$ Jorge Joaquín LLAMBÍAS, Tratado de derecho civil-Parte General, to II, ob. cit., p. 443. Esto vuelve relevante la denominación de documento notarial autentico que ofrecí al inicio 


\section{SEBASTIÁN JUSTO COSOLA}

particular y del privado-, se prueba per se; se prueba a sí mismo. Una serie de signos exteriores fácilmente identificables -timbres, sellos, firma del autorizante- son presuntivamente suficientes para estar a lo que resulta del documento ${ }^{1730}$. Si el documento notarial se exhibe como regular en cuanto a sus formas, el mismo se presume auténtico, y toda vez que la ley presume la autenticidad del instrumento considerado en sí mismo, releva a la parte que lo presenta de probar su autenticidad ${ }^{1731}$.

En general, la doctrina llega a la convicción que el fundamento de la dación de fe no radica en la percepción del oficial, sino en las necesidades del tráfico jurídico que conlleva directamente al amparo de la seguridad jurídica $^{1732}$. Sin embargo y tal cual lo he dejado expuesto en el cuerpo de esta tesis, me permito insistir nuevamente en que desde mi perspectiva, la sola referencia a la atribución legal no es en los tiempos actuales, enteramente suficiente. Definitivamente hace falta además otra tutela jurídica del derecho documental, que ocurre a partir de la creación de un elemento decisorio fidedigno que nace en manos de un profesional del derecho que cuenta con determinadas virtudes que desde un aspecto axiológico brinda mayor fuerza, vigor y certeza a los hechos que percibe y de los que da fe. La suma de los dos criterios exigidos para la dación de fe -los objetivos y los subjetivos- es lo que alcanza la excelencia en los efectos -y la eficacia general- del documento notarial ${ }^{1733}$.

del tratamiento del documento notarial, esquivando así las perspectivas clasificatorias que no hacen más que confundir los alcances de la mencionada fe.

${ }^{1730}$ Jorge Joaquín LLAMBÍAS, Tratado de derecho civil-Parte General, $\mathrm{t}^{\circ}$ II, ob. cit., p. 443.

${ }^{1731}$ Julio César RIVERA, Instituciones de derecho civil, t ${ }^{\circ}$ II, ob. cit., p. 435. Y sobre esto, el civilista argentino afirma: "La fe pública es concebida como un bien social porque es necesario para la seguridad jurídica que haya un instrumento que merezca tal fe por si mismo, sin necesidad de verificación posterior alguna. De alli que el derecho penal sancione severamente a quien adultera un instrumento público, máxime si es el funcionario encargado de otorgarlo"

${ }^{1732}$ José María ORELLE, De los instrumentos públicos ..., ob. cit., p. 548 y ss.

${ }^{1733}$ Las virtudes del autor del documento se exigen objetivamente a través del pedido del acta de conducta al momento de ingresar a la función notarial. 
LOS EFECTOS DE LA PUBLICIDAD EN EL DOCUMENTO NOTARIAL

12.1.5.1. Los alcances relativos a la plena fe del instrumento.

En el Código Civil y Comercial de La Nación, el instrumento público hace plena fe:

a) En cuanto a que se ha realizado el acto, la fecha, el lugar y los hechos que el oficial publico enuncia como cumplidos por el o ante él hasta que sea declarado falso en juicio civil o criminal.

Hacen plena fe los instrumentos públicos de casos puntuales ya harto vistos y analizados por la doctrina mayoritaria: realización del acto, fecha y lugar. Por su parte, la enunciación de los hechos que el oficial público enuncia como por él cumplidos o que ante él han ocurrido o se han desarrollado, también hacen plena fe por cuanto es su propia investidura lo que permite que el valor probatorio sea verdaderamente fuerte y relevante ${ }^{1734}$. En derecho nacional se enseña que la propia naturaleza de la función fedante marca la necesidad de esta primera fase, y por eso con razón se afirma que la dación de fe requiere de un soporte factico, un objeto; se da fe de algo, ese algo es un hecho, y éste debe ser percibido por el sujeto fedante ${ }^{1735}$. Sobre esto, también se argumenta que se habla de la dación de fe perceptible por los cinco sentidos, y no solamente por los más comunes, que son la vista y el oído, por lo que no deben restringirse las percepciones sensoriales ${ }^{1736}$. Estos actos, como así también en todos aquellos que reúnan los mencionados criterios, para ser negados, deben ser redargüidos de falso por acción civil o criminal.

\footnotetext{
${ }^{1734}$ Siempre que se expresa esto último, se hace especial referencia a la materialidad de los actos cumplidos en por él mismo o en presencia del oficial, y no de la sinceridad que a dichos acto corresponde.

${ }^{1735}$ José Carlos CARMINIO CASTAGNO, Teoría general del acto notarial y otros estudios, $\mathrm{t}^{\circ}$ I, ob. cit., p. 118 y cc.

${ }^{1736}$ José María ORELLE, De los instrumentos públicos ..., ob. cit., p. 549.
} 


\section{SEBASTIÁN JUSTO COSOLA}

b) En cuanto al contenido de las declaraciones sobre convenciones, disposiciones, pagos, reconocimientos y enunciaciones de hechos directamente relacionados con el objeto principal del acto instrumentado, hasta que se produzca prueba en contrario.

En los instrumentos públicos deben distinguirse las declaraciones auténticas de las autenticadas ${ }^{1737}$. Las auténticas, que son las que emite el oficial, escribano, notario o funcionario público hacen plena fe hasta que sean redargüidas de falso, siempre recordando que temas elementales, como los juicios notariales de capacidad se encuentran excluidos lógicamente del alcance de la $\mathrm{fe}^{1738}$. Las otras declaraciones, denominadas comúnmente autenticadas, son aquellas que tienen valor en el instrumento, pero que no necesitan ser redargüidas de falsas, precisamente porque son las manifestadas por personas que no tienen el don indelegable de la dación de fe. Las declaraciones de las partes acerca de las convenciones, disposiciones, pagos, reconocimientos y enunciaciones de hechos relacionados con el objeto principal del acto instrumentado, caerán por cualquier prueba en contrario. Objeto de la fe pública es el hecho perceptible del oficial de decir que ante el declararon, ante él se expresaron, ante él manifestaron. Pero la plena fe que emana del instrumento público no ampara la sinceridad de lo manifestado por los intervinientes en el instrumento ${ }^{1739}$.

\footnotetext{
1737 "Corresponde diferenciar la existencia material de los hechos que el escribano anuncia como cumplidos por él y sucedidos en su presencia, de las manifestaciones de las partes. Las declaraciones falsas por dolo, violencia, error, reserva mental o simulación, pueden conducir a la nulidad del negocio, pero no dan lugar al incidente de redargución de falsedad. El instrumento no puede declararse falso para las partes y verdadero para el escribano y compradores, por lo que la sentencia de falsedad hace cosa juzgada para todos" CNCiv, Sala H., 14/07/2000, La Ley, 2000-E, 613.

1738 "Si lo que se cuestiona es el estado mental del poderdante y no su capacidad civil, no se está ante uno de los supuestos amparados por la buena fe, ya que la declaración de que el otorgante está en su perfecta razón, no es hecho comprobado por el oficial publico" CNCiv, Sala D, 14/11/1989, ED, 139-130.

${ }^{1739}$ El presente punto merecería además un tratamiento de la falsedad, la diferencia sustancial que existe con la falsificación, la división de la primera en material e ideológica con todos los supuestos para analizar, las diferencias con los actos simulados, la relación con el código penal vigente a partir del artículo 292 del citado cuerpo legal y al menos una descripción del procedimiento de falsedad, todos temas que se omiten, muy lamentablemente, en aras a alcanzar el objetivo propuesto en el inicio del presente capítulo.
} 
LOS EFECTOS DE LA PUBLICIDAD EN EL DOCUMENTO NOTARIAL

12.1.5.2. La cuestión de la incolumidad formal.

Según ya también lo he referido, la misma es una especie de garantía de fe que se ha querido asignar al instrumento, y que consiste en el impedimento exigido por la ley para que el oficial público y los testigos puedan contradecir las constancias obrantes en el documento ${ }^{1740}$. En el Código Civil y Comercial de la Nación no está permitida la deposición del oficial o funcionario ni la de los testigos contra el instrumento ${ }^{1741}$, con el fin de resguardar la seguridad del instrumento legítimamente creado. La doctrina mayoritaria coincide con estas apreciaciones.

\subsubsection{La figura del contradocumento.}

Los autores en general remiten el tratamiento del presente artículo al desarrollo de la simulación. En nuestro país, la figura del contradocumento tiene una connotación negativa, muy a pesar de estar previsto en un código de leyes que hace presumir, por sobre todas las cosas, la bondad y la legitimidad de su articulado. Recordemos que sin dudas la simulación constituye un vicio de los actos o negocios jurídicos, ya que es en definitiva un defecto de buena $\mathrm{fe}^{1742}$. Pero también debe advertirse que existe la simulación licita, a la que se puede recurrir en determinadas circunstancias, para obtener de su aplicación un mejor resultado, tendiente a asegurar la voluntad y mas que ello, la verdadera intención de las partes al realizar un acto, la bonificación y seguridad en la circulación de títulos, documentos o instrumentos varios. En efecto, la simulación no es reprobada por la ley cuando a nadie perjudica ni tiene un fin ilícito. En este sentido, el contradocumento opera como prueba de la simulación, entendiendo por tal

1740 Jorge Joaquín LLAMBÍAS, Tratado de Derecho Civil-Parte General, t ${ }^{\circ}$ II, ob. cit., p. 444-445.

${ }^{1741}$ Conf. Art. 297 CCCN.

1742 Julio César RIVERA, Instituciones de derecho civil..., t II, ob. cit., p. 619. 


\section{SEBASTIÁN JUSTO COSOLA}

la constancia escrita del verdadero carácter del acto simulado ${ }^{1743}$. Si el principio es que la simulación licita a nadie afecta, puede tranquilamente admitirse en su faz documental que viene a alterar lo expresado en un instrumento público, ahora este principio tiene un límite impuesto más que por la ley, por el propio derecho: el daño a terceros interesados -los que verdaderamente tienen interés legitimo- de buena $\mathrm{fe}^{1744}$.

\subsubsection{La fe notarial, su eficacia y las expectativas sociales.}

Frente a las expectativas sociales, la fe no es más que un instrumento técnico profesional que entre tantos otros de importancia también notoria, sirven para garantizar la perdurabilidad, certeza, confianza y verdad contenida en un documento que de por sí, ya materialmente, transmite la seguridad jurídica con la sola exhibición (fuerza cartular extrínseca). Esto siempre ha sido así: los autores en su total generalidad comparten la idea que es más sencillo advertir los orígenes de la fe notarial en Alemania y los países longobardos que en el propio derecho romano, de cuya desmembración surgió la fe laica y la fe eclesiástica notarial entre otras divisiones relevantes. Pero siempre aceptando que la dación de fe al notario le es indispensable, y además, conforma una característica histórica esencial en la actividad notarial ${ }^{1745}$.

Es así entonces que la fe pública notarial se encuentra íntimamente relacionada con la cuestión de la eficacia del documento. Eficacia que se encuentra socialmente consolidada -en general no suele generar duda alguna el contenido de una escritura- y que sirve para justificar además el argumento relativo a la paz jurídica. Si no hay errores y no hay dudas del

${ }^{1743}$ Jorge Joaquín LLAMBÍAS, Tratado de Derecho Civil-Parte General, t ${ }^{\circ}$ II, ob. cit., p. 526.

${ }^{1744}$ Para la noción de terceros interesados, puede recurrirse a la comprensión analógica que emerge, entre tantas otras, de los artículos 2505 y 3135 del Código Civil de Vélez, y de la necesariamente armoniosa- interpretación de los artículos 20 y 21 de la ley registral $17801 / 68$.

${ }^{1745}$ Eduardo B. PONDÉ, Origen e historia del notariado, ob.cit., p. 133 y ss. 


\section{LOS EFECTOS DE LA PUBLICIDAD EN EL DOCUMENTO NOTARIAL}

contenido documental, es materialmente imposible que se genere un conflicto. Por ello es indispensable que el notario haga de la fe la mejor aplicación que le sea posible, cumpliendo con las significaciones relativas a la verdad y a lo verdadero tal cual fueran aquí expuestas.

La eficacia jurídica del documento es ciertamente considerada como un valor de indudable jerarquía, que en dirección objetiva y en última instancia pretende solidificar los efectos jurídicos de una determinada figura o institución ${ }^{1746}$. También la eficacia jurídica presenta una valoración subjetiva, que el tema central en el que debe centrarse lo que yo denomino sociología del derecho notarial, que en lo que en definitiva viene a demostrar que siempre existe una valoración social general sobre los documentos en sus diversas especies, y en lo que a este estudio importa, sobre los documentos notariales ${ }^{1747}$.

\subsubsection{La sociología del derecho notarial.}

Una de las últimas publicaciones de Theodor W. Adorno ubica a la sociología como una ciencia positiva, una ciencia particular de lo social, que se refiere tanto al concepto de sociedad y los hechos sociales, como a las interrelaciones sociales que ocurren dentro de esa misma sociedad ${ }^{1748}$. Se refiere el autor entonces a una reflexión teórica sobre la sociedad y sobre la esencia de la socialización ${ }^{1749}$, que luego irá acogiendo doctrinas específicas de temas que le interesan al hombre y al Estado -y que a nosotros nos

\footnotetext{
${ }^{1746}$ Antonio RODRIGUEZ ADRADOS, Fe pública, ob. cit., p. 175.

${ }^{1747}$ Ibídem. Dice el autor: "La misma palabra "fe" tiene evidentes resonancias éticas y religiosas, y la "confianza pública" de los ciudadanos en general-sin la cual, a la larga, un determinado tipo de documento público no podría subsistir-, es la parte de verdad que hay en la tradicional dirección subjetiva que, desde el punto de vista del destinatario del documento, concibe la fe pública como "creencia"-creer lo que no vimos- de las personas que pudieran venir afectadas por el documento; y mas erróneo seria, tomando en otro sentido el adjetivo pública, el pensar que aquella creencia pudiera ser impuesta por la autoridad pública".

${ }^{1748}$ Cfr. Theodor W. ADORNO, Filosofía y sociología, trad. Mariana Dimópulos, Eterna Cadencia, Buenos Aires, 2.015, p. 161.

${ }^{1749}$ Ibídem, p. 166.
} 


\section{SEBASTIÁN JUSTO COSOLA}

resultan por demás de trascendentes como la sociología del derecho-. La sociología es también una ciencia que crea y brinda el adecuado espacio además para el estudio de las instituciones sociales en general, para la reflexión acerca de las formas políticas establecidas y especialmente, para la investigación social empírica ${ }^{1750}$, que persigue a través del sistema de encuestas, la obtención de diversas mejoras dentro del destino social de diversos grupos ${ }^{1751}$. En lo que a este estudio importa, debe quedar en claro que objeto de la sociología no es el comportamiento del individuo -propio de la psicología-, sino los modos en que ocurren los comportamientos sociales $^{1752}$.

Sobre las bases apuntadas por el filósofo alemán, los sociólogos del derecho vienen hace tiempo considerando como uno de los temas centrales de la disciplina en referencia, el problema de las dificultades reales que surgen entre el confronte o enfrentamiento entre las expectativas que surgen de la ley y las expectativas sociales, todo directamente relacionado con el efectivo acceso del hombre a la justicia ${ }^{1753}$. Con esto, la sociología del derecho intenta dar respuesta a los problemas que aquejan a los hombres y las mujeres problematizados de nuestros días: en qué medida, ante un conflicto determinado e inevitable, pueden esas personas tener entrada, acceso, protección, defensa y respuesta de la justicia ${ }^{1754}$. Esto incluye, muy lamentablemente en la agenda actual, tener en cuenta la cuestión no solo del acceso, sino de la exclusión, que en acertada opinión de Martha Nussbaum, es el tema central que impone una frontera a la justicia ${ }^{1755}$.

Sin lugar a dudas esto es así porque la base de una sociedad de derecho descansa sobre normas que proporcionan tanto cohesión como conflicto; sin embargo, sea cual fuere la dirección social que determina una dirección de la norma, las mismas son insustituibles para el ser humano, porque en esta

\footnotetext{
${ }^{1750}$ Ibíd.

${ }^{1751}$ Ibídem, p. 167.

${ }^{1752}$ Ibídem, p. 172.

${ }^{1753}$ Cfr. Felipe FUCITO, Sociología del derecho, Universidad, Buenos Aires, 2.003, p. 287.

${ }^{1754}$ Cfr. Alfredo E. VES LOSADA, Sociología del derecho, Ábaco, Buenos Aires, 1.980, p. 32.

${ }^{1755}$ Cfr. Martha C. NUSSBAUM, Las fronteras de la justicia, Paidós, Barcelona, 2.012, 447 p.
} 
LOS EFECTOS DE LA PUBLICIDAD EN EL DOCUMENTO NOTARIAL

visión las normas conforman un sistema de control social ${ }^{1756}$ que supone alguna reflexión acerca de la vida social y de sus necesidades ${ }^{1757}$, y que reafirma su fundamentación en valores, usos, costumbres o inclusive otras leyes que sirven de sustento histórico ${ }^{1758}$. En definitiva, todas las normas tienen una justificación sociológica en cuanto a su existencia, y son necesarias para el control de la conducta, para hacer efectiva la cooperación, base de toda sociedad ${ }^{1759}$.

Si estos estudios son tan ciertos como ineludibles para el derecho actual, también al notariado le corresponde evaluar como la sociedad accede al servicio que ofrece y en última instancia, en qué medida la institución notarial colabora con la justicia. Por ello es que corresponde al notariado en su conjunto evaluar cómo y en qué medida la sociedad se acerca a las notarías para confeccionar un documento auténtico, en definitiva, para sentir lo justo en su estado de seguridad, sin dejar de perder de vista que tanto la seguridad como su contracara, el miedo público, existen en la sociedad cuando la misma alcanza la verdadera conciencia de la función que cumple en su seno, una determinada institución ${ }^{1760}$.

\subsubsection{1. ¿Cómo el hombre común accede al documento} notarial, en la plenitud de sus facultades y con el convencimiento de las bondades que el título le ofrece y garantiza?

Nuestro país presenta una innegable realidad que encrudecería un poco el análisis sociológico en el que nos veríamos envueltos si, teniendo en cuenta las pautas anteriormente establecidas, se alcanzara un resultado óptimo a

\footnotetext{
${ }^{1756}$ Cfr. Felipe FUCITO, Sociología General, Universidad, Buenos Aires, 1.999, p. 172.

${ }^{1757}$ Ibídem, p. 173.

${ }^{1758}$ Ibídem.

${ }^{1759}$ Ibídem.

${ }^{1760}$ Cfr. Cass R. SUNSTEIN, Leyes de miedo. Más allá del principio de precaución, Katz, Buenos Aires, 2.010, p. 11.
} 


\section{SEBASTIÁN JUSTO COSOLA}

través de la implementación de un determinado sistema de encuestas que sea lo suficientemente eficaz para revelar cuál es la situación real de los habitantes que no alcanzan a satisfacer el mínimo desarrollo humano y patrimonial primario. De los ejemplos más contundentes que puedan alcanzarse, la cuestión del acceso a la vivienda propia y digna es uno de los más preocupantes. Esta realidad preocupa al Estado y consecuentemente, al sistema de gobierno que se encuentre ocasionalmente ligado a él, y por esta razón el tema tiende siempre a politizarse en demasía. Pocos temas de interés académico son los que alcanzan a convivir entre teorías jurídicas y políticas como los relativos a los derechos humanos y dentro de ellos, el de acceso a la vivienda. Es la razón de que existan, en medios como los nuestros, organismos políticos como la Escribanía General de Gobierno. A través de la misma, el hombre común que logra concretar a través de cualquier vía la adquisición de la tierra, accede al derecho de escrituración a través de la titulación masiva, aun sin comprender demasiado las bondades que el propio documento le garantiza, salvo por la tradición, las costumbres y la fuerza de la publicidad cartular externa (dentro de este esquema, fácil le resultará asimilar la función notarial con el otorgamiento y la autorización de la escritura) ${ }^{1761}$.

Es probable entonces que desde un observatorio imaginario dedicado a analizar las cuestiones emergentes de la sociología del derecho notarial, se advierta que la recepción del documento notarial generalizada entre aquellos que persisten en alcanzar el desarrollo primerio y elemental a través del esfuerzo duro y permanente, sea bienvenida únicamente por la fuerza cartular exterior y no así, por lo que el documento contiene y establece, además de por otros signos exteriores visibles que terminan por cerrar la fuerza publicitaria de este tipo de instrumentación (actos públicos, constancias documentales, filmicas, fotográficas, entre otros medios de publicidad que se entienden como inherentes al acto del otorgamiento y entrega del documento notarial). Sin embargo, el hombre o la mujer que

\footnotetext{
${ }^{1761}$ Hasta tanto las relaciones económicas sean justas y equitativas en nuestro país y en el resto de América Latina -y den lugar a los mismos beneficios y a los mismos derechos por habitante y por familia-, la cuestión de la incidencia política en instituciones tan nobles como la notarial seguirá siendo habitual y seguirá fortaleciéndose hacia el futuro, porque es definitivamente, un lugar donde puede detentarse inclusive un cierto control social.
} 


\section{LOS EFECTOS DE LA PUBLICIDAD EN EL DOCUMENTO NOTARIAL}

retiran su documento, aun sin haberlo cotejado con otro cercano, e inclusive aun sin haber tenido un sistema de audiencias notariales previas que informaran la labor notarial a desarrollar al respecto, no dudan de su contenido, ese que muchas veces desconocen sobre todo, si es apreciado desde las cuestiones eminentemente técnicas. En estos casos, la voluntad no se analiza desde el querer, sino desde el esperar.

Existe voluntad cuando se proyectan en el acto o en el hecho a instrumentarse todos los contenidos relativos al discernimiento, a la intención y a la libertad. Y también existe voluntad cuando desde la libertad, la intención se muestra como un deseo relacionado con la eficacia, y el discernimiento se exhibe desde la confianza en una determinada función que tradicionalmente relaciona la historia con el presente bajo los mismos criterios y los mismos postulados. Aunque no se adviertan y no se desarrollen $a b$ initio los valores de justicia y seguridad, los mismos existen en el contenido a partir de las mencionadas aclaraciones, y al igual que la verdad (fe), vienen a demostrar que sea cual fuere el método por el cual las familias accedan a la escrituración de su vivienda, lo cierto es que la fuerza de la autenticidad cartular es sus dos proyecciones, convive en la ciencia o en la conciencia de la ciudadanía en general. En la titulación masiva, claramente puede fallar el principio que ordena que el notario, al receptar la voluntad de los comparecientes, trabaja denodadamente para alcanzar a proyectar los valores en el documento que se encuentra próximo a redactar. La falencia de la potencia de la autenticidad externa se reordena a partir de la fuerza de la publicidad cartular externa, que además si ocurre en un acto público, genera aun más fuerza que en el ámbito de una notaria privada. La fuerza exterior de la documentación de origen notarial es advertida y graficada de manera ejemplar inclusive, desde la literatura latinoamericana ${ }^{1762}$.

${ }^{1762}$ El genial Eduardo Galeano lo ha graficado de la siguiente manera, desde un ensayo que paradójicamente, lleva como título "Una clase de derecho": "Están haciendo cola los pobres de absoluta pobrecía. La ley se despierta temprano, hoy atiende el doctor a primera hora. El abogado ve que en la cola espera una anciana con un racimo de niños y un bebe en brazos. Cuando le llega el turno, ella muestra sus papeles. Los niños no son nietos: esa mujer tiene treinta años y nueve hijos. Viene a pedir ayuda. Ella había levantado un rancho de lata y madera en algún lugar de las orillas del Cerro de Montevideo. Creía que era tierra de nadie, pero era de alguien. Y ahora van a echarla de alli, ya le ha llegado esa cosa que se llama lanzamiento. El abogado la escucha. Revisa los papeles que ella ha traído. No hay 


\section{SEBASTIÁN JUSTO COSOLA}

\subsubsection{La idea de la verdad (fe) que protege el derecho.}

Más allá de las argumentaciones legales y doctrinarias referidas, y de la cuestión del impacto social de los instrumentos notariales, uno de los temas trascendentes del análisis de la fe es el que intenta descifrar a qué tipo de verdad esa atribución legal y virtuosa del individuo inviste de valor y eficacia. Desde lo científico este análisis no requiere más que el reconocimiento de que la verdad investida de fe es la que importa al derecho. Pero desde lo axiológico se impone un análisis mucho más profundo que merece a estas alturas ser referido. El criterio objetivo de la consideración de la fe pública, es el que ayuda en definitiva a sostener el principio de seguridad jurídica. Pero aquí intento demostrar que la seguridad jurídica únicamente no alcanza para corroborar el verdadero valor de la publicidad cartular interna que se complementa además con otros valores trascendentes. Si se considera como valor esencial dentro del aspecto intrínseco del documento a la justicia, debe insistirse en la valoración emergente de la autonomía de la voluntad de los comparecientes que tutela el notario antes y durante la creación documental, y por ello la referencia al criterio subjetivo de la fe pública también cobra relevancia. Es decir, interesa lo que importa al derecho, y también interesa lo que verdaderamente es. Consecuentemente, interesa determinar también el carácter interno de la fe.

La idea de verdad es amplia, y en lo que aquí respecta, importa que la misma pueda ser alcanzada por la protección de la fe pública, por cuanto de ello depende la coexistencia armónica en el documento de la justicia y de la seguridad jurídica. En sentido amplio, pueden existir cuatro significaciones

derecho, piensa el doctor en derecho: menea la cabeza, demora en hablar. Traga saliva y dice, mirando al suelo: Lo lamento, señora, pero...no hay nada que hacer. Cuando alza la mirada, ve que la hija mayor, una muchachita con cara de espanto, se está tapando las orejas con las manos". V. Eduardo GALEANO, Una clase de derecho, en Bocas del Tiempo, Catálogos- Siglo XXI, Buenos Aires, 2.004, p. 225. 


\section{LOS EFECTOS DE LA PUBLICIDAD EN EL DOCUMENTO NOTARIAL}

sobre la noción misma tanto de la verdad (Alétheia) como de lo verdadero (Alethés) $^{1763}$ :

a) Aquello que no está oculto ni disimulado; lo que es sincero y que no engaña;

b) Aquello que no está mezclado ni alterado por un elemento que le sea ajeno $^{1764}$

c) Aquello que es recto, que tiene y contiene rectitud;

d) Aquello que existe, que persiste en la identidad, la inmutabilidad y la incorruptibilidad, y que se mantiene más allá de todo cambio.

Esas significaciones que surgen de la verdad y de lo verdadero son aplicables a las maneras de ser, a las maneras de hacer, a las maneras de conducirse y a las formas de acción ${ }^{1765}$. La primera razón de la relevancia de la verdad declarada en sede notarial, contenedora de todas las descripciones anteriores y alcanzada por la protección de la fe pública -derivada de un aspecto estrictamente objetivo del ordenamiento-, determina la validez de la justicia (lo justo concreto) a partir de la máxima expresión de voluntad de las partes tutelada por un profesional del derecho en ejercicio de una función pública. La segunda razón de relevancia de la verdad, es la que determina que si las maneras de ser y de hacer, de conducirse y de ejecutar lo verdadero y lo justo exhiben el resultado directo de la exacta comprobación con el hecho que acontece frente a los sentidos, se corrobora la seguridad del documento y con ella, su absoluta vigencia y trascendencia.

No obstante lo antedicho, los ordenamientos jurídicos de todos los tiempos se esmeran por precisar los alcances de la fe comprensiva de la verdad, a la vez que proveen al hombre de herramientas especiales para que los documentos que alberguen contenidos contrarios a esa verdad, y que son creados con la intención de causar intencionalmente una serie de perjuicios irreparables, maliciosos y engañosos ya sea hacia alguno de los destinatarios o hacia terceras personas interesadas en esa celebración, puedan dejar de surtir los efectos atribuidos originariamente. Por ello se argumenta que

${ }^{1763}$ Cfr. Michel FOUCAULT, El coraje de la verdad, FCE, Buenos Aires, 2.010, p. 232.

${ }^{1764}$ Ibídem, p. 233.

${ }^{1765}$ Ibídem. 


\section{SEBASTIÁN JUSTO COSOLA}

ninguna fe pública es absoluta ${ }^{1766}$, y esa es la razón por la cual se advierte que la presunción de verdad contenida en la ley no implica, en realidad, una verdad real, pero en tanto no se demuestre su falsedad en sede judicial, es una verdad admitida para constituir y declarar derechos ${ }^{1767}$.

\subsubsection{Documento, prueba y verdad: El valor de la fe pública en el} proceso.

1766 Eduardo J. COUTURE, El concepto de fe pública, ob. cit., p. 32. Dice el autor: "Comencemos por admitir que ningún texto legal, en ningún sistema jurídico confiere a los instrumentos notariales -ni aun a los instrumentos públicos- una significación de verdad irrefragable",

${ }^{1767}$ Cfr. Rubén Augusto LAMBER, La escritura pública, to I, ob. cit., p. 15. Muy a pesar de estas opiniones, debo dejar en claro que por el contrario, yo opino que la verdad que se desprende del documento notarial es la real, y por ello es importante atribuirle a la misma las características atribuidas por el filósofo francés. En mi pensamiento, el documento es una consecuencia de los deberes éticos notariales aplicados, y por ello, de su adecuada estructuración y aplicación, no puede nunca surgir una verdad que no sea la real expresada en el documento, salvo que se declare frente al escribano algún hecho o negocio contrario a la verdad, pero que éste ultimo lo ignore completamente. Ante esta circunstancia, el notario se ampara en el ejercicio de su buena fe y de su buena diligencia. Para los casos en donde el notario advierta que se pretende declarar una verdad que no sea la real, se deberá abstener de realizar el documento, en ejercicio de los deberes éticos notariales de imparcialidad e independencia. Al afirmarse que la ley supone que la verdad declarada es la real, pero que solo es una suposición, se intenta dar protección a la parte contratante frente a la fuerza y el vigor de la fe pública. No hace falta argumentar que cuando el notario o escribano actúa en beneficio de la justicia, a conciencia y de acuerdo con el derecho, no hay posibilidad de que se albergue en el documento una verdad que no sea la propia y emergente de la voluntad real de los comparecientes. Ante la duda, debe imponerse en el notario el deber de abstención. Y si éste, reitero, fuera engañado en su buena fe, las herramientas previstas en los ordenamientos podrán derribar al documento en protección de las personas afectadas a partir especialmente, de las teorías de las simulaciones y falsedades, que en la actualidad se presentan a través de dos corrientes de pensamiento estructuralmente diferentes: la de origen romano, que se edifica sobre la exigencia de la protección de veracidad de los documentos, y la de influencia alemana, que teledirige los esfuerzos hacia la protección de la autenticidad objetiva del documento en razón de su función en el trafico jurídico. V. Manuel CORREDOR PARDO, Falsedad documental: ficción social del autor, ob. cit., p. 17. 


\section{LOS EFECTOS DE LA PUBLICIDAD EN EL DOCUMENTO NOTARIAL}

Sobre las líneas anteriormente expresadas, es relevante advertir que el tema de la fe (verdad) y de la prueba que de ella emerge en el estudio del derecho de procedimientos, viene siendo estudiado desde la filosofía del derecho con verdadero y apasionante entusiasmo. Evidentemente, el problema de la verdad (fe) ocupa en la vida del jurista actual una preocupación constante y permanente, por cuanto se insiste en que uno de los temas centrales de la justicia es precisamente, la valoración judicial de la prueba que permite al juez arribar al mencionado valor. Devenido a menos el valor de la norma por sobre los principios, el problema de la verdad en la moral y en el derecho se erige como cuestión central del derecho actual ${ }^{1768}$.

En este sentido, Marina Gascón Abellán presenta una obra formidable que intenta acercar al jurista a determinar la certeza de los hechos en el derecho $^{1769}$. La autora presenta una clasificación de la prueba desde el punto de vista de la estructura del procedimiento probatorio, donde se refiere a la prueba directa, a la deductiva y a la indirecta o inductiva ${ }^{1770}$. La primera se refiere al procedimiento para el conocimiento de los hechos fundamentado en la observación del propio sujeto juzgador; la prueba deductiva en cambio, tiene como fundamento la inferencia deductiva a partir de otras aserciones ya verificadas, y finalmente, la prueba inductiva se basa en inferencias de carácter inductivo, a partir de otras aserciones verificadas ${ }^{1771}$.Pero además la jurista llega a considerar las presunciones iuris et de iure, estas son, aquellas que están en el proceso para garantizar los valores que establecen como ciertos y verdaderos hechos en presencia de otros. Este tipo de presunciones revisten el carácter de absolutas, ya que no admiten prueba en contrario ${ }^{1772}, \mathrm{y}$ más trascendente que ello: "las presunciones iuris et de iure no hacen referencia a la carga de la prueba de un hecho pasado, sino que, por el contrario se enderezan a ejercer una influencia sobre los hechos futuros, a fin de que se conformen a la presunción establecida ${ }^{1773, " . ~ A l ~ a f i r m a r ~ l o ~}$

\footnotetext{
${ }^{1768}$ Cfr. Daniel A. HERRERA, La persona y el fundamento de los derechos humanos, Educa, Buenos Aires, 2.012, p. 29.

${ }^{1769}$ Cfr. Marina GASCÓN ABELLÁN, Los hechos en el derecho. Bases argumentales de la prueba, Marcial Pons, Madrid, 2.004, 230 p.

${ }^{1770}$ Ibídem, págs. 92-93.

${ }^{1771}$ Ibídem, p. 93.

1772 Ídem, p. 146.

${ }^{1773}$ Ibídem.
} 


\section{SEBASTIÁN JUSTO COSOLA}

antedicho, la autora se refiere como ejemplo característico de este tipo de pruebas, a la presunción legal de verdad de las tesis fácticas contenidas en las sentencias firmes ${ }^{1774}$, a la presunción de cosa juzgada, presente en el proceso para asegurar ciertos valores, como la seguridad jurídica ${ }^{1775}$. Otro es el enfoque que da al mismo tema Michele Taruffo ${ }^{1776}$. El autor considera que las pruebas directas e indirectas tienen importancia en función de la relación que ocurra entre el hecho de probar y el objeto de la prueba ${ }^{1777}$, y que no se analizan desde la estructura como argumentaba Gascón Abellán, en tanto que la distinción no es ontológica sino funcional y relacional ${ }^{1778}$. La prueba directa entonces, grafica que las dos enunciaciones tienen por objeto el mismo hecho, denominándose material a la prueba que tiene por objeto el hecho jurídicamente relevante ${ }^{1779}$. La prueba indirecta en cambio, ocurrirá cuando el objeto de prueba se encuentre conformado por un hecho distinto de aquel que deba ser probado en razón de ser jurídicamente relevante a los efectos decisorios ${ }^{1780}$. Y desde otra obra, la reflexión lo dirige a considerar la escritura pública como una regla de prueba legal que atribuye valor vinculante por ser un documento público redactado por sujetos específicos con específicas formalidades ${ }^{1781}$. En un primer acercamiento el reconocido autor resulta ser claro, conciso y contundente: "En efecto, si un documento ha sido redactado por un sujeto investido de una función pública de certificación, se puede presumir que su contenido corresponde a la verdad. Con una máxima de este tipo es posible concordar sin ninguna dificultad ${ }^{1782}$ ". Sin embargo, a poco de seguir la lectura, el autor comienza a bosquejar ciertas incertidumbres relacionadas con la oportunidad de normas 
LOS EFECTOS DE LA PUBLICIDAD EN EL DOCUMENTO NOTARIAL

o máximas que prevén este tipo de acontecimientos jurídicos, destacando que si las máximas referidas no fueran tales (es decir, si no fueran consideradas con validez como ley general) estaríamos en presencia de eventualmente, una valoración de probabilidad por cuanto también el documento público podría ser falso y en esas circunstancias, esas normas tendrían un valor contraepistémico, ya que llevarían al juez a tener por verdadero un documento que no se sabe si es o no es verdadero ${ }^{1783}$.

Frente a la no existencia de esas normas que denomina de prueba legal, el juez podría fácilmente desestimar los documentos si tuviera dudas razonablemente fundadas, corroboradas por pruebas indudables, acerca de su veracidad. Pero como existen, las mismas impiden al juez optar por la posibilidad de desecharlas ${ }^{1784}$; y en torno a esto, es el problema principal la falsedad del documento que impide al juez llegar a la verdad, ya que la misma ocurriría si puede comprobarse la falsedad a través de un procedimiento preestablecido, complicado y formalista ${ }^{1785}$. Y aquí entonces se encuentra la conclusión de lo afirmado: "Estas normas (reglas de prueba legal) operan como mecanismos de simplificación de la decisión, considerando como absoluta una regla de la experiencia que es razonable pero que, en realidad no tiene alcance general: su verdadera función consiste en evitar que el juez tenga que ocuparse de la veracidad de lo que está escrito en un documento público -salvo el caso excepcional de impugnación de autenticidad-. Por otro lado, la divergencia entre la falta de generalidad de la máxima de experiencia y el carácter tendencialmente absoluto de la presunción de autenticidad del documento representa precisamente el margen de error que las normas de prueba legal introducen. En este sentido, cumplen una función contraepistémica ${ }^{1786 " .}$

Pienso no le asiste razón al jurista en sus afirmaciones. De hecho, he transcripto el párrafo porque inclusive opino que del mismo surgen contradicciones evidentes. En efecto, si las normas de regla de prueba legal están previstas como método de simplificación, su fundamento será definitivamente el de la seguridad. No habría posibilidad de admitir un

\footnotetext{
${ }^{1783}$ Ibídem.

${ }^{1784}$ Ibídem, p. 187.

${ }^{1785}$ Ibídem.

${ }^{1786}$ Ibídem.
} 


\section{SEBASTIÁN JUSTO COSOLA}

medio de prueba del que dependa el resultado de un procedimiento si éste fuera dudoso o al menos, no fuera o no se acercara, -parafraseando al propio Taruffo- a la máxima de seguridad. La histórica prueba documental basada en la presunción de fe $-\mathrm{fe}$ equivalente a verdad- opera como una elemental garantía no sólo para la simplificación, sino para el resultado justo del proceso vislumbrado a partir de la sentencia de cosa juzgada, a la que arriba un juez con el máximo del convencimiento y cuyo fundamento está garantizado con buena fe legal y con buena fe creencia, porque proviene de un medio de prueba auténtico (para el derecho, no todo es relativo ${ }^{1787}$ ). Si tal como afirma Taruffo la verdadera finalidad de las reglas de prueba legal consiste en evitar que el juez tenga que ocuparse de la veracidad de lo que está escrito en el documento, porque intentar buscar la verdad fuera de él o porqué comenzar por considerar las anomalías de la fe-falsedades- cuando en realidad, según el jurista son casos excepcionales? Si se está en presencia de un instituto que brinda al derecho y a la justicia mucho más certezas que incertidumbres, considerar lo contrario a través de un planteamiento que permite establecer un margen de error mínimo fundamentado en una filosofía del pensamiento que vuelve a todo argumento racional como meramente relativo, pareciera ser que es absolutamente imprudente $\mathrm{y}$

1787 ¿Por qué existen ciertos hechos que se deben dar por ciertos? Precisamente porque el derecho necesita de ciertas realidades para poder sobre ellas, llegar la justicia. Llegar a determinar lo justo concreto en base a un material probatorio sujeto a los vaivenes de los sentimientos, cuando se tiene oportunidad de obtener, según el caso de que se trate, valoraciones ciertas que se comprueban por la fuerza del ordenamiento y la calidad del agente parece una tarea imprudente. El principio de la creación y de decisión judicial, de aplicación razonable del derecho y de creación en base a fuentes jurídicas tiene el límite de la comprobación con dación de fe anterior, que impide desconocer lo que en el mundo jurídico acontece con el mayor grado de objetividad. En este sentido, jamás la seguridad jurídica puede ser considerada como un freno para alcanzar una decisión justa, y sobre esa idea debe trabajar el jurista para llegar a alcanzar un resultado óptimo y justo, por cuanto desde el mismo momento en que se cuenta con un documento con fe se comienza por advertir un criterio de fuerte base sólida, y por esa razón el camino hacia la justicia es auspicioso desde su inicio. Aun así, el derecho cuenta con la herramienta de la falsedad, para desestimar los casos de corrupción documental, lo que vuelve el principio mencionado de interés absolutamente especial, todo ello sin contar que los efectos de la publicidad cartular son relativos en el marco global de los actos (si bien el documento es una fuente primaria de conocimiento, su ámbito de desenvolvimiento es acotado a quienes pueden haber tenido un interés especial o legitimo en tener contacto con él). Todo esto es elemento de la valoración judicial, pero que es secundario al tema de trabajar sobre lo que el derecho supone con elevado grado de certeza. 


\section{LOS EFECTOS DE LA PUBLICIDAD EN EL DOCUMENTO NOTARIAL}

además, que no adecuado para contribuir al desarrollo del derecho en paz. Como claramente lo fundamenta Sanahuja: "La función notarial es esencialmente autenticación de hechos. Si el hecho no se presenta como auténtico, el juez comprueba y determina el hecho concreto, para enlazar en él una consecuencia jurídica. La autenticidad evita al juez la operación de comprobación del hecho, para circunscribirse al conocimiento del derecho. Suple, pues, la función notarial una fase de la judicial, y como ésta, sólo puede imputarse al Estado como unidad del orden jurídico ${ }^{1788, "}$.

Claro que este análisis requiere además de ciertos tópicos iusfilosóficos que se tornan interesantes a la hora de determinar cómo es que un determinado jurista llega a evaluar un hecho, que herramientas debe utilizar, como llega a conformar el criterio de verdad ${ }^{1789}$. Comprobados esos pasos, el resultado obtenido será lo mas óptimo que pueda conformar la agenda de una ciencia no exacta como la jurídica.

Cierto es que vivimos en un momento especial en la vida del derecho; de cambios absolutos en la interpretación y en la teoría de la argumentación que lo vuelven más flexible a la variedad de opiniones y más rígido en cuanto a las verdaderas tenidas por ciertas en la generalidad de los casos. El modelo jurídico inspirado esencialmente, en el derecho francés de la codificación, que eleva a la ley como prácticamente la única fuente de derecho fidedigna y reconocida por las autoridades, y que convierte a los jueces en seres inanimados que repiten o reiteran los preceptos legales tal como fueran previstos ha mutado para siempre ${ }^{1790}$, orientándose hacia una teoría de la argumentación jurídica amplia que permite al jurista interpretar el derecho de muy variadas maneras, y muchas veces teniendo en consideración únicamente la aplicación de otras fuentes del derecho, cuando la ley no existe o no alcanza al caso concreto. No menos cierto es que tanto la historia y la tradición de ciertas instituciones clásicas para el jurista -y también inspiradas en aquél derecho- como la necesidad imperiosa de su existencia obligan al intérprete o argumentador del derecho a utilizarlas cuando la

\footnotetext{
1788 José M. SANAHUJA Y SOLER, Tratado de derecho notarial, $\mathrm{t}^{\circ}$ I, ob. cit., p. 21.

1789 José María R. ORELLE, Actos Jurídicos-Forma, en Jorge Horacio ALTERINI (Dir.Gen.), José W. TOBIAS (Dir. Tom.), Ignacio E. ALTERINI (Coord.), Código Civil y Comercial Comentado. Tratado Exegético, $\mathrm{t}^{\circ}$ II, ob. cit., p.382.

${ }^{1790}$ Amós Arturo GRAJALES y Nicolás Jorge NEGRI, Interpretación y aplicación del Código Civil y Comercial, ob. cit., p. 7 y ss.
} 


\section{SEBASTIÁN JUSTO COSOLA}

posibilidad del caso le permite obtenerlas de manera cierta y precisa. Según las recientes opiniones de Horacio Rosatti, en sus orígenes el derecho privado nacional -y especialmente el Código Civil de Vélez, que presenta una impronta fundante-, tuvo en miras la protección de una sociedad en expansión, pudiendo consolidar el esclarecimiento de las relaciones jurídicas a través de la seguridad jurídica de las transacciones, a la vez que operó como herramienta de consolidación política ${ }^{1791}$. En la actualidad, el Código Civil y Comercial de La Nación presenta una impronta diferente. Ya no es una prioridad desde lo jurídico instalar la seguridad jurídica de las transacciones, ni alcanzar desde lo político la unión nacional. La urgencia es la de adecuar los preceptos legales a la normativa constitucional, y por ello es que en la actualidad el cuerpo normativo en referencia integra el bloque infra-constitucional con jerarquía de ley común ${ }^{1792}$. Pero como ya he comprobado, esa nueva impronta no desconoció ciertos elementos fundantes del derecho en retiro, y uno de esos elementos es el documento con sus valores, sus efectos y la seguridad que de él emana (institución tradicional). Como intento argumentar desde este espacio, la creación documental reconoce las más varias fuentes, y cada una proyecta el valor de la elaboración desde diferentes perspectivas. Pero siempre los efectos se dirigen a lo mismo: otorgar el máximo de certeza a quien sea su destinatario. Una de esas fuentes de creación es la notarial, y la intención del notariado es la de crear documentos auténticos que alejen a los destinatarios del conflicto posterior, en sintonía con la esencia singular de la función notarial que es la de ayudar a que el derecho se desarrolle en un ámbito de paz.

Al mismo tiempo, la prueba obtiene como elemento esencial el documento narrado por el mismo profesional del derecho a cargo de una función pública. La narración, hecha en el marco de la fe pública, reconoce dos vertientes: La exactitud o fidelidad entre hecho y relato y su contracara, la integridad o ineficacia, absoluta o relativa, de lo que no se haya narrado ${ }^{1793}$. En razón de ello es que le asiste razón a Núñez Lagos cuando afirma que la teoría de la forma, en sentido tradicional, no llega a explicar la autenticidad

${ }^{1791}$ Cfr. Horacio ROSATTI, El Código Civil y Comercial desde el Derecho Constitucional, Rubinzal Culzoni, Santa Fe, 2.016, p.27.

1792 Ídem, p. 41.

${ }^{1793}$ Rafael NÚÑEZ LAGOS, Hechos y derechos en el Documento publico..., ob. cit., p. 35. 


\section{LOS EFECTOS DE LA PUBLICIDAD EN EL DOCUMENTO NOTARIAL}

del contenido de los documentos públicos ${ }^{1794}$. Entre otras cosas, los hechos de la narración documental no tienen el mismo valor, y son materia de prueba. Es así que existen entonces, en el contenido del documento ${ }^{1795}$ :

a) Hechos inconvertibles o con fe pública (verdad impuesta);

b) Hechos convertibles o de verdad supuesta (hechos narrados que no son evidencia directa del notario, como las declaraciones de voluntad de las partes);

c) Hechos adjuntos o verdad puesta (principio de prueba por escrito: declaraciones de verdad hechas por las partes).

En el documento notarial entonces conviven dos tipos de narración de los hechos. Los que dice el notario, ya sea por evidencia directa (fe pública) ya sea por evidencia indirecta (presunción iuris tantum). Y los que dicen las partes, que pueden clasificarse en aquellos que son declaraciones de voluntad (presunción iuris tantum) y en aquellos que son declaraciones de verdad (principio de prueba por escrito) ${ }^{1796}$. Parafraseando a Castán ${ }^{1797}$, diré que puede entonces comenzarse por concebir una nueva función del Estado, denominada legitimadora ${ }^{1798}$, que lo ayudará a alcanzar el cometido de su misión en orden a la realización del derecho: la declaración del derecho en vida normal, pacífica, mediante instituciones como el documento, que aseguran la legitimidad y autenticidad de los hechos y actos jurídicos como también así la publicidad que de tales actos se originan ${ }^{1799}$.

\footnotetext{
${ }^{1794}$ Ibídem, p. 62-63.

${ }^{1795}$ Ibídem, p. 68.

${ }^{1796}$ Ibídem, p. 69.

1797 José CASTÁN TOBEÑAS, Función notarial y elaboración notarial del derecho..., ob. cit., p. 36.

${ }^{1798}$ Ibídem. Dice CASTÁN refiriéndose a la función notarial: "Puede, pues, concebirse, una nueva función del Estado, la función legitimadora, y una nueva rama del derecho, el derecho legitimador, que comprende aquellas normas e instituciones por las cuales el Estado asegura la firmeza, legalidad, autenticidad y publicidad de los hechos jurídicos y de los derecho que son su consecuencia”.

1799
} 
SEBASTIÁN JUSTO COSOLA

\subsubsection{Las recapitulaciones esenciales: La fe pública y el sostén del} sistema de responsabilidad notarial.

Un antiguo trabajo del profesor Miguel Ángel Ciuro Caldani deja establecida la siguiente frase contundente: "La razón de ser del notario es la verdad, pero en definitiva debe contribuir a la realización de lo justo. Sobre la verdad y la justicia ha de lograrse la utilidad ${ }^{1800 " . ~ L a ~ v e r d a d ~ y ~ l a ~ f e, ~ e n ~ s e d e ~}$ notarial, siempre fueron consideradas hermanas siamesas. Es imposible visualizar la fe sin pensar que la misma se refiere, dentro de la órbita del derecho notarial, a la verdad misma. Desde la fe, o desde la verdad, dice Ciuro, el notario contribuye con la realización de lo justo. Desde mi posición, la fe incluye a la verdad por un lado y a la certeza por el otro. Pienso que así se amplía el panorama expositivo de este primer valor en tratamiento, incluyendo en el mismo tanto el aspecto subjetivo como el objetivo.

En el punto anterior hemos visto como autores consagrados combatían desde el proceso una noción de la prueba de los hechos que sea para el juez, indubitable y absolutamente certera ${ }^{1801}$. Definitivamente el sentido final de la verdad impuesta tiene un único objetivo: evitar discusiones sobre cuestiones que el legislador ha creído trascendentes y por ende, necesarias de cierta tutela especial. Es por esta razón que los documentos que tienen estas atribuciones presentan una garantía de protección y de circulación que es absolutamente elogiable desde varios tópicos de referencia:

a) Aceleración de los procedimientos judiciales o extrajudiciales;

b) Presunción de autenticidad;

c) Control de legalidad;

\footnotetext{
${ }^{1800}$ Miguel Ángel CIURO CALDANI, Valores de la actividad notarial, ob. cit., p. 14.

${ }^{1801}$ Ni Taruffo, ni Gascón Abellán, por citar solo algunos ejemplos, han atribuido el valor que tiene la prueba extraprocesal considerada como verídica proveniente de los documentos notariales. Quizás el temor a ese reconocimiento este fundado desde lo jurídico -y no sin cierta razón- en la posibilidad de encontrarse con que la fundamentación judicial en la sentencia ha encontrado sustento en un medio de prueba que presenta una verdad aparente, pero no real ni legítima.
} 
LOS EFECTOS DE LA PUBLICIDAD EN EL DOCUMENTO NOTARIAL

d) Consolidación de los efectos probatorios y ejecutivos, entre otros casos relevantes.

Sin embargo, muy a pesar de estos fines considerados y consagrados legislativamente, cierto es que puede darse un lugar a la interpretación negativa, y en última instancia, no dejar de pensar que aunque un derecho adquirido se proyecte como indudable desde un documento público que ha nacido respetando las formas impuestas, el mismo sea solo eso: una apariencia de certeza, que quizás no daña a la ley, pero sí y muy profundamente al derecho y consecuentemente, a la justicia ${ }^{1802}$. Desde lo jurídico entonces, puede asistirle cierta razón a quienes no encuentran fundada la prueba de los hechos fuera del proceso, al menos desde la imaginación de los actos efectuados sin razón o sin justicia fuera del alcance judicial.

Desde lo filosófico en cambio, la cuestión se explica de otra manera. La misión notarial en el ámbito del derecho, por su singular apreciación de los elementos jurídicos, es la de ser un artesano del derecho imponiendo el cavere en su misión, esto es, prevenir, precaver para el futuro ${ }^{1803}$. Por ello es que esa trascendente misión prima por sobre cualquier otra razón que pretenda ser equivalente en el ejercicio de su ministerio: del mismo se debe desprender, como premisa fundamental, un sentido y un amor por la justicia. El derecho, en opinión de Vallet, se realiza a través de un juicio de razón de justicia, y de ahí que se evite el silogismo que tiene o presenta la ley como premisa mayor, para entenderla sencillamente, como un instrumento más, de tantos otros existentes para su realización plena ${ }^{1804}$. Alcanzar lo justo en sede notarial es concretar definitivamente la labor misma del notario. No hay otra manera de ejercer la función fedante.

\footnotetext{
${ }^{1802}$ Pueden por ejemplo referirse aquí especialmente los casos que contemplan los supuestos de documentos de personas interpuestas creados para desviar los fines naturales -por ejemplo, filiación- o accidentales -en especial las acreencias- de la circulación del patrimonio.

${ }^{1803}$ Cfr. Juan Berchmans VALLET DE GOYTISOLO, La misión del notario, en Juan Francisco DELGADO DE MIGUEL (Coord.), Deontología Notarial, JDCNE, Madrid, 1.993, p. 422 .

${ }^{1804}$ Cfr. Juan Berchmans VALLET DE GOYTISOLO, Determinación de las relaciones jurídicas relativas a inmuebles susceptibles de trascendencia respecto a tercero, IER, Madrid, 1.965, p. 375.
} 


\section{SEBASTIÁN JUSTO COSOLA}

La concreción de la fe en el derecho, asimilada a la verdad, con el sentido de precaver para el futuro y con el fin de hacer cumplir lo justo en el documento, sería un tema de preocupación constante para el jurista que pretende producir y ejecutar la prueba en presencia de un juez, temiendo a la falsedad, si no fuera por el sistema de responsabilidad notarial que respalda el ejercicio de la dación de fe. Así, tan importante es la afirmación notarial de la concreción de los hechos en su presencia, como la responsabilidad que emana de esa afirmación. Este dato mayor se sustenta además con su consecuente correlato histórico. Solo por citar algún ejemplo de todos los que la historia confirma ${ }^{1805}$, recordemos que el Fuero Real establecía la siguiente pena ante la falsedad notarial: "Falsedad faziendo escrivano de la Corte del Rey en carta, o en previllejo, debe morir por ello" 1806 . En las Siete Partidas de Alfonso el Sabio la partida tercera (título dieciocho) lleva como título "de las escrituras por que se prueban los pleitos (...) para que no se olvidasen por el tiempo las cosas fue necesario reducirlas a escritura; principalmente las condiciones y pactos que diariamente hacen los hombres; asimismo, para saber si se cumplian

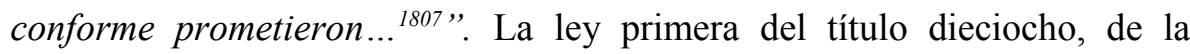
partida tercera, nos dice: "Escritura es toda carta que sea fecha por mano de escribano público de concejo, o sellada con sello del rey o de otra persona auténtica que se ha de creer. La utilidad que resulta de ella es servir como testimonio de cosas pasadas... ${ }^{1808 " . ~ P a r a ~ l a ~ l e g i s l a c i o ́ n ~}$ Alfonsina, el escribano es ome que es savidor de escribir ${ }^{1809}$, y la ley segunda del título dieciocho ordena a los escribanos de la Corte a ser buenos, leales y entendidos, y saber escribir bien; y los escribanos públicos puestos en las ciudades, villas y otros lugares, deben ser hombres libres, cristianos, de buena fama, saber escribir bien, entendidos en su oficio, y reservados para no descubrir nada de lo que mandasen escribir en secreto, a menos que fuese en perjuicio del rey o reino; asimismo, deben ser vecinos

${ }^{1805}$ Sebastián Justo COSOLA, Los deberes éticos notariales, ob. cit., págs. 55-89.

${ }^{1806}$ Bernardo PÉREZ FERNÁNDEZ DEL CASTILLO, Derecho Notarial, ob. cit., p. 8

${ }^{1807}$ Cfr. D. Ignacio VELASCO PÉREZ y una Sociedad de Abogados del Ilustre Colegio de esta Corte, Las siete partidas del sabio Rey D. Alfonso, Imprenta de los señores Viuda de Jordán e Hijos, Madrid, 1.843, p. 282.

${ }^{1808}$ Ibídem.

${ }^{1809}$ Ibídem. 


\section{LOS EFECTOS DE LA PUBLICIDAD EN EL DOCUMENTO NOTARIAL}

de aquel lugar donde fuesen escribanos, para conocer bien a los hombres que ante ellos pareciesen... ${ }^{1810 " . ~ P a r a ~ l o s ~ e s c r i b a n o s ~ d e ~ l a ~ C o r t e ~ d e l ~ R e y, ~ l a ~}$ pena por falsedad era la muerte, mientras que a los escribanos de la ciudad o la villa se les penaba de la siguiente manera: "cuando cometan falsedad en los pleitos que les mandaren escribir, deben cortarles la mano con que lo hacen, teniéndole además por hombre malo y sin honra, de manera que no pueda ser testigo ${ }^{1811}$ ".

En definitiva, estos son solo dos casos paradigmáticos y trascendentes en la propia historia del derecho, en donde se advierte que la responsabilidad que emergía de la falsedad que cometía el escribano, era tan grande como la función que éste prestaba. En definitiva, como en las Siete Partidas solía afirmarse: "Los escribanos deben ser honrados y guardados, porque su oficio es de utilidad común ${ }^{1812 \text { ". }}$

La conducta del notario es el único denominador común que une al primer antecedente escribanil con el notario o escribano actual. Esa conducta, que estudiada originariamente se inclinó por el titulo de ética en la función notarial, y que luego fue acomodándose a partir de la denominación deontología, siguió su evolución hasta la conformación en la actualidad de los deberes éticos notariales. La noción de deber le es al notario absolutamente inherente. Porque la dación de fe impone ese estricto sistema de responsabilidad notarial. De manera que si un documento notarial es creado de acuerdo a los deberes éticos notariales en general, pero esencialmente sin obviar ninguno de los deberes éticos notariales aplicados, no tendrá nunca razón de ser sospechado, y mucho menos de ser objeto de la burla o el daño hacia el derecho justo.

¿De qué manera entonces la fe notarial (verdad) resguarda al valor justicia y de qué forma proyecta la seguridad jurídica preventiva?:

a) A través de la aplicación de los deberes éticos de información, asesoramiento y consejo se cumple con la protección de la voluntad (real) de los requirentes;

\footnotetext{
${ }^{1810}$ Ibídem.

${ }^{1811}$ Ídem, p. 313.

${ }^{1812}$ Ibídem, p. 312.
} 
b) A partir de la concreción de la imparcialidad se cumple con la equidad, y desde la independencia se ahuyenta al derecho injusto o absurdo (abstención notarial); y

c) En la consolidación del deber ético integrado de legalidad (norma + regla + principios) se perpetúa la verdad al derecho.

En definitiva, todo esto viene a comprobar lo anteriormente expuesto por mi: la fe como verdad destaca las virtudes notariales, mientras que la fe como certeza concreta los efectos publicitarios del documento porque el Estado, al momento de habilitar para el ejercicio de la función al notario, ha pretendido que la dación de fe sea aceptada simplemente porque la misma es legalmente impuesta.

Dadas las presentes conclusiones, resta entonces visualizar la justicia y la seguridad desde la óptica notarial, para asegurar el valor de la paz y consecuentemente, el resultado final de la presente investigación. 


\section{Capítulo 13}

\section{Segundo Valor: La Justicia.}

\subsection{Introducción.}

Hasta aquí, las inquietudes teóricas y prácticas planteadas necesitadas de respuestas concretas relevantes, fueron de alguna manera encontrando reposo en los argumentos que provienen de la interpretación que puede este tesista realizar desde el derecho entendido en su cabal generalidad. $\mathrm{He}$ propiciado en ciertos aspectos además, la necesidad de recurrir a fuentes genuinas y originarias, las que a través de la instauración de las instituciones que considero tradicionales, vienen a comprobar que inclusive dentro del marco de un moderno derecho codificado como el que nos asiste, las mismas se vuelven necesarias para mantener estructuras jurídicas que durante siglos han sostenido a la ciudadanía en su conjunto. El cambio de paradigma en el estudio y en la aplicación del derecho privado argentino actual dirige al jurista al tratamiento de nuevas perspectivas de comprensión de la ciencia y del arte del derecho, desde un desarrollo general y amplio de instituciones rectoras como nunca antes se haya visto o ponderado. Con seguridad se afirma por los tiempos actuales que la coherencia del ordenamiento jurídico es una ficción no real pero necesaria, que ante los problemas interpretativos reconoce en la Constitución Nacional la norma ordenadora de los componentes esenciales que ese mismo orden jurídico proyecta ${ }^{1813}$. Los máximos valores y principios del derecho de nuestros días, más que en ningún otro momento, se encuentran presentes para orientar las resoluciones de los casos hacia determinados valores que el legislador ha creído como

${ }^{1813}$ Horacio ROSATTI, El código civil y comercial..., ob. cit., p. 106. 


\section{SEBASTIÁN JUSTO COSOLA}

relevantes para el desarrollo de la vida y de la convivencia pacífica. En definitiva, tal como se ha expresado, en la codificación del Siglo XXI son necesarios los valores y los principios ${ }^{1814}$.

Tan relevante es este cambio de paradigma, que la influencia de la recepción de los valores y los principios ha ido inclusive más allá del propio Código Civil y Comercial de La Nación, orientándose hacia ramas del derecho público donde no hace mucho tiempo atrás, era prácticamente imposible imaginar la intromisión de los baluartes del derecho como reguladores de postulados de orden público o de jerarquía (es el caso puntual del derecho administrativo $^{1815}$ ). La innegable influencia axiológica de la nueva concepción y comprensión jurídica entonces, es sumamente relevante y no puede de ningún modo, escapar al análisis jurídico por más singular y concreto que éste parezca. La Constitución Nacional, comprendida dentro del marco de un conjunto de prácticas de reconocimiento del derecho de una determinada sociedad, permite individualizar al sistema jurídico, precisamente porque la misma representa desde el origen el intento exitoso de fundar el proceso con el que se identifica al orden jurídico en una determinada sociedad ${ }^{1816}$.

No existen motivos suficientes entonces para exponer, en las obras jurídicas contemporáneas, un elemental tratamiento de la justicia, atendiendo a sus diversas y diferentes interpretaciones, es decir, a la dirección que se escoja para acceder a su conocimiento o la escuela que se elija para fundamentar las determinadas posiciones -esas mismas que entre los autores siempre tienden a considerarse como absolutas y predominantes-.

Para poder comprender los alcances de la norma jurídica entonces, es ineludible para el jurista atender la realidad social para la que fue concebida, la situación jurídica imperante al momento de su nacimiento y la realidad

\footnotetext{
${ }^{1814}$ Ricardo L. LORENZETTI, Fundamentos de derecho privado ..., ob. cit., p. 11.

${ }^{1815}$ Cfr. Carlos E. GUARIGLIA, Fundamento iusfilosófico del derecho administrativo, Educa y Universidad Católica de Uruguay, Buenos Aires, 2.016, p. 29. De manera categórica y determinante afirma el autor: "El fundamento del derecho administrativo residirá, entonces, en la centralidad de la persona y su dignidad inmanente". Era imposible pensar hasta prácticamente nuestros días que semejante orientación iba a irrumpir en el derecho administrativo, que desde siempre pondera la relación de supremacía de la Administración Pública por sobre cualquier otro postulado.

1816 Cfr. Carlos S. NINO, Fundamentos de derecho constitucional, Astrea, Buenos Aires, 2.013, p. 67.
} 


\section{LOS EFECTOS DE LA PUBLICIDAD EN EL DOCUMENTO NOTARIAL}

actual en la que la misma debe operar ${ }^{1817}$. La actualidad presenta un panorama de argumentación diferente al histórico: ya no se ama a los autores por sobre la sabiduría; el argumento de autoridad se torna más débil, tal como se afirma, frente al banco racional de prueba de toda tesis o teoría que necesariamente debe ser la realidad entendida en su absoluta integridad ${ }^{1818}$. Cuando para la decisión de un determinado caso no puede seguirse las normas presupuestas, ni los enunciados fundados de un sistema, ni reglas metodológicas, al decisor le queda "un campo de acción en el que tiene que elegir entre varias soluciones a partir de normas jurídicas, reglas metodológicas y enunciados de sistemas jurídicos no determinados ulteriormente $^{1819, "}$. Es indudable que en el tiempo actual, la presencia de valores y principios en el derecho es de ineludible referencia para obtener, en el caso concreto, oscuro o dudoso, la mejor respuesta posible.

Cierto es que la presentación de un panorama de la teoría de la justicia puede presentar un concepto autoritario, que siempre estará relacionado con los fines que el autor persiga al investigar para proponer resultados, y mucho más importante que ello: se relacionará íntimamente con la corriente de pensamiento que el autor adscriba para posicionar y defender su pensamiento ${ }^{1820}$. El propio concepto o sentido del término justo, es un adjetivo con variadas y diversas implicancias interpretativas, que puede aplicarse tanto a las personas, a los actos y a las instituciones, y también al nivel en donde se forma el acto de juzgar ${ }^{1821}$. En efecto, los términos justo, jurídico y justicia están relacionados de una manera especial dentro del saber de los juristas, aunque no sean voces unívocas, aunque puedan ser utilizadas

${ }^{1817}$ Cfr. Karl LARENZ, Metodología de la Ciencia del Derecho, Ariel Derecho, Barcelona, 2.001, p. 179.

${ }^{1818}$ Rodolfo Luis VIGO, Iusnaturalismo y neoconstitucionalismo, ob. cit., p. 10.

${ }^{1819}$ Cfr. Robert ALEXY, Teoría de la argumentación jurídica, Palestra, Lima, 2.010, p. 33.

${ }^{1820} \mathrm{La}$ opción o elección por una escuela o corriente de pensamiento determinará que los resultados a los que arribe serán total o parcialmente diferentes si se los invoca el positivismo, y dentro del mismo, dentro de todas sus vertientes; o desde el iusnaturalismo y sus múltiples teorías; o desde la escuela crítica, y de todas las escuelas que encuentren reposo en alguna de las tradicionales o tan siquiera tomando de ellas elementos fundantes, como el realismo jurídico escandinavo, la jurisprudencia de conceptos o el mismo tridimensionalismo, solo por citar un puñado de ejemplos probables y posibles de argumentación suficiente.

${ }^{1821}$ Cfr. Paul RICOEUR, Lo justo, Editorial Jurídica de Chile, Santiago, 1.997, p. 26. 


\section{SEBASTIÁN JUSTO COSOLA}

en ámbitos cercanos o alejados del derecho, y aunque permitan establecer ciertas orientaciones en razón de las perspectivas que se persigan al utilizarlas indistintamente ${ }^{1822}$. En el campo de la argumentación jurídica, lo central del esfuerzo consiste en ofrecer una respuesta al interrogante jurídico que se plantea ${ }^{1823}$. Esa respuesta en esta tesis, tiene una dirección definida, que es la que convierte al documento notarial en un elemento rector de decisión jurídica.

\subsubsection{Fundamentos de la corriente de pensamiento escogida.}

Desde la iusfilosofía se alcanza a comprender que la bondad o la maldad pueden tener escalas de comprensión primaria; pero lo justo en cada caso particular, requiere de otros análisis contundentes que vuelven a la comprensión de la justicia como un valor inexplicable desde una sola o única posición. Desde este hecho, reconozco que muchas fueron las obras que influyeron para que en algún momento la elección por una vía de pensamiento se consolidara en mi persona. En el ejercicio de la función notarial yo he escogido seguir un único sendero, de todos los que ofrece el derecho, y a veces diferente al que ordena la doctrina notarialista en general. Es un camino, que desde el comienzo va dirigiendo los esfuerzos hacia una determinada y coherente dirección, y del que no me he apartado nunca desde que por primera vez accedí a su conocimiento, cuando era estudiante de grado, a partir de las enseñanzas de uno de los más grandes civilistas que ha dado nuestro país ${ }^{1824}$. El derecho para mí, es el orden social justo.

Hace más de sesenta años, con estas palabras se dirigía George Renard a sus alumnos: "El derecho es la armadura de la justicia; el jurisconsulto es el servidor de la justicia; las facultades de derecho son las escuelas de la

${ }^{1822}$ Cfr. Félix Adolfo LAMAS, La experiencia jurídica, IEF-Santo Tomás de Aquino, Buenos Aires, 1.991, págs. 325 y ss (TD).

${ }^{1823}$ Rodolfo L. VIGO, Como argumentar jurídicamente, ob. cit., p. 9.

${ }^{1824}$ Es el caso de LLAMBIAS, para quien el derecho es el orden social justo. "Tal es la tesis de RENARD - dice el autor- a la que nosotros adherimos". Jorge Joaquín LLAMBIAS, Tratado de Derecho Civil. Parte General, t ${ }^{\circ}$ I, ob. cit., p. 20. 
justicia, y nosotros, profesores de derecho, faltaríamos al más esencial de nuestros deberes, sino enseñáramos, más allá de la legalidad, el culto y el amor a la justicia ${ }^{1825}$ ". Los legados académicos de Renard, resultado de la transcripción y traducción de una serie de conferencias dictadas en la facultad de derecho de Nancy, representan una forma de ver y sentir el derecho que desde siempre, me han conmovido profundamente ${ }^{1826}$. Desde el notariado, fue Juan Vallet de Goytisolo quien se ocupó esencialmente del tratamiento definitivo del tema de la justicia en ese sentido, y también como valor, como virtud, todo dentro del esquema del sistema jurídico que le tocó vivir y sentir. Los aportes generales de Vallet acerca de la justicia ${ }^{1827}$-y fuera de los que cuenta en sus obras consagradas ${ }^{1828}$ - fueron objeto de un sinnúmero de destacadas opiniones y de importantes reflexiones ${ }^{1829}$, y aun

${ }^{1825}$ Cfr. Georges RENARD, Introducción filosófica al estudio del derecho, $\mathrm{T}^{\circ} \mathrm{I}$, DedebecEdiciones Desclée de Brouwer, Buenos Aires, 1.947, p. 9.

${ }^{1826}$ No puede entonces sorprenderme, que el genial Juan Vallet, quizás a modo de homenaje, tenga tiempo suficiente para analizar y desarrollar de manera exquisita, algunos de los legados de Renard, y que fueran como advertí, oportunamente publicados en el habla castellana. Allí explica Vallet que la misión más importante que el jurista francés tenía por delante era la de intentar superar las tesis positivistas de Hariou y de su principal discípulo Gény, que afirmaban al derecho como un orden normativo casi exclusivamente legislado por el Estado, a la vez que consideraban a la naturaleza de las cosas únicamente como una resistencia de las cosas materiales a la propia voluntad legislada. Eso constituye, aunque con algunos reparos, para Vallet, su mérito más importante. Por idénticas razones motivadas en identidad de pensamiento, no dejaré pasar la oportunidad en el presente capítulo de referirme a esa obra tan siquiera someramente. Cfr. Juan Berchmans VALLET DE GOYTISOLO, La perspectiva del derecho natural y de su función que expone Georges Renard, Revista Verbo $\mathrm{n}^{\circ} 369-370$, Madrid, 1.998 , p. 841 y ss.

${ }^{1827}$ La obra entera de Vallet recibe notable recepción académica desde tres focos de indudable valor: La Revista Jurídica del Notariado (CGN); La Revista Verbo de la Fundación Speiro (http://www.fundacionspeiro.org/) y de las publicaciones de los Anales de la Fundación Elías de Tejada (http://www.fundacioneliasdetejada.org/). (Ultimo acceso: 29/08/2017).

${ }^{1828}$ Juan VALLET DE GOYTISOLO, En torno al derecho natural, ob. cit.,; Ideología, Praxis y Mito de la Tecnocracia, ob. cit., ; Sociedad de Masas y derecho, ob. cit.,; Mas sobre temas de hoy, Editorial Speiro, Madrid, 1.979 y Manuales de metodología jurídica, ob. cit.

${ }_{1829}$ Algunos de los comentarios que me han impactado notablemente: Ignacio Andrés GARCIA, Comentarios al libro En torno al Derecho Natural, Dialnet- Revista de Estudios Políticos y Constitucionales, Madrid, 1.977, p. 384-392; Philippe André VINCENT, En torno al derecho natural, Revista Verbo 148-149, Madrid, 1.976, p. 1287-1288; Javier NAGORE YÁRNOZ, Manuales de metodología jurídica, Revista Verbo 429-430, Madrid, 2004, págs. 889-894; Claudio FINZI, Ideología, Praxis y Mito de la Tecnocracia, Revista Verbo 173-174, Madrid, 1.979, págs. 471-475; Dalmacio NEGRO, La metodología jurídica de Vallet de Goytisolo ante la política, Revista Verbo 425-426, Madrid, 2.004, págs. 585-594 y Emilio 


\section{SEBASTIÁN JUSTO COSOLA}

más relevante que ello: fueron fuente de inspiración para la creación de notables tesis doctorales (En España se destacan las de Cristina FuertesPlanas Aleix ${ }^{1830}$, Estanislao Cantero Núñez ${ }^{1831}$ - con atinado comentario de Francesco Gentile ${ }^{1832}$ - , María del Carmen Fernández de la Cigoña ${ }^{1833}$ y Adolfo Jorge Sánchez Hidalgo ${ }^{1834}$, mientras que en Italia Federica Balcón ${ }^{1835}$ ha hecho lo propio: una tesis magistral sobre Vallet dirigida por el mencionado maestro Gentile).

Vallet fue además secundado por otros notables autores del derecho notarial que interpretaban y complementaban sus teorías como Isidoro Lora-Tamayo Rodriguez $^{1836}$ y Juan Francisco Delgado de Miguel ${ }^{1837}$. Entre todos los autores mencionados hay que reconocer una visión especial de la justicia, que la relaciona directamente con un inminente iusnaturalismo clásico, que es la corriente a la que adscribo desde que el derecho ocupa en mi vida un lugar trascendental. Todos ellos reconocen cierta influencia de pensamiento

SERRANO VILLAFAÑE, Estudios sobre fuentes del derecho y método jurídico, Revista Verbo 211-212, Madrid, 1.983, págs. 222-230 entre otros.

${ }^{1830}$ Cfr. Cristina FUERTES-PLANAS ALEIX, Filosofía política y jurídica de Juan Berchmans Vallet de Goytisolo, Fundación Matritense del Notariado, Madrid, 1.992 (TD).

${ }^{1831}$ Cfr. Estanislao CANTERO NÚÑEZ, El concepto del derecho en la doctrina española (1939-1998)-La originalidad de Juan Vallet de Goytisolo, Fundación Matritense del Notariado, Madrid, 2.000 (TD).

${ }^{1832}$ Cfr. Francisco GENTILE, El derecho natural en España: A propósito de una tesis de Estanislao Cantero sobre Juan Vallet de Goytisolo, Revista Verbo 375-376, Madrid, 1.999, p. 487.

1833 Cfr. María del Carmen DE LA CIGOÑA CANTERO, La función del jurista: Perspectivas y consideraciones del realismo jurídico contemporáneo: (La continuidad del pensamiento Aristotélico-Tomista), Universidad Complutense de Madrid, 2001. http://eprints.ucm.es/tesis/der/ucm-t24850.pdf (TD). (Último acceso: 29/08/2017)

${ }^{1834}$ Cfr. Adolfo Jorge SANCHEZ HIDALGO, Filosofia y método del derecho en Juan Berchmans Vallet de Goytisolo, Fundación Matritense del Notariado, Madrid, 2010 (TD).

${ }^{1835} \mathrm{http}$ ://www.fundacionspeiro.org/verbo/1999/V-375-376-P-554-555.pdf.

${ }^{1836}$ Cfr. Isidoro LORA-TAMAYO RODRIGUEZ, Derecho y crisis económica, Separata de la RJN, n XII extraordinario, Madrid, 2012, p. 168.

${ }^{1837}$ Cfr. Juan Francisco DELGADO DE MIGUEL, La deontología notarial frente a los clientes, a los colegas y al Estado, UINL, Asturias, 1.998, p. 31. 
LOS EFECTOS DE LA PUBLICIDAD EN EL DOCUMENTO NOTARIAL

de autores como Inmanuel Kant ${ }^{1838}$, Joaquín Costa ${ }^{1839}$, Michel Villey ${ }^{1840}$, José Castán Tobeñas, Francesco Carnelutti ${ }^{1841}$, Elías de Tejada ${ }^{1842}$, Michele Federico Sciacca ${ }^{1843}$ y entre otros, Biondo Biondi ${ }^{1844}$. Muchos de estos aportes serán referenciados en el cuerpo de este capítulo.

\subsubsection{Fundamentos del tratamiento de la justicia en una tesis de}

\section{derecho notarial.}

El tratamiento de la justicia como valor en una tesis de derecho notarial es esencial, ya que termina por decidir en el documento notarial, lo que antecede, lo que es y lo que comprende lo justo. Estoy convencido que el derecho a través de los juristas en su generalidad, es deudor de respuestas nobles y contundentes que puedan alcanzar la paz y la tranquilidad a la ciudadanía en general. Como he ya insistido anteriormente, el derecho es una disciplina que oscila entre el amor, la fuerza y el poder. Al no existir la potestad en el hombre común para determinar cuando un acto es o no es

${ }^{1838}$ Cfr. Juan Berchmans VALLET DE GOYTISOLO, La ciencia y el derecho en la concepción de Inmanuel Kant, Dialnet 2869978.pdf

${ }^{1839}$ Cfr. Juan Berchmans VALLET DE GOYTISOLO, Joaquín Costa en la metodología de la determinación del derecho (Cinco apartados de un libro), Dialnet 105111.pdf; y en La definición de derecho según Joaquín Costa, Dialnet 105148.pdf.

${ }^{1840}$ Juan Berchmans VALLET DE GOYTISOLO, Definición e interpretación del derecho según Michel Villey, Persona y derecho ${ }^{\circ}$ 25, Madrid, 1.991, p. 213; y en El retorno a la genuina definición aristotélico-romano-tomista del derecho por Michel Villey, Revista Verbo de la Fundación Speiro n 363-364, Madrid, 1.998, p. 262.

${ }^{1841}$ Cfr. Juan Berchmans VALLET DE GOYTISOLO, La conversión de Carnelutti al iusnaturalismo realista sin salir del normativismo, Revista Verbo de la Fundación Speiro $n^{\circ}$ 365-366, 1.998, p. 379.

${ }^{1842}$ Cfr. Juan Berchmans VALLET DE GOYTISOLO, Esbozo del pensamiento jurídico de Elías de Tejada, Revista Verbo 191-192, Madrid, 1.981, p. 105.

1843 Cfr. Juan Berchmans VALLET DE GOYTISOLO, Del racionalismo inmanente al voluntarismo utópico $y$, de su fracaso, al nihilismo, Revista Filosofía OGGI, $\mathrm{V}^{\circ} 3 \mathrm{~N}^{\circ} 4$, 1.980, reproducido en Revista Verbo de la Fundación Speiro № 191-192, Madrid, 1.981, p. 227 y ss.

$1844 \mathrm{http}: / /$ www.elnotario.es/index.php/los-grandes-del-notariado/2793-vallet-de-goytisolo-lavida-no-se-deja-aprisionar-en-palabras-0-6209789566891072. (Ultimo acceso: 29/08/2017). 


\section{SEBASTIÁN JUSTO COSOLA}

justo -ya que el ejercicio de la fuerza para cumplir el derecho es un monopolio del Estado-, queda entonces por entender al derecho como una parcela de la realidad del hombre, como tantas otras existen, que se mueve entre el amor y el poder. Establecer un punto medio entre estas dos virtudes, en algún modo contrapuestas entre sí, es el desafio actual del derecho notarial, que proyecta su esplendor en la creación y concreción del documento notarial entre personas que se preocupan mucho mas por hacer negocios que por consolidar lazos y relaciones fraternales.

Tanto la adecuada comprensión del valor de fe pública -entendido desde las dos perspectivas referidas-, como la influencia del objetivo de proyección notarial de la seguridad jurídica también se vuelven trascendentes. La atención única a la fe pública objetiva (certeza), puede determinar cuando un derecho es cierto, pero no necesariamente cuando es justo. Para que la $f e$ pública pueda consolidar el valor de la justicia, debe además coincidir tanto el valor de la certeza como el de la verdad (criterio subjetivo). Ni que decir del valor seguridad: mientras que una seguridad jurídica estática siempre priorizara al amor, la defensa de la seguridad jurídica en faz dinámica siempre orientara los esfuerzos para dar validez y sentido al poder.

De esta manera, frente a la pregunta acerca de la existencia de la relación que justifica el tratamiento de la justicia en una tesis doctoral referida al derecho notarial -derecho que en todo caso siempre ha proyectado como esenciales únicamente los valores de fe (certeza) y de seguridad jurídica, más cercanas a la escuela positiva del derecho-, se impone la respuesta imperecedera de Jorge Alterini de quien hago propias sus enseñanzas: " $E l$ énfasis que pongo en resaltar la significación de la seguridad jurídica, no olvida que la justicia es un valor de mayor jerarquía, tanto que Platón expresa que compendia y resume a todas las demás virtudes y Aristóteles la considera una virtud absoluta. Sin embargo, un orden mínimo y la seguridad son valores previos, o condicionantes, pues sin ellos es difícil alcanzar el espectáculo imponente de la justicia ${ }^{1845}$ "”.

Se trata entonces de comprender que el documento notarial contiene los tres valores referidos a la fe (certeza + verdad), a la justicia y a la seguridad;

1845 Cfr. Jorge Horacio ALTERINI, La seguridad jurídica y las incertidumbres en la usucapión de inmuebles, La Ley 02/07/2008, 1 - Academia Nacional del Derecho, 01/01/2008, 1, p. 3. 


\section{LOS EFECTOS DE LA PUBLICIDAD EN EL DOCUMENTO NOTARIAL}

son valores fundantes, y no pueden considerarse, desde una perspectiva notarial, sino coligados y fusionados, en la búsqueda del mejor derecho para el hombre, para la mujer, para la familia, para el desarrollo de una mejor sociedad.

La valoración del desarrollo que continúa estas líneas tiene que ver con el planteamiento de una visión integradora de los valores de fe y seguridad a partir del desarrollo de la justicia. Lo que implica aceptar que en definitiva, la misma no simplemente se justifica desde una sentencia que pone fin a una disputa, ya que puede encontrarse y leerse también -aunque con especial singularidad-, en otro elemento de decisión jurídica, como el documento notarial.

\subsubsection{Esquema escogido para el desarrollo de la justicia.}

Esta no es ni pretende ser una tesis de iusfilosofía ${ }^{1846}$. Si en cambio es mi deseo acercar, como ya he tenido la oportunidad de hacer en otras oportunidades $^{1847}$, ciertos conceptos de la filosofía del derecho que sirven y sustentan al derecho notarial ${ }^{1848}$, para que en esfuerzo común, ambas

\footnotetext{
${ }^{1846} \mathrm{Al}$ momento de referirse a la necesidad de la investigación profunda del derecho, José CASTÁN TOBEÑAS afirmaba lo siguiente: "Es indudable que el juez, y el jurista en general, necesitan de la filosofía jurídica, porque la aplicación y la investigación del derecho suponen una actitud previa ante el problema de la naturaleza, la esencia y los fines del derecho". Cfr. José CASTAN TOBEÑAS, La noción del derecho a través de los sistemas filosófico-jurídicos tradicionales y modernos, IER, Madrid, 1.947, p. 130. Éste es el sentido que atribuyo a la filosofía del derecho para auxiliar desde los fundamentos a la disciplina objeto de esta tesis doctoral.

1847 Cfr. Sebastián Justo COSOLA, Identidad natural en la evolución académica y jurisprudencial de los conceptos de filosofia del derecho y de derecho notarial. Necesidad impostergable de la reflexión iusfilosófica notarial, Roberto A. LUCERO ESEVERRI y Leonardo B. PEREZ GALLARDO (Coord.), Panorama actual del derecho notarial en Hispanoamérica, Júpiter Editorial, Buenos Aires, 2.011, p. 193-240.

${ }^{1848}$ Cfr. Sebastián Justo COSOLA, El concepto de derecho notarial a la luz de la naturaleza de la función (Diálogos entre Vallet de Goytisolo y Von Ihering), Leonardo B. PEREZ GALLARDO y Miguel Ángel ARÉVALO (Coord.), Escritos sobre derecho notarial, Gaceta Notarial, Lima, 2.013, p. 225-246.
} 


\section{SEBASTIÁN JUSTO COSOLA}

disciplinas puedan consolidarse en el documento ${ }^{1849}$. Por supuesto que en el presente análisis quedan absolutamente excluidas las referencias a obras de autores notariales que han confundido -pienso que de manera adrede- a la justicia como valor desde el concepto genérico que lo asimila a la jurisdicción, en razón de la protección de la autonomía del derecho notarial fundada en la instauración de un fuero notarial propio ${ }^{1850}$. La justicia, en la presente tesis -y de acuerdo a las pautas por mí aceptadas al momento de ingreso a la carrera doctora ${ }^{1851}$-, es tratada como valor, porque es esa definitivamente, la única posición desde la que se puede contribuir al desarrollo del derecho en paz (cavere) ${ }^{1852}$.

\subsection{Las bases y el punto de partida.}

El desarrollo teórico de la justicia considerada como un valor es altamente recomendable para cualquier estudio de derecho que pretenda alcanzar algún tipo de consagración o respuesta desde la recepción académica. Además de las orientaciones del pensamiento jurídico, los temas de tratamiento oscuros o poco claros suelen generar interpretaciones que no siempre encuentran adecuada recepción en quienes aplican razonablemente el derecho con el objetivo de dirimir un conflicto planteado.

\footnotetext{
${ }^{1849}$ Como resulta lógico, no cabe la advertencia que pone en alerta al lector acerca de que este tema no será tratado con la profundidad de un análisis crítico que en las obras magistrales acerca de la justicia se pueden aprovechar. Muy por el contrario, me serviré únicamente de los conceptos y las orientaciones que generen un vínculo con el documento notarial, sin desnaturalizar ni desviar el pensamiento original de los autores.

${ }^{1850}$ Cfr. Tomás Diego BERNARD (h), Temas de derecho e historia notarial, Ediciones Esnaola, Buenos Aires, 1.965, p. 12.

${ }^{1851}$ En todo caso, lo que estoy proponiendo es lo que está contemplado, hoy ya de manera indirecta, en el reglamento del doctorado en derecho de la Universidad Austral. http://www.austral.edu.ar/derecho/wp-content/uploads/2011/11/Plan-de-estudios-2008-2.pdf (Último acceso: 29/08/2017).

${ }^{1852}$ Alejo definitivamente la noción de la justicia de las cuestiones gremiales o de defensas de incumbencias, que desde el ejercicio político institucional se ejercen en defensa de los alcances de un determinado quehacer funcional. Estas actitudes propias de los hombres suelen olvidar que el fin del derecho es la justicia para el hombre y no para los gremios tal y como ellos la entienden y la postulan.
} 


\section{LOS EFECTOS DE LA PUBLICIDAD EN EL DOCUMENTO NOTARIAL}

Comencemos por recordar entonces, que la teoría de la justicia en Aristóteles comienza por señalar que es preciso considerar a que acciones se aplica, que especie de medio es la justicia y cuáles son los extremos en donde lo justo es un medio laudable ${ }^{1853}$. Con la justicia ocurre algo especial, enseña el filósofo nacido en Estagira: se tiene de ella una especie de retrato -al igual que de la injusticia-, porque todo el mundo está de acuerdo en llamar justicia a la cualidad moral que obliga a los hombres a practicar cosas justas ${ }^{1854}$. La justicia como virtud -y la injusticia como contracara a esa virtud-, en efecto, pueden entenderse en muchos sentidos ${ }^{1855}$; sin embargo, por diversas razones y circunstancias, todas las virtudes se encuentran en el seno de la justicia ${ }^{1856}$. El análisis aristotélico de la justicia alcanza una de las máximas expansiones y desarrollo en Santo Tomas de Aquino ${ }^{1857}$. Desde esta última concepción, la justicia versa especialmente sobre las cosas que se refieren a otro como a su propia materia ${ }^{1858}$; y por ello el acto de justicia se designa cuando se dice que da a cada uno su derecho ${ }^{1859}$. Desde esta perspectiva, el acto de justicia se constituye como voluntario, añadiendo la constancia y perpetuidad ${ }^{1860}$, porque para el acto de virtud debe primero obrarse a conciencia; luego elegir y por un fin legítimo, para finalmente, determinar que el obrar sea invariable ${ }^{1861}$. En palabras de Tomás Casares, la virtud de la justicia en Santo Tomás reside en la voluntad y no así en la inteligencia, porque la misma se refiere a la acción y no al discernimiento de lo verdadero y de lo falso ${ }^{1862}$; de ahí que en relación al derecho (Q. LVII) Tomás afirme que es propio de la justicia ordenar al hombre en sus relaciones con los demás ${ }^{1863}$ :

\footnotetext{
1853 ARISTÓTELES, Obras completas, t I, Bibliográfica Omeba, Buenos Aires, 1.967, p. 133.

${ }^{1854}$ Ibídem.

${ }^{1855}$ Ibídem, p. 134.

${ }^{1856}$ Ídem, p. 135.

${ }^{1857}$ SANTO TOMAS DE AQUINO, Suma teológica. La prudencia, la justicia y el derecho, $\mathrm{t}^{\circ}$ XI, Club de Lectores, Buenos Aires, 1.987, Q. LVIII, p. 116.

${ }^{1858}$ Ibídem, p. 117.

${ }^{1859}$ Ibídem.

${ }^{1860}$ Ibídem.

${ }^{1861}$ Ibídem.

${ }^{1862}$ Cfr. Tomás D. CASARES, La justicia y el derecho, Abeledo Perrot, Buenos Aires, 1.997, p. 20. Más adelante, explicará el autor: "La materia a la cual se refiere la voluntad en la justicia es el derecho, aquello que pertenece a otro".

${ }^{1863}$ SANTO TOMAS DE AQUINO, Suma Teológica, ob. cit., p. 108.
} 
"Lo recto que está en la obra de la justicia, aun prescindiendo de su relación con el agente, se constituye por comparación con otro; porque en nuestras acciones se dice ser justo lo que corresponde a otra cosa según alguna igualdad a otro (...) Y por esto especialmente a la justicia antes que a las demás virtudes se determina en sí mismo el objeto que se llama justo. $Y$ esto ciertamente es el derecho. Por lo cual es evidente que el derecho es

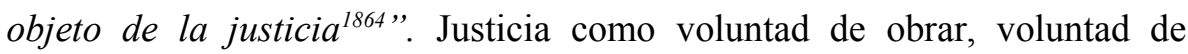
accionar; éste es el punto clave y trascendente.

\subsubsection{Breve panorama de las teorías magistrales de la Justicia.}

Hace tiempo ya que Enrique Ahrens enseñaba que una de las utilidades prácticas de la filosofía del derecho tiene por objeto desarrollar, a través de la inteligencia, el sentimiento de lo justo en el corazón del hombre, para así, poder inspirarlo a dirigir su vida de acuerdo a la justicia ${ }^{1865}$. También Gustav Radbruch comenzaba por reconocer que la idea del derecho no puede ser otra que la justicia ${ }^{1866}$. Rudolf Stammler -y con él, la celebración del retorno a la reflexión iusfilosófica del derecho natural- advertía que el derecho positivo, al igual que toda voluntad humana, se halla sujeto al aspecto crítico de saber si es o no es justo en un caso determinado ${ }^{1867}$. Para el autor, la palabra justicia tiene varios significados, entre los referidos a la fiel aplicación del derecho vigente por oposición a la arbitrariedad, y el juzgamiento en el sentido de ordenación jurídica, por cuanto la justicia es una cualidad fija de las aspiraciones jurídicas ${ }^{1868}$. Sin embargo, es oportuno destacar el punto en que el autor se refiere al fin de la justicia: como fin, la justicia es una virtud fundamental de un derecho ${ }^{1869}$, que puede alcanzarse

1864 Ibídem.

${ }^{1865}$ Cfr. Enrique AHRENS, Curso de derecho natural o de filosofía del derecho, trad. Pedro RODRIGUEZ HORTELANO y Mariano Ricardo DE ASENSI, Librería Editorial De BaillyBailliere e Hijos, Madrid, 1.903, p. 81.

${ }^{1866}$ Gustav RADBRUCH, Filosofia del derecho, ob. cit., p. 82.

${ }^{1867}$ Rudolf STAMMLER, Tratado de filosofía del derecho, ob. cit., p. 307.

1868 Ibídem, p. 309.

${ }^{1869}$ Ibídem, p. 311. 
aplicando la noción de la pureza de la voluntad a la voluntad jurídica en su carácter peculiar de vinculatoria ${ }^{1870}$. Ésta ultima vinculación toma los fines de uno como medios para otro y los fines del otro, a su vez, como medios del primero ${ }^{1871}$. Por ello "una voluntad vinculatoria será fundamentalmente justa cuando sus normas se hallen esencialmente orientadas en el sentido de la comunidad pura ${ }^{1872}$ ", ya que incluye las vinculaciones de los fines diversos de los hombres, que parten del concepto mismo de derecho como voluntad vinculatoria. Algún tiempo después de efectuadas estas enseñanzas, será Karl Larenz quien tomará de Stammler la expresión derecho justo para ampliarla y llevarla más allá de lo que en origen se pretendía o se buscaba en el inicio de la nueva reflexión iusfilosofica iusnaturalista ${ }^{1873}$.

También Emil Brunner advierte que en todo hombre vive un sentimiento de lo justo y de lo injusto ${ }^{1874}$. Que la vida humana necesita de una configuración de la sociedad mediante instituciones ${ }^{1875}$, y por esa razón, es que el conocimiento oscuro de lo justo y de lo injusto debe necesariamente elevarse al principio de justicia para que los ordenamientos de la sociedad humana cumplan con ella ${ }^{1876}$. Según el autor, el pensamiento de occidente sobre la justicia reconoce dos fuentes principales: a) la filosofía greco romana, que reconoce que nadie ha influido más que Aristóteles en la mencionada doctrina, y b) el cristianismo, que afirma que la máxima expresión absoluta y poderosa de la exigencia de justicia es la ofrecida por los profetas en la biblia $^{1877}$. En general esta opinión es compartida por los autores del derecho occidental, y también especialmente por aquellos que, como Paolo Prodi ${ }^{1878}$,

\footnotetext{
${ }^{1870}$ Ibídem.

${ }^{1871}$ Ibídem, p. 312.

${ }^{1872}$ Ibídem.

${ }^{1873}$ Cfr. Karl LARENZ, Derecho Justo. Fundamentos de ética jurídica, Civitas, Madrid, 2.001, p. 21.

${ }^{1874}$ Cfr. Emil BRUNNER, La justicia. Doctrina de las leyes fundamentales del orden social, trad. Luis RECASÉNS SICHES, Centro de Estudios Filosóficos-UNAM, México, 1.961, p. 10.

1875 Ídem, p. 11.

${ }^{1876}$ Ibídem.

${ }^{1877}$ Ibídem.

${ }^{1878}$ Cfr. Paolo PRODI, Una historia de la justicia. De la pluralidad de fueros al dualismo moderno entre conciencia y derecho, Katz, España, 2.008.
} 


\section{SEBASTIÁN JUSTO COSOLA}

presentan una historia de la justicia digna de los más absolutos elogios ${ }^{1879}$, desde donde se pretende poner de manifiesto un planteo superador de los conflictos a través de la aplicación de una norma de tipo unidimensional, aprovechando de la historia de la justicia en la humanidad, del nacimiento de constituciones y códigos que, sin la expansión sin límites del derecho positivo, puede ayudar a los hombres a enfrentar las crisis del derecho ${ }^{1880}$.

John Rawls, de ineludible cita, posiciona la idea principal de su teoría de la justicia afirmando que los principios que la inspiran son los que las personas libres y racionales interesadas en promover sus propios intereses aceptarían en una posición inicial de igualdad como definitorios de los términos fundamentales de su asociación ${ }^{1881}$. El objeto primario de la justicia entonces es para el autor la estructura básica de la sociedad ${ }^{1882}$, o también y más precisamente, el modo en que las grandes instituciones sociales distribuyen los derechos y deberes fundamentales y determinan la división de las ventajas provenientes de la cooperación social ${ }^{1883}$. Como ejemplo, entre otros tantos, cita a la protección jurídica de la libertad de pensamiento y de conciencia ${ }^{1884}$; notable expresión, y nunca más cercana su vinculación con el documento notarial y la seguridad jurídica que de él se desprende. Para el autor la justicia se encuentra relacionada con las instituciones sociales $^{1885}$, y como virtud, la misma es presentada como imparcialidad ${ }^{1886}$. Algún tiempo después de estas notables afirmaciones, Robert Alexy insistirá en que los principios de justicia de Rawls no son más que un intento por establecer una relación entre libertad e igualdad ${ }^{1887}$.

\footnotetext{
${ }^{1879} \mathrm{Su}$ obra esencialmente destaca la función de la justicia en relación a Dios, a los hombres, a la iglesia y los conflictos que esas relaciones han venido generando a lo largo de los años, relativos a la ley y la conciencia, a la antinomia entre la norma y la moral, y a lo que el denomina una norma unidimensional.

${ }_{1880}$ Ídem, p. 444.

${ }^{1881}$ Cfr. John RAWLS, Teoría de la justicia, Fondo de Cultura Económica, México, 2.012, p. 24.

1882 Ibídem, p. 20.

${ }^{1883}$ Ibídem.

${ }^{1884}$ Ibídem.

1885 Ídem, p. 17.

${ }^{1886}$ Ibídem.

${ }^{1887}$ Cfr. Roberto ALEXY, Teoría de los derechos fundamentales, trad. Carlos BERNAL PULIDO, Centro de Estudios políticos y constitucionales, Madrid, 2.008, p. 482.
} 


\section{LOS EFECTOS DE LA PUBLICIDAD EN EL DOCUMENTO NOTARIAL}

John Finnis ${ }^{1888}$, discípulo de L.A. Hart en Oxford, se refiere a la exigencia de la justicia desde la exigencia de la razonabilidad práctica ${ }^{1889}$. La tesis de Finnis plantea el primer principio práctico de la ley natural, el bien ha de hacerse y el mal evitarse, conjuntamente con los demás principios prácticos, son aprehendidos por evidencia ni bien se presenta la cuestión ética ${ }^{1890}$. La evidencia en el primer principio práctico hace alusión a proposiciones que por sí mismas son evidentes, lo que significa que no pueden ser sino percibidas como verdaderas por aquellos que alcancen a conocerlas en sus significados variables ${ }^{1891}$. Así, explica en nuestro país Massini que en todos los raciocinios prácticos que concluyen en los preceptos del derecho natural se encuentra presupuesto, implícita o explícitamente, el primer principio práctico que en contracción jurídica, puede formularse como lo justo a de hacerse y lo injusto evitarse ${ }^{1892}$. La exigencia de la justicia para Finnis existe entonces, porque la persona humana debe buscar la realización y el respeto a los bienes humanos no sólo para sí y en su beneficio, sino también en procura del beneficio de la comunidad. Toma a la justicia en su carácter general, y advierte que el complejo concepto de justicia comprende tres elementos:

1888 Cfr. John FINNIS, Ley Natural y derechos naturales, trad. Cristóbal ORREGO SANCHEZ, Abeledo Perrot, Buenos Aires, 2.000, p. 191.

${ }^{1889}$ La filosofia práctica pretende retomar la tradición clásica según la cual los fines y valores del obrar deben ser susceptibles de un conocimiento y de un control racional (Cfr. Carlos Ignacio MASSINI CORREAS, Filosofía del derecho, $\mathrm{t}^{\circ} \mathrm{I}$, LexisNexis, Buenos Aires, 2.005, p. 21). La razón humana es una sola, y la verdad siempre es adecuación a lo real: funciona como teoría y como práctica. Como teoría, se propone únicamente la contemplación de la verdad, y se aplica a las cosas que se ofrecen con la sola finalidad de la contemplación de lo real. Como práctica, la razón aprehende la verdad para dirigir una determinada acción del hombre, no es contemplar lo real, sino transformar lo real, por cuanto "el conocimiento práctico presupone el conocimiento teórico que lo funda y sobre el cual se apoya" (Cfr. Rodolfo Luis VIGO, Visión crítica de la historia de la filosofía del derecho, Rubinzal Culzoni, Santa Fe, 2.008, p. 29). Por ello es que Vallet afirma que la razón teórica, pura o especulativa parte de algunos principios conocidos a priori que permiten deducir conclusiones lógicamente consecuentes, mientras que la razón práctica se refiere a los principios a priori de la acción, de donde surge que no son nuestras ideas las que deben adecuarse a las cosas, sino las cosas a nuestras ideas. V. Juan Berchmans VALLET DE GOYTISOLO, Mas sobre temas de hoy, ob. cit., p. 4.

1890 Cfr. Carlos Ignacio MASSINI CORREAS, El derecho natural y sus dimensiones actuales, Ábaco, Buenos Aires, 1.999, p. 74.

${ }^{1891}$ Ibídem, p. 75.

${ }^{1892}$ Ibídem. 


\section{SEBASTIÁN JUSTO COSOLA}

a) La orientación hacia otro, que se refiere a las relaciones y tratos de cada uno con los otros ${ }^{1893}$;

b) El elemento deber, que implica lo que es adeudado o debido al otro, advirtiendo que la justicia no se refiere a toda relación o trato razonables entre personas, sino a las relaciones y tratos que son necesarios para evitar el mal, en definitiva, se trata de evitar algo que según la razón no debe $\operatorname{ser}^{1894}, \mathrm{y}$ c) El elemento igualdad, entendido en sentido analógico, pudiendo estar presente en variadas maneras, por lo cual sugiere pensar en una proporcionalidad o inclusive, en un contrapeso o equilibrio ${ }^{1895}$.

Estos tres elementos dan al concepto de justicia suficiente precisión para que sea útil, precisamente desde el análisis de la razonabilidad práctica ${ }^{1896}$. La razón práctica entonces, se refiere puntualmente a la capacidad de utilización de la razón para guiar el obrar ${ }^{1897}$. Capacidad de guía de nuestra razón para dirigir nuestro obrar: se debe perseguir lo bueno, y se debe evitar lo malo, es un principio general de la racionalidad práctica ${ }^{1898}$. Finnis es uno de los máximos expositores del iusnaturalismo clásico ${ }^{1899}$, y su obra es en la actualidad adoptada en varias naciones del derecho continental. Desde el

${ }^{1893}$ John FINNIS, Ley Natural y derechos naturales, ob. cit., p. 191.

${ }^{1894}$ Ibídem, p. 192.

${ }^{1895}$ Ibídem, p. 193.

${ }^{1896}$ Ibídem. Recordemos con Vigo que la mencionada razonabilidad en Finnis presupone una serie de exigencias que advierten que es lo que uno debe hacer, pensar o ser si ha de participar en el mencionado valor (V. Rodolfo LUIS VIGO, Perspectivas iusfilosóficas contemporáneas. La teoría jurídica de John Finnis, ob. cit., p. 373). Por ello explica Massini Correas que en los autores realistas los principios ético-jurídicos son formulados por la razón práctica, que parte de un elemento material dado por el conocimiento experiencial de las realidades humano- sociales, y también de un elemento formal que se provee de los primeros principios autoevidentes de la razón práctica. El contenido de los principios surge del conocimiento de las estructuras de la realidad especialmente del conocimiento práctico que algunos autores llaman bienes humanos básicos. V. Carlos Ignacio MASSINI CORREAS, Filosofia del derecho, $\mathrm{t}^{\circ} \mathrm{I}$, ob. cit., p. 270.

1897 Cfr. Alfonso GOMEZ-LOBO, Los bienes humanos. Ética de la Ley Natural, Mediterráneo, Santiago de Chile, 2.006, p. 21.

${ }^{1898}$ Ibídem, p. 20.

${ }^{1899}$ Cfr. Santiago LEGARRE, Alejandro MIRANDA MONTECINOS y Cristóbal ORREGO SÁNCHEZ (Edit.) La lucha por el derecho natural. Actas de las Jornadas en Homenaje a John Finnis. A 25 años de la publicación de Natural Law and Natural Rights, Cuadernos de extensión jurídica, Universidad de los Andes, Santiago de Chile, 2.006. 


\section{LOS EFECTOS DE LA PUBLICIDAD EN EL DOCUMENTO NOTARIAL}

notariado, fue Juan Francisco Delgado quien recogió parte trascendente de su doctrina, especialmente en lo referente a la duda acerca de la obediencia a la ley o la moral ${ }^{1900}$.

Otro autor, Josef Pieper, presenta a la justicia como una virtud ${ }^{1901}$; una virtud que encierra la idea de que hay que dar a cada uno lo suyo ${ }^{1902}$, y que además viene a comprobar que lo exigido por el recto ser del hombre no es tan solo que se haga lo justo, sino que sea además justo ${ }^{1903}$. El fundamento de toda justa ordenación sobre la tierra prescribe que el hombre dé al hombre lo que a éste corresponde ${ }^{1904}$. Así se explica que si el acto de justicia consiste en dar a cada uno lo suyo, es porque ese acto supone otro antecedente o precedente, por virtud del cual algo se constituye en propiedad de alguien; por ello para el autor la justicia es algo segundo, y presupone lo primero que es el derechoo $^{1905}$. De ahí es que su tesis afirme que si no se da por supuesta la existencia anterior de un algo que le sea debido a alguien ${ }^{1906}$ no puede darse deber de justicia alguno ${ }^{1907}$. Es que el débito irrevocable que alguien adquiere y que sirve de base a la justicia encuentra origen en primer lugar, en el establecimiento de pactos, contratos, promesas, disposiciones legales, y en segundo lugar, en la naturaleza misma de las cosas ${ }^{1908}$. Sin embargo, esta distinción no posee el carácter de la mutua exclusión de sus miembros ${ }^{1909}$. Así, la convención humana pública o privada no puede contradecir la naturaleza de la cosa, porque si lo hace, no fundará débito alguno y

\footnotetext{
${ }^{1900}$ Juan Francisco DELGADO DE MIGUEL, La deontología notarial..., ob. cit., p. 16.

${ }^{1901}$ Josef PIEPER, Las virtudes fundamentales, ob. cit., p. 85.

${ }^{1902}$ Ibídem, p. 86.

${ }^{1903}$ Ídem, p. 111.

${ }^{1904}$ Ibídem.

1905 Ídem, p. 89.

${ }^{1906}$ Ibídem, p. 90.

${ }^{1907}$ Ibídem, p. 91. Dice el autor: "El concepto de derecho, de lo debido, es una noción hasta tal punto radical y primaria que no se deja reducir a ninguna otra que le fuese anterior y de la cual pudiera ser derivada. Por eso es un concepto que no puede ser definido, sino, todo lo mas, descrito. Así, por ejemplo, cabe decir que lo debido, el suum, es lo que un individuo tiene derecho a reclamar de otro como algo que se le adeuda y que no corresponde a nadie más que a él, a lo cual conviene añadir que lo adeudado no solo puede ser una cosa, como es el caso de la propiedad, sino también una acción..."

${ }^{1908}$ Ibídem, p. 93.

${ }^{1909}$ Ibídem.
} 


\section{SEBASTIÁN JUSTO COSOLA}

correspondientemente, un derecho ${ }^{1910}$. Por eso, el debito se funda en la naturaleza misma del ser a quien es debido ${ }^{1911}$, y por idéntica razón, no es posible descubrir el fundamento del derecho ni la obligación de justicia mientras no se tenga una concepción del hombre y de su naturaleza ${ }^{1912}$.

Ya más adelante, Pieper dirá que la justicia también implica una referencia al otro ${ }^{1913}$, enseñando que ser justo implica reconocer al otro en cuanto otro, estar dispuesto a respectar cuando no se puede amar ${ }^{1914}$ : "El individuo justo es tal en la medida misma en que confirma al otro en su alteridad y procura darle lo que le corresponde ${ }^{1915}$ ". Así, la mirada para determinar lo justo no se dirige al otro, sino a uno; a quien está obligado a dar lo que se debe, en lugar de posicionarse frente al legítimo acreedor de quien algo le es debido $^{1916}$. La justicia así se expone como una acción externa; determina la esfera de lo justo y de lo injusto a partir de la acción exterior del hombre ${ }^{1917}$, siendo siempre posible determinar entre hacer justicia y ser justo ${ }^{1918}$, porque también en la justicia se permite cierta separación entre la acción y la intención ${ }^{1919}$. El autor considera que la justicia es la virtud suprema frente a las otras dos virtudes morales, la templanza y la fortaleza, afirmando que cuando más puramente el hombre expresa su esencia es cuando es justo ${ }^{1920}$. Sin lugar a dudas, la inclinación de Pieper reivindica el pensamiento de Santo Tomás de Aquino, a quien considera doctor universal de la cristiandad $^{1921}$, al igual que Giuseppe Graneris, que también consideraba al aquinate en su máximo esplendor, como moralista y filósofo que además,

\footnotetext{
1910 Ibídem. El autor cita a Santo Tomás: "Cuando algo se encuentra de por sí en contradicción con el derecho natural, no puede ser justificado por la voluntad humana".

${ }^{1911}$ Ibídem, p. 94. Sobre esto, afirma el autor: "un débito en el pleno sentido de la palabra, inviolable e irrevocable, solo puede darse a condición de que el sujeto portador del correspondiente summ esté de tal manera constituido que posea la facultad de reclamar como su derecho lo que se le debe".

${ }^{1912}$ Ibídem, p. 95.

1913 Ídem, p. 99.

${ }^{1914}$ Ibídem, p. 100.

1915 Ibídem.

${ }^{1916}$ Ibídem, p. 102.

${ }^{1917}$ Ibídem, p. 107.

${ }^{1918}$ Ibídem, p. 110.

${ }^{1919}$ Ibídem.

${ }^{1920}$ Ídem, p. 113.

${ }^{1921}$ Ibídem, p. 87.
} 


\section{LOS EFECTOS DE LA PUBLICIDAD EN EL DOCUMENTO NOTARIAL}

agregaba el oficio de la teología ${ }^{1922}$-por ejemplo, en la concreción de las virtudes teologales-.

Por otra parte, Michel Villey comienza por decir que la definición más tradicional del mundo occidental, por segura asociación, es la que dice que el arte del derecho se ordena a la justicia ${ }^{1923}$. El profesor francés advierte que la noción tradicional de justicia se encuentra influenciada por el idealismo ${ }^{1924}$, que reduce la filosofía a la razón pura objetiva, y que por esa razón, hay una imperiosa necesidad de vuelta a las fuentes ${ }^{1925}$. En esas fuentes, considera a Aristóteles como el fundador de la filosofía del derecho $^{1926}$. Enseña que en el sistema aristotélico las leyes que forman el armazón de la justicia general se relacionan y afectan al derecho, pero no son el derecho ${ }^{1927}$. A través del análisis del lenguaje griego, advierte que el derecho es un objeto, y si es un medio, será un justo medio objetivo en las cosas: "Es, por ejemplo, mi parte de impuestos sobre la renta, que yo debo pagar o que he pagado, y que no debe ser ni excesiva ni insuficiente ${ }^{1928 \text { ". }} \mathrm{La}$ misión del derecho no es que el individuo sea justo, ni la de regular su conducta: "Nada le importa al jurista que subjetivamente yo sea honesto y lleno de buenas intenciones hacia las finanzas públicas; únicamente le importa que pague mi impuesto; y todavía con más precisión (ahí reside la misión de la ciencia del derecho): le importa definir la parte del impuesto que me corresponde pagar ${ }^{1929}$. . De esta manera, la idea del derecho emerge de la idea de justicia, pero con Aristóteles el derecho conquista su autonomía ${ }^{1930}$.

\footnotetext{
${ }^{1922}$ Cfr. Giuseppe GRANERIS, Contribución tomista a la filosofia del derecho, Eudeba, Buenos Aires, 1.973, p. 11

${ }^{1923}$ Cfr. Michel VILLEY, Compendio de filosofía del derecho. Definiciones y fines del derecho, Eunsa, Pamplona, 1.979, p. 67.

${ }^{1924}$ Ibídem, p. 68. Refiere el autor: "Es verdad que los positivistas no han conseguido todavía suprimir la palabra justicia de nuestro vocabulario. De hecho, su uso es todavía bastante frecuente, aunque mucho más en los discursos de los politicos, en los grandes periódicos y en los sermones de los clérigos progresistas que en los tratados de derecho civil".

${ }^{1925}$ Ibídem, p. 69.

${ }^{1926}$ Ibídem, p. 71.

1927 Ídem, p. 76.

${ }^{1928}$ Ibídem, p. 86.

${ }^{1929}$ Ibídem, p. 87.

${ }^{1930}$ Ibídem.
} 


\section{SEBASTIÁN JUSTO COSOLA}

Ya en el fin, Herbert Spencer, enseña que la idea que el hombre tiene acerca de la justicia es vaga e indecisa, ya que se siempre se mezcla, indiscutiblemente, la idea con el sentimiento de justicia ${ }^{1931}$. Por ello es que la idea humana de la justicia es contenedora de dos elementos: uno positivo, que posiciona el reconocimiento del derecho de cada hombre a las actividades libres de toda traba con los beneficios consiguientes, y uno negativo, que implica el sentimiento consciente de los límites impuestos por la presencia de otros hombres que tienen y gozan de derechos análogos ${ }^{1932}$. Por ello es que la idea primordial que se presenta en la mente del hombre es la desigualdad ${ }^{1933}$.

Sin lugar a dudas pueden destacarse en sintonía con las menciones realizadas, notables aportes desarrollados por autores como Amartya Sen ${ }^{1934}$, Tomás Casares ${ }^{1935}$, Carlos Massini Correas ${ }^{1936}$, Rodolfo Vigo ${ }^{1937}$, Alfredo Colmo $^{1938}$, Jorge Portela ${ }^{1939}$, Javier Hervada ${ }^{1940}$, Luis García Soto ${ }^{1941}$ y Alfredo Palacios ${ }^{1942}$ entre tantísimos otros. Muchos de ellos, si bien no podrán ser considerados en la magnitud de sus contenidos, serán asimismo referenciados en el cuerpo del presente estudio en temas puntuales y específicos.

\subsubsection{Las otras posiciones acerca de la justicia.}

\footnotetext{
${ }^{1931}$ Cfr. Herbert SPENCER, La justicia, Heliasta S.R.L, Buenos Aires, 1.978, p. 31.

${ }^{1932}$ Ibídem, p. 32.

${ }^{1933}$ Ibídem.

${ }^{1934}$ Cfr. Amartya SEN, La idea de la justicia, trad. Hernando VALENCIA VILLA, Taurus, Madrid, 2.010.

1935 Tomás D. CASARES, La justicia y el derecho, ob. cit.

${ }^{1936}$ Carlos Ignacio MASSINI CORREAS, Filosofia del derecho, $\mathrm{t}^{\circ}$ II, ob. cit.

${ }^{1937}$ Rodolfo Luis VIGO, Las causas del derecho, ob. cit.

1938 Cfr. Alfredo COLMO, La justicia, Abeledo Perrot, Buenos Aires, 1.957.

${ }^{1939}$ Cfr. Jorge Guillermo PORTELA, La justicia y el derecho natural, Arequipa, 2.006.

${ }^{1940}$ Cfr. Javier HERVADA, Introducción crítica al derecho natural, Eunsa, Pamplona, 2.007.

${ }^{1941}$ Cfr. Luis GARCIA SOTO, Teoría de la justicia e idea del derecho en Aristóteles (TD), Marcial Pons, Madrid, 2.011.

${ }^{1942}$ Cfr. Alfredo L. PALACIOS, La justicia social, Editorial Claridad, Buenos Aires, 1.954.
} 
La elección por la escuela del derecho referida que fundamenta los valores en el interior del documento notarial tiene que justificar su importancia a partir un desarrollo objetivo que permita hacer inferir al lector de esta investigación que los resultados a los que se arriba tienen el indudable compromiso del equilibrio. Así, no hay ideas de pensamiento buenas o malas: lo que existe son nobles intenciones que intentan acercar al derecho una solución alternativa a las que se tienen habitualmente en cuenta, en procura de obtener los mejores resultados que sean posible alcanzar. La referencia a otras posiciones en torno al valor que pretendo justificar desde la corriente por mi escogida se vuelve imprescindible.

Otras posiciones se alejan entonces de los postulados de la escuela que he escogido como fundamento para el desarrollo del valor justicia dentro del documento notarial. Roscoe Pound plantea que si se sigue a los filósofos griegos se puede advertir que los mismos posicionan a la justicia como una virtud individual, y de ahí que sea el fin constante y continuo de dar a cada uno lo que le es propio, ya que se constituye como un principio de rectitudy justo trato de los hombres en sus relaciones reciprocas ${ }^{1943}$. En franca oposición a estas teorías, plantea un esquema de justicia judicial conforme a derecho ${ }^{1944}$, lugar desde donde intenta plantear las ventajas elementales de su teoría: combinación de posibilidades de certeza y flexibilidad judicial ${ }^{1945}$, imposición de medios de contención sobre los jueces ${ }^{1946}$, sostenimiento judicial del derecho contra el apasionamiento y el clamor ${ }^{1947}$, por cuanto el derecho presupone una vida media por la razón, y un proceso judicial llevado adelante por una técnica razonada aplicada a la experiencia ${ }^{1948}$. Alf Ross advierte que como principio general del derecho, la justicia delimita y brinda armonía a las pretensiones e intereses en conflicto en la vida social comunitaria ${ }^{1949}$. Si todos los problemas jurídicos son de distribución, la justicia equivale a un postulado de igualdad en la distribución o en el reparto

${ }^{1943}$ Cfr. Roscoe POUND, Justicia conforme a derecho, Editorial Letras S.A, México, 1.962, p. 2.

1944 Ídem, p. 73.

${ }^{1945}$ Ibídem, p. 76.

${ }^{1946}$ Ibídem.

${ }^{1947}$ Ibídem, p. 77.

${ }^{1948}$ Ibídem, p. 79.

${ }^{1949}$ Alf ROSS, Sobre el derecho y la justicia, ob. cit., p. 261. 


\section{SEBASTIÁN JUSTO COSOLA}

de las cargas y de las ventajas ${ }^{1950}$. Si la justicia es la igualdad considerada en un sentido absoluto, implica reconocer que todos deben hallarse en la misma posición que los demás, lo que implicaría que cada persona ocupe una idéntica posición jurídica, cosa que no puede asimilarse a la justicia ${ }^{1951}$. Para Ross "La justicia es la aplicación correcta de una norma, como cosa opuesta a la arbitrariedad ${ }^{1952}$ ". Afirmar que una norma es injusta no es más que una expresión emocional, por ella la ideología de la justicia no tiene cabida en un examen normativo desde la racionalidad ${ }^{1953}$.

Sobre esto, Manuel Atienza también reconoce que la idea de justicia siempre ha estado unida a la noción de igualdad, aunque la mencionada noción no siempre se haya entendido de la misma manera ${ }^{1954}$. La igualdad, en un sentido general, es un tipo de relación dada entre dos o más seres a propósito de una o de varias circunstancias, y de allí que se distingan dos nociones básicas de igualdad $^{1955}$, conceptualmente independientes ${ }^{1956}$ : la igualdad de características, referida a cuestiones de hecho en las que se efectúan las comparaciones ${ }^{1957}$, y la igualdad de trato, referida a una noción normativa, que determina que las personas deben ser tratadas, siempre o en determinadas circunstancias, de la misma manera. Pero el autor también se refiere a la idea de justicia y de libertad ${ }^{1958}$. En los tiempos actuales, la libertad puede relacionarse a tres nociones diferentes: la libertad negativa, como facultad de hacer o no hacer determinadas acciones sin ser obstaculizado por los demás, lo que nos hace una idea de abstención ${ }^{1959}$; una 
libertad de naturaleza politica, que transmite que es libre quien no tiene que obedecer otras normas que las que él mismo se ha impuesto, acercándonos a una idea de participación, que implica un poder para participar en la designación y control de los gobernantes y en la elaboración de las leyes ${ }^{1960}$; y la libertad material o real que sostiene que se es libre si se tiene capacidad real para actuar en cierto sentido ${ }^{1961}$.

Finalmente, Kelsen argumenta que la justicia es una característica posible pero no así necesaria de un determinado orden social ${ }^{1962}$. Para el autor vienés, también la justicia es una virtud pero solo cuando el hombre sea justo concordantemente con un orden que sea considerado justo, porque busca y aspira únicamente a la felicidad ${ }^{1963}$. La justicia como aspiración máxima del hombre a la felicidad no es siempre hallable -en razón de que un orden social justo no puede sostenerse sobre la idea de felicidad individual ${ }^{1964}$ - y por ello el hombre comienza a buscarla en la sociedad ${ }^{1965}$. Tampoco se halla la justicia en la libertad porque la misma se opone a todo orden social ${ }^{1966}$, ni tampoco puede encontrarse en una especia de jerarquización de los valores $^{1967}$. De esta forma, Kelsen argumenta que desde la historia se puede advertir una notable inutilidad en la búsqueda de una norma de conducta justa que tenga validez absoluta ${ }^{1968}$, porque la razón humana solo puede concebir valores relativos, razón por la cual considera que la justicia absoluta es un ideal irracional ${ }^{1969}$. El conocimiento racional solo plantea intereses humanos y por ello, se dan los conflictos de intereses ${ }^{1970}$, y para su dilucidación solo existen dos soluciones: o se satisface el uno a costa del otro, o se establece un compromiso entre ambos, sin establecer qué solución es la justa ${ }^{1971}$. El jurista entonces plantea una teoría relativista de los

\footnotetext{
${ }^{1960}$ Ibídem.

${ }^{1961}$ Ibídem.

${ }^{1962}$ Cfr. Hans KELSEN, ¿Qué es la justicia?, Fontamara, México, 1.997, p. 9.

${ }^{1963}$ Ibídem.

1964 Ídem, p.13.

${ }^{1965}$ Ibídem, p. 9.

${ }^{1966}$ Ibídem, p. 15.

${ }^{1967}$ Ibídem, p. 25.

1968 Ibídem, p. 75.

${ }^{1969}$ Ibídem.

${ }^{1970}$ Ibídem, p. 76.

${ }^{1971}$ Ibídem.
} 
valores $^{1972}$, que reconoce como principio moral fundamental al principio de tolerancia $^{1973}$, que no es otra cosa que exigir la buena voluntad para comprender las diferentes concepciones de los demás, no impidiendo su exteriorización, dentro de un orden positivo que garantiza la paz ${ }^{1974}$. Para el máximo exponente de la escuela positiva del derecho del siglo pasado, la tolerancia es la libertad de pensamiento ${ }^{1975}$, y quizás por ello el valor al que adscribe sea la paz: "En realidad, yo no sé si puedo decir que es la justicia, la justicia absoluta, este hermoso sueño de la humanidad. Debo conformarme con la justicia relativa, puedo decir únicamente lo que para mí es la justicia. Como la ciencia es mi profesión y, por lo tanto, lo más importante de mi vida, para mí la justicia es aquella bajo cuya protección puede florecer la ciencia y, con la ciencia, la verdad y la sinceridad. Es la justicia de la libertad, la justicia de la paz, la justicia de la democracia, la justicia de la tolerancia ${ }^{1976}$ ".

\subsubsection{Las relaciones de la justicia: sus clases principales y el bien} común.

Sobre la base de las teorías expuestas con anterioridad puede intentarse una aplicación práctica de los efectos de la justicia en el documento notarial. A partir del tratamiento de la estructura y del análisis de los componentes del mismo, he propuesto una descripción de la relación jurídica que a partir de los comparecientes ocurría dentro del documento notarial, relación que era tutelada por el notario. Pues bien, la noción de relación jurídica cobra mayor relevancia desde la perspectiva de la justicia: es relación de justicia o relación jurídica la que existe entre dos o más personas en razón de sus respectivos derechos o cosas que les pertenecen ${ }^{1977}$.

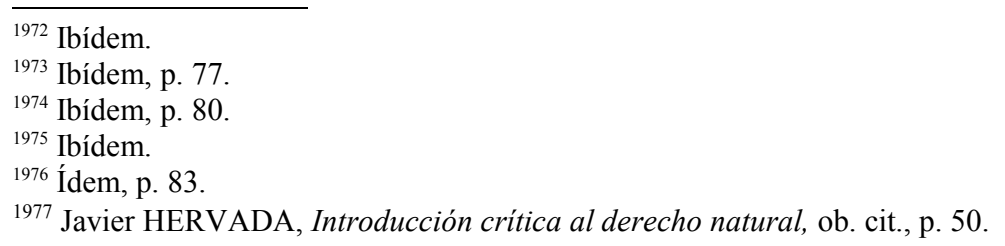


Ya prevista entonces la igualdad propia de lo justo -igualdad entre lo debido y lo dado ${ }^{1978}$-, la relación de justicia plantea como situación de propia existencia que los sujetos sean iguales, en una igualdad que permita satisfacer la deuda ${ }^{1979}$. De esta posición, importa destacar que existe una nota de alteridad en la relación de justicia, que parte de siempre suponer la distinción entre los sujetos, y que por tanto, indica que se requiere de dos o más personas en distinta y complementaria posición (se necesitan tanto acreedores como deudores) ${ }^{1980}$. La relación de justicia es, ante todo, una relación del deudor hacia el acreedor ${ }^{1981}$. El derecho en sentido estricto, requiere que el otro sea absolutamente distinto, independiente y sin subordinación para con el sujeto a quien se dirige la exigencia de la justicia $^{1982}$. De esta manera, no cabe la justicia en los casos en donde los sujetos comprendidos en la relación no tienen ni la independencia ni las distinciones señaladas (por ejemplo la relación entre esposos o entre padres e hijos, aunque se permita diferenciar, según Pieper, la justicia del amor como virtud $^{1983}$ ).

La determinación de los deberes y derechos de las personas comprometidas en la relación de justicia corresponde, según Hervada, al arte del derecho $^{1984}$. En sintonía, el tratamiento que realizara Carnelutti del arte del derecho también resulta esclarecedor ${ }^{1985}$. A esto agrega Vallet que en las relaciones jurídicas los principios y las normas actúan a posteriori, en primer lugar para efectuar la determinada calificación jurídica, para seguidamente poder configurarlas o rectificarlas con el objetivo jurídico de cuidar a la justicia $^{1986}$. En la consideración valletiana, la estructura básica de toda relación jurídica contempla una relación de vida (hombres, corporaciones,

\footnotetext{
${ }^{1978}$ Ibídem, p. 52.

1979 Ibídem, p. 51.

${ }^{1980}$ Ibídem, p. 52.

${ }^{1981}$ Ibídem, p. 53.

${ }^{1982}$ Rodolfo Luis VIGO, Las causas del derecho, ob. cit., p. 71.

${ }^{1983}$ Ibídem.

${ }^{1984}$ Javier HERVADA, Introducción crítica al derecho natural, ob. cit., p. 53.

1985 Cfr. Francesco CARNELUTTI, Arte del derecho. Metodología del derecho, El Foro, Buenos Aires, 2.006, p. 13 y ss.

${ }^{1986}$ Cfr. Juan Berchmans VALLET DE GOYTISOLO, Manuales de metodología jurídica, $\mathrm{t}^{\circ}$ IV, ob. cit., p. 66.
} 


\section{SEBASTIÁN JUSTO COSOLA}

entre otros ${ }^{1987}$ ), una posición de cada sujeto en la relación jurídica, el objeto o contenido de la relación, una consideración como justa o injusta de la relación de que se trate, una tipificación de la misma según clase y especie, una determinada relación jurídica y el acaecimiento de efectos jurídicos ${ }^{1988}$. La determinación de los derechos y deberes aludidos depende de los tres tipos de relaciones de justicia conocidos desde Aristóteles $^{1989}$ y considerados en su total esplendor desde Santo Tomas de Aquino ${ }^{1990}$, en donde la deuda adquiere distintas características y el derecho presenta rasgos diferentes ${ }^{1991}$ :

a) Justicia conmutativa, referida a lo debido entre personas -físicas y morales $^{1992}$

b) Justicia distributiva, referida a lo debido por la colectividad al individuo ${ }^{1993}$;

c) Justicia legal, referente a lo debido por el individuo a la colectividad $^{1994}$.

Es sobre estas relaciones que se argumentará que conforme con Aristóteles, hay una justicia general y unas formas de justicia particular ${ }^{1995}$. La justicia general explica porque no puede reducirse la justicia a un simple valor entre tantos otros, mientras que las formas particulares de justicia se encuentran representadas por la justicia conmutativa, que en proporción aritmética regula las relaciones individuales de una parte con la otra, y la justicia distributiva que por otro lado en proporción geométrica, viene a regular la relación del todo con las partes en la distribución de los bienes y de las

\footnotetext{
${ }^{1987}$ Ibídem, p. 67.

${ }^{1988}$ Ibídem, p. 68.

1989 ARISTÓTELES, Obras completas, IV tomos, Bibliográfica Omeba, Buenos Aires, 1.967.

${ }^{1990}$ SANTO TOMÁS DE AQUINO, Suma teológica. La prudencia, la justicia y el derecho, $\mathrm{t}^{\circ}$ XI, ob. cit., p. 116 y ss.

${ }^{1991}$ Javier HERVADA, Introducción crítica al derecho natural, ob. cit., p. 53.

${ }^{1992}$ Ibídem, p. 54.

${ }^{1993}$ Ibídem, p. 55.

${ }^{1994}$ Ibídem, p. 63.

${ }^{1995}$ Cfr. Juan Berchmans VALLET DE GOYTISOLO, En torno al derecho natural, Sala Editorial, Madrid, 1.973, p. 15.
} 
cargas comunes ${ }^{1996}$. Ambas son las más elementales ordenaciones del bien común ${ }^{1997}$, porque la justicia general es la que proporciona la más ardua ordenación en su recto sentido, que es menos matemática, y más difícil de manejar: el bien común ${ }^{1998}$.

En el primer supuesto de justicia conmutativa, la relación de deuda surge por el intercambio de bienes o por apoderamiento de los bienes del otro ${ }^{1999}$. Entran en esto supuesto la acción de intercambio de cosas (Compraventa, arrendamiento); la acción de traslación de una cosa (comodato, depósito) y el respecto al derecho ajeno (si no hay respeto, se genera un daño que genera restitución y compensación ${ }^{2000}$. Lo justo se mide aquí mediante la igualdad aritmética, medida que depende de la identidad o cualidad y valor de las $\operatorname{cosas}^{2001}$.En definitiva, lo que se exige es la igualdad de la contraprestación ${ }^{2002}$. Estamos en presencia de una justicia igualitaria que no mide lo justo en razón de las personas, sino de las $\operatorname{cosas}^{2003}$. La medida de lo justo es la perfecta y justa igualdad, una igualdad real ${ }^{2004}$. Aun así, la igualdad absoluta de las cosas reconoce su base en la igualdad de las personas, porque toda persona se presenta ante otra según "su nuda condición de sujeto o titular de derecho, condición que es exactamente igual a $\operatorname{tod}^{2005}{ }^{205}$. La justicia conmutativa entre personas presenta las conmutaciones o intercambios como sus actos principales ${ }^{2006}$.

Debe advertirse además, que si bien la forma más típica de justicia conmutativa es el contrato, cierto es que al referirse a la relación de un individuo para con otro individuo, los términos de esa relación muchas veces sobrepasan los referidos al contrato. En virtud de ello es que algunos autores

\footnotetext{
${ }^{1996}$ Ibídem.

${ }^{1997}$ Ibídem.

${ }^{1998}$ Ídem, p. 16.

${ }^{1999}$ Javier HERVADA, Introducción crítica al derecho natural, ob. cit., p. 54.

${ }^{2000}$ Ibídem.

${ }^{2001}$ Ibídem.

${ }^{2002}$ Jorge Guillermo PORTELA, La justicia y el derecho natural, ob. cit., p. 27.

${ }^{2003}$ Javier HERVADA, Introducción crítica al derecho natural, ob. cit., p. 54.

${ }^{2004}$ Ibídem.

${ }^{2005}$ Ibídem.

${ }^{2006}$ Ibídem, p. 55.
} 


\section{SEBASTIÁN JUSTO COSOLA}

amplían los supuestos a la fidelidad entre los esposos, o las relaciones amicales de los hombres entre $\mathbf{s i}^{2007}$.

Fuera del análisis anterior, la vida social comprende el desarrollo de colectividad siendo sus máximas expresiones el Estado y la comunidad internacional, y de ahí que existan dos tipos de justicia que regulen las relaciones que en la comunidad de produzcan.

La justicia distributiva, entonces, apunta a la relación de la sociedad con el individuo, en donde también se mantienen las relaciones de alteridad ${ }^{2008}$. Supuesta la alteridad, dice Hervada, la relación de justicia se originará si algo de la sociedad es derecho del individuo ${ }^{2009}$. La relación de justicia aparece allí donde lo colectivo se reparte entre sus miembros, en una distribución de lo común entre los individuos 2010 : "la justicia en la distribución reside, pues, en el paso a la esfera particular de lo que pertenece a la esfera colectiva ${ }^{2011}$,, o sea, de una distribución de bienes y cargas comunes a los individuos que conforman la comunidad. En las distribuciones solo hay título al reparto justo ${ }^{2012}$. La cosa es de la colectividad hasta que efectivamente se reparte al individuo; antes que ello, este último solo tiene la destinación de los bienes y cargas que se repartirán entre los diferentes componentes, radicando su derech ${ }^{2013}$, principalmente, en el trato a recibir como destinatario la mencionada distribución ${ }^{2014}$. En este tipo distributivo, lo justo se tendrá en cuenta de acuerdo a la posición que cada uno tenga respecto de la finalidad colectiva. La igualdad entonces, reside en la proporción, tratándose igual a los miembros de la colectividad cuando se los considera de modo proporcional a su posición relativa a los fines que se ha proyectado la colectividad ${ }^{2015}$. La igualdad en la justicia

\footnotetext{
${ }^{2007}$ Jorge Guillermo PORTELA, La justicia y el derecho natural, ob. cit., p. 28.

${ }^{2008}$ Ibídem, p. 56.

${ }^{2009}$ Ibídem, p. 57

${ }^{2010}$ Ibídem.

${ }^{2011}$ Ibídem.

${ }^{2012}$ Ibídem.

${ }^{2013}$ Ibídem, p. 58. Dice el autor: “¿Por qué el trato a recibir es un derecho? Porque como miembro que es participa del ser total de la colectividad y, por lo tanto, la colectividad vive por él; participa, pues, de los bienes y de las cargas de la colectividad según su condición de miembro. Estos le están destinados".

${ }^{2014}$ Ibídem, p. 57.

${ }^{2015}$ Ibídem, p. 58.
} 


\section{LOS EFECTOS DE LA PUBLICIDAD EN EL DOCUMENTO NOTARIAL}

distributiva reside en la proporción entre las cosas y las personas, a diferencia de la justicia conmutativa, que solo postula una igualdad en las $\operatorname{cosas}^{2016}$. Por ello es que se dice que, en resumen, esta fórmula puede resumir lo antedicho: "a cada cual según su condición, sus capacidades, su aportación a la sociedad y sus necesidades ${ }^{2017}$. Hay en esta consideración una igualdad geométrica, que ha resultado un verdadero laberinto de interpretaciones ${ }^{2018}$.

Finalmente, la justicia legal o general viene a hacer referencia a la posición de deuda del individuo hacia la comunidad, ya que los mismos también tienen con la colectividad un deber de justicia. Así, a la colectividad le corresponde un bien, el bien común colectivo, para alcanzar la finalidad a la que esencialmente esta ordenada (unión para alcanzar los fines) ${ }^{2019}$. Es el bien común el derecho de la comunidad frente a sus componentes y también es correlativamente la deuda que ellos tienen con la colectividad ${ }^{2020}$. El objeto del bien común, de donde hace emerger la deuda a su favor, es aquello que desde la colectividad se presenta como una obligación estricta ${ }^{2021}$. Más precisamente que ello, puede decirse que el objeto formal de la justicia general o legal es la ordenación al bien común ${ }^{2022}$. Precisamente es lo que señalan las leyes, y de ahí que estemos considerando el tipo de justicia legal. Las leyes son ordenaciones imperativas en función del bien común ${ }^{2023}$, y por ello, el individuo debe cumplir las leyes en procura de su relación con la colectividad. En este último caso, la igualdad existe entre lo ordenado por las leyes y lo efectivamente cumplido por el individuo ${ }^{2024}$. En la letra del propio Aristóteles: "Las leyes, siempre que estatuyen algo, tienen por objeto favorecer el interés general de todos los ciudadanos... ${ }^{2025 ” . ~ L a ~ j u s t i c i a ~}$

\footnotetext{
${ }^{2016}$ Ibídem, p. 59.

${ }^{2017}$ Ibídem.

${ }^{2018}$ Carlos Ignacio MASSINI CORREAS, Filosofia del derecho, $\mathrm{t}^{\circ}$ II, ob. cit., p. 31.

${ }^{2019}$ Javier HERVADA, Introducción crítica al derecho natural, ob. cit., p. 63.

${ }^{2020}$ Ibídem.

${ }^{2021}$ Ibídem.

2022 Jorge Guillermo PORTELA, La justicia y el derecho natural, ob. cit., p. 33.

${ }^{2023}$ Ibídem.

${ }^{2024}$ Ibídem, p. 64.

${ }^{2025}$ ARISTÓTELES, Obras completas, tº I, ob. cit., p. 135.
} 


\section{SEBASTIÁN JUSTO COSOLA}

general, enseña Vallet, ordena a su fin a las demás virtudes cardinales: prudencia, justicia (particular), fortaleza y templanza ${ }^{2026}$.

La mención a la teoría aristotélica de la justicia resulta esencial en estos tiempos, porque como dice Massini Correas, la misma viene cobrando inusitada actualidad, a través de la instauración de teorías fundadas en el estagirita formuladas por varios autores contemporáneos que cuestionan, de las corrientes que se alejan de las concepciones clásicas de la justicia olvidando, entre otras cosas, sus dimensiones virtuosas ${ }^{2027}$. Por ello, algunos de esos alcances específicos de las clases de justicia mencionadas pueden estudiarse en la obra ya referida de John Finnis, más cercana a la realidad que impone una actualización de conceptos cercanos a la razonabilidad práctica ${ }^{2028}$.

\subsubsection{Una referencia a la posición de Juan Berchmans} Vallet de Goytisolo.

Juan Vallet de Goytisolo entiende que el derecho centro su atención en la norma legal desde principios del siglo XIX hasta finalizada la segunda guerra mundial ${ }^{2029}$. Desde allí hasta los tiempos actuales, ha vuelto la justicia a ocupar la médula del concepto del derecho ${ }^{2030}$. En nuestro país, Rodolfo Vigo $^{2031}$ y Carlos Massini Correas ${ }^{2032}$ concuerdan con estas apreciaciones y de ellos, es el profesor mendocino quien describe que las causas de la crisis del positivismo jurídico obedecen, en definitiva, a cuatro razones, que se

\footnotetext{
${ }^{2026}$ Juan Berchmans VALLET DE GOYTISOLO, En torno al derecho natural, ob. cit., p. 111.

${ }^{2027}$ Carlos Ignacio MASSINI CORREAS, Filosofia del derecho, $\mathrm{t}^{\circ}$ II, ob. cit., p. 24.

${ }^{2028}$ John FINNIS, Ley natural y derechos naturales, ob. cit., p. 191 y ss.

${ }^{2029}$ Juan Berchmans VALLET DE GOYTISOLO, En torno al derecho natural, ob. cit., p. 70. Corresponde al ensayo titulado De la virtud de la justicia a lo justo jurídico.

${ }^{2030}$ Ibídem, p. 73.

${ }^{2031}$ Rodolfo Luis VIGO, Visión crítica de la historia de la filosofía del derecho, ob. cit., p. 10.

${ }^{2032}$ Carlos Ignacio MASSINI CORREAS, Filosofia del derecho, t ${ }^{\circ}$ I, ob. cit., p. 20.
} 


\section{LOS EFECTOS DE LA PUBLICIDAD EN EL DOCUMENTO NOTARIAL}

fundamentan desde naturalezas epistémicas, científicas, éticas y temporales ${ }^{2033}$.

También con Vallet recordamos que existen tres grandes grupos de clasificaciones en torno a las definiciones del derecho: aquellas que se centran en torno de la norma, las que posicionan su reconocimiento $y$ aplicación efectiva en la vida social, y las que lo ubican acorde con la justicia ${ }^{2034}$. Posicionados como pretendo en la última opción, el problema de la justicia es ponerse de acuerdo acerca de lo que verdaderamente $e l l a ~ e s^{2035}$. Así, la misma se encuentra contenida dentro de conceptos puramente formales, o es representada como un sentimiento, o como una virtud, como una idea, como un valor o como una realidad esencial ${ }^{2036}$. Enseña Vallet que para descubrir a la justicia no queda otra alternativa que recurrir e interrogar a la naturaleza, para ver si es posible descubrir el orden objetivo (jurídico) que ella encierra ${ }^{2037}$. Sin naturaleza, no puede existir la justicia ${ }^{2038}$, pues solo la naturaleza puede suministrar respuestas sustanciales a las preguntas de los juristas $^{2039}$. Para conocer la naturaleza ${ }^{2040}$, es indispensable el conocimiento de las causas finales (el fin como causa es aquello por lo que algo se hace ${ }^{2041}$ ) y la ayuda de las causas formales (lo que en cada ente especifica o determina la manera de ser del mismo, es el determinante intrínseco del ser $^{2042}$ ). Una visión finalista de la naturaleza comporta la pauta del bien común ${ }^{2043}$.

\footnotetext{
${ }^{2033}$ Cfr. Carlos Ignacio MASSINI CORREAS, Facticidad y razón en el derecho. Análisis crítico de la iusfilosofia contemporánea, Marcial Pons, Buenos Aires, págs. 15-16.

${ }^{2034}$ Juan Berchmans VALLET DE GOYTISOLO, De la virtud de la justicia a lo justo jurídico, ob. cit., p. 66-67.

${ }^{2035}$ Ibídem, p. 73.

${ }^{2036}$ Ibídem, p. 73-74.

${ }^{2037}$ Ídem, p. 84.

${ }^{2038}$ Ibídem, p. 85.

${ }^{2039}$ Ibídem, p. 86.

2040 Ídem, p. 29. Corresponde al ensayo titulado Controversias en torno al derecho natural.

${ }^{2041}$ Rodolfo Luis VIGO, Las causas del derecho, ob. cit., p. 73.

${ }^{2042}$ Ibídem, p. 155.

${ }^{2043}$ Cfr. Juan Berchmans VALLET DE GOYTISOLO, Controversias en torno al derecho natural- En torno al derecho natural, ob. cit., p. 30.
} 


\section{SEBASTIÁN JUSTO COSOLA}

El orden de la naturaleza es dinámico ${ }^{2044}$, y nada tiene de estático el derecho natural en su concepción clásica ${ }^{2045}$. El orden natural no excluye la acción del hombre, salvo si la misma fuera en contra de la naturaleza y pudiera generar desorden o crear artificios ${ }^{2046}$ que pongan en riesgo su estabilidad ${ }^{2047}$. Toda actuación humana conforme al orden dinámico y progresivo de la naturaleza es natural ${ }^{2048}$, y la libertad del hombre que se viera empobrecida por sus errores o limitada por sus pasiones puede optar por el desorden, pero deberá el hombre abstenerse a las consecuencias ${ }^{2049}$. Desde las ciencias naturales se dice que el hombre puede dominar a la naturaleza obedeciéndola. Piensa Vallet que lo mismo puede decirse en el campo social, político y jurídico ${ }^{2050}$. La visión clásica del universo no examina al hombre aislado sino formando parte de la sociedad ${ }^{2051}$. Así, se recibe un sistema de cuerpos intermedios que se desarrolla de abajo hacia arriba, como las plantas, que permite que se armonice lo múltiple con lo uno en su realidad concreta ${ }^{2052}$, y que se enfrenta a la sociedad de masas, formada por individuos desarraigados, manejada por el Estado desde una organización burocrática "centralizante", mecanizada y tecnocrática ${ }^{2053}$ : "He aqui cara a cara - comenta Vallet- de una parte, la

\footnotetext{
${ }^{2044}$ Ibídem, p. 31.

2045 Ídem, p. 32.

${ }^{2046}$ Ibídem, p. 35.

${ }^{2047}$ Ibídem, p. 36.

${ }^{2048}$ Ibídem.

${ }^{2049}$ Ibídem.

${ }^{2050}$ Ibídem, p. 38. Dice Vallet: "Se ha dicho que el hombre puede dominar la naturaleza, obedeciéndola. Asi se ha progresado en las ciencias naturales. Pero se ha olvidado la aplicación de ese principio, de modo general, a las ciencias morales y sociales, y casi nunca ha sido enfocado en su total plenitud, ni con la debida perspectiva histórica, desde el pasado $y$ hacia el futuro. Efectivamente, las ciencias aplicadas tienen muy en cuenta para sus realizaciones las leyes naturales de la fisica, la química, la biología, etc. Podemos decir que la libertad del hombre para volar, construir, sembrar y recolectar se mueve dentro de dichas leyes. El hombre puede vencer la ley de la gravedad ayudándose de las otras leyes físicas. Solo puede arrojarse desde lo alto, sin estrellarse, después de descubrir el paracaidas y utilizándolo. Sólo puede volar apoyándose en las leyes naturales; no puede hacerlo contra la naturaleza. Es que ¿acaso ocurre de modo totalmente diverso en las leyes morales y politicas?...Creemos que lo mismo podemos decir en el campo social, político y jurídico".

${ }^{2051}$ Ibídem, p. 41. Forma parte en la sociedad en la que naturalmente se halla inserto o en aquellas a las que se une espontáneamente.

${ }^{2052}$ Ibídem.

${ }^{2053}$ Ibídem.
} 


\section{LOS EFECTOS DE LA PUBLICIDAD EN EL DOCUMENTO NOTARIAL}

organización realista, arraigada, biológica, y de otra, la planificada, impuesta desde el poder, idealista, tecnificada y mecanizada ${ }^{2054}$ ".

$\mathrm{Si}$ el orden natural humano se compone de una serie de cuerpos intermedios, conformes al mismo y cada uno desde sus respectivas competencias, se alcanzará una adecuada autonomía jurídica tal que las familias y las comunidades locales y profesionales puedan ser creadoras de costumbres y así, lograr que el pueblo sea una comunidad viva ${ }^{2055}$. De esta forma, la función de Estado se reducirá a vigilar el respeto y la salvaguardia del orden natural, corregir las conclusiones desacertadas, dar estabilidad y fijeza a las normas de carácter general, resolver lo que no resuelvan las instancias inferiores y verificar las determinaciones que el orden exija ${ }^{2056}$.

La justicia no puede ser el sueño de un ideal irrealizable ${ }^{2057}$, y se ejercita en la tierra y no en el más allá de una comunidad mística: "Lo justo no puede ser lo imposible ni las calendas griegas. Lo justo no es el mundo tal como debiera ser, sino el acto que aqui mismo debo yo cumplir ${ }^{2058}$ ".

Del orden natural deriva un orden de lo justo -denominado derecho natural-, que como justo, debe ser exigible coactivamente en caso que no sea cumplido voluntariamente ${ }^{2059}$. El orden natural justo condiciona entonces por una parte, la legitimidad del derecho positivo "en cuanto constata la justicia de sus conclusiones y la adecuación y oportunidad de sus determinaciones, $y$, por otra parte, subsume y hace suyas las convenientes determinaciones adecuadas por el derecho positivo ${ }^{2060 " . ~ E n ~ d e f i n i t i v a, ~ h a y ~}$ una comprensión de lo justo natural (lo que no puede ser sino como es de acuerdo al derecho natural) y de lo justo positivo, que puede ser del modo en que la ley lo establezca, como la dirección de la marcha del tránsito, y desde que la ley lo establece, comienza a obligar como justo por naturaleza, en orden al principio de convivencia relevante para establecer el imperio de la justicia $^{2061}$.

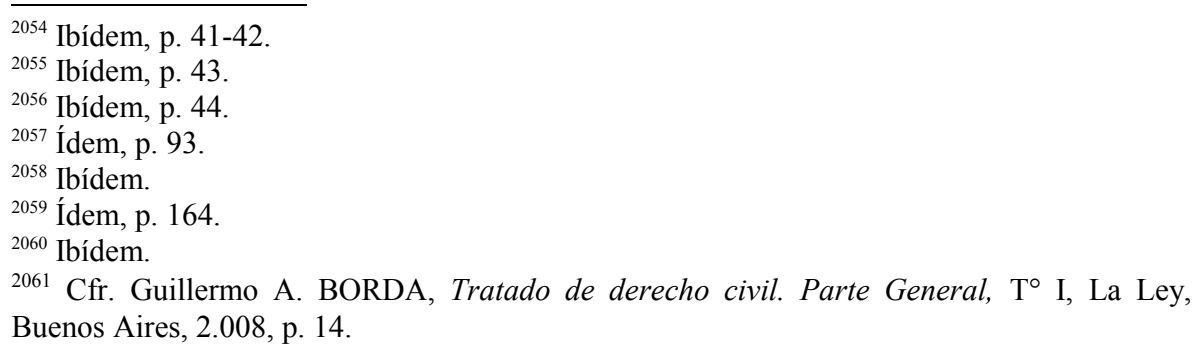




\section{SEBASTIÁN JUSTO COSOLA}

Unas últimas dos consideraciones acerca de algunas fuentes relevantes en la obra del jurista hispánico. Vallet adscribe a posiciones de determinados autores que suscriben la idea que advierte que adoptar una postura existencialista implicaría reconocer que la ciencia jurídica contemporánea ha equivocado su camino ${ }^{2062}$. Las fuentes del derecho deben encontrarse, según el autor, en el derecho romano que fueron quienes fijaron objeto, método y fines de la ciencia ${ }^{2063}$, en donde sobresale la celebérrima enunciación de Celso cuando enseña que ius est ars boni et aequi ${ }^{2064}$. "La ciencia del derecho -afirma Biondi- no es más que el sistema o arte de la justicia; la misión del jurista no es otra que la búsqueda de lo justo, sea en la aplicación, sea en la formación del derecho ${ }^{2065}$ ". Es el jurista quien tiene que admitir que la ciencia del derecho presupone la aplicación de un desarrollo del derecho que se dirige hacia la justicia ${ }^{2066}$. El jurista actual conoce las cosas humanas y las cosas divinas, no como objeto del conocimiento, sino en función de su misión, por ello es necesario que posea la suficiente autoridad sobre las cosas de la vida en toda su complejidad, lo que le permitirá entender en qué consiste la justicia ${ }^{2067}$. Sólo así la ciencia del derecho se no es otra cosa que el arte de lo justo ${ }^{2068}$, porque en definitiva "el arte evoluciona, pero tiende siempre a lo bello, como el arte del derecho tiende siempre a la justicia. Cambian las instituciones, se perfecciona la técnica, pero el objeto siempre será el mismo: ¡la justicia! ${ }^{2069}$ ".

También la obra de Vallet sufre influencia de autores como Michel Villey -en los términos en los que lo he expuesto ${ }^{2070}$ - y sin dudas, en los legados de José Castán Tobeñas; éste último advierte que por más que la justicia tenga

${ }^{2062}$ Cfr. Biondo BIONDI, La ciencia del derecho como arte de lo justo, AAMN, $\mathrm{t}^{\circ} \mathrm{IX}$, IER, Madrid, 1.957, p. 327.

${ }^{2063}$ Ibídem, p. 330.

${ }^{2064}$ Ibídem, p. 331. Dice BIONDI: “Ars se puede entender como sistema, o literalmente, como arte o técnica. Esto poco importa, pues lo que interesa es el objeto: lo bueno y equitativo, o sea lo justo. La ciencia del derecho tiende al bonum, entendido no como cualquier bienestar, sino como valor moral, ya sea individual o colectivo. El aequum supone igualdad, entendida como proporción para llegar a lo justo, bonum et aequum indica justicia”.

${ }^{2065}$ Ibídem.

2066 Ídem, p. 343.

${ }^{2067}$ Ibídem, p. 354.

${ }^{2068}$ Ibídem, p. 358.

${ }^{2069}$ Ibídem, p. 362. 
una base psicológica en la naturaleza humana y en la conciencia social del hombre, su concepto científico es dificultoso y atormentador ${ }^{2071}$. Se habla de la justicia en sentido general, en relación a la armonía o congruencia entre cualquier clase de objetos ${ }^{2072}$; en sentido más restringido, se refiere a la armonía o congruencia aplicada a las acciones humanas, abarcando el campo moral y jurídico o al orden jurídico ${ }^{2073}$. También en sentido amplio la justicia es una virtud universal, y en sentido más estricto también es un principio de armonía social ${ }^{2074}$, y también puede considerarse a la justicia desde un punto de vista subjetivo - sentimiento ${ }^{2075}$ - como el punto de vista objetivo -idea ${ }^{2076}$ Desde otro lugar, un significado vulgar de la justicia considera que la misma es el resultado de la aplicación judicial del derecho, mientras que un significado propio la justicia es una cualidad del derecho, con un contenido autónomo e independiente ${ }^{2077}$; finalmente, otro significado muy corriente es el que la asimila a lo aplicado a la controversia mediante un juicio o proceso $^{2078}$. Una visión integral de la justicia comprende todas las acepciones mencionadas, ya que mutuamente se complementan ${ }^{2079}$. Para el autor, la abstracción y tinte formal de la justicia, tantas veces criticado, es el único método omnicomprensivo de su cabal acepción, en la doctrina y en la vida, que la eleva a la consideración de un principio supremo de orden y de armonía $^{2080}$. Por ello, nociones como el bien común deben engarzarse en la teoría de la justicia ${ }^{2081}$, ya que la idea de justicia es, como todos los ideales, una fuerza y un instrumento selectivo ${ }^{2082}$, que necesita imperiosamente que el

\footnotetext{
2070 Juan Berchmans VALLET DE GOYTISOLO, Definición e interpretación del derecho según Michel Villey, ob. cit., p. 213.

${ }^{2071}$ Cfr. José CASTÁN TOBEÑAS, La idea de justicia en la tradición filosófica del mundo occidental y en el pensamiento español, IER, Madrid, 1.946, p. 8.

${ }^{2072}$ Ibídem.

${ }^{2073}$ Ibídem, p. 9.

${ }^{2074}$ Ibídem, p. 10.

${ }^{2075}$ Ibídem, p. 11.

${ }^{2076}$ Ibídem, p. 12.

${ }^{2077}$ Ibídem, p. 13.

${ }^{2078}$ Ibídem.

${ }^{2079}$ Ibídem.

${ }^{2080}$ Ídem, p. 77.

${ }^{2081}$ Ibídem, p. 78

${ }^{2082}$ Ibídem, p. 79.
} 


\section{SEBASTIÁN JUSTO COSOLA}

jurista descubra, en orientación a la ideología y a la tradición nacional ${ }^{2083}$. En definitiva, para Castán Tobeñas, la justicia como principio constitutivo y fin supremo del derecho -que se supone embebida del elemento de seguridad y orden- conforma una noción muy elaborada y absolutamente incontestable por su simplicidad y evidencia ${ }^{2084}$.

Desde aquí se explica, entre tantísimas otras cuestiones de relevancia y en modo resumido, que Vallet considere lo justo desde Celso ${ }^{2085}$, que considere las tradiciones en la vida social o que posiciones su idea de los cuerpos intermedios, para hacer frente a la idea y mito de la tecnocracia ${ }^{2086}$, en el seno de la sociedad de masas ${ }^{2087}$.

\subsection{Las recapitulaciones esenciales.}

Hecho el repaso de algunos de los aspectos relevantes de las teorías referidas, corresponde ahora realizar un resumen de todo lo mencionado en veinte acepciones, a modo de síntesis, y especialmente, para que sean tenidas en cuenta a la hora de justificar como opera la justicia en el documento notarial, que puede posicionarse de la siguiente manera:

1) La justicia como virtud implica aceptar un sentimiento por lo justo;

2) La idea de justicia -independientemente de las escuelas del derecho-, siempre debe ser la causa y el fundamento más relevante del derecho;

\footnotetext{
${ }^{2083}$ Ibídem, p. 83 .

${ }^{2084}$ Cfr. José CASTÁN TOBEÑAS, La justicia y su contenido a la luz de las concepciones clásicas y modernas, Servicio de Publicaciones de la Secretaría General Técnica del Ministerio de Justicia, Madrid, 1.967, p. 17.

2085 Juan Berchmans VALLET DE GOYTISOLO, Manuales de metodología jurídica, $\mathrm{t}^{\circ} \mathrm{I}$, ob. cit., p. 91.

2086 Juan Berchmans VALLET DE GOYTISOLO, Ideología, praxis y mito de la tecnocracia, ob. cit.

2087 Juan Berchmans VALLET DE GOYTISOLO, Sociedad de masas y derecho, ob. cit.
} 
LOS EFECTOS DE LA PUBLICIDAD EN EL DOCUMENTO NOTARIAL

3) Toda voluntad humana se encuentra sujeta al análisis de la justicia;

4) Pureza de la voluntad individual determinante de la voluntad jurídica;

5) Conformación de una sociedad justa mediante Instituciones adecuadamente justas;

6) Desarrollo de la justicia entre personas libres que promueven sus intereses en posición de igualdad;

7) Justicia como modo utilizado por las grandes instituciones en la distribución de derechos y deberes;

8) Justicia como tutela de la libertad de pensamiento y de conciencia y de la igualdad;

9) Justicia como imparcialidad;

10) Justicia como el débito al otro de lo que realmente corresponde;

11) Dar a cada uno lo suyo, porque antes existe una deuda preexistente por cumplir;

12) Justicia como respeto al otro;

13) Idea humana de desigualdad como representación del sentimiento de la justicia;

14) Una justicia conforme a derecho con identidad de método;

15) Justicia como aplicación correcta de una norma opuesta a la arbitrariedad;

16) Justicia y felicidad, compromiso entre personas a través de la tolerancia garantizada por la paz;

17) Justicia desde el orden natural y la razón práctica; 
18) Justicia en relación a la alteridad y a la naturaleza de las cosas;

19) Justicia y bien común;

20) Justicia y su relación con la seguridad jurídica.

13.3.1. El desenvolvimiento del valor justicia en el ejercicio de la función notarial. Necesidad de su comprensión primaria.

Las veinte direcciones esquematizadas anteriormente, no hacen más que poner en evidencia la notable relación que guarda el ejercicio del derecho notarial actual con la justicia. $\mathrm{Y}$ a lo que verdaderamente sobresale e importa, que es en definitiva el producto de la elaboración notarial del derecho que es el documento o instrumento notarial. Desde Rafael Núñez Lagos se viene refiriendo a los tres momentos de título notarial, tal cual en la presente investigación ya he referenciado:

a) El momento del examen de los títulos anteriores,

b) El momento de redacción del nuevo documento y

c) El momento de la inmunidad del nuevo título ${ }^{2088}$.

Pues bien, esos tres momentos consagrados de labor notarial documental contienen, en partes proporcionales, todas las menciones a la justicia esquematizadas anteriormente y deducidas de la doctrina que he traído al análisis para la presente demostración. En la tarea notarial todas las escuelas aportan los tópicos máximos de sus expresiones, y desde allí entonces pueden posicionarse cada uno como baluartes del documento notarial.

2088 Rafael NUÑEZ LAGOS, Tres momentos del título notarial, en Los esquemas conceptuales del instrumento público, ob. cit., p 215 y ss. 
LOS EFECTOS DE LA PUBLICIDAD EN EL DOCUMENTO NOTARIAL

La tarea de examinar los títulos antecedentes excede notoriamente el estudio de las escrituras, para alcanzar la relación notario-persona que está por encima de la tarea de investigación documental. Esa relación se nutre a través de las primeras audiencias notariales, donde se reflejan los deberes éticos de información, asesoramiento, concejo y la imparcialidad. Luego el notario se posicionará en la tarea de descubrir el momento en que su evidencia capte lo justo, porque toda voluntad humana se encuentra sujeta al análisis de la justicia y es deber ineludible notarial el de crear títulos seguros y auténticos para la prosperidad en base a los antecedentes que le sean correspondientes. De esa creación surgirán los alcances de la publicidad cartular en relación a la autenticidad interna. La creación documental referida se lleva adelante con la tutela del desarrollo de la justicia entre personas libres que promueven sus intereses con la pretensión de alcanzar la igualdad, la que alcanzan al momento de suscribir el documento que en el mismo momento es autorizado por la fe notarial. EL nuevo título se vuelve inmune de esta manera, porque la tutela notarial de la justicia que ordena darle a cada uno lo suyo, presupone el aspecto objetivo de la fe pública (certeza), confirma su aspecto subjetivo (verdad) y proyecta la seguridad que emana extrínseca e intrínsecamente del mismo. En el análisis de la publicidad cartular interna los valores funcionan equilibradamente y en armonía. Armonía que determina la paz.

\subsubsection{Casos frecuentes de ejercicio de tutela notarial} frente a la concreción de la justicia en el documento notarial.

Sucede que en sede notarial -y al momento previo de la conformación del hecho o negocio jurídico-, la representación de desigualdad de las partes comparecientes de lo suyo correspondiente es absolutamente notable y sin dudas, repetida y reiterada. En una compraventa, por ejemplo, siempre el vendedor asume que la cosa que traslada de su patrimonio hacia otro tiene un valor mayor que el establecido, mientras que el comprador, que recibe la 


\section{SEBASTIÁN JUSTO COSOLA}

cosa a su favor, piensa que el precio que por ella entrega es mucho más que suficiente. En una donación, el donante opina -aunque jamás piense en ejercer el derecho a reclamo alguno- que el gesto de gratitud que tiene con el donatario es de por sí, tan autosuficiente que permitiría al menos, que el deber de gratitud alcance su máximo esplendor. Sin embargo, y esto es más notable sobre todo en las donaciones efectuadas entre padres e hijos, los donatarios en general asumen que el acto de donación que implica trasladar los bienes de los padres a su patrimonio es un acto de obligada justicia. De ahí que cuando esta situación jurídica no ocurre, florezcan a la luz planteos de acciones propias de la protección de la -futura y eventual- legítima hereditaria -como las acciones de colación y reducción y ni que decir, las que plantean los hijos hacia sus progenitores relacionadas con los apoyos a la capacidad-, que en ocasiones son necesarias, que hacen a la justicia familiar, pero siempre y cuando haya sido el deseo de los padres el de favorecer con sus bienes a sus hijos. En esto, siempre he planteado que los bienes son de los padres o progenitores y que la legítima hereditaria -con todos sus bemoles- se debe computar en el mismo momento del fallecimiento. La opción de hacer lo que se desea con los bienes de cada uno le corresponde únicamente a los titulares, que por el imperio de la voluntad deciden realizar con ellos lo que más conviene a sus intereses patrimoniales, afectivos o sentimentales, cada uno sabe qué hacer en el momento oportuno-.

En un fideicomiso inmobiliario, siempre el fiduciante originario piensa que en un país como el nuestro su riesgo es tan grande que no alcanza la propia entrega de la cosa, una vez finalizada y multiplicada por mucho en valor, para generarle la satisfacción justa que se merece. Sin embargo, si decidiera ceder sus derechos antes de constituirse en fideicomisario, el cesionario beneficiario de su derecho pensará que es injusto que los valores considerados en la cesión sean tan excesivos en relación con el aporte originario, porque en definitiva, el riesgo no fue tanto ni tan angustiante. Hasta la entrada en vigencia del Código Civil y Comercial de la Nación, un conviviente no podía ser beneficiario de la protección del otrora denominado instituto del bien de familia, aunque tenga devoción y amor absoluto por su 
pareja, que es quien oficia como titular registral del inmueble ${ }^{2089}$. El hecho que el nuevo ordenamiento unificado considere un derecho a la protección de la vivienda es un paso fundamental para atenuar la sensación de injusticia y de desprotección que hasta la fecha de su efectiva entrada en vigencia han sentido y soportado quienes en familia grupal o unipersonal, no han accedido por propia voluntad o por simple imposibilidad al matrimonio conforme a las leyes positivas y vigentes ${ }^{2090}$. En materia de mandatos (poderes), quien oficia de mandante está destinado a creer que las facultades que otorga al mandatario son más que suficientes para la encomienda que le solicita, y siempre intenta restringirlas al máximo, para evitar luego el exceso en el ejercicio. Sin embargo, el mandatario no deja de preguntarse ¿pero cómo, el mandato no es un contrato fundamentado en la confianza? ¿Es justo que quien me ordena no confíe en mi desempeño? Las mismas sensaciones pueden trasladarse a las actas notariales. En la constatación de los hechos jurídicos concretos, es posible que el requirente considere que al contratar la labor notarial, el servicio profesional le permita obtener del profesional fedatario un resultado valorable positivamente. Sin embargo, muchas veces las diligencias muestran otra realidad desde la posición del requerido, que probablemente se encuentre preparado no sólo para responder, sino para argumentar lo contrario que ha sido objeto del requerimiento.

Frente a todas estas situaciones que se generan normalmente antes de la conformación del documento notarial, el escribano debe advertir lo justo de cada uno. No lo que él mismo piense que es lo justo, sino lo que corresponde de acuerdo ya no únicamente a la ley, sino lo que esté conforme con el derecho y a la voluntad de quienes concurren a la escribanía a solicitar el ministerio. Esa situación se vuelva a través de los deberes éticos de información, asesoramiento y consejo y una vez acordadas, se reflejan en el instrumento a través de la aplicación del deber ético integrado de legalidad (normas + reglas + principios). De manera directa la advertencia de la

${ }^{2089}$ Para ver los alcances de este tema antes de la derogación de la Ley Nacional 14.394: v. Jorge H. ALTERINI, Protección Constitucional de la Vivienda Familiar, JA 1992-IV-772, y María V. FAMÁ, La protección de la vivienda unipersonal; "Constitución del bien de familia a favor del titular de dominio sin familia”, RDPC 2011-I, Rubinzal-Culzoni, Santa Fe (2011). ${ }^{2090}$ Cfr. Aída KEMELMAJER de CARLUCCI, La aplicación del Código Civil y Comercial a las relaciones y situaciones juridicas existentes, Rubinzal-Culzoni, Santa Fe, 2.015, p. 129. 


\section{SEBASTIÁN JUSTO COSOLA}

injusticia puede determinar en el notario la abstención de la realización del trabajo encomendado. En definitiva, se sanean las desigualdades naturalmente concretadas en la imaginación de los comparecientes a través de la aplicación notarial del derecho que busca, para cada caso en concreto, la concreción del método justo a través de la aplicación del derecho prudente.

La creación del nuevo documento teniendo en cuenta las premisas referidas, supone sin lugar a dudas el agotamiento del deber ético de legalidad comprensivo de reglas, normas y principios, como así también de la aplicación extrema del deber ético de independencia para los casos de injusticia notoria.

Desde aquí se advierte la contribución notarial para la conformación de una sociedad justa, alejada del conflicto, que vive y transcurre su existencia mediante la fortaleza que le imprimen algunas instituciones, como la que ocupa el objeto principal de análisis de esta tesis, de acuerdo a su singular naturaleza. En el documento existe una tutela de la libertad de pensamiento y de conciencia, proyectándose a través de la independencia la protección de la igualdad. El notario viene a asegurar entonces, dada la voluntad, que las cargas y las recompensas se logren distribuir de acuerdo a lo justo de cada uno. Supuesta y elevada la voluntad individual a su máximo esplendor, resta decir que la alteridad se encuentra en proporción de equidad, porque es el notario quien evita que exista arbitrariedad. La voluntad individual se erige así en voluntad jurídica.

De esta manera, la inmunidad del nuevo título surgirá de la adecuación del principio de seguridad jurídica preventiva que en sede notarial, adquiere como hemos advertido, su máxima consagración. La inmunidad garantiza el bien común generalizado, demostrado entre nosotros a través de la libre y auténtica circulación de títulos notariales nobles, que reflejan la verdad de lo acontecido y evidenciado, en razón al orden natural, en respeto a la naturaleza de las cosas, a través de la consolidación del principio de razonabilidad práctica.

El desarrollo de la justicia como valor del documento notarial es absolutamente asombroso y, por ser ajeno a los tratamientos generales de la justicia y de los que ofician de juristas, es además conmovedor. El aporte notarial al derecho también se compromete con la tutela de lo justo concreto, 
LOS EFECTOS DE LA PUBLICIDAD EN EL DOCUMENTO NOTARIAL

esto es, con lo que a cada cual le pertenece de acuerdo a lo debido por el otro, debido a lo que por derecho le debe ser correspondido.

\subsubsection{Observación de la elaboración notarial del derecho en las diferentes perspectivas de la justicia: conmutativa, distributiva y legal.}

En el primer supuesto de justicia conmutativa analizado con anterioridad, la elaboración notarial del derecho buscará tutelar adecuadamente el intercambio de bienes. Si lo justo se mide en igualdad aritmética dependiente de la identidad o cualidad y valor de las cosas, la tarea notarial en el documento tiene que evitar los vicios que pueden surgir en virtud de su no concreción. Una adecuada tarea documentadora, desde este tipo de justicia, evita por ejemplo, la instauración del vicio de lesión, y en segundo término, de la formación de los demás vicios de la voluntad. También los vicios del acto son objeto de control notarial: adecuar las formas notariales a la creación del documento implica reconocer que la teoría del acto jurídico en su total esplendor se encuentra consolidada en el instrumento que la contiene. Si la tarea documental se forma desde la idea aceptada por las partes, no habrá motivos suficientes ni para justificar en el futuro una simulación, ni para dar lugar a un reclamo por falsedad documental ni sobre la materia, ni sobre la idea.

La justicia distributiva -relación de la sociedad con el individuo-, también se ve alcanzada por la tutela de la función notarial. Allí en donde lo colectivo se reparte entre sus miembros, el notario contribuye informando, asesorando o aconsejando acerca de las posibilidades que la sociedad, representada en el Estado, les otorga en relación a su propia y especial posición. Este es el tipo de justicia que en sede notarial cobra verdadera razón de existencia en razón de que su tutela contempla los beneficios que la sociedad otorga a las personas para que las mismas puedan alcanzar, en su máxima expresión, la 


\section{SEBASTIÁN JUSTO COSOLA}

conquista de los derechos humanos básicos ya referidos con anterioridad. Entre ellos encontramos el acceso a la vivienda digna, que de acuerdo a las leyes vigentes, encuentra eximición de tributos, o la protección integral de la vivienda a través de instituciones como la protección integral de la vivienda prevista normativamente en Código Civil y Comercial de La Nación. Lógicamente el reparto debe ser justo y equitativo. Entonces es el notario quien solicita, argumenta, comprueba y proyecta en el documento el resultado de sus averiguaciones, para que la colectividad pueda en su conjunto, darle a cada individuo lo que corresponda de acuerdo a su posición.

Finalmente, la justicia legal o general que hace referencia a la posición de deuda del individuo hacia la comunidad. Definitivamente esta es la labor más ardua y por ello, la que más congratulaciones conlleva en razón de la importancia del aporte notarial a este tipo de justicia. El ejemplo más característico es sin duda la actuación notarial como agente de retención, información, percepción, en definitiva, como agente de recaudación gratuito a favor de la colectividad en su conjunto. Bajo un estricto control, el notario ingresa periódicamente a las arcas fiscales el producto de su recolección de acuerdo a las leyes que regulan el derecho tributario y financiero nacional, alcanzando con ello la tutela justa del bien común. Pero hay otras actividades notariales de relevancia que coadyuvan a desarrollar este tipo de justicia. Las informaciones acerca del origen del dinero en las operaciones inmobiliarias, o las relativas a operaciones sospechosas que persiguen la finalidad de evitar negocios relacionados con el lavado de activos producto de acciones humanas provenientes de flagelos sociales actuales como el narcotráfico, o que intentan salvaguardar los derechos de las personas sometidas a vejaciones aberrantes como la trata de personas, entre otras, son muestras absolutas, imposibles de ser negadas, de que la función notarial plasmada en el documento contribuye a erigir los tres tipos de justicia en una sociedad que necesita de protección adecuada. 
LOS EFECTOS DE LA PUBLICIDAD EN EL DOCUMENTO NOTARIAL

13.3.2. Excursus: la justicia y su valoración cartular intrínseca en el documento notarial.

El valor referido a la fe pública entendida como certeza del derecho es relevante, pero no alcanza para probar lo justo como contenido esencial del documento. Dado el encuentro entre las partes, o el deber de la colectividad de brindar al individuo lo que le es debido, o el deber del individuo en retornar a la colectividad lo que le corresponde en aras al bien común, la tutela notarial alcanza a la justicia en las calificaciones jurídicas que realiza el notario a partir de la solicitud de los comparecientes o requirentes, para encuadrar tal o cual negocio jurídico que les resulte favorable a sus deseos negociales. Ese encausamiento notarial del derecho supone una obligación de diálogo e intercambio de ideas que debe efectuar el notario, imposible de ser delegada en otra persona que no reúna su condición. Es lo que en definitiva conforma una especie de auditoría, de contralor y de colaboración que termina por decidir que el acto que se realiza en base a la voluntad es un acto justo. Para ello, la fe (certeza) debe además contar con la anuencia de la fe (verdad). Ambas facetas de la fe pública son las que generan que el efecto del valor justicia pueda alcanzar la máxima expresión de seguridad. Si el acto se realiza bajo la tutela notarial, no habrá propietario que transfiera su derecho si no a través de un acto de su propia, emergente y libre voluntad (seguridad jurídica estática). Consecuentemente, ese documento notarial circulará negocialmente con las máximas previsiones de certeza, sin que sobre él pueda generarse ningún tipo de conjetura que llame la atención de su bondad (seguridad jurídica dinámica).

El valor justicia dentro del documento notarial conforma un aspecto de la publicidad cartular intrínseca. Dentro del principio de autenticidad interna, el valor sobresale desde las siguientes caracterizaciones fundamentales:

a) La justicia emerge del acto volitivo de obrar;

b) Comprende las relaciones entre las partes comparecientes y el notario (la orientación hacia el otro); 


\section{SEBASTIÁN JUSTO COSOLA}

c) Profundiza las nociones del deber (lo que es adeudado y lo que es debido al otro);

d) Se esmera por alcanzar la igualdad a través del contrapeso y del equilibrio;

e) La tutela notarial comprueba que la misma alcance la plenitud de sus efectos;

f) El principal efecto: la justicia como valor que atribuye a cada uno lo que es suyo.

A partir de las referidas caracterizaciones fundadas en los aportes académicos antes analizados, puede decirse que la justicia, desde la perspectiva intrínseca del documento notarial, no es de ningún modo la contracara de la seguridad jurídica, precisamente porque de lo justo concreto emerge tanto la acción de libre voluntad de trasmitir el derecho que alguna vez fuera al transmitente adjudicado, como la preocupación porque esa voluntad no viciada ni simulada se aleje de lo falso, ya que la misma determina, a través de la certeza y de la verdad, la perfecta circulación del documento en el trafico jurídico correspondiente. 


\section{Capítulo 14}

\section{Tercer Valor: La Seguridad jurídica.}

\subsection{Palabras introductorias.}

El tercer valor del documento, la seguridad jurídica, siempre fue considerado como fundacional del ejercicio y de la función notarial. De todos los valores jurídicos proyectados desde la iusfilosofía, es la seguridad jurídica el único que la doctrina nacional y extranjera se ha ocupado por desarrollar y asimilar al ejercicio del derecho notarial, precisamente porque la verdad ha sido desarrollada desde la idea objetiva de la fe pública, y porque la justicia como valor en el documento no encuentra antecedentes de tratamiento desde una proyección eminentemente axiológica. La cuestión de la seguridad en general -comprendida en toda su magnitud-, le es al notariado absolutamente consustancial, y por ello es que con frecuencia se suele aludir a la seguridad jurídica que emana de los instrumentos o documentos notariales a partir de los efectos que él mismo consolida y conforma a partir de su autorización (eficacia formal del principio de autenticidad externa + seguridad jurídica dinámica). Desde ahí que uno de los efectos por mí referenciados anteriormente -la certeza, relativa a la $f e$ pública en su aspecto objetivo- también sea en situaciones aplicada al valor seguridad. De esta forma, si la imparcialidad es la virtud elegida por antonomasia para describir el comportamiento del notario, la seguridad jurídica es el valor escogido para justificar su trascendencia.

Pero el tema en la actualidad presenta, desde mi opinión, una importancia que jamás ha proyectado en el tiempo que aconteció. La seguridad jurídica, comprendida como un valor del ordenamiento jurídico positivo, siempre 


\section{SEBASTIÁN JUSTO COSOLA}

encontró recepción en ciertas y determinadas pautas interpretativas específicas fundamentadas desde el positivismo legalista y el iluminismo, pensamiento que dominó gran parte de los años transcurridos entre los siglos XVII y XIX del milenio pasado, y que identificó a la misma con el goce amparado por el poder político y sin perturbaciones, de los derechos individuales y dentro de ellos, de la libertad y la defensa de la propiedad privada $^{2091}$. Por aquellos tiempos, la seguridad jurídica se erigía como un baluarte del derecho absolutamente indiscutible. Thomas Hobbes, por ejemplo, plantearía por aquellos años que la seguridad de los hombres que están preparados para alcanzar su propia conservación, no debe buscarse en las leyes de la naturaleza, sino en un determinado poder instituido para alcanzar la protección que evita que el hombre se fie de su propia fuerza y maña para protegerse contra los demás hombres ${ }^{2092}$. También John Locke argumentaría que los hombres que entran en la sociedad renuncian a la igualdad, libertad y poder ejecutivo que disponían en el estado de naturaleza, entregando esos valores al poder legislativo para que el mismo los disponga a favor del bien común; y en este sentido, quien tiene en sus manos el poder legislativo se encuentra en la obligación de gobernar mediante leyes fijas y establecidas, promulgadas y conocidas por el pueblo, estableciendo jueces imparciales que son los que se encargarán de resolver los litigios que se sucedan mediante aquellas leyes, todo encaminado con el único objeto de alcanzar la paz, la seguridad y el bien de la población ${ }^{2093}$. En sintonía, otro exponente de las corrientes de pensamiento referidas es sin dudas el Barón de Montesquieu; el mismo se refería a la libertad política del ciudadano como la tranquilidad de espiritu que proviene de la confianza que tiene cada uno en su seguridad siendo absolutamente necesario un gobierno tal que ningún ciudadano pueda temer a otro ${ }^{2094}$.

${ }^{2091}$ Cfr. Rodolfo L. VIGO, Aproximaciones a la seguridad jurídica, en Interpretación Jurídica (Del modelo iuspositivista legalista decimonónico a las nuevas perspectivas), RubinzalCulzoni, Santa Fe, 1.999, p. 266 y ss.

${ }^{2092}$ Cfr. Thomas HOBBES, Leviatán, Fondo de Cultura Económica, Buenos Aires, 2.009, págs. 137-138.

${ }^{2093}$ Cfr. John LOCKE, Segundo tratado sobre el gobierno. Un ensayo sobre el verdadero origen, alcance y fin del gobierno civil, Aguilar, Colonia Suiza, Uruguay, 2.010, p. 106.

${ }^{2094}$ Cfr. MONTESQUIEU, El espíritu de las leyes, Heliasta, Buenos Aires, 2.005, págs. 181182. 


\section{LOS EFECTOS DE LA PUBLICIDAD EN EL DOCUMENTO NOTARIAL}

Todo esto explica que en general, el tratamiento de la seguridad encuentre amplia recepción en las obras explicativas del derecho decimonónico y no tanto en las otras corrientes de pensamiento, que más que nada, han impulsado en todo caso comentarios críticos en torno a su figura. Desde este punto de vista, la seguridad jurídica no es más que un ideal normativo de primera magnitud en cualquier ordenamiento jurídico ${ }^{2095}$.

Paralelamente al desarrollo del valor en estudio, la idea de generación del derecho notarial formal comenzaba por comprenderse a partir del esquema de los formularios, que para demostrar su importancia se agrupaban en libros o cuadernos que hacían a su seguridad. Esta es una de las explicaciones y razones que justifican que la aplicación de la técnica notarial siempre se encuentra orientada hacia la concreción cierta de la ley en el documento, como modo de aplicación y comunicación de la ciencia ${ }^{2096}$, porque únicamente la ley otorga al individuo, bajo este paradigma, la seguridad que necesita.

A lo largo y a lo ancho de este trabajo me he esmerado por demostrar que el paradigma científico vigente en otros tiempos ha mutado absolutamente en la realidad actual, y con él, los valores y los principios alcanzan como nunca, un protagonismo absolutamente relevante, lo que vuelve en cierta manera más contundente la teoría jurídica actual, que ya no se nutre únicamente de la ley o las reglas para poder llegar a la solución de un caso, sino que busca entre el amplio abanico de fuentes la mejor solución, ponderando ciertos aspectos relevantes de la distinción primigenia entre reglas y principios ${ }^{2097}$. El denominado diálogo de fuentes es un llamado de atención al jurista práctico del derecho ${ }^{2098}$, que implica aceptar que en los tiempos actuales el valor verdad y en especial, el valor justicia pueden tener mucho más peso en la resolución del caso que el valor seguridad, comprendida como valor anexo a la certeza, gemelo y hasta ciertamente

${ }^{2095}$ Cfr. Humberto ÁVILA, Teoría de la seguridad jurídica, Marcial Pons, Madrid, 2.012, p. 565.

${ }^{2096}$ Cfr. Rubén A. LAMBER, Donaciones, Astrea, Buenos Aires, 2.008, p. 4 y ss; Natalio P. ETCHEGARAY, Escrituras y actas notariales, Astrea, Buenos Aires, 2.016, p. 3 y ss.

2097 Cfr. Juan CIANCIARDO, Problema y sistema. Una aproximación al pensamiento de Theodor Viehweg, en AFJS n ${ }^{\circ}$ 25, Abeledo Perrot, Buenos Aires, 2.006, p. 40.

2098 Cfr. Ricardo L. LORENZETTI, Código Civil y Comercial de La Nación, RubinzalCulzoni, Santa Fe, 2.015, p. 12. 


\section{SEBASTIÁN JUSTO COSOLA}

confundible con la fe pública objetiva. En esta tesis, los valores deben integrarse en el documento bajo la premisa de un objetivo común: alcanzar la paz.

\subsection{La justicia y la seguridad.}

Desde el desarrollo expositivo de las teorías axiológicas del derecho, la seguridad jurídica siempre fue presentada como la contracara de la justicia. Son ideas opuestas, ideas fundadas en raíces antagónicas, que sí se estudian a la luz de las épocas de ejercicio del derecho, pueden tener proyecciones absolutamente diferentes. Como ya hemos analizado, durante los tiempos del iluminismo y de la primera codificación, las ideas de ley y seguridad jurídica se impusieron al derecho como baluartes indispensables e insustituibles. Las leyes comenzaban a responder a un casuismo admitido y estimulado; los cuerpos legales admitían a la ley como la única fuente del derecho estable y definitiva en cuanto a que no fuera imprescindible su modificación; comenzaban a simplificarse las estructuras complejas teocéntricas del derecho, se reducía el campo de interpretación jurídica y los jueces de esos tiempos se vieron obligados a vincularse a los sistemas legales alejándose de los cauces de la equidad ${ }^{2099}$. Pero en la etapa de la codificación actual, la justicia tiene, por sobre todos los valores, una proyección primaria y esencial. Y el sistema de valoración del derecho no puede en los tiempos actuales, considerarse fuera de la razonabilidad ${ }^{2100}$ y de la argumentación ${ }^{2101}$. Es entre nosotros Enrique del Carril quien pone énfasis en ésta distinción y que, desde una perspectiva absolutamente neutral, avizora la importancia del desarrollo del derecho notarial actual. Si en el horizonte del derecho actual se debe sacrificar a la seguridad en pos de la justicia para no generar un sistema jurídico inhumano -lo justo se distribuye en el acto judicial que

${ }^{2099}$ Cfr. Víctor TAU ANZOÁTEGUI, La codificación en la Argentina, Librería Histórica Emilio J. Perrot, Buenos Aires, 2.008, p. 39.

${ }^{2100}$ Cfr. Juan CIANCIARDO, El principio de razonabilidad, Ábaco, Buenos Aires, 2.009, p. 33 y ss.

${ }^{2101}$ Cfr. Armando S. ANDRUET (h), Teoría general de la argumentación forense, Alveroni, Córdoba, 2.013, p. 97 y ss. 
decide que es lo que a cada uno corresponde (lo suyo), y por ello no es posible referirse a la seguridad del derecho-, la función notarial presenta un fundamento singular, precisamente porque se encuentra comprometida a dar a cada uno lo suyo antes del desarrollo del conflicto, con una autorictas que como atributo especial de la función permite brindar seguridad y previsibilidad a las relaciones jurídicas ${ }^{2102}$. Por esta razón es que la seguridad jurídica como baluarte no puede ser considerada desde una óptica general, sino que debe ser proyectada como un valor trascendente absolutamente relacionado con la función notarial desde un desarrollo elemental y conjunto con el valor de la justicia. Consecuentemente, debe desarrollarse entonces como un valor informante de las constituciones modernas, como una dimensión formal de la justicia, a cuyo logro se encomienda en gran parte el ejercicio de la función notarial ${ }^{2103}$.

\subsection{Los conceptos y los primeros alcances.}

Al lograrse confirmar la teoría que otorga a los principios la condición de ser normas rectoras del derecho ${ }^{2104}$, la seguridad jurídica definitivamente se convierte en uno de ellos, ubicándose así dentro de uno de los niveles más trascendentes del análisis del derecho ${ }^{2105}$. De manera indiscutida, se erige

${ }^{2102}$ Cfr. Enrique H. DEL CARRIL, Prólogo a mi libro Fundamentos del derecho notarial..., ob. cit., p. 21-22.

2103 Cfr. Leonardo B. PÉREZ GALLARDO, Constitución y notariado. Recepción constitucional de la función pública notarial. Especial referencia a la jurisprudencia constitucional, en Leonardo B. PEREZ GALLARDO (Coord.), Derecho Notarial Constitucional, Fondo Editorial del Colegio de Notarios de Lima, Perú, 2.017, p. 2.

${ }^{2104}$ Jorge MOSSET ITURRASPE, Derecho Civil Constitucional, ob. cit., p. 66.

${ }^{2105}$ Una tesis doctoral de la Facultad de Derecho de la Universidad de Buenos Aires defendida oportunamente por Carlos Blaquier, se refería a la seguridad jurídica como una cualidad del ordenamiento mediante el cual, dentro del mismo, toda persona puede conocer anticipadamente las consecuencias jurídicas de sus actos. Por aquel entonces, y no sin cierta dosis de razón y ecuanimidad, se argumentaba que tanto la seguridad como la inseguridad jurídica son simples puntos de referencia meramente conceptuales, que en la vida general no ocurren nunca, pero sobre los cuales la realidad participa acercándose a uno y a otro en mayor o menor grado. El autor concluye que a mayor grado de realización de seguridad mayor acercamiento al Estado de derecho y a la propia Constitución. Cfr. Carlos Pedro Tadeo 


\section{SEBASTIÁN JUSTO COSOLA}

como principio fundamental de todo sistema legal civil ${ }^{2106}, \mathrm{y}$ aunque sus remotos orígenes hayan sido asociados al derecho público, lo cierto que en la actualidad su importancia se proyecta incluso hacia los principios del derecho privado y el derecho de procedimientos, en figuras tales como las que se refieren a la publicidad e irretroactividad de la ley, a la legitimidad de las penas, al respeto por el debido proceso, a la cosa juzgada y entre otras, a la prescripción ${ }^{2107}$.

Nos encontramos en presencia de uno de los valores más importantes del derecho, esencial para la determinación de la seguridad económica de los países que la adoptan como paradigma ${ }^{2108}$, con exquisitos y variados enfoques desde lo académico, que provienen de todas las disciplinas jurídicas en las que el derecho fuera dividido para que pueda ser estudiado y comprendido, siempre como unidad, en su total y cabal magnitud y esplendor. En opinión del recordado Augusto Morello, la seguridad jurídica es un elemento esencial del Estado de Derecho, que consolida la libertad a través de la exigencia de confiabilidad del orden jurídico ${ }^{2109}$.

En España, el llamado principio de seguridad jurídica representa un rasgo del derecho mediante el cual los ciudadanos en general pueden conocer anticipadamente las consecuencias jurídicas que van a tener sus actos, y de esta manera, puedan preverse resultados predecibles y seguros ${ }^{2110}$. En tiempos más cercanos, se advierte que la exposición acerca del tema relacionado a la de seguridad en general predispone al jurista al menos a comprender dos tipos de sentidos emparentados con la expresión

BLAQUIER, Crisis de la seguridad jurídica y crisis del derecho, Biblioteca de la Facultad de Derecho de la Universidad de Buenos Aires, $n^{\circ}$ topográfico 251.048/1954 (Debe pedirse con el numero topográfico 250.819), p. 7 y ss. (TD).

${ }^{2106}$ Cfr. William D. ROGERS y Paolo WRIGHT-CAROZZA, La Corte Suprema de Justicia y la Seguridad Jurídica, Ábaco, Buenos Aires, 1.995, p. 32.

${ }^{2107}$ Ibídem, p. 33.

${ }^{2108}$ Cfr. Jorge Reinaldo VANOSSI, Constitución, seguridad jurídica y comercio, XV Reunión conjunta de las Academias Nacionales de Derecho y Ciencias Sociales de Buenos Aires, y Córdoba, Córdoba, 23-24/10/2003. http://www.acaderc.org.ar/doctrina/articulos/artconstitcionseguridadjuridia (Ultimo acceso: 29/08/2017)

${ }^{2109}$ Cfr. Augusto Mario MORELLO, El derecho en la vida, Librería Editora Platense, La Plata, 2.002, p. 15.

${ }^{2110}$ Cfr. Carlos MARÍN CALERO, De la seguridad jurídica a la garantía económica, RJN n ${ }^{\circ}$ 42, Madrid, 2.002, p. 106. 
mencionada: en uno, hay seguridad donde uno busca anclajes, puntos fijos, para explicar la presencia en el mundo (comprensión más significativa de la seguridad); en el otro, simplemente se plantea la seguridad del hombre común, que comienza por ser seguridad fisica. Vinculada a los dos planos mencionados, nace la seguridad jurídica ${ }^{2111}$.

\subsubsection{La expansión de la seguridad jurídica.}

Con el iluminismo la seguridad jurídica alcanza su máximo esplendor ${ }^{2112}$. La Corte Suprema de Justicia de la Nación se ha pronunciado a favor de la seguridad jurídica posicionándola como valor trascendente con jerarquía constitucional, sosteniendo que es una de las bases principales de sustentación de nuestro ordenamiento y cuya tutela innegable compete a los jueces $^{2113}$,.

Al recordar que en nuestro país la seguridad jurídica no se encuentra expresamente prevista en la parte dogmática de la Constitución Nacional aunque sin duda alguna se infiere de manera implícita de todo su articulado-, algunos autores aportan ciertos enfoques interesantes de la misma:

a) Desde la perspectiva sociológica, referida al grado de acatamiento al orden jurídico que tiene una determinada sociedad ${ }^{2114}$;

b) Desde una perspectiva que centra su análisis en la filosofía política, para poder imponer la obligación política hacia la consecución de un orden incontrovertible y también invulnerable ${ }^{2115}$;

\footnotetext{
2111 Jorge Horacio ALTERINI, La seguridad jurídica. Notariado y Registros, LL Temas Doctrinarios 2, ob. cit.

2112 En la magna obra de Montesquieu puede leerse lo siguiente: "La libertad filosófica consiste en el ejercicio de la propia voluntad. La libertad política consiste en la seguridad, o al menos en creer que se tiene la seguridad". Cfr. MONTESQUIEU, El espíritu de las leyes, Heliasta, Buenos Aires, 2.005, p. 208.

${ }^{2113}$ Cfr. Alberto DALLA VÍA, Transformación económica y seguridad jurídica, Librería Editora Platense, La Plata, 1.994, p. 13.

${ }^{2114}$ Ibídem, p. 11.

${ }^{2115}$ Ibídem.
} 


\section{SEBASTIÁN JUSTO COSOLA}

c) Desde la filosofía del derecho, que la describe desde una descripción de naturaleza óntica y ontológica, de la que resulta que el derecho es un orden y que la seguridad brinda al mismo el ordenamiento necesario como concepto primario de todo valor superior ${ }^{2116}$;

d) Desde el derecho en su aplicación práctica, como resultado de la aplicación jurisprudencial, la seguridad se explica desde la Constitución y desde los principios generales del derecho en ciertos institutos de relevancia: inviolabilidad de la cosa juzgada, irretroactividad de las leyes en materia penal y tributaria, principio de legalidad y relación con la no-confiscatoriedad, el respeto a la propiedad y los derechos ya adquiridos por el individuo, entre otros ejemplos ${ }^{2117}$;

e) Desde una visión eminentemente constitucional ${ }^{2118} \mathrm{y}$

f) Desde una perspectiva teleológica, que la posiciona inmejorablemente como la seguridad en lo justo, que precisamente viene a potenciar la seguridad de lo que se considera justo en una determinada época y que la sociedad necesita garantizar "por estimarlo ineludible para sus fines ${ }^{2119}$ ".

Pero también otros autores advierten que los elementos esenciales de la seguridad jurídica comprenden al orden constitucional, el control de constitucionalidad, el Estado de derecho, la ausencia de corrupción y de influencias, la razonabilidad en la aplicación de las normas y una efectiva administración de justicia ${ }^{2120}$. En definitiva, la figura en análisis cobra particular importancia, por cuanto si se la considera dentro del significado del valor, reconoce un primer abordaje en la esfera constitucional ${ }^{2121}$, para

\footnotetext{
${ }^{2116}$ Ibídem, p. 12.

${ }^{2117}$ Ibídem, p. 13.

${ }^{2118}$ Ibídem.

${ }^{2119}$ Ibídem, p. 14.

${ }^{2120}$ William D. ROGERS y Paolo WRIGHT-CAROZZA, La Corte Suprema de Justicia y la Seguridad Jurídica, ob. cit., p. 34.

${ }^{2121}$ Nos recuerda VANNOSI algunos de las menciones de la Seguridad Jurídica en nuestra Constitución:"Los derechos de "usar y disponer de la propiedad", "asociarse con fines útiles" y "ejercer toda industria lícita" regulados en el art. 14 de la Constitución Nacional, tienen que ver directamente con el proceso económico; los que se extienden por el art. 20 a los extranjeros que "gozan en el territorio de la Nación de todos los derechos civiles del
} 
que desde allí, su multiplicación por todas las disciplinas jurídicas sea coherente y razonada ${ }^{2122}$.

Sin embargo, debe tenerse presente que Germán Bidart Campos pudo demostrar con razón suficiente que el constitucionalismo actual ha logrado poner las cosas en su sitio; esto es, una clara referencia a la sustitución de la ley por la Constitución, considerada como un orden sustancial o material de valores $^{2123}$. Con ello -sostiene Bidart- “(...) parece bastante evidente que a la superlegalidad constitucional la acompaña y la alimenta una axiología de suficiente calidad suprapositiva ${ }^{2124}$ ". En este camino expositivo se ubica también Alfonso Santiago (h), que explica acertadamente el movimiento de constitucionalización del ordenamiento jurídico ${ }^{2125}$, y también Miguel Carbonell, que postula que los cuatro desafíos del nuevo constitucionalismo actual en América Latina se refieren a conocer la constitución, aplicarla bien, educar para el neoconstitucionalismo y contar con la sociedad ${ }^{2126}$. Es este último sentido, también la seguridad puede estudiarse desde la Constitución a partir del desarrollo de instituciones típicas y modernas, de práctica tan común en nuestros días, como las que se tutelan el derecho del consumidor $^{2127}$ o la que alientan el desarrollo de inversiones económicas ${ }^{2128}$.

ciudadano; pueden ejercer su industria, comercio y profesión; poseer bienes raíces, comprarlos o enajenarlos..." La igualdad de los derechos civiles para nacionales y extranjeros consagrada por la Constitución Nacional, tiene directamente que ver con la seguridad jurídica, y la posibilidad que a su amparo crecieran en el país las inversiones extranjeras, que coadyuvaran con el proceso económico" V. Jorge Reinaldo VANOSSI, Constitución..., ob. cit., p. 4.

${ }^{2122}$ Ya Helio ZARINI escribía que la seguridad, junto al orden, la justicia, el bien común, la defensa colectiva se eleva como finalidad y valor desde el propio preámbulo de la Constitución, con el fin de garantizar los beneficios de la libertad y la existencia de una estado democrático. V. Helio Juan ZARINI, Constitución Argentina ..., ob. cit., p. 13.

${ }^{2123}$ Germán BIDART CAMPOS, Nociones Constitucionales. Las intersecciones iusnaturalistas de la Constitución, ob. cit., p. 40.

${ }^{2124}$ Ibídem.

${ }^{2125}$ Alfonso SANTIAGO (h), En las fronteras entre el derecho constitucional y la filosofia del derecho..., ob. cit., pág. $170 \mathrm{y}$ ss.

${ }^{2126}$ Cfr. Miguel CARBONELL, Neoconstitucionalismo y derechos fundamentales, AdHoc, Buenos Aires, 2.013, p. 50 y ss.

2127 Cfr. Humberto QUIROGA LAVIÉ, Lecciones de derecho constitucional, Depalma, Buenos Aires, 1.995, p. 196.

${ }^{2128}$ Cfr. Aída KEMELMAKER DE CARLUCCI, Pautas económicas de interpretación y seguridad jurídica 


\section{SEBASTIÁN JUSTO COSOLA}

También debe decirse que la seguridad jurídica conforma el interés de la agenda del jurista preocupado por el control de razonabilidad de las leyes. Si el derecho está conformado por reglas y por sus diferentes niveles de interpretación desde lo técnico (Poder Legislativo) y desde lo corriente (Poder Ciudadano), dado el conflicto en la interpretación del alcance de la norma habrá un juez que solucione la controversia ${ }^{2129}$, intentando alcanzar la racionalidad como método para evitar la arbitrariedad ${ }^{2130}$.

Finalmente, el análisis del valor seguridad se extiende hacia la posición de autores que postulan lo fundamentos esenciales del principio de proporcionalidad como método razonable de análisis legislativo, desde donde pueden estudiarse notables teorías de aplicación de los principios de proporcionalidad y razonabilidad de las leyes para la adecuada ponderación de los derechos fundamentales positivizados en la Constitución Nacional. De esta manera, se plantean de manera original ${ }^{2131}$, metódica ${ }^{2132}$ y desarrollada 2133 las máximas de razonabilidad o de proporcionalidad que prescriben todo tipo de regulación de derechos fundamentales, sobre la idea de respetar tres tipos de sub-principios especiales: adecuación o idoneidad de la norma, necesidad y principio de proporcionalidad ${ }^{2134}$. Todo lo que significa

en la jurisprudencia de la Corte Suprema de la Nación, XV Reunión conjunta de las Academias Nacionales de Derecho y Ciencias Sociales de Buenos Aires, y Córdoba, Córdoba, 23-24/10/2003. http://www.acaderc.org.ar/doctrina/articulos/artpautaseconomicas (Último acceso: 29/08/2017).

2129 Cfr. Diana Regina CAÑAL, El contenido formal y sustancial del derecho: una contradicción aparente (Una mirada desde el derecho del trabajo) (TD), Biblioteca de la Facultad de Derecho de la Universidad de Buenos Aires, $n^{\circ}$ topográfico 253.521/2005, p. 6.

${ }^{2130}$ Ibídem, p. 8 y ss.

${ }^{2131}$ Cfr. Juan CIANCIARDO, El ejercicio regular de los derechos, Ad Hoc, Buenos Aires, 2.007 , p. 281 y ss. (TD). También del mismo autor Principio de proporcionalidad y concepto de derecho. Una aproximación desde la tesis del positivismo jurídico, Ad Hoc, Buenos Aires, 2.009 , p. 57 y ss.

${ }^{2132}$ Cfr. Laura CLÉRICO, El examen de proporcionalidad en el derecho constitucional argentino, Edudeba, Buenos Aires, 2.009, p. 23 y ss. (TD).

${ }^{2133}$ Cfr. Roberto M. A. SAGGESE, El control de razonabilidad en el sistema constitucional argentino, Rubinzal Culzoni, Santa Fe, 2.010, p. 134 y ss (TD).

${ }^{2134}$ Juan CIANCIARDO, El ejercicio regular..., ob. cit., p. 283 y ss; Laura CLERICO, El examen de proporcionalidad..., ob. cit., p. 15 y Roberto M.A. SAGGESE, El control de razonabilidad..., ob. cit., p. 225 y ss. 
LOS EFECTOS DE LA PUBLICIDAD EN EL DOCUMENTO NOTARIAL

comprender que en definitiva, la seguridad jurídica y la justicia son los fundamentos tanto de la legalidad como de la razonabilidad ${ }^{2135}$.

\subsubsection{El objeto de tutela.}

Importantes estudios nos ponen al tanto de lo difícil que resulta analizar la pluralidad semántica de la seguridad jurídica ${ }^{2136}$. Así, se plantea la necesidad de justificar la importancia de la seguridad jurídica desde todo su enorme arquetipo: seguridad del derecho, por el derecho, frente al derecho, de los derechos, bajo el derecho, por un derecho, como un derecho y en el derecho $^{2137}$. Siendo un valor, el objeto de tutela no puede sino consolidarse desde una baremo general tutor del derecho en su total esplendor y magnitud. De esta forma, las distintas dimensiones de la seguridad permiten el mínimo de confiabilidad, calculabilidad y previsibilidad del ordenamiento jurídico ${ }^{2138}$.

\subsection{Aproximaciones iusfilosóficas a la seguridad jurídica.}

La idea de derecho, argumenta Radbruch, se encuentra en la justicia igualitaria, por ello es que para el autor el concepto de derecho se alcanza desde la noción de la justicia ${ }^{2139}$. Sin embargo, el contenido de derecho, debe alcanzarse a través del análisis de los fines que persigue. La justicia y la

\footnotetext{
${ }^{2135}$ Roberto M. A. SAGGESE, El control de razonabilidad..., ob. cit., p. 60 y ss.

${ }^{2136}$ Cfr. Humberto AVILA, Teoría de la seguridad jurídica, Marcial Pons, Madrid, 2.012, p. 65.

${ }^{2137}$ ibídem.

${ }^{2138}$ ibídem, p. 66.

${ }^{2139}$ Gustav RADBRUCH, Filosofia del derecho, ob. cit., p. 143. La obra presenta un estudio preliminar de Joaquín ALMOGUERA CARRERES, que refiere que la presente publicación responde a lo que se conoce como "el ultimo Radbruch iusnaturalista", para quien además la fuerza de la ley se funda en la necesidad en lugar del derecho y la validez. V. p. 21 y ss.
} 
utilidad, o adecuación del derecho a un fin, son los dos primeros elementos del derecho. Precisamente porque es el derecho, ante todo, una ordenación, necesita del tercer elemento, que es la seguridad jurídica 2140 . "Si no puede fijarse lo que es justo, hay que establecer lo que debe ser jurídico ${ }^{2141}$ ", dice el autor, por ello la positividad del derecho en este supuesto es un propio supuesto de justicia: "tan propio es del concepto del derecho justo el ser positivo, como es tarea del derecho positivo ser justo en sus contenidos ${ }^{2142}$ ". Radbruch postula la existencia de un orden seguro por sobre la idea de justicia y de su finalidad, a las que considera tareas secundarias del derecho ${ }^{2143}$ : "La primera, consentida igualmente por todos, es la seguridad, es decir, el orden, la paz ${ }^{2144, "}$.

Ya he adelantado que un análisis iusfilosófico del derecho no evitará referirse a los conflictos entre la justicia y la seguridad. La seguridad jurídica exige positividad, que parte de suponer que se cuenta con una determinada fuerza: hay unión entre derecho y fuerza, que son sin embargo, criterios contrarios $^{2145}$. La seguridad jurídica, conjuntamente con la justicia y la finalidad, dominan al derecho, aunque tengan contradicciones, inclinándose más o menos alguno de los tres principios de acuerdo a la época que le toque al derecho desarrollarse ${ }^{2146}$. En palabras del propio Radbruch: "En interés de la seguridad jurídica existe la santidad de la cosa juzgada, de modo que el fallo de contenido injusto conserva su fuerza de obligar para el caso concreto, y aun trasciende en forma de precedente a la singularidad del caso. En la prescripción, en la usucapión, en la protección de la posesión civil y en el statuo quo internacional, se otorgan efectos justificantes al estado antijurídico en méritos de la firmeza, es decir, de la seguridad de la vida jurídica ${ }^{2147}$,.

Otro autor, Luis Recasens Siches, también se refiere a la seguridad como valor fundamental de lo jurídico, sin la cual no puede haber derecho

\footnotetext{
${ }^{2140}$ Ibídem, p. 144.

${ }^{2141}$ Ibídem.

${ }^{2142}$ Ibídem.

${ }^{2143}$ Ibídem, p. 145.

${ }^{2144}$ Ibídem.

${ }^{2145}$ Ibídem, p. 147.

${ }^{2146}$ Ibídem, p. 149

${ }^{2147}$ Ibídem, p. 148.
} 


\section{LOS EFECTOS DE LA PUBLICIDAD EN EL DOCUMENTO NOTARIAL}

alguno $^{2148}$. Sin embargo, comienza por advertir que la misma no conforma un valor supremo, y que por ello debe estar al servicio de los valores de rango superior como la justicia, la utilidad común entre otros ${ }^{2149}$. Desde esta perspectiva, el concepto de derecho comprende en esencia formal la idea de seguridad $^{2150}$. De ahí es que afirme en famosa alocución lo siguiente: "Sin seguridad no hay derecho, ni bueno, ni malo, ni de ninguna clase ${ }^{2151}$ ". De esta manera, su posición termina por advertir que la seguridad es la razón de ser del derecho, pero no es su fin supremo. Entonces la seguridad es un valor inferior, en relación al valor superior de justicia, pero recobra particular importancia por cuanto del cumplimiento de los valores inferiores depende la efectividad de la realización de los valores superiores ${ }^{2152}$. Para Luis Legaz y Lacambra la idea de seguridad jurídica va ineludiblemente ligada a la idea de legalidad, precisamente porque la seguridad jurídica legitíma a la legalidad ${ }^{2153}$. Para el autor, la justicia es el valor más importante, y el orden y la seguridad se realizan al amparo o con la tutela de la justicia ${ }^{2154}$. La seguridad es una exigencia ineludible del derecho, una dimensión ontológica del mismo ${ }^{2155}$.

Otro autor, Helmut Coing, entiende que la moderna teoría del derecho destaca sin dudas al principio de seguridad jurídica ${ }^{2156}$ : la misma supone que tanto derechos, como posiciones de poder y de posesión, una vez fundadas,

${ }^{2148}$ Cfr. Luis RECASENS SICHES, Filosofía del derecho, Porrúa, México, 2.008, p. 224.

${ }^{2149}$ Ibídem.

${ }^{2150}$ Ibídem.

${ }^{2151}$ Ibídem.

${ }^{2152}$ Ibídem, p. 225. En sentido similar, Agustín BASAVE enseña que en la vida social la justicia no puede realizarse sin la seguridad, y la seguridad no puede ser verdaderamente segura si priva la justicia. Para el autor, la justicia exige la seguridad pero la seguridad requiere ser justa. En efecto, concuerda con afirmar que justicia, seguridad y bien común son fines del derecho, y conforman el alma del orden normativo, ya que se erigen como principios inmanentes y trascendentes a las leyes positivas. V. Agustín BASAVE FERNÁNDEZ DEL VALLE, Filosofía del derecho, Porrúa, México, 2.013, p. 720.

${ }^{2153}$ Cfr. Luis LEGAZ Y LACAMBRA, Filosofia del derecho, Bosch, Barcelona, 1.979, p. 603. Y va mas allá de las mencionadas apreciaciones: "La legitimidad radical de uno ordenamiento jurídico está en la justicia que encarna".

${ }^{2154}$ Ibídem, p. 605.

2155 Ibídem, p. 610. Más adelante destacará las exigencias de la seguridad, que en la perspectiva del autor son las que consienten en que la ignorancia del derecho no excusa de su cumplimiento, el problema de la fuerza jurídica de la cosa juzgada, la no retroactividad de las leyes y la exigencia por los derechos adquiridos que aplica la teoría de la irretroactividad de las leyes. 


\section{SEBASTIÁN JUSTO COSOLA}

deben subsistir sin que nadie las discuta ni las perturbe, porque también las decisiones jurídicas, una vez formuladas, deben ser mantenidas ${ }^{2157}$. El hombre siempre aspira a crear instituciones duraderas que le sirven de protección, y por ello el derecho debe ofrecer esa certeza, que el autor llama calculabilidad ${ }^{2158}$. "Al servicio de la seguridad jurídica -dice Coing- están todas las instituciones que precisan y mantienen los derechos existentes, como los registros públicos, la exigencia de escritura, etc, instituciones procesales como la firmeza de la sentencia, o jurídico privadas como la constructividad del tenor literal de una declaración, o la precisión de un comportamiento conocido en el tránsito jurídico ${ }^{2159}$ ". El concepto de conciencia jurídica ${ }^{2160}$ desde la perspectiva del autor comprende los deseos humanos de orden, paz y seguridad, siendo el ultimo sumamente relevante: "El hombre querría asegurar y garantizar su propia persona y felicidad, y eliminar de su existencia el azar y el destino. A ese fin se orienta la seguridad jurídica en la medida en que los peligros considerados pertenecen a la vida social ${ }^{2161}$ ".

Manuel Atienza opina que la seguridad jurídica en sentido amplio es la que proporciona el derecho para prever, hasta un determinado punto, la conducta humana y sus consecuencias ${ }^{2162}$. Pero como la capacidad de prevención es limitada y variable, es posible distinguir tres niveles de seguridad: a) el nivel del orden, en donde el derecho, como sistema de de control social, alcanza a lograr un mínimo de previsibilidad ${ }^{2163}$; b) nivel de certeza, que presenta una

${ }^{2156}$ Cfr. Helmut COING, Fundamentos de filosofía del derecho, trad. Juan Manuel MAURI, Asde Ediciones Previas, Córdoba, Argentina, 1.995, p. 29.

${ }^{2157}$ Ibídem.

${ }^{2158}$ Ibídem.

${ }^{2159}$ Ibídem.

${ }^{2160}$ Ídem, p. 57. Dice el autor que debe entenderse por concepto moderno de conciencia jurídica a los valores que organizan el orden jurídico y las reglas fundamentales resultantes.

${ }^{2161}$ Se llega a esto mediante dos fenómenos históricamente documentables: la tradición para la firmeza del derecho lograda a través del curso del tiempo, y las transformaciones frecuentes que dieron impulso al derecho con seguridad jurídica. Recordemos en este punto que el tema de la tradición fue relevante en el pensamiento valletiano. A través de la destrucción total de las tradiciones y las costumbres heredadas, entre otras circunstancias significativas, se alcanza a consolidar la sociedad masificada. Cfr. Juan Berchmans VALLET DE GOYTISOLO, Sociedad de masas y derecho, ob. cit., p. 115 y ss.

${ }^{2162}$ Manuel ATIENZA, El sentido del derecho, ob. cit., p. 193.

${ }^{2163}$ Ibídem. 


\section{LOS EFECTOS DE LA PUBLICIDAD EN EL DOCUMENTO NOTARIAL}

norma jurídica precisa que cuenta con el respaldo del Estado para asegurar su cumplimiento ${ }^{2164}$; y c) nivel de seguridad jurídica en sentido estricto, referido exclusivamente a la capacidad de un ordenamiento jurídico para volver previsibles, seguros, los otros valores, que son la libertad y la igualdad. De esta manera, la justicia puede definirse como "la seguridad de que el derecho nos proporciona un máximo de libertad y de igualdad ${ }^{2165}$ ".

También Werner Goldschmidt plantea el tema de la seguridad jurídica en el mundo jurídico compuesto, pero desde una visión tridimensional ${ }^{2166}$. Desde lo sociológico, debe darse un perfecto orden de repartos ${ }^{2167}$; b) Desde lo normológico, se afirma que para que las normas produzcan seguridad jurídica deben ser claras, determinadas y exhaustivas, con un claro enfoque del futuro para que puedan ser vinculatorias para todos ${ }^{2168}$. También supone la irretroactividad ${ }^{2169}$ y las vinculaciones de las normas con todo el mundo jurídico $^{2170}$. Finalmente, desde lo dikelógico, la seguridad jurídica es el resultado del funcionamiento de la división de poderes y el cumplimiento de los derechos humanos ${ }^{2171}$. Sin seguridad jurídica, reconoce el autor, no existe un orden real, ni un ordenamiento normológico, ni un ordenamiento normológico justo ${ }^{2172}$.

Finalmente, Rodolfo Vigo realiza algunas consideraciones iusfilosoficas de la seguridad jurídica $^{2173}$ : la misma, con antecedentes muy remotos, es aprehendida por nosotros desde la noción moderna instalada a partir del siglo XVII de nuestra era, en donde se constituye en valor $^{2174}$. Desde aquí se advierten diversas posiciones doctrinarias en torno a la seguridad jurídica: a)

\footnotetext{
${ }^{2164}$ Ibídem.

${ }^{2165}$ Ibídem, p. 194.

${ }^{2166}$ Cfr. Werner GOLDSCHMIDT, Justicia y verdad, Fedye, Buenos Aires, 1.978, p. 514.

${ }^{2167}$ Ibídem, p. 517.

${ }^{2168}$ Ibídem, p. 518.

${ }^{2169}$ Ibídem.

${ }^{2170}$ Ibídem, p. 519.

${ }^{2171}$ Ibídem, p. 523.

${ }^{2172}$ Ibídem, p. 524.

${ }^{2173}$ Cfr. Rodolfo Luis VIGO, Interpretación jurídica, Rubinzal Culzoni, Santa Fe, 1.999, p. 265. El ensayo se titula Aproximaciones a la seguridad jurídica.

${ }^{2174}$ Ibídem, p. 266.
} 


\section{SEBASTIÁN JUSTO COSOLA}

Las negativistas ${ }^{2175}$; b) Las que la consideran como un valor principal $^{2176}$; c) Aquellas que la enrolan como un valor autónomo ${ }^{2177}$; d) las que la subsumen $y$ asimilan dentro del valor justicia ${ }^{2178}$, y e) Aquellas que la consideran como un valor anexo o adjetivo a la justicia ${ }^{2179}$. Esta última teoría plantea -en sintonía con lo analizado por Atienza- que la seguridad jurídica es la capacidad del ordenamiento jurídico para asegurar los valores de libertad e igualdad. Es en definitiva la seguridad un valor adjetivo respecto de los dos mencionados, que componen la idea de justicia ${ }^{2180}$. El autor plantea que el derecho tiene un mínimo contenido de justicia ${ }^{2181}$, y que dado esto, lo que queda es alcanzar diversos grados de perfección, lugar donde se adscribe la seguridad jurídica ${ }^{2182}$. Es la misma una nota accidental del derecho, pero ello no atenta en su desmedro ${ }^{2183}$, porque en última instancia, la propia experiencia de la humanidad demuestra las ventajas de vivir con un derecho que además de justo, sea seguro porque puede brindar previsibilidad jurídica $^{2184}$. Definitivamente la nota característica del documento notarial con fe y justicia es la previsibilidad jurídica de certeza; certeza que se asimila al concepto de seguridad jurídica.

\footnotetext{
${ }^{2175}$ Ibídem, p. 267. Dice el autor: "Son todos aquellos que ignoran, desconfian o rechazan la seguridad jurídica". Entre ellos se encuentra Hans Kelsen, para quien la seguridad es una ficción.

${ }^{2176}$ Ibídem, p. 268. Explica el autor que "esta perspectiva...visualiza la seguridad no solo como algo valioso para el derecho sino como el fin u objetivo más importante a conseguir por el mismo, incluso a costa de la justicia". Se encuentran en esta posición tanto Gustav Radbruch como el profesor de la Universidad Autónoma de México Luis Recasens Siches que expresó una frase contundente: "La seguridad es el valor fundamental de lo jurídico (...) sin seguridad no hay derecho, ni bueno, ni malo, ni de ninguna clase (...) la seguridad es el motivo radical o la razón de ser del derecho".

${ }^{2177}$ Ibídem. Son aquellos autores, como Eduardo García Maynez o Carlos Cossio, que reconocen a la seguridad un objeto propio y peculiar que no le permite ser asimilada a la justicia.

${ }_{2178}$ Ibídem, p. 269. En esta línea se encuentran los profesores Gregorio Peces Barba, Carlos Massini Correas, y en cierta medida, Enrique Pérez Luño.

${ }^{2179}$ Ibídem, p. 270. Es el caso del propio Rodolfo Vigo y del profesor Manuel Atienza, que rescatan la idea de seguridad como algo valioso que ayuda al derecho a alcanzar un mejoramiento, pero en funcionamiento complementario, adscripto o anexo a la justicia.

${ }^{2180}$ Ibídem.

${ }^{2181}$ Ibídem.

${ }^{2182}$ Ibídem, p. 271.

${ }^{2183}$ Ibídem.

${ }^{2184}$ Ibídem, p. 272.
} 
LOS EFECTOS DE LA PUBLICIDAD EN EL DOCUMENTO NOTARIAL

\subsubsection{La seguridad como valor en el plexo axiológico} jurídico de Carlos Cossio (fundamentos de la posesión).

En algún tiempo en nuestro país, Carlos Cossio alcanzó a plantear que la exploración ontológica del ser jurídico va a radicarse en el problema de los valores jurídicos ${ }^{2185}$, siempre en que lo óntico sea el fundamento de lo empírico, y lo ontológico sea el fundamento de lo axiológico ${ }^{2186}$. El autor consiente en que si la visión axiológica del derecho apareciera en el plano ontológico mediante la intuición emocional de lo vivido ${ }^{2187}$, habrá titulo suficiente para comprender que es valor jurídico todo valor de conducta bilateral $^{2188}$. Se explica entonces que el valor jurídico sea un valor de alteridad, el valor del hacer compartido, el valor del comportamiento conjunto, y no así un valor para un destinatario que no fuere protagonista ${ }^{2189}$. En palabras del propio Cossio: "Esto significa que todo valor de conducta bilateral es un valor bilateral de conducta; o lo que es lo mismo, que todo valor de alteridad es un valor con alteridad. En consecuencia, sobre la base de la esencia óntica del Derecho -la conducta en su interferencia

${ }^{2185}$ Cfr. Carlos COSSIO, Los valores jurídicos, AFD, ${ }^{\circ}$ IV, Sociedad Española de Filosofía Jurídica y Política, Madrid, 1956, p. 29. No obstante que el autor reconozca que "la presente investigación ontológica es el de que esta se refiere a los valores de persona, en su oposición a los valores de cosas, lo que corresponde exactamente a la oposición de los substratos egológicos y mundanales" considero acertado hacer la comparación de la actuación de los valores en el mundo del derecho, independientemente de su desenvolvimiento dentro de los objetos o sobre/acerca de las personas. La idea de persistir en la búsqueda de valores descriptibles desde la más pura objetividad en las cosas y en las instituciones alumbra al propio pensamiento y es, sin duda, una invitación a la meditación constante y permanente.

${ }^{2186}$ Ibídem, p. 28.

${ }^{2187}$ Ídem, p. 33. Dice el autor: "Con anarquía de fundamentos, y aun sin elucidar fundamento alguno, desde Sócrates y Platón la línea de oro del pensamiento jusfilosófico grecooccidental ha visto en la justicia el valor propio del Derecho. Pero Calícles y Maquíavelo lo vieron en el poder; Duguit, en la solidaridad; Jhering y Kelsen, en la paz; Recasens Siches, bajo la sugestión de Radbruch, en la seguridad. Otros han tomado una combinación de dos de ellos, como Radbruch, que se refiere a la seguridad y la justicia. Santo Tomás nos remite al bien común..."

${ }^{2188}$ Ibídem.

${ }^{2189}$ Ibídem. 


\section{SEBASTIÁN JUSTO COSOLA}

intersubjetiva o conducta compartida-, se puede decir ahora que, por esencia, todo valor bilateral de conducta es valor jurídico ${ }^{2190}$ ".

Esta es la razón, quizás esencial, para comprender porque existe un plexo axiológico privativo del Derecho, ya que no puede afirmarse a priori-salvo por el prejuicio-, que únicamente habría de haber un único valor jurídico ${ }^{2191}$. Más claramente lo argumenta Germán Bidart Campos: "Los valores jurídicos viven en la conducta jurídica y se engarzan en lo que Cossio llama "un plexo", o sea, una serie de valores que se agrupan y traban entre sí, siendo los inferiores fundantes de los superiores, y los de más abajo menos valiosos que los de más arriba; los superiores no pueden realizarse sin los inferiores; éstos son más fuertes y constituyen la apoyatura fáctica de los otros ${ }^{2192}$ ".

El plexo entonces presenta una estructura fundamental conformada con tres radios divergentes a partir de un centro común y con un valor fundante o sustantivo por cada radio ${ }^{2193}$.

a) En razón de la coexistencia en cuanto circunstancia ${ }^{2194}$, que puede ser protectora $\mathrm{u}$ hosti1 ${ }^{2195}$-produciendo la sensación de amparo o desamparo- se refiere al orden y la seguridad ${ }^{2196}$.

\footnotetext{
${ }^{2190}$ Ibídem.

${ }^{2191}$ Ibídem.

${ }^{2192}$ Cfr. Germán José BIDART CAMPOS, La historicidad del hombre, del derecho y del Estado, Ediciones Manes, Buenos aires, 1.965, p. 119.

${ }^{2193}$ Carlos COSSIO, Los valores jurídicos, ob. cit., p. 34.

${ }^{2194}$ Ibídem.

2195 Ídem, p. 35. Dice el autor: "En esto juega el hecho de que al vernos protegidos nos sentimos seguros; y al revés, de que vivimos la inseguridad cuando la circunstancia nos toca con el poderio de la pura fuerza bruta. Por eso el pararrayos da seguridad al hogar en los días de tormenta; y el fortín de las avanzadas daba seguridad a la ciudad contra los malones de indios. Por eso hay inseguridad cuando el tigre del circo se escapa de su jaula, lo mismo que la hay cuando se escala un despenadero resbaloso. Obviamente la coexistencia también puede desplegarse como desnuda fuerza bruta, colocándonos, en su caso extremo, en esa situación de impotencia con que la fuerza bruta se hace palpar".

${ }^{2196}$ Ibídem, p. 39. Dice el autor: "Pero todo esto nos hace ver que el horizonte del valor fundante, en este caso la seguridad, tiene, como limite donde comienza el desvalor, su propio $y$ diferente valor porque posibilita una nueva alternativa sobre la base de un valor fundado, $o$ adjetivo. La alternativa está entre el riesgo y su superación. En esta coyuntura va a surgir el orden como valor jurídico".
} 


\section{LOS EFECTOS DE LA PUBLICIDAD EN EL DOCUMENTO NOTARIAL}

b) En razón de la coexistencia en cuanto personas ${ }^{2197}$, el autor se refiere a una meditación sobre el poder y la $p a z^{2198}$, desde donde considera la hipótesis de la discordia ${ }^{2199}$.

c) En razón de la coexistencia en cuanto sociedad ${ }^{2200}$, el autor se refiere a la cooperación y a la solidaridad ${ }^{2201}$, lugar desde considera la hipótesis del aislamiento $^{2202}$.

La estructura del plexo axiológico jurídico desde los tres radios axiológicos demuestra, a partir del axioma ontológico de la libertad jurídica, el juego reciproco de la autonomía y la heteronimia que necesariamente se dan en la

\footnotetext{
${ }^{2197}$ Ídem, p. 45.

${ }^{2198}$ Ibídem, p. 47. Expresa el autor: "También sobre este horizonte del valor fundante, en este caso la

paz, cabe la posibilidad de una nueva alternativa sobre la base de un valor fundado o adjetivo. La alternativa esta ahora entre el conflicto y su superación. Y en esta coyuntura va a surgir el poder como valor

jurídico. Pues no se supera un conflicto esquivándolo, sino dominándolo. La escurridiza inestabilidad de la paz por ser valor de autonomía determina aqui también la idea de otorgarle firmeza para superar el conflicto coexistencial".

${ }^{2199}$ Ibídem. Dice el autor: "Aquí el prójimo no es una incógnita, es un enemigo; ahora se requiere que la autonomía del prójimo nos ataque para que emerja la discordia. La discordia surge, pues, de la coexistencia en cuanto reunión de personas cuando la autonomía del prójimo se despliega como agresión"

2200 Ídem, p. 52.

${ }^{2201}$ Ibídem, p. 54. Dice el autor: "También sobre este horizonte del valor fundante, en este caso la

solidaridad, cabe la posibilidad de una nueva alternativa sobre la base de un valor fundado o adjetivo. La alternativa esta ahora entre la fragmentación y su superación. $Y$ en esta coyuntura va a surgir la

cooperación como valor jurídico. Pues no se supera una fragmentación ni esquivándola ni dominándola; se la supera intercalando una materia adhesiva, esto es, soldándola".

${ }^{2202}$ Ibídem. Dice el autor: "En la hipótesis del aislamiento que estarnos considerando, la suerte

en común es, a todas luces, fragmentación de un todo; no es ni riesgo ni conflicto. Por debajo del horizonte de la solidaridad, convivir resulta, ya, disgregante porque la desimplicacion está en la propia suerte en común. Si la fragmentación coexistencial no es superada, ella es el substrato del aislamiento como sentido axiológico. Aqui el prójimo no es una incógnita ni un enemigo, sino un extraño; ahora se requiere que la autonomía del prójimo lo desacople para que emerja el aislamiento. El aislamiento surge, pues, de la coexistencia en cuanto suerte en común cuando la autonomía del prójimo se despliega corno alejamiento, aunque se trate de un pasivo alejamiento".
} 


\section{SEBASTIÁN JUSTO COSOLA}

coexistencia, mostrando el valor o el desvalor de una y otra ${ }^{2203}$. Por ello, desde la coexistencia en cuanto a la razón suficiente, Cossio se refiere a la justicia ${ }^{2204}$, que como valor superior, asume un papel rector, por cuanto es un valor del todo ${ }^{2205}$. Se aporta así al derecho una razón más de meditación: la que dirige a considerar que el problema de la justicia se proyecta y se despliega en un plexo de valores ${ }^{2206}$.

La seguridad en definitiva, encuentra su valor frente al orden, situación amparada por la justicia como valor rector, lo que viene a afirmar en el plexo que el jurista frente a la norma no tiene nunca una actitud neutra o neutral, sino que desarrolla su actividad invocando un determinado valor ${ }^{2207}$. Los valores establecidos en el plexo, cobran verdadero sentido en instituciones prácticas relevantes en el estudio de la presente tesis, como la posesión. De las teorías más trascendentes que se han brindado a partir de la interpretación de los fundamentos de esta figura esencial del derecho, los autores más reconocidos han planteado que la función social, la naturaleza jurídica y el verdadero fundamento de la posesión está asegurada por los valores de paz, orden, justicia, seguridad jurídica y respeto, imponiéndose quizás, en opinión de la doctrina generalizada, el valor seguridad como elemento rector por sobre los demás ${ }^{2208}$.

\footnotetext{
${ }^{2203}$ Ídem, p. 58.

${ }^{2204}$ Ibídem, p. 70.

${ }^{2205}$ Ibídem, p. 72. Dice el autor: "Quiere decir lo siguiente: ónticamente, en ese plexo la -dimensión ontológica de la justicia aparece como entendimiento comunitario; por eso la justicia juega como razón suficiente. Y ontológicamente la justicia, cuando se logra, da razón del Derecho por su situación óntica en el plexo de los valores jurídicos; por eso la justicia viene a ser la racionalización del Derecho".

${ }^{2206}$ Ibídem, p. 73.

${ }^{2207}$ Carlos COSSIO, La teoría egológica del derecho y el concepto jurídico de libertad, ob. cit., p. 409.

${ }^{2208}$ Cfr. Antonio HERNÁNDEZ GIL, La función social de la posesión, Real Academia de Jurisprudencia y Legislación (Ensayo de teorización sociológica-jurídica), Madrid, 1.967, p. 59 y ss.
} 
LOS EFECTOS DE LA PUBLICIDAD EN EL DOCUMENTO NOTARIAL

\subsubsection{La seguridad jurídica y el desarrollo del derecho privado.}

Enseña Mosset Iturraspe que la seguridad jurídica es un valor o un principio del derecho y del ordenamiento ${ }^{2209}$. Sin embargo, hay que diferenciar dos enfoques y visiones diferentes del análisis del valor en estudio:

a) La seguridad jurídica de la visión liberal ${ }^{2210}$, que pretende instaurar la inmutabilidad o permanencia de las normas, códigos y leyes; la inmutabilidad del contrato considerado como obra necesariamente justa de los hombres libres; el respeto absoluto a la idea de propiedad privada; una limitación al quehacer judicial, la presunción del "derecho conocido por todos" y una noción de anti-juridicidad que sólo existe frente a una clara y concreta violación de la legalidad $^{2211} ; \mathrm{y}$

b) La seguridad jurídica como función social, que prioriza la justicia con equidad, la buena fe, la solidaridad o la búsqueda del bien común ${ }^{2212}$, que trae una humanización del derecho transmitiendo que por sobre todas las cosas tiene que consolidarse el imperio de la justicia y la equidad real; una distinción entre la situación de cada persona, conforme a sus facultades y poderes; un juez preocupado por la verdad que puede incluso revisar los negocios jurídicos de las partes, y que puede además condenar al resarcimiento de todo daño injusto causado a una víctima inocente sin importar que exista o no exista norma que considere el supuesto de hecho y finalmente, un control del ejercicio regular de los derechos con sanción de nulidad a aquellos que sean excesivos ${ }^{2213}$.

\footnotetext{
${ }^{2209}$ Jorge MOSSET ITURRASPE, Derecho civil constitucional, ob. cit., p. 160.

${ }^{2210}$ Ibídem, p. 161.

${ }^{2211}$ Ibídem, p. 162.

${ }^{2212}$ Ibídem, p. 161.

${ }^{2213}$ Ibídem, p. 162. Mosset postula que la seguridad jurídica tiene que ver más precisamente con la aplicación del derecho por los jueces, pero sin embargo, expresa: "Una de las paradojas de los tiempos de inseguridad-sentida más que existente- es, por una parte, el afán de "judicializar" un gran número de cuestiones que podrían ventilarse fuera de la justicia institucionalizada y, por otra parte, desconfiar de esa justicia y calificarla de
} 


\section{SEBASTIÁN JUSTO COSOLA}

Al adscribir al sentido de la seguridad como función social, se le impone al jurista aplicar el valor en estudio sin descuido a las condiciones de justicia de cada caso en concreto en el que le toque decidir. Desde esta primera perspectiva, se advierte entonces que la seguridad tiene que ver con el derecho aplicable y también con la labor de los jueces; que es lo mismo que referir a que la misma se desprende tanto del ordenamiento como de las sentencias ${ }^{2214}$.

Atilio Alterini advierte que saber a qué atenerse concierne a la seguridad, al grado de certeza y al grado de estabilidad de una situación determinada, que como consecuencia permite la previsión de lo que pueda en el futuro acontecer $^{2215}$. Como valor, la seguridad jurídica confirma la certeza y la permanencia de las situaciones jurídicas, aquellas que están regladas por sistema el derecho, que ha sido regularmente establecido en términos iguales para todos ${ }^{2216}$. El hecho que la seguridad jurídica genere certidumbre, hace previsibles las relaciones con la prosperidad, el adelanto y el bienestar ${ }^{2217}$. Para el recordado civilista: "La seguridad y la justicia son valores jurídicos

corrupta”,

2214 No obstante, recordemos también que lo sostenido en realidad abarca no solo a la seguridad jurídica, sino también a los demás principios y paradigmas constitucionales. Según Goldschmidt y Bidart Campos, por ejemplo, es el ámbito del poder judicial el más rico para apreciar el fundamento de las normas y los principios constitucionales a través de su interpretación y aplicación. Cfr. Werner GOLDSCHMIDT, Introducción filosófica al derecho. La teoría trialista del mundo jurídico y sus horizontes, LexisNexis, Buenos Aires, 2.005, p. 464 y ss y Germán José BIDART CAMPOS, Filosofía del derecho constitucional, Ediar, Buenos Aires, 1.969, p. 111 y ss.

2215 Cfr. Atilio Aníbal ALTERINI, La inseguridad jurídica, Abeledo Perrot, Buenos Aires, 1.993, p. 16. Más adelante el autor afirmará lo siguiente: "Lo seguro genera confianza, puesto que confia quien tiene una esperanza firme, quien tiene fe (fides) '”.

2216 Ibídem, p. 19. El autor terminará por plantear: a) una seguridad por medio del derecho, dada cuando el ordenamiento jurídico garantiza el no avasallamiento por terceros de los derechos ajenos; b) una seguridad como certidumbre del derecho, que comienza por suponer la existencia de normas jurídicas ciertas que hacen emerger los derechos de las personas que serán respetados, y c) una seguridad como estabilidad del derecho, que es consecuencia de un sistema legislativo debidamente ordenado, previsor del cumplimiento de ciertos recaudos para la modificación de las normas jurídicas a través del órgano que las dicta, que debe tener competencia suficiente y sujeción a los procedimientos establecidos.

2217 Ibídem, p. 23. Recuerda el autor que las mencionadas alocuciones no nos resultan ajenas desde el preámbulo de la Constitución Nacional (afianzar la justicia, promover al bienestar general, proveer lo conducente a la prosperidad del país, al adelanto y bienestar). 
relacionados entre sí. Esta vinculación puede ser concebida en situación de conflicto -como alternativa entre seguridad y justicia-, o en un marco de armonía, esto es, asumiendo al derecho como un compromiso entre una y otra, para que simultáneamente hayan seguridad y justicia ${ }^{2218}$ ". Desde esta posición, la seguridad es un componente de la justicia ${ }^{2219}$, sumándose a la consideración de Radbruch que hace tiempo advertía que la pugna de la justicia con la seguridad jurídica es en definitiva, un conflicto de la justicia consigo misma ${ }^{2220}$.

Abel Cornejo argumenta que la noción elemental de la seguridad jurídica impone cierta confiabilidad en una justicia que reposa sobre lo razonable ${ }^{2221}$. El debate acerca del valor en referencia no puede únicamente suscribirse al ámbito de la decisión judicial, sino a "la responsabilidad de todos los que se ocupan de la cosa pública ${ }^{2222 " . ~ Y ~ p o s i c i o n a ~ d e ~ m a n e r a ~ i n m e j o r a b l e ~ q u e ~ u n o ~}$ de los conceptos más interesantes de la seguridad dirige a considerar la previsibilidad de ciertas decisiones jurídicas, como la de los magistrados, que hace ver cuál será su respuesta a través de un fallo frente al asunto que le ha sido sometido a su examen ${ }^{2223}$. Es previsibilidad, según el autor, requiere de una convicción popular generalizada de la actuación independiente del magistrado, que únicamente estará sujeta a la valoración de su conciencia ${ }^{2224}$. Tiene que existir fe, en el caso, en el poder judicial, y también fe en las otras instituciones republicanas ${ }^{2225}$; solo así, a través de la seguridad jurídica se puedan consolidar la libertad y el estado de derecho ${ }^{2226}$. El valor seguridad,

\footnotetext{
2218 Ídem, p. 46.

${ }^{2219}$ Ibídem.

${ }^{2220}$ Ibídem, p. 47 y ss. Para analizar las relaciones entre la seguridad jurídica, la justicia y el bien común es necesario comprender que la justicia exige que haya seguridad jurídica y que correlativamente, la seguridad jurídica reclama que haya justicia, muy a pesar que en ocasiones se dé prevalencia a la justicia o el bien común debilitándose así a la propia seguridad. Todo es cuestión de medida y de cada caso -explica Alterini- "Con demasiada seguridad jurídica puede quedar sofocada la aspiración de lograr, mediante el derecho, la justicia y la suma total del bienestar general. Con escasa seguridad jurídica se va hacia el caos".

${ }^{2221}$ Cfr. Abel CORNEJO, Seguridad jurídica, Virtudes, Salta, (no cita año de edición), p. 15.

${ }^{2222}$ Ibídem, p. 19.

${ }^{2223}$ Ibídem, p. 17.

${ }^{2224}$ Ibídem, p. 20.

${ }^{2225}$ Ibídem.

2226 Ídem, p. 23.
} 


\section{SEBASTIÁN JUSTO COSOLA}

desde la perspectiva judicial, destaca tanto a la cosa juzgada como al tiempo del proceso. La cosa juzgada deja de ser juzgada cuando se está en presencia de algún caso que involucre vejación o violencia sobre los derechos humanos fundamentales ${ }^{2227}$. Y el largo tiempo de duración del proceso opera como enemigo acérrimo de la seguridad jurídica ${ }^{2228}$ : En todos los casos, siempre es necesario acotar los plazos para alcanzar resultados óptimos, resultados justos.

Finalmente, Pablo Manili presenta un acabado enfoque de la seguridad jurídica, quizás el más moderno y completo hasta estos días ${ }^{2229}$. Según el autor, para considerar que en un país existe una grado medianamente aceptable de seguridad jurídica deben ocurrir, entre otros, los siguientes requisitos $^{2230}$ : a) plena vigencia del Estado de Derecho y de los derechos humanos fundamentales, b) adecuada protección del derecho de propiedad, de legalidad y del debido proceso desde la constitución y desde las leyes; c) un sistema tributario no confiscatorio, estable, que respete adecuadamente el derecho de defensa del contribuyente ${ }^{2231}$; d) una jurisprudencia estable, y e) un Poder Judicial independiente, serio, creíble y eficiente ${ }^{2232}$. La confianza, la estabilidad del sistema jurídico, la posibilidad de previsión o pronóstico de riesgos y la certidumbre son elementos típicos de la seguridad jurídica, y de ahí que el autor considere dentro de sus postulados esenciales la noción de garantía del Estado que brinda a las personas un sistema jurídico que las protege, conformado por leyes ciertas, escritas, estables, justas y razonables, como así también por el respeto por los derechos humanos fundamentales, ante cualquier violación que provenga del propio Estado o de los particulares ${ }^{2233}$.

\footnotetext{
${ }^{2227}$ Ibídem, p. 60.

${ }^{2228}$ Ibídem, p. 61.

${ }^{2229}$ Cfr. Pablo L. MANILI, La seguridad jurídica. Una deuda pendiente, Hammurabi, Buenos Aires, 2.011.

${ }^{2230}$ Ibídem, p. 45.

${ }^{2231}$ Ibídem, p. 46.

${ }^{2232}$ Ibídem.

${ }^{2233}$ Ibídem, p. 57.
} 
LOS EFECTOS DE LA PUBLICIDAD EN EL DOCUMENTO NOTARIAL

\subsubsection{La función de la seguridad jurídica en el ejercicio del derecho notarial.}

Hace un tiempo prolongado ya que José Mezquita de Cacho advertía que la función notarial era preventiva, y tendía a consolidar la máxima seguridad jurídica, ya que la misma podía dividirse en etapas ${ }^{2234}$. Así, el autor enseñaba que el notario se posiciona en una primera etapa, que denomina claramente como de acción extra-documental ${ }^{2235}$, comprensiva del consejo, la promoción del equilibrio contractual, control pre documental de realidad y legalidad, el control de identidad subjetiva comprensivo del control de capacidad, del interés legitimo y de la legitimación operativa; el control de la voluntad negocial real, de la realidad objetiva, de legalidad de contenido y de forma del acto. Dentro de esta etapa de acción extra-documental también se encuentran los aspectos anti-procesales de la función notarial ${ }^{2236}$, que son los referidos a la colaboración procesal, la acción arbitral y la acción de consolidación o promoción transaccional. Consolidada la primera, la segunda etapa de prevención esta exclusivamente dedicada al documento y sus efectos ${ }^{2237}$, entre las que se encuentran la forma documental, las funciones instrumentales generales y especiales, y los efectos sustantivos, referidos a la representación material, las funciones traditorias, las de legalidad formal, las publicadoras del documento, la de los efectos subrogatorios, la de los prelativos, los de inoponibilidad a terceros, los de eficacia, y muy especialmente hacia el final ${ }^{2238}$, los efectos perentorios, ejecutivos y probatorios.

Quizás estas advertencias hayan influido para que Vallet de Goytisolo, en su metodología del derecho haya pensado que la función jurídica notarial pertenezca al ámbito del cavere, un ámbito de cautela, precaución, protección y argumentación del derecho para que la seguridad jurídica no se vea de ninguna manera vulnerada por un acto posterior precisamente porque

${ }^{2234}$ Cfr. José L. MEZQUITA DEL CACHO y Jesús LOPEZ MEDEL, El notariado y los registros, Centro de Publicaciones del Ministerio de Justicia, Madrid, 1.986, p. 84.

${ }^{2235}$ Ibídem.

${ }^{2236}$ Ídem, p. 106.

${ }^{2237}$ Ídem, p. 109.

${ }^{2238}$ Ídem, p. 133 y sig. 


\section{SEBASTIÁN JUSTO COSOLA}

la actuación notarial, cumplidas las etapas descriptas, determina en el documento el derecho justo, la propia cosa justa que a cada cual corresponde de acuerdo a las determinadas potencias. Y sin duda me han iluminado para pensar que en el ejercicio del derecho notarial actual, los deberes éticos notariales aplicados tantas veces por mi referidos en el cuerpo de esta investigación (información, asesoramiento y consejo; imparcialidad e independencia $y$ deber de legalidad integrada comprensivo de reglas, normas y principios) sirven para consolidar la seguridad jurídica que se vuelve indudable desde la autorización misma del documento.

Sobre lo antedicho, pienso que la función que proyecta la seguridad en el documento notarial se advierte desde dos de los más relevantes fines que se encuentran descriptos en las obras de derecho notarial:

a) El primero, relativo a la previsibilidad, se relaciona con la fuerza vinculatoria del instrumento que contiene al acto que fuera autorizado, con todos los valores de la autenticidad externa analizados anteriormente. Esa fuerza determina la denominada circulabilidad del documento, y por ello una de las constantes preocupaciones notariales tiene que ver con la autorización de documentos que no ofrezcan en el futuro, ningún tipo de observación formal. De allí que cobren vigencia en estas líneas las argumentaciones anteriores acerca de la fuerza de la autenticidad extrínseca, con todos los signos exteriores que sirven de guía y de prueba para advertir que el documento portante de la voluntad es absolutamente legítimo y autosuficiente ${ }^{2239}$.

b) El segundo fin, relacionado con la conservación, viene a demostrar que la seguridad jurídica en el documento existe ad perpetuam, y muy independientemente que el mismo sea o no sea utilizado de manera regular y constante. Si bien la finalidad notarial en la

${ }^{2239}$ En este último sentido se expide amplia y notablemente la ponencia de la Delegación Argentina presentada en el tema II del XXVII Congreso Internacional del Notariado celebrado en Lima, Perú, en el transcurso del año 2013. V. A.A.V.V, Seguridad del tráfico inmobiliario: la necesidad de instrumentos de regulación, Fernando TRUEBA BUENFIL (Coord. Int.) Eduardo Gabriel CLUSELLAS (Coord. Nac.), RN 974, 2.013, p. 339-427. 
LOS EFECTOS DE LA PUBLICIDAD EN EL DOCUMENTO NOTARIAL

elaboración instrumental del derecho persigue la conformación de títulos circulables, la idea de conservación se relaciona no solo con la posibilidad de expedición de testimonios o copias frente al desgaste, al deterioro o la pérdida, sino también con una labor innata de resguardo ordenado de los documentos matrices para que sean accesibles a cualquier consulta que cuente con respaldo jurídico, inclusive aquellas que tengan como objetivo la realización de estudios históricos o políticos acreditados. Sobre esta finalidad de resguardo se aplican todos los principios relativos a la oponibilidad de los actos y de los instrumentos.

\subsubsection{Recapitulaciones esenciales.}

Veamos entonces algunas conclusiones interesantes, extraídas de los conceptos antes apuntados, que vuelven absolutamente trascendente el desarrollo de la seguridad jurídica como valor esencial del derecho y especialmente a lo que este estudio importa, del documento notarial:

1) La discusión acerca de la seguridad jurídica compete a todos aquellos que se ocupan de la cosa pública, y no se circunscribe únicamente a la decisión judicial:

2) La seguridad jurídica vigoriza la fe en las instituciones republicanas y no únicamente en el Poder Judicial;

3) El jurista frente a la norma nunca tiene una actitud neutral, sino que invoca a valores;

4) La seguridad jurídica se consolida entonces, a través del control de legalidad y de razonabilidad, como principio general del derecho;

5) Institución que consolida la libertad a partir de la exigencia de confiabilidad del ordenamiento jurídico; 
6) Acatamiento confiable del orden jurídico por la sociedad;

7) Respeto y protección al derecho de propiedad;

8) Seguridad jurídica como lo justo necesario de garantía social;

9) Ausencia de corrupción;

10) Proyección de los derechos de los consumidores y aseguramiento de las inversiones económicas;

11) Consideración de la razonabilidad y ponderación de los derechos fundamentales:

12) La seguridad jurídica como valor anexo de la justicia, que garantiza su desarrollo como razón de ser del derecho y de la justicia como fin último del mismo;

13) Seguridad jurídica que garantiza que las decisiones jurídicas justas no serán discutidas ni perturbadas;

14) Seguridad jurídica como tutela del orden jurídico que protege su certeza y que ayuda a desenvolver la capacidad para hacer previsibles otros valores;

15) Seguridad jurídica que confirma la irretroactividad de las leyes;

16) Seguridad jurídica y contribución a un derecho estable;

17) Seguridad jurídica y apoyo a la creencia de una justicia razonable;

18) Seguridad jurídica reflejada en el asesoramiento jurídico para instrumentar negocios razonables y justos;

19) Seguridad jurídica y previsibilidad: certeza y saber a qué atenerse, y

20) Seguridad jurídica innata en la conciencia de todo hombre que aspira al progreso y al bienestar. 
LOS EFECTOS DE LA PUBLICIDAD EN EL DOCUMENTO NOTARIAL

\subsection{La seguridad jurídica y el documento notarial.}

Según vengo refiriendo, el valor en estudio es considerado como un estandarte primario de la función notarial ${ }^{2240}$. Desde la función notarial, la seguridad se estudia como una consecuencia mediata e inmediata del documento notarial elaborado a conciencia, con ley, uso y razón ${ }^{2241}$. En palabras de Isidro Muñoz Rivera: "No hay otra seguridad jurídica en el derecho notarial, que la derivada del instrumento público generada por el notario $^{2242 ",}$

Este razonamiento empero, no deja de reconocer la circunstancia fundamental que consolida al documento notarial: la puesta en práctica de los deberes éticos notariales aplicados anteriores a la confirmación documental, ya que son ellos lo que permiten una adecuada estructuración del documento, que hecho de acuerdo a esas condiciones, desprenderá sin dudas la máxima consolidación posible del principio de la seguridad jurídica en su faz preventiva ${ }^{2243}$. Desde allí que el notariado advierta una cierta preocupación por plantear antes de la concreción de la labor documental, las posibles contingencias y desafíos que esto traerá aparejado, acciones que

\footnotetext{
${ }^{2240}$ En cada conclusión de jornadas, encuentros, congresos o mesas destinadas a estudiar el derecho notarial, la mención a la seguridad jurídica resulta tan habitual como oportuna. A modo de ejemplo, recordemos que al concluir las reflexiones acerca de la misión y función del notariado en el tercer milenio, la XXXII Jornada Notarial Bonaerense celebrada en el año 1.999, declaró como principio del ejercicio notarial: la seguridad jurídica es un medio que posibilita alcanzar la paz social. V. Norma Elena CIURO DE CASTELLO y Laura GARATE (Comp.), Jornada Notarial Bonaerense..., ob. cit., p. 296.

2241 En nuestro país, un ensayo dedicado a considerar la temática desde una visión eminentemente notarial del derecho, sostiene que la idea de la seguridad jurídica en el derecho privado es el producto de la valoración de importancia que han hecho los particulares en torno a sus relaciones jurídicas, y que a través de la intervención notarial la misma noción se acrecienta, porque en definitiva la intervención notarial supone un eficaz instrumento para consolidar la seguridad jurídica, circunstancia que se logra destacando muchas de sus facetas, como la del control de legalidad. Marina C. ZUVILIVIA, El notario y la seguridad jurídica, ob. cit., pág. 133 y ss.

${ }^{2242}$ Cfr. Isidro MUÑOZ RIVERA, La función del derecho notarial, Escriva-Otoño 2014, México, 2.014, p. 75.

${ }^{2243}$ Sebastián Justo COSOLA, Fundamentos de derecho notarial, ob. cit., p. 235 y ss.
} 


\section{SEBASTIÁN JUSTO COSOLA}

otorgan previsibilidad frente a los temores, y planteo de las defensas frente a las posibles vicisitudes posteriores.

En algún tiempo y lugar, Vallet de Goytisolo trazó la pauta de lo que pretendo, alcance a comprenderse naturalmente en este capítulo, desprendida lógicamente de la singularidad propia y característica de la función notarial: "El notario tiene frente a los demás juristas una posición ventajosa para apreciar esa intersección de las normas y los hechos; es decir, la vida jurídica (...). El catedrático tiene una visión del derecho preponderantemente teórica; el juez y el abogado, una visión patológica, ven al derecho cuando sufre alguna enfermedad, cuando no funciona normalmente. El notario lo ve desenvolverse y desarrollarse en su normalidad; tiene de él una visión puramente vital ${ }^{2244 " .}$

A lo largo y a lo ancho de este capítulo me he esmerado por destacar ciertos planteos y argumentos coincidentes entre los autores acerca de las bondades de la seguridad jurídica. Uno de esos temas trascendentes nos ponía al tanto de su reflejo instrumental en y desde la sentencia judicial. Es preciso entonces, realizar un estudio comparativo entre la sentencia judicial y la escritura pública, para lograr una visualización de ambas instituciones, esencialmente complejas, que proyectan seguridad jurídica, sobre derechos ya decididos, en procura de alcanzar la máxima efectividad.

\subsubsection{En torno a las sentencias judiciales.}

En una distinguida obra, Alfredo Rocco considera que en las relaciones ordinarias de la vida, la satisfacción de los intereses protegidos por la norma jurídica en general, es cumplida de manera espontánea por los propios interesados ${ }^{2245}$. Sin embargo en determinadas circunstancias, las personas desmerecen a las normas en razón de tener motivos que se resumen en dos clases:

\footnotetext{
${ }^{2244}$ Juan Berchmans VALLET DE GOYTISOLO, La misión del notario, ob. cit., p. 423.

${ }^{2245}$ Cfr. Alfredo ROCCO, La sentencia civil, El Foro, Buenos Aires, 2.003, p. 16.
} 
LOS EFECTOS DE LA PUBLICIDAD EN EL DOCUMENTO NOTARIAL

a) Incierta tutela concedida por el derecho a algunos intereses concretos $^{2246}$

b) Incumplimiento de mala voluntad de quien tiene que acatar la norma que tutela el interés (caso menos frecuente) ${ }^{2247}$.

Es por esta razón que se justifica la actividad jurisdiccional, cuyo objeto es esencialmente la contribución a la realización de los intereses previstos por el derecho objetivo pero cuando por alguna de esas circunstancias la tutela resulta ser ineficaz, o lo que es lo mismo, cuando las normas generales de conducta encuentran por algún motivo ciertos obstáculos para su efectiva actuación $^{2248}$. En este esquema, la función jurisdiccional presenta tres funciones distintas:

a) Función de acreditar el derecho del caso concreto;

b) Función de realización forzosa del interés tutelado por la norma, y

c) Función de conservación del estado existente en espera del acreditamiento y de la realización ${ }^{2249}$.

La sentencia es un acto de declaración del juez, que resume la función jurisdiccional y tiende a definir una litis que ocurre en un determinado proceso con el fin de hacer efectivo el mantenimiento del orden jurídico ${ }^{2250}$. La actividad que las partes y el juez desarrollan en el proceso, persigue el fin común de definición de la controversia, a través de la declaración judicial de existencia o inexistencia de una voluntad legislativa que garantice la pretensión tanto del actor como del demandado ${ }^{2251}$. Sobre esto, se acuerda que la sentencia aplica la ley preexistente ${ }^{2252}$, aunque se suele disentir en

2246 Ibídem, p. 17.

${ }^{2247}$ Ibídem, p. 19.

${ }^{2248}$ Ibídem, p. 22.

2249 Ídem, p. 56. Desde aquí puede decirse que el procedimiento civil presenta, en relación a las tres funciones delimitadas, tres procedimientos diferentes: a) procedimiento de prueba; $b$ ) procedimiento de ejecución forzosa, y c) procedimiento de aseguramiento y conservación.

2250 Cfr. Ana María CAPOLUPO DE DURAÑONA y VEDIA, La sentencia. Su fundamentación. Recursos (TD), Biblioteca de la Facultad de Derecho de la Universidad de Buenos Aires, $\mathrm{n}^{\circ}$ topográfico 253.383, p. 7.

${ }^{2251}$ Ibídem.

${ }^{2252}$ Ibídem, p. 10. 


\section{SEBASTIÁN JUSTO COSOLA}

afirmar que la misma implica ya sea una mera declaración del derecho anteriormente establecido, o una nueva creación ${ }^{2253}$ (de aquí que se admita en doctrina el tratamiento de la sentencia como hecho, como derecho y como documento $^{2254}$ ). Para muchos autores, la sentencia se conforma con un acto mental del juez, que contiene un juicio lógico, y en apreciación de algunos otros autores, contiene además un acto de voluntad del juez ${ }^{2255}$.

Para el mismísimo Rocco, la sentencia es además "el acto por el cual el Estado, por medio del órgano de la jurisdicción destinado para ello (juez), aplicando la norma al caso concreto, indica aquella norma jurídica que el derecho concede a un determinado interés ${ }^{2256}$ ". A través de la sentencia, el juez cumple con distintos objetivos, entre los que se destacan los referidos a la culminación del deber de pronunciamiento, al ejercicio del enjuiciamiento representando al poder de la jurisdicción, la elaboración de un fallo con consecuencias de derecho o la creación de normas jurídicas ${ }^{2257}$. En este sentido, la misma viene a ser un tipo de decisión judicial que entre otros fines, persigue resolver las diferencias con una manifestación definitiva ${ }^{2258}$, y esa es la razón por la cual, al momento de analizar su naturaleza jurídica, se suele considerar a la elaboración de la sentencia como "un proceso lógico que consiste en confrontar los hechos expuestos en la demanda con los que el derecho establece para su aplicación $n^{2259}$ ".

${ }^{2253}$ Ibídem.

${ }^{2254}$ Ibídem, p. 11 y ss. Como hecho, la sentencia se asimila a un fenómeno resultante de la actividad del hombre o de la naturaleza (siendo la actividad del juez puramente externa que prescinde de su contenido y de la voluntad jurídica), mientras que como acto pasa a considerarse como una apreciación intelectual, un proceso crítico del cual forma parte la lógica y también la voluntad, y por ello mismo como acto, la misma se presenta como una operación de carácter crítico de los hechos, en la búsqueda de la verdad, lugar en donde el cual se perfila el juez como un verdadero historiador que compulsa documentos, escucha testigos, aprecia el parecer de los especialistas y saca conclusiones de los hechos ocurridos. Finalmente, en su faz de documento, la sentencia es un instrumento público que se constituye como elemento material e indispensable para reflejar sus efectos y su existencia hacia el mundo jurídico, que refleja la expresión del juicio del juez acerca de una cuestión determinada que ha sido sometida a su decisión.

${ }^{2255}$ Ibídem, p. 59.

${ }^{2256}$ Alfredo ROCCO, La sentencia civil, ob. cit., p. 57.

${ }^{2257}$ Cfr. Osvaldo Alfredo GOZAÍNI, Teoría general del derecho procesal, Ediar, Buenos Aires, 1.996, p. 239.

${ }^{2258}$ Ibídem, p. 240.

${ }^{2259}$ Ibídem. 
LOS EFECTOS DE LA PUBLICIDAD EN EL DOCUMENTO NOTARIAL

La sentencia es sólo un tipo de resolución judicial -aunque la más importante-, y es el acto del órgano jurisdiccional en cuya virtud se decide actuar o denegar la actuación de la pretensión o petición (extra) contenciosa que fuera objeto del proceso ${ }^{2260}$. En resumen, las sentencias judiciales son el fruto de elaboración de un juez que piensa, estudia, razona y aplica el derecho que corresponde al caso concreto de acuerdo a su noble saber y entender (hoy, razonabilidad judicial). Lógicamente, le resultará imposible al juez apartarse de las leyes que ordenan un determinado comportamiento, pero a través de la sana crítica racional podrá argumentar el derecho de la mejor manera que le parezca posible, convencido que la solución es justa y apropiada para el caso en cuestión. A través de la sentencia entonces, el juez decide y dice el derecho, sobre casos jurídicos fáciles, y también sobre casos jurídicos difíciles, que como recuerda Manuel Atienza, pueden serlo por diversas razones que pueden ocurrir en pluralidad o en singularidad, ya sea porque no existe -o no está claro que exista- norma jurídica válida que sea aplicable al caso, o porque existe la norma pero con una interpretación problemática; también por la dificultad de adecuar la producción de los hechos a lo prescripto por la norma, y finalmente por el reconocimiento de la producción de los hechos pero no así de su calificación jurídica ${ }^{2261}$.

14.5.2. Las “respuestas" a las sentencias. La teoría de la impugnación procesal y los dictámenes consultivos.

Los ordenamientos jurídicos proveen al hombre de las herramientas necesarias para que quien ha sido desfavorecido tanto por una sentencia como por un determinado laudo, pueda ejercer el derecho de recurrir hacia otras instancias en búsqueda de otra respuesta diferente que satisfaga de mejor manera sus (aparentemente) convincentes pretensiones. De esta forma,

${ }^{2260}$ Cfr. Adolfo E. C. BORTHWICK, Nociones fundamentales del proceso (O una selección -de elite- de autores de derecho procesal abordando los temas trascendentes del proceso), Mave, Corrientes, 2.001, p. 373.

${ }^{2261}$ Cfr. Manuel ATIENZA, Tras la justicia, Ariel, Barcelona, 1.997, p. 149. 


\section{SEBASTIÁN JUSTO COSOLA}

la teoría de la impugnación procesal es la que decide la firmeza de la sentencia, a través de la aplicación o no concreción de las vías impugnativas, y dentro de ellas, de los recursos procesales ${ }^{2262}$. De ahí que existan los recursos y sus diferentes clases y modos de ejercicio, hasta el límite que el orden jurídico establezca en aras de la necesidad de la cosa juzgada.

Sin embargo, hay un tema que merece particular atención. El hecho de la cosa juzgada cobra vital importancia, y permite que el principio de seguridad jurídica sea el que triunfe, siempre y cuando no se solicite un pedido de opinión -de acuerdo a la naturaleza de la causa y si es que estuviese previsto-, frente a la inminente fundamentación de la decisión judicial instrumentada, de eminente carácter consultivo. La mayor parte de los países de raigambre romanista como el nuestro adscribe a estas posibilidades, sobre todo en ciertos temas trascendentes. $Y$ es bueno tener en consideración que en esa especie de vía también recursiva, no únicamente se persigue el dictado de una sentencia, sino lo que es aun más trascendente; la emisión de una fundada opinión, que se justifica en la experticia, en los sabios consejos prudenciales, y en la comprensión del derecho en su desarrollo multicultural. Desde mi perspectiva, las opiniones de los Consejos Consultivos, en infinidad de ocasiones, suelen ser tan relevantes como las sentencias que deciden el derecho, porque precisamente son las que dan las pautas para decidir ese derecho en pugna ${ }^{2263}$.

${ }^{2262}$ Adolfo E. C. BORTHWICK, Nociones fundamentales del proceso..., ob. cit., p. 313.

${ }^{2263}$ La decisión en la causa "Miguel Ángel Ekmekdjian c/ Gerardo Sofovich y otros" es quizás la más paradigmática para traer aquí como ejemplo En la misma se impone en la Corte Nacional una decisión judicial fundamentada en derecho, pero especialmente en una fuente de indudable valor como una opinión consultiva emitida por un organismo internacional tan trascendente como la Comisión Interamericana de Derechos Humanos en el seno del Pacto de San José de Costa Rica (CSJN. Fallos 315:1492). Recordemos que en ese caso trascendental, se estaba en presencia de la supuesta imposibilidad del ejercicio de derecho a réplica porque el mismo no había sido reglamentado por el Congreso Nacional aunque si estaba reconocido en el art. 14 del Pacto de San José de Costa Rica (V. Humberto QUIROGA LAVIÉ, Lecciones de derecho constitucional, ob. cit., p. 120). De los apartados 21 y 22 del fallo de la Corte Suprema de Justicia de la Nación puede extraerse lo siguiente: "Ante la consulta hecha a dicho tribunal (se refiere a la Corte Interamericana de Derechos Humanos) acerca de si cuando el art. 14.1 dispone que el derecho de rectificación o respuesta se ejercerá "en las condiciones que establezca la ley", quiere decir que dicho derecho solo es exigible una vez que se emita una ley formal que establezca las condiciones en que el mismo puede ser concretamente ejercido, contestó rechazando este argumento y afirmando que alli se consagra un derecho de rectificación o respuesta a favor de toda persona, ya que "el sistema 


\section{LOS EFECTOS DE LA PUBLICIDAD EN EL DOCUMENTO NOTARIAL}

De todo lo antedicho entonces puede concluirse lo siguiente:

a) El primer principio general en materia de derecho procesal es que la sentencia, para resguardar el valor justicia, siempre va a estar sujeta a revisión, hasta que el derecho establezca, para cada caso en particular y también en protección a la seguridad jurídica, que existe la cosa juzgada ${ }^{2264}$.

b) Muy a pesar de ello, la sentencia que aun posea el beneficio de la cosa juzgada, puede inclusive ser ampliamente debatida a partir de la emisión de una opinión de un consejo consultivo (no habría motivos suficientes para negar una opinión consultiva aun luego de dictada la sentencia), y aunque la opinión por esencia y naturaleza no sea vinculante, podrá generar sin duda doctrina a su favor o en su contra, y lo que es más importante: la posibilidad que otra jurisprudencia

mismo de la Convención está dirigido a reconocer derechos y libertades a las personas y no a facultar a los Estados para hacerlo" (Opinión consultiva...) Llegó a la opinión unánime en el sentido de que el art. 14.1 "reconoce un derecho de rectificación o respuesta internacionalmente exigible" y que la frase "en las condiciones que establece la ley" se refiere a cuestiones tales como "si los afectados tienen derecho a responder en espacio igual o mayor, cuando debe publicarse la respuesta una vez recibida, en que lapso puede ejercerse el derecho, que terminología es admisible, etc (...) Que en dicha opinión consultiva la Corte Interamericana sostuvo que "todo Estado parte que no haya ya garantizado el libre y pleno ejercicio del derecho de rectificación o respuesta, está en la obligación de lograr ese resultado, sea por medio de legislación o cualesquiera otras medida que fueren necesarias según su ordenamiento jurídico interno para cumplir ese fin" (CSJN. Fallos 315: 1514). V. especialmente CIDDHH. Opinión Consultiva OC-7/86 del 29 de Agosto de 1.986. Exigibilidad del derecho de Rectificación o respuesta (Arts. 14.1, 1.1 y 2 de la Convención Americana sobre DDHH).

${ }^{2264}$ Sin embargo, una visión singular de la cosa juzgada es la ofrecida por el genial Ricardo Guibourg en el marco de la Jornada de Debate Interdisciplinaria entre filósofos y constitucionalistas celebrada el 25 de abril del año 2017 en la Facultad de Derecho de La Universidad de Buenos Aires. En esa oportunidad, el iusfilósofo analítico se refería a la cosa juzgada como una institución jurídica curiosa. Es que en efecto, al establecer que una vez agotados los recursos procesales para el caso concreto el mismo queda resuelto sin poder seguir debatiéndose judicialmente, lo que la institución hace es conceder una especie de sacralidad legal a una decisión en ciertas y determinadas circunstancias formales, que afirma una decisión que inclusive, puede ser contraria al propio sistema judicial que la bendice como cosa juzgada. Es así que la cosa juzgada se vuelve necesaria para poner fin a las controversias dando a las partes seguridad jurídica, aunque aun pueda amparar una solución injusta. Cfr. Ricardo GUIBOURG, Filosofia para el derecho-Jornada de debate interdisciplinaria entre iusfilósofos y constitucionalistas, $\mathrm{BDaD}$ año $16 \mathrm{n}^{\circ} 284$, Buenos Aires, 18 de Mayo de 2.017, p. 9. 


\section{SEBASTIÁN JUSTO COSOLA}

adopte esos lineamientos y cambie definitivamente el rumbo de lo que hasta ese momento se había consolidado judicialmente.

Esta es una tesis doctoral que intenta justificar tanto jurídica como filosóficamente, la importancia y trascendencia del documento notarial. Con lo antes expuesto no se trata entonces de desconocer las bondades y virtudes del sistema judicial, sino de explicar, en modo eminentemente comparativo, la fuerza del documento notarial y su comparación con la emergente de la sentencia, ambos instrumentos con publicidad cartular intrínseca y extrínseca (fuerza + potencia) que deciden el derecho. Quizás por ello autores como Carlos Gattari hayan desarrollado estudios formidables que intentan comparar las actividades del juez y del escribano en relación con la certeza y con la seguridad jurídica que emergen de sus respectivas actuaciones, desde la propia aplicación del proloquio iura novit curia, que como principio y según el autor, es una atribución que la naturaleza atribuye a ambos juristas por igual ${ }^{2265}$.

\subsubsection{En torno a las escrituras públicas.}

La escritura pública es el documento notarial principal, protocolar y con valor de instrumento público ${ }^{2266}$. El Código Civil y Comercial de La Nación brinda una definición de la escritura pública, donde se destacan como elementos esenciales de las mismas la matricidad, el protocolo, el autor y el contenido $^{2267}$. El documento notarial por excelencia es la escritura

${ }^{2265}$ Cfr. Carlos Nicolás GATTARI, El juez, el notario y la ley extranjera, Ediciones Librería Jurídica La Plata, Buenos Aires, 1.974, p. 15.

${ }^{2266}$ Natalio Pedro ETCHEGARAY y Vanina Leila CAPURRO, Derecho notarial aplicado, ob. cit., p. 275.

${ }^{2267}$ Cristina Noemí ARMELLA, Escrituras públicas. Código Civil y Comercial de la Nación. Comentado..., ob. cit., p. 760. 


\section{LOS EFECTOS DE LA PUBLICIDAD EN EL DOCUMENTO NOTARIAL}

pública $^{2268}$, y desde mi posición, la escritura pública es el documento notarial auténtico por antonomasia ${ }^{2269}$.

Los autores en general acuerdan en darle a la escritura el valor trascendente del que goza en la actualidad; sin embargo, dentro del estudio del derecho notarial sustantivo, una de las cuestiones que realzan la atención del jurista es la que refiere a las innumerables y diferentes denominaciones que se escogen para designar lo mismo. Al igual que en el desarrollo del documento notarial, la cuestión conceptual tiene aquí una relevancia especial. Algunos autores se refieren a las escrituras públicas y se encargan de definir y precisar el alcance de sus conceptos ${ }^{2270}$. Otros en cambio, advierten que la escritura pública es un instrumento público, o al menos, su especie más importante ${ }^{2271}$, y a esto se agrega que su contenido principal en el acto o negocio jurídico allí contenido que es autorizado por un notario en ejercicio de sus funciones, ya que la escritura, como conocimiento para el derecho, constituye los hechos y los dichos de la audiencia notarial ${ }^{2272}$. En otra sintonía, autores clásicos en cambio se refieren al instrumento público notarial, y dentro de su seno, al análisis de la escritura pública ${ }^{2273}$. Dentro de esta última consideración, hay casos absolutamente particulares, que diferencian específicamente el acto notarial, el instrumento público y el negocio jurídico en forma elogiosa y contundente ${ }^{2274}$. Finalmente, debe considerarse que la mayoría de los autores insisten en referirse al documento notarial y a su especie principal, la escritura pública ${ }^{2275}$.

\footnotetext{
${ }^{2268}$ Carlos Marcelo D'ALESSIO, Escrituras públicas. Código Civil y Comercial de la Nación Comentado, ob. cit., p. 159.

${ }^{2269}$ Tan importante y medular es para el notariado la referencia a la escritura pública, que autores como Rubén Lamber han optado oportunamente, por denominar la escritura pública a su obra quizás más trascendente, comprensiva a del derecho notarial y registral, civil, comercial y patrimonial de incidencia en el ejercicio de la función fedante. V. Rubén Augusto LAMBER, La escritura pública, IV Tomos, ob. cit.

${ }^{2270}$ Por ejemplo, José Adrian Negri, Argentino I. Neri y José María Mustapich.

${ }^{2271}$ Es el caso de María Teresita Acquarone, Adriana Nélida Abella y José María R. Orelle.

${ }^{2272}$ Carlos Nicolás GATTARI, Manual de derecho notarial, ob. cit., p. 53.

${ }^{2273}$ Es el evidente caso de Carlos Emérito González, de quien fuera uno de sus discípulos, Rubén Augusto Lamber y del procesalista uruguayo Eduardo Couture.

${ }^{2274}$ Cfr. José Carlos CARMINIO CASTAGNO, Teoría General del Acto Notarial y otros estudios, $\mathrm{t}^{\circ} \mathrm{I}$, Ediciones del Autor, Paraná, 2.006, p. 31 y ss.

${ }^{2275}$ Puede citarse aquí a Cristina Noemí Armella, Eduardo Bautista Pondé, Carlos A. Pelosi, Francisco Martínez Segovia, Mario Antonio Zinny y Carlos Marcelo D'Alessio entre tantos
} 


\section{SEBASTIÁN JUSTO COSOLA}

De manera que como primer reflexión puede argumentarse que el artículo intenta por primera vez instaurar una suerte de definición al describir que la escritura es el instrumento matriz extendido en el protocolo. Con esto se destaca un aspecto esencial de la misma de acuerdo a la doctrina mayoritaria, aunque a la luz de los tiempos actuales, la misma resulta inconclusa por ser diminuta. De los propios fundamentos de la comisión redactora del cuerpo normativo unificado vigente, se desprende que la verdadera función notarial no es simplemente la de dar fe, sino la de proteger y resguardar los actos trascendentes que la ciudadanía ha confiado a la institución ${ }^{2276}$. En otras palabras, se admite que una de las notas características del documento notarial actual no es la que destaca únicamente su confección, sino la elaboración notarial del derecho previa a la instrumentación, comprendida entre otros quehaceres, por los deberes éticos notariales aplicados que el escribano capta y aplica por evidencia durante el transcurso de la creación notarial del derecho. Toda esta teoría inclusive se aplica a las actas notariales, que el ordenamiento unificado actual trata y desarrolla en una especie de novedad legislativa ${ }^{2277}$. Desde aquí que el tratamiento de la fe

otros. La reconocida enciclopedia jurídica nacional Omeba no contiene el tratamiento de la voz escritura pública; en el tomo correspondiente a esa voz, se remite al referirse a la escritura a la voz instrumento público, que tan bien desarrolla Luis Boffi Boggero asimilando y ensamblando perfecta y armoniosamente sus efectos al de las escrituras públicas. Cfr. Luis María BOFFI BOGGERO, Instrumento público, EJO, Driskill S.A, Buenos Aires, 1.996, págs.211-237.

${ }^{2276}$ Todo esto se encuentra descripto de manera clara y contundente en los fundamentos que la comisión redactora elevara oportunamente al Poder Ejecutivo del entonces anteproyecto de reforma, al referirse al conjunto de solemnidades de los documentos matrices: "Todo ello demuestra que la esencia de la función notarial no es la de conferir fe pública como habitualmente se afirma, sino que su esencia es la de brindar protección a los ciudadanos en los actos y negocios de máxima trascendencia, legislativamente seleccionados, a través de un conjunto de operaciones jurídicas que son las que fundamentan su eficacia erga omnes". Ricardo Luis LORENZETTI, Elena HIGHTON de NOLASCO y Aída KEMELMAJER de CARLUCCI, Código Civil y Comercial de la Nación..., ob. cit., p. 543.

${ }^{2277}$ Como novedad en materia de técnica legislativa, se incorporan las actas notariales al cuerpo del Código Civil y Comercial de La Nación, sin dejar de recordar que en el Código de Vélez estaban consideradas en la enumeración meramente enunciativa que se advertía en la parte general de los instrumentos públicos. Se conceptualiza a las actas dentro de la teoría del instrumento público, autorizado por notario competente, a requerimiento de una persona, con interés legítimo y que tiene por objeto constatar la realidad o verdad de un hecho que el notario ve, oye o percibe por sus sentidos. No obstante lo antedicho, ya se venía enseñando que las actas no tienen un contenido negocial, sino esencialmente probatorio, por lo que en ellas se trata de documentar acciones o hechos. Otros autores advierten en cambio que las 
notarial como valor -en doble perspectiva- y la imparcialidad notarial como virtud cobre trascendencia en el presente estudio.

En suma, el notario tiene una manera de decir el derecho a partir de la voluntad libre e igualitaria de las partes que requieren de sus servicios, y esa es la conformación y estructuración de la escritura pública, contenedora de hechos o de actos jurídicos. A partir de la autorización, la misma se esmerará por consolidar el derecho en la paz.

\subsubsection{Las respuestas a las escrituras públicas. Teoría general de} las ineficacias y la impugnación de la autenticidad.

Las doctrinas tradicionales de nuestro país han entendido a la nulidad como una sanción de carácter legal que priva de sus efectos propios a los actos jurídicos en virtud de una causa existente en el momento de la celebración $^{2278}$. Dentro del esquema normativo, puede ocurrir un hecho perfecto, que es el correspondiente con lo que el mismo esquema dispone -conformación del hecho jurídico-, o también puede existir un hecho imperfecto cuando hay o existe ausencia de cualquiera de sus elementos

actas son instrumentos públicos que tienen por misión la autenticación, comprobación y fijación de hechos. La doctrina extranjera parece coincidir con estas apreciaciones, al mismo momento de reconocer que lo que existe en ellas es un mero hecho, y por esa razón, misión del notario es únicamente ver y oír, sin penetrar en el fondo del asunto, limitando su actuación únicamente a la narración de los hechos, no manipulando ni alterando los sucesos tal cual acontecen en su presencia. El Código en referencia describe también los requisitos que tiene que cumplir el escribano o notario al momento de realizarlas. El principio general reenvía a las actas, como primera medida, a los requisitos de las escrituras públicas. Sin embargo, es bueno tener en cuenta que la conformación estructural de las actas es totalmente diferente a la de la escritura negocial. Mientras que en estas las estipulaciones o declaraciones encuentran reposo en el orden previsto que sigue los lineamientos de la fe pública, las actas lo que existe son dos partes bien diferenciadas: a) el acto del requerimiento y b) el acto del diligenciamiento.

${ }^{2278}$ Jorge Joaquín LLAMBÍAS, Tratado de Derecho Civil..., t t II, ob. cit., p. 565; Julio César RIVERA, Instituciones de Derecho Civil..., t ${ }^{\circ}$ II, ob. cit., p. 694. Desde el notariado, José María MUSTAPICH, Tratado teórico y práctico de derecho notarial, $\mathrm{t}^{\circ} \mathrm{I}$, ob. cit., p. 441 y ss; Sonia LUKASZEWICZ, Nulidad e inexistencia de los actos jurídicos, en Cristina Noemí ARMELLA (Dir.), Tratado de Derecho Notarial, Registral e Inmobiliario, t ${ }^{\circ}$ III, Ad Hoc, Buenos Aires, 1.998, p. 13 y ss. 


\section{SEBASTIÁN JUSTO COSOLA}

componentes $^{2279}$. De ahí entonces que el concepto de validez sea la contracara del de invalidez, o mejor dicho, que la invalidez se defina a partir de la validez ${ }^{2280}$.

Al considerar las anormalidades del acto jurídico, la doctrina comienza a tratar los supuestos dentro de lo que se considera, una teoría general de las ineficacias. Al hablar de ineficacias entonces, se consideran los efectos del acto en su ser, en su sustancia; la estructura del mismo no satisface todos los requisitos que impone la ley para efectivamente ser un acto jurídico ${ }^{2281}$. En definitiva, puede decirse que dentro de la teoría general de las ineficacias se encuentran instituciones de los más variados orígenes, dentro de los cuales es posible distinguir aquellas causales que provienen de vicios existentes en el momento mismo de la formación del acto ${ }^{2282}$, siendo entonces la nulidad una sanción de invalidez prescripta por la ley que sufre el acto jurídico por adolecer de un defecto constitutivo ${ }^{2283}$.

Sobre esto, debe reconocerse que desde hace algún tiempo relevante, esta afirmación viene siendo puesta en duda por autorizada doctrina, que contrariamente ha considerado la posibilidad de que el antiguo Código de Vélez también haya receptado, a partir del análisis de su articulado y de las reglas de interpretación, la teoría de las nulidades implícitas o virtuales, es decir, aquellas que carecen de previsión legal expresa pero que pueden surgir para las partes en razón de que resulte del negocio que celebran la falta de algún requisito esencial previsto, o del choque o conflicto entre el contenido negocial acordado por las mismas con alguna disposición de derecho de carácter coactivo o imperativo ${ }^{2284}$. Desde aquí entonces que otras

${ }^{2279}$ Cfr. Ernesto E. NIETO BLANC, Nulidad en los actos jurídicos, Ad Hoc, Buenos Aires, 2.005 , p. 28

${ }^{2280}$ Ibídem, p. 35.

${ }^{2281}$ Cfr. Jorge Horacio ALTERINI, Elsa Beatriz ANGELANI, Pablo María CORNA y Gabriela Alejandra VAZQUEZ, Hacia una teoría general de las ineficacias, ED 172-942, 1.997 , p. 953.

${ }^{2282}$ Cfr. María Emilia LLOVERAS de RESK, Tratado teórico-práctico de las nulidades, Depalma, Buenos Aires, 1.991, p. 3.

${ }^{2283}$ Ibídem, p. 28. De ahí que la autora comparta que el propio concepto de nulidad encierra la idea de que la misma es una sanción, únicamente establecida por la ley, que ocurre frente a la existencia de un vicio en el acto consistente en la falta o carencia de algún requisito o cualidad que debía estar en el presente de acuerdo a lo ordenado en la propia ley.

${ }^{2284}$ Cfr. Marcelo LÓPEZ MESA, Ineficacia y nulidad de los actos jurídicos. Procesales y administrativos, BdeF, Buenos Aires, 2.015, p. 7. 


\section{LOS EFECTOS DE LA PUBLICIDAD EN EL DOCUMENTO NOTARIAL}

doctrinas afirmen que no es absolutamente indispensable que la sanción de nulidad esté expresada de manera formal en la respectiva norma ${ }^{2285}$.

Hechas las aclaraciones referidas a la parte general del tratamiento de la teoría de las ineficacias, se impone afirmar que el Código Civil y Comercial de La Nación en vigencia prevé expresamente la nulidad en las escrituras públicas $^{2286}$. Al considerar a las nulidades en las escrituras, nos posicionamos frente al estudio de las nulidades instrumentales y no específicamente del acto o negocio jurídico, aunque la teoría general sea la misma para avalar el propio significado y el alcance de la nulidad ${ }^{2287}$. De esta manera, y según se insiste, en sede notarial no hay más nulidades que las previstas en el Código Civil ${ }^{2288}$-y en la actualidad, en el ordenamiento en vigencia-.Sin embargo, la propia escritura pública, como especie del instrumento público, también acarrea las nulidades propias de aquel ${ }^{2289}$. Los supuestos son claros, no necesitan explicación alguna que no haya sido ya dada por la doctrina mayoritaria, con los alcances también ya establecidos y asumidos como

${ }^{2285}$ Ibídem, p. 11. El derogado Código Civil contenía dos normas expresas que permitían avalar lo que se acaba de exponer. En efecto, una de ellas (Art. 1037) consagratoria del carácter expreso de las nulidades, y otra, de carácter general, (Art. 18), que abría la puerta a la teoría de las nulidades virtuales tal cual la doctrina lo ha venido sosteniendo. Pero el Código Civil y Comercial de La Nación no contiene normas similares dentro del régimen general de las ineficacias. De este modo, Marcelo López Mesa advierte con preocupación suficiente que existe un vacío en el nuevo ordenamiento "que puede tornar conjetural la declaración de nulidades". Muy a pesar de ello, es el propio López Mesa quien propone hacer una hermenéutica integradora en un trabajo digno de elogio, para precisamente poder completar el régimen general de las ineficacias, con normas no solamente del nuevo código unificado, sino especialmente con aquellas de jerarquía constitucional. V. ob. cit., p. 536 y ss.

${ }^{2286}$ Art. 309 del CCCN. Relación con el Código Civil de Vélez: Art.1004. Fuente directa: Art. 286 del Proyecto de Unificación de 1998.

${ }^{2287}$ Sobre este tema, es altamente recomendable tener en cuenta la distinción entre negotium e instrumentum. La misma origina una dicotomía especial, ya que se contempla, por un lado, la nulidad sustancial, material o de fondo, propia del negocio; y por el otro, la nulidad formal instrumental o documental que es la propia del documento público. Cfr. Gastón Augusto ZAVALA, Nulidades instrumentales, en Cristina Noemí ARMELLA (Dir.), Tratado de Derecho Notarial, Registral e Inmobiliario, t ${ }^{\circ}$ III, Ad Hoc, Buenos Aires, 1.998, p. 133.

2288،Las fallas formales de la escritura no causan su nulidad a no ser que ellos se hubiese establecido expresamente por ley" CNFed. Crim. y Corr., Sala I, 20/06/1979, ED, 93-299.

${ }^{2289}$ En efecto, puede una escritura se nula por violación de la competencia territorial notarial, que en definitiva, es una regla general de nulidad prevista en el instrumento público y no específicamente en el presente capitulo. Los casos son exactamente los mismos que los previstos en la legislación civil vigente. 


\section{SEBASTIÁN JUSTO COSOLA}

naturales ${ }^{2290}$. No obstante, resulta oportuno aclarar que las demás inobservancias no vuelven nulas a las escrituras, pero derivan al notario al ámbito de la responsabilidad disciplinaria en sus dos vertientes: en razón de las formas y en razón de la conducta (deberes éticos) ${ }^{2291}$.

Finalmente, queda por reconocer que otra de las respuestas a la consolidación de la escritura pública está referida a la cuestión de las falsedades. Si la finalidad del instrumento público es la acreditación fehaciente de la existencia de todo acto $u$ hecho en presencia del escribano, notario u oficial público, cuyos efectos se asimilaran a los de la plena o máxima prueba, es bueno recordar con Eduardo Couture que ninguna prueba puede ser plenamente perfecta -aunque la misma se encuentre revestida de fe pública-, ya que los actos de los hombres librados a la sinrazón pueden causar daños irreparables. Para ello entonces se prevé la institución de la redargución de falsedad, como protección a los actos de los fedatarios que no se corresponden ni con su investidura ni con su función de garantía, justicia y seguridad, y lógicamente un buen sistema de responsabilidad notarial que está destinado a separar o apartar a los malos profesionales del ejercicio fedatario funcional ${ }^{2292}$. Este tema ya fue tenido en cuenta al momento de considerar críticamente lo transmitido por Michele Taruffo, y a ese punto remito, para comprobar definitivamente porque razón no es posible consolidar una teoría que niegue los valores del documento notarial en razón de una posible y eventual falsedad.

\subsection{Cuestiones provenientes de los estudios comparativos entre las} sentencias y las escrituras públicas.

Expuesta detalladamente la relación de la seguridad jurídica con el documento notarial, y hechas las referencias necesarias hacia la sentencia

\footnotetext{
2290 "La acción de nulidad de una escritura pública debe tramitar con la citación del escribano autorizante del acto" CNCiv., Sala D, 28/07/1977, La Ley, 1978-A, 115.

${ }^{2291}$ Sebastián Justo COSOLA, Los deberes éticos notariales, ob. cit. p. 341.

${ }^{2292}$ Eduardo J. COUTURE, El concepto de fe pública. Introducción al estudio del derecho notarial, ob. cit., págs. 110 y ss.
} 
judicial que dirime la controversia para realizar sobre ella, un estudio comparativo con la escritura pública, corresponde ahora realizar la tarea, advirtiendo que para la misma utilizaré el siguiente método expositivo:

a) Determinación de las bases que conforman los fundamentos tanto de la sentencia como de la escritura pública;

b) Exposición de los elementos comunes.

c) Exposición de las diferencias.

d) Conclusiones del método comparativo efectuado.

\subsection{1. a) Determinación de las bases que conforman los}

\section{fundamentos.}

El Código Civil y Comercial de la Nación es un código de principios, y en esta dirección, presenta un nuevo paradigma del derecho que es merecedor -como he venido argumentando-, de un análisis especial. Un código de baluartes exige una comprensión armoniosa de todo el cuerpo normativo, es más: exige la convivencia de reglas, normas, valores y principios a los que atribuye el carácter ya no de ley, sino de derecho. La comprensión del título preliminar del nuevo cuerpo legal resulta ser esencial, por cuanto el mismo debe ser concebido como una puerta de entrada tanto al código como al resto del sistema jurídico ${ }^{2293}$. Todos los artículos que conforman el título preliminar presentan un gran significado valorativo; por ello el mismo presenta una notable utilidad en el campo de la interpretación jurídica -o criterio de argumentación jurídica razonable-. Desde allí el notorio y necesario efecto expansivo que presenta, tanto para todos los casos que se

${ }^{2293}$ Cfr. Ricardo Luis LORENZETTI, Titulo preliminar, en Ricardo Luis LORENZETTI (Director), Código Civil y Comercial de La Nación Comentado, $\mathrm{t}^{\circ}$ I, Rubinzal-Culzoni, Santa Fe, 2.014, p. 25. 


\section{SEBASTIÁN JUSTO COSOLA}

contemplan en el cuerpo normativo como así también para los otros ámbitos normativos ${ }^{2294}$.

El cambio de modelo del nuevo derecho privado es innegable y absolutamente trascendente, de manera que este tema no puede no tener la importancia y el reflejo académico que merece. El jurista que pretenda comprender este relativamente moderno sistema de interpretación normativa, debe necesariamente recurrir y conocer las reglas del título preliminar para determinar en cada caso lo justo que a cada cual corresponde, y como también ya he referido, en un amplio y necesario diálogo de fuentes. De aquí entonces que la doctrina se refiera a la constitucionalización del derecho privado, con sus pertinentes aclaraciones $^{2295}$, precisamente porque ese amplio diálogo de fuentes se inicia en la Constitución Nacional ${ }^{2296}$.

Así es entonces que puede afirmarse sin temor a equivocación alguna, que en gran medida, el reconocimiento de la Constitución como fuente del derecho es un reconocimiento que en definitiva, dirige a jurista preparado a captar de su seno los principios, valores y derechos humanos que tienen capacidad de generar en él mismo, las respuestas y los interrogantes frente a los casos que se le planteen ${ }^{2297}$. El paradigma jurídico al que hemos estado hasta hace relativamente poco tiempo acostumbrados a recurrir frente a los casos complejos -aplicación de la ley luego de la interpretación y de haber encontrado en ella "la respuesta adecuada"- debe entonces mutar

\footnotetext{
${ }^{2294}$ Ibídem.

${ }^{2295}$ Horacio ROSATTI expresa: "Desde nuestra perspectiva, más allá del discutible rotulo de "constitucionalización del derecho privado" que -sin desconocer su desarrollo doctrinarioparece colocarnos frente a una obviedad (¿podría haber un derecho privado anticonstitucional?) o, peor aún, frente a una opción (:podría el derecho privado elegir no estar "en línea" con la Constitución Nacional?), lo que deja en claro el párrafo transcripto es el legítimo deseo de los redactores originarios de vincularse de un modo más estrecho con la normativa de jerarquía superior, evitando cierto solipsismo reinante en otras 'pocas en las que el Código Civil parecía girar sobre sí mismo, ignorando (o desafiando) al texto constitucional”. Cfr. Horacio ROSATTI, El Código Civily Comercial..., ob. cit., p. 51.

2296 Por ello es que algunos autores, al considerar el alcance normativo de la constitucionalización del derecho privado, se refieren a que necesariamente hay que analizar dos dimensiones: la normativa y la dikelógica (o axiológica). Cfr. Julio César RIVERA y Luis Daniel CROVI, Derecho Civil-Parte General, Abeledo Perrot, Buenos Aires, 2.016, p. 8.

${ }^{2297}$ Rodolfo Luis VIGO, Interpretación (Argumentación) jurídica en el Estado de Derecho Constitucional, Ob. cit., p. 28.
} 


\section{LOS EFECTOS DE LA PUBLICIDAD EN EL DOCUMENTO NOTARIAL}

absolutamente hacia un criterio argumentativo de ejercicio jurídico -estudiar el "caso" con su variedad de fuentes, donde habrá siempre más que una respuesta adecuada y en el cual la delicada tarea jurídica es la de escoger de todas ellas cual es la que se pretende que prospere o consienta ${ }^{2298}$. Si el derecho está conformado por reglas y por sus diferentes niveles de interpretación desde lo legislativo y desde lo ciudadano, acontecido el conflicto en la interpretación del alcance de la norma siempre existirá un juez con imperium que solucione la controversia ${ }^{2299}$, en la búsqueda -como ya he afirmado líneas atrás- de la racionalidad como método para evitar la $\operatorname{arbitrariedad}^{2300}$. A esas alusiones, debe agregarse que el derecho no solo está compuesto por normas, sino también por reglas y por principios.

Ello me obliga a dirigir los esfuerzos, dentro del título preliminar, hacia un tema que merece especial atención para este punto. $\mathrm{Y}$ es el relativo a la cuestión de la razonabilidad ${ }^{2301}$. La referencia a la misma en las sentencias que esgrimen los jueces en el título preliminar está relacionada específicamente con el pensamiento de lo que se denomina razón práctica prudencial ${ }^{2302}$; significa reconocer que el juez debe resolver todos los asuntos sean sometidos a su jurisdicción mediante una decisión que tiene que presentar cierto criterio de argumentación racional ${ }^{2303}$. En este sentido, aplicar la razonabilidad es llegar a alcanzar la mejor respuesta que el caso plantea a partir de la deducción realizada por el jurista frente a las respuestas ponderativas o de balance que se suceden entre derechos competitivos ${ }^{2304}$.

\footnotetext{
${ }^{2298}$ Ibídem.

2299 Diana Regina CAÑAL, El contenido formal y sustancial del derecho: una contradicción aparente, ob. cit., p. 6 .

${ }^{2300}$ Ibídem, p. 8 y ss.

${ }^{2301}$ En los Fundamentos del CCCN se esgrime que el requisito de la razonabilidad se encuentra constituido por un estándar de control de la decisión judicial, castigando a aquellas resoluciones que arriban a resultados disvaliosos o anti-funcionales.

${ }^{2302}$ Cfr. Renato RABBI-BALDI CABANILLAS, Título preliminar. Art. 3, en Julio César RIVERA-Graciela MEDINA (Dir.). Mariano ESPER (Coord.), Código Civil y Comercial de La Nación Comentado, $\mathrm{t}^{\circ}$ I, La Ley, Buenos Aires, 2.014, págs. 68.

${ }^{2303}$ En todos los raciocinios prácticos que concluyen en los preceptos del derecho natural se encuentra presupuesto, implícita o explícitamente, el primer principio práctico que en contracción jurídica, puede formularse como lo justo a de hacerse y lo injusto evitarse. Cfr. Carlos Ignacio MASSINI CORREAS, El derecho natural y sus dimensiones actuales, Ábaco, Buenos Aires, 1.999, p. 74.
} 


\section{SEBASTIÁN JUSTO COSOLA}

En el presente análisis, no hay razón posible para negar el principio de analogía en el oficio del jurista. Los notarios deben resolver los asuntos que llegan a las notarías, creando el derecho sobre el documento que también sean razonablemente fundados. La razonabilidad entonces se aplica a ambos juristas por igual.

Desde mi perspectiva, la referencia a la razonabilidad en el Código Civil y Comercial de La Nación puede ser considerada desde dos partes bien diferenciadas:

a) El deber de resolver, propio del juez, que es inalienable e inseparable de su persona (jurisdicción), salvo por causas que la propia ley le autoriza a esgrimir antes ciertos y determinados casos complejos (excusación);

b) La decisión que surja de ese deber de resolver debe ser fundada razonablemente, para no caer en la doctrina de la arbitrariedad ${ }^{2305}$, partiendo de la idea de la presunción de coherencia de esa determinada decisión.

También el notario debe responder al alcance de ese deber de resolver. Frente al requerimiento, el notario tiene el deber de resolver (competencia), salvo los casos en que la ley o la conciencia lo obligan a no aceptar o a rechazar el acto o hecho que pretende ser autorizado. En el primer supuesto, por ejemplo, las prohibiciones establecidas en el cuerpo del Código referidas a la competencia en razón de las personas. En el segundo, la invocación por ejemplo, del deber ético notarial de independencia, frente a la toma de razón notarial que el acto que se está pronto a realizar, absolutamente legal, puede generar daño en terceros ajenos a esa celebración. Al referirse a la razonabilidad notarial, se considera la idea de que el notario ha aceptado

${ }^{2304}$ Renato RABBI-BALDI CABANILLAS, Título preliminar. Art. 3, ob. cit., p. 69. El autor cita a Perelman, compartiendo que la razonabilidad es "una sintesis que combina la preocupación de la seguridad jurídica con la equidad, la búsqueda del bien común con la eficacia en la realización de los fines admitidos", de donde "más que al legislador, es al juez al que se confiará la realización de esa sintesis".

${ }^{2305}$ Ricardo L. LORENZETTI, Título preliminar, en Ricardo L. LORENZETTI (Dir.). Miguel F. DE LORENZO y Pablo LORENZETTI (Coord.), Código Civil y Comercial de La Nación comentado, $\mathrm{t}^{\circ} \mathrm{I}$, ob. cit., p. 40 y ss. 
realizar el trabajo que se le ha encomendado, por cuando lo cree dentro del marco de la legalidad integrada y del deber ético de la imparcialidad.

La razonabilidad notarial impone al escribano la tarea de encontrar, entre el dialogo de fuentes, la mejor respuesta para el caso que se le plantea, ponderando soluciones, alternativas y decisiones para que el documento notarial no sea ni arbitrario ni injusto. En este sentido, las líneas directrices de la concreción de la razonabilidad notarial pueden resumirse en las siguientes:

a) El obrar notarial parte de la idea del conocimiento y apunta al control racional;

b) Ese conocimiento supone la idea que manda a que del mismo el notario extraiga conclusiones valiosas;

c) Recepción de la voluntad de los requirentes adecuada al nuevo derecho;

d) Arribo a un resultado justo (el bien debe hacerse, el mal evitarse)

e) Aplicación de los conocimientos integrados con la equidad.

Para escoger la mejor solución posible y así, cumplir con la razonabilidad destinada a evitar el potencial conflicto del derecho (sobre todo en materia de derechos fundamentales ${ }^{2306}$ ), el hombre de derecho escoge, entre algunos otros métodos, el camino de la ponderación ${ }^{2307}$. Es así que el mismo, si es prudente, no puede pensar que la aplicación del derecho que se concreta con su labor pueda traer consigo problemas posteriores ${ }^{2308}$.

\footnotetext{
${ }^{2306}$ Sobre este tema: Juan CIANCIARDO, El ejercicio regular de los derechos, ob. cit.

${ }^{2307}$ El sistema de ponderación ha recibido ciertas críticas. Para ver la respuesta a esas críticas y la conformación estructural de la teoría: Robert ALEXY, La construcción de los derechos fundamentales, Ad-Hoc, Buenos Aires, 2.010, p. 27 y ss.

${ }^{2308} \mathrm{Si}$ esto es así, "la aplicación de normas jurídicas no es sino una subsunción lógica bajo premisas mayores formadas abstractamente". V. Robert ALEXY, Teoría de la argumentación jurídica, ob. cit., p. 27.
} 


\section{SEBASTIÁN JUSTO COSOLA}

\subsection{2. b) Los elementos comunes.}

Tanto la sentencia judicial como la escritura pública son instrumentos públicos, y gozan de los efectos generales de la autenticidad ya tratados en el cuerpo de esta tesis. En cuanto a su creación, ambos responden a elementos formales que deben respetarse para poder concluir en un documento genuino que no acarré alguna sanción por los vicios de forma ${ }^{2309}$. Ambos son declarativos de los derechos que a cada parte corresponde.

\subsection{3. c) Las diferencias.}

Un primer tema a considerar en que el notario, a diferencia del juez, no vierte en el documento una apreciación fundada de lo que es el derecho para cada uno, sino que su tarea está destinada a configurar la decisión que los comparecientes o requirentes pretenden para sí, dándole un marco jurídico a sus pretensiones (normas + reglas + principios), las que en origen, siempre se presentan como posibles. Ningún documento negocial notarial refleja una opinión notarial, que pueda luego estar sujeta a ser valorada por algún organismo superior. Por esta razón expuse que ante las manifestaciones autenticas notariales, manifestaciones auténticas de verdad que recogen el mismo momento fehaciente por si (exactitud en materia de fe comprendida desde el aspecto subjetivo), lo que queda ante su negación es la aplicación de las herramientas procesales mencionadas, cuyos resultados nunca establecerán si la apreciación notarial del derecho fue o no fue adecuada al caso concreto (afirmando o desechando la escritura), sino que simplemente vendrán a confirmar si una escritura es nula -o inexistente, para alguna

\footnotetext{
${ }^{2309}$ Entre ellos, se diferencian en ambos institutos aquellos que provienen de la competencia material -las leyes especiales de organización y función del Poder Judicial y las relativas a la organización notarial respectivamente-, de aquellos requisitos que surgen de las cuestiones de la competencia personal -toma de posesión del cargo (juez) y juramento y autorización del acto (notario); régimen de excusación y recusación (juez) y régimen de inhabilidades e incompatibilidades (notario); cuestiones de jurisdicción (juez) y cuestiones de competencia territorial (notario), entre otras.
} 
doctrina-, si es inoponible frente a alguien que tenga interés sobre ella en razón de una simulación, o si adolece de falsedad ${ }^{2310}$.

Establecidas las premisas iniciales, debe decirse que la principal diferencia a destacar entre la sentencia y la escritura pública es que la primera dilucida una controversia, mientras que la segunda estructura el derecho en la paz. Ambos institutos resuelven el tema de la justicia, pero mientras la sentencia lo hace a favor de quien resulte ser beneficiado con la valoración judicial, el documento notarial lo resuelve en un ámbito de paz, ajeno y alejado del conflicto, repartiendo a cada compareciente o requirente, de acuerdo a sus pretensiones iniciales, el derecho justo que le corresponde, en razón del deber ético de imparcialidad y la aplicación de la legalidad integrada ${ }^{2311}$, lo que en definitiva viene a garantizar el valor de seguridad desde el concepto analizado de previsibilidad. La imparcialidad judicial dirime el conflicto, la notarial equilibra los intereses para que los mismos alcancen el valor de la justicia. Consecuentemente, la función judicial reconoce el iudicare función relacionada con la resolución de conflictos- mientras que la notarial postula el responderé, compartida con el ejercicio de la abogacía -resolver las dudas, aconsejar y dictaminar- pero especialmente la del cavere prevenir, precaver- que es la tarea definitivamente consolidada en el notariado mundial ${ }^{2312}$. La valoración notarial del derecho se encuentra antes de la conformación documental, y desde allí es que el notario decide no solo si es posible o no el negocio jurídico o el hecho a documentar, sino que además decide de qué manera lo hará conforme no solo a la ley, sino al derecho.

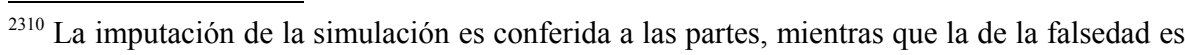
un ataque contra la actuación fedataria, salvo en los casos donde se pruebe que las partes requirentes hicieron insertar en el documento declaraciones falsas, que el notario nunca podría haber podido percibir por sí mismo (Art. 293 Cód. Penal).

${ }^{2311}$ Desde aquí es que con Núñez Lagos pueda afirmarse que hay en el acto y en documento un valor de autenticidad, que otorga la fuerza de probar, y un valor de legalidad, que da la fuerza de obligar. V. Rafael NUÑEZ LAGOS, Los esquemas conceptuales..., ob. cit., p 118.

${ }^{2312}$ La verdadera valoración notarial del derecho -en términos de Vallet, la argumentación notarial del derecho- surge de los momentos previos a la conformación documental del derecho: la información, el asesoramiento y el consejo, la imparcialidad y la independencia, deberes éticos notariales aplicados que conjuntamente con la legalidad integrada -comprensiva de normas, reglas y principios- consolidan la autentica y actual función notarial.
} 


\section{SEBASTIÁN JUSTO COSOLA}

La diferencia que secunda a la relatada, tiene que ver con la cosa juzgada. De acuerdo a lo antes analizado, la cuestión de la cosa juzgada en sede judicial se vuelve relevante para consolidar la seguridad del derecho que se declara en la sentencia, una vez que se haya concluido, de acuerdo al caso de que se trate, la posibilidad de utilizar la vía recursiva para que el accionante goce de una respuesta favorable a sus pretensiones o al menos, de la mejor respuesta posible. De esta manera la seguridad jurídica consolida la justicia, en los términos analizados anteriormente. La noción de cosa juzgada es ajena en sede notarial, pero no así el referido concepto de previsibilidad. El derecho que proyecta una determinada publicidad notarial cartular queda firme desde el mismo momento de la autorización con las formalidades exigidas de acuerdo a cada lugar de ejercicio funcional.

\subsection{4. d) Conclusiones del método comparativo efectuado.}

La seguridad jurídica notarial que emana del documento con publicidad cartular interna y externa concreta en su seno la justicia escogida por las partes y plasmada en el documento en el mismo momento de la culminación del negocio o hecho jurídico que se refleja en el documento notarial (acto de tutela notarial). Sobre el mismo, no existe apelación posible, salvo los referidos casos expuestos al tratar la teoría de las ineficacias y las cuestiones relativas a la falsedad, recordando que en las mencionadas teorías no se proyectan las discusiones acerca de la opinión notarial razonablemente fundada de los derechos comprometidos en el documento -elaboradas a partir del acto de voluntad de los comparecientes-, sino cuestiones inherentes a la bondad o maldad de los hombres que en determinadas circunstancias, actúan sin razón suficiente.

Visto de este modo, podría ocurrirle a alguien la inquietud por preguntarse, una y otra vez ¿cuál es el motivo por el cual no se encuentra prevista la posibilidad de una revisión del derecho que se encuentra consolidado en una escritura pública? A la clásica respuesta histórica relativa tanto a la actuación objetiva funcional de acuerdo a pautas objetivas de ejercicio 


\section{LOS EFECTOS DE LA PUBLICIDAD EN EL DOCUMENTO NOTARIAL}

proveniente del poder estatal como a la necesidad del comportamiento notarial adecuado a los valores éticos y morales, se le agrega por estos tiempos los fundamentos esgrimidos por la comisión redactora del novísimo Código Civil y Comercial de La Nación, ya proyectados en el cuerpo de esta tesis doctoral: la necesidad de la sociedad de contar con el resguardo de los actos relevantes a los que el ordenamiento decide brindarles mayor protección.

Cierto es que algunos académicos de los últimos tiempos vienen demostrando un marcado interés por sugerir que la decisión judicial es la vía adecuada para alcanzar lo justo tanto ante el acaecimiento del conflicto como ante la composición de un acuerdo. Existen nombres y títulos sugerentes en obras de jerarquía, que orientan al estudioso no sólo a creer, sino también a asumir que no existe otra alternativa para la conformación de la justicia que la constitucionalización y la judicialización del derecho ${ }^{2313}$. El Código Civil y Comercial de La Nación definitivamente propicia la judicialización del derecho; en efecto, además de las relevantes y decisorias opiniones que advirtieron de la necesidad de dejar sin efecto ciertos actos que antes de la entrada en vigencia del nuevo código no conformaban estrictamente una relación jurídica preexistente ${ }^{2314}$, con sólo advertir la enorme profusión de normas de naturaleza procedimental que en él se receptan puede alcanzarse la comprensión acerca de que el contenido ideológico del derecho actual tiende a considerar que los actos nobles (ética y moral) y justos (derecho) únicamente pueden alcanzarse a través de una decisión judicial.

${ }^{2313}$ V. Luis PRIETO SANCHÍS, Interpretación jurídica y creación judicial del derecho, Temis, Bogotá-Lima, 2.005, 296 p.; Rodolfo Luis VIGO, Constitucionalización y judicialización del derecho..., ob. cit.

${ }^{2314}$ Es el claro ejemplo de las donaciones diferidas, también denominadas oferta de donación o donaciones sujetas a posterior aceptación. V. Aída KEMELMAJER DE CARLUCCI, La aplicación del Código Civil y Comercial a las relaciones y situaciones jurídicas existentes, ob. cit., pág. 156 y ss. En idéntico sentido, v. Gustavo A. BONO, El artículo $7^{\circ}$ frente a los derechos reales: esquema general y consideración especial de las adquisiciones por usucapión y por donación, RDPC 2015-1, Rubinzal-Culzoni, Santa Fe, 2.015, p. 377 y ss; Alejandro BORDA y A.A.V.V, Derecho Civil-Contratos, La Ley, Buenos Aires, 2.016, p. 833 y Noemí L. NICOLAU y Carlos A. HERNÁNDEZ (Dir.) Sandra A. FRUSTAGLI (Coord.), Contratos en el Código Civil y Comercial de La Nación, La Ley, Buenos Aires, 2.016, p. 941. 


\section{SEBASTIÁN JUSTO COSOLA}

Juzgar lo apropiado o lo inapropiado de la realidad mencionada no tiene ni relevancia ni trascendencia académica. Es una realidad, una característica de los sistemas jurídicos contemporáneos, que se asume como lo que es y que se acompaña desde la reflexión teórica y práctica. Pero también puede intentarse sobre ella, la proyección de un complemento, o mejor dicho, la presentación de otra alternativa -de seguro, de las muchas más que existen-, para llegar a conformar como objeto de la decisión jurídica a todas aquellas que sirvan y sean eficaces para obtener el mejor resultado que en materia de atribución de derechos, sea posible humanamente alcanzar. Alejadas entonces las fundamentaciones gremiales o políticas - en ocasiones tan dañinas y tan alejadas de mis más íntimas convicciones-, debe imponerse el criterio que ordena que no es a través del combate, el desprestigio o la crítica despiadada de lo establecido sin razón ni sentido, sino a partir de la conformación de las ideas y de las fundamentaciones serias y coherentes en que debe darse una propuesta de otras alternativas que en materia jurídicodecisoria, sea posible considerar (obtención instrumental de verdad + certeza + justicia + previsibilidad). Alternativas que no vengan a suplantar ni a imponerse, sino que sean capaces de acompañar el modelo jurídico real actual y admitido. Posiciones que ayuden a que se alcancen de manera definitiva, las necesidades jurídicas de la ciudadanía que todos componemos, en el ámbito espacial en el que nos toca ubicarnos tan fugaz como naturalmente. $\mathrm{Y}$ esa alternativa la conforma desde mi perspectiva, el documento notarial auténtico con toda su referida proyección cartular.

El descuido del análisis del valor justicia que se consolida en el documento notarial, -valor promovido por la fe pública que alcanza la consolidación previsible a través de la seguridad jurídica-, constituye una de las omisiones más relevantes de los juristas en general, preparados para informar y educar a las generaciones para el futuro. Si el documento notarial auténtico, con la debida fuerza cartular descripta, se conforma sobre los valores que lo componen, se perpetuará para los tiempos, repartiendo a cada cual lo que le corresponde, de acuerdo con la verdad, en base a lo certero, y con proyección adecuada de previsibilidad. El documento notarial es un instrumento sumamente relevante en las sociedades actuales, que desde otras perspectivas -con diferente naturaleza, composición y estructura, pero en la búsqueda de un mismo resultado-, acompaña a las sentencias judiciales en 
LOS EFECTOS DE LA PUBLICIDAD EN EL DOCUMENTO NOTARIAL

la búsqueda de la consolidación del mejor derecho, o quizás, de lo nunca mejor expresado que hasta ahora: del derecho cierto, verídico, seguro y justo determinante del efecto que provoca la paz. 
SEBASTIÁN JUSTO COSOLA

.550. 


\section{Capitulo 15}

\section{Los efectos de la publicidad en el documento notarial: trascendencia y valoración.}

\subsection{Palabras iniciales}

En el capítulo final de la tesis doctoral se me impone exhibir el resultado alcanzado, a partir de la suma de las conclusiones parciales que fui describiendo en los capítulos antecedentes. Debo dejar constancia que las mismas fueron obtenidas a lo largo de todo el período de tiempo que me ha llevado realizar la presente investigación, y a medida que iba avanzando, etapa por etapa, institución por institución. Este es un dato para nada menor, si se tiene en cuenta que durante esa línea de tiempo, asistimos a la reforma del histórico y consolidado Código Civil, con todo lo que ello implica o trae consigo. Esa misma situación que me ha dejado en suspenso durante algún tiempo -sobre todo el dedicado a la eliminación y/o reformulación de tratamientos ya realizados-, hoy me permite presentar un nuevo panorama que considero, puede alcanzar a conformar desde aquí, una mejor o mas dedicada atención al documento por parte de quienes se encuentran encargados de enseñar y transmitir el derecho desde la normalidad y no únicamente desde los efectos patológicos que del mismo se desprenden. Siempre he sostenido que cerca de quien incumple con el derecho desde cualquiera de sus modos de manifestación, hay mucha mayor cantidad de personas que cumple natural o teledirigidamente con sus postulados casi diría, por hábito o por virtud. Esta realidad impone de alguna manera 


\section{SEBASTIÁN JUSTO COSOLA}

considerar que otros elementos de decisión jurídica son relevantes para argumentar el derecho, y no solo únicamente aquellos que deciden el conflicto o declaran la certeza o incerteza de los derechos en expectativa.

Con el mismo espíritu que he planteado al inicio de la presente, el ánimo y el esfuerzo de mi parte están siempre dirigidos a presentar otras vías alternativas de comprensión de los elementos jurídicos de los que se sirve el hombre para admitir o solucionar sus situaciones, que muchas veces tienen que advertirse desde un trato comparativo, que de ninguna manera intenta menospreciar o desvirtuar a los otros elementos decisorios absolutamente consolidados y por demás de necesarios y trascendentes (esencialmente los judiciales y los administrativos).

Debo asimismo reconocer que al momento de proponer el tema del documento notarial como centro del desarrollo de la investigación, aspiraba yo a despertar primero la inquietud, y luego el verdadero interés del jurista que llegara eventualmente a interesarse por ahondar en sus líneas. Pretendía con ello que desde aquí y para los tiempos que vengan, se consolidara sobre el mismo una lectura y comprensión de sus efectos absolutamente diferente de la que habitualmente se considera en los ámbitos o foros de discusiones y planteamientos académicos. Mientras que la visión común del documento lo hace únicamente merecedor del calificativo de formal, la perspectiva que aquí se plantea es la que determina su verdadero sentido: el de ser un elemento sustancial del derecho. La forma brinda seguridad, pero la sustancia agrega a esa seguridad los otros valores implicados y descriptos, lo que convierte al documento notarial en un claro y contundente elemento de decisión jurídica. Se alcanza definitivamente a demostrar aquí entonces, la trascendencia y valoración de los efectos publicitarios internos y externos del documento notarial, justificados como ha quedado expuesto, a partir del tratamiento en conjunto de varias disciplinas del derecho.

Hubiera sido bastante más complejo justificar una tesis como ésta desde un cuerpo de leyes que desde la propia teoría general propone la concreción de normas y fuentes de diversa naturaleza a las que hoy nos asisten. Pero no deja de serlo el hecho de cuidar que la misma no deje la duda o la posibilidad de una inadecuada interpretación en las conclusiones que presente, que permitan hacer inferir resultados que desde la propia 
abstracción que naturalmente emerge de la exposición de los valores o los principios, puedan generar la contracara de lo que aquí he denostadamente perseguido: la consolidación definitiva de un derecho cierto, verídico, justo y seguro en el documento, la máxima creación notarial del derecho. La adscripción a la corriente iusnaturalista en modo alguno puede hacer inferir que el intérprete del derecho puede modificar de manera drástica y autoritaria el sentido de la norma cuando se ha optado oportunamente por un determinado sendero normativo ${ }^{2315}$. Y ese es un estándar que debe tenerse en cuenta en las líneas que a continuación se proyectan.

Quiero finalmente expresar que es la comprobación de los valores en el documento determinan que el mismo se transforme en un elemento esencial para la vida en sociedad. Me siento satisfecho de sentir que esa semilla ha quedado de aquí en más sembrada en tierra fértil. El tiempo que demore en germinar no es relevante si la decisión de dar por aprobadas otras bondades emergentes del contenido del documento ha podido quedar comprendida y demostrada.

\subsection{Las primeras comprobaciones}

Durante todo el desarrollo hasta aquí acontecido no he negado ni ignorado cuestiones indudables analizadas en el derecho patrio, que no requieren más que la exposición de los motivos y especialmente, de las influencias que forja sobre el objeto central del análisis de la presente tesis doctoral. En efecto, en los tiempo actuales, tanto la cuestión de la fuerza innegable de la publicidad posesoria como la referida a la adecuada publicidad registral, se impone tan necesaria como invalorable. Sin embargo, esas situaciones no han sido obstáculo para que pueda alcanzar a demostrarse, que la publicidad que emerge del documento notarial, con todos los alcances y consecuencias analizadas, sea la única que contiene, además del valor extrínseco, todos los

${ }^{2315}$ Cfr. Marcelo E. URBANEJA, Practica Notarial de contratos usuales. Modelos según normativa nacional y local, $\mathrm{n}^{\circ} 1$, Astrea, Buenos Aires, 2.016, págs. VIII-IX. 


\section{SEBASTIÁN JUSTO COSOLA}

valores intrínsecos que hacen a la conformación estructural del derecho en su seno. En este sentido, el documento notarial y más específicamente, la escritura pública:

a) Alcanza la plena fe de lo dicho, afirmado, oído o comprobado por el escribano a través de sus sentidos (certeza), cuyo resultado es el contenido proyectado (acto) en el instrumento valorado como la única realidad que al derecho le interesa (verdad);

b) Consolida la libre voluntad de las partes requirentes frente al notario que las tutela, de acuerdo a las pretensiones que cada una pretende para sí (justicia), y

c) Otorga la máxima eficacia tanto en la circulación del documento (previsibilidad) como en el cuidado de las constancias de los hechos y de los derechos emergentes de las matrices y demás instrumentos anexos ad perpetuam (conservación ordenada).

La idea del documento notarial y del efecto de la publicidad cartular extrínseca e intrínseca es necesaria y altamente trascendente para el derecho actual $^{2316}$. ¿Cuál es la razón que avala la mencionada afirmación, si siempre se ha considerado sin inconveniente alguno la temática desde el análisis de los efectos meramente extrínsecos? Es que como hasta la fecha, los estudios con los que contamos para corroborar la importancia de los efectos publicitarios emergentes del documento únicamente son los referidos a los casos mencionados en el cuerpo principal de esta investigación, siempre referentes al examen de los títulos antecedentes, o a las constancias que surgen de los textos matrices en general y en todos los documentos anexos a las matrices, de origen administrativo, judicial o registral. Esa es la situación que, corroborada por la determinación objetiva de la fe pública, viene a

${ }^{2316}$ Se requiere tener una visión del notariado totalmente distinta a la que los juristas en general, asimilan por costumbre. Y además, hay que intentar alejarse de la comprensión natural de que la función notarial es ejercida formal y matemáticamente por una persona que se aleja de la interpretación y argumentación del derecho para actuar como un mero documentador de las normas y las fuentes del derecho. Es una tarea compleja, inclusive para muchos autores de derecho notarial. 


\section{LOS EFECTOS DE LA PUBLICIDAD EN EL DOCUMENTO NOTARIAL}

provocar la innegable certeza del documento notarial, todo de acuerdo a los efectos que el mismo provoca, con la sola exhibición, en el desarrollo del tráfico jurídico.

Pero desde la expresión sustantiva del derecho, el efecto emergente de la publicidad del documento creado por el notario luego de la audiencia con los comparecientes, permite hacer una lectura de los valores que se proyectan en del mismo. Desde el paradigma que ordena seguir el derecho consustanciado en el Código Civil y Comercial de la Nación vigente en nuestro país, este aspecto cobra, como en ninguna otra época, una relevancia determinante inclusive, desde la fundamentación de la propia institución notarial. Si el derecho actual pretende repartir lo justo a cada uno a través de una particular visión que, por sobre todas las cosas, impone a la Constitución Nacional como principal elemento valorativo de argumentación, el documento notarial como singular elemento de decisión jurídica no puede prescindir de la exposición de los valores que contiene y que lo ayudan a consolidarse.

En definitiva, son los valores y su pacífica convivencia dentro de su interior, los que logran posicionar al documento como una institución rectora de la decisión jurídica alejada tanto del conflicto como de la controversia. Los tres valores aludidos y argumentados anteriormente únicamente pueden convivir de manera equilibrada en el seno del documento notarial, y no así en las otras formas de publicidad que el derecho también permite y proyecta. Esa es la razón por la cual, a pesar de la innegable importancia del instituto posesorio y de la institución registral, debe concluirse que los dos últimos mencionados no logran contener y equilibrar, desde su contenido, la convivencia de los valores en su conjunto relativos a la fe (certeza + verdad), a la justicia y a la seguridad, en igual grado de equilibrio que los mismos alcanzan como contenido del documento, y por ende, no pueden proyectar la plenitud de sus efectos al sistema publicitario que cada una determina causando, en muchas circunstancias, el acaecimiento del conflicto que requiere definitivamente del arbitrio judicial que debe finalizar la controversia.

En síntesis: La fuerza de la autenticidad extrínseca emergente del documento notarial proviene de la potencia de la autenticidad intrínseca que él mismo contiene y resguarda, omnicomprensiva de todos los valores 
descriptos, que funcionan dentro del elemento contenido en equilibrio constante y armónico.

\subsection{El documento notarial como elemento y argumento de decisión} jurídica.

Justificar los valores en el documento notarial a partir de la exposición del principio de publicidad cartular intrínseca - y especialmente la justicia-, es en cierta manera y como ha quedado demostrado, una necesidad de instaurar la vertiente realista clásica en la discusión académica notarial. Se intenta dejar demostrado que para la aplicación y concreción de los valores al notario no le alcanza con acudir al pensamiento general de elaboración jurídica en base a lo acordado por las partes concurrentes al acto y a lo dispuesto por la ley, sino que debe aplicar el conocimiento que de ellas obtenga en base al orden y a la reflexión, para que del mismo emerja el mejor documento que sea posible alcanzar. Pensar es simplemente aplicar una idea sobre el hecho; pero el acto de conocer es asumir el entendimiento de lo realmente aprehendido ${ }^{2317}$, no reduciéndolo jamás a lo que debería ser para ajustarse a las reglas de un tipo de conocimiento arbitrariamente elegido por nosotros ${ }^{2318}$.

De esta forma, pensar el acto notarial implicaría la utilización de las estructuras que, -al igual que la geometría-, se encuentran lógicamente relacionadas, todas componiendo una unidad ${ }^{2319}$. En cambio conocer el acto notarial, implica como primera medida un acto de creencia, que permite estar inclinado a tomar una proposición como verdadera ${ }^{2320}$; a partir de ello, todos quienes se encuentran frente al acto logran admitir que el

${ }^{2317}$ Cfr. Etienne GILSON, El realismo metódico, Rialp, Madrid, 1.974, p.172.

2318 Ídem, p. 184.

2319 Cfr. Ricardo A. GUIBOURG, La construcción del pensamiento. Decisiones metodológicas, Colihue, Buenos Aires, 2.006, págs. 9-10.

${ }^{2320}$ Cfr. Ricardo A. GUIBOURG, Saber derecho, Abeledo Perrot, Buenos Aires, 2.013, p. 128. 
LOS EFECTOS DE LA PUBLICIDAD EN EL DOCUMENTO NOTARIAL

conocimiento es la verdad que decimos $\operatorname{conocer}^{2321}$, en base a la formalización de un método comúnmente aceptado ${ }^{2322}$-en el caso, el acto de formalización de la elaboración notarial del derecho-.

Independientemente de las posiciones que esgrimen los autores que exponen sus teorías desde las diferentes escuelas de pensamiento, he tratado de demostrar anteriormente que se acuerda que en los tiempos actuales el sentido $^{2323}$ y los mandatos ${ }^{2324}$ del derecho se dirigen siempre al análisis de la justicia, con lo que la preocupación por lo justo en el seno del documento reviste carácter esencial.

Pero todo esto no tendría sentido si el documento notarial no alcanza a considerarse como un elemento y argumento que decide el derecho. ¿Qué derecho es el que decide? El derecho que está destinado a proyectarse en la paz; ese que cumple y al que adscribe la mayor cantidad de personas de modo natural y permanente. Quizás sea por lo natural de su acaecimiento, que este tratamiento se haya vuelto en todo este tiempo absolutamente inusual. La necesidad de demostrar los efectos ejecutivos y probatorios del documento notarial está motivada por aseverar la fuerza del mismo ante el acaecimiento del problema. Lo que viene a demostrar en cierta forma, que las personas humanas solemos prepararnos para enfrentar las controversias en lugar de aceptar lo que espontáneamente se cumple por simple y sencillo comportamiento. Esta tesis proyecta otros efectos del documento, que son los que lo convierten en elemento de decisión trascendente, porque el derecho que en él se contiene está destinado a resguardar la paz.

\subsubsection{La naturaleza del documento notarial decisorio.}

\footnotetext{
${ }^{2321}$ Ibídem.

${ }^{2322}$ Ídem, p. 129.

${ }^{2323}$ Manuel ATIENZA, El sentido del derecho, ob. cit., p. 325. Dice el autor: "Lo que da sentido al derecho -y a ocuparse profesionalmente del derecho- no puede ser otra cosa que la aspiración a la justicia o, para decirlo en términos más modestos y más realistas: la lucha contra la injusticia".

${ }^{2324}$ Cfr. Owen FISS, Los mandatos de la justicia, Marcial Pons, Buenos Aires, 2.013, p. 57.
} 


\section{SEBASTIÁN JUSTO COSOLA}

Se me impone proyectar ese alcance y además, descifrar cuál es la naturaleza de esa decisión de derecho. Con Ricardo Guibourg se alcanza a comprender que "el derecho puede encararse, tanto del punto de vista realista como desde una teoría normativista, como un conjunto o sistema de criterios de decisión ${ }^{2325}$ ". Criterios que sin duda alguna, van a aplicarse para resolver las controversias que se susciten, con el último respaldo de la fuerza $^{2326}$. De esta manera, los criterios de decisión judicial ocupan claramente un lugar central en el discurso jurídico general, pero no son los únicos ni necesariamente los definitivos que hayan de prevalecer ${ }^{2327}$. Otros criterios pueden ser relevantes, y son aquellos que descartada la vía autoritaria de la subordinación directa, proponen el camino de la introspección, el diálogo y el consenso ${ }^{2328}$. En estos últimos, todos los juristas están involucrados y llamados a su aplicación, ya que el derecho, al preocuparse por el establecimiento de equilibrio dinámico, persigue la instauración de "un modelo fundado en la identificación y explicitación pública de los sistemas de criterios de decisión (que sea) capaz de reducir el

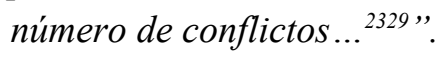

De esta manera, una decisión jurídica, para constituirse como tal, tendría que contener una serie de valores que le sirvan de sustento y fundamento, además de los procedimientos formales que en cada caso se tengan que respetar para llegar tanto a la jurisdicción como al ámbito de la competencia que el derecho determine legalmente para cada caso en especial. La decisión jurídica adjetivada con la cuestión de la discrecionalidad es precisamente, una decisión que no es rutinaria; es una decisión que realiza un determinado jurista que se encuentra con más de una norma para aplicar a los hechos, y

\footnotetext{
${ }^{2325}$ Ricardo A. GUIBOURG, Saber derecho, ob. cit., p. 223.

${ }^{2326}$ Ídem, p. 229.

${ }^{2327}$ Ibídem.

${ }^{2328}$ Ibídem.

2329 Ídem, p. 238. Y continua el autor: "De paso, los ciudadanos sabrían a qué atenerse, obtendrian decisiones más rápidas cuando las necesitaran, los jueces conservarían su independencia y la administración de justicia quedaría más transparente sujeta al escrutinio público, sin someterse por eso al poder mediático. La entera actitud de los ciudadanos y de los operadores jurídicos frente al derecho experimentaría un cambio profundo en términos de contención, respeto y eficacia".
} 
LOS EFECTOS DE LA PUBLICIDAD EN EL DOCUMENTO NOTARIAL

que además, se encuentra con la desviación de la atención hacia más de una interpretación jurídica adecuada ${ }^{2330}$.

En este sentido, debe quedar en claro un hecho absolutamente innegable: el único homo juridicus autorizado para aplicar el imperium decisorio es el juez. El notario, al elaborar el derecho en el documento en un ámbito de paz, colabora con una actividad de tutoría para que la voluntad de las partes, que es lo verdaderamente justo, alcance los resultados por ellas proyectados. El notario no tiene -ni tiene que tener- imperium; el notario tiene autorictas, esto es, capacidad jurídica y legal para colaborar con la justicia dando previsibilidad a los actos que autoriza. Esa actividad le viene reglada desde la ley, y si bien puede asimilarse en este sentido a un profesional del derecho con ciertas facultades especiales para ejercer la autoridad, lo trascendente es advertir que ese ejercicio es absolutamente necesario para el desarrollo del tráfico jurídico de las sociedades que problematizadas. El poder de la fe pública que viene de la ley brinda certeza, y lo cierto para el derecho encierra detrás -y de acuerdo a los motivos expuestos con anterioridad- la idea de verdad.

El notario elabora el derecho a partir de las calificaciones que realiza al momento de configurar los actos en el documento, con sustento en los deberes cumplidos de asesoramiento información y concejo que suponen las audiencias notariales previas que preceden al acto instrumental, generando una auditoria, un control y una colaboración que guía la voluntad de las partes al rumbo por ellas escogido, generando el cumplimiento del valor justicia. Esta afirmación permite reconocer que existen otros documentos, como el de naturaleza notarial, que acompañan a los de origen judicial en la búsqueda de la consolidación de decisiones jurídicas justas. Por ello se ha justificado en el cuerpo de la presente investigación, la importancia de la publicidad cartular intrínseca del documento notarial que expone y demuestra los valores considerados desde una perspectiva y un resultado decisorio que proyectará a la postre, los demás efectos extrínsecos. En definitiva, el documento notarial auténtico abraza una naturaleza decisoria fundada en la autorictas que el Estado asume y delega para que la misma sea realizada por los notarios, que son a quienes se encarga realizar la

${ }^{2330}$ Cfr. Carlos A. ETALA, Diccionario jurídico de interpretación y argumentación, Marcial Pons, Buenos Aires, 2.016, p. 96. 
correspondiente dación de fe en los actos que alcanza a su competencia, donde se encuentran todos aquellos relevantes y referidos con anterioridad, para que las personas en general alcancen el desarrollo normal de la vida de relación, desde el lugar donde decidan a la misma proyectar ${ }^{2331}$.

\subsection{La justicia y la seguridad jurídica se proyectan y conviven en} armonía en el documento notarial, y determinan el cuarto valor consecuente: la paz.

Uno de los esfuerzos más relevantes de este estudio lo conforma la idea de explicitación y comprobación de la existencia de los valores intrínsecos en el documento notarial auténtico. Comprobada ya la fe notarial y su naturaleza -que nutre de lo cierto y lo verídico al acto instrumentado-, pienso que no asiste razón alguna para visualizar algún conflicto interno $-\mathrm{o}$ dentro del estudio del derecho notarial general-, entre la justicia y la seguridad jurídica.

La exposición resumida del plexo jurídico esbozado por Carlos Cossio persigue el fundamento de exhibir como los valores de la filosofía y del derecho pueden o disputarse, o enfrentarse o subsumirse unos a otros. Originariamente, la cuestión de los valores jurídicos presentó ciertas dudas iniciales, relacionadas entre otras cosas, con el descuido de la utilización de los términos, por la exposición de una multiplicidad de tablas o plexos axiológicos, por la utilización de un lenguaje confuso -y también por la asimilación de los valores a lo irreal, a lo que no existe, a lo que simplemente vale $^{2332}$-, para luego llegar a consolidar una etapa donde se los llega a considerar como una cualidad oformalidad de los actos humanos que los constituye como buenos, o lo que es similar, como estimables

\footnotetext{
${ }^{2331}$ Esta aseveración incluye además los documentos realizadas para/por las personas jurídicas reconocidas en el ordenamiento positivo.

${ }^{2332}$ Cfr. Carlos I. MASSINI CORREAS, El derecho, los derechos humanos y el valor del derecho, Abeledo Perrot, Buenos Aires, 1.987, p. 175.
} 
positivamente desde el punto de vista de la perfección humana ${ }^{2333}$. Los valores jurídicos propiamente dichos se refieren a la conducta humana, y consisten en una cualidad de esa conducta que la perfecciona como jurídica; esa cualidad valiosa se denomina justicia, tomando prestado el término a la virtud de la voluntad que nos mueve a dar a cada uno lo que es suyo ${ }^{2334}$.

Para evitar que la colisión entre los valores genere un daño al derecho, se aplican entre otras cosas las denominadas jerarquías, de ahí que Cossio haya postulado el valor justicia, Kelsen postule el valor de la paz, entre otros grandes maestros del derecho en general.

En la historia de la filosofía de los valores, como ya he referido, la justicia y la seguridad jurídica se encuentran enfrentadas. Pero he felizmente llegado al convencimiento que reconoce que en el contenido del documento notarial, ello no ocurre. La seguridad jurídica que emana del documento y que brinda previsibilidad, supone la concreción de lo justo tanto por la repartición de lo que las partes se hicieron como por la asimilación del cumplimiento notarial estricto de los deberes éticos notariales aplicados generadora del efecto de la justicia. Desde esa hermosa y fantástica regla de aplicación, el notario advierte lo justo de cada uno, para luego poder redactar el documento e imprimirlo, sobre la idea generada en ese ámbito tutelado. Ante lo justo bilateral, captado por el notario, conforme a los que los comparecientes pretenden para sí, no habrá consideraciones de injusticia, precisamente porque la voluntad se enmarca en las fuentes del derecho que permiten argumentar de la mejor manera el derecho en la actualidad. Entonces las dudas iniciales se despejan con el asesoramiento o el consejo; las desigualdades se tornan iguales a través de la imparcialidad. Los daños potenciales a terceros interesados se esfuman ante la aplicación del deber de independencia. EL derecho entero vive y se desarrolla en el documento consolidando en el mismo la ley, los valores y eventualmente los principios que haya que reconocer. Lo justo bilateral así cobro sentido y relevancia, y ante la insatisfacción de cualquiera de estos tópicos, el deber de abstención notarial de la realización del acto no permite que el mismo cause o genere una injusticia posterior.

${ }^{2333}$ Ídem, p. 194.

${ }^{2334}$ Ibídem, p. 196. 


\section{SEBASTIÁN JUSTO COSOLA}

En este esquema, ¿Quién llegaría a plantear lo injusto del hecho o negocio autenticado, si antes de la celebración fueron participes y conscientes de los suyo de cada uno? Pretender generar una inestabilidad u observabilidad en un documento otorgado libremente (voluntad) y autorizado (fe y seguridad jurídica) siendo previamente advertidos los comparecientes de lo que a cada uno corresponde (justicia) por un jurista que ejerce el derecho alejado y en prevención del conflicto (tutela), es un acto de mala fe que no debe merecer ningún tipo de consideración o tratamiento jurídico. En el sentido de estas afirmaciones -como también ya he argumentado-, las herramientas dadas para la protección derivada de la seguridad jurídica deben posicionarse clara y firmemente: ante los abusos de la autoridad notarial, siempre existirá la posibilidad de demostrar judicialmente los vicios del acto, o los vicios de la voluntad, que en nuestras naciones encuentran asidero en la legislación y jurisprudencia vigentes y más especialmente, en el sistema de responsabilidad notarial, único por su eficacia y mas por su valoración.

Pero eso no implica admitir a una justicia regularmente observadora y crítica de la seguridad jurídica que emana del documento. Es precisamente la justicia observadora de conductas adecuadas a la voluntad las que generan una injusticia sobre lo querido, lo justo, lo realmente pretendido por la parte que no ha sido lesionada desde el documento notarial. Así, el valor seguridad no puede ser contradicho con otro valor, la justicia. Ambos deben complementarse, y si lo justo antecede a lo seguro pudiendo esto último dar sello de autenticación de lo primero, no tendrá más motivos el hombre para desconfiar de las instituciones impuestas por la tradición y vigentes por necesidad de confianza.

En definitiva, puede sostenerse acabadamente que el documento notarial causa la seguridad porque ese efecto emerge de la concreción previa de la justicia. Existe seguridad destinada a la previsibilidad y a la conservación precisamente porque la misma se genera una vez que se encuentra consolidada la justicia. La justicia tiene además, el sello de la fe determinante de la certeza de lo que el documento proyecta y la verdad que del mismo indudablemente emerge. La suma de valores en el documento siempre se interrelacionan en igualdad de jerarquías, y por ello todos generan la potencia que emerge de lo que he decidido en esta tesis denominar publicidad cartular intrínseca. La fuerza si, tiene los efectos ya 


\section{LOS EFECTOS DE LA PUBLICIDAD EN EL DOCUMENTO NOTARIAL}

tratados y deseados por la doctrina general notarial argentina y extranjera. Pero la potencia determina el nacimiento de los valores y con ellos, de los efectos más trascendentes.

Algo relevante queda aún por referir. La justicia y la seguridad jurídica, previa consolidación de la fe-certeza y verdad-, determinan la paz. La misma es considerada según algunos autores como fin último del derecho ${ }^{2335}$.Como ya lo he dejado expuesto, Hans Kelsen es uno de los juristas que considera que la justicia es un ideal irracional, y que el valor al que el derecho debe adscribir es la $p a z^{2336}$.

Desde mi visión, el derecho debe claramente adscribir a la paz; pero no puede la misma erigirse como baluarte del mismo que atienda a su última finalidad. Más bien ella es una consecuencia, un resultado querido y esperado por las personas, emergente de la repartición equitativa de lo que a cada cual corresponde. Cuando este resultado no ocurre, cuando la paz no alcanza a consolidarse, la decisión del conflicto por la autoridad con imperium es inevitable (esto justifica las apreciaciones de Vallet referidas a que el derecho es una parcela de la realidad del hombre que oscila entre el amor y la fuerza; se recurre al amor para cumplir espontáneamente por hábito o por virtud, y es necesaria la fuerza del Estado para que el cumplimiento del derecho sea siempre garantizado).

Lo antedicho implicaría aceptar que el conflicto es también un elemento del derecho. Con el sustento de esta tesis, yo pienso que el conflicto motivado por las conductas humanas dispares o disvaliosas, es en todo caso un resultado posible y probable del derecho, tal como lo es el resultado normal o biológico del cumplimiento espontáneo, pero de ninguna manera puede ser considerado como un elemento del mismo. Desde esta perspectiva, la paz es y debe ser el resultado natural de un acto celebrado con justicia, avalada por la fe y con el efecto de la seguridad, como ocurre con los hechos y actos que, respetando toda la conformación axiológica que he intentado exponer, emergen del documento notarial.

El fin último del derecho es la justicia. La lucha por el derecho no es otra cosa que la lucha por la instauración de lo justo, y por ello, dado lo justo con

${ }^{2335}$ Karl LARENZ, Derecho justo..., ob. cit., p. 42.

${ }^{2336}$ Cfr. Hans KELSEN, Teoría general del derecho y del estado..., ob. cit., p. 14 y cc. 


\section{SEBASTIÁN JUSTO COSOLA}

todas las características descriptas, el efecto inmediato es la obtención de un resultado alejado del litigio probable o posible, mientras que el mediato es el que confirma la instauración de la paz.

\subsubsection{La autorización notarial del documento y la consolidación} de la paz.

Karl Larenz enseñaba que la paz en versión jurídica, desarrollada en su esplendor como el señorio del derecho en las relaciones entre los hombres, necesita de reglas por las cuales los hombres rijan su vida en común; también de jueces que decidan el conflicto, y además, de un poder organizado que obligue coactivamente el cumplimiento del derecho ${ }^{2337}$. Sin embargo, será el mismo jurista quien más adelante reconozca que no puede mantenerse un criterio de coacción del derecho, porque en definitiva un ordenamiento que se mantiene solo por la coacción y no predominantemente por su obediencia voluntaria por parte de la mayoría apenas sería algo mejor que el estado de naturaleza de Hobbes ${ }^{2338}$.Es necesario entonces que el ordenamiento jurídico, para afirmarse y desarrollarse, pueda contar con un poder protector que bloquee los arreglos violentos de los conflictos entre los particulares o entre los grupos sociales y vuelva a colocar dentro de los límites marcados por el ordenamiento a cualquiera que lo desobedezca ${ }^{2339}$. Hans Kelsen planteaba hábilmente que la paz es una situación que simplemente se caracteriza por la ausencia de la fuerza; sin embargo, es necesario el empleo de la fuerza en las relaciones de los individuos, porque

${ }^{2337}$ Karl LARENZ, Derecho justo..., ob. cit., p. 44. Más adelante el autor admite lo siguiente: "La paz efectiva solo predomina donde cada uno puede confiar en que los tribunales o los que detentan el poder le reconocerán a su derecho; donde cada uno pueda contar con que el otro se comportará con arreglo a derecho, no solo en los contratos, sino en general, donde no domina el temor, sino la certeza; donde los hombres no se comportan unos con otros de forma inamistosa, sino cooperativa".

${ }^{2338}$ Ibídem, p. 45. Se refiere al estado de naturaleza que HOBBES planteara en el Leviatán, en la afirmación que existe una especie de sobre-estimación de la fuerza física que hace suponer la imposición de un sujeto frente a otro.

${ }^{2339}$ Ibídem. 


\section{LOS EFECTOS DE LA PUBLICIDAD EN EL DOCUMENTO NOTARIAL}

el orden social no excluye de ninguna manera actos coercitivos que vienen a garantizar la paz $^{2340}$ (esta situación se extiende inclusive hacia los Estados parte del mundo, porque el jurista vienés aspira a consolidar la paz internacional a través del derecho ${ }^{2341}$ ).

El documento notarial con publicidad cartular intrínseca es en este sentido, un verdadero baluarte del derecho y de la paz. Una consolidación de la certeza, la verdad y la justicia que, aplicada adecuadamente con el criterio de prudencia notarial referido, definitivamente evita el conflicto. Dejando de lado análisis jurídicos eminentemente notarialistas, son muy pocos los filósofos y juristas del derecho en general quienes se han remitido a las bondades del documento y a los principios que del mismo emanan cuando se ha realizado de acuerdo al derecho. Esta tesis ha intentado reunir a muchos de aquellos autores que han aportado una visión filosófica y notarialista destinada a asegurar la trascendencia del derecho en la paz.

Sin embargo, es necesario reconocer que por más que hayan sucedido en el tiempo algunos aportes notables -incluso paradigmáticos-, la situación real perceptible por el hombre y la mujer de nuestros días, de sentir que tanto lo justo como la paz se consolidan luego de ocurrido el proceso de judicialización de una situación que se ha elevado a conflicto, es lo que en última instancia confirma nuestro acostumbramiento a vivir y convivir dentro de la anormalidad. Lo normal es la vida sana, vivida y sentida de acuerdo a lo que a cada cual corresponde. Lo ajeno es lo que causa una anormalidad, y si lo afirmado se logra sentir de otra manera, habrá que esperar un enorme cambio social que posicione el derecho desde la paz, cada vez más lejos de una situación que pueda generar algún tipo de controversia en el futuro.

El resultado de la confirmación de los valores en equilibrio dentro del documento notarial, deriva la atención del litigio y acerca la sensación de previsibilidad. ¿Qué es lo que se previene? Se previene que no ocurra el conflicto. Es necesario alejarse inclusive de las tesis que propugnan la jerarquía de los valores en este tema. Sin descuidar los planteos hasta aquí realizados, lo que verdaderamente importa es que existen tres valores

${ }^{2340}$ Cfr. Hans KELSEN, La paz por medio del derecho, Losada, Buenos Aires, 1.946, p. 27.

${ }^{2341}$ Ídem, p. 36. 


\section{SEBASTIÁN JUSTO COSOLA}

esenciales para el derecho que coexisten en el documento notarial, y que son determinantes para la consolidación de un cuarto valor (paz) que es lo que en definitiva augura el hombre y la mujer de nuestro tiempo. Todo esto hace pensar en cuanta razón le asistía a nuestros maestros del arte notarial, cuando afirmaban, en el caso de Monasterio, que la función notarial, a través del documento, daba vida e impulso a la declaración biológica de los derechos en la normalidad; o en el caso de Vallet, cuando enseñaba que el derecho es -de nuevo lo traigo aquí- una parcela de la realidad humana que oscila entre el amor y la fuerza. A esta última expresión, debe permitírseme agregarse mi convencimiento y mi aporte: que la idea de fuerza para el derecho sea siempre una acción de excepción; y que la idea del cumplimiento espontáneo, sea siempre la regla general. La función notarial creadora del derecho en el documento se consolida clara y definitivamente en el marco del cumplimiento espontáneo. Quizás sea éste el compromiso más importante que tengamos que asumir los profesores de derecho en la actualidad. Transmitir la idea del cumplimiento espontáneo por el deber mismo y por el respeto al otro que a nuestro lado se desarrolla y vive. Enseñar que la patología causada por el incumplimiento de la ley o del derecho no puede ni debe ser analizada como una teoría del poder de la conducta, sino más bien como una desviación del deber que ordena el correcto y adecuado desenvolvimiento. Revalorizar los elementos de decisión jurídica que cumplen una tarea de profilaxis es en definitiva, comenzar a transitar un nuevo sendero en la enseñanza y en la aplicación y concreción del derecho. El más necesitado en momentos en donde la comunidad generalizada necesita de una cobertura de esperanza. Quizás de difícil abordaje. Pero sin dudas, el más prominente de todos.

15.4. La valoración de la publicidad del documento notarial: armonía y contención.

La utilización del método comparativo me ha puesto en la fantástica necesidad de exponer los tres sistemas de publicidad de los derechos reales 
con los que cuenta en general, la ciudadanía nacional y extranjera que adopta un mismo sistema jurídico continental. De acuerdo a ese esquema, debe concluirse que existen y existirán siempre conflictos personales a favor o en defensa de los derechos implicados que las personas intentan alcanzar durante todo el transcurso de su vida. El principio legal ordena realizar los derechos de acuerdo a lo que legítimamente a cada cual corresponde, pero el paradigma de la realidad nos impone aceptar que esta situación ideal no es en un todo posible. El hecho que el derecho proyecte las relaciones de poder, los interdictos y las defensas al uso y disfrute de las cosas aun ajenas, viene a comprobar que la situación ideal de regularización del ejercicio de los derechos reales lejos está de alcanzarse y consolidarse. Desde este punto de vista, podría entonces intentarse la siguiente conclusión:

a) La posesión fundamenta su eficacia publicitaria en la fuerza emergente del derecho;

b) La registración fundamenta su existencia tanto en la prioridad como en la publicidad noticia (exhibición + información);

c) El documento fundamenta la fuerza y la potencia tanto en la certeza (legal) como en la seguridad.

Afirmar lo antedicho implica ante todo, fijar posición al respecto. Lo expuesto conforma un primer punto de vista, que reconoce los alcances de cada institución desde un criterio real - y ciertamente avalado por decisiones jurisprudenciales relevantes-, pero que inevitablemente derivará los casos que se susciten a los conflictos que siempre terminarán por originarse.

Las instituciones en tratamiento determinan además, pautas que permiten encontrar, entre todas ellas, los necesarios puntos de contacto para que las mismas puedan funcionar de la manera más armoniosa que les sea posible. Este método ayudará además a lograr el necesario alejamiento de las teorías autonómicas extremas, que intentan siempre imponer -sobre los apoyos mayoritarios académicos o las líneas jurisprudenciales consolidadas a través del tiempo- la idea que una institución es más relevante que la otra. Al tener que acudir el jurista en la actualidad a la fuente originaria de todos los derechos y los deberes, y no tanto a la norma parcializada del tema en 


\section{SEBASTIÁN JUSTO COSOLA}

discusión, la tesis de la imposición de derechos y ejercicios mejores y peores comienza a perder adeptos y con ello, a generar criterios sostenidos a partir de las influencias negatorias de la composición de intereses desde la paz.

Las tres publicidades emergentes de la proyección de los derechos reales que el derecho actual exhibe son jerarquizadas. Y es precisamente esa jerarquía lo que les permite desarrollarse con el máximo grado de esplendor. El ejercicio irregular del derecho siempre tenderá a que las mismas convivan en situación de conflicto ${ }^{2342}$. Pero la propuesta y elaboración de un derecho con autorictas proveniente de la ley tiene otra fundamentación, que es la expuesta en esta tesis, y tiene una misión finalísima, que es la que las dirige a convivir en un máximo de armonía para evitar en el futuro, la sustanciación del conflicto. El documento notarial, por su singular misión y función, es el único que contiene en su seno la convivencia equilibrada de los valores referidos, y con ello, la proyección de los nobles efectos publicitarios emergentes de la posesión y del registro, dando importancia esencial a la cuestión declarativa de las partes otorgantes (confesión), realizando las comprobaciones que sean necesarias en cada acto en concreto, y brindando el respaldo necesario a la publicidad que perfecciona las transmisiones a través de la adecuada y obligada registración. Es definitivamente en el centro del documento notarial en donde se consolidan en armonía las otras dos instituciones, y le sirven de respaldo para alcanzar la máxima seguridad (previsibilidad + conservación), que como hemos visto, supone a la $f e$ (certeza + verdad) y exhibe ampliamente desde la voluntad tutelada, un acertado y coherente panorama de la justicia.

\footnotetext{
${ }^{2342}$ Ese principio de realidad social al que me refería recientemente -y que fuera expuesto en el cuerpo de esta tesis en el momento de desarrollar la sociología del derecho notarial- impone e impondrá, por muchísimo tiempo más, que los conflictos a los que estamos acostumbrados a enseñar en las aulas universitarias sigan siendo tan comunes y posibles como frecuentes e inmodificables. Es imposible entonces que el hombre necesitado de tierra, y por ende, de hogar, pretenda una titulación justa si ni siquiera puede acceder al beneficio de la adquisición libre y depurada, porque definitivamente habitamos un país que presenta largas extensiones de tierras pero muy pocas oportunidades para su acceso. Esta realidad es la que se impone en nuestro suelo patrio, siempre recordando que desde el desarrollo del derecho de propiedad, en conjunción con los elementos emergentes de la seguridad jurídica en el desarrollo del principio de publicidad registral, debe priorizarse el acceso a la consolidación del dominio para asentar a la familia antes que potenciar el tráfico inmobiliario, en ocasiones despiadado e injusto.
} 
LOS EFECTOS DE LA PUBLICIDAD EN EL DOCUMENTO NOTARIAL

15.4.1. Resultado de la comprensión de los efectos publicitarios individualizados de la publicidad posesoria y registral.

Si se analizan individualmente los efectos publicitarios de las otras instituciones referidas y analizadas, fácilmente puede llegar a comprenderse que la producción de efectos es sumamente diferente a la que plantea la convivencia armónica axiológica del documento notarial. De esta manera:

a) El hecho de la posesión presenta sin duda alguna, un fuerte respaldo de la publicidad noticia general -publicidad posesoria- que es la que incluso exhibe el reconocimiento jurídico; pero carece del resguardo del documento $-\mathrm{o}$ justo título, en los términos jurídicos adecuados-.

b) La publicidad registral logra consolidar mayor seguridad jurídica que la que le proviene del examen extrínseco del documento que ingresa al registro. La publicidad registral desde su doble perspectiva -formal y material- contiene un esquema del documento, pero se advierte incapacitada de comprobar el hecho fáctico posesorio-traditivo (determinante del nacimiento del derecho real) por lo que solo queda confiar en las declaraciones que se efectúan en el seno del documento que ingresa para su perfeccionamiento publicitario con respecto a terceros. Esta situación no brinda al registrador la posibilidad de alcanzar la plenitud de la certeza a través de la mera registración, por lo que en definitiva desde el registro lo único que puede potenciarse es el principio de seguridad jurídica dinámica, pero no así la estática. Esta es la razón por la cual los autores dedicados al estudio profundo de la temática son consientes en reconocer que la debida registración, en variadas ocasiones, no alcanza a publicitar la verdad real, o dicho de otro modo; puede el registro dar publicidad de un hecho jurídico que 
proyecte una verdad registral ajena a lo verdaderamente extrarregistral. Lo registrado entonces puede o no coincidir con la verdad real, precisamente porque es materialmente imposible su efectiva comprobación.

\title{
15.4.2. Esquemas de la exposición y del tratamiento.
}

\author{
Efectos del Documento Notarial \\ (Posesión (traditio como confesión)+ Efectos intrínsecos y extrínsecos + \\ Registración)
}

Efectos de la Posesión

[Efectos publicitarios externos (- Documento)]

Efectos publicitarios de la Registración

[Efectos publicitarios reflejos desde el documento (- Posesión)]

Lo que en definitiva se explica desde los cuadros es una ponderación de instituciones, motivada esencialmente por la vigencia de los valores que en cada una viven y persisten. El documento notarial se realiza definitivamente bajo la tutela de los valores referidos. En este esquema, le resulta imposible a la posesión y su fuerza contener el valor de certeza, de verdad y de seguridad -aunque sí el de justicia-, y tampoco le resultará posible a registración 
contar con los valores de verdad y de justicia, aunque si probablemente pueda contar con el valor seguridad -en alusión a la seguridad jurídica dinámica.

\section{Documento Notarial}

[Fe (certeza y verdad) + Justicia + Seguridad (Estática y dinámica) $]$

\section{Posesión}

(Justicia)

\section{Publicidad Registral}

(Seguridad dinámica)

En este esquema, atribuir a la justicia el carácter de valor supremo, implica aceptar que el conflicto entre el documento y la posesión es en definitiva, un conflicto que no reconocerá fin alguno por cuanto lo que se siempre se producirá es un choque que tiene como protagonista al mismo valor superior, con proyección exacta de la misma jerarquía, donde el criterio decisorio judicial deberá tener en cuenta las cuestiones técnicas jurídicas aplicables a cada caso, pero teniendo en cuenta las fuentes jurídicas generales que en general, se erigen desde las mismas líneas directrices (prioridad, ejercicio del derecho real a partir de la posesión, fecha anterior, transcurso del tiempo, etc.).No se trata de discutir si existe o no existe el valor justicia en la institución posesoria o en la institución documental. Se trata de tener otra visión de la justicia, y de entenderla en el documento como una socia esencial de la seguridad y de la verdad. Definitivamente, debe comprenderse que en el derecho notarial la justicia y la seguridad no encuentran motivos para estar enemistadas. Y nuevamente: porque es únicamente en el documento en donde pueden convivir pacíficamente, se posicionan los baluartes desde una determinada situación singular que el propio ordenamiento jurídico admite y valora. De esta manera, la justicia y la 


\section{SEBASTIÁN JUSTO COSOLA}

seguridad, consolidadas como indubitables a partir de la fe (certeza +verdad) refuerzan una de las causas del documento, que es la de transmitir la paz. Como ya he expresado a lo largo y a lo ancho de esta tesis, el notario descubre a los derechos en su biología misma, y los documenta, precisamente por ejercer un magisterio de paz.

\section{Documento Notarial}

$[$ Fe pública (certeza y verdad $)+$ Justicia + Seguridad (estática y dinámica $)=$ Paz]

\subsection{Consideraciones finales.}

Al maestro español Antonio Monasterio debemos el concepto de función notarial determinante de la declaración biológica de los derechos en la normalidad: "Para asegurar el imperio normal del derecho, se requiere en nuestro concepto, crear un instrumento de proyección de la relación jurídica, sustantivo o incondicionado, que lleve consigo presunción de legitimidad en todos sus elementos constitutivos, personal, real y plástico y, por tanto, que valga por sí, sin necesidad de robustecerlo y sin que deba ser probado él mismo, no solo entre aquellos entre quienes media la relación, sino que también respecto a los que, en el tiempo, lleguen o puedan llegar a ser sujetos de ella (autenticidad) y respecto al mismo poder público (fuerza ejecutiva $)^{2343}$ ". Desde nuestro continente y felizmente en nuestro país, otro gran maestro del derecho civil, el recordado y siempre vigente Alfredo Colmo nos dejaba como legado esta fantástica enseñanza: “(...) cuando se comprenda que por encima de pequeños textos menos mal concebidos que

${ }^{2343}$ Cfr. Antonio MONASTERIO GALI, Biología de los derechos en la normalidad, Edic. de la UNA, La Plata, 1.966, p. 99. 


\section{LOS EFECTOS DE LA PUBLICIDAD EN EL DOCUMENTO NOTARIAL}

expresados, están los aludidos grandes principios, sedimento ineludible de cualesquiera leyes; cuando se sea capaz de una jurisprudencia superior y creadora, que contemple el derecho en lo complejo de su dinamismo, bien lejos del espiritu formulista y del errado simplismo según el cual todo se resuelve en la operación lógica de un silogismo, en cuya virtud se encasille el caso ocurrente en tal o cual precepto legal; cuando todo ello se practique se tendrá una noción mucho más cabal de la justicia. Y cuando se logre hacer entrar en la conciencia colectiva, mediante decisiones que prevengan o impidan las contiendas... con criterio que siempre sancione la verdad efectiva y haga comprender lo peligroso de los pleitos y lo firme de las soluciones privadas, entonces se habrá realizado el ideal de estas cosas: la mejor justicia es la que tiende a hacer inútil o innecesaria a la justicia ${ }^{2344}$ ". Con la mayor precisión que me fuera posible alcanzar, me he propuesto describir hasta aquí tanto los efectos generales y particulares de la publicidad emergente del documento notarial tal como lo he proyectado, como el principal fundamento que potencia a los mencionados efectos como sustanciales y guías del ordenamiento y del derecho en general frente a otros efectos que también proyectan las demás instituciones con publicidad jerarquizada admitidas y sostenidas, de la misma manera, tanto desde la ley como desde el derecho.

Para alcanzar ese objetivo, acudí a un esquema de realización propia que, según sostengo, ayuda a visualizar que lo determinante a tener en cuenta desde el documento notarial está dirigido a comprender la composición de su estructura, la conformación de sus componentes y dentro de ellos, el resplandor emergente de los efectos publicitarios cartulares que se advierten desde un análisis formal (exterior) o que se estudian desde un análisis sustantivo (interior). El documento es fuente de conocimiento, lo que implica reconocer en el principio de oponibilidad; la oponibilidad únicamente estará dirigida hacia quienes efectivamente han tenido la posibilidad de conocer su contenido, precisamente porque con él se resguardan los principios que ordenan respetar la privacidad de los actos. Con las mencionadas características, esa fuente de conocimiento se transforma en rectora cuando logra integrar en un mismo documento - y en

${ }^{2344}$ Alfredo COLMO, La justicia, ob. cit., págs. 58-59. 


\section{SEBASTIÁN JUSTO COSOLA}

cada lugar específico de la estructura y de los componentes que lo conforman- la fuerza de la publicidad extrínseca o principio de publicidad cartular externa con la potencia de la publicidad cartular intrínseca o principio de publicidad cartular interna. En este sentido, los valores jurídicos asimilados a lo bueno que emergerán del documento son los provenientes de la fe pública objetiva (certeza del derecho) y subjetiva (la verdad en el derecho), de la justicia (voluntad + tutela) y de la seguridad jurídica del querer (estática) y de la previsibilidad (dinámica).

Los valores jurídicos desarrollados en el documento no presentan jerarquías; se asumen y se interrelacionan de manera equilibrada, ayudando cada uno en el orden expuesto- a dar origen al otro en un perfecto estado de encadenamiento. De esta manera, la atribución de la investidura y nombramiento de los agentes, del procedimiento reglado y consolidado positivamente que viene a regir su actuación y consecuentemente con ello, la instrumentación coetánea de todo aquello que en ejercicio de la función se presencia, es el resultado de una suma de garantías objetivas que el ordenamiento exige para consolidar la certeza. La certeza es una cualidad sumamente relevante para el derecho, que permite hacer inferir al jurista intérprete que la misma contiene la verdad, otra cualidad de la fe a la que se arriba teniendo especialmente en cuenta las virtudes del autor. Esa verdad no es absoluta, y puede definitivamente derribarse frente al decisorio con imperium judicial cuando el sistema de responsabilidad notarial emite un alerta y esa señal a través de los medios de prueba admitidos por el ordenamiento jurídico alcanza a comprobarse. Mientras eso no ocurre, la autorictas notarial prevista y ordenada en la ley hace presuponer tanto la certeza como la verdad.

La certeza y la verdad del derecho proyectado en el documento no hacen más que potenciar la voluntad de quienes en su seno han realizado diversas y diferentes concesiones. No cualquiera de ellas, sino las que consideraron equitativas y justas. Ese resultado -emergente del pensamiento de cada cual-, se vuelve efectivo a partir del ejercicio de tutela notarial; la auditoria, el contralor, la colaboración con lo querido y lo pretendido por las partes involucradas en el documento y la concreción de los deberes éticos notariales aplicados genera el efecto de justicia. 
Lo cierto, lo seguro y lo justo requieren además, de una investidura que garantice que esa unión de valores pueda alcanzar definitivamente la máxima valoración jurídica por el hombre y la mujer, para quienes en definitiva están destinados los esfuerzos de interpretación y argumentación jurídica. En este sentido, quien efectúa una determinada concesión en un acto traslativo lo hace únicamente bajo su exclusiva voluntad, otorgando de manera libre el acto respectivo; y a esa recepción de la voluntad se responde, con similares criterios, de acuerdo a lo que el ordenamiento recepta y prescribe de las más variadas formas: aceptación, conformidad, asentimiento, renuncia, entre otros modos normales y naturales previstos para alcanzar la efectividad pretendida para cada hecho y para cada acto. La suma de todos esos extremos, cumplidos en el orden propuesto, generan el efecto de previsibilidad tanto del instrumento como de todo su contenido. Esa previsibilidad, destinada a durar en el tiempo que sea necesario, fundamenta la paz, cualidad a la que el derecho debe necesariamente adscribir, ya que únicamente la suma de todos los valores implicados puede efectivizar el no acaecimiento del conflicto posterior. La falta de alguno de esos valores no puede en modo alguno garantizar la paz, por ello es que tanto los efectos publicitarios alcanzados desde la posesión como los provenientes de la publicidad formal y material registral son relevantes pero insuficientes para alcanzar el último valor jurídico descripto. De ahí que los ordenamientos jurídicos positivos que regulan la vida privada de los hombres y mujeres que habitan una determinada nación que vive y se desarrolla de acuerdo al derecho prevean ciertas herramientas para las defensas publicitarias de la posesión -interdictos y defensas determinadas- y que aminoren definitivamente la fuerza publicitaria registral -efectos no convalidantes del registro inmobiliario-. Esas defensas no se justifican ni se advierten en el documento notarial descripto en las leyes positivas, que únicamente puede encontrar el peligro de la invalidez a través tanto de las teorías de la ineficacias como de la teoría de la impugnación antes descripta, pero que de ninguna manera llegarán a consolidarse si desde el mismo se advierten y se proyectan, de nuevo, los efectos publicitarios intrínsecos y extrínsecos, proyectando los valores referidos, todos juntos determinantes de la paz. 
SEBASTIÁN JUSTO COSOLA 
LOS EFECTOS DE LA PUBLICIDAD EN EL DOCUMENTO NOTARIAL

\section{BIBLIOGRAFÍA GENERAL}

A.A.V.V, Seguridad del tráfico inmobiliario: la necesidad de instrumentos de regulación, Fernando TRUEBA BUENFIL (Coordinador Internacional) Eduardo Gabriel CLUSELLAS (Coordinador Nacional.), Revista Notarial 974, La Plata, 2.013.

ABELLA, Adriana Nélida (Dir.), Estudios de derecho inmobiliario, Zavalía, Buenos Aires, 2.012.

ABELLA, Adriana Nélida ABELLA, Derecho notarial (Derecho documental-responsabilidad notarial), Zavalía, Buenos Aires, 2.010.

ABELLA, Adriana Nélida, Documento notarial, Revista Notarial n ${ }^{\circ} 941, \mathrm{La}$ Plata, 2002.

ABELLA, Adriana Nélida, Derecho inmobiliario registral, Zavalía, Buenos Aires, 2.009.

ABELLA, Adriana Nélida y SABENE, Sebastián E., El boleto de compraventa. Acuerdos previos. Aspectos y consecuencias, en Adriana Nélida ABELLA (Dir.), Estudios de derecho inmobiliario, Zavalía, Buenos Aires, 2.012.

ABELLA, Adriana Nélida y SABENE, Sebastián E., Vivienda, en Eduardo G. CLUSELlAS (Coord.), Código Civil y Comercial. Comentado, Anotado $y$ Concordado, $\mathrm{t}^{\circ} \mathrm{I}$, Astrea-FEN, Buenos Aires, 2.015.

ABELLA, Adriana Nélida y REGIS, Ariel, De los instrumentos públicos, en Eduardo G. CLUSELLAS (Coord.), Código Civil y Comercial. Comentado. Anotado y Concordado, $\mathrm{t}^{\circ} \mathrm{I}$, Astrea-FEN, Buenos Aires, 2.015.

ABREU DE POLANCO, Rhadys I., Lecciones de derecho notarial, Servicios Gráficos Integrados, Santa Domingo, 2.005.

ABREUT de BEGHER, Liliana, Derechos reales, Hammurabi, Buenos Aires, 2.016.

ACADEMIA ARGENTINA DE LETRAS, Diccionario del habla de los argentinos, La Nación, Buenos Aires, 2.008.

ACQUARONE, María Teresita (Dir.) y AA.VV, Derecho Inmobiliario, Di Lalla, Buenos Aires, 2.010. 
ADORNO, Theodor W., Filosofia y sociología, trad. Mariana DIMÓPULOS, Eterna Cadencia, Buenos Aires, 2.015.

ADROGUÉ, Manuel I, GUTIÉRREZ ZALDIVAR, Álvaro, ARRAGA PENIDO, Mario O., y AMUY, Juan Carlos, Temas de derechos reales, Plus Ultra, Buenos Aires, 1.986.

ADROGUÉ, Manuel I., La transmisión de la posesión por causa de muerte, en Manuel I. ADROGUÉ, Álvaro GUTIÉRREZ ZALDIVAR, Mario O. ARRAGA PENIDO y Juan Carlos AMUY, Temas de derechos reales, Plus Ultra, Buenos Aires, 1.986.

ADROGÚE, Manuel, La escritura pública y el derecho registral, en Curso de derecho registral inmobiliario, Ediciones Pannedille, Buenos Aires, 1.971.

AFTALIÓN, Enrique, VILANOVA, José y RAFFO, Julio, Introducción al derecho, LexisNexis- Abeledo Perrot, Buenos Aires, 2.004.

AGRAZ, César Eduardo, Derecho notarial comparado en la República Mexicana, Porrúa e Instituto Internacional del Derecho y del Estado, México, 2.011.

AGUILAR BASURTO, Luis Arturo, La función notarial. Antecedentes, naturaleza y nuevas tendencias de la función notarial, Ubijus, México, 2.015 .

AHRENS, Enrique, Curso de derecho natural o de filosofia del derecho, trad. Pedro RODRIGUEZ HORTELANO y Mariano Ricardo DE ASENSI, Librería Editorial De Bailly-Bailliere e Hijos, Madrid, 1.903.

ALBALADEJO, Manuel, Compendio de derecho civil, José María Bosch Editor, Barcelona, 1.997.

ALCHOURRÓN, Carlos E., y BULYGIN, Eugenio, Sistemas normativos, Astrea, Buenos Aires, 2.012.

ALESSIO ROBLES, Miguel, Temas de derechos reales, Porrúa, México, 2.015 .

ALEXY, Robert, Teoría de los derechos fundamentales, Trad. Carlos BERNAL PULIDO, Centro de Estudios políticos y constitucionales, Madrid, 2.008 .

ALEXY, Robert, Teoría de la argumentación jurídica, Palestra, Lima, 2.010 .

ALEXY, Robert, La construcción de los derechos fundamentales, Ad-Hoc, Buenos Aires, 2.010.

ALFONSÍN, Raúl, Fundamentos de la República Democrática. Curso de Teoría del Estado, Eudeba, Buenos Aires, 2.006. 
LOS EFECTOS DE LA PUBLICIDAD EN EL DOCUMENTO NOTARIAL

ALLENDE, Guillermo L., Panorama de derechos reales, La Ley, Buenos Aires, 1.967.

ALLENDE, Guillermo L., La posesión, Abeledo Perrot, Buenos Aires, 1.959.

ALLENDE, Guillermo L., Metodología y modernas orientaciones en materia de derechos reales, Cooperadora del Centro de Derecho y Ciencias Sociales, Buenos Aires, 1.962.

ALLENDE, Ignacio M., La institución notarial y el derecho, Abeledo Perrot, Buenos Aires, 1.969.

ALTERINI, Atilio Aníbal, La inseguridad jurídica, Abeledo Perrot, Buenos Aires, 1.993.

ALTERINI, Atilio Aníbal, Código Civil Sistematizado, La Ley, Buenos Aires, 2.010.

ALTERINI, Atilio Aníbal, Estudio de títulos, en Jorge H. ALTERINI (Dir.) e Ignacio E. ALTERINI (Coord.), Derecho Notarial, Registral e Inmobiliario. Doctrinas magistrales 1897-2012, to II, La Ley, Buenos Aires, 2.012, p. 495-516.

ALTERINI, Jorge Horacio, La locación y los derechos reales con función equivalente, Editora Platense, La Plata, 1.970 (TD).

ALTERINI, Jorge Horacio (Dir.) y ALTERINI, Ignacio Ezequiel (Coord.), Derecho Notarial, Registral e Inmobiliario. Doctrinas Magistrales 18972012, VII Tomos, La Ley y Colegio de Escribanos de la Ciudad de Buenos Aires, Buenos Aires, 2.012.

ALTERINI, Jorge Horacio, Certificados registrales. Reserva de prioridad y medidas judiciales, Revista Notarial $n^{\circ}$ 949, La Plata, 2.004.

ALTERINI, Jorge Horacio, La seguridad jurídica y las incertidumbres en la usucapión de inmuebles, La Ley 02/07/2008, 1- Academia Nacional del Derecho, 01/01/2008.

ALTERINI, Jorge Horacio, ANGELANI, Elsa Beatriz, CORNA, Pablo María y VÁZQUEZ, Gabriela Alejandra, Hacia una teoría general de las ineficacias, ED 172-942, 1.997.

ALTERINI, Jorge Horacio, Boleto de compraventa. Efectos de la entrega de la posesión entre las partes, Revista del Notariado $\mathrm{n}^{\circ} 796$, Ciudad de Buenos Aires, 1.984.

ALTERINI, Jorge Horacio, Gravitación de la reforma al artículo 2505 del Código Civil (Con especial referencia a las proyecciones de la tradición y al concepto de terceros), ED to 43, Buenos Aires, 1.972. 
ALTERINI, Jorge Horacio, La buena fe y la publicidad inmobiliaria registral y extrarregistral. Con una armonización entre la tradición y la inscripción registral, LL on line AR/DOC/497/2012.

ALTERINI, Jorge Horacio, La seguridad jurídica. Notariado y Registros, LL Temas Doctrinarios, 2 2007, 01/01/2007, 53- LLO, cita online: AR/DOC/495/2012.

ALTERINI, Jorge Horacio, Primeras consideraciones sobre los derechos reales en el proyecto de código, Academia Nacional del Derecho 2012 (Septiembre), 04/09/2012.

ALTERINI, Jorge Horacio, Protección constitucional de la vivienda familiar, JA 1992-IV-772.

ALTERINI, Jorge Horacio, Protección posesoria, en Cuestiones Esenciales en derechos reales, Carlos Gustavo VALLESPINOS (Director), LexisNexisAbeledo Perrot, Buenos Aires, 2.002.

ALTERINI, Jorge Horacio, Seguridad jurídica con costos razonables, fortaleza del régimen jurídico inmobiliario argentino, Reunión Plenaria de la Comisión de Asuntos Americanos de La UIN, Mar del Plata, 2.005. Cuadernillo de la UNA- EL crédito Inmobiliario Hipotecario, Biblioteca Central del Colegio de Escribanos de la Provincia de Buenos Aires.

ALTERINI, Jorge Horacio, Claves para tener en cuenta, Supl. Empresa, negocios y el nuevo Código Civil y Comercial, Thomson Reuters-La Ley, Diario La Nación, 30/08/2015.

ALTERINI, Jorge Horacio; FIGUEROA MÁRQUEZ, David; GARCÍA COLLANTES, José Manuel, PÉREZ FERNÁNDEZ DE CASTILLO, Bernardo y PIGNANELLI, Aldo, Mesa redonda: El notariado latino. Análisis comparativo entre el sistema jurídico documental latino y el anglosajón. Costo del contencioso y de las indemnizaciones, Revista del Notariado 888, Ciudad de Buenos Aires, 2.007.

ÁLVAREZ CAPEROCHIPI, José Antonio, Derecho inmobiliario registral, Ediciones Legales, Lima, 2.012.

ÁLVAREZ GARDIOL, Ariel, Manual de introducción al derecho, Juris, Rosario, 1.995.

ÁlVAREZ GARDIOL, Ariel, Pensamiento jurídico contemporáneo, Fundación para el desarrollo de las ciencias jurídicas, Rosario, Santa $\mathrm{Fe}$, 2.009 .

ÁLVAREZ GARDIOL, Ariel, La estructura de una teoría general del derecho, Fundación para el Desarrollo de las Ciencias Jurídicas, Rosario, 2.012 . 
ÁLVAREZ SALA-WALTHER, Juan, La representación y la calificación notarial, Revista Escritura Pública, Consejo General del Notariado Español, Madrid, 2.003.

ANDORNO, Luis O. y MARCOLÍN, Marta, Ley Nacional Registral Inmobiliaria 17801, Comentada y Anotada, Hammurabi, Buenos Aires, 1999.

ANDORNO, Luis, Publicidad Registral. Principios Registrales, en Cuestiones esenciales en derechos reales, Gustavo VALLESPINOS (Director), LexisNexis- Abeledo-Perrot, Buenos Aires, 2.002.

ANDRINO HERNÁNDEZ, Manuel, El sello notarial, Anuario Iberoamericano de Derecho Notarial $\mathrm{n}^{\circ}$ 2, Consejo General del Notariado, Madrid, 2.003.

ANTEPROYECTO de Código Civil unificado con el Código de Comercio 2012, Ediciones Códice, 2.012.

ANDRUET (h), Armando S., Teoría general de la argumentación forense,

Alveroni, Córdoba, 2.013.

ARANGIO-RUIZ, Vicenzo, Instituciones de Derecho Romano, Depalma, Buenos Aires, 1.986.

ARANGO, Rodolfo, El concepto de derechos sociales fundamentales, Universidad Nacional de Colombia-Legis, Bogotá, 2.005.

ARATA, Roberto Mario, Estudios para una historia del documento notarial, Colegio de Escribanos de la Provincia de Buenos Aires, La Plata, 1.980.

ARAUZ CASTEX, Manuel y LLAMBÍAS, Jorge Joaquín, Derecho CivilParte General, II Tomos, Editorial Perrot, Buenos Aires, 1.955.

ARAUZ CASTEX, Manuel, Derecho Civil. Parte General, II tomos, Empresa Técnico Jurídica Argentina, Buenos Aires, 1.965.

ARDISSONI, Élida Sara, Tradición de bienes inmuebles y muebles registrables, Universidad, Buenos Aires, 1.987.

AREÁN, Beatriz Alicia, La tradición y sus distintas funciones en el campo de los derechos reales y de las relaciones posesorias, Biblioteca de la Facultad de Derecho de la Universidad de Buenos Aires, $\mathrm{n}^{\circ}$ topográfico 252.343/1981 (TD).

AREÁN de DÍAZ DE VIVAR, Beatriz, Tutela de los derechos reales y del interés de los terceros, Abeledo Perrot, Buenos Aires, 1.979.

ARIAS CAU, Javier y PRIETO, Matías Leonardo, El contrato de compraventa, en Cristina Noemí ARMELLA (Dir.) y Mariano ESPER (Coord.), Corte Suprema de Justicia de la Nación. Máximos precedentes. Contratos, t $^{\circ}$ II, La Ley, Buenos Aires, 2.014. 
ARIAS MONTOYA, Oswaldo, Comentarios a la actualidad notarial peruana, Gaceta Notarial, Lima, 2.011.

ARISTÓTELES, Obras completas, IV Tomos, Bibliográfica Omeba, Buenos Aires, 1.967.

ARMELLA, Cristina Noemí (Dir.) y ESPER, Mariano (Coord.), Corte Suprema de Justicia de la Nación. Máximos precedentes. Contratos, III Tomos, La Ley, Buenos Aires, 2.014.

ARMELLA, Cristina Noemí (Dir.) y ESPER, Mariano (Inv.), Summa Notarial, Registral e inmobiliaria, VI Tomos, Abeledo Perrot y Universidad Notarial Argentina, Buenos Aires, 2.013.

ARMELLA, Cristina Noemí (Dir.) y ESPER, Mariano (Inv.), Summa de Contratos, VII Tomos, Abeledo Perrot, Buenos Aires, 2012.

ARMELLA, Cristina Noemí (Dir.), Tratado de Derecho Notarial, Registral e Inmobiliario, III Tomos, Ad Hoc, Buenos Aires, 1.998.

ARMELLA, Cristina Noemí y AAVV, Función Notarial y Responsabilidad, Revista Notarial no 886 -887, La Plata, 1.986.

ARMELLA, Cristina Noemí y COSOLA, Sebastián Justo, Abordaje teórico y práctico del adelantamiento de la mayoría de edad-Ley 26.579. Ad Hoc, Buenos Aires, 2.011.

ARMELLA, Cristina Noemí, De los instrumentos públicos, en Alberto J. BUERES (Dir.) y Elena I. HIGHTON (Coord.), Código Civil y normas complementarias. Análisis doctrinario y jurisprudencial, $\mathrm{T}^{\circ} 2^{\circ} \mathrm{C}$, Hammurabi, Buenos Aires, 1.999.

ARMELlA, Cristina Noemí, Instrumentos públicos, Código Civil y Comercial. Comentado, anotado y concordado, Eduardo Gabriel CLUSELLAS (Coord.), $\mathrm{t}^{\circ} \mathrm{I}$, Astrea-FEN, Buenos Aires, 2.015.

ARMELLA, Cristina Noemí, La función notarial y los Registros de la Propiedad, Revista Notarius n ${ }^{\circ}$ 12, Colegio de Notarios de Lima, 2.002.

ARMELLA, Cristina Noemí, ORIOL, Julieta Ema y PIAZZA, Marta Rosa, El documento notarial. Su valor probatorio, Revista Notarial $\mathrm{n}^{\circ}$ 909, Colegio de Escribanos de la Provincia de Buenos Aires, 1.991.

ARRUÑADA, Benito, Análisis económico del notariado, Consejo General del Notariado, Madrid, 1.995.

ASEFF, Lucía María, Argumentación jurídica y semiosis social, Juris, Rosario, 2.003 (TDI).

ATIENZA, Manuel, El sentido del derecho, Ariel, Barcelona, 2.012.

ATIENZA, Manuel, Tras la justicia, Ariel, Barcelona, 1.997.

AVILA, Humberto, Teoría de la seguridad jurídica, Marcial Pons, Madrid, 2.012 . 
LOS EFECTOS DE LA PUBLICIDAD EN EL DOCUMENTO NOTARIAL

ÁVILA ÁlVAREZ, Pedro, Estudios de Derecho Notarial, Ediciones Nauta S.A, Barcelona, 1.962.

AZZARRI, Juan Cruz, El fallo "grupo Clarín": El derecho de propiedad y los derechos adquiridos:

http://www.colabogados.org.ar/larevista/pdfs/id18/el-fallo-grupo-clarin.pdf (Ultimo Acceso: 13/08/2017).

BADRAN, Juan Pablo, Acciones posesorias y reales. Teoría y práctica, Lerner Editora S.R.L, Córdoba, 2.015.

BALBÍN, Carlos F., Impacto del Código Civil y Comercial en el derecho administrativo, Astrea y DPI Cuántico, Buenos Aires, 2.016.

BARDALLO, Julio R., Relaciones jurídicas notariales, $\mathrm{RdN} \mathrm{n}^{\circ} 717$, Buenos Aires, 1.971.

BARRIOS GONZÁLEZ, Boris, Derecho notarial panameño, Cultural Portobelo, Panamá, 2.006.

BASAVE FERNÁNDEZ DEL VALLE, Agustín, Filosofía del derecho, Porrúa, México, 2.013.

BECERRA PALOMINO, Carlos Enrique, El honor de dar fe. Ensayos de Derecho Notarial, Editorial Jurídica del Perú, Lima, 2.015.

BELLUSCIO, Augusto César (Director) y ZANNONI, Eduardo A. (Coordinador), Código Civil y leyes complementarias, 9 Tomos, Astrea, Buenos Aires, 2.001-2009.

BELLVER CANO, Antonio, Principios de régimen notarial comparado, Librería General de Victoriano Suarez, Madrid (No cita año de edición).

BENEDETTI, Julio César, La posesión. Teoría y práctica de su amparo, Astrea, Buenos Aires, 1.976 (TD).

BERNARD, Tomás Diego (h), Temas de derecho e historia notarial, Ediciones Esnaola, Buenos Aires, 1.965.

BERNARD, Tomás Diego, EJO, voz escriba, Editorial Driskill S. A, Buenos Aires, Tomo X, 1.993, p. 579.

BERTOLINO, Pedro J., La verdad jurídica objetiva, Depalma, Buenos Aires, 1.990 .

BETTI, Emilio, Teoría general del negocio jurídico, Editorial Comares S.L, Granada, 2.000.

BIDART CAMPOS, Germán J., Nociones constitucionales. Las intersecciones iusnaturalistas de la Constitución, Ediar, Buenos Aires, 2.007 .

BIDART CAMPOS, Germán José, Filosofía del derecho constitucional, Ediar, Buenos Aires, 1.969. 
BIDART CAMPOS, Germán José, La historicidad del hombre, del derecho $y$ del Estado, Ediciones Manes, Buenos aires, 1.965.

BIELSA, Rafael, Los conceptos jurídicos y su terminología, Depalma, Buenos Aires, 1.961.

BIONDI, Biondo, La ciencia del derecho como arte de lo justo, AAMN- $\mathrm{t}^{\circ}$ IX, Instituto Editorial Reus, Madrid, 1.957.

BLANCO, Guillermo P., Curso de antropología filosófica, Educa, Buenos Aires, 2.002.

BLAQUIER, Carlos Pedro Tadeo, Crisis de la seguridad jurídica y crisis del derecho, Biblioteca de la Facultad de Derecho de la Universidad de Buenos Aires, $\mathrm{n}^{\circ}$ topográfico 251.048/1954, p. 7 (debe pedirse con el numero topográfico 250.819) (TDI)

BOFFI BOGGERO, Luis María, Instrumento público, Enciclopedia Jurídica Omeba, Driskill S.A, Buenos Aires, 1.996.

BOLÁS ALFONSO, Juan, El papel del notariado europeo en el nuevo espacio jurídico y económico, Revista Escritura Pública, Consejo General del Notariado Español, Madrid, 2.004.

BONILLA, Carlos E., Tratado de documentología, La Rocca, Buenos Aires, 2.014 .

BONILLA MALDONADO, Daniel (Coord.), La función social de la propiedad, Eudeba, Buenos Aires, 2.013.

BONO, Gustavo A., El artículo $7^{\circ}$ frente a los derechos reales: esquema general y consideración especial de las adquisiciones por usucapión y por donación, RDPC 2015-1, Rubinzal-Culzoni, Santa Fe, 2.015.

BORDA, Guillermo A., La reforma de 1968 al Código Civil, Perrot, Buenos Aires, 1.971.

BORDA, Guillermo A., Manual de derecho Civil. Derechos Reales, Delfina M. BORDA (Actual.), La Ley, Buenos Aires, 2.008.

BORDA, Guillermo, Tratado de derecho civil. Parte General, to I, La Ley, Buenos Aires, 2.008.

BORDA, Alejandro y A.A.V.V, Derecho Civil-Contratos, La Ley, Buenos Aires, 2.016.

BORTHWICK, Adolfo E.C., Nociones fundamentales del proceso (O una selección - de elite-de autores de derecho procesal abordando los temas trascendentes del proceso), Mave, Corrientes, 2.001.

BOTERO BERNAL, Andrés, (Coord.), Filosofia del derecho Argentina, Temis, Bogotá, Colombia, 2.008.

BRANDELLI, Leonardo (Coord.), Ata Notarial, Sergio Antonio Fabris Editor, Sao Paulo, 2.004. 
LOS EFECTOS DE LA PUBLICIDAD EN EL DOCUMENTO NOTARIAL

BRANDI TAIANA, Maritel M., La transmisión de dominio de inmuebles en el derecho español, $\mathrm{RN}^{\circ}{ }^{\circ}$ 948, La Plata, 2.004.

BRUNNER, Emil, La justicia. Doctrina de las leyes fundamentales del orden social, traducción de Luis RECASÉNS SICHES, Centro de Estudios Filosóficos-UNAM, México, 1.961.

BUERES, Alberto J., Responsabilidad civil del escribano, Hammurabi, Buenos Aires, 1.984.

BUERES, Alberto J., Código Civil y Comercial de La Nación analizado, comparado y concordado, III tomos, Hammurabi, Buenos Aires, 2.017.

BUNGE, Mario, Ética y ciencia, Siglo Veinte, Buenos Aires, 1.985.

BUNGE, Mario, La ciencia. Su método y su filosofía, Sudamericana, Buenos Aires, 2.009.

BUNGE, Mario, Las ciencias sociales en discusión, Sudamericana, Buenos Aires, 1.999.

BUNGE, Mario, Sistemas sociales y filosofia, Sudamericana, Buenos Aires, 1.999.

CALATAYUD SIERRA, Adolfo, La obligación notarial de suministrar datos al catastro, $\mathrm{RJdN} \mathrm{n}^{\circ}$ 33, Madrid, 2.000.

CANTERO NÚÑEZ, Estanislao, El concepto del derecho en la doctrina española (1939-1998)-La originalidad de Juan Vallet de Goytisolo, Fundación Matritense del Notariado, Madrid, 2.000 (TD).

CAÑAL, Diana Regina, El contenido formal y sustancial del derecho: una contradicción aparente (Una mirada desde el derecho del trabajo), Biblioteca de la Facultad de Derecho de la Universidad de Buenos Aires, ${ }^{\circ}$ topográfico 253.521/2005 (TD).

CAPOLUPO DE DURAÑONA y VEDIA, Ana María, La sentencia. Su fundamentación. Recursos, Biblioteca de la Facultad de Derecho de la Universidad de Buenos Aires, $\mathrm{n}^{\circ}$ topográfico 253.383. (TD)

CAPON FILAS, Mario J. y ETCHEVERS, Pedro, La publicidad registral en las VIII Jornadas Nacionales de Derecho Civil, ED 98-827.

CARBONELL, Miguel, Neoconstitucionalismo y derechos fundamentales, Ad-Hoc, Buenos Aires, 2.013.

CARDENAS MONTFORT, Emilio, Notarial services in Nafta. The North American Free Trade Agreement, Author Edition, Montreal Cánada, 2.004.

CARMINIO CASTAGNO, José Carlos, Algunas disquisiciones sobre la forma jurídica, en Teoría General del Acto Notarial y otros estudios, $\mathrm{t}^{\circ} \mathrm{I}$, Edición del autor, Paraná, 2.006.

CARMINIO CASTAGNO, José Carlos, Teoría general del acto notarial y otros estudios, II Tomos, Edición del Autor, Paraná, 2.006. 


\section{SEBASTIÁN JUSTO COSOLA}

CARNELUTTI, Francesco, Arte del derecho. Metodología del derecho, El Foro, Buenos Aires, 2.006.

CARNELUTTI, Francesco, La figura jurídica del notariado, Reus, Madrid, 1.954.

CARNELUTTI, Francesco, Teoría del falso y el daño y el delito, El Foro, Buenos Aires, 2.004.

CARNELUTTI, Francesco, Teoría general del derecho, trad. Francisco Javier OSSET, Editorial Revista de Derecho Privado, Madrid, 1.955.

CARRAL Y DE TERESA, Luis, Derecho Notarial y Derecho Registral, Porrúa, México, 2007.

CARRANZA TORRES, Luis R., El hipertexto, la página web y su constatación por escribano público, ED 229-17.

CARRICA, Pablo A., Derecho Documenta (Instrumentos públicos, privados y particulares), La Ley, Buenos Aires, 2.003.

CARRIO, Genaro, Notas sobre lenguaje y derecho, LexisNexis-Abeledo Perrot, Buenos Aires, 2.006

CASARES, Tomás D., La justicia y el derecho, Abeledo Perrot, Buenos Aires, 1.997.

CASTÁN TOBEÑAS, José, Función notarial y elaboración notarial del derecho, Reus, Madrid, 1.946.

CASTÁN TOBEÑAS, José, La justicia y su contenido a la luz de las concepciones clásicas y modernas, Servicio de Publicaciones de la Secretaría General Técnica del Ministerio de Justicia, Madrid, 1.967.

CASTÁN TOBEÑAS, José, Prólogo de la obra de José María MENGUAL Y MENGUAL, Elementos de derecho notarial, t ${ }^{\circ}$ I (Prel.), Librería Bosch, Barcelona, 1.931.

CASTÁN TOBEÑAS, José, La idea de justicia en la tradición filosófica del mundo occidental y en el pensamiento español, IER, Madrid, 1.946.

CASTAN TOBEÑAS, José, La noción del derecho a través de los sistemas filosófico-jurídicos tradicionales y modernos, IER, Madrid, 1.947.

CASTÁN VAZQUEZ, José María, Las bases iusnaturalistas del derecho privado hispanoamericano, Academia Nacional del Derecho y Ciencias Sociales de Córdoba, http://www.acaderc.org.ar/doctrina/articulos/las-basesiusnaturalistas-del-derecho-privado.

CASTILLO OGANDO, Nelson Rudys, Derecho notarial, II Tomos, Trajano Potentini Editorial, Santo Domingo, 2.007.

CERÁVOLO, Francisco, Revitalización de los valores esenciales del notariado, $\mathrm{RN} \mathrm{n}^{\circ}$ 796, La Plata, 1.971. 
LOS EFECTOS DE LA PUBLICIDAD EN EL DOCUMENTO NOTARIAL

CHICO Y ORTÍZ, José María, Teoría, práctica y formula de la calificación registral, Marcial Pons, Madrid, 1.977-1978.

CHINEA GUEVARA, Josefina, La función notarial como garante de la seguridad jurídica contractual en el ordenamiento jurídico cubano, en Derecho Notarial, Leonardo B. PEREZ GALLARDO e Isidoro LORATAMAYO (Coord.), T ${ }^{\circ}$ I, Félix Varela, La Habana, 2.006.

CIANCIARDO, Juan (Dir.), Multiculturalismo y universalismo de los derechos humanos, Ad-Hoc, Buenos Aires, 2.008.

CIANCIARDO, Juan, El ejercicio regular de los derechos, Ad-Hoc, Buenos Aires, 2.007 (TD).

CIANCIARDO, Juan, El principio de razonabilidad. Del debido proceso sustantivo al moderno juicio de proporcionalidad, Ábaco, Buenos Aires, 2.009 .

CIANCIARDO, Juan, Principio de proporcionalidad y concepto de derecho. Una aproximación desde la tesis del positivismo jurídico, Ad-Hoc, Buenos Aires, 2.009.

CIANCIARDO, Juan, Problema y sistema. Una aproximación al pensamiento de Theodor Viehweg, en AFJS n 25, Abeledo Perrot, Buenos Aires, 2.006,

CIFUENTES, Santos, Negocio Jurídico, Astrea, Buenos Aires, 2.004.

CIFUENTES, Santos, Derechos Personalísimos, Astrea, Buenos Aires, 2.008 .

CIFUENTES, Santos, Código Civil Comentado y Anotado, Coordinado por Fernando Alfredo SAGARNA, $\mathrm{t}^{\circ}$ II, $3^{\circ}$ ed., La Ley, Buenos Aires, 2.011.

CIURO CALDANI, Miguel Ángel, Introducción al derecho, la disciplina de la Unidad del derecho, $2^{\circ}$ Encuentro de Profesores de Introducción al Derecho, UNLP, 2.002.

CIURO CALDANI, Miguel Ángel, Valores de la actividad notarial, Gaceta del Notariado ${ }^{\circ}$ 7, Rosario, 1.979.

CIURO CALDANI, Miguel Ángel, Notas trialistas sobre la filosofia del derecho registral, RIyD Vol. VIII, Rosario, 1.988.

CIURO DE CASTELLO, Norma Elena (Recop.), Jornadas Notariales Argentinas (1944-2008), FEN, La Plata, 2.010.

CIURO DE CASTELLO, Norma Elena y GARATE, Laura (Comp.), Jornada Notarial Bonaerense. Colegio de Escribanos de la Provincia de Buenos Aires, FEN, La Plata, 2.007.

CLERC, Carlos Mario, El derecho de dominio y sus modos de adquisición, Ábaco, Buenos Aires, 1.982 . 
CLERC, Carlos Mario, La posesión de cosas muebles, Biblioteca de la Facultad de Derecho de la Universidad de Buenos Aires, $\mathrm{n}^{\circ}$ topográfico 253.231/1994 (TD).

CLERC, Carlos Mario, Derechos Reales en el nuevo Código Civil y Comercial de La Nación, Erreius, Buenos Aires, 2.016.

CLÉRICO, Laura, El examen de proporcionalidad en el derecho constitucional argentino, Eudeba, Buenos Aires, 2.009 (TDI).

ClUSELlAS, Eduardo G. (Coord.), Código Civil y Comercial. Comentado, anotado y concordado., 8 Tomos, Astrea-Fen, Buenos Aires, 2.015.

COGHLAN, Antonio R., Teoría general de derecho inmobiliario registral, Abeledo Perrot, Buenos Aires, 1995.

COING, Helmut, Fundamentos de filosofia del derecho, Trad. Juan Manuel MAURI, Asde Ediciones Previas, Córdoba, Argentina, 1.995.

COLMO, Alfredo, La justicia, Abeledo Perrot, Buenos Aires, 1.957.

COMPAGNUCCI DE CASO, Rubén Héctor, El negocio jurídico, Astrea, Buenos Aires, 1.992.

COMPAGNUCCI DE CASO, Rubén Héctor, Manual de obligaciones, Astrea, Buenos Aires, 1.997.

CÓRDOBA, Marcos M. (Dir.), GARRIDO CORDOBERA, Lidia M. y KLUGER, Viviana (Coord.), Tratado de la buena fe en el derecho, II Tomos, La Ley, Buenos Aires, 2.005.

CORNA, Pablo María, Prescripción adquisitiva, Ediciones Carra, Buenos Aires, 1.984 .

CORNEJO, Abel, Seguridad jurídica, Virtudes, Salta, (sin cita del año de edición).

CORNEJO, Américo Atilio, Derecho registral, Astrea, Buenos Aires, 2.001. CORREDOR PARDO, Manuel, Falsedad documental: ficción social del autor, UEC, Bogotá, 2.007.

COSOLA, Eduardo Justo, Ser éticos, RE-Colescba, La Plata, 1.999.

COSOLA, Sebastián Justo, Cuestiones registrales del automotor y reclamo de daños y perjuicios derivados de un accidente, en Marcelo J.LÓPEZ MESA (Dir.), Responsabilidad por accidentes de tránsito, $\mathrm{t}^{\circ}$ III, La Ley, Buenos Aires, 2.014.

COSOLA, Sebastián Justo, El concepto de derecho notarial a la luz de la naturaleza de la función (Diálogos entre Vallet de Goytisolo y Von Ihering), en Leonardo B. PEREZ GALLARDO y Miguel Ángel ARÉVALO (Coord.), Escritos sobre derecho notarial, Gaceta Notarial, Lima, 2.013.

COSOLA, Sebastián Justo, Escritura pública y acta, en Julio César RIVERA y Graciela MEDINA (Dir.) y Mariano ESPER (Coord.), Código 
LOS EFECTOS DE LA PUBLICIDAD EN EL DOCUMENTO NOTARIAL

Civil y Comercial de La Nación comentado, t ${ }^{\circ}$ I, La Ley, Buenos Aires, 2.014 .

COSOLA, Sebastián Justo, Fundamentos del Derecho Notarial. La concreción del método, $\mathrm{t}^{\circ} \mathrm{I}$, Ad- Hoc, Buenos Aires, 2.013.

COSOLA, Sebastián Justo, Identidad natural en la evolución académica y jurisprudencial de los conceptos de filosofía del derecho y de derecho notarial. Necesidad impostergable de la reflexión iusfilosófica notarial, en Roberto A. LUCERO ESEVERRI y Leonardo B. PEREZ GALLARDO (Coord.), Panorama actual del derecho notarial en Hispanoamérica, Júpiter Editorial, Buenos Aires, 2.011.

COSOLA, Sebastián Justo, Instrumentos públicos, en Julio C. RIVERA y Graciela MEDINA (Dir.) y Mariano ESPER (Coord.), Código Civil y Comercial de La Nación, t $^{\circ}$ I, La Ley, Buenos Aires, 2.014.

COSOLA, Sebastián Justo, Interpretación iusfilosófica de los principios notariales, RTFD n ${ }^{\circ}$ 11, Madrid, 2008.

COSOLA, Sebastián Justo, La prudencia notarial, Gaceta Notarial, Lima, 2.014 .

COSOLA, Sebastián Justo, Los deberes éticos notariales, Ad-Hoc, Buenos Aires, 2.008 .

COSOLA, Sebastián Justo, Perfiles ético-jurídicos de los principios de legalidad notarial y registral (Armonía y complementariedad), en Estudios de Derecho Notarial Iberoamericano (Homenaje a Nery Roberto Muñoz), Coordinado por Leonardo PÉREZ GALLARDO, Infoconsult Editores, Guatemala, 2.013.

COSOLA, Sebastián Justo; DEL CARRIL, Enrique Horacio; MONTESANO, Luis y FINN, Santiago, Ética de las profesiones jurídicas (Abogados, jueces, notarios), Ad-Hoc, Buenos Aires, 2.010.

COSOLA, Sebastián Justo, La capacidad, la minoridad y el principio de razonabilidad notarial (Argumentación de la teoría de la personalidad humana a partir del art. 3 del Código Civil y Comercial de La Nación), RNC n 94, Córdoba, 2.016.

COSSIO, Carlos, La teoría egológica del derecho y el concepto jurídico de libertad, Editorial Losada,

Buenos Aires, 1.944.

COSSIO, Carlos, Los valores jurídicos, AFD-SEFJP n ${ }^{\circ}$ IV, Madrid, 1956.

COSTANZO, Mariano y COSOLA, Sebastián Justo, La inexactitud registral a partir del significado de calificación. Premisas normativas y principistas para la determinación de la naturaleza y solución del conflicto, $29^{\circ} \mathrm{JNA}, \mathrm{t}^{\circ}$ I, FEN, La Plata, 2.010. 
COUTURE, Eduardo J., La fe pública notarial, en Alberto VILLALBA WELSH y Daniel LARRIQUETA, Temas de Derecho Notarial, Publicación del CEM, Buenos Aires, 1.948.

COUTURE, Eduardo, El concepto de Fe Pública. Introducción al estudio del derecho notarial, Fas, Rosario, 2.005.

CRAWFORD, Colin, La función social de la propiedad y la capacidad humana de prosperar, en Daniel BONILLA MALDONADO (Coord.), La función social de la propiedad, Eudeba, Buenos Aires, 2.013.

CREUS, Carlos, BUOMPADRE, Jorge E., Falsificación de documentos en general, Astrea, Buenos Aires, 2.004.

CUAUHTÉMOC GARCIA AMOR, Julio Antonio, Historia del derecho notarial, Trillas, México, 2.000.

CUETO RUA, Julio, Fuentes del derecho, Abeledo Perrot, Buenos Aires, 1.971.

CULASSO, María Florencia y TABARES, Julieta C., Compraventa y permuta, en Noemí L NICOLAU y Carlos A. HERNÁNDEZ (Dir.)- Sandra A. FRUSTAGLI (Coord.), Contratos en el Código Civil y Comercial de La Nación, La Ley, Buenos Aires, 2016.

CURA GRASSI, Domingo C., Derechos Reales. Posesión, Ad Hoc, Buenos Aires, 2.009.

CURA GRASSI, Domingo C., Derechos reales: reflexiones en torno a la ansiada seguridad juridica. Publicidad posesoria y registral: seguridad dinámica vs. Seguridad estática, ED 234-816.

CURA GRASSI, Domingo C., Contratación Inmobiliaria: Aspectos notariales y registrales. Recaudos previos, ED 261, nro. 13696, 27/03/2015.

D'ALESSIO, Carlos Marcelo, Instrumentos públicos, en Código Civil y Comercial de la Nación Comentado, Ricardo Luis LORENZETTI (Dir.), Federico DE LORENZO y Pablo LORENZETTI (Coord.), $t^{\circ}$ II, RubinzalCulzoni, Santa Fe, 2.015.

DALLA VÍA, Alberto, Transformación económica y seguridad jurídica, Librería Platense, La Plata, 1.994.

DASSEN, Julio y VERA VILLALOBOS, Enrique, Manual de Derechos Reales (Parte General. Posesión. Defensa posesoria), Tea, Buenos Aires, 1.962.

DE CASTRO Y BRAVO, Federico, El negocio jurídico, Civitas, Madrid, 2.002.

DE LA CIGOÑA CANTERO, María del Carmen, La función del jurista: Perspectivas y consideraciones del realismo jurídico contemporáneo: (La continuidad del pensamiento Aristotélico-Tomista), Universidad 
LOS EFECTOS DE LA PUBLICIDAD EN EL DOCUMENTO NOTARIAL

Complutense de Madrid, 2001. http://eprints.ucm.es/tesis/der/ucmt24850.pdf (TD).

DE LA MATA PIZAÑA, Felipe y GARZÓN JIMÉNEZ, Roberto, Bienes y derechos reales, Porrúa, México, 2.013.

DE LA TORRE DIAZ, Francisco Javier, Ética y deontología jurídica, Dykinson, Madrid, 2.000.

DE REINA TARTIÈRE, Gabriel, Manual de Derecho Registral Inmobiliario, La Ley, Buenos Aires, 2.004.

DE REINA TARTIÈRE, Gabriel, Principios registrales. Estudio del derecho registral inmobiliario argentino, Heliasta, Buenos Aires, 2.009.

DE SANTO, Víctor, Diccionario de Ciencias Jurídicas, politicas, sociales y de economía, Universidad, Buenos Aires, 1.996.

DEIMUNDO, Santiago Raúl, Pensamiento y sentimiento sobre el notariado, Depalma, Buenos Aires, 1.989 .

DEL CARRIL, Enrique Horacio, Interpretación, neoconstitucionalismo y ética profesional, en Sebastián J. COSOLA, Enrique H. DEL CARRIL, Luis MONTESANO y Santiago FINN, Ética de las profesiones jurídicas (Abogados, jueces, notarios), Ad-Hoc, Buenos Aires, 2.010.

DEL CARRIL, Enrique Horacio, Prólogo al libro de Sebastián Justo COSOLA, Fundamentos del derecho notarial. La concreción del método, Ad-Hoc, Buenos Aires, 2.013.

DEL VECCHIO, Giorgio, El concepto de la naturaleza y el principio del derecho, Trad. Mariano CASTAÑO, Hijos de Reus, Madrid, 1.916.

DEL VECCHIO, Giorgio, Filosofia del derecho, Librería Bosch, Barcelona, 1.991.

DEL VECCHIO, Giorgio, Los principios generales del derecho, Ara Editores, Lima, 2.006.

DELGADO DE MIGUEL, Juan Francisco, La deontología notarial frente a los clientes, a los colegas y al Estado, Gráficas Summa, Asturias, 1.998.

DELGADO DE MIGUEL, Juan Francisco, Principios generales de deontología notarial, en Leonardo B. PEREZ GALLARDO e Isidoro LORA-TAMAYO RODRIGUEZ (Coord.), Derecho Notarial, t ${ }^{\circ}$ II, Félix Varela, La Habana, 2.007.

DELGADO DE MIGUEL, Juan Francisco, Deontología Notarial, JDCNE y CGNE, Madrid, 1.992.

DELGADO DE MIGUEL, Juan Francisco, Acerca del fundamento moral de los principios deontológicos profesionales, en Ética de las Profesiones Jurídicas: Estudios sobre deontología, Vol. I, UCSM- Murcia, España, 2.003 . 
DELGADO DE MIGUEL, Juan Francisco, Código Notarial de la Unión Europea, II Tomos, Consejo General del Notariado Español, Madrid, 2.0032005.

DELGADO DE MIGUEL, Juan Francisco, La aprobación de los principios generales de deontología notarial de la UINL y su consideración como modelo de código deontológico notarial, $\mathrm{RJdN} \mathrm{n}^{\circ}$ 52, Madrid, 2.004.

DELGADO DE MIGUEL, Juan Francisco, La esencia deontológica de la profesión notarial, en Deontología Notarial, JDCNE y CGNE, Madrid, 1.992.

DELGADO DE MIGUEL, Juan Francisco, La integridad de la prestación del servicio notarial, RJdN $\mathrm{n}^{\circ} 38, \mathrm{CGN}$, Madrid, 2.001.

DEVIS ECHANDÍA, Hernando, Compendio de la prueba judicial, II Tomos, Rubinzal-Culzoni, Santa Fe, 2.000.

DI MARTINO, Ana María, Derecho notarial, Marben, Asunción, 2.009.

DI PIETRO, Alfredo y LAPIEZA ELLI, Ángel Enrique, Manual de Derecho Romano, Abeledo Perrot, Buenos Aires, 2.010.

DI PIETRO, Alfredo, Evolución histórica de la publicidad inmobiliaria, en Alberto MOLINARIO (Coord.), . Curso de derecho registral inmobiliario, Ediciones Pannedille, Buenos Aires, 1.971.

DI PIETROMICA, Viviana C., Régimen tributario de la actuación notarial, Abeledo Perrot, Buenos Aires, 2.009.

DIAZ DE GUIJARRO, Enrique, ¿Son funcionarios públicos los escribanos?, JA, to 31 , Compañía Impresora Argentina, Buenos Aires, 1.931, p. 256-263.

DIEZ, Lilia Noemí, Ley Nacional Registral Inmobiliaria: Una mirada a treinta años de su vigencia..., RdN n 856, Ciudad Autónoma de Buenos Aires, 1.999.

DIEZ, Lilia Noemí, La función del registrador de la propiedad; distinta de la del escribano, RdN-ER n ${ }^{\circ} 170,2.001$.

DIEZ-PICAZO, Luis y GULLÓN, Antonio, Sistema de derecho civil, vol. III (Derechos reales), tomos I y II, Tecnos, Madrid, 2.013.

DODDA, Zulma Aurora DODDA y FRANCHINI, María Florencia, Digesto de Disposiciones Técnico Registrales, III Vol., FEN, La Plata, 2.011 .

DODDA, Zulma Aurora y URBANEJA, Marcelo Eduardo, Principio de inscripción. Rogación. Documento inscribible. Publicidad previa y sus efectos en la seguridad jurídica, RN n 956, La Plata, 2.007.

DOMINGUEZ MENA, Antonio, El notario y los Registros. Registros Inmobiliarios, mercantiles, de anotaciones personales y otros. La función 
LOS EFECTOS DE LA PUBLICIDAD EN EL DOCUMENTO NOTARIAL

calificadora del notario en la elaboración documental, RJdN $\mathrm{n}^{\circ} \mathrm{VI}$ (Extraordinario), Madrid, 2.004.

DWORKIN, Ronald, Los derechos en serio, Ariel, Barcelona, 2.002.

DWORKIN, Ronald, Una cuestión de principios, Siglo XXI, Buenos Aires, 2.012 .

EKMEKDJIAN, Miguel Ángel, Manual de la Constitución Argentina, LexisNexis, Buenos Aires, 2.007.

ESCOBAR DE LA RIVA, Eloy, Tratado de derecho notarial, Marfil, Valencia, 1.957.

ESPER, Mariano, Manual de Contratos Civiles y Comerciales. Parte Especial, Abeledo Perrot, Buenos Aires, 2.011 (Versión digital de la aplicación Thomson Reuters Proview).

ESPER, Mariano, Boleto de Compraventa, en Julio César RIVERA y Graciela MEDINA (Dir.)-Mariano ESPER (Coord.), Código Civil y Comercial de La Nación comentado, $\mathrm{t}^{\circ}$ III, La Ley, Buenos Aires, 2.014.

ETALA, Carlos Alberto, Diccionario jurídico de interpretación y argumentación, Marcial Pons, Buenos Aires, 2.016.

ETCHEGARAY, Natalio Pedro, Boleto de compraventa. Marcelo DE HOZ (Colab.), Astrea, Buenos Aires, 2.009.

ETCHEGARAY, Natalio Pedro y CAPURRO, Vanina Leila, Derecho notarial aplicado, $\mathrm{t}^{\circ} \mathrm{I}$, Colección Función Notarial-Natalio Pedro ETCHEGARAY (Coord.), Astrea, Buenos Aires, 2.011.

ETCHEGARAY, Natalio Pedro, Escrituras y Actas Notariales, Astrea, Buenos Aires, 2.010/2016.

ETCHEGARAY, Natalio Pedro, Protocoleando (Notariado y lunfardo), Editorial de la Cultura Urbana, Avellaneda, 2.012.

FAIRÉN, Manuel, Derechos reales y de crédito (Apuntes dogmáticos para el criterio de su distinción), Revista del Notariado de España $n^{\circ}$ XXIII, 1959; Segunda Parte: Revista del Notariado de España ${ }^{\circ}$ XXIV, 1959; Tercera Parte: Revista del Notariado de España ${ }^{\circ}$ XXV-XXVI, 1.959 y Cuarta Parte (Conclusión): Revista del Notariado de España $n^{\circ}$ XXXI, Colegio de Notarios de España, Madrid, 1.961.

FALBO, Miguel Norberto, La inscripción registral y sus efectos, en Cristina Noemí ARMELLA (Dir.) y Mariano ESPER (Inv.), Summa Notarial, Registral e Inmobiliaria, Abeledo Perrot y UNA, Buenos Aires, 2.013.

FALBO, Miguel Norberto, Las reformas al código civil y su significación con relación a la función notarial, Colescba, La Plata, 1.968. 
FALCÓN, Enrique M., Comentario al Código Procesal Civil y Comercial de la Nación y leyes complementarias, II Tomos, Abeledo Perrot, Buenos Aires, 1.998.

FAMÁ, María Victoria, La protección de la vivienda unipersonal; "Constitución del bien de familia a favor del titular de dominio sin familia", Rev. Derecho Privado y Comunitario, Rubinzal-Culzoni, Santa Fe, 2011-1.

FARINATI, Eduardo N., Contrato de compraventa, en Marcelo J. HERSALIS (Coord.), Incidencias del Código Civil y Comercial. Contratos en particular, Hammurabi, Buenos Aires, 2.015.

FAYT, Carlos S., Los poderes implícitos de la Corte Suprema de Justicia de La Nación, La Ley, Buenos Aires, 2.006.

FAZIO de BELLO, Marta E., Actos jurídicos y documentos inscribibles, La Rocca, Buenos Aires, 1998.

FAZIO, Marta Encina, La función social de la propiedad privada en el derecho contemporáneo, Biblioteca de la Facultad de Derecho de la Universidad de Buenos Aires, $\mathrm{n}^{\circ}$ topográfico 252.251/1973 (TD).

FENOCHIETTO, Carlos E., Código Procesal Civil y Comercial de la Provincia de Buenos Aires, Astrea, Buenos Aires, 1.999.

FERNÁNDEZ CASADO, Miguel, Tratado de la notaría, $\mathrm{t}^{\circ}$ I, Imprenta de la viuda de M. Minuesa de Los Ríos, Madrid, 1.895.

FERNÁNDEZ SESSAREGO, Carlos, Derecho de las personas, Editora Jurídica Grijley, Lima, 2.004.

FERNÁNDEZ SESSAREGO, Carlos, Derecho y persona, Astrea, Buenos Aires, 2.015.

FERRO, Manuel J., Práctica de la usucapión, Ediciones Jurídicas, Buenos Aires, 2.012.

FINNIS, John, Ley natural y derechos naturales, Estudio Preliminar de Cristóbal ORREGO SANCHEZ, Abeledo Perrot, Buenos Aires, 1.998.

FIORINI, Bartolomé A., Manual de Derecho Administrativo, II tomos, La Ley, Buenos Aires, 1.968.

FIORINI, Bartolomé A., Teoría jurídica del acto administrativo, Abeledo Perrot, Buenos Aires, 1.969.

FIORINI, Bartolomé A., Acto administrativo e instrumento público. El método constitucional, Revista Jurídica La Ley, $\mathrm{t}^{\circ}$ 146, Buenos Aires, 1.972, p. 1017-1026.

FISS, Owen, Los mandatos de la justicia. Ensayos sobre derecho y derechos humanos, Marcial Pons, Buenos Aires, 2.013.

FONT BOIX, Vicente; SIMÓN SANTONJA, Vicente L, DE LA ESPERANZA MARTINEZ-RADIO, Antonio y MADRIDEJOS 
LOS EFECTOS DE LA PUBLICIDAD EN EL DOCUMENTO NOTARIAL

SARASOLA, José, Sistemas jurídicos y documento, la forma escrita en las legislaciones latinas, sociales y anglosajonas, Revista de Derecho Notarial Español n¹17-118, Madrid, 1.982.

FONTBONA, Francisco I. J, Estudio de cuestiones. Principio de publicidad. Certificaciones, en Jorge Horacio ALTERINI (Dir.) e Ignacio Ezequiel ALTERINI (Coord.), Derecho Notarial, Registral e Inmobiliario. Doctrinas Magistrales (1897-2012), t ${ }^{\circ}$ IV, La Ley y Colegio de Escribanos de la Ciudad de Buenos Aires, 2.012.

FOSTER, Sheila y BONILLA MALDONADO, Daniel, La función social de la propiedad en perspectiva comparada, en Daniel BONILLA MALDONADO (Coordinador), La función social de la propiedad, Eudeba, Buenos Aires, 2.013.

FOUCAULT, Michel, El coraje de la verdad, Fondo de Cultura Económica, Buenos Aires, 2.010.

FOUCAULT, Michel, Las palabras y las cosas (Una arqueología de las ciencias humanas), Siglo XXI Editores, Buenos Aires, 2.012.

FOUCAULT, Michel, Obrar mal, decir la verdad (La función de la confesión en la justicia), Siglo XXI Editores, Buenos Aires, 2.014.

FOUCAULT, Vigilar y castigar. Nacimiento de la prisión, Siglo Veintiuno Editores, Buenos Aires, 2.015.

FUCITO, Felipe, Sociología General, Universidad, Buenos Aires, 1.999.

FUCITO, Felipe, Sociología del derecho, Universidad, Buenos Aires, 2003.

FUENTESECA DEGENEFFE, Cristina, La posesión mediata e inmediata, Ediciones Legales, Lima, 2.013.

FUERTES-PLANAS ALEIX, Cristina, Filosofia política y jurídica de Juan Berchmans Vallet de Goytisolo, Fundación Matritense del Notariado, Madrid, 1.992 (TDI).

GALEANO, Eduardo, Bocas del Tiempo, Catálogos- Siglo XXI, Buenos Aires, 2.004.

GALLARDO RUEDA, Arturo, Fe pública y seguridad juridica, Instituto Nacional de Estudios Jurídicos- Anuario de Derecho Civil, Madrid, 1.949.

GALLINO, Eduardo, Introducción a los principios de Unidroit para los contratos del comercio internacional, en Ana Raquel NUTA (Dir.) y Julieta GALLINO (Coord.), Tratado de Derecho Privado Notarial, Ad Hoc, Buenos Aires, 2.006.

GARCIA CONI, Raúl R., Derecho Registral Aplicado, Ediciones Librería Jurídica, La Plata, 1.972.

GARCIA CONI, Raúl R., Registración Inmobiliaria Argentina, Depalma, Buenos Aires, 1.983. 
GARCIA CONI, Raúl, ¿Que inscriben los registros inmobiliarios?, Libro Homenaje al Profesor L. M. E., Universidad, Buenos Aires, 1.980.

GARCIA CONI, Raúl, y FRONTINI, Ángel A., Derecho registral aplicado, LexisNexis, Buenos Aires, 2.006.

GARCIA MORENTE, Manuel, Lecciones preliminares de filosofia, Losada, Buenos Aires, 1.993.

GARCIA RUA, Oscar, El proceso disciplinario del escribano, Ábaco, Buenos Aires, 2.003.

GARCIA SOTO, Luis, Teoría de la justicia e idea del derecho en Aristóteles, Marcial Pons, Madrid, 2.011 (TDI).

GARRIDO CHAMORRO, Pedro, La Función Notarial, sus costes y sus beneficios, Consejo General del Notariado, Madrid, 2.000.

GARRIDO CORDOBERA, Lidia, Incidencias del Código Civil y

Comercial. Contratos en general, Hammurabi, Buenos Aires, 2.015.

GASCÓN ABELLÁN, Marina, Los hechos en el derecho. Bases

argumentales de la prueba, Marcial Pons, Madrid, 2.004.

GATTARI, Carlos Nicolás, El objeto de la ciencia del derecho notarial, Depalma, Buenos Aires, 1.969.

GATTARI, Carlos Nicolás, Manual de Derecho Notarial, Abeledo Perrot, Buenos Aires, 2.008.

GATTARI, Carlos Nicolás, El juez, el notario y la ley extranjera, Ediciones Librería Jurídica La Plata, Buenos Aires, 1.974.

GATTARI, Carlos Nicolás, El protocolo notarial. Corporalidad. Contenido. Valores, en Jorge H. ALTERINI (Dir.) e Ignacio E. ALTERINI (Coord.), Derecho Notarial, Registral e Inmobiliario. Doctrinas Magistrales 18972012, t ${ }^{\circ}$ I, La Ley, Buenos Aires, 2.012.

GATTARI, Carlos Nicolás, Instrumento notarial y documento administrativo, en Práctica Notarial 5, Depalma, Buenos Aires, 1.988.

GATTI, Edmundo y ALTERINI, Jorge Horacio, El derecho real. Elementos para una teoría general, Abeledo Perrot, Buenos Aires, 1.998.

GATTI, Edmundo y ALTERINI, Jorge Horacio, Prehorizontalidad y boleto de compraventa, Fedye, Buenos Aires, 1.973.

GATTI, Edmundo, Derechos Reales. Teoría General, Lajouane, Buenos Aires, 2.006, (TD).

GATTI, Edmundo, Derechos subjetivos (Poderes y facultades) y Relaciones Jurídicas (Absolutas y relativas), LexisNexis, Buenos Aires, 2.005.

GELLI, María Angélica, Constitución de la Nación Argentina. Comentada y Concordada, II Tomos, La Ley, Buenos Aires, 2.014. 
LOS EFECTOS DE LA PUBLICIDAD EN EL DOCUMENTO NOTARIAL

GENTILE, Francisco, El derecho natural en España: A propósito de una tesis de Estanislao Cantero sobre Juan Vallet de Goytisolo, Revista Verbo 375-376, Madrid, 1.999.

GHIRARDI, Olsen, El common law de los Estados Unidos de Norteamérica. Génesis y Evolución, Academia Nacional del Derecho y Ciencias Sociales de Córdoba, p. 1, en secc. doctrina www.acaderc.org.ar GILSON, Etienne, El realismo metódico, Rialp, Madrid, 1.974.

GIMÉNEZ ARNAU, Enrique, Introducción al derecho notarial, Revista de Derecho Privado, Madrid, 1.944.

GIMÉNEZ ARNAU, Enrique, Derecho notarial español, III Volúmenes, Ediciones de la Universidad de Navarra, Pamplona, 1.964-1966.

GIMÉNEZ ARNAU, Enrique, Derecho Notarial Español, Revista Internacional del Notariado ${ }^{\circ} 64,1.966$.

GIMÉNEZ ARNAU, Enrique, Derecho Notarial, Ediciones de la Universidad de Navarra S.A, Pamplona, 1.976.

GIOJA, Ambrosio L., Ideas para una filosofia del derecho, II Tomos, Sucesión de Ambrosio L. Gioja, Buenos Aires, 1.973.

GOLDSCHMIDT, Werner, Introducción filosófica al derecho. La teoría trialista del mundo jurídico y sus horizontes, Lexis Nexis, Buenos Aires, 2.005 .

GOLDSCHMIDT, Werner, Justicia y verdad, Fedye, Buenos Aires, 1.978.

GOLDSTEIN, Mateo, Dominio, EJO, $\mathrm{t}^{\circ}$ IX, Driskill, Buenos Aires, 1.993.

GOMÁ SALCEDO, José Enrique, Derecho Notarial, Dykinson, Madrid, 1.992.

GOMEZ-LOBO, Alfonso, Los bienes humanos. Ética de la Ley Natural, Mediterráneo, Santiago de Chile, 2.006.

GÓMEZ-MARTINHO FAERNA, Augusto, La función del notario en la Unión Europea, CGN, Madrid, 1.999.

GONZALES BARRÓN, Gunther, Tratado de Derechos Reales, II Tomos, Jurista Editores E.I.R.L, Lima, 2.013.

GONZALES BARRÓN, Gunther, Derecho registral y notarial, II Tomos, Jurista Editores, Lima, 2.012.

GONZÁLEZ BARRÓN, Gunther, Derecho Notarial, Jurista Editores, Lima, 2.016 .

GONZÁLEZ PALOMINO, José, Salutación a Carnelutti, en Francisco CARNELUTTI, La figura jurídica del notariado, Colección Biblioteca Notarial I, Lima, 2.011.

GONZÁLEZ PALOMINO, José y GIMÉNEZ ARNAU, Enrique, Instituciones de Derecho Notarial, II Tomos, IER, Madrid, 1.945. 
GONZÁLEZ, Carlos Emérito, Teoría General del Instrumento Público (Introducción al derecho notarial argentino y comparado), Ediar, Buenos Aires, 1.953.

GONZÁLEZ, Carlos Emérito, Derecho Notarial, Fedye, La Plata, 1.971.

GONZÁLEZ, Carlos Emérito, Constitución de Sociedades Anónimas, Abeledo Perrot, Buenos Aires, 1.958.

GORDILLO, Agustín, Orden público como principio no general del derecho argentino, LL 2015-F, 1041. AR/DOC/3877/2015.

GOZAÍNI, Osvaldo Alfredo, Teoría general del derecho procesal, Ediar, Buenos Aires, 1.996.

GRAJALES, Amós Arturo y NEGRI, Nicolás, Argumentación Jurídica, Astrea, Buenos Aires, 2.014.

GRAJALES, Amós Arturo y NEGRI, Nicolás Jorge, Interpretación y aplicación del Código Civil y Comercial, Astrea, Buenos Aires, 2.016.

GRANERIS, Giuseppe, Contribución tomista a la filosofia del derecho, Eudeba, Buenos Aires, 1.973.

GRIFFA, Norberto y RUSSO, Eduardo Ángel, Los conceptos jurídicos fundamentales del derecho, en Héctor F. ROJAS PELLERANO, Introducción al derecho, Centro Editor Argentino, Buenos Aires, 1.984.

GUARDIOLA, Juan José, Apostillas de los derechos reales en el nuevo código civil y comercial de la Nación, eldial.com (2015).

GUARIGLIA, Carlos E., Fundamento iusfilosófico del derecho administrativo, Educa y Universidad Católica del Uruguay, Buenos Aires, 2.016 .

GUIBOURG, Ricardo A., GHIGLIANI, Alejandro M. y GUARINONI, Ricardo V., Introducción al conocimiento científico, Eudeba, Buenos Aires, 1.993.

GUIBOURG, Ricardo, Saber derecho, Abeledo Perrot, Buenos Aires, 2.013 .

GUIBOURG, Ricardo, El derecho ante el enfoque analítico, A.A.V.V., Olsen GHIRARDI (Director), AAVV, Diez Años, Córdoba, 2008.

GUIBOURG, Ricardo, Una concepción analitica del derecho, en Andrés BOTERO BERNAL (Coord.), Filosofia del derecho Argentina, Temis, Bogotá, Colombia, 2.008.

GUIBOURG, Ricardo A., La construcción del pensamiento. Decisiones metodológicas, Colihue, Buenos Aires, 2.006.

GUIBOURG, Ricardo, Filosofia para el derecho-Jornada de debate interdisciplinaria entre iusfilósofos y constitucionalistas, $\mathrm{BDaD}$ año $16 \mathrm{n}^{\circ}$ 284, Buenos Aires, 2.017. 
LOS EFECTOS DE LA PUBLICIDAD EN EL DOCUMENTO NOTARIAL

GURFINKEL DE WENDY, Lilian N, Adquisición, transmisión, extinción y oponibilidad, en Julio César RIVERA y Graciela MEDINA (Dir.)-Mariano ESPER (Coord.), Código Civil y Comercial de La Nación comentado, $\mathrm{t}^{\circ} \mathrm{V}$, La Ley, Buenos Aires, 2.014.

GURFINKEL DE WENDY, Lilian, Derechos Reales, II Tomos, Abeledo Perrot, Buenos Aires, 2.010.

GURFINKEL de WENDY, Lilian, Escrituración, La Ley, Buenos Aires, 2.007 .

GURFINKEL DE WENDY, Lilian, Posesión y tenencia. Disposiciones generales, en Julio César RIVERA y Graciela MEDINA (Dir.) Mariano ESPER (Coord.), Código Civil y Comercial de La Nación comentado, $\mathrm{t}^{\circ} \mathrm{V}$, La Ley, Buenos Aires, 2.014.

GUTIERREZ Y GONZÁLEZ, Ernesto, Derecho de las obligaciones, Porrúa, México, 2.014.

GUTIERREZ ZALDIVAR, Álvaro, Los notarios en el common law, RdN $\mathrm{n}^{\circ}$ 866, Buenos Aires, 2.001.

GUTIERREZ ZALDIVAR, Álvaro, II Reunión Anual de la National Notary Association : informe del delegado del Colegio de Escribanos de Capital Federal, RdN n ${ }^{\circ} 772$, Buenos Aires, 1.980.

GUTIÉRREZ ZALDIVAR, Mario O. ARRAGA PENIDO y Juan Carlos AMUY, Temas de derechos reales, Plus Ultra, Buenos Aires, 1.986.

GUZMAN BRITO, Alejandro, MASSINI CORREAS, Carlos I, MONTEJANO, Bernardino, SOLER MIRALLES, Julio y VIGO, Rodolfo Luis, La función judicial, Prólogo de Abelardo ROSSI, Depalma, Buenos Aires, 1.980 .

GUZMÁN FARFÁN, Saúl F, Derecho notarial y registros públicos, Imprenta de Colorgraf-Rodríguez, Cochabamba, 2.000.

HAIRABEDIÁN, Maximiliano, Prueba testimonial. En el sistema acusatorio y adversarial, Astrea, Buenos Aires, 2.016.

HART, Herbert L. A., El concepto de derecho, Trad. Genero CARRIÓ, Abeledo Perrot, Buenos Aires, 2.004.

HARTMANN, Nicolai, Ética, Encuentro, Madrid, 2.011.

HERNÁNDEZ, Antonio María (h), El caso Fayt y sus implicancias constitucionales, ACADERC-Advocatus, Córdoba, 2.001.

HERNÁNDEZ GIL, Antonio, La función social de la posesión (Ensayo de teorización sociológico-jurídica), Real Academia de Jurisprudencia y Legislación, Madrid, 1.967.

HERNANDÉZ GIL, Antonio, La función social de la posesión, Alianza Editorial, Madrid, 1.969. 


\section{SEBASTIÁN JUSTO COSOLA}

HERNANDO COLLAZOS, Isabel, El principio de legitimación registral y su tratamiento jurisprudencial, Civitas, Madrid, 1.990.

HERRERA, Daniel Alejandro, La persona y el fundamento de los derechos humanos, Educa, Buenos Aires, 2.012.

HERRERA, Marisa, Manual de derecho de las familias, (Col. Natalia DE LA TORRE y Silvia E. FERNÁNDEZ), Abeledo Perrot, Buenos Aires, 2.015 .

HERSALIS, Marcelo J., Boleto de compraventa, en Alberto J. BUERES, Código Civil y Comercial de La Nación analizado, comparado y concordado, $\mathrm{t}^{\circ} \mathrm{I}$, Hammurabi, Buenos Aires, 2.017.

HERVADA, Javier, Lecciones de Filosofia del derecho, Editorial de la Universidad de Pamplona SA, 1.990.

HERVADA, Javier, Introducción crítica al derecho natural, Eunsa, Pamplona, 2.007.

HESSEN, Johannes, Teoría del conocimiento, Losada, Buenos Aires, 1.954.

HIGHTON de NOLASCO, Elena Inés, El escribano como tercero neutral, Revista del Notariado $\mathrm{n}^{\circ}$ 875, Buenos Aires, 1.999.

HIGHTON de NOLASCO, Elena Inés, Responsabilidad del estado por los escribanos por quien no es propietario. El caso de enajenación, LL 1977-C.

HIGHTON, Elena Inés, Derechos reales. Volumen 1: Posesión, Ariel, Buenos Aires, 1.979.

HIGHTON, Elena Inés, Propiedad horizontal y prehorizontalidad, Colaboración Elena C. NOLASCO, Hammurabi, Buenos Aires, 2007.

HIGHTON, Elena Inés (Dir.) VITALE, Angélica G.E (Codir.), ABREUT, Liliana y BLANCO LARA, Ricardo, La función notarial en la comunidad globalizada, Rubinzal Culzoni, Santa Fe, 2.005.

HOBBES, Thomas, Leviatán. O la materia, forma y poder de una República Eclesiástica y Civil, Fondo de Cultura Económica, Buenos Aires, 2.009 .

IGLESIAS, Juan, Derecho Romano (Instituciones de derecho privado), Ariel, Barcelona, 1.958.

KALINOWSKI, Georges, El problema de la verdad en la moral y en el derecho, Eudeba, Buenos Aires, 1.979.

KANT, Inmanuel, Principios metafísicos del derecho, Ediciones Espuela de Plata, España, 2.004.

KELSEN, Hans, ¿Qué es la justicia?, Fontamara, México, 1.997.

KELSEN, Hans, Contribuciones a la teoría pura del derecho, Centro Editor de América Latina, Buenos Aires, 1.969. 
LOS EFECTOS DE LA PUBLICIDAD EN EL DOCUMENTO NOTARIAL

KELSEN, Hans, La idea del derecho natural y otros ensayos, Editorial Losada, Buenos Aires, 1.946.

KELSEN, Hans, Teoría General de las normas, Trillas, México, 1.994.

KELSEN, Hans, Teoría General del derecho y del Estado, trad. de Eduardo GARCIA MAYNEZ, Imprenta Universitaria, México, 1.949.

KELSEN, Hans, Teoría pura del derecho, trad. de Roberto J. VERNENGO, Porrúa, México, 2.007.

KELSEN, Hans, La paz por medio del derecho, Losada, Buenos Aires, 1.946.

KEMELMAJER de CARLUCCI, Aída, Registro de la Propiedad Inmueble. Ley 17.801, en Eduardo A. ZANNONI (Dir.) y Aída KEMELMAJER de CARLUCCI (Coord.), Código Civil y Leyes Complementarias. Comentado, Anotado y Concordado, $\mathrm{t}^{\circ}$ 13, Astrea, Buenos Aires, 2.012.

KEMELMAJER de CARLUCCI, Aída, La calificación registral en materia de automotores (Diferencias con el sistema inmobiliario), RDPC-2009-2, $\mathrm{T}^{\circ}$ I, Rubinzal Culzoni, Santa Fe.

KEMELMAJER de CARLUCCI, Aída, Calificación registral de instrumentos de origen judicial, en Carlos Gustavo VALLESPINOS (Dir.), LexisNexis-Abeledo Perrot, Buenos Aires, 2.002.

KEMELMAKER DE CARLUCCI, Aída, Pautas económicas de interpretación y seguridad jurídica en la jurisprudencia de la Corte Suprema de la Nación, XV Reunión conjunta de las Academias Nacionales de Derecho y Ciencias Sociales de Buenos Aires, y Córdoba, Córdoba, 2324/10/2003.

http://www.acaderc.org.ar/doctrina/articulos/artpautaseconomicas.

KEMELMAJER DE CARLUCCI, Aída, La autonomía de la voluntad en el derecho de familia argentino, en Derecho de las familias, de la infancia y de la adolescencia, Infojus, Buenos Aires, 2.015.

KEMELMAJER de CARLUCCI, Aída, La aplicación del Código Civil y Comercial a las relaciones y situaciones jurídicas existentes, RubinzalCulzoni, Santa Fe, 2.015.

KEMELMAJER de CARLUCCI, Aída, Pautas para interpretar el Código, en Código Civil y Comercial. Concordado con el régimen derogado y referenciado con legislación vigente, Astrea, Buenos Aires, 2.015, p. 1-15.

KENNEDY, Duncan, La enseñanza del derecho como forma de acción politica, Siglo Veintiuno Editores, Buenos Aires, 2.012.

KIELMANOVICH, Jorge L., Código Procesal Civil y Comercial de la Nación. Comentado y Anotado, IV Tomos, La Ley, Buenos Aires, 2.013 (Versión digital Thomson Reuters Preview). 
KHUN, Thomas S., La estructura de las revoluciones cientificas, Fondo de Cultura Económica, México, 2.013.

KIPER, Claudio M., Juicio de escrituración (Conflictos derivados del boleto de compraventa), Hammurabi, Buenos Aires, 2.004.

KIPER, Claudio, Tratado de los Derechos Reales. Código Civil y Comercial de La Nación, II Tomos, Rubinzal Culzoni, Santa Fe, 2.016.

KIPER, Claudio (Dir.) y DAGUERRE, Luis O. (Coord.), Aplicación Notarial del Código Civil y Comercial de La Nación, III Tomos, Rubinzal Culzoni, Santa Fe, 2.015.

LAFAILLE, Héctor y ALTERINI, Jorge Horacio, Derecho Civil. Tratado de los derechos reales, VI Tomos, La Ley, Buenos Aires, 2.010.

LAMAS, Félix A., Los principios internacionales (Desde la perspectiva de lo justo concreto), Ediciones Forum, Buenos Aires, 1.974.

LAMAS, Félix Adolfo, La experiencia jurídica, Instituto de Estudios Filosóficos Santo Tomás de Aquino, Buenos Aires, 1.991 (TDI).

LAMBER, Néstor Daniel, Título preliminar, en Eduardo G. CLUSELLAS

(Coord.), Código Civil y Comercial. Comentado, anotado y concordado, $\mathrm{t}^{\circ}$ 1, Astrea-FEN, Buenos Aires, 2.015.

LAMBER, Rubén Augusto, Donaciones, Astrea, Buenos Aires, 2.008.

LAMBER, Rubén Augusto, Derecho Civil aplicado, Colección Función Notarial n 3, Astrea, Buenos Aires, 2.010.

LAMBER, Rubén Augusto, La escritura pública, IV Tomos, FEN, La Plata, 2.003-2006.

LAPA, Eduardo L., Manual del martillero público y del corredor, Abeledo Perrot, Buenos Aires, 2.009.

LAQUIS, Manuel A., La reforma del artículo 2505, en Examen y crítica de la reforma del Código Civil, Augusto Mario MORELLO (Coord.), $t^{\circ} 3$ : Contratos-Reales, Editora Platense, La Plata, 1.974.

LARENZ, Karl, Derecho Justo. Fundamentos de ética jurídica, Civitas, Madrid, 2.001.

LARENZ, Karl, Metodología de la Ciencia del Derecho, Ariel Derecho, Barcelona, 2.001.

LARENZ, Karl, Base negocial e incumplimiento contractual, Comares, Madrid, 2.003.

LARRAUD, Rufino, Curso de derecho notarial, Depalma, Buenos Aires, 1.966.

LARRAUD, Rufino, La fe pública aun, Los Anales del Notariado Argentino, $\mathrm{t}^{\circ}$ III, Instituto Argentino de Cultura Notarial, Buenos Aires, 1.965. 
LOS EFECTOS DE LA PUBLICIDAD EN EL DOCUMENTO NOTARIAL

LASARTE, Carlos, Derechos reales y derecho hipotecario. Principios de Derecho Civil, $\mathrm{t}^{\circ}$ V, Marcial Pons, Madrid, 2.009.

LATINO, Jorge Alberto, Ora pro nobis notarii. En torno a san Ginés y a la Cofradía Porteña, Revista del Notariado 925 (Jul-Sep 2016), Buenos Aires, 2.017 .

LAVALLE COBO, Jorge E., De las obligaciones que nacen de los contratos, en César A. BELLUSCIO (Dir.) y Eduardo A. ZANNONI (Coord.), Código Civil y leyes complementarias. Comentado, anotado y concordado, $\mathrm{t}^{\circ}$ 5, Astrea, Buenos Aires, 2.007.

LAZZARI, Eduardo, Medidas Cautelares, II tomos, Librería Editora Platense, La Plata, $1.997\left(\mathrm{t}^{\circ} \mathrm{I}\right)$ y $2000\left(\mathrm{t}^{\circ} \mathrm{II}\right)$.

LEGARRE, Santiago, MIRANDA MONTECINOS, Alejandro, y ORREGO SÁNCHEZ, Cristóbal (Edit.), La lucha por el derecho natural. Actas de las Jornadas en Homenaje a John Finnis. A 25 años de la publicación de Natural Law and Natural Rights, Cuadernos de Extensión Jurídica, Universidad de los Andes, Santiago, 2.006.

LEGAZ y LACAMBRA, Luis, Filosofia del derecho, Bosch, Barcelona, 1.979 .

LEIVA FERNANDEZ, Luis F. P, Ensayos de Derecho Civil y Técnica Legislativa, La Ley, Buenos Aires, 2.007.

LIBRO Congresos y Jornadas Nacionales de Derecho Civil, La Ley, Buenos Aires, 2.005

LIBRO Memorias del cincuentenario 1948-1998- Unión internacional del Notariado Latino- XXII Congreso Internacional del Notariado Latino, Buenos Aires, Bogotá, Colombia, 1.998.

LIBRO Primer Congreso Notarial Argentino, Actas y Antecedentes, Buenos Aires, 1.917 (no refiere editorial pero todo indica que fue impreso en talleres de impresión de la Capital Federal).

LIMODIO, Gabriel y BARBIERI, Javier, Introducción al saber jurídico, Educa, Buenos Aires, 2.006.

LINAGE CONDE, Antonio, Un precedente de la publicidad registral en el mundo antiguo, Revista Del Notariado de España ${ }^{\circ}$ LXXVI, Madrid, 1.972. LLAMBÍAS, Jorge Joaquín, Tratado de Derecho Civil. Parte General, Act. De Patricio RAFFO BENEGAS, II Tomos, Editorial Perrot, Buenos Aires, 1.991.

LLOVERAS DE RESK, María Emilia, La responsabilidad civil del escribano público, ED, Buenos Aires, $\mathrm{n}^{\circ}$ 5825, 23/09/1984.

LLOVERAS DE RESK, María Emilia, Tratado teórico-práctico de las nulidades, Depalma, Buenos Aires, 1.991. 


\section{SEBASTIÁN JUSTO COSOLA}

LOCKE, John, Segundo tratado sobre el gobierno. Un ensayo sobre el verdadero origen, alcance y fin del gobierno civil, Aguilar, Colonia Suiza, Uruguay, 2.010.

LÓPEZ DE ZAVALIA, Fernando, Adquisición de derechos reales, en Carlos Gustavo VALLESPINOS (Dir.), Cuestiones esenciales en derechos reales, LexisNexis, Buenos Aires, 2002.

LOPEZ DE ZAVALIA, Fernando, Curso Introductorio al Derecho Registral, Víctor P. de Zavalía, Buenos Aires, 1.983.

LÓPEZ DE ZAVALÍA, Fernando, Derechos Reales, II Tomos, Zavalía, Buenos Aires, 1.989.

LÓPEZ DEL CARRIL, Nelson J., Publicidad de los derechos reales, Depalma, Buenos Aires, 1.965.

LOPEZ LASTRA, Julio E., Que es el derecho, Editora Platense, La Plata, 1.972.

LÓPEZ MESA, Marcelo J, Ineficacia y nulidad de los actos jurídicos. Procesales y administrativos, BdeF, Buenos Aires, 2.015.

LÓPEZ MESA, Marcelo J., El conocimiento y el conocimiento jurídico, Ediciones del Centro de Estudiantes de Derecho, Facultad de Ciencias Jurídicas y Sociales-UNLP, La Plata, 1985.

LÓPEZ MESA, Marcelo J., Responsabilidad por accidentes de tránsito, III Tomos, La Ley, Buenos Aires, 2.014.

LÓPEZ, María Teresa, Nociones de Axiología Jurídica, AFCJS-UNLP tº XXV, La Plata, 1.966.

LÓPEZ, María Teresa, Introducción al derecho, III tomos, Ediciones del Centro de Estudiantes de Derecho, Facultad de Ciencias Jurídicas y SocialesUNLP, 1.996.

LORA-TAMAYO RODRIGUEZ, Isidoro PEREZ GALLARDO, Leonardo B., Estructura del instrumento publico notarial: una aproximación desde el derecho español y el derecho cubano, en Derecho Notarial, Leonardo B. PEREZ GALLARDO e Isidoro LORA-TAMAYO RODRIGUEZ (Coord.), $\mathrm{T}^{\circ}$ II, Félix Varela, La Habana, 2.007.

LORA-TAMAYO RODRÍGUEZ, Isidoro, Aplicación por el notario de la equidad, RJdN n ${ }^{\circ}$ 53, Madrid, 2.005.

LORA-TAMAYO RODRIGUEZ, Isidoro, Aplicación por el notario de la equidad, en Derecho Notarial, Leonardo B. PEREZ GALLARDO e Isidoro LORA-TAMAYO RODRIGUEZ (Coord.), $T^{\circ}$ I, Félix Varela, La Habana, 2.006 .

LORA-TAMAYO RODRIGUEZ, Isidoro, Derecho y crisis económica, Separata de la RJdN n ${ }^{\circ}$ XII-Extraordinario, Madrid, 2012. 
LOS EFECTOS DE LA PUBLICIDAD EN EL DOCUMENTO NOTARIAL

LORA-TAMAYO RODRÍGUEZ, Isidoro, La seguridad jurídica del contrato, Revista de Derecho Notarial $\mathrm{n}^{\circ}$ CXVI, Madrid, 1.982.

LORENZANO, César Julio, La estructura del conocimiento científico, Zavalía, Buenos Aires, 1.995.

LORENZETTI, Ricardo Luis, Teoría de la decisión judicial. Fundamentos de Derecho, Rubinzal Culzoni, Santa Fe. 2.006.

LORENZETTI, Ricardo Luis, Tratado de los contratos, IV Tomos, Rubinzal Culzoni, Santa Fe, 1.999-2004.

LORENZETTI, Ricardo Luis, Título preliminar, en Ricardo L. LORENZETTI (Dir.). Miguel F. DE LORENZO y Pablo LORENZETTI (Coord.), Código Civil y Comercial de La Nación comentado, tº I, RubinzalCulzoni, Santa Fe, 2.014.

LORENZETTI, Ricardo Luis, Fundamentos de derecho privado. Código Civil y Comercial de la Nación Argentina, Thomson Reuters-La Ley, Buenos Aires, 2.016.

LORENZETTI, Ricardo Luis, HIGHTON de NOLASCO, Elena Inés y KEMELMAJER de CARLUCCI, Aída, Código Civil y Comercial de la Nación. Proyecto del Poder Ejecutivo de La Nación redactado por la Comisión de reformas designada por decreto 191/2011, Rubinzal Culzoni, Santa Fe, 2.012.

LOZADA BRAVO, María Luisa; AGUILAR TARDÍO, María Silvia y FLORES MEDINA, Lilia Gladys, De la escritura pública notarial, El País, Santa Cruz de la Sierra, 2.011.

LUKASZEWICZ, Sonia, Nulidad e inexistencia de los actos jurídicos, en Cristina Noemí ARMELLA (Dir.) Tratado de Derecho Notarial, Registral e Inmobiliario, $\mathrm{t}^{\circ} \mathrm{III}$, Ad Hoc, Buenos Aires, 1.998.

LUVERÁ, Miguel Ángel, Sistemas de constitución y transmisión de derechos reales sobre inmuebles en Latinoamérica, Academia Nacional del Derecho y Ciencias Sociales de Córdoba, doctrina: http://www.acaderc.org.ar/doctrina/articulos/sistemas-de-constitucion-ytransmision-de-derechos

MacINTYRE, Alasdair, Tras la virtud, Crítica, Barcelona, 2.004.

MALDONADO, Daniel (Coord.), La función social de la propiedad, Eudeba, Buenos Aires, 2.013.

MALIZIA, Roberto, Del Dominio, Código Civil y Comercial de La Nación. Comentado, Julio César RIVERA y Graciela MEDINA (Dir.), Mariano ESPER (Coord.), $\mathrm{t}^{\circ} \mathrm{V}$, La Ley, Buenos Aires, 2.014.

MANILI, Pablo L., La seguridad jurídica. Una deuda pendiente, Hammurabi, Buenos Aires, 2.011. 
MARIACA VALVERDE, Juana Aidée, Teoría y técnica notarial, Artes Gráficas Sagitario, La Paz, 2.006.

MARIANI DE VIDAL, Marina, Interdicto de adquirir, Víctor P. de Zavalía, Buenos Aires, 1.971.

MARIANI DE VIDAL, Marina, Curso de derechos reales, III Tomos, Zavalía, Buenos Aires, 1.993.

MARIANI DE VIDAL, Marina, Derechos reales inmobiliarios: ¿inscripción constitutiva?, LL 22/02/2012, I.

MARIANI DE VIDAL, Marina, La defensa de la posesión y la tenencia en el proyecto de Código Civil y Comercial de la Nación. Primeras reflexiones, ED 251-606.

MARIANI DE VIDAL, Marina y ABELLA, Adriana Nélida, Derechos reales, II tomos, Zavalía, Buenos Aires, 2.016.

MARIENHOFF, Miguel S., Tratado de Derecho Administrativo, $\mathrm{t}^{\circ} \mathrm{I}$, Abeledo Perrot, Buenos Aires, 1.965.

MARÍN CALERO, Carlos, De la seguridad jurídica a la garantía económica, Revista Jurídica del Notariado $\mathrm{n}^{\circ}$ 42, Madrid, 2.002.

MARINELLI, Luis César, Registro de la Propiedad, Catastro territorial y la actividad notarial, FEN, La Plata, 2.009.

MARTÍNEZ ESCRIBANO, Celia, Control notarial de la legalidad, Cuadernos Civitas- Thomson Reuters, Pamplona, 2.010.

MARTINEZ, Zenón, La posesión, Universidad Nacional del Litoral, Santa Fe, 1.939 .

MARTINEZ PAZ, Fernando, Introducción al Derecho, Ábaco, Buenos Aires, 2.005.

MARTÍNEZ SEGOVIA, Francisco, Función notarial, Delta Editora, Buenos Aires, 1.997.

MARTINEZ URRUTIA, Luis, Libertad notarial, Palacio del Libro, Buenos Aires, 1.931.

MASSINI CORREAS, Carlos Ignacio, El derecho natural y sus dimensiones actuales, Ábaco, Buenos Aires, 1.999.

MASSINI CORREAS, Carlos Ignacio, El derecho, los derechos humanos y el valor del derecho, Abeledo Perrot, Buenos Aires, 1.987.

MASSINI CORREAS, Carlos Ignacio, Filosofia del derecho, III Tomos, LexisNexis-Abeledo Perrot, Buenos Aires, 2.005-2008.

MASSINI CORREAS, Carlos Ignacio, Facticidad y razón en el derecho. Análisis crítico de la iusfilosofía contemporánea, Marcial Pons, Buenos Aires, 2.015. 
LOS EFECTOS DE LA PUBLICIDAD EN EL DOCUMENTO NOTARIAL

MASSINI CORREAS, Carlos Ignacio, La prudencia jurídica, LexisNexisAbeledo Perrot, Buenos Aires, 2.006.

MAZEAUD, Henri, MAZEAUD, León y MAZEAUD, Jean, Lecciones de derecho civil, Parte Segunda, Vol. IV, trad. Luis ALCALÁ-ZAMORA Y CASTILLO, Ejea, Buenos Aires, 1.960.

MÉNDEZ COSTA, María Josefa, Los principios jurídicos en las relaciones de familia, Rubinzal-Culzoni, Santa Fe, 2.006.

MENDOZA DEL MAESTRO, Gilberto, Responsabilidad civil del registrador público, Gaceta Notarial, Lima, Perú, 2.011.

MENGUAL Y MENGUAL, José María, Elementos de derecho notarial, $\mathrm{t}^{\circ} \mathrm{I}$ (Prel.), Librería Bosch, Barcelona, 1.931; t ${ }^{\circ}$ II-1 (introducción y parte general), Librería Bosch, Barcelona, 1.932; $\mathrm{t}^{\circ}$ II-2 (Introducción y parte general-Continuación), Librería Bosch, Barcelona, 1.933 y $\mathrm{t}^{\circ}$ II-3 (Introducción y parte general-Conclusión), Librería Bosch, Barcelona, 1.934. MESSINEO, Francesco, Doctrina General del Contrato, II Tomos, Ejea, Buenos Aires, 1.986.

MEZQUITA DEL CACHO, José L. y LOPEZ MEDEL, Jesús, El notariado y los registros, Centro de Publicaciones del Ministerio de Justicia, Madrid, 1.986.

MOISSET DE ESPANÉS, Luis y VACCARELLI, Horacio, Sistema Registral Inmobiliario Argentina-Paraguay, Zavalía, Buenos Aires, 1.994.

MOISSET DE ESPANÉS, Luis, Publicidad Registral, Zavalía, Buenos Aires, 2.003.

MOISSET de ESPANÉS, Luis y VENTURA, Gabriel B, La tradición escrituraria, Zeus, Rosario, 1.986, $\mathrm{t}^{\circ}$ 40, J-50.

MOLINARIO, Alberto D., Interpretación de la protección posesoria actual en función de la historia interna, Separata de Anales de la Facultad de Ciencias Jurídicas y Sociales-Universidad Nacional de La Plata, La Plata, 1.963.

MOLINARIO, Alberto D. (Coord.), Curso de derecho Registral Inmobiliario, Pannedille Ediciones, Buenos Aires, 1.971.

MOLINARIO, Alberto D., De las relaciones reales, Universidad, Buenos Aires, 1.981 .

MOLINARIO, Alberto D., Derecho patrimonial y derecho real, La Ley, Buenos Aires, 1.965.

MOLINARIO, Alberto D., Del derecho registral y del derecho registral inmobiliario, en Curso de derecho registral inmobiliario, Ediciones Pannedille, Buenos Aires, 1.971. 
MOLINARIO, Alberto D., La enseñanza de las potestades y las relaciones jurídicas, en http://www.leivafernandez.com.ar/Molinario ens potest.pdf. MOLLEDA FERNANDEZ LLAMAZARES, José Antonio, Deber de servicio y juicio notarial de legalidad, Anales de la Academia Matritense del Notariado, $\mathrm{t}^{\circ}$ XXI, Madrid, 1.978.

MONASTERIO GALI, Antonio, Biología de los derechos en la normalidad, Ediciones de la Universidad Notarial Argentina, La Plata, 1.966.

MONDRAGÓN FIESCO, Silvia, La pluma y el papel (Semblanza histórica del notariado mexiquense), Foem, México, 2013.

MONTESQUIEU, El espiritu de las leyes, Heliasta, Buenos Aires, 2.005.

MORA VARGAS, Herman, La función notarial, Editorial Investigaciones Jurídicas S.A, San José de Costa Rica, 2.013.

MORELLO, Augusto Mario, El derecho en la vida, Librería Editora Platense, La Plata, 2.002.

MORELLO, Augusto M, SOSA, Guadalberto L., BERIZONCE, Roberto O. y TESSONE, Alberto, Manual de códigos procesales en lo civil y comercial de la Provincia de Buenos Aires y de La Nación, Librería Editora PlatenseAbeledo Perrot, Buenos Aires, 1.997.

MORELLO, Augusto Mario, El boleto de compraventa inmobiliaria, Editora Platense, La Plata, 1.966.

MORELlO, Augusto Mario, El abogado, el juez y la reforma del Código Civil, Librería Editora Platense, La Plata, 1.969.

MORELLO, Augusto Mario, El boleto de compraventa inmobiliaria: su fuerza sociológica y la necesidad cualificada de tutelarlo, JA 1994-IV-182.

MOSSET ITURRASPE, Jorge y NOVELLINO, Norberto, La obligación de escriturar, La Rocca, Buenos Aires, 2.001.

MOSSET ITURRASPE, Jorge, Derecho civil constitucional, Rubinzal Culzoni, Santa Fe, 2.011.

MOUCHET, Carlos y ZORRAQUIN BECÚ, Ricardo, Introducción al derecho, Editorial Perrot, Buenos Aires, 1.962.

MUGUILlO, Roberto A., Publicidad, Astrea, Buenos Aires, 2.005.

MUÑOZ RIVERA, Isidro, La función del derecho notarial, Escriva, México, 2.014.

MUÑOZ, Nery Roberto y MUÑOZ ROLDÁN, Rodrigo, Derecho registral inmobiliario guatemalteco, Infoconsult Editores, Guatemala, 2.005.

MUÑOZ, Nery Roberto, El instrumento público y el documento notarial, Ediciones Guatemala, C.A, Guatemala, 2.004. 
LOS EFECTOS DE LA PUBLICIDAD EN EL DOCUMENTO NOTARIAL

MUÑOZ, Nery Roberto, Introducción al estudio del derecho notarial, Guatemala C.A, Guatemala, 2.004.

MUSTAPICH, José María, Tratado teórico y práctico de derecho notarial, III Tomos, Ediar, Buenos Aires, 1.955-1.957.

MUSTAPICH, José María, Escrituras públicas (En el proyecto de Reformas al Código Civil), Editorial Guillermo Kraft Ltda., Buenos Aires, 1.941.

NAVAS, Raúl (h), Derechos reales de propiedad, uso y goce, Oxford, Buenos Aires, 1.999.

NEGRI, José A., Obras completas, III Tomos, Colegio de Escribanos de la Capital Federal, Buenos Aires, 1.966.

NERI, Argentino I., Ciencia y arte notarial, IV Tomos, Editorial Ideas, Buenos Aires, 1.945.

NERI, Argentino I., Tratado teórico y práctico de derecho notarial, 8 Volúmenes, Depalma, Buenos Aires, 1.969-1976.

NERI, Argentino I., La función notarial en su doble aspecto: subjetivo y objetivo, en Jorge H. ALTERINI (Dir.)-Ignacio E. ALTERINI (Coord.), Derecho Notarial, Registral e Inmobiliario. Doctrinas Magistrales 18972012, tº I, La Ley, Buenos Aires, 2.012, p. 223-237.

NICOLAU, Noemí L y HERNÁNDEZ, Carlos A. (Dir.) FRUSTAGLI, Sandra A. (Coord.), Contratos en el Código Civil y Comercial de La Nación, La Ley, Buenos Aires, 2.016.

NIETO BLANC, Ernesto E., Nulidad en los actos jurídicos, Ad Hoc, Buenos Aires, 2.005.

NINO, Carlos Santiago, Introducción al análisis del derecho, Astrea, Buenos Aires, 2.005.

NINO, Carlos S., Algunos modelos metodológicos de la ciencia jurídica, Oficina Latinoamericana de investigaciones jurídicas y sociales, Universidad de Carabobo, Venezuela, 1.979.

NINO, Carlos Santiago, Fundamentos de derecho constitucional, Astrea, Buenos Aires, 2.013.

NINO, Carlos Santiago, La validez del derecho, Astrea, Buenos Aires, 2.003 .

NOVELLINO, Norberto J., Ejecuciones. Judicial-Bancaria-Notarial, Astrea, Buenos Aires, 2.011.

NUÑEZ LAGOS, Rafael, El documento medieval y Rolandino, Ediciones de la Universidad Notarial Argentina, La Plata, 1.968.

NUÑEZ LAGOS, Rafael, El documento medieval y Rolandino, publicación del Ilustre Colegio Notarial de Madrid, España, 1.950. 
NUÑEZ LAGOS, Rafael, El documento medieval y Rolandino, publicación de la Asociación Nacional del Notariado Mexicano, México, 2.001.

NUÑEZ LAGOS, Rafael, Hechos y derechos en el documento público, Instituto Nacional de Estudios Jurídicos, Madrid, 1.950.

NUÑEZ LAGOS, Rafael, Concepto y clases de documentos, en Los esquemas conceptuales del instrumento público, Estudio preliminar de Sebastián Justo COSOLA, Gaceta Notarial, Lima, 2.013.

NÚÑEZ LAGOS, Rafael, Estudios sobre el valor jurídico del documento notarial, Academia Matritense del Notariado, Alcalá de Henares, 1.945.

NUÑEZ LAGOS, Rafael, Fe Pública, en Los esquemas conceptuales del instrumento público, Est. Prel. de Sebastián Justo COSOLA, Colección Biblioteca Notarial ${ }^{\circ}$ 3, Lima, 2.013.

NUÑEZ LAGOS, Rafael, Los esquemas conceptuales del instrumento público, libro homónimo, Gaceta Notarial, Lima, 2.013.

NUÑEZ LAGOS, Rafael, Los esquemas conceptuales del instrumento público, Instituto de España y Real Academia de Jurisprudencia y Legislación, Madrid, 1.953.

NUÑEZ LAGOS, Rafael, Tres momentos del título notarial, en Los esquemas conceptuales del instrumento público, Gaceta Notarial, Lima, 2.013 .

NÚÑEZ LAGOS, Rafael, Documento público y autenticidad de fondo, en Jorge H. ALTERINI (Dir.)-Ignacio E. ALTERINI (Coord.), Derecho Notarial, Registral e Inmobiliario. Doctrinas Magistrales 1897-2012, t $^{\circ}$ I, La Ley, Buenos Aires, 2.012, p.747-770.

NUÑEZ PALOMINO, Pedro Germán, Comentarios a la ley del notariado, Gaceta Notarial, Lima, 2.014.

NUSSBAUM, Martha C., Las fronteras de la justicia, Paidós, Barcelona, 2.012.

NUTA, Ana Raquel (Dir.) y GALLINO, Julieta (Coord.), Tratado de Derecho Privado Notarial, Ad Hoc, Buenos Aires, 2.006.

OQUENDO LÓPEZ, Álvaro Héctor, Compilaciones de derecho notarial para Bolivia, Cadena Editora, Sucre, 2.007.

ORDOÑEZ ORTIZ, Alberto e IZQUIERDO DAVILA, Germán, Derecho registral y seguridad jurídica, Cuenca, Ecuador, 2.006.

ORELLE, José M. R, Actos e instrumentos notariales, La Ley, Buenos Aires, 2.008 (TDI).

ORELLE, José María, De los instrumentos públicos, en Augusto C. BELLUSCIO (Director) y Eduardo A. ZANNONI (Coordinador), Código 
LOS EFECTOS DE LA PUBLICIDAD EN EL DOCUMENTO NOTARIAL

civil y leyes complementarias- Comentado, anotado y concordado, $\mathrm{t}^{\circ} 4$, Astrea, Buenos Aires, 2.001.

ORELLE, José María R., La autenticación de firmas en la República Argentina. Estudio comparativo de las normativas provinciales, Academia Nacional del Notariado, Buenos Aires, 2.007.

ORELLE, José María R., Impuesto de sellos y la autenticación notarial de firmas, $\mathrm{RN} \mathrm{n}^{\circ}$ 963, La Plata, 2.009.

ORELLE, José María R., Actos Jurídicos, en Jorge Horacio ALTERINI (Dir. Gen.), José W. TOBIAS (Dir. tom.), Ignacio E. ALTERINI (Coord.), Código Civil y Comercial Comentado. Tratado Exegético, t ${ }^{\circ}$ II, Thomson Reuters- La Ley, Buenos Aires, 2.016.

ORTEGA Y GASSET, José, La rebelión de las masas, Biblioteca de Grandes Pensadores, Madrid, 2.004

ORTIZ de DI MARTINO, Lucila, Manual de Derecho Notarial, Marben, Asunción, 2007.

ORTIZ de DI MARTINO, Lucila, Manual de Derecho Registral, Marben, Asunción, 2.009.

OSSORIO Y FLORIT, Manuel, Código Civil y Leyes Complementarias. Anotados, Comentados y Actualizados, $\mathrm{t}^{\circ}$ II y III, Ediciones Librería Jurídica, La Plata 1.972-1973.

OTERO Y VALENTÍN, Julio, Sistema de la función notarial, Artes Gráficas N: Poncell, Barcelona, 1.933.

OVEJERO, Daniel, La posesión, Compañía Impresora Argentina S.A, Buenos Aires, 1.942.

PADILLA, René A., Estudios de derecho civil y registral, Ediciones El Graduado, Tucumán, 1.995.

PALACIO, Lino Enrique, Manual de derecho procesal civil, 21 ed., La Ley, Buenos Aires, 2.014 (Versión de la aplicación Thomson Reuters Proview)

PALACIOS, Alfredo L., La justicia social, Editorial Claridad, Buenos Aires, 1.954.

PALMIERI, Jorge H., La fuerza ejecutiva de la copia certificada de una escritura pública. Comentario Breve, ED 177-363.

PAPAÑO, Ricardo J.; KIPER, Claudio M.; DILLON, Gregorio A. y CAUSSE, Jorge R., Derecho Civil. Derechos Reales, Javier A. PAPAÑO (Colab.) II Tomos, Astrea, Buenos Aires, 2.012.

PAZ-ARES, Cándido, El sistema notarial. Una aproximación económica, Consejo General del Notariado, Madrid, 1.995.

PELOSI, Carlos A., El derecho notarial como derecho autónomo, en Los anales del notariado argentino, Vol. VII t ${ }^{\circ}$ 2, IACN, Buenos Aires, 1.975. 
PELOSI, Carlos A., El Documento Notarial, Astrea, Buenos Aires, 1.987. PELOSI, Carlos A, Estudios jurídicos notariales, Abeledo Perrot, Buenos Aires, 1.965.

PELOSI, Carlos A., Las notas en el protocolo, en Jorge H. ALTERINI (Dir.) e Ignacio E. ALTERINI (Coord.), Derecho Notarial, Registral $e$ Inmobiliario. Doctrinas Magistrales 1897-2012, t I, La Ley, Buenos Aires, 2.012, p. 1365-1403.

PEÑA GUZMÁN, Luis A., Curso de Derecho Privado Romano. Derechos Reales, Talleres Gráficos Miguel Violetto S.R.L, Tucumán, 1.952.

PEÑA GUZMÁN, Luis Alberto, Derecho Civil. Derechos Reales, III Tomos, Tipográfica Editora Argentina (TEA), Buenos Aires, 1.975.

PEÑALVER, Eduardo M., Memorias de la propiedad, en Daniel BONILLA MALDONADO (Coord.), La función social de la propiedad, Eudeba, Buenos Aires, 2.013.

PEPE, Marcelo Antonio y MENDIZÁBAL, Gonzalo Alejo, El orden público y la rigidez oflexibilidad en los derechos reales, LL 2009-D p. 871.

PERALTA MARISCAL, Leopoldo L., Vivienda, en Julio César RIVERA y Graciela MEDINA (Dir.), Mariano ESPER (Coord.), Código Civil y Comercial de La Nación Comentado, $\mathrm{t}^{\circ}$ I, La Ley, Buenos Aires, 2.014.

PÉREZ BARBERÁ, Gabriel, Delitos de falsedad documental, Hammurabi, Buenos Aires, 2.013.

PÉREZ FERNÁNDEZ DEL CASTILLO, Bernardo, Derecho Notarial, Porrúa, México, 2.007.

PÉREZ FERNÁNDEZ DEL CASTILLO, Bernardo, Derecho Registral, Porrúa, México, 2.013.

PEREZ FERNANDEZ DEL CASTILLO, Bernardo, Doctrina Notarial Internacional, Porrúa y Asociación Nacional del Notariado Mexicano, 2013. PÉREZ FERNANDEZ DEL CASTILLO, Bernardo, Orígenes e historia del notariado en México, Porrúa y Asociación Nacional del Notariado Mexicano, México, 2009.

PEREZ GALLARDO, Leonardo B., Diligencias y notas en el instrumento público notarial: un acercamiento a su estudio, en Estudios de derecho notarial Iberoamericano (Libro homenaje al prof. Dr. Nery Roberto MUÑOZ), Infoconsult Law, Guatemala, 2.013.

PÉREZ GALLARDO, Leonardo B. e Isidoro LORA TAMAYO RODRÍGUEZ, Derecho Notarial, III Tomos, Ediciones Félix Varela, La Habana, 2.006-2008. 
LOS EFECTOS DE LA PUBLICIDAD EN EL DOCUMENTO NOTARIAL

PEREZ GALLARDO, Leonardo B. (Coord.), Derecho Notarial Constitucional, Fondo Editorial del Colegio de Notarios de Lima, Perú, 2.017.

PEREZ LASALA, José Luís, Derecho Inmobiliario Registral, Depalma, Buenos Aires, 1.965.

PÉREZ LOZANO, Néstor O, La función notarial creadora de derecho, RN $n^{\circ}$ 942, La Plata, 2.002.

PÉREZ LUÑO, Antonio Enrique, Trayectorias contemporáneas de la filosofia y la teoría del derecho, Palestra, Lima, 2.005.

PETIT, Eugène, Derecho Romano, Porrúa, México, 2.013.

PETTORUTI, Carlos Enrique y SCATOLINI, Julio César, Elementos de introducción al derecho, La Ley, Buenos Aires, 2.005.

PETTORUTI, Carlos Enrique, Conocimiento, interpretación y aplicación del derecho en la perspectiva del proyecto del Código Civil y Comercial de La Nación, RN n 977, La Plata, 2.014.

PIAZZA, Marta Rosa, Responsabilidad civil del notario. El seguro llamado de mala praxis. Sus diferencias con el seguro de título, Cristina Noemí ARMELLA (Col.) AIDN n 3, Madrid, 2.004.

PICHETTO, Roque Jacinto, Comentarios históricos y jurídicos del notariado, Talleres Gráficos D'Accurzio, Mendoza, 1.947.

PIEPER, Josef, Las virtudes fundamentales, Rialp, Madrid, 2.003.

PINA TORIBIO, César, Temas notariales, Corripio, Santo Domingo, 1.993.

PIOMBINO, Alfred E., Notary Public HandBook. A guide for New York,

East Coast Publishing, Poughkeepsie, New York, 1.993.

PONDÉ, Eduardo Bautista, La función notarial no es función pública, $\mathrm{RN} \mathrm{n}^{\circ}$ 917, La Plata, 1.994.

PONDÉ, Eduardo Bautista, Origen e historia del notariado, Depalma, Buenos Aires, 1.967.

PONDÉ, Eduardo Bautista, Tríptico Notarial, Depalma, Buenos Aires, 1.977.

PORTALIS, Jean-Etienne, Discurso preliminar sobre el proyecto de Código Civil presentado el primero de pluvioso del año IX por la comisión designada por el gobierno consular, Abeledo Perrot, Buenos Aires, 1.959.

PORTELA, Jorge Guillermo, La justicia y el derecho natural, Arequipa, 2.006.

POUND, Roscoe, Justicia conforme a derecho, Editorial Letras S.A, México, 1.962.

PRIETO SANCHÍS, Luís, Interpretación jurídica y creación judicial del derecho, Temis, Bogotá-Lima, 2.005. 
PRODI, Paolo, Una historia de la justicia. De la pluralidad de fueros al dualismo moderno entre conciencia y derecho, Katz, España, 2.008.

PRÓSPERI, Fernando F., Régimen legal de automotores, La Rocca, Buenos Aires, 1.997.

QUATROMANO, Marcelo R., Tradición y consenso como modos diferentes de adquirir el dominio. El sistema de la tradición en la Argentina y sus excepciones, ED 212-920.

QUINTANA, Eduardo Martín, Visión de la cultura y de la historia, Cooperadora de Derecho y Ciencias Sociales, Buenos Aires, 1.975.

QUINTELA, Leónidas Ariel, Las acciones neutrales en el ámbito profesional de los escribanos, IJ Editores, Buenos Aires, 2.013.

QUIROGA LAVIÉ, Humberto, Lecciones de derecho constitucional, Depalma, Buenos Aires, 1.995.

RABBI-BALDI CABANILLAS, Renato (Coord.), Las razones del derecho natural-Estudio introductorio a la segunda edición, $2^{\circ}$ edic, Ábaco, Buenos Aires, 2.008.

RABBI-BALDI CABANILLAS, Renato, Título preliminar, en Julio César RIVERA-Graciela MEDINA (Dir.)- Mariano ESPER (Coord.), Código Civil y Comercial de La Nación Comentado, t ${ }^{\circ}$ I, La Ley, Buenos Aires, 2.014.

RABINOVICH-BERKMAN, Ricardo, Principios generales del derecho latinoamericano, Astrea, Buenos Aires, 2.006.

RADBRUCH, Gustav, Filosofia del derecho, Reus, Madrid, 2.008.

RAWLS, John, Teoría de la justicia, Fondo de Cultura Económica, México, 2.012 .

RAZ, Joseph, ALEXY, Robert y BULYGIN, Eugenio, Una discusión sobre la teoría del derecho, Marcial Pons, Madrid, 2.007.

REALE, Miguel, Teoría tridimensional del derecho, Edeval, Valparaíso, 1.978 .

REALE, Miguel, Filosofia del derecho, t ${ }^{\circ}$ I- Introducción filosófica general, Pirámide, Madrid, 1.979.

RECASENS SICHES, Luis, Sociología, Porrúa, México, 1.963.

RECASENS SICHES, Luis, Filosofia del derecho, Porrúa, México, 2.008.

RENARD, Georges, Introducción filosófica al estudio del derecho, III Tomos, Debedec- Ediciones Desclée de Brower, Buenos Aires, 1.947.

REZZÓNICO, Juan Carlos, Principios fundamentales de los contratos, Astrea, Buenos Aires, 1.999.

RICOEUR, Paul, Lo justo, Editorial Jurídica de Chile, Santiago, 1.997.

RIPERT, Georges y BOULANGER, Jean, Tratado de Derecho Civil (Según el tratado de Planiol), trad. de Delia GARCIA DAIREAUX y Superv. de 
LOS EFECTOS DE LA PUBLICIDAD EN EL DOCUMENTO NOTARIAL

Jorge Joaquín LLAMBÍAS, Las Obligaciones, T IV, La Ley, Buenos Aires, 1.964.

RIVERA, Julio César y MEDINA, Graciela (Dir.)-Mariano ESPER (Coord.), Código Civil y Comercial de La Nación comentado, VI Tomos, La Ley, Buenos Aires, 2.014.

RIVERA, Julio César, Instituciones de Derecho Civil. Parte General, II Tomos, Abeledo Perrot, Buenos Aires, 2.010.

RIVERA, Julio César y CROVI, Luis Daniel, Derecho Civil-Parte General, Abeledo Perrot, Buenos Aires, 2.016.

RIVERO VALDÉS, Orlando, Temas de derechos reales, Editorial Félix Varela, La Habana, 2.007.

ROCCO, Alfredo, La sentencia civil, El Foro, Buenos Aires, 2.003.

ROCCO, Emma Adelaida, Boleto de compraventa, La Ley, Buenos Aires, 2.009 .

RODRÍGUEZ ADRADOS, Antonio, El notario: Función privada y función pública. Su inescindibilidad, Escritos Jurídicos, Vol. $n^{\circ}$ II, CGN, Madrid, 1.996.

RODRIGUEZ ADRADOS, Antonio, El documento notarial y la seguridad jurídica, Escritos Jurídicos, Vol. n III, CGNE, Madrid, 1.996.

RODRIGUEZ ADRADOS, Antonio, Documento, Escritos Jurídicos, Vol. $\mathrm{n}^{\circ}$ III, CGN, Madrid, 1.996.

RODRIGUEZ ADRADOS, Antonio, El instrumento público. Requisitos de forma y fondo, Escritos Jurídicos, Vol. n III, CGN, Madrid, 1.996.

RODRIGUEZ ADRADOS, Antonio, El notario y el documento notarial, Escritos Jurídicos, Vol. n ${ }^{\circ}$ II, CGN, Madrid, 1.996.

RODRÍGUEZ ADRADOS, Antonio, Sistemas notariales existentes en el mundo. Características del notariado latino, Escritos Jurídicos, Vol. $n^{\circ}$ II, CGN, Madrid, 1.996.

RODRIGUEZ ADRADOS, Antonio, El documento en el código civil, Escritos Jurídicos, Vol. n ${ }^{\circ}$ III, CGN, Madrid, 1.996.

RODRIGUEZ ADRADOS, Antonio, El documento notarial y la seguridad jurídica, Escritos Jurídicos, Vol. n III, CGN, Madrid, 1.996.

RODRÍGUEZ ADRADOS, Antonio, Escritos Jurídicos, VI Volúmenes, CGN, Madrid, 1995-1996.

RODRIGUEZ ADRADOS, Antonio, Fe pública, Escritos Jurídicos, Vol. n ${ }^{\circ}$ II, CGN, Madrid, 1.996.

RODRIGUEZ ADRADOS, Antonio, Principios Notariales, REN, Ilustre Colegio Notarial de Madrid, 2.006. 
ROGERS, William D. y WRIGHT-CAROZZA, Paolo, La Corte Suprema de Justicia y la Seguridad Jurídica, Ábaco, Buenos Aires, 1.995.

ROJAS PELLERANO, Héctor F., Temas de la teoría general del derecho notarial, $\mathrm{RdN} n^{\circ} 734,1.974$.

ROJAS PELLERANO, Héctor F., Introducción al derecho, Centro Editor Argentino, Buenos Aires, 1.984.

ROJAS, Nerio, Medicina Legal, Librería El Ateneo Editorial, Buenos Aires, 1.958.

ROJINA VILlEGAS, Rafael, Derecho Civil Mexicano, Adriana ROJINA GARCÍA (Concord.), IV Tomos, Porrúa, México, 2.009-2014.

ROSATTI, Horacio, El código Civil y Comercial desde el Derecho Constitucional, Rubinzal Culzoni, Santa Fe, 2.016.

ROSS, Alf, Sobre el derecho y la justicia, Eudeba, Buenos Aires, 1.963.

ROSSI, Abelardo F., Aproximación a la justicia y a la equidad, Ediciones de la Universidad Católica Argentina, Buenos Aires, 2.000.

ROSSI, Abelardo F., Algunos modos del saber humano, El Derecho, Buenos Aires, 2.003.

RUSSO, Eduardo Ángel, Teoría general del derecho, LexisNexis- Abeledo Perrot, Buenos Aires, 2.004.

RUSSO, Eduardo Ángel y MAS, Analía Haydee, Introducción al estudio general del derecho, Editorial Docencia, Buenos Aires, 2.000.

SÁBATO, Ernesto, Uno y el universo, Obra Completa, Seix Barral, Buenos Aires, 2.009.

SABENE, Sebastián E., Registro Catastral, Zavalía, Buenos Aires, 2.013.

SAGGESE, Roberto M. A., El control de razonabilidad en el sistema constitucional argentino, Rubinzal Culzoni, Santa Fe, 2.010 (TDI).

SALAS, Acdeel Ernesto, Código Civil y leyes complementarias anotados, $\mathrm{t}^{\circ}$ I, Depalma, Buenos Aires, 1.971.

SALEILLES, Raymundo, La posesión. Elementos que la constituyen y su sistema en el Código Civil del Imperio Alemán, Librería General de Victoriano Suarez, Madrid, 1.909.

SALERNO, Marcelo Urbano, Derecho civil profundizado, Ciudad Argentina y Universidad del Museo Social Argentino, Buenos Aires, 1.998.

SALIERNO, Karina Vanesa, La adquisición legal del derecho real del subadquirente de buena fe y la trascendencia del estudio de titulos, $\mathrm{RN} \mathrm{n}^{\circ}$ 978, La Plata, 2.014.

SALVAT, Raymundo M, Tratado de derecho civil argentino. Parte General, Víctor N. ROMERO del PRADO (Actual,), to II, Tipográfica Editora Argentina S.A, Buenos Aires, 1.958. 
LOS EFECTOS DE LA PUBLICIDAD EN EL DOCUMENTO NOTARIAL

SALVAT, Raymundo M, Tratado de derecho civil argentino. Derechos Reales, Manuel J. ARGAÑARAZ (Actual.), $\mathrm{t}^{\circ} \mathrm{I}$, Tipográfica Editora Argentina S.A, Buenos Aires, 1.961.

SAMPAYO, Nelly Generosa, De las escrituras públicas y la función notarial: arts. 997 y concordantes del código civil y sus posibles reformas, Biblioteca de la Facultad de Derecho de la Universidad de Buenos Aires, ${ }^{\circ}$ topográfico 251.059/1956 (TD).

SANAHUJA Y SOLER, José María, Tratado de Derecho Notarial, II Tomos, Bosch, Barcelona, 1.945.

SÁNCHEZ HIDALGO, Adolfo Jorge, Filosofia y método del derecho en Juan Berchmans Vallet de Goytisolo, Fundación Matritense del Notariado, Madrid, 2010 (TDI).

SANTIAGO, Alfonso (h), En las fronteras entre el Derecho Constitucional y la Filosofía del Derecho, Marcial Pons, Buenos Aires, 2.010.

SANTO TOMAS DE AQUINO, Suma teológica. La prudencia, la justicia y el derecho, $\mathrm{t}^{\circ} \mathrm{XI}$, Club de Lectores, Buenos Aires, 1.987.

SATTA, Salvatore, Poesía e verità nella vita del notaio, Rivista di Diritto Processuale, Biblioteca del Ilustre Colegio de Notarios de Madrid, 1.955.

SAUCEDO, Ricardo Javier, Notas de subsanación, RN n 943, La Plata, 2002.

SAUCEDO, Ricardo J., Publicidad Registral, en Lilian N. GURFINKEL DE WENDY, Derechos Reales, T ${ }^{\circ}$ II, Abeledo Perrot, Buenos Aires, 2.010.

SAUCEDO, Ricardo Javier, Los límites de la calificación registral respecto de los títulos que provocan mutaciones reales inmobiliarias, en Cristina Noemí ARMELLA (Dir.) y Mariano ESPER (Invest.), Summa notarial, registral e inmobiliaria, $\mathrm{t}^{\circ} \mathrm{I}$, Buenos Aires, 2.013.

SAUCEDO, Ricardo Javier, Régimen del notariado en el Mercosur, Ediciones Jurídicas, Buenos Aires, 1.998.

SAVOURÉ, Dominique, DUMONTET, Benjamín y GALLIEZ, Lionel, Ponencias del notariado francés, CINL-UIN, De Bussac-Clermont-Ferrand, París, 2.010.

SCOTO, Duns, Tratado del primer principio, Aguilar, Buenos Aires, 1.964. SCOTTI, Edgardo O., Derecho Registral inmobiliario, Universidad, Buenos Aires, 1.980 .

SEGOVIA, Lisandro, El Código Civil de la República Argentina (Con su explicación y crítica bajo la forma de notas), Tomos Primero y Segundo, Imprenta de Pablo E. Coni Editor, Buenos Aires, 1.881.

SEGOVIA, Lisandro, El código civil argentino anotado, Félix Lajouane Editor, Buenos Aires, 1.894. 
SEN, Amartya, La idea de la justicia, Traducción de Hernando VALENCIA VILLA, Taurus, Madrid, 2.010.

SERNA, Pedro y TOLLER, Fernando, La interpretación Constitucional de los Derechos Fundamentales. Una alternativa a los conflictos de derechos, La Ley, Buenos Aires, 2.000.

SIERZ, Susana Violeta, Derecho Notarial concordado, Dilalla, Buenos Aires, 2.007.

SMITH, Juan Carlos, El desarrollo de las concepciones iusfilosoficas, Abeledo Perrot, Buenos Aires, 1.999.

SOARES, Antonino E., El escribano y la fe pública, Imprenta San Martin, Buenos Aires, 1.915.

SPENCER, Herbert, La justicia, Heliasta S.R.L, Buenos Aires, 1.978.

SPOTA, Alberto Gaspar, Curso sobre temas de derecho civil, Instituto Argentino de Cultura Notarial, Buenos Aires, 1971.

SPOTA, Alberto Gaspar, Art. 2355 del Cód. Civil (Ref. Ley 17711) y posesión legítima del comprador de buena fe con boleto de compraventa inmobiliaria, ED 98-821.

STAMMLER, Rudolf, Tratado de filosofía del derecho, Reus, Madrid, 2.008 .

STIGLITZ, Rubén, El objeto y la causa en los contratos, Depalma, Buenos Aires, 1991.

SUNSTEIN, Cass R., Leyes de miedo. Más allá del principio de precaución, Katz, Buenos Aires, 2.010.

TAPIA RAMIREZ, Javier, Bienes. Derechos reales, derechos de autor y registro público de la propiedad, Porrúa, México, 2.016.

TARUFFO, Michele, La prueba de los hechos, Trotta, Madrid, 2.011.

TARUFFO, Michele, Simplemente la verdad. El juez y la construcción de los hechos, Marcial Pons, Madrid, 2.010.

TAU ANZOÁTEGUI, Víctor, La codificación en Argentina (1810-1870). Mentalidad Social e ideas jurídicas, Librería Histórica Emilio J. Perrot, Buenos Aires, 2.008.

TINAGEROS LOZA, Víctor, Naturaleza jurídica del notario, Gaceta Notarial, Lima, 2013.

TINANT, Eduardo Luis, El hombre y su búsqueda, en Secundum Legem (Revista Jurídica del Centro de Estudiantes de Derecho-UNLP), Año $1 \mathrm{n}^{\circ} 5$, La Plata, 1.997.

TITO PUCA, Carlos Ricardo, Decreto del notariado, Gaceta Notarial, Lima, 2010. 
LOS EFECTOS DE LA PUBLICIDAD EN EL DOCUMENTO NOTARIAL

TOLLER, Fernando M., Sistema de citas y redacción en derecho. Manual Hispanoamericano, Marcial Pons, Buenos Aires, 2.016.

TRANCHINI, Marcela H.; BUSTINGORRI, María M, MARRUPE, Jorge $\mathrm{B}$, y FALBO, Marcelo N., Tradición, posesión y registro, $\mathrm{RN} \mathrm{n}^{\circ} 891, \mathrm{La}$ Plata, 1.987.

TRIGO REPRESAS, Félix A., La persona humana y sus derechos fundamentales en la Constitución Nacional de 1853 y el derecho civil, en AAVV, Homenaje al Sesquicentenario de la Constitución Nacional (18532003), $t^{\circ}$ II, Academia Nacional del Derecho y Ciencias Sociales de Córdoba-Advocatus, 2003, p. 28 y ss.

TRUEBA BUENFIL, Fernando e IBARROLA MURO, Jorge Claudio, El arte de la memoria notarial-Los trabajos y los días de los notarios del Estado de México: 1808-1937, Foem, México, 2.013.

URBANEJA, Marcelo Eduardo, Relevancia de la posesión en el régimen jurídico del automotor, Diario El Derecho, UCA, Buenos Aires, 05/07/2011.

URBANEJA, Marcelo Eduardo, Tradición, "constituto posesorio", "traditio brevi manu" e inmueble ocupado por un tercero: su reflejo escriturario, $\mathrm{RN}^{\circ}$ 957, La Plata, 2.007.

URBANEJA, Marcelo Eduardo, Practica Notarial de contratos usuales. Modelos según normativa nacional y local, $\mathrm{n}^{\circ} 1$, Astrea, Buenos Aires, 2.016 .

VALDES, Horacio y ORCHANSKY, Benito, Lecciones de derechos reales, $t^{\circ}$ I, Ediciones Lerner, Buenos Aires, 1.969.

VALIENTE NOAILLES (h), Luis M., Obligaciones reales, Depalma, Buenos Aires, 1.961.

VALLESPINOS, Carlos Gustavo (Dir.), Cuestiones esenciales en derechos reales, LexisNexis, Buenos Aires, 2.002.

VALLET DE GOYTISOLO, De la virtud de la justicia a lo justo jurídico, En torno al derecho natural, Organización Sala Editorial, Madrid, 1.973.

VALLET DE GOYTISOLO, Joaquín Costa en la metodología de la determinación del derecho (Cinco apartados de un libro), Dialnet 105111.pdf;

VALLET DE GOYTISOLO, Juan Berchmans, Definición e interpretación del derecho según Michel Villey, Persona y Derecho n 25, Madrid, 1.991.

VALLET DE GOYTISOLO, Juan Berchmans, El retorno a la genuina definición aristotélico-romano-tomista del derecho por Michel Villey, Revista Verbo de la Fundación Speiro n 363-364, Madrid, 1.998.

VALLET DE GOYTISOLO, Juan Berchmans, En torno al derecho natural, Organización Sala Editorial, Madrid, 1.973. 


\section{SEBASTIÁN JUSTO COSOLA}

VALLET DE GOYTISOLO, Juan Berchmans, Esbozo del pensamiento jurídico de Elías de Tejada, Revista Verbo 191-192, Madrid, 1.981.

VALLET DE GOYTISOLO, Juan Berchmans, Estudios sobre derecho de cosas, Montecorvo, Madrid, 1.973.

VALLET DE GOYTISOLO, Juan Berchmans, Ideología, Praxis y Mito de la Tecnocracia, Escelicer, Madrid, 1.971.

VALLET DE GOYTISOLO, Juan Berchmans, Función autenticadora de las relaciones jurídicas, estudiada por el derecho notarial formal o técnico, en Derecho Notarial, Leonardo B. PEREZ GALLARDO e Isidoro LORATAMAYO RODRIGUEZ (Coordinadores), $T^{\circ}$ I, Félix Varela, La Habana, 2.006.

VALLET DE GOYTISOLO, Juan Berchmans, La buena fe, la inscripción y la posesión en la mecánica de la fe pública, Estudios sobre derecho de cosas, Montecorvo, Madrid, 1.971.

VALLET DE GOYTISOLO, Juan Berchmans, La función notarial de tipo latino, en Juan Francisco DELGADO DE MIGUEL (Compilador), Deontología Notarial, Junta de Decanos de los Colegios Notariales de España, Madrid, 1.992.

VALLET DE GOYTISOLO, Juan Berchmans, La perspectiva del derecho natural y de su función que expone Georges Renard, Revista Verbo ${ }^{\circ} 369$ 370, Madrid, 1.998.

VALLET DE GOYTISOLO, Juan Berchmans, Manuales de metodología jurídica, IV Tomos, Consejo General del Notariado, Madrid, 2.004.

VALLET DE GOYTISOLO, Juan Berchmans, La buena fe en las transmisiones inmobiliarias a non domino, en Marcos M. CÓRDOBA (Dir.). Lidia M. GARRIDO CORDOBERA y Viviana KLUGER (Coord.), Tratado de la buena fe en el derecho, $\mathrm{t}^{\circ}$ II, La Ley, Buenos Aires, 2.005, págs. 274284.

VALLET DE GOYTISOLO, Juan Berchmans, Mas sobre temas de hoy, Publicaciones de la Editorial Speiro, Madrid, 1.979.

VALLET DE GOYTISOLO, Juan Berchmans, Panorama de Derecho Civil, Bosch, Barcelona, 1.973.

VALLET DE GOYTISOLO, Juan Berchmans, Controversias en torno al derecho natural- En torno al derecho natural, Organización Sala Editorial, Madrid, 1.973.

VALLET DE GOYTISOLO, Juan Berchmans, Definición e interpretación del derecho según Michel Villey, Persona y derecho n 25, Madrid, 1.991.

VALLET DE GOYTISOLO, Juan Berchmans, Del racionalismo inmanente al voluntarismo utópico y, de su fracaso, al nihilismo, Revista Filosofía 
LOS EFECTOS DE LA PUBLICIDAD EN EL DOCUMENTO NOTARIAL

OGGI, $V^{\circ} 3 \mathrm{~N}^{\circ} 4,1.980$, reproducido en Revista Verbo de la Fundación Speiro $\mathrm{N}^{\circ}$ 191-192, Madrid, 1.981.

VALLET DE GOYTISOLO, Juan Berchmans, El orden natural y el derecho- En torno al derecho natural, Organización Sala Editorial, Madrid, 1.973.

VALLET DE GOYTISOLO, Juan Berchmans, en La definición de derecho según Joaquín Costa, Dialnet 105148.pdf.

VALLET DE GOYTISOLO, Juan Berchmans, Ideología, praxis y mito de la tecnocracia, Montecorvo, Madrid, 1.975.

VALLET DE GOYTISOLO, Juan Berchmans, La ciencia y el derecho en la concepción de Inmanuel Kant, Dialnet 2869978.pdf

VALLET DE GOYTISOLO, Juan Berchmans, La conversión de Carnelutti al iusnaturalismo realista sin salir del normativismo, Revista Verbo de la Fundación Speiro n ${ }^{\circ}$ 65-366, 1.998.

VALLET DE GOYTISOLO, Juan Berchmans, La función notarial de tipo latino, en Deontología Notarial, de Juan Francisco DELGADO DE MIGUEL (Comp.), DCNE-CGNE, Madrid, 1.992.

VALLET DE GOYTISOLO, Juan Berchmans, La misión del notario, en Juan Francisco DELGADO DE MIGUEL, Deontología notarial, Junta de Decanos de los Colegios Notariales de España-Consejo General del Notariado Español, Madrid, 1.992.

VALLET DE GOYTISOLO, Juan Berchmans, Orígenes del notariado latino en Italia y en España, RJdN n ${ }^{\circ}$ 47, Madrid, 2003.

VALLET DE GOYTISOLO, Juan Berchmans, Determinación de las relaciones jurídicas relativas a inmuebles susceptibles de trascendencia respecto a tercero, IER, Madrid, 1.965.

VALLET DE GOYTISOLO, Juan Berchmans, Seguridad jurídica estática y seguridad jurídica dinámica, RJdN n³3, Madrid, 2.003.

VALLET DE GOYTISOLO, Juan Berchmans, Sociedad de masas y derecho, Taurus, Madrid, 1.968.

VANNI, Icilio, Filosofia del derecho, Librería de Francisco Beltrán, Madrid, 1.922.

VANOSSI, Jorge Reinaldo, Constitución, seguridad jurídica y comercio, XV Reunión conjunta de las Academias Nacionales de Derecho y Ciencias Sociales de Buenos Aires y Córdoba, Córdoba, 23-24/10/2003. http://www.acaderc.org.ar/doctrina/articulos/artconstitcionseguridadjuridia VARGAS de VALLANIA, Marta G., BENJAMÍN de RUIZ, Marta S. y BONETTO DE CIMA, Ángela B., La inexactitud registral y su proyección 
negocial. Artículo 1051, la problemática de terceros y la inexactitud registral y extrarregistral, Depalma, Buenos Aires, 1.985.

VELASCO PÉREZ, Ignacio, y una Sociedad de Abogados del Ilustre Colegio de esta Corte, Las siete partidas del sabio Rey D. Alfonso, Imprenta de los señores Viuda de Jordán e Hijos, Madrid, 1.843.

VENTURA, Gabriel, El régimen registral del automotor, ACADERC, sección doctrina on line.

VENTURA, Gabriel B., El boleto de compraventa frente al embargo del vendedor, ACADERC, Sección doctrina on line.

VENTURA, Gabriel B., Los títulos notariales y la posesión, Anuario de Derecho Civil de la Universidad Católica de Córdoba, t ${ }^{\circ}$ VIII, 2.003.

VENTURA, Gabriel B., Ley 17.801. Registro de la propiedad inmueble. Comentada. Anotada, Hammurabi, Buenos Aires, 2.009.

VENTURA, Gabriel B., Los derechos reales incorporados en el Código Civil y Comercial de La Nación y la publicidad registral, en Claudio KIPER (Dir.); Luis O. DAGUERRE (Coord.), Aplicación notarial del Código Civil $y$ Comercial de La Nación, $\mathrm{t}^{\circ}$ III, Rubinzal-Culzoni, Santa Fe, 2.015.

VENTURA, Gabriel B., Hechos y actos jurídicos, en Alberto J. BUERES (Dir.), Código Civil y Comercial de La Nación y normas complementarias, $\mathrm{t}^{\circ}$ 1B, Hammurabi, Buenos Aires, 2.016.

VERDEJO REYES, Pedro C., Derecho notarial, Editorial Pueblo y Educación, La Habana, 1.990.

VERDROSS, Alfred, La filosofia del derecho del mundo occidental, Centro de Estudio Filosóficos-Universidad Nacional Autónoma de México, México, 1.962.

VES LOSADA, Alfredo, Sociología del derecho, Ábaco, Buenos Aires, 1.980, p. 317.

VIGO, Rodolfo Luis y GATTINONI de MUJÍA, María (Dir.), Tratado de derecho judicial, Abeledo Perrot, Buenos Aires, 2013.

VIGO, Rodolfo Luís, Como argumentar jurídicamente, Abeledo Perrot, Buenos Aires, 2.012.

VIGO, Rodolfo Luis, Las causas del derecho, Abeledo Perrot, Buenos Aires, 1.983.

VIGO, Rodolfo Luis, Iusnaturalismo y neoconstitucionalismo, Educa, Buenos Aires, 2015.

VIGO, Rodolfo Luis, Constitucionalización y neoconstitucionalismo: Riesgos y prevenciones, Acerbo de la Biblioteca Jurídica Virtual del Instituto de Investigaciones jurídicas de la Universidad Nacional Autónoma de México, en www.juridicas.unam.mx 
VIGO, Rodolfo Luis, La injusticia extrema no es derecho (de Radbruch a Alexy), La Ley, Buenos Aires, 2006.

VIGO, Rodolfo Luis, Interpretación constitucional, LexisNexis-Abeledo Perrot, Buenos Aires, 2.004.

VIGO, Rodolfo Luis, Integración de la ley, Astrea, Buenos Aires, 1.978.

VIGO, Rodolfo Luis, Las causas del derecho, Abeledo Perrot, Buenos Aires, 1.983 .

VIGO, Rodolfo Luis, Los principios jurídicos (Perspectiva Jurisprudencial), Depalma, Buenos Aires, 2.000.

VIGO, Rodolfo Luis, Comentarios al capitulo I del título preliminar, Biblioteca Digital de la UCA. http://www.pensamientocivil.com.ar/system/files/2015/01/Doctrina463.pdf

VIGO, Rodolfo Luis, Constitucionalización y judicialización del derecho (Del Estado de Derecho Legal al Estado de Derecho Constitucional), Porrúa, México, 2.013.

VIGO, Rodolfo Luis, De la ley al derecho, Porrúa, México 2005.

VIGO, Rodolfo Luis, Prólogo a la obra de Alfonso SANTIAGO (h), En las fronteras entre el derecho constitucional y la filosofia del derecho, Marcial Pons, Buenos Aires, 2.010.

VIGO, Rodolfo Luis, Interpretación jurídica (Del modelo iuspositivista legalista decimonónico a las nuevas perspectivas), Rubinzal Culzoni, Santa Fe, 1.999 .

VIGO, Rodolfo Luís, Perspectivas Iusfilosóficas Contemporáneas, Lexis Nexis, Buenos Aires, 2.006.

VIGO, Rodolfo Luis, Visión crítica de la historia de la filosofía del derecho, Rubinzal Culzoni, Santa Fe, 2.008.

VIGO, Rodolfo Luis, Aproximaciones a la seguridad jurídica, en Interpretación Jurídica (Del modelo iuspositivista legalista decimonónico a las nuevas perspectivas), Rubinzal-Culzoni, Santa Fe, 1.999.

VIGO, Rodolfo Luis, Iusnaturalismo y neoconstitucionalismo. Coincidencias y diferencias, Educa, Buenos Aires, 2015.

VIGO, Rodolfo Luis, Interpretación (Argumentación) jurídica en el Estado de Derecho Constitucional, Rubinzal Culzoni, Santa Fe, 2.015.

VILLALBA WELSH, Alberto, Hacia una teoría egológica del Derecho notarial, Ediciones de la Universidad Notarial Argentina (UNA), 1.967.

VILLALBA WELSH, Carlos Alberto, El derecho notarial a la luz de la teoría egológica, Ediciones de la Universidad Notarial Argentina, 1.967.

VILLARO, Felipe Pedro Y BIDART, Raúl E., Legislación registral inmobiliaria, Editorial Campos S.C.A, Buenos Aires, 1.972. 
VILLARO, Felipe Pedro, Elementos de derecho registral Inmobiliario, Scotti, La Plata, 2003.

VILLARO, Felipe Pedro, Elementos de derecho registral. Colección

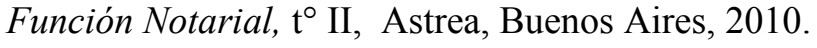

VILLARROEL CLAURE, Ramiro, Fundamentos de derecho notarial y registral inmobiliario, Alexander, Cochabamba, 2.005.

VILLEGAS, Héctor B, Curso de finanzas, derecho financiero y tributario, Astrea, Buenos Aires, 2.016.

VILLEY, Michel, Compendio de filosofia del derecho. Definiciones y fines del derecho, Eunsa, Pamplona, 1.979.

VILLEY, Michel, En torno al contrato, la propiedad y la obligación, Ghersi Editor, Buenos Aires, 1.981.

WAYAR, Ernesto, Boleto de Compraventa, en Ricardo L. LORENZETTI (Dir.)- Miguel F. DEL LORENZO y Pablo LORENZETTI (Coord.), Código

Civil y Comercial de La Nación Comentado, Rubinzal Culzoni, Santa Fe, 2.015 .

WEISS, Karen Maína y ZAVALA, Gastón Augusto, Eficacia ofensiva de la publicidad registral inmobiliaria, $\mathrm{RN} \mathrm{n}^{\circ}$ 965, La Plata, 2.010.

ZANNONI, Eduardo A. (Dir.) y KEMELMAJER DE CARLUCCI, Aída (Coord.), Código Civil y leyes complementarias, Tomos 10 a 13, Astrea, Buenos Aires, 2.005-2012.

ZANNONI, Eduardo A., Derecho Civil-Derecho de Familia, 2 Tomos, Astrea, Buenos Aires, 2.006.

ZANNONI, Eduardo A., Derecho Civil-Derecho de las Sucesiones, 2 Tomos, Astrea, Buenos Aires, 2.001.

ZARINI, Helio Juan, Constitución Argentina. Comentada y concordada, Astrea, Buenos Aires, 1.996.

ZATTA, María Carla, Deberes y Derechos, en Tratado de Derecho Notarial, Registral e Inmobiliario, Cristina N. ARMELLA (Dir.), $\mathrm{t}^{\circ} \mathrm{I}$, AdHoc, Buenos Aires, 1.998.

ZAVALA, Gastón Augusto, Nulidades instrumentales, en Cristina Noemí ARMELLA (Dir.), Tratado de Derecho Notarial, Registral e Inmobiliario, $\mathrm{t}^{\circ}$ III, Ad Hoc, Buenos Aires, 1.998, p. 121-181.

ZAVALA, Gastón Augusto, Subsanación de los documentos notariales, en Cristina N. ARMELLA (Dir.), Tratado de Derecho Notarial, Registral e Inmobiliario, $\mathrm{t}^{\circ}$ III, Ad-Hoc, Buenos Aires, 1.998, p. 219-239.

ZAVALA, Gastón Augusto, La forma notarial, en AIDN n ${ }^{\circ}$ 2, Juan Francisco DELGADO DE MIGUEL (Dir.), CGN, Madrid, 2.003. 
LOS EFECTOS DE LA PUBLICIDAD EN EL DOCUMENTO NOTARIAL

ZINNY, Mario Antonio y MASSICCIONI, Silvia Maela, Manual de Derechos Reales, Juris, Rosario, 2.009.

ZINNY, Mario Antonio, El acto notarial (Dación de fe), Depalma, Buenos Aires, 2.000.

ZINNY, Mario Antonio, Conocimientos útiles para la práctica del derecho, Ad Hoc, Buenos Aires, 2.007.

ZINNY, Mario Antonio, La base de la teoría general de derecho, Ad-Hoc, Buenos Aires, 2.010.

ZINNY, Mario Antonio, Comentarios a la base de la teoría general del derecho, Ad-Hoc, Buenos Aires, 2.012.

ZINNY, Mario Antonio, La enseñanza del derecho y los estudios comparados, Nova Tesis, Rosario, 2.014.

ZIULU, Adolfo Gabino, Derecho Constitucional, II Tomos, Depalma, Buenos Aires, 1997-1998.

ZULETA PUCEIRO, Enrique, Elementos de teoría del derecho, Abeledo Perrot, Buenos Aires, 2.013.

ZULETA PUCEIRO, Enrique, Paradigma dogmático y ciencia del derecho, Revista de Derecho Privado, Madrid, 1.981.

ZULETA PUCEIRO, Enrique, Teoría del derecho. Una introducción crítica, Depalma, Buenos Aires, 1.987.

ZUVILIVIA, Marina C., El notario y la seguridad jurídica, Juris, Rosario, 2.008 . 
SEBASTIÁN JUSTO COSOLA

$\cdot 626$. 